\title{
28. A NEOGENE GLOBIGERINACEAN BIOCHRONOLOGIC TIME-SCALE OF THE SOUTHWESTERN PACIFIC
}

\author{
Paul Brönnimann, University of Geneva, Switzerland \\ and Johanna Resig, Hawaii Institute of Geophysics, Honolulu, Hawaii
}

\section{CONTENTS}

I. Introduction
a) General Remarks
b) Acknowledgments

1235

1236

II. Fundamental Concepts

1237

a) The Paleontological Event

b) The Correlation Value of a Globigerinacean Biochronologic Time-Scale

c) Biochronologic Significance of Neogene Globigerinacean GenusGroups

d) The Biochronologic Resolution of Neogene Globigerinacean GenusGroups

e) The Distribution of Globigerinacean Events in Time

III. Remarks on the Resolution of a Cenozoic Integrated Biochronologic Time-Scale

IV. Choice of a Globigerinacean Zonal Scheme for the Southwestern Pacific

V. Observations on the Globigerinacean Zonations of Holes 62.1 and 64.1

a) Hole 62.1

1246

1248

\section{INTRODUCTION}

\section{a) General Remarks}

After preliminary examinations of the planktonic foraminifera for age determinations in the course of drilling during Leg 7 of the Deep Sea Drilling Project, the writers undertook in their respective laboratories more detailed taxonomic analyses of the samples from Sites 62, 63 and 64, situated in the south-western Pacific (Figure 1). Hole 62.1, in particular, furnished a virtually uninterrupted sequence of Middle Miocene to Recent chalks and chalk oozes rich in calcareous and siliceous microfossils. In combination with the cores
VI. Correlation of Hole 62.0 with 62.1 and 64.0 with 64.1

VII. Observation of the Globigerinacean Zonations of Sites 63 and 65

a) Site 63

b) Site 65

1258

VIII. Paleoecology, Sites 62, 63, 64

a) Sediment Composition

b) Paleobathymetry

c) Coiling Direction

1260

d) Test Pigmentation

1264

e) Specific Climatic Indicators

IX. Biserial Planktonics

X. Taxonomy

a) New Taxa

b) Taxonomic Notes

XI. References

XII. Plates

1328 from Sites 63 and 64, this highly calcareous pelagic sedimentary sequence may be extended downward stratigraphically at least to the base of the Neogene. The purpose of the additional taxonomic work was to establish for the southwestern Pacific a Neogene biochronologic time-scale based on a more complete set of globigerinacean taxa than that used in the shipboard examinations. This globigerinacean biochronologic time-scale serves as a framework for an integrated standard zonal scheme for this region in which radiolarian and nannofloral paleontologic events are incorporated. An integrated zonal scheme will obviously afford a greater biochronologic resolution 


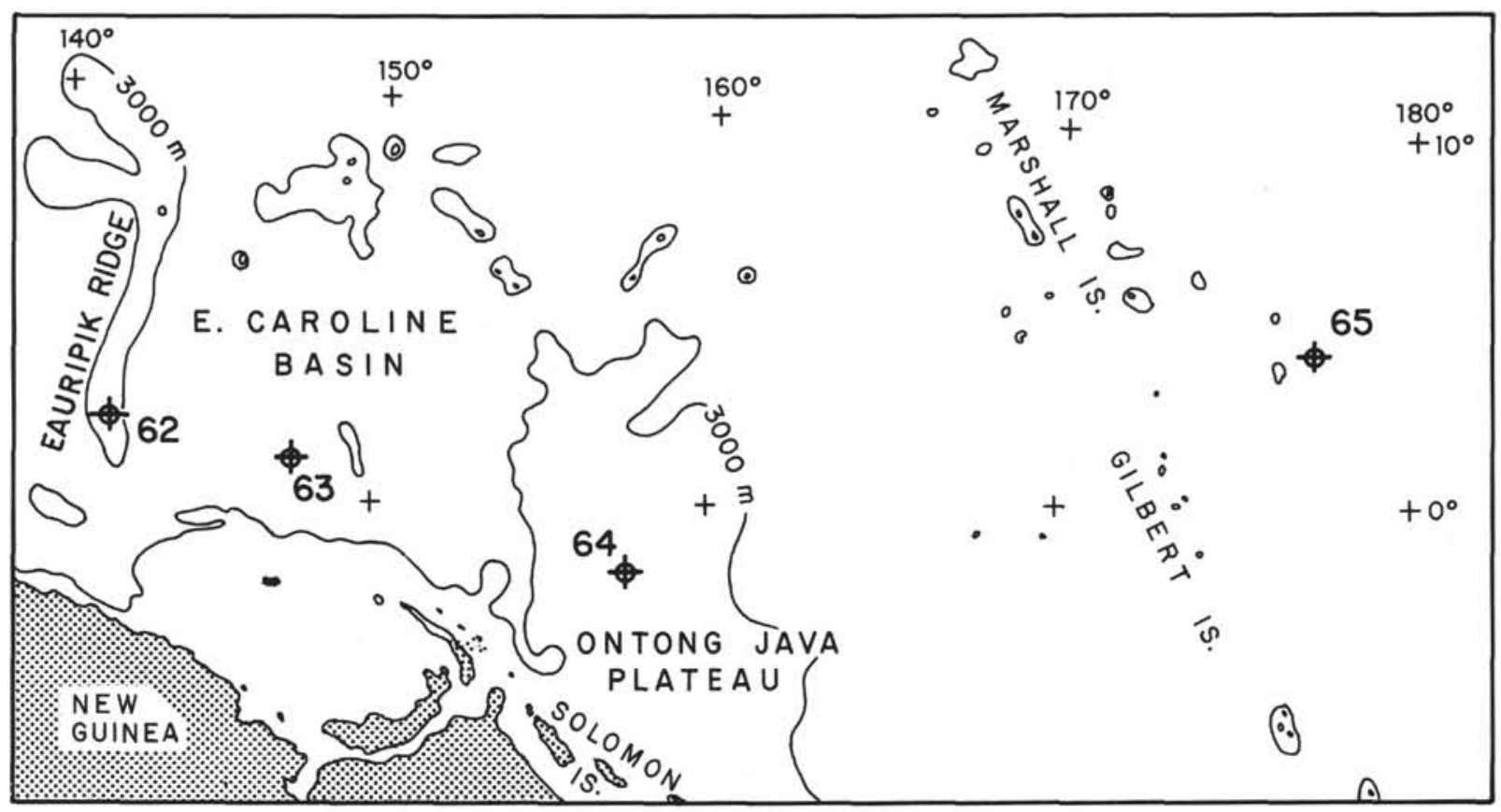

Figure 1. Location of Sites 62,63, 64 and 65, at which foraminifera were contained in the strata.

than that offered by a globigerinacean, or a radiolarian or a nannofloral zonation alone.

In the present contribution we have first attempted to review the fundamental notions underlying any biozonation, independent of the fossil group employed in its construction. It will be shown that a biochronologic time-scale has more than local correlative value only when its time points are marked by evolutionary paleontologic events which occurred quasisimultaneously over wide areas, or "instantaneously" in the sense of Harrington (1965). The globigerinacean biochronologic time-scale developed in the southwestern Pacific further shows that the genus-groups Globorotalia s.l. and Globigerina together furnish 65 per cent of the "instantaneous" paleontologic events. As Banner and Blow's zonal scheme employs 67 per cent of Globorotalia s.l. and Globigerina events, and combines average biochronologic resolution with welldefined zonal boundaries, it may be considered as the most advanced globigerinacean zonal scheme available today. However, as the taxonomic possibilities of the different globigerinacean genus-groups are by far not exhausted, it will certainly be possible to improve the power of the biochronologic resolution of Banner and Blow's scheme considerably. In future revisions, not only this aspect but also some of the difficulties encountered in the application of Banner and Blow's zonal scheme in the southwestern Pacific should be considered. They are discussed in the commentaries to the biozonations of the various cored sections.
The zonations in terms of $\mathrm{N}$. and $\mathrm{P}$. units are based on the faunal analyses sheets of the cores. These analyses are synoptically displayed in the range charts for each genus group. In their totality the range charts represent the standard globigerinacean biochronologic time-scale for the southwestern Pacific, hence the basis of any globigerinacean zonation which might be proposed for that region.

Finally, new globigerinacean taxa encountered in Holes 62.1 and 64.1 are described and illustrated by scanning micrographs, and taxonomic notes on some of the particular groups are added.

\section{b) Acknowledgments}

We thank the Deep Sea Drilling Project for the invitation to participate on Leg 7 and our colleagues for their cooperation and discussions on taxonomic, stratigraphic and sedimentologic problems during the voyage and the post-cruise conference in La Jolla. We also acknowledge gratefully the generous help given by R. Cifelli, Smithsonian Institution, Washington, during our examination of the type collections in the U.S. National Museum, and by the management of British Petroleum Co. Ltd. and W. H. Blow, during a weeklong visit in the B.P. Research Centre, Sunbury-onThames. The latter organization permitted us extensive use of the scanning microscope. Our appreciation is also due to Frances L. Parker, Scripps Institution of Oceanography, La Jolla, who discussed with us many 
of the taxonomic problems of Pacific Globigerinacea and donated topotype material of some of the species described in her papers of 1962 and 1967. We also thank L.W. Isham, Smithsonian Institution, Washington, for the drawings of some of the new taxa described in the present paper and J. M. Very, Laboratory of Paleontology, University of Geneva, for his experienced assistance at the scanning microscopes in Zurich and Geneva.

\section{FUNDAMENTAL CONCEPTS}

\section{a) The Paleontological Event}

In a remarkable paper on the relationship between space, things, time and events in stratigraphy, Harrington (1965) introduced the concept of paleontological (paleobiological) and geological events of which there are two kinds, the "instantaneous" events and the "flow" events. The "instantaneous" paleontological events are the events which, tabulated in chronological order, permit construction of a biochronologic time-scale. An "instantaneous" paleontological event can be defined as any genetically fixed, phenotypically reflected feature in the test morphology which occurs in a geologically brief interval. A biochronologically significant event should be morphologically easily detectable, of wide-spread occurrence, and from appearance to disappearance so short-lived that it can be considered as "geologically instantaneous or quasi-instantaneous". The paleontological "flow" events have more than "infinitesimal duration" if we may transfer the definition given for a geological "flow" event by Harrington (1965, p. 1611) to its paleontological or paleobiological counterpart.

Features on which "instantaneous" paleontologic events are based appear either abruptly, or gradually over a short interval of time, usually modify orthogenetically over some length of time, and then also disappear either abruptly, or gradually over a short period of time. If the time-space between appearance and disappearance is long, then two events can be recognized; if this time-space is short in geological terms, then appearance and disappearance may be considered as a single event. The paleontologic events are evolutionary features and taxonomically reflected by the evolutionary appearances and disappearances of taxa. The structure and power of resolution of any biochronologic time-scale depend on the kind and number of "instantaneous" paleontological events used in its construction. Any zonal scheme which may be designed originates from a biochronologic time-scale. There are no universal biochronologic time-scales and each one is representative of a certain set of sedimentary-ecologic conditions only. However, all biochronologic time-scales consist of chronologically arranged "instantaneous" paleontological events. We are therefore more interested in the nature of globigerinacean paleontological events and in the basic biochronologic time-scale derived from them than in any particular zonal scheme which may have been proposed using planktonic foraminifera rather intuitively and without much regard to their time significance.

There are two groups of evolutionary morphologic features by which "instantaneous" paleontological events can be defined. The first group comprises the morphologic features of the "yes-no" type. It is the more important group. It furnishes most of the principal time-points of key-events in the sense of Harrington (1965) because it permits unambiguous definition of "instantaneous" paleontologic events. Zonal boundaries and datum planes should be based, preferably, on such clear-cut key-events. Morphologic characters of the "yes-no" type are, for instance, the presence or absence of an umbilical bulla; the number of apertures of a chamber or bulla; the direction of coiling of the test; the presence or absence of sutural supplementary openings; the formation of a completely embracing end-chamber as in Orbulina universa d'Orbigny; certain elements of the wall structure such as the presence or absence of keels, wall-spines, tubulospines or of tubulopustules. Datum planes defined by such unequivocal "instantaneous" paleontological events are for instance the Globigerinoides datum as indicated by the evolutionary appearance of Globigerinoides quadrilobatus primordius Blow and Banner, 1962, from an ancestral globigerine, probably Globigerina praebulloides occlusa Blow and Banner, 1962 , by the formation of a single dorsal small supplementary aperture, and the Orbulina datum which is placed at the evolutionary appearance of Orbulina universa d'Orbigny, 1939, from Orbulina suturalis Brönnimann, 1951, its ancestor, by developing a completely embracing end-chamber. The Globigerinatella datum, characterized by the evolutionary appearance of Globigerinatella insueta Cushman and Stainforth, 1945, from an as yet unknown ancestral globigerine, is a biochronologically highly significant key-event which can be recognized unambiguously (Blow, 1969, p. 330). The abrupt evolutionary disappearance of Globigerinatella insueta in the basal part of Zone N. 9 can also be used as a datum plane in this sense.

The second and less important group of morphologic features on which paleontologic events are based are of the intergrading type. These features are relative in nature, vary from individual to individual and need qualifying statements such as lower-higher, largersmaller, more-less, etc., in order to become taxonomically meaningful. In their description enter statements of comparison which in many cases can be expressed quantitatively. In other cases only a qualitative approach is possible. Hence an ambiguous element, subject to the observer's interpretation, is introduced 
in the definition of the corresponding "instantaneous" paleontologic event. Examples of intergrading morphologic features are furnished by the characters of a trochospire, such as its height and width; the opening and depth of the umbilical cavity; the total number of whorls; the number of chambers per whorl; the ornamental and apertural features. An intergrading morphologic feature is also represented by the degree of axial compression of a chamber, and by the formation of a keel. At first sight the latter feature seems to belong to those of the "yes-no" type. However any student of the Globorotalia (Turborotalia) tosaensis Takayanagi and Saito $\rightarrow$ Globorotalia (Globorotalia) truncatulinoides (d'Orbigny) lineage knows that a keel is not always clearly recognizable (see remarks on lineages, p. 1277 of this paper). Such difficulties exist also when the inception of a keel occurs proterogenetically. The presence of a keel on the last-formed chamber of an individual of the tosaensis-truncatulinoides lineage may be difficult to establish even under the best conditions of preservation. There are even different opinions among micropaleontologists whether or not a keel should be signified as present when it exists only on one or some chambers but not on all chambers of the final whorl. Some recognize Globorotalia (Globorotalia) truncatulinoides when only one chamber of the final whorl is keeled, whereas others would still place such a form in Globorotalia (Turborotalia) tosaensis and would accept truncatulinoides only when a keel surrounds the periphery of all chambers of the final whorl. The "instantaneous" paleontologic event defined by the presence or the absence of a keel in the tosaensistruncatulinoides lineage lends itself, therefore, to subjectively different interpretations which are reflected in its time significance. The keel evolves in the tosaensistruncatulinoides lineage palingenetically, that is it occurs first on the last-formed chamber of the final whorl, and in the course of time invades also the penultimate and then the earlier chambers of the final whorl. The paleontologic event based on the keel formation in the tosaensis-truncatulinoides lineage determines the boundary between Zones N. 21 and N. 22 and according to the biostratigrapher's interpretation of the keel this boundary will vary in time. Berggren (1969) has shown that the keel of Globorotalia (Globorotalia) truncatulinoides evolved palingenetically over all the chambers of the last whorl in approximately 50,000 years, or on a single chamber in about 10,000 years. The development of a keel in Blow and Banner's (1966) Globorotalia (Turborotalia) peripheroacuta $\rightarrow$ Globorotalia (Globorotalia) praefohsi $\rightarrow$ Globorotalia (Globorotalia) fohsi lineage occurred, according to Berggren (1969), over about 500,000 years, but more likely in less time than that. Berggren (1969, Tables 1 to 7) also tabulated in million years the stratigraphic ranges of most of the globigerinacean taxa used in Banner and Blow's zonal scheme and of the globigerinacean datum planes proposed by him in his combined biochronologic-radiometric time-scale. However, for most intergrading features we still lack data about the time space in years from their evolutionary inception to their completion. Eventually, the time factor will have to be considered for the evaluation of the biochronologic significance of all "instantaneous" paleontologic events based on intergrading morphologic features. In fact, the time element will become more and more important with increased power of resolution of the globigerinacean biochronologic time-scale. This is so because evolutionary morphologic features emerging over short intervals of time biochronologically carry more weight than those which from inception to completion cover long intervals of time. The notion "instantaneous" paleontologic event, which may be unhesitatingly used in the early stages of development of a biochronologic time-scale, will need quantification in the course of its perfection from a rather crude and approximate to a refined and more precise biochronologic system. The globigerinacean biochronologic time-scale for the southwestern Pacific, as represented by the chronologic succession of "instantaneous" paleontologic events in Holes 62.1 and 64.1 , seems already to be sufficiently advanced to justify selective treatment according to the time significance of the events, and to base paleontologic events of the intergrading type preferably on those features which are more rapidly completed than others through the working of evolution.

The "instantaneous" paleontologic events emanating from intergrading morphologic features are biochronologically less significant according to their quality, but more significant as far as their number is concerned. In fact, most "instantaneous" paleontologic events are defined by intergrading morphologic, hence ambiguous, features and therefore are biochronologically less precise than those of the "yes-no" type which can be accurately determined in time and independently of the observer's opinion. A globigerinacean biochronologic time-scale, in fact, utilizes a mixture of qualitatively different "instantaneous" paleontological events. The fewer, and the more useful ones, are defined by features of the "yes-no" type; the more numerous, and generally less useful ones, are defined by features of the intergrading type. All these paleontological events need further evaluation of their time-significance. The quality of a zonal scheme depends, therefore, on the careful analysis and selection of the paleontological events used in its construction.

If an "instantaneous" paleontologic event is based on a morphologic feature which is difficult to detect, its biochronologic significance is diminished and its recognition will depend on both preservation and observer. Hence, it will introduce a subjective element even if it falls in the "yes-no" category. Such a feature, for 
example, is the small supplementary dorsal sutural aperture in Sphaeroidinella dehiscens immatura (Cushman), 1919, here elevated from forma to subspecies rank, which defines the lower boundary of Zone N. 19 of Banner and Blow. Aside from the difficulty of detecting this feature, it is not clearly established, in our opinion, at what stage a small tripartite opening at the intersection of the dorsal sutures qualifies as an aperture. It is recommended that the sample be ultrasonically cleaned and that the determination of Sphaeroidinella dehiscens immatura be accepted only if the opening shows an elevated border. Only then can and should Sphaeroidinella dehiscens immatura be recognized, and only then will it be possible to distinguish this taxon consistently from "Sphaeroidinellopsis" subdehiscens paenedehiscens Blow, 1969, apparently its immediate ancestor, which lacks this aperture.

"Instantaneous" paleontologic events of the "yes-no" and of the intergrading type are expressed by the evolutionary appearance, be it only as a single individual within a population, or the evolutionary disappearance of a certain taxon. These events are represented on the globigerinacean biochronologic time-scale by discrete points in time. They define the abstract notion of life-range of a taxon. To be meaningful as time elements, "instantaneous" paleontologic events represented by evolutionary appearance and disappearance of taxa require further careful analysis of the evolution of the morphologic features on which they are based. This prerequisite is only in a very few cases satisfactorily fulfilled, such as in the evolutionary lineage of Praeorbulina glomerosa circularis (Blow) to Orbulina suturalis Brönnimann to Orbulina universa d'Orbigny. Most lineages proposed based on the inception and the orthogenetic modification of a certain structural feature still need meticulous examination before they can be accepted and biochronologically used. Reference is here made to the paper by Kennett and Geitzenauer (1969) in which, on the basis of the alternating occurrence of Globorotalia (Globorotalia) truncatulinoides and of Globorotalia (Turborotalia) tosaensis in Eltanin Core 21-5, from the Pacific-Antarctic Rise at $36^{\circ} 41^{\prime} \mathrm{S}$ and $93^{\circ} 38^{\prime} \mathrm{W}$, doubt is raised on the existence of a tosaensistruncatulinoides lineage. These authors imply that although Globorotalia (Turborotalia) tosaensis seems to be the most likely ancestor of Globorotalia (Globorotalia) truncatulinoides "the evolution may well be more complicated than the bioseries in tropical areas suggests". It is underscored that this remark refers to one of the most generally accepted bioseries.

Paleontologic "flow" events involving the evolutionary development of taxa, such as the preferred direction of coiling of a certain taxon, can only be expressed by the statistic evaluation of whole populations throughout the life-range of the taxon. In our work we have used essentially "instantaneous" paleontologic events determined by the evolutionary appearance and disappearance of taxa. Paleontologic "flow" events expressed by statistical evaluations of populations have been neglected, with the exception of the determination of the preferred direction of coiling of the genus Pulleniatina Cushman.

\section{b) The Correlation Value of a Globigerinacean Bio- chronologic Time-Scale}

As we have explained in the section on paleontological (or paleobiological) events, only those derived from evolutionary considerations can be used in the construction of a globigerinacean biochronologic timescale, so that a zonal scheme emanating from it is applicable, within the same set of ecologic-sedimentary conditions, over wide distances. Cifelli (1969) suggested that the evolution of Cenozoic planktonic foraminifera was closely linked to fluctuations of the thermal structure of the oceanic water-masses. At two times, in the earliest Tertiary and in the Oligocene, the oceanic water-masses suffered severe cooling and, through degradation of thermal barriers, became uniformly cool. In the post-Danian to upper Eocene and in the post-Oligocene to Holocene intervals, the temperature of oceanic water-masses gradually increased and thermal barriers were restored, separating cold and warm water "parcels" as we know them to exist in the seas of today. The two major radiations of planktonic foraminifera occurred during these longer time intervals. The Paleogene radiation started in the late Paleocene-early Eocene and ended abruptly at the end of the late Eocene; the Neogene radiation began in the early Miocene and is still going on, as shown by the common occurrence of the morphotypically extreme Globorotalia (Globorotalia) truncatulinoides (d'Orbigny) and Globorotalia (Globorotalia) cultrata (d'Orbigny) group. These periods of radiation were characterized by the development of the keeled globorotalid (with conical and dorso-ventrally strongly compressed end-forms), orbuline, hastigerine, truncorotaloid and globigerinoid morpho-types. The two shorter periods of cooling and the cold water "parcels" restored during the periods of increased temperature, are characterized by the globigerinid, turborotalid and globigerinitid morphotypes. In terms of morphotypes, the Neogene radiation is essentially a repetition of the Paleogene radiation (iterative evolution). With the exception of the Danian and Oligocene time-intervals, when uniformly cool water-masses prevailed and the number of morphotypes was strongly reduced, the analysis of evolutionary lineage of planktonic foraminifera must take into account the environmental subdivision of the oceanic waters into cold water and warm water "parcels". Also to be considered are environmental changes as they occur in the areas outside the oceanic basins - on the continental shelves, and in marginal seas, such as the Mediterranean in its present 
configuration. Berggren (1969) pointed out that in such areas, population structures of planktonic foraminifera may shift rapidly, which makes it very difficult to follow entire evolutionary series through time. So-called "local extinctions" or "local appearances", due to shifting populations caused by environmental changes, may result in erroneous determination of the real ranges of taxa (Blow, 1969; Jenkins, 1969). Also to be considered when studying evolutionary series of planktonic foraminifera are the conditions of sedimentation. Only when basinal sedimentation through time was virtually continuous, and occurred above the depth of strong solution of calcium carbonate, can we be reasonably sure that the fossil record will reflect the real evolutionary appearances and disappearances of taxa.

It is quite clear that a biochronologic time-scale, and any zonal system based upon it, has more than local correlative value only when it is supported by evolutionary "instantaneous" paleontologic events which also occurred quasi-simultaneously in the region with which correlation was to be established. Zonal boundaries and datum planes derived from "instantaneous" paleontologic events which occurred either in the cool or in the warm water Globigerinacea will essentially be synchronous only in sediments which were deposited either in the cool or in the warm water "parcels" of Cenozoic water-masses. Blow (1969) further suggested that "some heterochronous repetitive evolutionary sequences" were unsuitable for biochronologic purposes and, in consequence, unsuitable for correlation. At the present state of knowledge on iterative evolution within the Globigerinacea it may indeed seem advisable not to use heterochronous quasi-homeomorphs in a biochronologic system and as zonal or datum plane markers. However, as our knowledge on the working of iterative evolution in the Globigerinacea increases, we will be in a much better position than now to differentiate between diachronous near-homeomorphs on purely morphologic grounds, and to introduce them into biochronologic time-scale and zonal schemes. Reference is made to Globigerinoides subquadratus subquadratus Brönnimann, 1954, which is a virtual homeomorph of Globigerinoides ruber (d'Orbigny), 1839. In fact, the adult morphologies are so closely similar that Globigerinoides subquadratus subquadratus was quite generally and erroneously put in synonymy with the latter species (Bolli, 1957). However, Cordey (1967) has not only shown that the life ranges of these near-homeomorphs are distinct and without overlap, Globigerinoides ruber occurring from Zone N. 23 to Zone N. 20, and Globigerinoides subquadratus subquadratus from Zone N. 13 to Zone N. 4, that is without any overlap in time, but that their ontogenetic developments were also quite different. It can be added further that their adult morphologies can be distinguished when meticulously examined. The morphologic analysis of Globigerinoides subquadratus subquadratus and its separation from the younger near-homeomorph, Globigerinoides ruber, is a typical example of the difficulties involved in separating diachronous near-homeomorphs and assigning them to different but apparently parallel iterative evolutionary lineages. It is of interest to note that intensive morphologic work with entire populations of planktonic foraminifera makes the micropaleontologist conscious of the existence of minute morphologic differences which are difficult to express in writing or by an artist's illustration. In this respect, the scanning micrographs which not only depict the overall morphology of a test, but also details of its too often neglected surface and apertural structures, represent a highly important contribution to the morphologic description of planktonic foraminifera. From a purely morphologic viewpoint, observations with the scanning microscope offer the only serious method for the study of diachronous near-homeomorphs. In the course of our work, we have also come to recognize the older near-homeomorph of Globigerinoides elongatus (d'Orbigny), 1826, in the form of Globigerinoides subquadratus Brönnimann subelongatus Bronnimann and Resig, n. subsp. Here also the life ranges are not overlapping: Zone N. 22 to Zone N. 20 for Globigerinoides elongatus, and Zone N. 8 to Zone N. 6 for Globigerinoides subquadratus subelongatus. Globigerina nepenthes nepenthes Todd, 1957, recorded from Zone N. 20 to Zone N. 14, and Globigerina nepenthoides Brönnimann and Resig, n. subsp., which starts at the base of Zone N. 6 and extends to Zone N. 13, are also near-homeomorphs. Other near-homeomorphs could be cited within the Globorotalia (Turborotalia), Globorotalia (Globorotalia), Globigerinitas and Globigerinas genus-groups. Although it is correct that iterative evolution may lead to erroneous relative dating and hence erroneous correlation, such errors can virtually be avoided when entire populations are taxonomically analyzed and scanning micrographs are employed. Data planes are regarded by Blow (1969) as misleading when based on the extinction of taxa. We agree that they should not replace "formally defined zones". On the other hand, we accept them as biochronologically valuable whether or not they are based on the first or last appearance of a taxon, as long as these points in time reflect real evolutionary "instantaneous" paleontologic events. Datum planes are marked by important "instantaneous" paleontologic events.

They represent in Harrington's words (1965, p. 1642) "The easily detectable and wide-spread occurrence of the result of a short-lived event, so short-lived in fact, as to be classed as geologically instantaneous or quasi-instantaneous" (the writer's italics). Datum planes cut the continuity of time into discrete intervals of limited duration, and we concur with Harrington's view that "our brain is incapable of visualizing time in 
any other way". In short, datum planes are biochronologically extremely useful concepts. They not only help us to grasp the idea of time but they permit, incorporated in a zonal scheme, a rapid relative age determination without the necessity of referring to a time-consuming complete taxonomic analysis of a population.

\section{c) Biochronologic Significance of Neogene Globigeri- nacean Genus-Groups}

The number of "instantaneous" paleontologic events represented by evolutionary appearances and disappearances of taxa recorded in a genus-group, within a definite interval of time, seems to be a criterion of its biochronologic significance. Naturally, this is only true assuming that the "instantaneous" paleontologic events carry the same weight, that is, that they occur in a population in a comparable number of specimens, that they are defined by morphologic features of the same taxonomic rank, and that their determination is not subject to observational errors. However, as the two first-mentioned factors differ from event to event, and the third factor cannot be eliminated, the biochronologic significance of a genus-group does not represent a simple function of the number of paleontological events over a time interval. Indeed, this function is modified by any one of the listed factors. An "instantaneous" paleontologic event which is defined by a clear-cut morphologic feature, easily and unambiguously recognizable, and occurring in many specimens of a given population, is biochronologically much more important than that which is defined by a taxonomically low-ranking intergrading feature, which is difficult to detect, and occurring in only a few specimens of a population. Hence the number of "instantaneous" paleontologic events of a genus-group over a time interval is at best a low-grade approximation of their biochronologic significance. However, as even an approximation may provide information on the usefulness of certain planktonic foraminiferal genera for biochronologic purposes, we have tabulated the evolutionary appearances and disappearances of taxa of species and subspecies rank within the genera encountered in Hole 62.1. It should be mentioned that the samples had not been completely analyzed, so that the real number of paleontologic events of this type will be slightly greater than indicated in Table 1 . The total number of "instantaneous" paleontologic events recognizable within a completely analyzed population depends naturally on the observer's taxonomic interpretation. This number is therefore likely to change from observer to observer.

Hole 62.1 seems to be well suited for the determination of the number of "instantaneous" paleontologic events per globigerinacean genus-group. This hole was continuously cored from Zone N. 23 to Zone N. 13 (Recent to the upper part of the Middle Miocene). Its sediments were deposited apparently without interruption, above the depth of strong solution of calcium carbonate, in generally warm oceanic waters. The planktonic foraminiferal material from Hole 62.1, therefore, meets the set of ecologic-sedimentary conditions under which true evolutionary appearances and disappearances may be recorded and a biochronologic time-scale constructed.

The coring stopped above the horizon of extinction of Cassigerinella chipolensis (Cushman and Ponton) which, according to Berggren (1969, Table 1), is placed at 14.5 million years (b.p.). The time interval covered by the cores of Hole 62.1 is therefore somewhere between 14 million years (b.p.), represented by the Globigerina nepenthes nepenthes datum, and 14.5 million years (b.p.). The base of Zone N. 13 is at about 15.75 million years (b.p.). For convenience we have approximated the time interval represented by Hole 62.1 to 14.5 million years. The number of "instantaneous" paleontologic events per genus-group recorded in Hole 62.1 is tabulated below in decending order (Table 1):

TABLE 1

\begin{tabular}{|c|c|c|}
\hline Genus-group & $\begin{array}{c}\text { Number of } \\
\text { "Instantaneous" } \\
\text { Paleontologic } \\
\text { Events }\end{array}$ & Percentage \\
\hline 1. Globorotalia s.1. & 71 & 42.0 \\
\hline 2. Globigerina & 40 & 23.5 \\
\hline 3. Globigerinoides & 14 & 8.0 \\
\hline 4. Pulleniatina & 12 & 7.0 \\
\hline 5. Globoquadrina & 6 & 3.5 \\
\hline 6. Hastigerina & 5 & 3.0 \\
\hline 7. Orbulina & 5 & 3.0 \\
\hline 8. Sphaeroidinellopsis & 5 & 3.0 \\
\hline 9. Candeina & 3 & 1.5 \\
\hline 10. Globigerinita & 3 & 1.5 \\
\hline 11. Sphaeroidinella & 3 & 1.5 \\
\hline 12. "Globanomalina" & 2 & 1.0 \\
\hline 13. Hastigerinella & 2 & 1.0 \\
\hline 14. Turborotalita & 1 & 0.5 \\
\hline Total: & 172 & 100.0 \\
\hline
\end{tabular}

This tabulation shows that the genus-groups Globorotalia s.l. and Globigerinas make up 65.5 per cent of all the "instantaneous" paleontologic events recorded over about 14.5 million years, the genus-groups Globigerinoides and Pulleniatina -15.0 per cent, and the 
remaining ten genus-groups -19.5 per cent. Globorotalia s.I., Globigerina Globigerinoides and Pulleniatina, arranged in descending order, would therefore seem to be the biochronologically most significant genus-groups. We do not think that these genus-groups are taxonomically exhausted, and future work will certainly increase the number of taxa and of "instantaneous" paleontologic events within them. The smaller genus-groups, on the other hand, seem to be biochronologically rather insignificant. Some of them, above all Sphaeroidinellopsis, Globigerinita, Turborotalita and Globoquadrina should be taxonomically revised. Such a revision is not only needed to enhance their biochronologic usefulness but also to arrive at a better understanding of their phylogenetic relationships within the Globigerinacea.

A well-established planktonic foraminiferal zonal scheme based on a selected number of "instantaneous" paleontologic events should give essentially the same overall results regarding the biochronologic significance of genus-groups as those obtained from a biochronologic time-scale using a considerably greater number of taxa. The results presented in Table 1 may be considered as a standard against which the quality of a zonal scheme, valid for the same set of ecologic and sedimentary conditions, can be measured. In the following compilation we determined the number of "instantaneous" paleontologic events per genus-group used in Banner and Blow's zonal scheme for the time interval from Zone N. 23 to the base of Zone N. 13, that is over about 15.75 million years. The results are tabulated below (Table 2):

\section{TABLE 2}

\begin{tabular}{|c|c|c|}
\hline Genus-group & $\begin{array}{c}\text { Number of } \\
\text { "Instantaneous" } \\
\text { Paleontologic } \\
\text { Events }\end{array}$ & Percentage \\
\hline 1. Globorotalia s.1. & 9 & 50.0 \\
\hline 2. Globigerina & 3 & 17.0 \\
\hline 3. Sphaeroidinella & 2 & 11.0 \\
\hline 4. Sphaeroidinellopsis & 2 & 11.0 \\
\hline 5. Globoquadrina & 1 & 5.5 \\
\hline 6. Pulleniatina & 1 & 5.5 \\
\hline Total: & 18 & 100.0 \\
\hline
\end{tabular}

In addition, this compilation, extending over about 15.75 million years as against the 14.5 million years approximated by the cored interval of Hole 62.1, shows that the genus-groups Globorotalia s.l. and Globigerina with 67.0 per cent of the total events are the biochronologically most significant ones. This compares extremely well with the 65.5 per cent shown in Table 1 for the same genus-groups in Hole 62.1. However, instead of the genus-groups Globigerinoides and Pulleniatina, which in Hole 62.1 are biochronologically the second most significant groups, we find in Banner and Blow's scheme the genus-groups Sphaeroidinella and Sphaeroidinellopsis with 22.0 per cent, followed by the genus-groups Globoquadrina and Pulleniatina with 11.0 per cent of the total "instantaneous" paleontologic events. None of the minor genus-groups, apart from Sphaeroidinellopsis and Sphaeroidinella and none of the paleontologic events of the Globigerinoides genus-groups were employed in Banner and Blow's scheme. The selection of the genus-groups Globoquadrina and Pulleniatina by Banner and Blow is probably due to the abundant representation of these groups and by the ease with which their various taxa can be recognized.

\section{d) The Biochronologic Resolution of Neogene Glo- bigerinacean Genus-Groups}

The biochronologic resolution offered by a genusgroup is expressed by the quotient of the time interval over which its "instantaneous" paleontologic events have been recorded and the number of "instantaneous" paleontologic events. This quotient, measured in years per event, is shown in Table 3 for each genus-group encountered in Hole 62.1. The number of "instantaneous" paleontologic events has been adjusted for multiple occurrences and the time interval for liferanges shorter than 14.5 million years, as those of the genus-groups Sphaeroidinella (about 4.5 million years), Pulleniatina (about 9 million years), and "Globanomalina" (about 2 million years).* For all other genus-groups the time interval is approximately 14.5 million years.

On the basis of the adjusted number of "instantaneous" paleontologic events and adjusted time intervals, we find that the Globigerinacea as a whole possess in the interval of 15.5 million years an average power of biochronologic resolution of about 860,000 years. The genus-groups Globorotalia s.l., Globigerina and Pulleniatina have in the same time interval a power of biochronologic resolution of about $270,000,500,000$ and 820,000 years, respectively. It is in each case greater than that of the Globigerinacea taken as a whole, and much greater than the resolution of Banner and Blow's zonal scheme where the estimated duration of a Neogene zone is about 1.12 million years. The other genus-groups approaching the estimated average length of a Neogene zone of 1.12 million years are "Globanomalina" with 1 million years, Globigerinoides with 1.05 million years, Sphaeroidinella with 1.5 million years. Under the assumption that no new taxa would be encountered, concentration on the genusgroups Globorotalia s.l., Globigerina and Pulleniatina alone would permit construction of a zonal scheme of a greater power of biochronologic resolution than that 
TABLE 3

\begin{tabular}{|c|c|c|c|}
\hline Genus-groups & $\begin{array}{l}\text { Number of } \\
\text { "Instantaneous" } \\
\text { Paleontologic } \\
\text { Events }\end{array}$ & $\begin{array}{l}\text { Number of } \\
\text { "Instantaneous" } \\
\text { Paleontologic } \\
\text { Events Adjusted } \\
\text { for Multiple } \\
\text { Occurrences }\end{array}$ & $\begin{array}{l}\text { Approximate } \\
\text { Biochronologic } \\
\text { Resolution } \\
\text { in Years Per } \\
\text { Genus-group }\end{array}$ \\
\hline 1. Globorotalia s.1. & 71 & 54 & 270,000 \\
\hline 2. Globigerina & 40 & 29 & 500,000 \\
\hline 3. Globigerinoides & 14 & 14 & $1,050,000$ \\
\hline 4. Pulleniatina* & 12 & 11 & 820,000 \\
\hline 5. Globoquadrina & 6 & 5 & $2,900,000$ \\
\hline 6. Hastigerina & 5 & 4 & $3,630,000$ \\
\hline 7. Orbulina & 5 & 5 & $2,900,000$ \\
\hline 8. Sphaeroidinellopsis & 5 & 5 & $2,900,000$ \\
\hline 9. Candeina & 3 & 3 & $4,800,000$ \\
\hline 10. Globigerinita & 3 & 3 & $4,800,000$ \\
\hline 11. Sphaeroidinella* & 3 & 3 & $1,500,000$ \\
\hline 12. "Globanomalina"* & 2 & 2 & $1,000,000$ \\
\hline 13. Hastigerinella & 2 & 2 & $7,250,000$ \\
\hline 14. Turborotalita & 1 & 1 & $14,500,000$ \\
\hline Total: & 172 & 141 & \\
\hline
\end{tabular}

proposed by Banner and Blow which, for the almost identical interval of 15.75 million years from the base of Zone N. 13 to Zone N. 23, affords a resolution of about 875,000 years. It is quite obvious that Banner and Blow's zonal scheme far from exhausts the existing taxonomic possibilities of the genus-groups Globorotalia s.l. and Globigerina.

\section{e) The Distribution of Globigerinacean Events in Time}

In the history of the Globigerinacea evolutionary appearances and disappearances of taxa seem to be unevenly distributed. This is already evident for the relatively short time interval of about 14.5 million years represented by the cored sections of Hole 62.1. We have compiled in Table 4 the total number of "instantaneous" paleontologic events of all globigerinacean taxa recognized for the Middle Miocene (uppermost part), Upper Miocene, and Pliocene to Recent intervals, Zones N. 13 to N. 23.

The "instantaneous" paleontologic events of the Globigerinacea are about three times more crowded in the Pliocene to Recent and about twice as crowded in the uppermost portion of the Middle Miocene than in the Upper Miocene.
We cannot satisfactorily explain the unequal occurrence of "instantaneous" paleontologic events during this time interval from the uppermost Middle Miocene to the Recent, which is characterized by generally decreasing paleotemperatures (Devereux, 1967). Crowding of paleontologic events in a time interval signifies increased radiation in the sense of Cifelli (1969). However, to corroborate Cifelli's evolutionary pattern proposed for the Globigerinacea in which there are periods of strong radiation in the upper Paleocene, in the early and middle Eocene and in the early to middle Miocene, would require more data than available to us from Leg 7. In the future, other warm water western Pacific sites of the Deep Sea Drilling Project might provide a composite section furnishing the total number of "instantaneous" paleontologic events of the Globigerinacea throughout the Cenozoic. The number of events during the various time intervals might then be compared with the curve of the paleotemperatures of this region. It seems quite possible, in view of the rather high incidence of "instantaneous" paleontologic events in the Pliocene to Recent interval, that more physical factors than temperature of water-masses alone may be involved in controlling the radiation pattern of the Cenozoic Globigerinacea. 
TABLE 4

\begin{tabular}{llccc}
\hline \multicolumn{1}{c}{ Epochs } & Zones & $\begin{array}{c}\text { Estimated } \\
\text { Duration } \\
\text { (million years) }\end{array}$ & $\begin{array}{c}\text { Total Number } \\
\text { of "Instantaneous" } \\
\text { Paleont. Events of } \\
\text { Globigerinacea }\end{array}$ & $\begin{array}{c}\text { One "Instantaneous" } \\
\text { Paleontological } \\
\text { Event Per }\end{array}$ \\
\hline $\begin{array}{l}\text { Pliocene to } \\
\text { Recent }\end{array}$ & $\begin{array}{l}\text { N. } 19 \text { to } \\
\text { N. 23 }\end{array}$ & 5.0 & 90 & 560,000 years \\
Upper Miocene & $\begin{array}{l}\text { N. 15 } \\
\text { (middle) } \\
\text { to N. 18 }\end{array}$ & 7.0 & 40 & $1,750,000$ years \\
$\begin{array}{l}\text { Middle Miocene } \\
\text { (uppermost } \\
\text { part only) }\end{array}$ & $\begin{array}{l}\text { N. 13 } \\
\text { (upper part) } \\
\text { to N. 15 } \\
\text { (middle) }\end{array}$ & 2.5 & 42 & 790,000 years \\
\hline
\end{tabular}

\section{REMARKS ON THE RESOLUTION OF A CENOZOIC INTEGRATED BIOCHRONOLOGIC TIME-SCALE}

Employing new radiometric data from the Californian Miocene and geologic information from DSDP Leg 3, Berggren (1969) constructed a revised radio-biochronologic time-scale for the Cenozoic Era, in which Banner and Blow's forty-three biozones and several datum planes, based on appearances and disappearances of biochronologically pertinent taxa, were plotted. The estimated duration of the Cenozoic of 65 million years (Berggren, 1969, Table 4) yields an estimated average duration of 1.51 million years per biozone. Or, if the Paleogene of 42.5 million years and the Neogene of 22.5 million years were treated separately, the estimated average length in absolute units would be 1.93 million years for a Paleogene and 1.12 million years for a Neogene biozone. It is quite obvious, as stressed by Berggren in his paper, that the proposed revised radio-biochronologic time-scale provides only estimated average durations of paleontologic time intervals. It is worthwhile to note that these values are of the same order of magnitude, for example, as those estimated for cephalopod zones of the Jurassic Period. According to Arkell (1956) and Howarth (1964), the estimated average duration of a cephalopod zone over the whole Jurassic Period of 55 to 60 million years is about 1 million years. If only the Liassic Epoch of 20 to 25 million years is considered, the estimated duration of a cephalopod biozone is 1.1 to 1.5 million years, for the Bajocian to the Oxfordian of 34 million years, it is about 1.2 million years. These values contrast with those obtained by Gygi and MacDowell (1970) for the Upper Jurassic of northern Switzerland, where the duration of a cephalopod zone has been estimated at about 2 million years. It is rather surprising that the most advanced plankton foraminiferal zonation of the Cenozoic Era does not offer greater resolution than the cephalopod zonation of the
Jurassic Period. In fact, Jurassic biostratigrapher commonly utilize subzones and arrive at an even greater biochronologic resolution than Cenozoic foraminiferal biostratigraphers. Also, the calcareous nannoplankton zonation compiled by Martini and Worsley (1970) for the interval from Zone N. 4 to Zone N. 23 does not offer greater resolution than that based on planktonic foraminifera. The average duration of one of the twenty-one Neogene nannoplankton zones (NN zones of Martini and Worsley) is about 1.24 million years, even longer than that of the average Neogene Globigerinacea zone. It seems to us that the Cenozoic Globigerinacea and calcareous nannoplankton zonations are still in an early stage of investigation. The important aspect of Berggren's compilation is the possibility of quantitative studies of Cenozoic biologic history (Berggren, 1969; Tables 2, 3) through the combination of a relative with an absolute time-scale. The paleontologist will be able to place in this radio-biochronologic framework additional "instantaneous" and "flow" paleontologic events which will increase the number of relative time points and hence amplify its power of resolution. Further it will enable him to estimate more closely the rates of evolution of Cenozoic taxa and the rates of sedimentation, and to examine the evolution of physical and chemical factors of the environment and the interrelationship between these and the evolution of the organisms.

By combining the calcareous nannofloral and radiolarian biozonations developed by Martini and Worsley and by Riedel and Sanfilippo, respectively, (Brönnimann, et al., herein) with that developed by us for the same core material, an integrated planktonic foraminiferal-calcareous nannofloral-radiolarian zonal scheme is introduced for the Cenozoic tropical to subtropical sediments of the southwestern Pacific. Through overlapping aonal boundaries, the biochronologic resolution of such an integrated zonal scheme 
surpasses considerably that based on each group alone. In the new high-resolution zonal scheme for tropical to subtropical sediments using nannofloral, radiolarian and planktonic foraminiferal data, the Radiolaria are checked against the calcareous elements. Hence, the integrated radiolarian zonation will enable the biostratigrapher to correlate regions that have noncalcareous oceanic sediments with those in which the depth of sedimentation remained above the calcium carbonate compensation depth.

It is here emphasized that the evolutionary lineages and radiation patterns, and in consequence the biochronologic time-scale, of the Cenozoic Globigerinacea are better known than are those of the other microfossil groups used in the integrated zonal scheme. The historic interest in the Globigerinacea has given them a sort of biochronologic guiding or "yardstick" function, and in the Cenozoic biochronologic time-scale Radiolaria and calcareous nannofossils are plotted against the planktonic foraminifera. In Cenozoic world-wide biostratigraphy, the Globigerinacea play a role similar to that of the cephalopods in the Mesozoic and in certain time intervals of the Paleozoic. The Globigerinacea are, and most probably will continue to be, the biochronologic standard against which the other calcareous and noncalcareous microfossil events will be measured.

\section{CHOICE OF A GLOBIGERINACEAN ZONAL SCHEME FOR THE SOUTHWESTERN PACIFIC}

Through the publication of Banner and Blow's (1965) progress report on a Neogene zonation based on planktonic foraminifera and of Blow's (1969) comprehensive paper in which he emended many of the earlier zonal definitions, a well-defined scheme with 43 biozones applicable to planktonic faunas deposited under tropical to subtropical conditions became available. It is certainly the most advanced globigerinacean zonal scheme in use today. In the following pages we will refer to it as Banner and Blow's zonal scheme. This biozonation was the result of the examination of numerous samples from many widely separated stratigraphic successions (Blow, 1969, p. 200). In the course of their activities as micropaleontologists with British Petroleum Company Ltd., the zonal scheme underwent extensive pre-publication checks and counter-checks, which ensured an uninterrupted sequence of biologically defined time intervals of relatively short duration from the Danian to the Recent.

Though we have employed Banner and Blow's zonal scheme in our work, this does not mean that we subscribe to it in all of its details. There are a few boundary problems which became apparent in the course of our work and which will require the reevaluation of certain taxa as zonal markers. Also, some of Banner and Blow's evolutionary series need reexamination and may have to be abandoned or modified. However, such changes, if necessary at all, will not essentially diminish the usefulness of Banner and Blow's scheme as a well-established and apparently complete zonal succession of average biochronologic resolution. It further offers the advantage of a nomenclatorial "shorthand" system of N. and P. zones, facilitating to a large measure communication among paleontologists and between paleontologists and geologists.

In our introductory remarks we have discussed the relationship between a general biochronologic timescale using all "instantaneous" paleontological events and a zonal scheme derived from it by a selection of "instantaneous" paleontological events. This selection differs from zonal scheme to zonal scheme according to the subjective judgments of their authors, and from this it is quite clear that Banner and Blow's zonal scheme is not the only possible one. However, multiplication of zonal schemes is highly undesirable, and it is here proposed that Banner and Blow's zonal system be accepted for tropical to subtropical sediments with the understanding that it will have to be revised by future taxonomic and stratigraphic work. In this context, it should be mentioned that, in order to accomodate additional zones, the $\mathrm{N}$. and $\mathrm{P}$. zonal nomenclature will have to be enlarged by the introduction of suitable affixes to the zonal terms. As previously mentioned, future taxonomic work will depend heavily upon scanning electron microscopy for the unraveling of evolutionary series through the detailed examination of surface and apertural structures, and of ontogenetic stages. Such studies will undoubtedly improve the present system of classification and permit the isolation of many new taxa of specific and subspecific rank. This proliferation of new taxa will in turn result in a more refined zonal system with increased biochronologic resolution.

Banner and Blow (1965) and Blow (1969) used for the definition of their zonal boundaries taxa distinguished by rather fine morphologic criteria. Their meticulous approach to globigerinacean morphology is indicated by the subspecific and infrasubspecific rank of many biochronologically important taxa. Consequently, this approach led to a relatively good biochronologic resolution. But being taxonomically more demanding, it required that other workers develop a much more detailed knowledge of the morphology of plankton foraminifera and of their evolutionary modifications (including the unraveling of quasi-homeomorph taxa), than might have been needed if other zonations had been used. Banner and Blow's and Blow's splitting of taxa seems at first to have gone too far. However, this impression changes rapidly in the course of intensive work with stratigraphic succession of populations of Cenozoic Globigerinacea; the paleontologist will generally arrive at the conclusion that most of Banner and 
Blow's and Blow's new taxa are well founded. The genera-groups Globorotalia s.1., Globigerina, Globoquadrina and Globigerinita even seem to warrant more detailed and exhaustive taxonomic treatment.

\section{OBSERVATIONS ON THE GLOBIGERINACEAN ZONATIONS OF HOLES 62.1 and 64.1}

\section{a) Hole 62.1}

The continuously cored section of Hole 62.1 from the uppermost part of the Middle Miocene (Zone N. 13) to the Recent (Zone N. 23) shows an apparently uninterrupted succession in terms of sedimentation and of Banner and Blow's zonal scheme. Therefore, it seems reasonable to accept the chronologic distribution of the "instantaneous" paleontological events recorded over this interval as a standard biochronologic timescale for the southwestern Pacific, and it will be seen that Banner and Blow's zonal scheme is upheld in its essential points. The following is a summary of the biozonation of Hole 62.1, from top to bottom (Table $5)$ :

\section{TABLE 5}

\begin{tabular}{|c|c|c|}
\hline Stages & Zones & Cores \\
\hline \multirow{3}{*}{$\begin{array}{l}\text { Recent to } \\
\text { Pleistocene }\end{array}$} & N. 23 & Section 1 of Core 1 \\
\hline & N. 22 & $\begin{array}{l}\text { Section } 2 \text { of Core } 1 \text { to } \\
\text { Section } 1 \text { of Core } 5\end{array}$ \\
\hline & N. 21 & $\begin{array}{l}\text { Section } 2 \text { of Core } 5 \text { to } \\
\text { Section } 6 \text { of Core } 6\end{array}$ \\
\hline \multirow[t]{2}{*}{ Pliocene } & $\begin{array}{l}\text { N. } 20 \\
\text { (including } \\
\text { N. 19) }\end{array}$ & $\begin{array}{l}\text { Section } 1 \text { of Core } 7 \text { to } \\
\text { Section } 6 \text { of Core } 12\end{array}$ \\
\hline & N. 18 & $\begin{array}{l}\text { Section } 1 \text { of Core } 13 \text { to } \\
\text { Section } 2 \text { of Core } 15\end{array}$ \\
\hline \multirow[t]{3}{*}{$\begin{array}{l}\text { Upper } \\
\text { Miocene }\end{array}$} & N. 17 & $\begin{array}{l}\text { Section } 3 \text { of Core } 15 \text { to } \\
\text { Section } 5 \text { of Core } 22\end{array}$ \\
\hline & N. 16 & $\begin{array}{l}\text { Section } 6 \text { of Core } 22 \text { to } \\
\text { Section } 5 \text { of Core } 29\end{array}$ \\
\hline & N. 15 & $\begin{array}{l}\text { Section } 6 \text { of Core } 29 \text { to } \\
\text { Section } 6 \text { of Core } 31\end{array}$ \\
\hline \multirow{2}{*}{$\begin{array}{l}\text { Middle } \\
\text { Miocene } \\
\text { (uppermost } \\
\text { part) }\end{array}$} & N. 14 & $\begin{array}{l}\text { Section } 1 \text { of Core } 32 \text { to } \\
\text { Section } 6 \text { of Core } 32\end{array}$ \\
\hline & $\begin{array}{c}\text { N. } 13 \\
\text { (Base of zone } \\
\text { not cored) }\end{array}$ & $\begin{array}{l}\text { Section } 1 \text { of Core } 33 \text { to } \\
\text { Section } 4 \text { of Core } 39\end{array}$ \\
\hline
\end{tabular}

The following remarks on certain zonal boundaries are the result of a rather detailed but not exhaustive taxonomic analysis of the planktonic foraminiferal faunas encountered in Hole 62.1. It is suggested that these remarks be considered in a revision of Banner and Blow's zonal scheme.

\section{Top of Zone N. 15}

As we have subspecifically distinguished between Globorotalia (Turborotalia) acostaensis acostaensis Blow, 1959 (pl. 23, fig. 2, 4, 5) and Globorotalia (Turborotalia) acostaensis tegillata Brönimann and Resig, n.subsp. (pl. 23, fig. 3, 6, 7, 10), the definition of the top of Zone N. 15 is herewith emended to occur immediately above or at the evolutionary appearance of Globorotalia (T.) acostaensis tegillata. Globorotalia acostaensis tegillata extends from Zone N. 18, perhaps Zone N. 20/19, to the base of Zone N. 16. Hence it precedes in time Globorotalia acostaensis acostaensis, recorded from the upper part of Zone N. 16 to the upper part of Zone N. 22, where it is only questionably recorded at its base by Blow (1969), p. 272, figure 8). According to Blow (1969), Globorotalia (T.) acostaensis acostaensis is derived from Globorotalia (T.) continuosa Blow, 1959 (pl. 36, fig. 7, 8). During a visit to his laboratory in January, 1970, W. H. Blow most kindly showed one of us (P.B.) a suite of specimens picked to represent a continuous evolutionary series from Globorotalia (T.) continuosa to Globorotalia (T.) acostaensis acostaensis. These forms overlap over a very brief interval of time in Hole 62.1 (Cores 22 and 23), and theoretically Globorotalia (T.) continuosa could be the ancestor of acostaensis acostaensis. However, we are not convinced that this evolutionary relationship really exists and, pending detailed population analyses and scanning microscope examinations, we prefer to leave this question open. Equally we are not in a position to discuss, without access to adequate scanning observation and micrographs, the possible evolutionary relationship between Globorotalia (T.) acostaensis tegillata and Globorotalia (T.) continuosa two forms which in their apertural features differ quite considerably. Globorotalia (T.) continuosa with its "comma"-shaped aperture appears to be more nearly related to the Globorotalia (T.) siakensis LeRoy, 1939 (Plate 34, Figures 1, 2, 4; Plate 35, Figures 1-8) and the Globorotalia (T.) mayeri Cushman and Ellison, 1939 (Plate 34, Figure 8) groups of forms than to Globorotalia (T.) acostaensis tegillata and Globorotalia (T.) acostaensis acostaensis. On the other hand, there seems to exist reliable morphologic evidence that Globorotalia (T.) acostaensis tegillata is the immediate ancestor of Globorotalia (T.) acostaensis acostaensis. The thin plate-like extension of the lip of Globorotalia (T.) acostaensis tegillata (Plate 33, Figures 3,6) seems to pass through one and perhaps several iterative reductive phases terminating in the strong, slightly extended and rounded rim lining the aperture of Globorotalia (T.) acostaensis acostaensis from the periphery to the umbilicus, as illustrated in the drawing of the holotype (Blow, 1969, pl. 9, fig. 13-15). However, even this suggested evolutionary series, which occurs near the top of Zone N. 16, needs further study with the aid of scanning micrographs, of stratigraphically successive populations. In Hole 62.1, Globorotalia (T.) 
acostaensis acostaensis and Globorotalia (T.) acostaensis tegillata overlap from Zone N. 16 to Zone N. 18, and perhaps even longer, so that iterative evolution from tegillata to acostaensis cannot be excluded.

\section{Base and Top of Zone N. 17}

The base of Zone N. 17 is defined by the evolutionary appearance of Globorotalia (Globorotalia) tumida plesiotumida Blow and Banner, 1965 (Plate 29, Figures 8, 9), from its immediate ancestor Globorotalia (Globorotalia) merotumida Blow and Banner, 1965 (Plate 39, Figures 10, 11; Plate 30, Figures 3, 6; Plate 31, Figures 5, 6) (Blow, 1969, p. 251). The descriptions by Banner and Blow (1965), although exhaustive as far as the text is concerned, need amplification by scanning micrographs showing the ranges of variation of the two taxa in successive populations. The differences between Globorotalia (Globorotalia) tumida tumida (Brady), 1877 and Globorotalia (G.) tumida plesiotumida on the one hand, and between Globorotalia (G.) tumida plesiotumida and Globorotalia merotumida on the other, require detailed illustration. The scanning micrographs of ideotypes of Globorotalia (G.) tumida plesiotumida by Blow (1969, pl. 47, fig. 6-8) and of Globorotalia (G.) merotumida (1969), pl. 45, fig. 4, 9) are a definite improvement on the original illustrations, but inadequate for the understanding of these difficult taxa. The writers experienced serious difficulties in distinguishing these tumid globorotalias, even after prolonged and intensive work involving analysis of numerous stratigraphically successive populations. Similar observations and remarks were also made by Parker (1967) concerning Globorotalia (G.) merotumida and Globorotalia (G.) tumida plesiotumida, both of which appear to this author difficult to define in the Pacific material. After having examined paratypes in the collections of W. H. Blow, R. Cifelli and F. L. Parker, and the U.S. National Museum, and compared them with our specimens from Hole 62.1, we were able to develop by the "usual subjective approach" (Parker, 1967, p. 182) a "feeling" for the morphologic differences between these taxa. In fact, we believe that Blow and Banner were correct in splitting these tumid forms from Globorotalia (G.) tumida tumida and differentiating them by nomenclature. However, the evolutionary series proposed by Blow (1969) linking Globorotalia (Globorotalia) paralenguaensis Blow, 1969 with Globorotalia (G.) merotumida and this species with Globorotalia (G.) tumida plesiotumida needs revision as we have encountered Globorotalia (G.) merotumida as low as Zone N. 13, whereas Blow (1969, fig. 12, p. 276) recorded Globorotalia $(G$.) paralenguaensis only from the upper part of Zone N. 15 to the lower part of Zone N. 16. The occurrence of Globorotalia (G.) merotumida in Zone N. 13 has been orally confirmed by W. H. Blow on the basis of his own observations of deep sea cores. Perhaps, Globorotalia (G.) paralenguaensis is an evolutionary off-shoot of Globorotalia $(G$.) merotumida. It is apparent that the purely typologic and qualitative approach as used by Blow (1969) and other in evaluating evolutionary relationships may lead to quite erroneous conclusions, especially when the relative timing of the "instantaneous" paleontologic events has not yet been unambiguously established. Moreover, the examination of possible evolutionary lineages should be based not only on morphologic studies, but also on quantitative population analyses in the sense of Bettenstaedt (1962) and Grabert (1959). As there still remains a residual subjective element regarding the identification of Globorotalia (G.) tumida plesiotumida, the recognition of this biochronologically important tumid subspecies will vary to some extent from observer to observer, so that the boundary between Zones N. 16 and N. 17 will be influenced as to its position in time. This subjective element also exists regarding the distinction between Globorotalia (G.) tumida tumida and Globorotalia (G.) tumida plesiotumida. We refer the reader to Banner and Blow's (1965) comparative diagnosis between tumida tumida and tumida plesiotumida, which considers intergrading morphologic features alone, such as, the size of the test, the increase in the height of the whorl, the development of the carina, the thickness of the test wall, the development of granules on earlier chambers, the tumidity of the test, and finally the apertural features. For this reason, the top of Zone N. 17 may also be placed differently by different authors.

\section{Top of Zone N. 18}

The top of Zone N. 18 as defined by Blow (1969) is the "first" (the writers' quotation marks) evolutionary appearance of Sphaeroidinella dehiscens (Parker and Jones) immatura (Cushman), 1919 (Plate 15, Figure 3), here given subspecific rank, from its immediate ancestor "Sphaeroidinellopsis" subdehiscens paenedehiscens Blow, 1969 (Plate 15, Figure 2). The recognition of the small dorsal sutural aperture in Sphaeroidinella dehiscens immatura depends to a large extent on the preservation and on the cleaning methods used and to a smaller degree also on the observer, because the criteria defining a supplementary dorsal aperture seem to be quite subjective. These factors make the identification of the earliest Sphaeroidinella dehiscens immatura a rather problematic affair which naturally reflects on the biochronologic position of the top of Zone N. 18-the base of Zone N.19. We here accept these taxa in their conventional sense and do not wish to declare ourselves on Bé and Hembleben's (1970) suggestion that Sphaeroidinella dehiscens is a terminal growth stage of Globigerinoides sacculifer (Brady), 1877 (= Globigerinoides quadrilobatus sacculifer).

\section{Recognition of Zone N. 19}

Although the base of Zone N. 19 (the top of Zone N. 18) can only be determined within a certain interval 
of time whose limits depend on the above mentioned factors, the top of Zone N. 19 could not be recognized in the terms of Banner and Blow's zonal scheme. Its defining taxon, Globorotalia (Turborotalia) pseudopima Blow (Plate 33, Figures 8,9) elevated from subspecies to species rank (Blow, 1969, MS), was encountered in Hole 62.1 from Zone N. 23 to near the base of Zone N. 18. We have therefore included Zone N. 19 within the lower range of Zone N. 20, and it is here suggested that another diagnostic species be looked for to determine the top of Zone N. 19, or that Zone N. 19 be included in a new zonal unit N. 19/N. 20 which would possess a relatively good lower limit. Likewise, its upper limit would be clearly determined by the evolutionary appearance of Globorotalia (Turborotalia tosaensis Takayanagi and Saito, 1962 (Plate 27 , Figures 3,5 ), in which we include the thin-walled Globorotalia (Turborotalia) tosaensis tenuitheca Blow, from its immediate ancestor the Globorotalia (Turborotalia) crassaformis (Galloway and Wissler), 1927, group of forms (Plate 27, Figures 6, 7, 8). The Globorotalia (T.) crassaformis group of forms is easily distinguishable by the lobate periphery of the flat spiral surface from the virtually non-lobate individuals of the Globorotalia (T.) tosaensis group. Because the peripheral outline is an intergrading feature, which only in the course of a certain interval of time will go from a distinctly lobate to a non-lobate outline, the determination of the point in time where Globorotalia (G.) tosaensis can unambiguously be distinguished from Globorotalia (G.) crassaformis again depends on a subjective decision. This evolutionary series requires population studies and new morphologic investigation with the aid of scanning micrographs before being generally accepted. Detailed taxonomic work on the globigerinas and globorotalias occurring over the interval of the here combined Zones N. 19/N. 20, will probably lead to a finer zonal division than that originally proposed by Banner and Blow. We have counted the evolutionary appearances and disappearances of 54 globigerinacean taxa in this interval, that is 54 "instantaneous" paleontological events. This is a fairly high number of biochronologic points over an interval covering not quite 2 million years (Berggren, 1969, Table 1) and, even considering the fact that some of them coincide in time, their chronologic distribution would certainly provide the basic framework for more than two zones.

\section{Base of Zone N. 22}

The base of this zone is defined by Blow (1969, p. 261) by the "first" (the writers' quotation marks) evolutionary appearance of Globorotalia (Globorotalia) truncatulinoides (d’Orbigny), 1839 (Plate 27, Figures 1, 2, 4; Plate 28, Figures 1-6) which is believed to be derived from Globorotalia (T.) tosaensis by palingenetic formation of a keel (see remark on this lineage in Section VI). We recognize Globorotalia (G.) truncatulinoides when only the last chamber of the final whorl shows a carinate periphery. Apart from the fact that the presence of a keel is sometimes difficult to establish, this feature is unequivocal and therefore clearly defines the base of Zone N. 22. It is considered to represent an "instantaneous" paleontological keyevent in the sense of Harrington.

\section{Base of Zone N. 23}

Blow (1969) did not formally propose the base and top of the Holocene Zone N.23, which he called the Globigerina calida calida/Sphaeroidinella dehiscens excavata Assemblage Zone. In Hole 62.1, we recorded Globigerina calida calida Parker, 1962 (Plate 50, Figure 1-3) from Zone N. 21 to the Recent. Sphaeroidinella dehiscens excavata, as defined by Banner and Blow, did not occur in the "surface samples" of Hole 62.1 or in "surface samples" of other holes which started above the calcium carbonate compensation depth. As subjective interpretation determines the point of evolution of Globigerina calida calida from Globigerina calida praecalida Blow, 1969 (Plate 50, Figures 1-3), which begins near the base of Zone N. 16 in Hole 62.1, it is suggested that the evolutionary appearance of Globigerina calida calida should not be used in the future formal definition of Zone N. 23.

Samples which contained Hastigerina adamsi Banner and Blow, 1959 (Plate 14, Figures 1,2) were assigned to Assemblage Zone N. 23, and it is here proposed that the evolutionary appearance of this easily recognizable species be used to define the base of a formally defined Zone N. 23 (the top of Zone N. 22). As in the case of the combined Zones N.19/N.20, here, too, further morphologic work on stratigraphically successive populations is needed to establish the "instantaneous" paleontologic events which may be used to subdivide the interval from the base of Zone N. 22 to the Recent, covering about 1.85 million years (Berggren, 1969, Table 1). A small-scale biochronologic subdivision of the Pleistocene to Recent interval, possibly with the aid of paleontologic "flow" events such as coiling direction, is, in the writers' opinion, feasible and necessary to date and to correlate more accurately the environmental changes which occurred during this biologically important interval.

\section{b) Hole 64.1}

Hole 64.1 is represented by a continuous set of cores covering the interval from the lower Miocene Zone N. 8 through N. 6 , and by individual cores sampling the lower Miocene Zone N. 4, the Oligocene Zones N. 3 and N. 2, and the Eocene Zones P. 16 and P. 14 or older. Drilling terminated at 985 meters in cherty limestone of middle Eocene age. Throughout the section, the noncorroded aspect of the tests shows that deposition was consistently above the depth of strong solution of calcium carbonate. 
The following summarizes the zonation of Hole 64.1, from top of bottom (Table 6):
The Oligocene interval, represented by Zones N. 2 and N. 3, yields no keeled globorotalias. The turborotalias

TABLE 6

\begin{tabular}{|c|c|c|}
\hline Stages & Zones & Cores \\
\hline \multirow{3}{*}{ Lower Miocene } & N. $7 /$ N. 8 & $\begin{array}{l}\text { Section } 1 \text { of Core } 1 \text { to } \\
\text { Section } 6 \text { of Core } 2\end{array}$ \\
\hline & N. 6 & $\begin{array}{l}\text { Section } 1 \text { of Core } 3 \text { to } \\
\text { Section } 6 \text { of Core } 5\end{array}$ \\
\hline & N. 4 & $\begin{array}{l}\text { Sections } 1 \text { to } 5 \text { of Core } 6 \\
\text { (Section } 6 \text { of Core } 6 \text { missing) }\end{array}$ \\
\hline \multirow[t]{2}{*}{$?$} & Uncored interval & $\begin{array}{l}\text { Section } 5 \text { of Core } 6 \text { and } \\
\text { Section } 1 \text { of Core } 7\end{array}$ \\
\hline & N. 3 & $\begin{array}{l}\text { Sections } 2 \text { to } 4 \text { of Core } 7 \\
\text { (Section } 1 \text { of Core } 7 \text { missing) }\end{array}$ \\
\hline Oligocene & N. 2 & $\begin{array}{l}\text { Section } 4 \text { of Core } 7 \text { to } \\
\text { Section } 2 \text { of Core } 8 \\
\text { (Sections } 3 \text { to } 6 \text { of Core } 8 \text { missing) }\end{array}$ \\
\hline$?$ & $\begin{array}{c}\text { Uncored interval } \\
?\end{array}$ & Sections 3 to 6 of Core 8 \\
\hline Upper Eocene & P. 16 & $\begin{array}{l}\text { Sections } 1 \text { to } 3 \text { of Core } 9 \\
\text { (Sections } 4 \text { to } 6 \text { of Core } 9 \text { missing) }\end{array}$ \\
\hline \multirow[t]{2}{*}{$?$} & $\begin{array}{l}\text { Uncored interval } \\
?\end{array}$ & Sections 4 to 6 of Core 9 \\
\hline & & Section 1 of Core 10 \\
\hline $\begin{array}{l}\text { Upper Eocene } \\
\quad \text { or } \\
\text { Middle Eocene }\end{array}$ & P. 14 or older & $\begin{array}{l}\text { Sections } 2 \text { to } 6 \text { not examined } \\
\text { in detail because foraminifera } \\
\text { are poorly preserved. }\end{array}$ \\
\hline
\end{tabular}

are the dominant morphotype, accompanied by globigerine, globigerinitid, and cassigerinellid morphotypes. This association of morphotypes agrees well with Cifelli's (1969) interpretation of the Oligocene as an interval of reduction of morphotypes, displaying a remarkable similarity to the Danian with its prevalence of turborotaliid and globigerine morphotypes. It is noteworthy that this reduction in morphotypes is of world-wide occurrence, probably in connection with strong cooling of water-masses. The keeled globorotaliid morphotype in the form of Globorotalia (Globorotalia) praemenardii archeomenardii Bolli, 1957 (Plate 30, Figure 9) occurs for the first time in the upper part of the lower Miocene, indicating approach to a first maximum of the Neogene radiation in Zone N. 13. According to Cifelli (1969, p. 160), the Neogene radiation starts with the inception of the globigerinoid morphotype at the base of the lower Miocene, Zone N.4, in the form of Globigerinoides quadrilobatus primordius Blow and Banner, 1962 (Plate 13, Figures 6, 9), Globigerinoides quadrilobatus altiaperturus Bolli, 1954 (Plate 13, Figures 7, 8) and Globigerinoides obliquus obliquus Bolli, 1957 (Plate
11, Figure 4). These seem to be early developments from globigerine ancestors and are almost simultaneously followed by Globigerinoides subquadratus subquadratus Brönnimann, 1954, Globigerinoides subquadratus subelongatus Brönnimann and Resig, n. subsp. (Plate 13, Figures 1, 2, 4, 5), Globigerinoides quadrilobatus praeimmaturus Brönnimann and Resig, n. subsp. (Plate 9, Figures 1-4), Globigerinoides sicanus praesicanus Brönnimann and Resig, n. subsp. (Plate 10, Figure 1) and Globigerinoides sicanus sicanus De Stefani, 1950 (Plate 10, Figure 2), and others. The evolutionary appearance of the genus-groups Globigerinoides and Globoquadrina seems to mark better than any other "instantaneous" paleontological event the beginning of the Neogene radiation. It is emphasized that a great many "instantaneous" paleontologic events occur in the early Miocene which might be used to introduce an even finer globigerinacean zonation than that used in Banner and Blow's zonal scheme.

The following comments refer to the zonal units recognized in Hole 64.1. 


\section{Assemblage of Section 1 of Core 10}

The Sections 2 to 6 of Core 10 did not yield identifiable planktonic foraminifera. Numerous wellpreserved Globorotalia (Globorotalia) spinulosa of Bolli, 1957, non Cushman, and Truncorotaloides rohri Brönnimann and Bermudez, 1953, in the assemblage of Section 1 of Core 10 indicate an age not younger than Zone P. 14, that is, not younger than the base of the late Eocene (Blow, 1969, Figure 19).

\section{The Oligocene Interval}

The Oligocene interval was sampled only in its topmost zonal units, Zones N. 2 and N. 3. These zones are characterized by the concurrence of Globigerina ciperoensis angulisuturalis Bolli, 1957, and well-preserved typical Globorotalia (Turborotalia) opima opima Bolli, 1957 (Plate 22, Figure 4). Globorotalia (T.) opima opima occurs throughout Zones N. 3 and N. 2. According to Blow (1969) it extends downward through Zone N. 1, and individuals affined with Globorotalia (T.) opima opima were recorded by Blow in Zone P. 19. Both Globorotalia (T.) opima opima and its subspecies opima nana Bolli, 1957 (Plate 22, Figure 5) extend into Zone N.3. The top of the Oligocene interval, by definition the top of Zone N.3, lies somewhere between Cores 6 and 7 .

\section{The Limits of Zone N. 4}

The base of the lower Miocene is by definition (Blow, 1969) the base of Zone N.4. As mentioned above the lower portion of Zone N. 4 falls within the gap in coring between Cores 6 and 7. The top of Zone N. 4 is defined by the evolutionary disappearance of Globorotalia (Turborotalia) kugleri Bolli, 1957 (Plate 39, Figures 1, 3, 4, 5). According to Blow (1969, p. 273, Figure 9), Globorotalia (Turborotalia) mendacis Blow, 1969 (Plate 39, Figures 6, 7, 8) does not extend to the top of Zone N.4 together with Globorotalia (T.) kugleri. The species occur together in Core 6, indicating that only the lower portion of Zone N. 4 was cored. Globorotalia (Turborotalia) pseudokugleri Blow, 1969, was reported from Sections 2 to 4 of Core 7, Zone N. 3.

\section{Recognition of Zone N. 5}

The base of Zone N. 6 is fixed by the evolutionary appearance of Globigerinatella insueta Cushman and Stainforth, 1945. The first individuals of Globigerinatella insueta are usually small forms with only a few supplementary, areal, rounded pores, surrounded by raised rims, in addition to a fairly large inframarginal slit-like opening. The rate of evolution of this monotypic genus is so rapid, however, that these early forms are usually accompanied by larger individuals with greater numbers of pores and without primary apertures. Their immediate ancestors seem to be
Globigerina-like, but the lineage has not yet been determined. Representatives of this early evolutionary stage of Globigerinatella insueta are illustrated on Plate 21, Figures 1 through 5. They occur at the base of Core 5, and hence Zone N.5, according to Blow characterized by the development of Globoquadrina dehiscens dehiscens (Chapman, Parr and Collins), 1934, from Globoquadrina dehiscens praedehiscens Blow and Banner, 1962, was not sampled and lies between Cores 5 and 6. The genus-group Globoquadrina starts in Zone N. 4 in Hole 64.1, with the here undifferentiated Globoquadrina dehiscens group of forms. We did not recognize any globoquadrinas in Zones N. 3 and N. 2 . According to Blow (1969), they occur definitely in Zone N. 2, perhaps already in Zone N. 1 which was not sampled in Hole 64.1.

Blow (1969, p. 339) believes that the triangular, tooth-like apertural flaps of "forms such as altispira, galavisi and triangularis constitute a biocharacter for supra-specific distinction". We are not sure that this is the case and think that the genus Globoquadrina Finlay, 1947, should be defined by additional morphologic features if this is at all possible. Detailed examination of ontogenetic stages of surface and apertural features by scanning micrographs and evolutionary studies on stratigraphically successive populations of globoquadrinas is indispensable to the resolution of this vexing taxonomic problem. Blow (1969) is working on a revision of the genus-group Globoquadrina which, we hope, will present us with biochronologically useful taxa. In this context it might be mentioned that we have been unable to recognize some of the globoquadrine taxa used rather extensively by Blow (1969). We do not place Globigerina galavisi Bermudez, 1961 (Plate 8, Figures 2, 3), for instance, in the genus Globoquadrina. One of us (P.B.) has examined the holotype of Globigerina galavisi in the collections of the U.S. National Museum. Its rather large rim-like lip, which is not at all triangular, does not suggest a "globoquadrine" affinity for this species. We have also examined the holotype of Globoquadrina larmeui Akers, 1955, in the collections of the U.S. National Museum. This species possesses a large, elongate, tooth-like extension covering the aperture of the spirally flattened, umbilically closed, small, dehiscens-like test, with four chambers in the last whorl. We believe that this form, if not identical, is closely allied to Globoquadrina dehiscens dehiscens and that Blow's (1969, p. 342) remark that this "taxon appears to be quite unrelated to the $G$. dehiscens dehiscens lineage and, most likely, develops from " $G$. [= Globoquadrina] baroemoensis" " is not supported by pertinent morphologic facts and is, therefore, quite gratuitous.

\section{Top of Zone N. 6}

The upper limit of Zone N. 6 is clearly defined by the evolutionary disappearance of Globigerinita unicava 
unicava (Bolli, Loeblich and Tappan), 1957 (Plate 25, Figure 4), a morphologically distinct species.

\section{Determination of Zones N. 7 and N. 8}

Apart from the definition of the base of the interval represented by Zones N. 7 and N. 8, which is fixed by the extinction of Globigerinita unicava unicava (Bolli, Loeblich and Tappan), we were unable to apply the zonal definitions proposed by Blow (1969) for Zones N. 7 and N.8. It seems that the ranges of certain biochronologically important taxa differ in the southwest Pacific from those established by Blow from other data. According to Blow (1969, p. 228), the evolutionary appearance of Globigerinoides sicanus sicanus de Stefani, 1950 (Plate 10, Figure 2) marks the top of Zone N. 7, but in Hole 64.1 this species occurs already at the top of Zone N. 6 in association with Globigerinita unicava unicava. This species therefore cannot be used as a marker for the upper limit of Zone N. 7. Hence, Zone N. 7 cannot be recognized in Hole 64.1. The top of Zone N. 7, or the base of Zone N. 8, cannot be established on the basis of the "first" evolutionary appearance of Globigerinoides sicanus sicanus. As the "first" evolutionary appearance of Orbulina suturalis Brönnimann is most probably above the cored section of Hole 64.1, neither can we establish the top of Zone N. 8. Globigerinatella insueta has been recorded from the lowermost sample of Zone N. 6 up to and including the uppermost part of Core 1 of Hole 64.1. However, the concurrence of Praeorbulina transitoria (Blow), 1956, and Praeorbulina glomerosa curva (Blow), 1956, in Section 2 of Core 1, with Globigerinatella insueta and without Orbulina suturalis suggests that the cores of Sections 2 to 5 of Core 1 are representative of Zone N.8. Globigerinita stainforthi stainforthi (Bolli, Loeblich and Tappan), 1957 (pl. 24, fig. 1-4) which should not, extend to the top of Zone N. 7 according to Blow (1969), coexists with Globigerinoides sicanus sicanus and disappears before this species. The entire range of Globigerinita stainforthi stainforthi is in Hole 64.1 from and including Zone N. 6 to the interval here labeled Zone N. 7/N. 8, just before the appearance of the genus-group Praeorbulina Olsson, 1964.

\section{CORRELATION OF HOLE 62.0 WITH 62.1 AND 64.0 WITH 64.1}

Cores from the exploratory borings at each site were analyzed in order to determine precisely the relationship of the continuously cored section to the entire stratigraphic succession at the site. The results for each core are listed below:

$$
\text { 62.0-1-1 (81-83) }
$$

Species: Candeina nitida praenitida, Globigerina bulloides, G. calida calida, G. calida praecalida, $G$. conglomerata conglomerata, $G$. hexagona, $G$. pseudofoliata, Globigerinita glutinata glutinata, G. glutinata parkerae, G. glutinata juvenilis, Globigerinoides bollii, $G$. conglobatus, $G$. obliquus extremus, G. obliquus obliquus, G. quadrilobatus immaturus, G. quadrilobatus quadrilobatus, G. quadrilobatus sacculifer forma typica, G. quadrilobatus trilobus, Globoquadrina altispira altispira, G. altispira globosa, G. dehiscens dehiscens, Globorotalia (T.) acostaensis acostaensis, G. (T.) acostaensis humerosa, G. (T.) anfracta, G. (G.) cultrata cultrata, G. (G.) cultrata menardii, G. (G.) margaritae, G. (G.) multicamerata, $G$. (T.) scitula scitula, $G$. (G.) tumida flexuosa (rt.), G. (G.) tumida tumida, $G$. (G.) ungulata, Hastigerina siphonifera siphonifera, Orbulina universa universa, Pulleniatina obliquiloculata obliquiloculata, P. obliquiloculata praecursor, $P$. primalis, Sphaeroidinella dehiscens immatura, Sphaeroidinellopsis seminulina seminulina, S. subdehiscens paenedehiscens, S. subdehiscens subdehiscens, Turborotalita humilis.

Zone: N. 19.

Correlation: This core correlates with Hole 62.1, Core 10 , that is of the same depth ( 90 meters) subsurface. Both cores are without the Pulleniatina spectabilis lineage and the contained Pulleniatina plexus is almost exclusively dextrally coiled. Both cores contain Globigerina pseudofoliata and are without Globigerinoides ruber.

$$
\text { 62.0-2-1 (122-124) }
$$

Species: Candeina nitida nitida, Globigerina decoraperta decoraperta, $G$. conglomerata venezuelana, $G$. hexagona, $G$. nepenthes nepenthes, Globigerinita glutinata glutinata, G. uvula, Globigerinoides bollii, $G$. conglobatus, G. obliquus extremus, G. quadrilobatus quadrilobatus, $G$. quadrilobatus sacculifer forma typica, G. quadrilobatus trilobus, Globoquadrina altispira altispira, G. altispira globosa, $G$. dehiscens dehiscens, Globorotalia (T.) acostaensis tegillata, G. (T.) acostaensis acostaensis, $G$. (G.) cultrata cultrata, G. (G.) cultrata menardii, G. (T.) obesa, G. (G.) tumida plesiotumida, Hastigerina siphonifera siphonifera, Orbulina suturalis, O. universa universa, Sphaeroidinellopsis seminulina seminulina, S. subdehiscens subdehiscens, Turborotalita humilis.

Zone: N. 17.

Correlation: A comparable fauna is contained in the lower portion of Core 21 of Hole 62.1 , both from 204 meters subsurface. 
62.0-3-1 (110-112)

Species: Globigerina decoraperta decoraperta, G. conglomerata venezuelana, $G$. hexagona, $G$. nepenthes nepenthes, Globigerinita glutinata glutinata, G. glutinata incrusta, G. glutinata juvenilis, Globigerinoides bollii, $G$. obliquus extremus, G. obliquus obliquus, G. quadrilobatus immaturus, G. quadrilobatus sacculifer forma typica, Globoquadrina altispira altispira, $G$. altispira globosa, G. dehiscens dehiscens, Globorotalia (G.) cultrata cultrata, G. (G.) cultrata menardii, G. (G.) merotumida, Orbulina suturalis, O. universa universa, Sphaeroidinellopsis seminulina seminulina, $S$. subdehiscens subdehiscens, Turborotalita humilis.

Zone: N. 15.

Correlation: This sample is not unlike that from a comparable depth, 300 meters, in Hole 62.1 (the lower part of Core 31).

Faunal data, therefore, confirm the conformity in depth of comparable horizons of the two holes at Site 62. The analysis of additional cores from Hole 62.0 follows:

\section{0-4-1 (109-111)}

Species: Cassigerinella chipolensis, Globigerina ciperoensis angustiumbilicata, G. nepenthoides?, Globigerinatella insueta, Globigerinita glutinata glutinata, Globigerinoides obliquus obliquus, G. quadrilobatus immaturus, $G$. sicanus sicanus, G. subquadratus subquadratus, Globoquadrina altispira, G. altispira globosa, G. dehiscens dehiscens, Globorotalia (T.) clemenciae, G. (T.) minutissima, G. (T.) peripheroronda, G. (T.) siakensis, Globorotaloides variabilis, Turborotalita humilis.

Zone: N. 8 (lower).

Correlation: This sample, at 395 meters subsurface, lies 30 meters below the base of the continuous section of Hole 62.1, that terminates in Zone N. 13. The assemblage correlates with that of Hole 64.1, Core 2, from a depth of 442 meters on the Ontong Java Plateau. The fauna is that of the lower portion of Zone N. 8, before the appearance of Globorotalia (G.) praemenardii archeomenardii.

\section{0-5-2 (109-111)}

Species: Cassigerinella chipolensis, Globigerina ciperoensis angustiumbilicata, $G$. conglomerata venezuelana, Globigerinita uvula, Globigerinoides subquadratus subquadratus, Globoquadrina altispira globosa, Globorotalia (T.) kugleri, G. (T.) mendacis, G. (T.) minutissima, G. (T.) siakensis.
Zone: N. 4 .

Correlation: The assemblage is typical of the upper portion of N.4, lacking Globigerina ciperoensis angulisuturalis. The core lies about 100 meters below the preceeding core and 80 meters above the base of the sedimentary section at this site. A comparable horizon was sampled in Core 6 of Hole 64.1 on the Ontong Java Plateau.

In contrast to the procedure at Site 62 , no overlap in coring between the two holes at Site 64 was attempted. Nevertheless, it becomes apparent from comparison of faunas in cores alternating in stratigraphic position down the two holes in the lower portion of the section, that the same stratigraphic succession was penetrated by both holes. The discontinuous cores of Hole 64.0 served principally to facilitate the sampling of lower Miocene strata in the subsequent boring.

Analyses of the faunas in Hole 64.0 confirm, in about the first 400 meters of sediment, a corresponding stratigraphic thickness of Zones through approximately the middle Miocene at Sites 64 and 62. The older zones are thicker at Site 64. Faunal determinations for Hole 64.0 are:

\section{0-1-1 (109-111)}

Species: Candeina nitida nitida, Globigerina conglomerata conglomerata, G. dutertrei, G. hexagona, $G$. rubescens (pink), Globigerinita glutinata glutinata, G. glutinata juvenilis, G. glutinata parkerae, Globigerinoides conglobatus, G. quadrilobatus quadrilobatus, $G$. quadrilobatus sacculifer forma typica, $G$. ruber (white), Globorotalia (T.) acostaensis humerosa, G. (T.) crassaformis crassaformis, G. (G.) cultrata cultrata, G. (G.) cultrata menardii, G. (T.) scitula scitula, G. (G.) tumida tumida, $G$. (G.) ungulata, Hastigerina pelagica, $H$. siphonifera siphonifera, $H$. adamsi, Orbulina universa universa, Pulleniatina obliquiloculata finalis, P. obliquiloculata obliquiloculata, Sphaeroidinella dehiscens dehiscens, Turborotalita humilis, T. iota.

Zone: N. 23.

\section{0-1-6 (105-107)}

Species: The assemblage is generally like that of the above sample with the exception that both redpigmented and white Globigerinoides ruber occur, as well as $G$. sacculifer forma $\alpha$, and Globorotalia (G.) tumida flexuosa. The sample is without Hastigerina adamsi. 


\section{Zone: N. 22 .}

Remarks: It is suggested that the sample represents the upper portion of Zone N.22, beyond the range of Globorotalia (T.) tosaensis. The boundary between N. 23 and N. 22 occurs between 64.0-1-1 (109-111) and $64.0-1-2$ (100-102), as Sections 2 to 5 of this core were examined and found to be identical in species content to Section 6.

\section{0-2-1 (109-111)}

Species: Globigerina calida praecalida, G. conglomerata conglomerata, $G$. decoraperta decoraperta, $G$. hexagona, Globigerinita glutinata glutinata, Globigerinoides obliquus extremus, G. obliquus obliquus, G. quadrilobatus immaturus, G. quadrilobatus quadrilobatus, G. quadrilobatus sacculifer forma typica and forma $\alpha, G$. quadrilobatus trilobus, Globoquadrina altispira altispira, G. altispira globosa, Globorotalia (T.) acostaensis acostaensis, $G$. (T.) acostaensis humerosa, G. (G.) cultrata cultrata, $G$. (G.) cultrata menardii, $G$. (G.) margaritae, $G$. (T.) pseudopima, G. (G.) tumida flexuosa (extreme, sinistral), G. (G.) tumida tumida (dextral), G. (G.) ungulata, Hastigerina siphonifera siphonifera, Orbulina universa universa, Pulleniatina obliquiloculata obliquiloculata (dextral), P. obliquiloculata praecursor (dextral), P. primalis (dextral), Sphaeroidinella dehiscens immatura, Sphaeroidinellopsis seminulina seminulina, $S$. subdehiscens paenedehiscens, S. subdehiscens subdehiscens, Turborotalita humilis.

Zone: N. 19.

Remarks: The fauna is typical of about middle N. 19, after the coiling change of the genus Pulleniatina from sinistral to dextral, but before the first appearance of Sphaeroidinella dehiscens dehiscens. (See section on coiling ratios for this core.)

\section{0-2-6 (109-111)}

Species: Differences between this and the above sample involve the absence of extremely flexed, sinistrally coiled Globorotalia (G.) tumida flexuosa and the reduction of the Pulleniatina plexus to left coiled specimens of Pulleniatina primalis.

Zone: N. 19 .

\section{0-3-1 (109-111)}

Species: Candeina nitida nitida, Globigerina bulloides, $G$. conglomerata venezuelana, $G$. decoraperta decoraperta, Globigerinita glutinata glutinata, G. uvula, Globigerinoides conglobatus, G. obliquus extremus, G. obliquus obliquus, G. quadrilobatus immaturus, G. quadrilobatus quadrilobatus, G. quadrilobatus sacculifer forma typica, Globoquadrina altispira altispira, G. altispira globosa, G. dehiscens dehiscens, Globorotalia (T.) acostaensis acostaensis, G. (T.) acostaensis humerosa, G. (T.) acostaensis tegillata, G. (G.) cultrata cultrata, G. (G.) cultrata menardii, $G$. (T.) hirsuta, $G$. (T.) lenguaensis, $G$. (G.) merotumida, G. (G.) multicamerata, G. (T.) scitula scitula, G. (G.) tumida plesiotumida, Hastigr erina siphonifera siphonifera, Orbulina universa bilobata (frequent), O. universa universa, Sphaeroidinellopsis seminulina seminulina, S. subdehiscens subdehiscens, Turborotalita humilis.

Zone: N. 17.

Remarks: The absence of Pulleniatina suggests this to be lower Zone N. 17. Section 6 (109-111) was also examined and found to have a comparable population, with the addition of Globigerina nepenthes.

\section{0-4-1 (109-111)}

Species: Globigerina conglomerata venezuelana, $G$. hexagona, $G$. nepenthes, Globigerinita glutinata glutinata, G. uvula, Globigerinoides bollii, G. obliquus obliquus, G. quadrilobatus immaturus, Globoquadrina altispira altispira, $G$. altispira globosa, $G$. dehiscens dehiscens, Globorotalia (G.) cultrata cultrata, G. (G.) cultrata menardii, Globorotaloides variabilis gr., Sphaeroidinellopsis seminulina seminulina, $S$. subdehiscens subdehiscens.

Zone: N. 15.

Remarks: This age determination is subject to some reservation due to the apparent absence of Globorotalia (T.) continuosa. Sections 2 to 5 were examined and found to be similar to Section 1. In all of these sections, Globigerina nepenthes is frequent to abundant and well developed, whereas Globorotalia (T.) siakensis is absent. Globorotalia (G.) multicamerata and $G$. (G.) merotumida were noted in some of the sections.

\section{0-4-6 (109-111)}

Species: Globigerina bulbosa, G. decoraperta decoraperta, G. hexagona, G. nepenthes (rare), Globigerinita glutinata glutinata, G. uvula, Globigerinoides bollii, G. obliquus obliquus, G. quadrilobatus immaturus, $G$. quadrilobatus quadrilobatus, $G$. quadrilobatus sacculifer forma typica, G. quadrilobatus trilobus, Globoquadrina altispira altispira, $G$. altispira globosa, Globorotalia (T.) clemenciae, G. (T.) continuosa, G. (G.) cultrata cultrata, G. (G.) cultrata menardii, $G$. (T.) lenguaensis, $G$. (T.) minutissima, $G$. (T.) scitula scitula, $G$. (T.) siakensis (abundant), Globorotaloides variabilis gr., Hastigerina siphonifera siphonifera, Orbulina universa universa, Sphaeroidinellopsis seminulina kochi, $S$. seminulina seminulina, $S$. subdehiscens subdehiscens. 
Zone: N. 14.

Remarks: Because the concurrence of Globorotalia (T.) siakensis and Globigerina nepenthes establishes the age of this sample, the boundary between Zones N. 14 and N. 15 is placed between 64.0-4-6 (109-111) and 64.0-4-5 (108-110).

\section{0-5-1 (109-111)}

Species: Globigerina conglomerata venezuelana, Globigerinita glutinata glutinata, G. uvula, Globigerinoides obliquus obliquus, G. quadrilobatus immaturus, G. quadrilobatus trilobus, G. subquadratus, Globoquadrina altispira altispira, G. altispira globosa, $G$. dehiscens advena, $G$. dehiscens dehiscens, Globorotalia (T.) clemenciae, G. (T.) continuosa, $G$. (T.) mayeri, G. (T.) peripheroacuta, G. (T.) peripheroronda, $G$. (G.) praemenardii praemenardii, $G$. (T.) scitula scitula, G. (T.) siakensis, Globorotaloides variabilis gr., Orbulina suturalis, O. universa universa, Sphaeroidinellopsis seminulina seminulina?

Zone: N. 10.

Remarks: The age designation is based upon the absence of advanced forms in the fohsi and cultrata lineages. Section 3, which is perhaps the best preserved section of Core 5, contains Cassigerinella chipolensis. This core, at a depth of 409 to 418 meters subsurface lies 15 meters above the continuously cored section of Hole 64.1 , that covers the interval from N.8 or N.9 down to and including part of N. 6 .

\section{0-6-1 (109-111)}

Species: Cassigerinella chipolensis, Globigerina binaiensis, G. conglomerata venezuelana, Globigerinita glutinata glutinata, G. glutinata incrusta, G. uvula, G. unicava unicava, Globigerinoides quadrilobatus altiaperturus, G. quadrilobatus immaturus, G. quadrilobatus quadrilobatus, G. quadrilobatus trilobus, Globoquadrina altispira altispira, G. altispira globosa, $G$. dehiscens dehiscens, $G$. dehiscens praedehiscens, Globorotalia (T.) clemenciae, G. (T.) minutissima, $G$. (T.) siakensis, Globorotaloides variabilis gr.,

Zone: N. 5 .

Remarks: Sections 2 to 6 of this core recovered the same population.

\section{0-7-1 (109-111)}

Species: Cassigerinella chipolensis, Globigerina binaiensis, $G$. ciperoensis angustiumbilicata, $G$. conglomerata venezuelana, Globigerinita glutinata glutinata, G. glutinata incrusta, G. unicava unicava, $G$. uvula, Globigerinoides quadrilobatus primordius, Globoquadrina altispira globosa, G. dehiscens dehiscens, $G$. dehiscens praedehiscens, Globorotalia (T.) clemenciae, G. (T.) kugleri, G. (T.) mendacis, G. (T.) minutissima, G. (T.) siakensis, Globorotaloides variabilis gr.

Zone: N. 4 .

Remarks: The concurrence of Globorotalia (T.) $\mathrm{ku}$ gleri and Globigerinoides quadrilobatus primordius establishes the age of this section as well as the other sections of Core 7 that have a similar faunal content.

\section{0-8-1 (26-28)}

Species: Cassigerinella chipolensis, Globigeirna anguliofficinalis, $G$. ciperoensis angulisuturalis, G. ciperoensis angustiumbilicata, $G$. galavisi, $G$. cf. officinalis, G. prasaepis, G. sellii, G. tripartita, Globigerinita dissimilis ciperoensis, $G$. dissimilis dissimilis, $G$. unicava unicava, Globoquadrina baroemoenensis, Globorotalia (T.) mendacis, G. (T.) opima nana, $G$. (T.) opima opima, G. siakensis, and many juvenile forms.

Zone: N. 2 .

Remarks: This sample occurs stratigraphically between Hole 64.1 , Cores 7 and 8 , that are also of Zone N. 2.

$$
\text { 64.0-10-1 (109-111) }
$$

Species: Cassigerinella chipolensis, Chiloguembelina cubensis gr., Globigerina ampliapertura, G. galavisi, G. prasaepis, G. tapuriensis, G. tripartita, Globigerinita unicava primitiva, Globorotalia (T.) clemenciae, G. (T.) increbescens, G. aff. kugleri, G. (T.) opima nana, G. (T.) opima opima.

\section{Zone: N. 19.}

Remarks: Core 10 completed the hole at a subsurface depth of 848 to 851 meters. A considerable portion of ash is present in the sediment.

\section{OBSERVATIONS ON THE GLOBIGERI- NACEAN ZONATIONS OF SITES 63 AND 65}

\section{a) Site 63}

Site 63 at 4472 meters water depth is near the present calcium carbonate compensation level, and for most of its Neogene history lay below the depth of strong solution of calcium carbonate. As a result of solution, the biostratigraphic section from lower Miocene to Recent is condensed about one-half over those sections at Sites 62 and 64 . In contrast to the younger assemblages in which the foraminiferal remains are 
residues, the Oligocene assemblages at the bottom of the section are fairly well preserved, signifying a major change in the depositional environment at Site 63 from Oligocene to post-Oligocene time.

Coring at this site was continuous through most of the lower Miocene and through the middle Miocene. Penetration totaled 566 meters, predominantly of nannofossil chalks, for which the foraminiferal biostratigraphy is summarized in Table 7 . The hole was completed in basalt intrusive into Oligocene sediment.

The occurrences of species are recorded on Charts VI and VII. We wish to emphasize that these are not species range charts, equivalent to the range documentation for Sites 62 and 64. Even some of the species generally concentrated through selective solution show discontinuous distribution and probably were dissolved from the intermediate samples. This introduces the principal complication inherent to this section: that such dissolution might also effect the extremities of the species ranges. There is evidence that this has happened in some instances. For example, the first appearance of the genus Orbulina d'Orbigny, which defines the base of the initial zone (N.9) of the middle Miocene, does not occur at Site 63 until Zone N. 13, corresponding with the first appearance of Sphaeroidinellopsis subdehiscens subdehiscens (Blow). Furthermore, the last occurrence of this modern genus at Site 63 is in Zone N. 19. However, by viewing the ranges of index species against the background of their faunal associations in well preserved sections it was possible to select those most reliable for age determination.

The following remarks are addended to explain our position on the zonal determinations indicated:

\section{The Oligocene Zones N. 1 and N. 2}

Foraminiferal faunas of these zones, although fairly well-preserved, are of low species diversity. Briefly, N. 1 was determined on the basis of Globigerina ampliapertura in the absence of Pseudohastigerina spp. and Globigerina ciperoensis angulisuturalis, and N. 2 was based upon the concurrence of angulisuturalis with Globorotalia opima opima. The uppermost Oligocene, N. 3, might be represented in Core 5 of Hole 63.0, as this core contains an assemblage in which the most diagnostic species, Globigerinita stainforthi praestainforthi and Globorotalia (T.) pseudokugleri might be assigned to either the uppermost Oligocene or the lowermost Miocene.

\section{Lower and middle Miocene Boundaries}

This section of the hole was almost continuously cored in order to obtain a downward extension of the complete stratigraphic section from Site 62. Although successful in regard to the recovery of nannofossil and radiolarian remains, the foraminiferal tests provided an indication of age, in most instances, but proved generally unreliable in the determination of "events". Therefore, this portion of the section was largely repeated at Site 64 in order to obtain more reliable foraminiferal assemblages. The criteria for recognizing the various zones differ somewhat at Site 63 from those in the calcareous ooze section at Site 64. Most of the species at Site 63 have shorter stratigraphic ranges than at Site 64 , and this may be due to the fact that unless the species were represented by an abundance of individuals, it might not show up in assemblages where many tests were dissolved. Disconcerting range discrepancies between this site and Site 64 may thus be given this plausible explanation, although other explanations may apply.

Figure 2 shows the distribution of the key taxa relied upon in the zonal determinations. Zone N. 6 is placed below the continuous occurrence of Globorotalia (T.) peripheroronda. The top of Zone N. 7 is placed below the occurrence of Globigerinoides sicanus sicanus. In both instances, it is speculated that earlier forms of these species probably occurred here, but they may not have been as numerous as their later representatives. The boundaries of these zones are at best tentative as based upon foraminifera. The top of N. 8 is placed below the earliest occurrence of Globorotalia (T.) mayeri, and the top of N.9 at the last occurrence of Globigerinoides diminutus, after the last occurrences of Globigerinatella insueta and Globigerinoides sicanus sicanus and before the first occurrence of Sphaeroidinellopsis seminulina kochi. Zones N. 10, 11 and 12 could not be differentiated. Recorded in this interval was a single occurrence of Globorotalia (G.) praemenardii praemenardii, as well as the first occurrence of Globorotalia (T.) peripheroacuta and the last occurrence of Globorotalia (T.) peripheroronda. The base of N. 13 is placed at the first occurrence of Sphaeroidinellopsis subdehiscens subdehiscens and the top of this zone below the first occurrence of Globigerina nepenthes. Finally, Zone N. 14 was identified on the concurrence of Globigerina nepenthes and Globorotalia (T.) siakensis, which has its upper limit in this zone.

\section{Upper Miocene to Quaternary Zones}

Core 5 of Hole 63.1 is placed questionably within Zone N. 15 on the basis of the absence of both Globorotalia (T.) siakensis, which has its latest occurrence in Zone N. 14 and Globorotalia (T.) acostaensis acostaensis, which first appears in Zone N.16. Zonation based upon the absence of specific taxa is always open to an element of doubt in the sediment type represented here. However, as $G$. (T.) siakensis appears to be one of the species most resistant to solution, it would seem that, at least, its absence is real. Globorotalia (T.) acostaensis tegillata, the early evolutionary form of the 
TABLE 7

Summary of Globigerinacean Zonation at Site 63

\begin{tabular}{|c|c|c|c|}
\hline $\begin{array}{c}\text { Samples } \\
\text { Hole-Core-Section }\end{array}$ & $\begin{array}{l}\text { Depth Below } \\
\text { Sea Floor } \\
\text { (m) }\end{array}$ & Age & Zone \\
\hline $63.0-1-1$ & 1.1 & Quaternary & N. $22-23$ \\
\hline $\begin{array}{l}63.1-1-2 \text { to } \\
63.2-1-4\end{array}$ & $\begin{array}{r}5.6 \\
16.6\end{array}$ & Late Pliocene & N. 21 \\
\hline $\begin{array}{l}63 \cdot 2-2-1 \text { to } \\
63 \cdot 2-2-4\end{array}$ & $\begin{array}{l}21.1 \\
25.6\end{array}$ & Early Pliocene & N. 19 \\
\hline $\begin{array}{l}63 \cdot 2-2 \cdot 6 \text { to } \\
63 \cdot 2-3-4\end{array}$ & $\begin{array}{l}28.6 \\
35.6\end{array}$ & Late Miocene & N. 18 \\
\hline $\begin{array}{l}63.0-2-2 \text { to } \\
63.0-2-6\end{array}$ & $\begin{array}{l}63.5 \\
69.6\end{array}$ & Late Miocene & N. 16 \\
\hline $\begin{array}{l}63.1-5-1 \text { to } \\
63.1-5-5\end{array}$ & $\begin{array}{l}102.1 \\
106.6\end{array}$ & Late Miocene & N. $15 ?$ \\
\hline $\begin{array}{l}63.1-6-1 \text { to } \\
63.1-6-3\end{array}$ & $\begin{array}{l}111.1 \\
114.1\end{array}$ & Middle Miocene & N. 14 \\
\hline $\begin{array}{l}63.1-6-4 \text { to } \\
63.1-8-5\end{array}$ & $\begin{array}{l}115.6 \\
136.1\end{array}$ & Middle Miocene & N. 13 \\
\hline $\begin{array}{l}63.1-8-6 \text { to } \\
63.1-9-5\end{array}$ & $\begin{array}{l}137.6 \\
145.1\end{array}$ & Middle Miocene & N. $10-12$ \\
\hline $\begin{array}{l}63 \cdot 1-9-6 \text { to } \\
63 \cdot 1-10-4\end{array}$ & $\begin{array}{l}146.5 \\
153.6\end{array}$ & Middle Miocene & N. 9 \\
\hline $\begin{array}{l}63.1-10-5 \text { to } \\
63.1-11-5\end{array}$ & $\begin{array}{l}155.1 \\
172.1\end{array}$ & Early Miocene & N. 8 \\
\hline $\begin{array}{l}63.1-13-1 \text { to } \\
63 \cdot 1-13-6\end{array}$ & $\begin{array}{l}175.1 \\
182.6\end{array}$ & Early Miocene & N. $7 ?$ \\
\hline $\begin{array}{l}63.1-14-2 \text { to } \\
63 \cdot 1-14-6\end{array}$ & $\begin{array}{l}186.6 \\
192.6\end{array}$ & Early Miocene & N. $6 ?$ \\
\hline $\begin{array}{l}63 \cdot 0-4-1 \text { and } \\
63 \cdot 0-4-2\end{array}$ & $\begin{array}{l}231.1 \\
232.6\end{array}$ & Early Miocene & N. 4 \\
\hline $63.0-5-2$ & 354.6 & Late Oligocene-Early Miocene & N. $3-4$ \\
\hline $\begin{array}{l}63.0-6-1 \text { and } \\
63 \cdot 0-6-6\end{array}$ & $\begin{array}{l}459.1 \\
466.6\end{array}$ & Late Oligocene & N. 2 \\
\hline $\begin{array}{l}63 \cdot 0-7-1 \text { to } \\
63 \cdot 0-9-4\end{array}$ & $\begin{array}{l}535.1 \\
558.6\end{array}$ & Oligocene & N. 1 \\
\hline
\end{tabular}

species, occurs without its advanced form in the lower samples of the next higher core taken some 30 meters up the hole, suggesting that this core is somewhere in the lower to middle portion of Zone N.16. The uppermost Miocene Zone N. 18 was so designated on the basis of the occurrence of the highly durable species Globorotalia (G.) tumida tumida in association with its ancestors $G$. (G.) tumida plesiotumida and $G$. (G.) merotumida and before the first appearance of Sphaeroidinella dehiscens immatura. It is of note that within Zone N.18 as so designated, is the only occurrence of Pulleniatina spectabilis spectabilis, with its ancestor $P$. spectabilis praespectabilis. Although spectabilis praespectabilis was recorded in N. 18 as well as in N. 19 at Site 62, spectabilis spectabilis occurred only in Zone N. 19 at that site. Probably the Zone N. 18/N. 19 boundary should be lowered slightly at Site 63 to include that portion of the section containing $P$. spectabilis spectabilis, but in order to do this one would have to assume that the first occurrence of Sphaeroidinella dehiscens immatura is in error and that earlier specimens had been dissolved. 


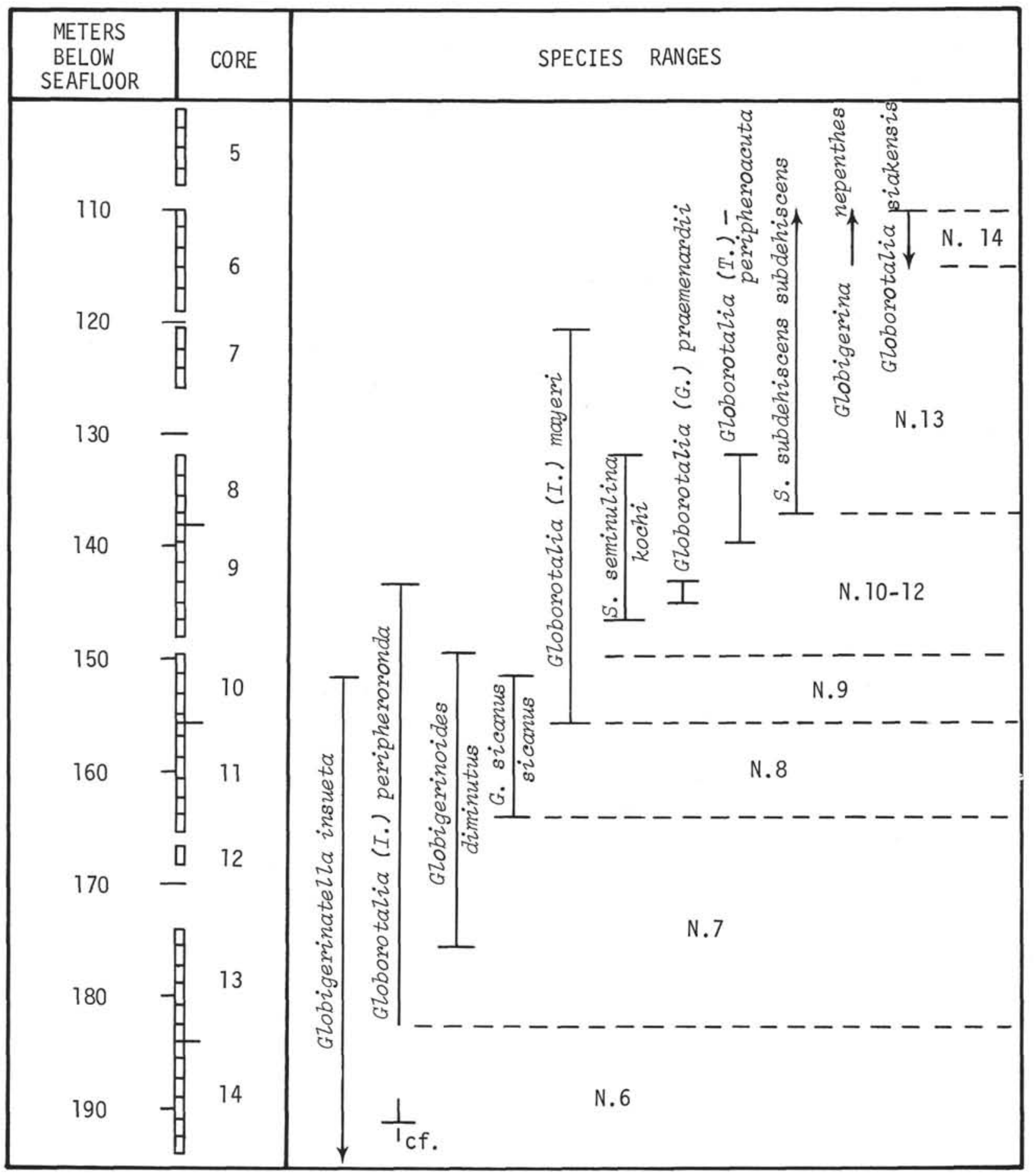

Figure 2. Ranges of significant species in the lower and middle Miocene of Hole 63.1.

\section{Zonation of the Uppermost 25 Meters}

Although a fair number of cores were taken in the Pliocene-Quaternary interval, it is remarkable that no zonal boundaries were recovered. No sample was recovered for Core 2, Section 5 of Hole 63.2, where the N. 18/19 juncture should occur, nor in the lower two sections of Core 1 or between Cores 1 and 2 of
Hole 63.2, where the bounds of N. 20 should be contained. Between Zone N. 21 and the top of the core designated N. 22-23, is a section barren of planktonic foraminifera. The lower Pliocene Zone N. 19 was distinguished by the occurrence throughout of Sphaeroidinella dehiscens immatura, alone in the lower portion and accompanied by $S$. dehiscens dehiscens in 
the upper portion. It is to be noted here that in Core 3, Section 1 of Hole 63.1, S. dehiscens immatura occurs with Globorotalia (T.) pseudopima, in accord with the longer range actually occupied by that species (refer to Site 62) than previously designated by Blow (1969). Zone N.21 is characterized by the presence of Globorotalia (T.) tosaensis without G. (G.) truncatulinoides, and finally, the upper meter and a half of sediment, occurring above a barren section, is assigned questionably to the Quaternary on the basis of the almost total right coiling of the population of Pulleniatina obliquiloculata obliquiloculata (see on Coiling Direction, this report).

\section{b) Site 65}

Foraminifera were recovered in only three samples of the generally noncalcareous sediment sequence at this site. A turbidite sampled in Hole 65.0, Core 14, Section 5, at about 126 meters subsurface, contained the following heterogeneous assemblage: Globotruncana cf. fornicata Plummer (late Cretaceous); Globorotalia (G.) velascoensis (Cushman) (late Paleocene to early Eocene); Hantkenina alabamensis Cushman, Globorotalia (T.) centralis Cushman and Bermúdez (middle to late Eocene); Globigerina ampliapertura Bolli, G. prasaepis Blow, G. tripartita Koch, Globorotalia (T.) opima nana Bolli, Pseudohastigerina barbadoensis Blow (late Eocene to Oligocene).

About 20 meters deeper in the hole, Core 17, core catcher contained a remarkable collection of large benthics. Bathysiphon (to 1.5 centimeters in length) and Reophax (to 9 millimeters in length) with walls constructed of sponge spicules and fine sand in brownish cement were dominant. A single specimen of the genus Budashevaella was found. This genus ranges from late Eocene to Miocene in the Kamchatka area, from where it was described. Several large specimens of Cibicides complete the assemblage.

Hole 65.1, Core 1, core catcher, located stratigraphically between the above samples, contained middle to late Eocene planktonic tests showing solution effects. Some of the included species were: Globigerina ampliapertura Bolli, G. galavisi Bermúdez, G. prasaepis Blow, Globigerinita unicava primitiva Blow and Banner, Globorotalia (T.) centralis Cushman and Bermúdez, G. (G.) spinulosa of Bolli, 1957, non Cushman, and Truncorotaloides rohri Brönnimann.

\section{PALEOECOLOGY, SITES 62, 63, 64}

\section{a) Sediment Composition}

Selected samples from the less consolidated portions of sediment towards the top of the sections at Sites 62 and 64 were wet seived without any previous mechanical breakdown to attain the 62 -micron sand fraction (Table 8) and the 44 to 62 micron fine fraction
(Table 9). The finer sieve trapped essentially all of the micro-foraminifera, foraminiferal fragments, and small radiolarians. Thus, separation was effected between the principal components of foraminifera and radiolarians, and nannofossils, which compose most of the fine fraction $<44$ microns. Mineral fragments and other biological remains are negligible, placing the sediment in the category of a true deep sea ooze.

The results indicate about 14 to 39 weight per cent of the sediment in about the upper 215 meters at Site 62 is sand, with lowest percentages generally below 115 meters. Figures for some comparable stratigraphic horizons at Site 64 are somewhat higher. The sand fraction consists almost exclusively of foraminifera in the younger strata. A tendency for radiolarians to increase in numbers in the lower Miocene samples analyzed from Site 64 relates directly to decreasing grain size of the sediment.

Nannofossils constitute about 55 per cent of the sediment weight in a sample of Pliocene strata and one of Quaternary age at Site 64, and about 75 to 80 per cent of the sediment in three samples of late Miocene and Pliocene strata from Site 62. This may be attributable to a greater water depth at that site (at the present 2591 meters, it is about 540 meters deeper than that of Site 64) allowing solution to concentrate the relatively resistant nannofossils. Therefore, the section at Site 64 might be expected to contain a somewhat more complete spectrum of foraminiferal assemblages.

\section{b) Paleobathymetry}

In Table 10 aspects of the foraminiferal composition and preservation at the three sites are presented. Benthic foraminifera are exclusively those of a deep water environment and attest to the persistency of that condition. The commonly represented genera are: Bulimina, Cassidulina, Cibicides, Gyroidina, Laticarinina, various Nodosariidae, Pleurostomella, Uvigerina, Pyrgo, and Eggerella. The benthics are concentrated somewhat through the differential solution of foraminifera at Site 63, but are otherwise rather evenly distributed throughout the cores.

Modification of assemblages due to solution is most effective among the planktonics. Two plateaus in calcium carbonate solution are recognizable in modern deep-sea oozes and those of the cores. At the compensation level, all calcium carbonate is removed from the sediment. In addition, a level at which solution of calcium carbonate strongly effects the sediment composition, the lysocline, intersects the sea-floor at about 3700 meters in the central tropical Pacific (Berger, 1967), and at about the same depth on the slopes of the Ontong Java Plateau. 
TABLE 8

Composition of Sand Fraction Selected Samples, DSDP, Leg 7

\begin{tabular}{|c|c|c|c|c|c|c|c|}
\hline Site & Core & Section & $\begin{array}{l}\text { Depth } \\
\text { in Section } \\
(\mathrm{cm})\end{array}$ & N. Zone & $\%$ Sand & $\%$ Radiolaria & $\%$ Foraminifera \\
\hline \multirow[t]{24}{*}{62.1} & 1 & 2 & $109-111$ & 22 & 38.3 & 8.9 & 91.1 \\
\hline & 2 & 3 & $109-111$ & 22 & 22.7 & 0.7 & 99.3 \\
\hline & 4 & 5 & $109-111$ & 22 & 38.6 & 0.0 & 100.0 \\
\hline & 4 & 6 & $109-111$ & 21 & 25.5 & 0.5 & 99.5 \\
\hline & 6 & 1 & $109-111$ & 21 & 22.9 & 2.5 & 97.5 \\
\hline & 6 & 2 & $109-111$ & 21 & 18.9 & 11.9 & 88.1 \\
\hline & 6 & 3 & $109-111$ & 21 & 27.3 & 0.4 & 99.6 \\
\hline & 6 & 4 & $109-111$ & 21 & 23.8 & 8.3 & 91.7 \\
\hline & 6 & 5 & $109-111$ & 21 & 28.8 & 0.0 & 100.0 \\
\hline & 6 & 6 & $109-111$ & 21 & 33.2 & 3.8 & 96.2 \\
\hline & 9 & 2 & $109-111$ & 19 & 18.5 & 0.5 & 99.5 \\
\hline & 10 & 6 & $109-111$ & 19 & 15.9 & 0.9 & 99.1 \\
\hline & 12 & 1 & $109-111$ & 19 & 24.8 & 2.5 & 97.5 \\
\hline & 12 & 2 & $109-111$ & 19 & 26.4 & 1.8 & 98.2 \\
\hline & 12 & 3 & $109-111$ & 19 & 27.8 & 0.7 & 99.3 \\
\hline & 12 & 4 & $109-111$ & 18 & 18.0 & 1.9 & 98.1 \\
\hline & 13 & 3 & $128-130$ & 18 & 13.5 & 2.9 & 97.1 \\
\hline & 13 & 4 & $98-100$ & 18 & 16.1 & 1.6 & 98.4 \\
\hline & 13 & 6 & $96-98$ & 18 & 15.0 & 1.8 & 98.2 \\
\hline & 14 & 1 & $109-111$ & 18 & 25.8 & 0.3 & 99.7 \\
\hline & 16 & 1 & $109-111$ & 17 & 18.6 & 0.7 & 99.3 \\
\hline & 19 & 1 & $109-111$ & 17 & 21.5 & 0.4 & 99.6 \\
\hline & 20 & 1 & $109-111$ & 17 & 23.1 & 0.3 & 99.7 \\
\hline & 23 & 1 & $109-111$ & 16 & 13.9 & 8.9 & 91.1 \\
\hline 64.0 & 1 & 1 & $109-111$ & 22 & 41.3 & 1.3 & 98.7 \\
\hline 64.0 & 2 & 1 & $109-111$ & 19 & 36.9 & 1.1 & 98.9 \\
\hline 64.0 & 3 & 1 & $109-111$ & 17 & 22.7 & 9.6 & 90.4 \\
\hline 64.1 & 4 & 1 & $109-111$ & 6 & 14.7 & 24.2 & 75.8 \\
\hline 64.1 & 5 & 1 & $109-111$ & 5 & 9.9 & 75.7 & 24.3 \\
\hline
\end{tabular}

It is convenient to utilize the term lysocline for this level, although the original definition employs a solution index that can only be used on material containing modern species. For the purpose of this study, the lysocline will denote a critical level of strong solution at which most smaller planktonic foraminifera as well as those with thin-walled or highly to moderately perforate tests (e.g. Globigerinoides ruber) are dissolved. As very small tests are more numerous than large specimens in modern and well preserved fossil oozes, the deposition of strata relative to the lysocline is easily discerned. Coincidentally, the removal of foraminiferal bulk tends to increase the proportions of calcareous nannofossils and radiolarians below this level, providing another means of recognizing this reference. The lysocline and compensation levels were elevated and depressed in past times either absolutely or relative to the movement of the sea floor, and their connotation in this report is independent of depth. 
TABLE 9

Composition of Fine Fraction Selected Samples, DSDP Leg 7

\begin{tabular}{|c|c|c|c|c|c|c|c|c|c|}
\hline Site & Core & Section & $\begin{array}{l}\text { Depth } \\
\text { in Section } \\
(\mathrm{cm})\end{array}$ & $\begin{array}{c}\text { N. } \\
\text { Zone }\end{array}$ & $\begin{array}{c}\% \text { Sediment } \\
44-62 \mu\end{array}$ & $\begin{array}{c}\% \text { Radiolaria } \\
44-62 \mu\end{array}$ & $\begin{array}{c}\% \text { Foraminifera } \\
44-62 \mu\end{array}$ & $\begin{array}{c}\text { \% Foraminifera } \\
\text { Fragments } \\
44-62 \mu\end{array}$ & $\begin{array}{l}\% \text { Sediment } \\
<44 \mu\end{array}$ \\
\hline 62.1 & 6 & 1 & $109-111$ & 21 & 2.3 & 4.4 & 19.5 & 76.1 & 74.8 \\
\hline 62.1 & 10 & 6 & $109-111$ & 19 & 2.6 & 0.7 & 39.0 & 60.3 & 81.5 \\
\hline 62.1 & 16 & 1 & $109-111$ & 17 & 3.4 & 0.4 & 73.5 & 26.1 & 78.0 \\
\hline 64.0 & 1 & 1 & $109-111$ & 22 & 6.0 & 6.5 & 53.2 & 40.3 & 52.7 \\
\hline 64.0 & 2 & 1 & $109-111$ & 19 & 6.7 & 4.0 & 42.7 & 53.3 & 56.4 \\
\hline
\end{tabular}

The material of Sites 62 and 64 was deposited above the lysocline. The contained foraminifera are generally well-preserved, showing mostly only the effects of breakage with removal from the indurated sediment at depth in the holes. The validity of species ranges in those sections is supported by the good condition of their fossil assemblages.

Site 63 , at 4472 meters, is presently below compensation depth and was in the same relative position or slightly above the compensation level in late Pliocene time. In the interval early Oligocene-late Miocene, the site lay between the lysocline and the compensation level, except for a brief period above the lysocline in the early middle Miocene. Incomplete faunas characterize this interval and the reliability of species ranges is questionable, as the dissolution is disproportionate from horizon to horizon. In the Oligocene, deposition occurred above the lysocline and the numerous foraminiferal specimens are stained salmon and brown conformable to the unusual colors of their sediment matrices.

\section{c) Coiling Direction}

Orientation of the spiral coil was examined in three instances. Specimens of Globorotalia truncatulinoides are only dextrally coiled, eliminating the possibility of relating sinistral development to glacial stages as in the Atlantic. Globorotalia tumida is generally sinistrally coiled throughout its range in the cores, except for a period in the early Pliocene (Zone N. 19) when the species and particularly the flexuose variant becomes predominantly dextrally oriented. The span of the interval of right coiling, in which specimens are up to 100-per cent dextral in some samples, is indicated with the results of studies on Pulleniatina (Figure 3). Two unusual developments in the morphology of Globorotalia tumida also occur in this interval: a dextrally coiled variant with limbate and raised dorsal sutures, depressed spiral suture, and elevated circum-umbilical region sometimes bearing secondary ridge deposits; and, a sinistral variant that is extremely flexuose. The coiling and morphological deviations in Globorotalia tumida occurred together with a change in coiling direction of certain members of the genus Pulleniatina.

The initial shift of coiling direction of Pulleniatina from left to right is effected suddenly and forms a horizon of correlation between the three sites (Figure 3 , as above). This horizon occurs at approximately the same subsurface depth at Sites 62 and 64 . The coiling change has been traced in other parts of the tropical Pacific, and associated with the top of the Gilbert "a" event at 3.7 million years (Hays et al., 1969). As depicted in the continuous coring at Site 62, after intervening intervals of right coiling, left coiling again dominates the population in late Pliocene (N. 21) and in early Pleistocene (N. 22) times. These shorter intervals of left coiling occupy a similar stratigraphic position in the eastern tropical Pacific and occur there in sections of reversed magnetism of the Matuyama Epoch (Hays et al., op. cit.).

In the area of the Eauripik Rise-East Caroline Basin, there is some evidence that climatic cooling may have accompanied the intervals of left coiling Pulleniatina in Zones N. 21 and N.22, as suggested by the presence of some modern temperate to cold water foraminiferal species and the cold water coccolith, Coccolithus pelagicus (see coccolith section, this report). The initial left-coiling populations of Pulleniatina may also have developed under cooler water temperatures. This is supported by peculiarities in diversity and species representation among the contemporary radiolarians that are suggestive of the Central Pacific Water Mass assemblages (see radiolarian section, this report). Foraminiferal evidence from New Zealand indicates that the Antarctic convergence was shifted to a position about $39^{\circ} \mathrm{S}$ latitude during the uppermost Miocene Kapitean Stage (Kennett, 1968), and it is reasonable to expect an effect on the tropical populations from a shift of such magnitude. 
TABLE 10

Summary of Condition of Foraminiferal Assemblages

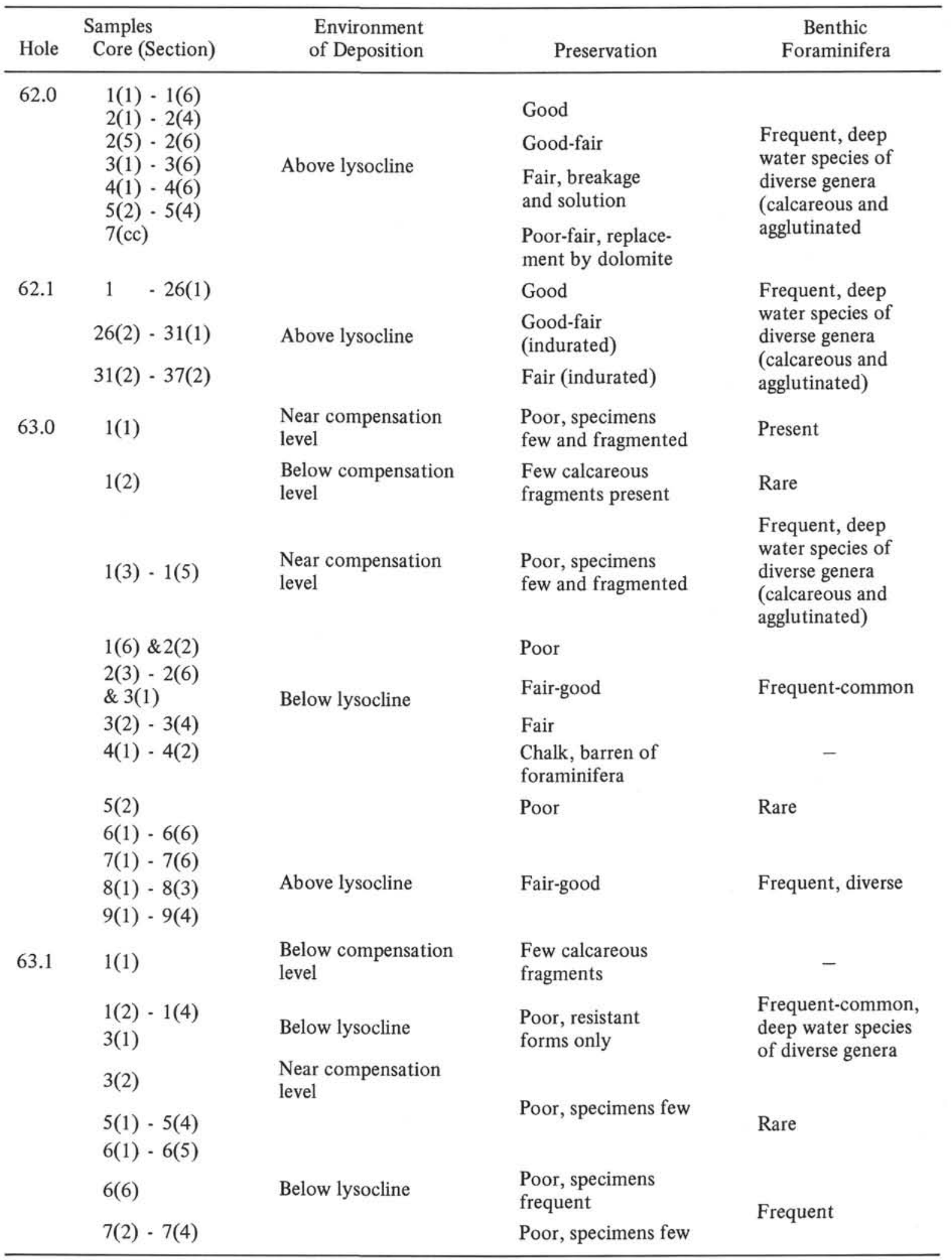


TABLE 10 - Continued

\begin{tabular}{|c|c|c|c|c|}
\hline Hole & $\begin{array}{l}\text { Samples } \\
\text { Core (Section) }\end{array}$ & $\begin{array}{l}\text { Environment } \\
\text { of Deposition }\end{array}$ & Preservation & $\begin{array}{c}\text { Benthic } \\
\text { Foraminifera }\end{array}$ \\
\hline \multirow[t]{21}{*}{63.1} & $8(3)$ & \multirow{19}{*}{ Below lysocline } & $\begin{array}{l}\text { Poor, specimens } \\
\text { frequent }\end{array}$ & Frequent-common \\
\hline & $8(4)-8(5)$ & & Poor & \multirow{5}{*}{ Frequent } \\
\hline & $8(6)$ & & Poor, specimens & \\
\hline & $9(1)$ & & frequent & \\
\hline & $9(2)-9(3)$ & & Poor & \\
\hline & $\begin{array}{c}9(4)-9(6) \\
10(1)-10(2)\end{array}$ & & Fair-good & \\
\hline & $10(3)$ & & Poor, specimens few & Rare \\
\hline & $10(4) \cdot 10(5)$ & & Fair-good & \multirow{2}{*}{ Frequent } \\
\hline & $11(1)$ & & Poor & \\
\hline & $11(2)$ & & Poor, specimens few & - \\
\hline & $11(3)$ & & Poor & Rare \\
\hline & $11(4)-11(5)$ & & Fair-good & Frequent \\
\hline & $11(6)$ & & Barren of foraminifera & - \\
\hline & $12(2)$ & & & \\
\hline & $13(1)-13(4)$ & & Poor & \multirow{2}{*}{ Frequent-rare } \\
\hline & $13(5)$ & & Fair-good & \\
\hline & $13(6)$ & & Poor & \multirow[t]{2}{*}{ Rare } \\
\hline & $14(1)$ & & $\begin{array}{l}\text { No planktonic foram- } \\
\text { inifera }\end{array}$ & \\
\hline & $14(2)-14(3)$ & & Poor & Rare-frequent \\
\hline & $14(4) \cdot 14(5)$ & Above lysocline & Good & \multirow{2}{*}{ Frequent } \\
\hline & $14(6)$ & Below lysocline & Poor & \\
\hline \multirow[t]{3}{*}{63.2} & $1(1)$ & $\begin{array}{l}\text { Near compensation } \\
\text { level }\end{array}$ & $\begin{array}{l}\text { Poor, specimens few } \\
\text { and fragmented }\end{array}$ & $\begin{array}{l}\text { Present, mainly } \\
\text { Cassidulina }\end{array}$ \\
\hline & $1(2) \cdot 3(2)$ & Below lysocline & $\begin{array}{l}\text { Poor, few species } \\
\text { and fragmented } \\
\text { specimens }\end{array}$ & \multirow{2}{*}{$\begin{array}{l}\text { Frequent to common, } \\
\text { deep water species } \\
\text { of diverse genera } \\
\text { (calcareous and } \\
\text { agglutinated) }\end{array}$} \\
\hline & $3(3)-3(4)$ & & $\begin{array}{l}\text { Poor-fair, fauna } \\
\text { incomplete }\end{array}$ & \\
\hline \multirow[t]{10}{*}{64.0} & $1(1) \cdot 1(6)$ & & & \multirow{5}{*}{$\begin{array}{l}\text { Frequent, deep } \\
\text { water species of } \\
\text { diverse genera }\end{array}$} \\
\hline & $2(1)-2(6)$ & & & \\
\hline & $3(1)-3(6)$ & Above lysocline & Good & \\
\hline & $4(1)-4(6)$ & & & \\
\hline & $5(1)-5(6)$ & & & \\
\hline & $6(1)-6(6)$ & & $\begin{array}{l}\text { Good-fair } \\
\text { (semi-indurated) }\end{array}$ & \multirow{5}{*}{ Rare } \\
\hline & $7(1)-7(5)$ & & $\begin{array}{l}\text { Fair, specimens fragile } \\
\text { and broken }\end{array}$ & \\
\hline & $7(6)$ & & Good & \\
\hline & $8(1)-8(3)$ & & Fair-poor (indurated) & \\
\hline & $10(1)-10(2)$ & & Poor-fair & \\
\hline
\end{tabular}


HOLE 62.1

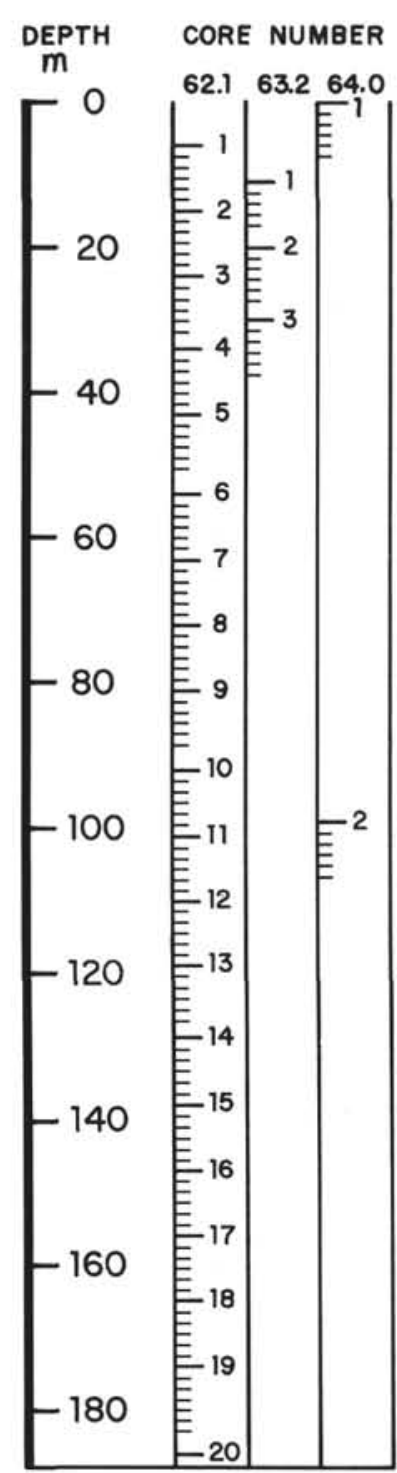

AGE COILING OF PULLENIATINA SPP.

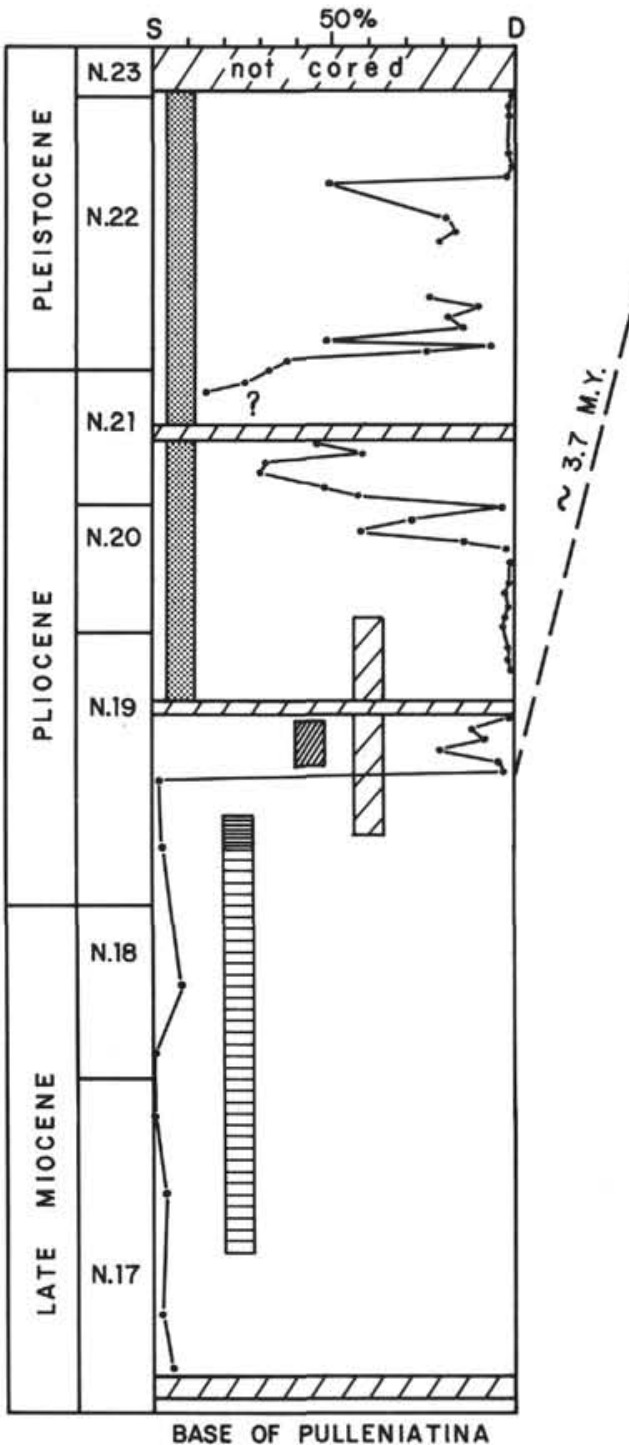

HOLE 63.2

HOLE 64.0

COILING OF PULLENIATINA SPP.
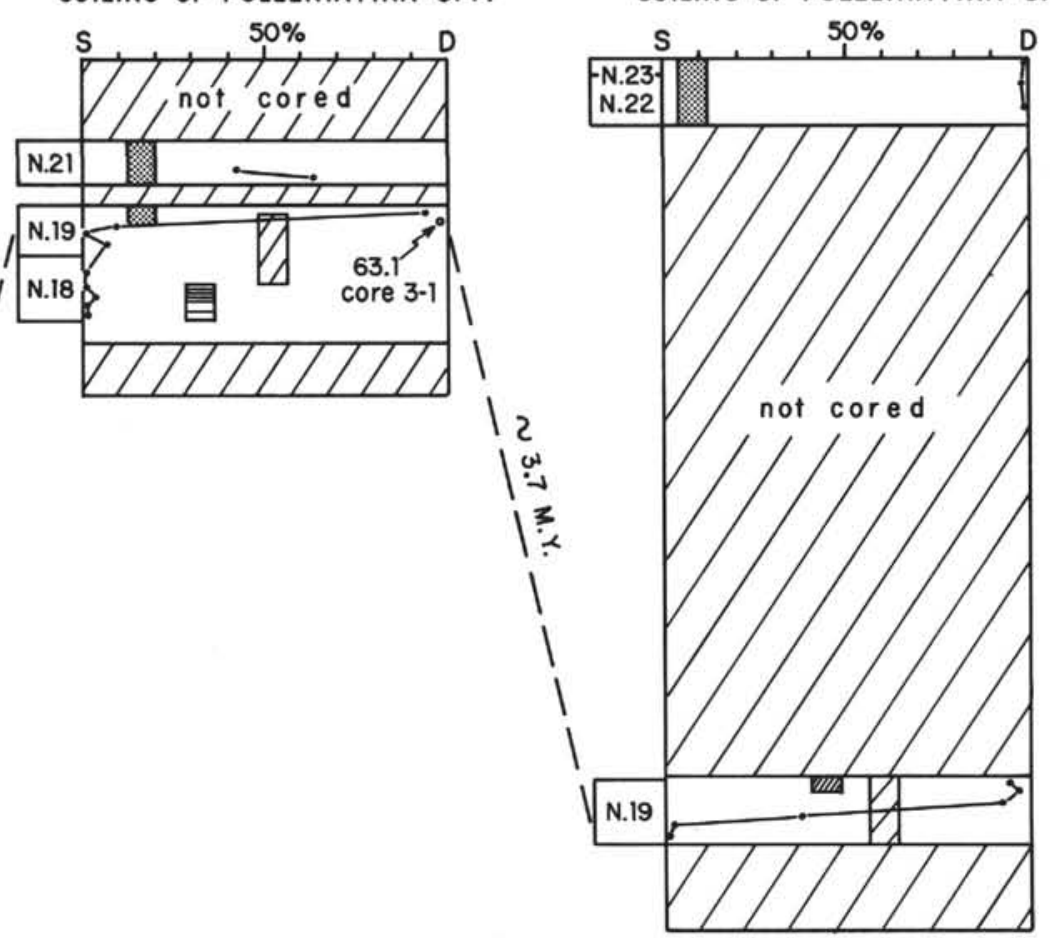

\section{REFERENCE SPECIES}

SPHAEROIDINELLA DEHISCENS DEHISCENS

目 PULLENIATINA SPECTABILIS SPECTABILIS

目 PULLENIATINA SPECTABILIS PRAESPECTABILIS

TLOBOROTALIA TUMIDA FLEXUOSA (EXTREME SINISTRAL)

D GLOBOROTALIA TUMIDA FLEXUOSA Q VAR. (DEXTRAL) 


\section{d) Test Pigmentation}

Assemblages containing numerous red to pink Globigerinoides ruber (d'Orbigny) were sampled in the Pleistocene (upper N.22) sections of Holes 62.1 (Core 1, Section 3, 17-19 cm, and Core 2, catcher) and 64.0 (Core 1, Sections 2-6). It is of interest that this color variant, while typical of the Atlantic realm, has not been recovered from Pacific plankton (Bé, 1969). A few red tests have been observed in Pacific bottom sediments (F. L. Parker, personal communication), however, the surface sediments of the Ontong Java Plateau, that are known to be Recent in age, contain only white $G$. ruber. Thus, it appears that the sporadic occurrence of red tests in the surface sediments might be attributed to reworking.

Causative factors effecting the production of redpigmented individuals are not yet known. The temporal distribution of Atlantic specimens suggests that temperature might be a stimulus because the relative proportion of red to white tests is greater in plankton during the warm summer months (Bé, 1960; Cifelli, 1962). Furthermore, red tests predominate in horizons of temperature maxima in cores of extra-tropical Atlantic waters (Emiliani, 1969). On t'ie other hand, presence of some modern temperate to cold water foraminiferal species and the cores (Emiliani, op. cit.), and present water temperatures of the Pacific hardly appear to be prohibitive. Whatever the cause, if subtle changes in a complex of oceanographic conditions provide the stimulus for the production or influx of red-pigmented individuals, then it might prove feasible to utilize deposits of red tests as levels of correlation in certain areas of the Pacific.

\section{e) Specific Climatic Indicators}

The general nature of the foraminiferal assemblages of the cores is tropical to subtropical, inclusive of species reported from the classic Tertiary localities of the Caribbean. Pliocene and younger assemblages are comparable to Bradshaw's (1959) modern Equatorial, West-Central Fauna, linked with water temperatures greater than $20^{\circ} \mathrm{C}$ and fluctuating only 1 to $2^{\circ} \mathrm{C}$ seasonally, but most of the species range into subtropical waters.

Considering only the section at Site 62 , three species indicative of more temperate waters occur today. These are: Globigerina bulloides d'Orbigny, distributed continuously in the sub-polar to cool temperate waters higher than $30^{\circ}$ latitude in the north Pacific, and only occasionally present in equatorial waters; Globorotalia (T.) inflata (d'Orbigny), a component of the CentralWater Fauna between $25^{\circ}$ and $40^{\circ} \mathrm{N}$ latitude, which invades the subtropics in winter months; and Globorotalia (G.) truncatulinoides (d'Orbigny), of highest frequency in the Central-Water Fauna, but appearing occasionally in equatorial waters.

Because the sporadic occurrence of these species in tropical waters is not in itself unusual, more significant might be attached to their relative concentrations in the assemblages. Globorotalia (T.) inflata occurs only rarely, but only throughout Zone N. 21 and the lower portion of Zone 22. Although Globigerina bulloides, which ranges down through the middle Miocene, was noted in about 20 samples from mid-Zone N. 19 to the top of Zone N.22, it is frequent to common only in Core 5, Sections 2 and 3. The immediate ancestor of Globorotalia (G.) truncatulinoides is also common in Section 2. This occurrence coincides with a beforementioned major peak in sinistral coiling of Pulleniatina spp. and in the abundance of a cold-water coccolith. The distribution of these cold water species, therefore, supports the idea of a deterioration of climatic conditions in the late Pliocene (upper N.21).

Globorotalia (G.) truncatulinoides is frequent to common in Core 2, Sections 3 and 4, Core 3, Section 2, and Core 4, Section 3. These occurrences are restricted to the lower two-thirds of Zone N. 22 in which there is a tendency for left coiling elements to appear in the populations of Pulleniatina. Again, this suggests climatic influences tending to moderate in the tropical latitudes. Interestingly enough, in the upper portion of Zone N.22, where Pulleniatina is almost exclusively dextral, $G$. truncatulinoides is essentially absent. Peculiarly, no evidence is apparent for the influx of cooler waters into the region in the younger Pleistocene, which is considered to be the glacial portion of the Pleistocene by most workers.

\section{BISERIAL PLANKTONICS}

Two groups of biserial planktonics are stratigraphically discrete in the cored sections: species of Chiloguembelina occur in Eocene and Oligocene strata, and several species of Streptochilus Brönnimann and Resig, n. gen., evolved in the interval from lower Miocene to Recent. We believe the Neogene biserial forms to be planktonic because of their morphological similarities to Heterohelix and Chiloguembelina, their abundance not in itself unusual, more significance might be attached to their relative their absence in assemblages effected by differential solution, as opposed to the concentration in those assemblages of undisputed deep water benthic species. They have not been reported in oceanic plankton tows, but because they are less numerous in Recent sediment than in earlier deposits, their numbers may be diminishing and the prospect of finding them in the water column may be dim. In fact, it is possible that they have recently become extinct. Added to this is the complication that they are of an unfortunate size for ease of discovery. Their smaller 
dimension would allow them to pass through nets of about 200 mesh that are commonly used in the collection of planktonic foraminifera, whereas at the same time, because the tests are relatively large, they might escape the attention of those involved in concentrating nannoplankton from water samples. In short, because the small biserials have not been reported in the plankton is no reason to discount their planktonic affinity at this time. As an aside, it might be noted that on several occasions living specimens of a small foraminifer identified as Bolivina vaughani Natland was centrifuged from neritic surface waters off Los Angeles by one of us (J.R.) and other specimens were later reported from plankton of the same general area by Lidz (1966). This particular species also lives on the underlying sea floor, but the fact that it appears to be the only "benthic" occurring frequently in the plankton seems to indicate that it may spend part of its lifetime as a pelagic.

As in Chiloguembelina, the outer rim of the eccentric aperture of Streptochilus tends to project in a short collar. However, in Streptochilus, an inflection of the inner margin of the collar extends inward to connect with the proximal point of the collar of the foramen. The resulting platelike structure may serve the same purpose but is of different construction than the tooth plates of certain benthic groups. Hofker (1963) reported "tooth plates" in the type species of Chiloguembelina, Gümbelina midwayensis Cushman, 1940, as well as in several other species of the genus, and claimed that the tooth plates emerged to form a lip and that the "small but typical toothplates form the lips, or flanges, mentioned by Loeblich and Tappan and by Beckman" in their descriptions of Chiloguembelina. Several specimens of Chiloguembelina midwayensis from the same stratigraphic horizon and about one-half mile from the type locality of the type species in Sumter County, Alabama, were kindly made available to us from the collections of the U.S. National Museum by R. Todd. These specimens appear to have simple interiors, with the lips originating on the exterior of the chambers and not as the outer expression of tooth plates. In lieu of a greater sampling of the type species to substantiate this observation, numerous specimens of Chiloguembelina cubensis (Palmer) from the material of this cruise were examined and these definitely show no evidence of tooth plates or other internal modification. It is clear that the entire genus group Chiloguembelina needs reexamination, preferably with the aid of stereoscan illustration, in order to clarify the varied observation. In addition to the question of tooth plates, it would be of interest to establish if there is a basis of generic subdivision according to differences in the configuration of the aperture of species assigned to this genus, as noted by Beckman (1957).
Regardless of the state of Chiloguembelina, the apertural modification of the Neogene biserial planktonics is sufficiently distinct from either the Hofkerian concept of Chiloguembelina or Chiloguembelina as presently defined, to warrant their group separation. Without considering details of the taxonomy of this unique group, which is handled in the succeeding section of this report, it is of significance that four morphological types are easily distinguishable and stratigraphically restricted (Figure 4). In type $a$, Streptochilus tokelauae (Boersma), the test is elongate with smooth, nearly quadrate, semi-inflated chambers. This species, described from late Pliocene-sub-Recent cores from off Tokelau Island (Kierstead et al., 1969), also occurs in Hawaii Institute of Geophysics sediment samples from the Ontong Java Plateau, dated as Recent by $\mathrm{C}^{14}$. At Site 62 , its stratigraphic range extends to near the base of the Pliocene, where it was also recovered in the solitary core barrel (Hole 64.0, Core 2) from Zone N. 19 on the Ontong Java Plateau.

Type $b$, Streptochilus globigerum (Schwager) has inflated chambers, tending to become globular in the later stages, and ornamented with rugae. It ranges from the late middle Miocene to the early Pliocene and its late Miocene dominance is interrupted by the evolution of type $c$, Streptochilus latum Brönnimann and Resig, n. sp., in the middle of Zone N. 16 through N. 17. The spot-sampled Zone N. 17 on the Ontong Java Plateau (Hole 64.0, Core 3) also contained type $c$. This species is like type $a$ in smoothness, porosity, and chamber inflation, but the chambers increase more rapidly in breadth and the sutures show a shallow flexure.

The oldest of the group, type $d$, Streptochilus pristinum Brönnimann and Resig, n.sp., is relatively small with a straight lateral profile in the early portion and the only significant chamber inflation in the last formed chambers of adults. Specimens are generally less numerous than the aforementioned types and are restricted to the middle Miocene (upper N. 13 to lower N. 15) at Site 62, but, perhaps because of slightly better preservation of the sediment biocomponents, they extend down to the lower Miocene (N. 4) at Site 64.

The Neogene biserial planktonics do not occur at Site 63 , where they were most likely eliminated through differential solution, along with other small and delicate planktonics. Chiloguembelina is abundant in the Oligocene strata at that site.

\section{TAXONOMY}

\section{a) New Taxa}

The following new taxa have been established after examination of large suites of specimens from the 


\section{DISTRIBUTION OF BISERIAL PLANKTONIC FORAMINIFERA \\ HOLE 62.1}

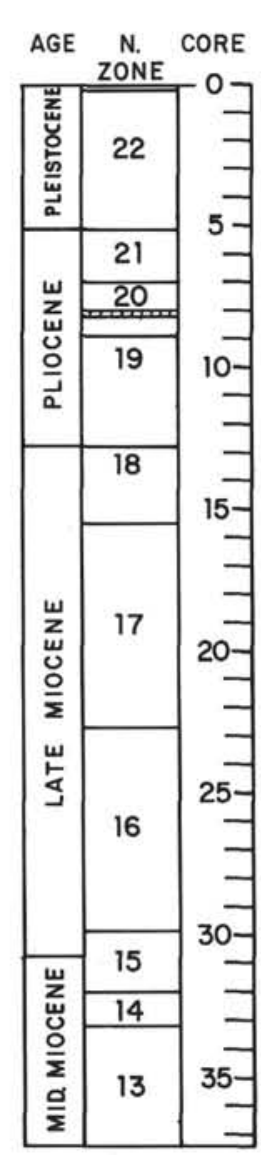

Mrare

common to abundant

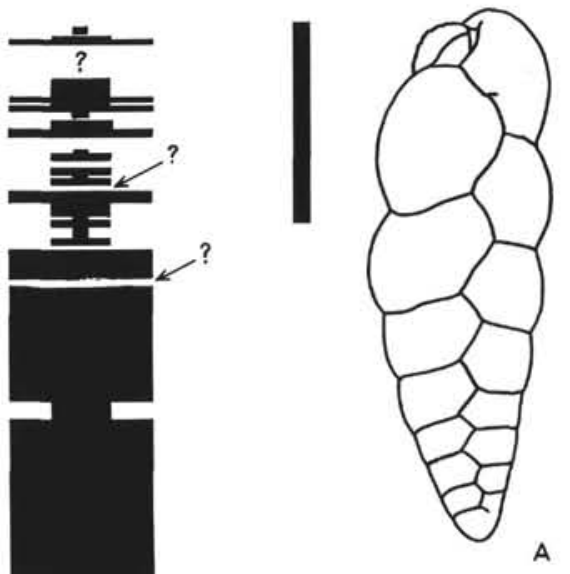

A
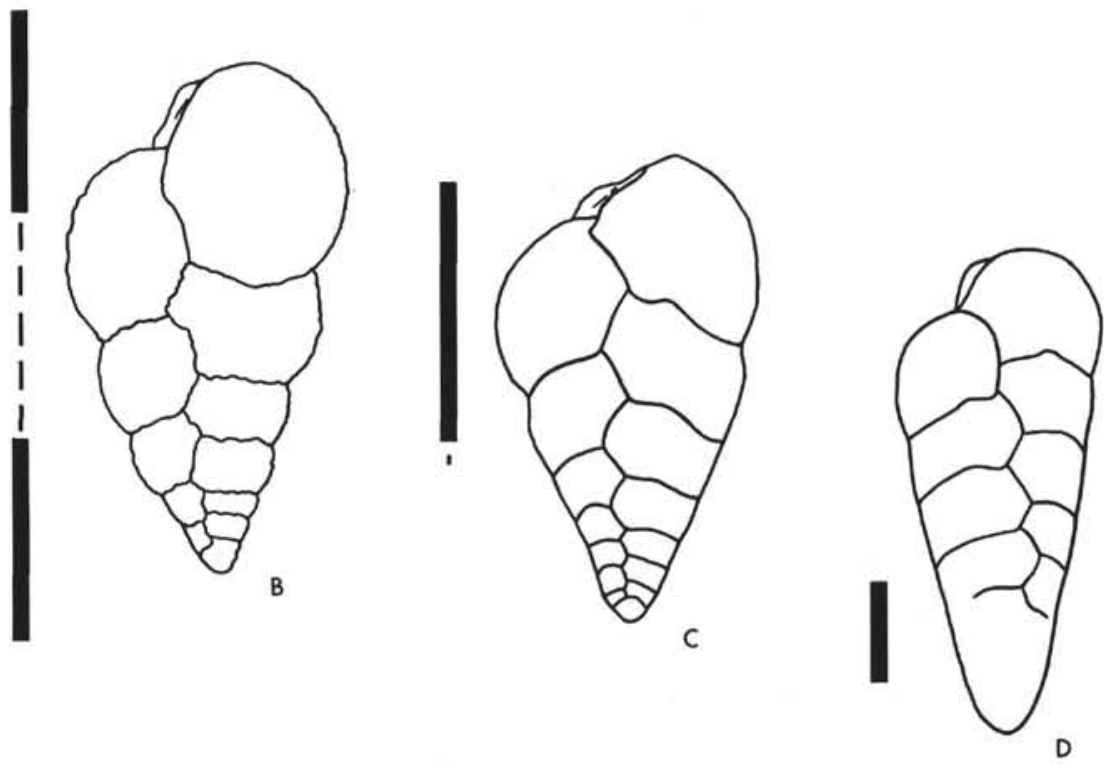

Figure 4. Stratigraphic range and abundance of biserial planktonics at Hole 62.1. A, Streptochilus tokelauae (Boersma); B, Streptochilus globigerum (Schwager); C, Streptochilus latum Brönnimann and Resig, n. gen., n. sp.; D, Streptochilus pristinum Brönnimann and Resig, n. gen., n. sp. 
holotypic samples and from other samples of Holes 62.1 and 64.1. Each new taxon is based on a detailed description of the holotype using light microscope and scanning microscope data. Under "Remarks" we have furnished additional information on the comparison between the new taxon and existing morphologically related taxa and on the morphology of paratypes, which in many cases are illustrated by scanning micrographs. The selection of the holotype remains, unavoidably, a subjective matter, and only in conjunction with the information obtained from paratypes should its description be taxonomically applied. This procedure is usually followed as a matter of course, and the combination of holotype and paratypes opens a sufficiently wide, but not too wide, a field to place in the same taxon intermediate forms between holotype and paratype or forms close to the paratypes. It will be seen that in the following descriptions, paratypes and holotype of a given taxon are morphologically most closely related, and in many cases the paratypes could virtually replace the holotype. This close relationship again is a matter of subjective selection and probably does not account for the real variation which exists in a given fossil globigerinacean "population".

The population approach to taxonomy, applicable to Recent populations, does not lend itself to fossil "populations" which in one of the conventional 2-centimeter punch samples of a core consist not only of one generation but of many thousands of generations of specimens or populations. We therefore prefer to adhere in our taxonomic work as closely as possible to the typologic approach, as advocated by Blow (1969), rather than to adopt a necessarily misleading and unrealistic population approach. It is emphasized that the here proposed new species and subspecies account for only some of the more obvious new taxa which exist but have either not been described or not been recognized in the rich globigerinacean material obtained from the samples of Holes 62.1 and 64.1. Future taxonomic work should no longer be restricted to purely faunistic inventories but should be enlarged by detailed evolutionary studies covering stratigraphically successive samples. An evolutionary approach is necessary to better individualize the many as yet not recognized near-homeomorphs and to better understand groups of genetically related forms.

\section{Genus Globigerina d'Orbigny, 1826}

Globigerina microfoliata Brönnimann and Resig, n. sp. (Plate 6, Figures 4, 5, 6; Plate 43, Figure 1)

\section{Description of Holotype}

The very small-sized test is a fairly high, broadly turriline, but not pointed, trochospire consisting of more than 12 chambers. There are four fairly rapidly decreasing in size, subglobular to somewhat axially compressed chambers in the final whorl. The ultimate chamber is tangentially larger ( 75 microns) than radially ( 22 microns). The intercameral and spiral sutures are deeply incised on the dorsal side and the cameral sutures also on the ventral side. The cameral sutures are radial on both sides. The deep incision of the intercameral radial sutures and the well-separated subglobular to axially slightly compressed chambers of the final whorl produce, in dorsal and in ventral view, a distinct lobate outline of the test. This lobation is also seen in side view because the final chamber is slightly displaced toward the umbilical side. The aperture is directed into the umbilical cavity. It is an arched opening of about 35-micron diameter, surrounded by a lip-less border. In the deep umbilical cavity of about 17- to 20-micron diameter, the opening of the penultimate chamber is discernible. The wall is calcareous, thin, with irregularly distributed, relatively large wall pores. The openings of the wall pores are about 1 to 3 microns in diameter. They lie in smooth-contoured, shallow, funnel-like depressions of maximum 5-micron diameter. In between the pores occur, also irregularly distributed, low-rounded pustules which exhibit minute axially situated openings of from less than 1 micron to about 1 micron diameter. The maximum diameter of the holotype is about 175 microns; its axial height is about 125 microns. The specimen coils to the left. It is from Hole 62.1, Core 8, Section 3, 15-17 centimeters, Zone N. 20 (including N. 19). It is illustrated on Plate 6, Figure 6.

\section{Remarks}

Under the optical microscope the surface appears glossy, smooth to minutely pustulate. The scanning micrographs on the other hand show a minutely granular surface. The diameters of paratypes from Hole 62.1, Core 8, Section 5, 16-18 centime ters, Zone N. 20 (including N. 19) range from about 100 to 200 microns. The ultimate chamber of paratypes may be considerably longer radially than that of the holotype, thus increasing the lobation of the test in paratypes. Also, the height of the trochospire is very variable, from a distinctly turriline to a flattened cone. The coiling of the paratypes is random. The paratypes illustrated by the scanning micrographs of the dorsal side, Plate 6, Figures 4 and 5, are both damaged in the early portion of the trochospire leaving only the final whorl intact. The ratio of increase of the tangential diameter of the chambers of the final whorl, which throughout are tangentially larger than radially, are $1: 1.33: 1.54: 1.83$, and $1: 1.34: 1.1: 1.65$. The walls of the early chambers are at least 2 or 3 layered, through the addition of supplementary layers in the course of growth.

This very small Globigerina resembles in its general morphology Globigerina falconensis Blow, 1959, and Globigerina multilobata Romeo, 1965. It differs from 
falconensis by its small size, by the lobate outline, by the frequent umbilical displacement of the final chamber, by its lip- and rimless aperture and finally by its different wall and surface development. Globigerina multiloba Romeo, 1965, which according to Romeo's illustration (Romeo, 1965, plate 118) does not possess a discrete lip, is homeomorphic in size and umbilical aperture to Globigerina microfoliata. The outline of the test however is by far less regularly lobate and the surface of the test less smooth than in the new species from the southwestern Pacific. Furthermore, the number of chambers in the final whorl, normally 6 to 7, exceptionally 5, is greater than that in Globigerina microfoliata where 3 to 4 chambers, maximum 5 chambers, occur in the final whorl. Stratigraphically, Globigerina multiloba has been recorded in the basal Messinian, in the Orbulina suturalis Zone of Selli (1960). It is therefore clearly older than Globigerina microfoliata. An interesting Recent quasi-homeomorph of Globigerina microfoliata has been described from the North Atlantic by Cifelli and Smith (1970, Plate 3, Figures 4 and 5) under the name Globigerina quinqueloba egelida Cifelli and Smith, 1970. Though in general morphology this subspecies of quinqueloba is close to Globigerina microfoliata, the minutely and densely pustulate surface and the slightly up-turned liplike apertural margin of quinqueloba egelida distinguish these small globigerines.

\section{Stratigraphic Range}

Globigerina microfoliata Brönnimann and Resig, n. sp., has been recorded in Hole 62.1, from Core 8, Section 2 to Core 12, Section 5, that is, from the upper part of Zone N. 20 (including N. 19) to near the base of this zone.

Globigerina nepenthes Todd delicatula Brönimann and Resig, n. subsp. (Plate 1, Figures 1, 2, 3, 7, 10)

\section{Description of Holotype}

The relatively large-sized in its early portion, bluntlyrounded, high trochospire consists of more than 12 chambers with 5 chambers in the last whorl. The early chambers of the trochospire are masked by secondary shell substance. The chambers are subglobular on the spiral side and elongate-pointed toward the umbilicus, as seen in lateral and umbilical view. The final chamber is peripherally broadly rounded and rests across the umbilicus on the antepenultimate and penultimate chambers. This somewhat obliquely off-set and towering position on the final chamber is typical of the forms of the nepenthes group. The umbilicus is open and exposes the aperture of the penultimate chamber. The cameral sutures of the final whorl are well-defined on umbilical and spiral sides and fairly deep between the last chambers of the trochospire, creating for this portion of the test a slightly lobate outline.
The aperture, about 175 microns wide and 70 microns high, is a large broad arch crossing from antepenultimate to penultimate chambers. It is bordered by an upturned imperforate smooth-walled to minutely pustulate, narrow rim of about 10 microns thickness. Very minute pustules occur laterally on the inside of the rim. This rim does not fuse with the apertural wall, which is thin, perforate, and in its lower portion covered with only poorly developed, bluntly rounded, individual pustules. The other portions of the surface of the ultimate chamber are stronger pustulate. The pustules start to coalesce laterally, developing an initial polygonal meshwork. The outer wall formations of the earlier chambers of the final whorl are by contrast very strong. The pustules in the spaces between the wall pores, of about 5 to 10 microns in diameter, fuse basally and laterally forming the funnel-shaped polygonal compartments, each surrounding a deeply set pore. The pustules in the polygonal corners are pointed and higher than the sharp-edged interconnecting walls. The polygonal surface pattern on the spiral side of the early chambers is masked by secondary shell substance. The pustules and the polygonal walls show on the scanning micrograph of the holotype, Plate 1, Figure 7, a smooth surface and nothing can be said about their ultrastructure. The holotype coils to the left. The maximum diameter of the holotype is about 375 microns; its axial height-without the ultimate chamber-is about 250 microns. The ultimate chamber is about 100 microns high and 175 microns wide. The specimen is from Hole 62.1, Core 13, Section 2, 36-38 centimeters, Zone N.18. It is illustrated on Plate 1, Figure 7.

\section{Remarks}

Globigerina nepenthes delicatula Brönnimann and Resig, n. subsp., is distinguished from Globigerina nepenthes nepenthes Todd, 1957, by the relatively large, thin-walled, almost transparent, broadly rounded final chamber, the large aperture, and by the upturned smooth-walled, unfused with the apertural wall, rimlike lip. We have examined the holotype of Globigerina nepenthes nepenthes in the collections of the U.S. National Museum and have found that the ultimate chamber is much smaller than the preceding ones, that it lies tightly over the umbilicus, and that the aperture is a very low, elongate arch provided with a strongly pustulate, rounded border which is not upturned.

The features of the specimens illustrated on Plate 1, Figures 4 and 6, and by Blow (1969, pl 14, fig. 5) correspond closely with those of the holotype. The specimen illustrated by Plate 1, Figure 9, under the name of Globigerina nepenthes picassiana Perconig, 1968 , is interpreted as a subspecies of Globigerina nepenthes nepenthes. According to Perconig (1968), Globigerina nepenthes picassiana has the same stratigraphic range as Globigerina nepenthes nepenthes, 
which in this author's stratigraphy extends from the Tortonian to the lower Pliocene. The scanning micrographs of paratypes, Plate 1, Figures 1, 2 and 10, exhibit a minute granulation on the surface of the final chamber and on the upturned apertural border. The large pustules and the interconnecting walls of the polygonal meshwork of the preceding chambers are made up of small pustules or "crystallites". As Globigerina nepenthes nepenthes and Globigerina nepenthes delicatula coexist in the same samples, we do not think that these subspecies are environmental variants, but rather that the phenotypic differences are genotypically controlled. The maximum diameter of paratypes of Globigerina nepenthes delicatula range from about 150 to 475 microns. They coil both to the left and to the right.

\section{Stratigraphic Range}

Globigerina nepenthes delicatula, n. subsp., ranges in Hole 62.1, from Core 13, Section 2 to Core 30, Section 3, that is from Zone N. 18 to Zone N. 15. The stratigraphic range of Globigerina nepenthes nepenthes is slightly longer, from Zone N. 20 (including N. 19) to Zone N. 14.

Globigerina nepenthoides Brönnimann and Resig, n. sp. Plate 7, Figures 4 through 9)

\section{Description of Holotype}

The small-sized test consists of about 10 to 15 chambers arranged in a moderately high but, in its initial portion, not pointed trochospire with 4 chambers in the final whorl. The peripherally broadly rounded ultimate chamber is radially and tangentially equidimensional, about 110 microns, and is placed nepenthes-like with somewhat extended and flattened ventral face across the umbilicus. The subglobular chambers increase rapidly in size except for those of the final whorl which are separated by well-incised, intercameral sutures producing slightly lobate outlines as seen in spiral and side views. The wall is calcareous, perforate, and its surface distinctly pustulate with short blunt composite pustules. The bases of the pustules are fused and surround the deeply set small rounded pores by polygonal compartments. The polygonal walls are broad, rounded and minutely pustulate. The aperture is an elongate arch, relatively low in comparison with its length and going across three chambers. It is about 100 microns long and about 20 microns high. The thin-walled slightly upturned apertural face forms a distinct, thick, irregularly finely to coarsely pustulate border. The scanning micrograph of the apertural side of the holotype, Plate 7, Figure 6, exhibits wall pores down to the apertural border.

The holotype coils to the right. The maximum diameter of the holotype is about 255 microns, its maximum axial height, without the ultimate chamber, about 150 microns. The holotype is illustrated on Plate 7, Figure 6. It is from Hole 64.1, Core 2, Section $6,15-17$ centimeters, Zone N. 7/N. 8 .

\section{Remarks}

Globigerina nepenthoides is homeomorphic in the above described morphologic features with Globigerina nepenthes nepenthes Todd and, in particular, Globigerina nepenthes delicatula Brönnimann and Resig, n. subsp.

In the final whorl, however, Globigerina nepenthoides is less tightly coiled and therefore more lobate than most of the individuals of the stratigraphically younger Globigerina nepenthes group, whose subspecies normally show slightly lobate to non-lobate, ovoid outlines. Reference is here made to the illustrations of Globigerina nepenthes nepenthes by Blow (1969, pl. 14, fig. 5) and in the present paper, Plate 1 , Figures 4 and 6, and of Globigerina nepenthes delicatula, Plate 1, Figures 1, 2, 3, 7, and 10. One specimen of this subspecies, Plate 1, Figure 10, shows a more lobate outline than normally seen. Although in large adults of Globigerina nepenthoides the up-turned apertural rim may be quite thick and strongly pustulate, the lip of Globigerina nepenthes nepenthes is comparatively much more strongly structured by perpendicular incisions and has a single row of regularly arranged pustules, which may fuse in its distal portion with the chamber wall as shown by the side view of Globigerina nepenthes nepenthes, Plate 1, Figure 4. The ultimate chamber and the lip of Globigerina nepenthes delicatula, on the other hand, are thinnerwalled than that of nepenthes nepenthes and approaches in this characteristic those of Globigerina nepenthoides. Typical Globigerina nepenthes delicatula have very thin upturned lips, normally almost smooth to minutely pustulate, occasionally showing a slight structuring by vertical lines. Globigerina nepenthoides differs from Globigerina falconensis Blow, with which it is associated from Zone N. 13 to the uppermost part of Zone N.6, by its high trochospire, the nepentheslike somewhat oblique position of the ultimate chamber, the elongate low-arched aperture, and by the upturned apertural border. Further, its wall seems to be generally thinner than that of Globigerina falconensis. The surface structures of Globigerina falconensis and of Globigerina nepenthoides are very similar. Both species have perforate calcareous walls, and the rounded deeply set pores are also found in Globigerina falconensis to be surrounded by bluntly pointed basally fused pustules. The relatively regularly structured lip of Globigerina falconensis is closer to that of Globigerina nepenthes nepenthes than to that of Globigerina nepenthoides. Reference is made to the illustrations of typical Globigerina falconensis, Plate 3, Figures 1, 2, and 4, and to the metatype of Globigerina falconensis figured by Blow (1969, pl.16, fig. 1), 
which is not particularly well-preserved but shows the strongly structured thick wall quite well. Globigerina nilotica Viotti and Mansour, 1969, is probably indentical with Globigerina falconensis, at least in part. The illustration of this species (Viotti and Mansour, 1969, p. 447, pl.6) shows in fact a mixture of rather different apertural morphologies. However, the individuals figured on Plate 6, Figures 1, 2, 3 and 4 could be assigned to the Globigerina falconenis group of forms. The maximum diameters of paratypes of Globigerina nepenthoides range from 150 to 225 microns. The scanning micrographs of paratypes Plate 7, Figures $4,5,7$, and 9 , show strongly pustulate tests. The ultimate chamber of the specimen, Plate 7, Figures 4 and 5, from Hole 64.1, Zone N. 7/N. 8, has a minutely granular texture. The polygonal meshwork is not yet developed but accumulation of small pustules or "crystallites" indicates the position of the future large pustules of the polygonal corners. The wall pores occur on the ultimate chamber down to the apertural border. In places, the wall pores are defined by whitish thin annuli which seem to rise slightly above the surface of the wall.

\section{Stratigraphic Range}

Globigerina nepenthoides n. sp., has been observed in Holes 62.1 and 64.1 over the interval from N. 13 to the base of N.6. The ranges of its younger homeomorphs Globigerina nepenthes nepenthes and Globigerina nepenthes delicatula are from Zone N. 20 (including N. 19) to the base of N. 14 and from N. 20 (including N. 19) to the upper part of N. 15 , respectively.

Globigerina pseudodruryi Brönnimann and Resig, n. sp. (Plate 7, Figures 1 and 2)

\section{Description of Holotype}

The fairly large test is a tightly coiled, in the initial portion bluntly rounded, low trochospire with four chambers, only slightly increasing in size, in the last whorl. The cameral sutures are distinct but shallow, hence the outline of the test as seen in spiral and umbilical views is virtually not lobate. In umbilical view, the chambers of the last whorl, with the exception of the ultimate one, are more or less wedge-shaped, elongate, narrowing, almost pointed toward the shallow umbilicus, and broadly rounded peripherally. The ultimate chamber is subglobular about $215 \mathrm{microns}$ in tangential, and about 100 microns in radial diameter, with a relatively small, high-arched aperture of about 75 microns length and about 35 microns height, set well in the umbilicus and devoid of any distinct rim or liplike border. The ultimate chber spans the three previous chambers of the final whorl in nepenthes-like fashion. Wedge-shaped chambers are well-known in the final whorl of Globigerina druryism, Akers, 1955, as illustrated by Blow
(1969, pl. 14, fig. 4) and by Plate 5, Figures 1 and 2 of this paper, and in Globigerina nepenthes nepenthes Todd, 1957 (Blow, 1969, pl. 14, fig. 5; Plate 1, Figure 4 of this paper). The calcareous walls are perforate, and their surfaces are coarsely ornamented with heavy, dull-pointed, basally fused pustules, which on the early chambers of the trochospire almost close the wall pores. The holotype coils to the left. The maximum diameter of the holotype is about 375 microns, its axial height about 275 microns. It is from Zone N. 6 of Hole 64.1 and illustrated by the scanning micrograph of a somewhat oblique apertural view, Plate 7, Fig. ure 1 .

The scanning micrographs show that the pustules and the interconnecting walls of the polygonal meshwork are composite structures made up of numerous small pustules or "crystallites". The apertural border is imperforate and finely pustulate.

\section{Remarks}

Globigerina pseudodruryi, n. sp., is a homeomorph in its general form of Globigerina druryi Akers, but differs from this stratigraphically younger globigerine by its small rimless aperture and the more elongate wedge-shaped form of the early chambers of the last whorl as seen in umbilical view. The holotype of Globigerina druryi, deposited in the collections of the U.S. National Museum, was examined by Brötechupper, nnimann and found to possess wedgeshaped chambers also, but the apertural face is drawn out in the form of an acutely-edged rather strongly projecting eaves-like plate, which is strongly pustulate. The maximum diameter of a paratype illustrated by the spiral view, Plate 7, Figure 2, is 350 microns. Globigerina nepenthes nepenthes is regarded as a subspecies of Globigerina druryi by Bandy and Ingle (1970, Plate 1, Figure 5). From the stratigraphic situation as established in Hole 62.1, an evolutionary series from Globigerina druryi to Globigerina nepenthes would be quite possible. This possible evolutionary series needs further study in stratigraphically successive populations with the help of scanning observations. The stratigraphically older Globigerina pseudodruryi, on the other hand, does not seem to be directly related to Globigerina druryi which, according to Blow (1969, p. 266, fig. 2), extends from Zone N. 11 to Zone N. 14, nor to the Globigerina nepenthes-delicatula group of forms.

\section{Stratigraphic Range}

Globigerina pseudodruryi, n. sp., was found from Zone N. 7/N. 8 into Zone N. 6 of Hole 64.1. It does not seem to overlap stratigraphically with Globigerina druryi which was recorded in Hole 62.1 in Zone N. 13. In Hole 64.1 Zone N. 13 was not cored and Globigerina druryi was not encountered. 


\section{Genus Globigerinita Brönnimann, 1951}

Globigerinita boweni Brönnimann and Resig, n. sp. (Plate 26, Figures 1 through 4)

\section{Description of Holotype}

The very small-sized test is a high trochospire of about 12 chambers with four chambers that gradually increase in size in the final whorl and an umbilically situated bulla opening toward the penultimate chamber. The subglobular bulla of 50 microns maximum diameter has an opening of about 20 microns maximum diameter. It rests on the ultimate, antepenultimate and ante-antepenultimate chambers. The initial portion of the trochospire is not pointed. The subglobular chambers of the final whorl are separated on umbilical and spiral sides by well-depressed, radial, cameral sutures. Also the spiral suture is distinct. In spiral and umbilical view, the outline is lobate and in side view bluntly convex on the spiral side. On the umbilical side, the broadly rounded bulla protrudes slightly in side view. Without bulla, the umbilical side is virtually flat. The primary aperture, which is umbilical, can be seen through the opening of the bulla. It is a small arched opening with a distinct narrow border of granular appearance. The apertural margin of the bulla, on the other hand, is not thickened nor separated from the bulla wall but is irregularly pustulate and faintly up-turned. The umbilicus is shallow and broad. The calcareous wall of the normal chambers is thin, finely perforate, and the surface is pustulate. The pustules are largest on the umbilical sides of the chambers, densely set, blunt to pointed distally as shown by the scanning micrographs (Plate 26, Figures 2 and 4), and in between the densely set pustules minute openings of the perforations are discernible. In places it seems that the large rounded pustules are interconnected by radiating thin walls, and in between these connections open the wall pores. In fact these minute openings seem to surround the pustules not vice versa as described for most Globigerinacea, and there is no sign of a polygonal meshwork. The pustules are composites of minute elements. The bulla is very thin-walled and very finely pustulate and perforate. The maximum diameter of the holotype is about 130 microns; its axial height is about 100 microns. The specimen coils to the left. It is from Hole 64.1, Core 7, Section 2, 33-35 centimeters; Zone N. 3. It is illustrated on Plate 26, Figure 1. The species is named for Dr. Vaughan Bowen, Woods Hole Oceanographic Institution, Woods Hole, Massachusetts, U.S.A.

\section{Remarks}

By the lower trochospire, the low and arched primary aperture and the single-aperture umbilical bulla Globigerinita boweni, n. sp., differs from the equally small but high trochospires of Globigerinita uvula (Ehrenberg) from Hole 62.1 and of Globigerinita aff. Globigerinita uvula (Ehrenberg) from Hole 64.1.
Globigerinita uvula is normally a much higher trochospire of about 3 or more whorls, with 5, occasionally 4 chambers in the final whorl and, as shown by the scanning micrographs, Plate 22, Figures 7 and 8 , possesses a brilliant, finely to coarsely pustulate wall. The bulla of uvula is much more flattened than that of Globigerinita boweni, usually with apertures at the intersection of the bulla with the cameral sutures of the final whorl. Furthermore, the principal aperture is much larger than that of Globigerinita boweni, n. sp., but also is provided with a distinct rim. Parker (1962, pl. 8, fig. 14-26; 1967, pl. 17, fig. 8 and 9) has well illustrated Globigerinita uvula which was recorded in most samples from N. 17 to N. 23, Globigerinita aff. Globigerinita uvula from Hole 64.1 is closer to Globigerinita boweni than to Globigerinita uvula. The affine form occurs in Hole 64.1 from Core 1 to 7 , that is from Zones N. 7/N. 8 to N. 3. Paratypes of Globigerinita boweni, n.sp., from Core 7, Section 2, Hole 64.1 , coil randomly. The maximum diameter of paratypes across the final whorl ranges from about 100 to 150 microns. A remarkable feature of the outer wall formations is the absence of the polygonal meshwork.

\section{Stratigraphic Range}

Globigerinita boweni, n.sp., has been recorded in Hole 64.1, Core 7, Sections 2 to 4, Zone N. 3. It accompanies Globorotalia (T.) cifellii Brönnimann, and Resig, n. sp. Globorotalia (T.) nkborwni Brönnimann and Resig, n.sp., and Globorotalia (T.) pseudokugleri Blow, 1969. These species are only recorded in Sections 2 to 4 of Core 7.

\section{Genus Globigerinoides Cushman, 1927}

Globigerinoides pseudosellii Bronnimann and Resig, n. sp.,

(Plate 9, Figure 7, 8 and 9)

\section{Description of Holotype}

The medium-sized axially compressed, tightly coiled trochospire consists of at least 8 chambers with 3 chambers in the final whorl. The ultimate chamber is slightly larger than the entire preceding test. The outline of the test in umbilical and spiral view is broadly oval: 350 microns maximum length against 300 microns maximum breadth. In side view, the test is axially flattened, with about 250 microns axial height, and umbilically concave. The intercameral sutures of the final whorl are well incised. The sutures of the early trochospire are indistinct. The chamber arrangement and the form of the test are closely homeomorphic to those of Globigerina sellii Borsetti, 1959 (Plate 8, Figure 9), which however is stratigraphically much older than Globigerinoides pseudosellii (Blow, 1969 , pl. 19, fig. 4-6). The primary aperture of the holotype of Globigerinoides pseudosellii is a short, rather low-arched opening in umbilical position. It is 
situated at the intersection of the umbilical intercameral sutures. The primary aperture is about 100 microns long, and about 48 microns high. The arch is slightly lower in its central position than laterally. The border is fully pustulate and an imperforate band or lip is not detectable. There is only a single supplementary aperture in the form of a very small slit-like opening of about 20 microns in length at the intersection of the suture between the ultimate chamber and that separating the ultimate and the penultimate chamber of the penultimate whorl.

The calcareous walls are coarsely pustulate and perforate. The large, composite pustules coalesce laterally and form polygonal compartments, each with a wall pore in its funnel-like depression. The walls of the polygons consist, like the pustules, of smaller units or "crystallites". On the early chambers of the tight trochospire the pustules seem to be enlarged and almost close the openings to the wall pores.

The maximum diameter of the holotype is about 350 microns. It coils to the left. The specimen is from Hole 64.1, Core 3, Section 6, 33-35 centimeters; Zone N. 6.

\section{Remarks}

As already mentioned, Globigerinoides pseudosellii, n. sp., closely is homeomorphic in its gross morphology to Globigerina sellii Borsetti. It also resembles in umbilical view Globigerinoides sicanus praesicanus Brönnimann and Resig, n. subsp., which however differs clearly from Globigerinoides pseudosellii by the larger almost globular ultimate chamber, the elongate slit-like primary and the large equally slit-like secondary apertures, by the absence of an umbilical depression, and by the absence of axial compression of the chambers of the final whorl. The maximum diameter of paratypes from Hole 64.1 ranges from about 320 to 370 microns.

In comparison with Globigerinoides sicanus praesicanus, Globigerinoides pseudosellii generally has somewhat smaller tests. The outer wall formations of Globigerinoides pseudosellii as illustrated by the scanning micrographs of the umbilical and spiral sides of paratypes, Plate 9, Figures 7 and 9, are characterized by a very strong pustulation. The pustules are composite structures and normally interconnected by equally composite polygonal walls. On the apertural face of the specimen illustrated by Plate 9, Figure 7, the basic polygonal meshwork is modified by the formation of short irregular ridges. On the early trochospiral chambers, the pustules are laterally enlarged and considerably reduce the openings of the polygonal compartments, which have in their centers the wall pores. The rounded wall pores of the ultimate chamber of the specimen illustrated on Plate 9, Figure 9 reach diameters of about 4 to 5 microns.

\section{Stratigraphic Range}

Globigerinoides pseudosellii, n. sp., has been recorded in Hole 64.1, from Core 1, Section 1 to Core 3, Section 6 , that is from Zone N. 7/N. 8 to the top of Zone N. 6.

\section{Globigerinoides quadrilobatus (d'Orbigny) praeimmaturus Brönnimann and Resig, n. subsp. (Plate 9, Figures 1 through 4) \\ Description of Holotype}

The medium-sized subglobular to ovoid test is a low trochospire with 4 subglobular chambers, rapidly increasing in size, in the final whorl. The ultimate chamber virtually equals in size the previously formed portion of the test. The initial chambers are tightly coiled and their sutures masked by secondary shell substance. The outline of the test in umbilical and spiral view is broadly oval, almost equidimensional and oval, longer than wide, in side view. The general shape of the test compares well with that of Globigerinoides cellatus (Subbotina), 1958, as illustrated by Banner and Blow (1965, p. 108, text-fig. 5a,b). There is only a very slight umbilical depression. The "primary aperture" is a narrow, umbilical, interiomarginal slit of about 100 microns in length and less than 10 microns in height. The "primary aperture" follows the gentle umbilical rounding of the antepenultimate chamber, which is the middle chamber as seen in the umbilical view, and it is of the same height throughout. The "primary aperture" is devoid of any lip or rim and shows in the scanning micrograph (Plate 9, Figure 4) strong, blunt, composite pustules which are basically fused. Such strong pustules and interconnecting walls are typical for the entire surface of the test (Plate 9, Figure 1). They surround funnel-like depressions with small rounded pores in their centers of up to 5 microns diameter. On the earlier chambers of the final whorl, the pustules become completely fused laterally, developing around the wall pores a coarse polygonal meshwork. In a longitudinal section of a paratype from Hole 64.1, Core 2, Section 6, 15-17 centimeters, as illustrated by the scanning micrograph, Plate 9, Figure 2, the real primary aperture is not visible from the outside of the test. It is, in fact, hidden under the overhanging subglobular ultimate chamber and is represented by a large arched opening of about 45 microns height leading into the narrow space between ultimate and antepenultimate chambers. This narrow space opens then in the form of an incurved slit between ultimate and antepenultimate chambers, described above as "primary aperture". On the spiral side a single, very small secondary opening, of about 20-micron diameter, also a gently incurved elongate triangular slit, occurs between the last chambers of the 
ultimate and penultimate whorls. In contrast to the slit-like "primary aperture" this elongate secondary slit seems to be the real opening. The intercameral sutures of the final whorl are well incised.

The calcareous wall is thick, with strong composite bluntly pointed pustules which surround the deeply set perforations in groups of 4 to 6 .

The holotype coils to the right. The maximum diameter of the holotype is about 220 microns; its axial height is about 188 microns. The holotype is from Hole 64.1, Core 1, Section 4, 33-35 centimeters; Zone N. 7/N. 8 and is illustrated on Plate 9, Figure 1.

\section{Remarks}

Globigerinoides quadrilobatus praeimmaturus Brönnimann and Resig, n. subsp., is related in its chamber arrangement to Globigerinoides quadrilobatus immaturus LeRoy, 1939, which occurs according to Blow (1969) from Zone N. 4 to Zone N. 23, and in its contours and slit-like "primary aperture" to Globigerinoides cellatus (Subbotina), 1958. It differs from both species by its hidden primary aperture, and from Globigerinoides quadrilobatus immaturus also by the narrow slit-like "primary" opening and by its virtually equidimensional test as seen in umbilical and spiral view. From the similar subglobular trochospires of Globigerinoides sicanus praesicanus Brönnimann and Resig, n.subsp., and Globigerinoides pseudoselli Brönnimann and Resig, n. sp., it differs by the apertural features and by the position of the primary aperture at the intersection of the sutures between the ultimate and penultimate-antepenultimate chambers and the penultimate and antepenultimate chambers in praesicanus and in pseudosellii (Plate 10, Figures 5, 6 and 8; Plate 9, Figures 7, 8 and 9). The longitudinally sectioned specimen illustrated by Plate 9 , Figure 2 , is about 300 microns in maximum diameter. The maximum diameter of the ultimate chamber is about 250 microns and its maximum height about 134 microns. These dimensions agree practically with the dimensions of the previously formed test. The maximum thickness of the wall of the ultimate chamber of the preceding whorl is about 3 microns. On the basis of the axial height, the linear increase from penultimate to ultimate whorl is $1: 2$. The maximum diameters of paratypes from Hole 64.1, Core 1, Sections 1, 2 and 4, range from about 200 to 300 microns.

\section{Stratigraphic Range}

Globigerinoides quadrilobatus praeimmaturus, n. subsp., has been recorded from Zone N. $7 /$ N. 8 to Zone N. 6. It is common in Zone N. 7/N. 8.
Globigerinoides sicanus praesicanus

Brönnimann and Resig, n. subsp.

(Plate 10, Figures 5, 6 and 8)

\section{Description of Holotype}

The medium-sized test is a low apparently somewhat streptospiral trochospire with three large axially compressed subglobular chambers both in the ultimate and the penultimate whorls. The arrangement of the early chambers is indistinct. The final chamber is flattened on the apertural side and makes up slightly more than one-half of the test. Its maximum diameter on the apertural side is about 475 microns. It shows a tendency to envelope the preceding chambers. In spiral and in umbilical view the outline of the test is broad oval to subcircular, in axial view broadly convex not pointed over the spiral, slightly concave over the umbilical side. The sutures are well incised. The large umbilicus is shallow and occupied by a large arched aperture of about 200 microns in width and about 75 microns in height which is devoid of lip or rim but whose margin is covered with strong pointed pustules. There are two small triangular supplementary sutural apertures on the spiral side at the intersections of the sutures between the penultimate whorl and the chambers of the final whorl. These openings may be partially closed by protruding pustules. Their maximum diameter is about 20 to 25 microns. The wall is calcareous and its surface is strongly pustulate and perforate. The maximum diameter of the holotype is 525 microns, its axial height about 375 microns. The holotype is from Hole 64.1, Core 4, Section 2 at 33-35 centimeters, Zone N. 6 and is illustrated on Plate 10, Figure 8 .

\section{Remarks}

Globigerinoides sicanus praesicanus n. subsp., resembles in its umbilical morphology Globigerina sellii Borsetti, 1959, and Globigerina tapuriensis Blow and Banner, 1962. Reference is made to the illustrations of Blow (1969, pl. 16, fig. 7 and 8 (G. tapuriensis); pl. 19, fig. 4 (primitive form of $G$. sellii), fig. 6 (typical $G$. sellii)), of Blow and Banner (1962), pl. X, fig. L, M and N ( $G$. selli given as Globigerina oligocaenica Blow and Banner) and fig. H. J. and $\mathrm{K}$ ( $G$. tapuriensis given as Globigerina tripartita tapuriensis Blow and Banner) and of Soediano (1969, Pl. III, fig. 1A-C (given as intermediate forms between $G$. tripartita and $G$. sellii)). However, the supplementary sutural openings clearly distinguish Globigerinoides sicanus praesicanus, n. subsp., from the listed globigerinas, with which it might be confounded if the openings were not visible. By the arched, large primary aperture, the shallow but well-developed umbilical depression and the apparent slight streptospiral coiling Globigerinoides sicanus praesicanus differs from Globigerinoides quadrilobatus trilobus (Reuss), 1850. Globigerinoides sicanus sicanus de Stefani, 1950, has a much larger ultimate chamber 
than the new subspecies and a slit-like primary aperture, which is much lower than in Globigerinoides sicanus praesicanus, n. subsp. Typical Globigerinoides sicanus praesicanus occurs stratigraphically below the first appearance of Globigerinoides sicanus sicanus in N. 6. It seems that Globigerinoides sicanus sicanus evolved from Globigerinoides sicanus praesicanus by evolutionary changes affecting the size of the ultimate chamber, the umbilical depression which gradually shallows and disappears, and the primary aperture which changes from a fairly large, high-arched opening to an elongate slit. Reference is made to Blow's re-illustration of the holotype of Globigerinoides sicanus sicanus $(1969$, pl. 3 fig. 10 and 11) and to the illustrations of Globigerinoides bisphericus Todd (= Globigerinoides sicanus sicanus de Stefani) in Loeblich et al. (1957), pl. 27, fig. 1 and 1b) which clearly show these differences. An intermediate stage between Globigerinoides sicanus praesicanus and Globigerina sicanus sicanus which already possesses a sicanus-type primary aperture is illustrated on Plate 10, Figures 1, 4 and 7. Parallel with the described evolutionary changes, the size of the test as a whole increases. The holotype of Globigerinoides sicanus sicanus shows a maximum diameter of about 600 microns (fide Blow, 1969), the specimens illustrated by Loeblich et al. about 675 microns whereas paratypes of Globigerinoides sicanus praesicanus from Hole 64.1, Core 3, Section 1, 33-35 centimeters and Core 4, Section 3, 17-19 centimeters, as illustrated on Plate 10, Figures 5 and 6, have maximum diameters of only 400 to 550 microns. The evolutionary trend from Globigerinoides sicanus praesicanus to Globigerinoides sicanus sicanus is documented in our material by a series of transitional forms. The scanning micrographs, Plate 10, Figures 5, 6 and 8 , show that the surface is provides with blunt pustules, probably with a central canal, and that 4 to 6 pustules fuse basally and laterally to form a polygonal wall around a tunnel-like depression with a rounded wall pore in its center.

\section{Stratigraphic Range}

Typical Globigerinoides sicanus praesicanus, n. subsp., has been observed from N. 6 to N. 4, affine forms with only a single supplementary aperture, in Zone N.7/N.8. It precedes and overlaps typical Globigerinoides sicanus sicanus.

Globigerinoides subquadratus Brönnimann subelongatus Brönnimann and Resig, $\mathrm{n}$. subsp.

(Plate 13, Figures 1, 2, 4 and 5)

\section{Description of Holotype}

The large test is a high trochospire of more than 10 subglobular chambers arranged in whorls of 3 chambers each. The initial portion of the trochospire is very tightly coiled and bluntly rounded so that the total number of whorls and chambers cannot be determined.
The cameral and spiral sutures are well incised. The outline of the test is somewhat lobate, as seen in side and in spiral view. The last-formed, arched aperture is situated at the intersection of the sutures between the ultimate, penultimate and antepenultimate chambers. The supplementary openings are also situated at the intersections of sutures. Each chamber of the ultimate and penultimate whorls has two sutural openings. The chambers increase rapidly in size from whorl to whorl. Secondary sutural openings do not seem to occur in the chambers of the tightly coiled, early, elongate, trochospiral portion of the test. The principal arched aperture lies in a shallow umbilical depression. Its height is about 70 microns, and its width about 50 microns. It does not possess any lip, and its border is covered with strong individual, composite pustules. The calcareous wall is thick, pustulate and perforate. The scanning micrograph of the holotype Plate 13, Figure 1 shows that some of the tips of the isolated pustules of the final chamber are slightly eroded and expose minute rounded openings. On the earlier chambers the 4 to 6 large pustules surrounding a wall pore are basally and laterally fused, and form polygonal thick-walled compartments. Also on the earlier chambers the tips of the pustules are occasionally worn exposing minute openings which may represent canallike perforation of the pustules. The maximum diameter of the holotype, illustrated on Plate 13, Figure 1, is 425 microns. The holotype coils to the left. It is from Hole 64.1, Core 1, Section 5, 33-35 centimeters, Zone N.7/N.8, where it is associated with Globigerinoides subquadratus subquadratus Brönnimann, 1954.

\section{Remarks}

Globigerinoides subquadratus subelongatus, n. subsp., differs from Globigerinoides subquadratus subquadratus Brönnimann by its high trochospire. The other features of the test are identical. The form of the final aperture varies greatly from a typically high arch, occasionally with slightly inclined sides, to a low, broad arch (Plate 13, Figures 1, 2 and 5). In the same way that Globigerinoides subquadratus subquadratus is closely homeomorphis to Globigerinoides ruber (d'Orbigny), 1839, the new subspecies is homeomorphic to Globigerinoides elongatus (d'Orbigny), 1826, which however closely shows only one supplementary sutural opening per chamber (Banner and Blow, 1960, pl. 3, Fig. 10a-c). The position of the final aperture in Globigerinoides elongatus Plate 13, Figure 3, from Hole 62.1, Zone N. 21, is at the intersection of the suture of the ultimate chamber with that between the penultimate and antepenultimate chambers, hence identical with that in Globigerinoides subquadratus subelongatus, Plate 13, Figures 1 and 2, from Hole 64.1, Zone N. 7/N. 8. The final chamber of Globigerinoides elongatus in the illustrated individual is strongly flattened and somewhat angular; the final 
aperture is a high-elongate arch and the sides of the aperture converge toward the sutural intersection. This specimen agrees well with the lectotype of Globigerinoides elongatus designated by Banner and Blow (1960, pl. 3, fig. $10 \mathrm{a}-\mathrm{c}$ ), from the Recent of the Adriatic Sea near Rimini, with the exception that the sides of the final apertures do not converge as strongly toward the sutural intersection as in our specimen. Parker (1967, pl.22, fig. 2-4) illustrated as Globigerinoides ruber (d'Orbigny), specimens which we would assign to Globigerinoides elongatus. In Globigerinoides subquadratus subelongatus, the final opening tends more to be a broadly rounded arch whose sides do not form a pointed base. The height of this arch, however, varies considerably from individual to individual. The apertural rim of Globigerinoides elongatus is also covered by pointed, isolated pustules, which expose the minute openings of canals. On the penultimate and earlier chambers the pustules fuse basally forming the funnel-like depression already described for Globigerinoides subquadratus subelongatus. The scanning micrograph of the penultimate chamber of Globigerinoides elongatus, Plate 13, Figure 3 shows that the 4 to 6 pustules surrounding a wall pore have tubular processes (= broken-off spines), which are clearly isolated from the surrounding wall material and are incorporated in the wall only in the course of its thickening during growth. Minute openings also occur on the interconnecting walls between the larger pustules. A paratype of Globigerinoides subquadratus subelongatus illustrated on Plate 13, Figure 2, possesses three arched apertures in the final chamber. The maximum diameter of four paratypes from Hole 64.1 ranges from 450 to 525 microns.

\section{Stratigraphic Range}

Globigerinoides subquadratus subelongatus, n. subsp., has been recorded in the interval from Zone N. 8 to Zone N. 6, that is, within the total range of Globigerinoides subquadratus subquadratus which extends from Zone N. 13 to Zone N.4. It occurs apparently intermittently and with variable frequency which suggests that the new subspecies could be a mere ecologic variant of subquadratus subquadratus.

\section{Genus Globoquadrina Finlay, 1947}

Globoquadrina altispira (Cushman and Jarvis) conica Brönimann and Resig, n. subsp.

(Plate 22, Figure 1)

\section{Description of Holotype}

The large-sized test is a high conical trochospire of four whorls with 4.5 chambers in the final whorl. The initial portion of the trochospire is composed of very small chambers, and is rounded. Its sutures are not discernible because they are masked by shell substance.
The chambers of the following three whorls increase rapidly in size from whorl to whorl, but only gradually within the same whorl. The sutures are distinct and strongly depressed. This depression of the sutures and the subglobular, in radial direction somewhat flattened, chambers produce a lobate outline in umbilical, spiral and side views. The umbilicus is deep, open and exposes the apertures of the penultimate and antepenultimate chambers. The umbilical sides of the chambers are flattened and extend into pustulate, triangular tooth-like extensions like those found in Globoquadrina altispira altispira (Cushman and Jarvis), 1936. The large umbilical aperture shows a thin, smooth border on both sides of the triangular extensions, which may be heavily pustulate as shown by the scanning micrograph (Plate 22, Figure 1). The heavy calcareous wall is perforate, with pore openings of up to 10 microns in diameter. The surface is pustulate. Individual, elongate, distally blunt to pointed pustules occur above the more finely pustulate portion of the flattened apertural face. These pustules fuse along their bases, and in the course of growth from four-to-sixsided angular compartments each with a deeply set wall pore in its center. This polygonal meshwork is welldeveloped on the first and second chambers of the final whorl. The maximum diameter of the final whorl of the holotype is about 400 microns, its maximum axial height about 435 microns. The specimen coils to the left. It is illustrated on Plate 22, Figure 1, and comes from Hole 62.1, Core 30, Section 1, 15-17 centimeters; Zone N. 15.

\section{Remarks}

Globoquadrina altispira conica, n. subsp., is not a common form, although it may occasionally occur in floods as in Hole 62.1 Core 30, Section 1, 15-17 centimeters, Zone N. 15. It differs from the spirally more rounded, globose Globoquadrina altispira altispira (Cushman and Jarvis), 1936, by the higher almost conical spiral side. In many individuals of Globoquadrina altispira conica the whorls are arranged in angular tiers as seen in lateral view. The height of the trochospiral itself is rather variable within a population. Comparison with Globoquadrina altispira altispira from Hole 62.1, Core 9, Section 3, Plate 38, Figure 1, exhibits for that form a more open umbilicus, almost smooth-walled "teeth" and a finer cancellated surface than in the new subspecies.

\section{Stratigraphic Range}

Globoquadrina altispira conica, n. subsp. has been recorded in Hole 62.1 from Core 29, Section 4 to Core 32 , Section 4 , that is, over a rather short interval of time which goes from the base of Zone N. 16 to Zone N. 14. 
Globoquadrina altispira (Cushman and Jarvis), 1936, forma occlusa

Brönimann and Resig, new forma

We have consistently encountered in the interval from Core 8, Section 3 to Core 39 of Hole 62.1, and from Core 1 to Core 5 of Hole 64.1, that is essentially throughout the occurrence of Globoquadrina altispira altispira (Cushman and Jarvis) from Zone N. 20 (including N. 19) to Zone 6 (probably including N. 5), a smaller, more tightly coiled representative of the altispira group with a more closed umbilical cavity than usually seen in typical Globoquadrina altispira altispira. At this time we consider this slightly different altispira as a mere forma not as a new subspecies of the altispira group. The genus-group Globoquadrina Finlay, 1947, needs revision. It is morphologically a difficult group and the writers experienced serious taxonomic problems when they attempted to distinguish some of the taxa introduced by Akers (1955), Blow and Banner (1962), Bermúdez (1959) and LeRoy (1939). The remarks by Blow $(1969$, p. 339) and by Parker (1967, p. 163,164$)$ on the status of Globoquadrina are cited as evidence of the problematic taxonomy of this genusgroup in which Parker even includes Globorotaloides Bolli, 1957, and "some species which have been referred to Globorotalia, Turborotalia and/or Globigerina by some authors." For these reasons we have used Globoquadrina in its conventional sense as typified by Globoquadrina dehiscens (Chapman, Parr and Collins, 1934) and did not venture into a taxonomic analysis of the genus-group. Blow (1969), however, makes extensive use of the different species of Globoquadrina in his range-charts and also in the zonal definitions. The Globoquadrina dehiscens dehiscens datum plane, characterized by the evolutionary appearance of Globoquadrina dehiscens dehiscens in Hole 64.1, Core 6, Section 4, Zone N. 4, seems to be an important point in time, highly useful in the globigerinacean biochronologic time-scale. According to Blow (1969), the first globoquadrines appear already in Zone N.2, with doubtful forms of Globoquadrina baroemoensis LeRoy, 1939, already in Zone N. 1. The ancestors are so far unknown.

As far as Globoquadrina larmeui Akers, 1955, is concerned, we cannot distinguish it from Globoquadrina dehiscens dehiscens. We examined the holotype of Globoquadrina larmeui in the collections of the U.S. National Museum, and regard it as a small dehiscens-like form, spirally flat, with four chambers in the final whorl, closed umbilicus and a large elongate tooth-like flap covering the aperture. We agree in this point with Parker (1967) who put Globoquadrina larmeui into synonymy with Globoquadrina dehiscens.

\section{Genus Globorotalia Cushman, 1927 \\ Subgenus Globorotalia \\ Cushman, 1927}

Globorotalia (Globorotalia) tumida (Brady)

lata Brönimann and Resig, n. subsp.

(Plate 29, Figure 3; Plate 49, Figures 4 and 5)

\section{Description of Holotype}

The test is small- to medium-sized for the species, strongly tumid and heavy-keeled. The keel of the ultimate chamber in umbilical view is about 50 microns thick. In spiral and umbilical view, its outline is broadly oval. The spiral side is strongly convex and the umbilical side almost flat, excepting for the final chamber which is slightly convex. The trochospire of more than 12 chambers is very tightly coiled in the early portion and development of secondary calcite layers masks the sutures between the first chambers. The last whorl consists of five chambers which rapidly increase in size. The ultimate chamber is about 525 microns wide and almost equals in its largest diameter the width of the test. Its maximum length is about 350 microns. The spiral sutures of the last whorl are slightly depressed and the intercameral sutures between the three last chambers of the final whorl are deeply incised near their axial portion and are virtually even with the chamber surfaces peripherally. The intercameral sutures are more strongly curved on the spiral side and almost radial on the umbilical side, where they are strongly incised. The umbilical side shows five chambers, rapidly increasing in size, separated by a narrow but deep umbilicus. The umbilicalextra umbilical aperture is a low, elongate opening covered by a strongly pustulate, thick plate-like lip with a denticulate margin 125 microns in length and 100 microns maximum width. The ventral portions of the early chambers and the keel of the first and second chambers of the ultimate whorl are strongly pustulate. The heavy walls are calcareous, perforate and the spiral surface of the chambers pustulate, with the exception of the ultimate and penultimate chambers which are less pustulate on the spiral side. The holotype is from Hole 62.1, Core 4, Section 3, $15-17$ centimeters, Zone N. 22. The specimen coils to the left. It is illustrated on Plate 29, Figure 3. Its maximum width is 550 microns and its maximum length 115 microns. Its axial height is about 360 microns.

\section{Remarks}

Globorotalia (Globorotalia) tumida lata, n. subsp., differs by its tangentially wide end-chamber from Globorotalia tumida tumida (Brady), 1877, and by its tumid, heavy-keeled test from the representatives of the cultrata group. The paratype, Plate 49 , Figures 4 and 5 , has a maximum diameter of 600 microns. The specimen coils to the right. It possesses a lip with strong, 
pointed, elongate pustules which extend perpendicularly from its margin; also the umbilical pustules are strong and pointed. The maximum diameters of paratypes range from about 620 to 800 microns.

\section{Stratigraphic Range}

Globorotalia tumida lata, n. subsp., occurs only over the very short interval from the lower part of Zone N. 22 to the base of N21.

\section{Genus Globorotalia Cushman, 1927 Subgenus Turborotalia Cushman and Bermúdez, 1949}

Globorotalia (Turborotalia) acostaensis Blow tegillata Brönnimann and Resig, n. subsp.

(Plate 33, Figures 3, 6, 7, and 10)

\section{Description of Holotype}

The medium-sized test is a flat trochospire consisting of at least 12 subglobular chambers with five chambers in the final whorl. The early chambers increase rapidly, those of the final whorl only gradually and the ultimate chamber is slightly smaller than the penultimate one. The chambers of the final whorl in spiral view are tangentially slightly larger than radially with the exception of the ultimate one which is about equidimensional. The cameral and the spiral sutures are well defined and depressed, and the outline of the test is therefore lobate in spiral and umbilicate views. The early cameral sutures are oblique, whereas those between the chambers of the final whorl are radial. In lateral view the spiral side is virtually flat and the final chambers somewhat displaced ventrally; the umbilical side is faintly concave. The chambers are not compressed in axial direction. In umbilical view, five chambers are visible; the fifth is partially masked by a large tegilla, as shown by the scanning micrograph (Plate 33, Figure 3). The tegilla starts as a strong peripheral lip and, toward the umbilicus, develops into an angular plate covering most of the umbilicus, which is about 120 microns in diameter. The tegillate umbilical coverying is densely but finely pustulate in its central portion. Its maximum diameter is about 100 microns. The corners of the umbilical plate extend into the sutural depressions. They are tangentially-wide end-chamber from Globorotalis tumida tumida (Brady), 1877, and radially directed. The aperture is a low umbilical-extraumbilical arch of about a 15 -microns height covered in its umbilical portion by the strong tegilla. The wall is calcareous, perforate, and the surface is pustulate. The scanning micrograph of the umbilical side shows strong, pointed, individual pustules in the vicinity of the umbilicus on the early chambers of the final whorl. On the other portion of the surface, the pustules are fused in their basal portions, blunt, and form polygonal walls around the deeply set poral openings of the 2- to 4-micron diameter. The ventral side of the penultimate chamber exhibits details of the pustular structures. As in the case of Globorotalia (T.) pseudopumilio Brönnimann and Resig, n.sp., and Globorotalia (T.) planespira Brönnimann and Resig, n. sp., here also the pustules are made up of small elements or "crystallites" discernible as clearer points on the darker background of the scanning micrograph. The maximum diameter of the holotype is about 355 microns. The specimen coils to the right, and is illustrated on Plate 33 , Figure 3 . It is from Hole 62.1, Core 15, Section 1, 15-17 centimeters, Zone N. 18.

\section{Remarks}

Globorotalia (T.) acostaensis tegillata, n. subsp., differs from Globorotalia acostaensis acostaensis Blow, 1959, as typified by Blow (1969, pl.9, fig. 13-15), by the umbilical tegilla which in well-preserved individuals covers not only the axial cavity but may extend into the umbilical sutural depressions. Globorotalia (T.) acostaensis tegillata occurs stratigraphically first in Hole 62.1 at the base of Zone N. 16, whereas typical representatives of Globorotalia (T.) acostaensis acostaensis appear in Hole 62.1 for the first time in the uppermost part of Zone N. 16. The tegillate subspecies is the older form from which the non-tegillate subspecies seems to have evolved by reduction of the tegilla into a thick rim-like lip, as exhibited by the holotype of Globorotalia (T.) acostaensis acostaensis. The evolutionary sequence from Globorotalia (T.) acostaensis tegillata to Globorotalia acostaensis acostaensis seems to be fairly well-established, as in our material transitional forms are well represented. Parker (1967) has figured a series of the tegillate subspecies as Globoquadrina acostaensis (Blow) on Plate 24, Figures $3,5,6,7$ and 8 . These figures show the tegilla in extreme modification, masking not only the umbilicus but extending deeply into the radial umbilical sutures. The number of chambers in the final whorl varies in Parker's specimens from 4 to 6 . This variation is also found in our paratypes of Globorotalia (T.) acostaensis tegillata. We believe that Parker's (1967) individual illustrated on Plate 24, Figures 10 and 11, referred by her to Globoquadrina humerosa (Takayanagi and Saito), represents Globorotalia (T.) acostaensis tegillata. A questionable individual of the new subspecies seems to be also illustrated by Parker's (1967) Plate 25, Figure 4, also placed by her in Globoquadrina humerosa. It should be noted that the tegilla of Globorotalia (T.) acostaensis tegillata is morphologically an umbilical-sutural extension of the apertural lip and not a development of an isolated tooth-like structure, as in known to occur in Globorotalia (T.) dutertrei and in Globorotalia (T.) acostaensis humerosa as shown by the scanning micrograph Plate 33, Figure 1. Such tooth-like structures, if fused, would not form a simple extension of the rim of the final aperture but a structure of spiral nature following from one 
aperture to the next one. Paratypes of Globorotalia (T.) acostaensis tegillata coil randomly. Maximum diameters of seven paratypes from Core 15, Section 1, and Core 16, Section 1, range from about 200 to 400 microns.

\section{Stratigraphic Range}

Globorotalia (T.) acostaensis tegillata, n. subsp., has been recorded in Hole 62.1, questionably from the base of Zone N. 20 (including N. 19), certainly from the base of Zone N. 18 down to the base of Zone N. 16. It is well-developed in Zones N. 17 and N. 16. This species is the marker for the base of Zone N. 16 .

Globorotalia (Turborotalia) cifellii

Brönnimann and Resig, n. sp.

(Plate 42, Figure 1-9)

\section{Description of Holotype}

The very small-sized test is a spirally flat trochospire of about 12 chambers with 5 chambers in the last whorl which first slowly then rapidly increase in size as added. The early chambers of the trochospire are masked by secondary shell material and strong pustules. The cameral sutures on the spiral and umbilical sides are radial and broadly incised, recalling those of Globigerina ciperoensis angulisuturalis Bolli, 1957. Between the ultimate and the penultimate chamber, the suture is about 8 microns wide. The outline, as seen in dorsal and ventral view, is lobate. The subglobular chambers are somewhat flattened on the dorsal and convex on the ventral side, and pointed toward the small umbilicus. The aperture is a very small, low, umbilical-extraumbilical arch, which does not reach the periphery of the test. It is similar to that of Globorotalia (T.) nkbrowni Brönnimann and Resig, n. sp. It is provided with a slightly protruding, small plate-like lip with coarsely pustulate margin. Aperture and lip are shown in detail by the scanning micrographs, Plate 42 , Figures 4, 6, 7 and 9. The calcareous wall is perforate and the surface is strongly pustulate. The scanning micrograph of the umbilical side of the holotype exhibits relatively large pores of 2 to 3 microns in diameter which are surrounded by numerous minute pustules. From this minutely pustulate surface protrude irregularly distributed much larger, blunt to pointed pustules of 5 to 9 microns in diameter. These larger pustules are composite formations. Some of the larger pustules may fuse and develop short, more or less continuous ridges as shown by the scanning micrograph of a paratype, Plate 42, Figure 1. The maximum diameter of the holotype is 125 microns; its axial height about 75 microns. The specimen coils to the right. It is from Hole 64.1, Core 7, Section 2, Zone N. 3. The holotype is illustrated on Plate 42, Figures 2 and 3. The species is named for R. Cifelli, Smithsonian Institution, Washington, D. C., U.S.A.

\section{Remarks}

By its small, low, arched umbilical-extraumbilical aperture and its strongly pustulate surface, and by the wide sutural depressions, Globorotalia (T.) cifellii, n. sp., differs from all other small turborotaliids. Paratypes from Hole 64.1, Core 7, Section 2 range in maximum diameter from about 100 to 175 microns. Most of them coil to the right.

\section{Stratigraphic Range}

In Hole 64.1, Globorotalia (T.) cifellii, n. sp., has been recorded in Core 7, Sections 2 to 4, Zone N. 3, where it is accompanied by Globorotalia (T.) nkbrowni Brönnimann and Resig, n.sp., Globorotalia (T.) pseudokugleri Blow, 1969, and Globigerinita boweni Brönnimann and Resig. n. sp.. These three species are restricted to the intervals indicated above.

Globorotalia (Turborotalia) incisa

Brönnimann and Resig, n. sp.

(Plate 45, Figures 5 and 7; Plate 46, Figures 1 through 8)

\section{Description of Holotype}

The medium-sized test is a low, tightly coiled trochospire of about 12 chambers which increase rapidly in size and change in the course of growth from a tangentially to a radially elongate, or at least equidimensional, subglobular shape. The early chambers form a slightly elevated but not pointed trochospire. There are four chambers in the final whorl. The spiral and cameral sutures of the final whorl are strongly incised, but narrow, cutting each chamber clearly from its neighboring chambers. Hence the outline of the test, as seen in spiral view, is only slightly lobate almost to nonlobate. At the intersections of cameral and spiral dorsal sutures, there occur rather deep but narrow depressions but no supplementary sutural apertures. The cameral sutures are radial on both the umbilical and the spiral side. The radial intercameral suture between ultimate and penultimate chambers is virtually a continuation of the spiral suture separating the final chamber from the preceding coil. This characteristic is nearly the same for the intercameral sutures between penultimate and antepenultimate and between antepenultimate and ante-antepenultimate chambers, which is probably the reason, together with the deep incision of the suture, why the chambers of the final whorl break off so easily. In lateral view, the chambers are peripherally broadly rounded and at least the ultimate and penultimate ones somewhat compressed in axial directions. In umbilical view the chambers are pointed toward the deep and small umbilicus, of about 15 microns diameter, which is large enough to expose a portion of the aperture of the penultimate chamber. The final aperture is a low umbilical-extraumbilical arch, about 10 to 20 microns high, with a distinct but narrow and thick-walled rim-like border which, as 
shown on the scanning micrographs, Plate 46 , Figures 1 and 8 , is pustulate. The wall is calcareous, of heavy appearance, perforate, and its surface is densely pustulate. The umbilical pustules on the early chambers are heavier than those on the later ones, and pointed to bluntly rounded. The pustules which coalesce into funnel-like compartments around the deeply set pores, seem to be composed of smaller units as described for Globorotalia (T.) planispira Brönnimann and Resig, n.sp., and Globorotalia (T.) pseudopumilio Brönnimann and Resig, n. sp. The maximum diameter of the holotype is 275 microns; its axial height is 175 microns. The specimen is illustrated on Plate 46, Figure 1. It is from Hole 62.1, Core 8, Section 3, 15-17 centimeters, Zone N. 20 (including N. 19).

\section{Remarks}

The number of chambers in the final whorl varies from 3.5 to 5 in paratypes of Globorotalia (T.) incisa n. sp. The small individuals with 3.5 to 4 chambers in the final whorl are tightly coiled, those with five chambers show a tendency to coil less tightly. The final chamber(s) in large forms break(s) off easily along the deeply incised cameral and spiral sutures. The pustulate surface and the general morphology place Globorotalia (T.) incisa, in the vicinity of Globorotalia (Turborotalia) obesa Bolli, 1957, illustrated by scanning micrographs, Plate 50, Figures 7 and 8 , from which it differs by the tight coiling of the trochospire, the deeply incised cut-like sutures, the less obese shape of the final chambers, and the different surface structure. Also, the aperture of Globorotalia (T.) obesa is considerably larger than that of Globorotalia (T.) incisa.

Globorotalia (T.) incisa seems to be related to Globorotalia (Turborotalia) pseudopachyderma Cita, PremoliSilva and Rossi, 1965, which shows throughout a tightly coiled test with 4 chambers in the final whorl. It is illustrated by the scanning micrograph, Plate 45 , Figure 8. The final chamber is, in contrast to that of Globorotalia (T.) incisa, strongly oppressed and normally smaller than the penultimate chamber. The apertural features are identical in both species. Due to the more tight mode of coiling, the radial sutures of Globorotalia (T.) pseudopachyderma appear to be less deeply cut than those of Globorotalia (T.) incisa, but they are still distinct and sharply defined. On the ultimate chamber of paratypes of Globorotalia (T.) incisa, Plate 46, Figures 2, 3, 4, 5 and 6, the large pointed to bluntly pointed pustules are irregularly distributed and fairly widely spaced. In between the larger pustules occur numerous minute ones. The larger pustules are axially "canaliculate" as can be seen on the scanning micrograph, Plate 46 , Figure 4 . The detail of the specimen, Plate 46, Figure 3, illustrated on Plate 46, Figure 7, suggests that the minute pustules are in fact short spines. Also the larger pustules of
Globorotalia (T.) pseudopachyderma are "canaliculate". The outer wall formations of pachyderma and incisa are identical, suggesting the genetic relationship of the two forms. Globorotalia (T.) pseudopachyderma and Globorotalia (T.) incisa are clearly closely allied and associated in most samples of the interval Zone N. 20 (including N. 19), to Zone N. 18, that is, in Hole 62.1 from Core 8, Section 3 to Core 13, Section 4. The maximum diameter of topotypes of Globorotalia (T.) incisa ranges from about 150 to 375 microns. The direction of coiling of paratypes is random.

\section{Stratigraphic Range}

Globorotalia (T.) incisa occurs first in Zone N. 20 (including Zone N.19), where it is common to abundant, and it extends down to Zone N. 18, generally less frequent than in Zone N. 20 (including Zone N. 19), that is in Hole 62.1 from Core 8 , Section 3 to Core 14, Section 1.

Globorotalia (Turborotalia) nkbrowni

Brönnimann and Resig, n. sp.

(Plate 40, Figures 1 through 8)

\section{Description of Holotype}

The very small-sized test is a low trochospire of more than 10 chambers with 6 chambers in the last whorl. The initial portion of the trochospire is masked by secondary shell substance, almost flat, and slightly depressed in respect to the two last chambers of the final whorl. The chambers of the last whorl increase rapidly in size and tend to move toward the umbilical side. In lateral view the subglobular chambers are broadly rounded peripherally. The umbilicus is minute and deep. The cameral sutures are radial on the spiral and the umbilical side, and well incised. The aperture is a low arch extending from the umbilicus toward the periphery. It is bordered by a narrow rim. The calcareous perforate wall is thin, and its surface, devoid of a polygonal meshwork, is pustulate. The pustules are low-rounded, composite structures. They are of different size, almost touch each other and seem to be interconnected by radial walls. The wall pores are minute openings in the narrow spaces between the pustules and are separated by the radiating walls. This type of outer wall formation has also been found in Globigerinita boweni Brönnimann and Resig, n. sp. A particular feature of the holotype of Globorotalia (T.) knbrowni is the single sutural opening which occurs on the spiral suture separating the ultimate chamber from the penultimate whorl. This secondary aperture measures about 5 microns across. It is bordered by a strong, pustulate rim of about 3 microns thickness.

The maximum diameter of the holotype is about 100 microns; its axial height about 40 microns. It is from Hole 64.1, Core 7, Section 2, 33-35 centimeters, Zone N.3. The holotype is illustrated on Plate 40, Figure 2. It coils to the left. 
This species is named for the late Noël King Brown, Jr., Houston, Texas, U.S.A.

\section{Remarks}

Paratypes typically show 5 to 7 , normally 6 , chambers, which gradually increase in size, in the final whorl as added. Coiling is random. The maximum diameter varies around 100 microns. These specimens are, in general morphology, close to Globorotalia (Turborotalia) gemma Jenkins, 1965, which according to Blow (1969) extends from P. 16 to the lower part of Zone N. 1, whereas Globorotalia nkbrowni, n. sp., has been recorded only in Zone N. 3. The surface of Globorotalia (T.) gemma, as illustrated by the scanning micrograph (Blow, 1969, pl. 34, fig. 9) of the spiral side of a specimen from Zone P. 19, Lindi area, Tanzania, is sparsely pustulate and the dorsal radial sutures are oblique. The specimen lacks a secondary opening on the dorsal side. Paratypes of Globorotalia (T.) knbrowni invariably exhibit this secondary opening. By the outer formation and by the secondary opening Globorotalia (T.) knbrowni differs from all other minute turborotaliids.

\section{Stratigraphic Range}

Globorotalia (T.) nkbrowni, n. sp., has been recorded in Hole 64.1, Core 7, Sections 2 to 4, Zone N. 3, where it is accompanied by Globorotalia (T.) cifellii and Globorotalia (T.) pseudokugleri Blow.

\section{Globorotalia (Turborotalia) palpebra \\ Brönnimann and Resig, n. sp. \\ (Plate 3, Figure 3) \\ Description of Holotype}

The small-sized low trochospire consists of more than 8 subglobular chambers, with four in the final whorl. The initial portion of the trochospire is not pointed and the earliest chambers are masked by secondary shell substance. The chambers of the final whorl increase gradually in size. They are axially compressed. Spiral and radial sutures are well incised. This gives the test a lobate outline in spiral and umbilical view. In lateral view, the umbilical side is almost flat. The final chamber, seen umbilically, is slightly elongate in a radial direction. The aperture extends from the shallow umbilicus to an extraumbilical, peripheral position. The apertural wall is drawn out in a slightly arched thin-walled, peripherally somewhat upturned pustulate lip. The surface of the thin walls are covered by widely spaced large, pointed, "canaliculate" isolate pustules which show in places a tendency to fuse laterally without formation of a distinct polygonal meshwork. The walls are perforated by large and widely spaced wall pores, and in between the pores occur pinpointlike openings. The maximum diameter of the holotype is about 180 microns. The specimen coils to the right.
It is from Hole 62.1, Core 6, Section 5, 15-17 centimeters; Zone N. 21, and is illustrated on Plate 3, Figure 3.

\section{Remarks}

By its thin, relatively sparsely pustulate and perforate walls, the thin lid-like strongly pustulate lip, the "canaliculate" pustules, the globorotaliid aperture and the axially compressed chambers of the final whorl, Globorotalia (Turborotalia) palpebra, n. sp., can be easily distinguished from forms such as Globigerina falconensis Blow, 1959, which is heavier, has a thicker lip, an umbilical aperture and a polygonal surface structure. Globorotalia (T.) palpebra is, in its surface structure, close to the globigerines which occur in Hole 62.1, from Core 1, Section 2 to Core 5, Section 2, that is from Zone N. 22 to Zone N. 21, illustrated by text-figure 4 under the name of Globigerina aff. $G$. falconensis Blow. Also these forms are characterized by a sparse pustulation, devoid of polygonal structures. Paratypes of Globorotalia (T.) palpebra coil to the right.

\section{Stratigraphic Range}

Globorotalia (T.) palpebra has been recorded in Hole 62.1 from Core 4 , Section 6 to Core 15 , Section 5, that is from the base of Zone N. 22 to the top of Zone N. 17. The ranges of Globigerina aff. G. falconensis and of Globorotalia (T.) palpebra overlap slightly.

\section{Globorotalia (Turborotalia) parkerae}

Brönnimann and Resig, n. sp.

(Plate 43, Figures 7 and 10; Plate 47, Figures 4 and 6; Plate 48, Figures 2 and 3)

\section{Description of Holotype}

The very small test consists of about 12 to 13 chambers arranged in a flat trochospire with 5 chambers in the final whorl. The early subglobular chambers increase very slowly in size as added; those of the final whorl, however, increase rapidly, and at the same time they start to become more and more elongate in a radial direction. The final chamber is about 75 microns long and about 50 microns wide and makes up half of the maximum diameter of the test. This long chamber of bulbous appearance clearly dominates the test. Whereas the minute initial chambers, which are not radially elongate, on the spiral side are separated by oblique sutures, those of the final whorl are separated by radial, well-incised sutures, so that the chambers of the final whorl are well separated peripherally and produce a lobate outline of the test. The sutures on the umbilical side are radial and well incised. In lateral view, the chambers of the final whorl are distinctly compressed in an axial direction. In umbilical view, the chambers extend into the shallow and small umbilicus. The aperture is an umbilical-extraumbilical arch with a 
distinct thin-walled plate-like lip with a faintly pustulate border. The wall is calcareous, thin, almost transparent in stratigraphically young individuals, and, under the light microscope, of a brilliant appearance. As shown by the scanning micrographs (Plate 43, Figure 7) the surfaces of the first three chambers are finely pustulate in the vicinity of the umbilicus. The ultimate chamber also shows small pustules on the plate-like lip and on the apertural face above the lip. The surface of the umbilical side is very finely granular, and a few pinpoint-like wall pores can be detected toward the apertural face. The maximum diameter of the holotype is about 150 microns, and its maximum axial height is about 60 microns. The holotype, illustrated on Plate 43, Figure 7, is from Core CAP HG 41, 0-1 centimeter. The specimen coils to the left. The species is named for Frances L. Parker, Scripps Institution of Oceanography, La Jolla, who kindly donated the material.

\section{Remarks}

The early stage of Globorotalia (T.) parkerae, n. sp., recalls the coiling as seen in Globorotalia (Turborotalia) pumilio Parker, 1962, described from the Recent of CAP $41 \mathrm{HG}, 0-1$ centimeter. The adult stage of Globorotalia (T.) parkerae develops the characteristic elongate chambers and the lobate outline of the test and is quite different from Globorotalia (T.) pumilio Parker, 1967 (Pl. 18, fig. 5 a-c). We have figured this species by a scanning micrograph of a topotype, Plate 48, Figure 1. The holotype of Globorotalia (T.) parkerae originates from the same sample as the holotype of Globorotalia (T.) pumilio. The maximum diameter of paratypes of Globorotalia (T.) parkerae from CAP HG 41, 0-1 centimeter, ranges from about 100 to 160 microns. In the material from Hole 62-1, most of the individuals referred to as Globorotalia aff. Globorotalia (T.) parkerae exhibit similar morphologic features as the holotype and the paratypes of Globorotalia (T.) parkerae. As shown by the scanning micrographs, Plate 48, Figures 5, 6 and 7, the radial elongation of the final chamber is less than that shown by Globorotalia (T.) parkerae. In addition, the walls are less transparent and are perforated by rather large, round, irregularly distributed wall pores, which seem to be absent in Globorotalia (T.) parkerae. The aperture of Globorotalia aff. Globorotalia (T.) parkerae does not seem to have the plate-like lip. The surface of the walls is brilliant to dull and, besides the perforations, possesses also distinct rounded pustules which are particularly well developed on the ultimate and penultimate chambers. The early chambers of the final whorl show only a very few perforations and no pustules. It seems that perforations and pustules are morphologically interdependent. The morphologic differences between Globorotalia (T.) parkerae and Globorotalia aff. Globorotalia (T.) parkerae as exhibited by the scanning micrographs, may perhaps suggest that the latter should be taxonomically separated from Globorotalia (T.) parkerae. The maximum diameter of specimens of Globorotalia aff. Globorotalia (T.) parkerae from Hole 62.1, Core 3, Section 2, Bottom sample, ranges from about 70 to 150 microns, which agrees well with the maximum diameters measured of Globorotalia (T.) parkerae. The comparison of the scanning micrographs of Globorotalia aff. Globorotalia (T.) parkerae, with those of Globorotalia (Turborotalia) anfracta Parker, 1967, from Hole 62.1, Core 3, Section 2, Bottom samples, Plate 43, Figures 2, 3 and 6 , shows a different test morphology but similar irregularly distributed large rounded pores. Similar perforations occur also on Globigerina microfoliata Brönnimann and Resig, n. sp., Plate 6, Figures 4, 5 and 6, and Plate 43, Figure 1, and on Globigerina aff. Globigerina quinqueloba Natland, 1938, Plate 43, Figures 8 and 9 , both of which have been encountered in the same sample from which we described Globorotalia aff. Globorotalia (T.) parkerae and Globorotalia (T.) anfracta (pl. 43, fig. 2, 3,6). We do not think that these affinities are accidental, but rather that they reflect a related genetic make-up which cannot be expressed by our actual and admittedly artificial taxonomic system. We refer to a similar suggestion regarding the grouping proposed for the representatives of the species Globigerinita glutinata (Egger), 1893. Globorotalia (T.) parkerae clearly differs in its outline, characterized by the strongly radially elongate final chamber, from Globorotalia (Turborotalia) neominutissima Bermúdez and Bolli, 1969, with its more rounded-lobate outline, described from the Pliocene Cumana Formation, Estado Sucre, Venezuela (Bermúdez and Bolli, 1969, pl.13, fig. 10-12). According to the description, Globorotalia (T.) neominutissima is a small species, the maximum diameter of the holotype measures about 210 microns, and the wall is strongly pustulate. The aperture, to judge from the illustration, however, is more umbilical-extraumbilical than peripheral as in Globorotalia (T.) parkerae, Globorotalia aff. Globorotalia (T.) parkerae, and Globorotalia (T.) anfracta. This feature combined with the umbilically overhanging final chamber places Globorotalia (T.) neominutissima rather in the neighborhood of Globigerina quinqueloba Natland or perhaps Globigerina multiloba Romero, 1965.

\section{Stratigraphic Range}

Globorotalia aff. Globorotalia (T.) parkerae, n. sp., has been recorded in Hole 62.1 from Zone N. 23 to the upper part of Zone N.20, that is from Core 1, Section 1 to Core 7 , Section 5 . 
Globorotalia (Turborotalia) planispira

Brönnimann and Resig, n. sp.

(Plate 36, Figures 4 and 6; Plate 44, Figures 1, 2, 3 (?), $4,5,7$ and 8 )

\section{Description of Holotype}

The small test of about 12 to 13 chambers forms a dorsally flat trochospire with 5 chambers in the final whorl. The outline of the test both in dorsal and ventral view is subcircular. The chambers increase gradually in size as added with the exception of the ultimate chamber which is smaller than the penultimate one and slightly displaced toward the umbilical side. The chambers are tangentially longer than radially, at least the 3 to 4 final ones. The penultimate chamber is about 100 microns in tangential and about 75 microns in radial direction, measured in spiral view. They are distincly compressed in axial direction and spirally more flattened than umbilically. Peripherally they are broadly rounded. The well-incised cameral sutures are oblique on the spiral side throughout most of the ontogeny and radial on the ventral side. The initial coil is very slightly depressed in respect to the chambers of the final whorl. The umbilical side shows the chambers of the final whorl enclosing a deep and small axial cavity of about 20 microns diameter. The aperture is a low slit extending from the umbilicus to the periphery beneath a thick-walled, pustulate platelike lip of about 10 microns maximum width. The calcareous wall is perforate and its surface pustulate. Over the early umbilical portion of the test the pustules become rather prominent and pointed. The scanning micrograph, Plate 44, Figure 4, shows that the larger, rounded, blunt pustules, forming funnel-like polygonal compartments around the depressed widely spaced small wall pores, are composed of numerous smaller units. The specimen coils to the right. The maximum diameter of the holotype is about 240 microns, its axial height about 125 microns. It is illustrated on Plate 44, Figure 4. It is from Hole 62.1, Core 6, Section 5, 15-17 centimeters, lower part of Zone N. 21.

\section{Remarks}

The characteristic features of Globorotalia (T.) planispira, n. sp., are the consistently flat trochospire, the tangentially wide chambers of the final whorl, the slight umbilical displacement of the final chamber, which is usually smaller than the penultimate one, the prominent apertural plate-like rim, and the composite pustules and interconnecting polygonal walls. All examined paratypes coil to the right. The new species is associated almost throughout its range with Globorotalia (T.) pseudopumilio Brönnimann and Resig, n. sp. In a paratype illustrated on Plate 44, Figure 2, a supplementary spiral aperture occurs at the intersection of the suture between the ultimate and penultimate chambers with the spiral suture. Besides the supplementary dorsal aperture of about 20 microns maximum width, it exhibits an irregular subglobular chamber covering part of the initial, flattened coil. The supplementary aperture is surrounded by an almost smooth, slightly rounded, imperforate border. The apertural surface above the lip is also imperforate and covered with small individual pustules. Rounded wall pores start to occur immediately above the point where they are surrounded by fused large, bluntly rounded, composite pustules. A linear surface pattern created by aligned small pustules occurs radiating toward the secondary aperture. This radiating pattern is also discernible on the ultimate chamber of the specimen illustrated by the scanning micrograph of a side view, Plate 44, Figure 5. Also, the paratype illustrated by the scanning micrograph, Plate 44, Figure 1, exhibits, on the umbilical side, the radiating linear surface pattern. The maximum diameter of paratypes, including the questionable form, ranges from about 130 to 250 microns. Globorotalia (T.) planispira is similar to Globorotalia (T.) pseudopumilio Brönniman and Resig, n. sp., in the multiple pustules, the flattened and occasionally somewhat depressed initial coil, the aspect of the perforations, but differs from Globorotalia (T.) pseudopumilio mainly in the dorsally flattened chambers of the final whorl, in the umbilically displaced final chamber, in the subcircular outline as seen in dorsal view and in the absence of "canaliculate" pustules.

\section{Stratigraphic Range}

Globorotalia (T.) planispira, n. sp., occurs in Hole 62.1 from the lower part of Zone N. 22 to the middle part of Zone N. 20 (including N. 19), that is from Core 4, Section 1 to Core 10 , Section 4 .

\section{Globorotalia (Turborotalia) pseudopumilio}

Brönnimann and Resig, n. sp.

(Plate 43, Figures 4 and 5)

\section{Description of Holotype}

The very small test consists of about 11 to 12 chambers arranged in a flat trochospire with 5 subglobular chambers in the final whorl. The chambers of the initial whorl are minute and increase only little during growth. The five chambers of the final whorl are much larger than the previously formed ones and they increase gradually in size. In spiral view, the initial whorl is somewhat depressed in respect to the chambers of the final whorl. The early sutures are oblique, those between the chambers of the final whorl are ventrally and dorsally more or less radial and well incised so that the contour of the test is lobate. The chambers of the final whorl, which are either not compressed or only very slightly compressed in an axial direction, are equidimensional in a tangential and radial direction, as seen in spiral view. The ultimate chamber is about 85 microns in radial diameter. The height of the final chamber is about 80 microns. The umbilical side shows a deep but small umbilicus of about 15 
microns diameter. The aperture is an umbilicalextraumbilical arch, higher toward the periphery than toward the umbilicus. In side view the aperture is about 50 microns wide and is bordered by a narrow, thin-walled plate of 5 to 10 microns width. The calcareous wall is perforate and covered irregularly with bluntly rounded pustules of differing diameters which may fuse to form polygonal walls around the wall pores, of less than 1 to about 2 microns diameter, which are in the centers of low, funnel-like depressions. Scanning micrographs (Plate 43, Figures 4 and 5) exhibit pustules which are composites of numerous small units (crystallites) or small pustules. Some of them possess pinpoint-like openings in which fine spines rooted in the living specimens. The maximum diameter of the holotype is about 187 microns, its axial height about 100 microns. The specimen coils to the right. It is illustrated on Plate 43, Figure 6 and comes from Hole 62.1, Core 6, Section 5, 15-17 centimeters, lower part of Zone N. 21.

\section{Remarks}

In respect to gross morphology Globorotalia (T.) pseudopumilio, n. sp., seems to be related to Globorotalia (T.) pumilio Parker, 1962, which however is smaller, has at least six chambers in the final whorl, 5.5 to 7 according to Parker (1962, p. 238, pl. 6, fig. 2, 3), a brilliant, smooth surface and strongly oblique cameral sutures on the spiral side. The chambers of the final whorl of Globorotalia (T.) pumilio do not increase as rapidly in size, and the low-arched aperture is much smaller than in Globorotalia (T.) pseudopumilio. Furthermore, Parker's species has a more rounded outline than Globorotalia (T.) pseudopumilio which is rather elongate in spiral and umbilical outline.

Topotypes of Globorotalia (T.) pumilio from CAP HG 41, 0-1 centimeter, kindly donated by Frances L. Parker, with maximum diameters of about 125 to 150 microns, are rounded-lobate in spiral and umbilical outline, have a smooth brilliant surface, and an opaque wall. The specimens have 6 to 7 chambers in the ultimate whorl. The scanning micrograph (Plate 48, Figure 1) of the umbilical view of a specimen from CAP HG-41, 0-1 centimeter, permits the addition of the following morphologic data to Parker's excellent description:

The specimen, which coils to the left, possesses six chambers in the final whorl. The radial cameral sutures are well-incised and produce the lobate outline. The umbilicus is small-about 3 to 4 microns in diameterand deep. The aperture is a low elongate arch extending from the umbilicus toward the periphery without reaching it. There does not seem to be a discrete apertural rim. The surface of the chambers is minutely granular, almost smoothly brilliant, and toward the umbilical depression is covered by individual, minute pustules which are somewhat stronger on the oldest chamber of the final whorl than on the ultimate chamber. The topotypes are spirally rather flat and not convex as already mentioned by Parker (1962), and they correspond rather well with Parker's illustrations published in 1967 (pl. 18, fig. 5 a-c). In this aspect Globorotalia (T.) pumilio and Globorotalia (T.) pseudopumilio are very similar.

The height of the trochospire of paratypes of Globorotalia (T.) pseudopumilio ranges considerably. The initial coil, although always flattened, may be either depressed or slightly elevated in respect to the subglobular chambers of the final whorl. The maximum diameter of the paratypes is around 200 microns. The number of chambers of the final whorl varies from 5 to 7. The direction of coiling of holotype and paratypes is to the right. Globorotalia (T.) pseudopumilio is associated almost throughout its range with Globorotalia (T.) planispira Brönnimann and Resig, n.sp., with which it has the multiple pustules in common.

\section{Stratigraphic Range}

Globorotalia pseudopumilio, n. sp., has been recorded in Hole 62.1 from the lower part of N. 22 to the middle part of N. 20 (including N. 19), Core 4, Section 1 to Core 10 , Section 5 .

Globorotalia (Turborotalia) riedeli

Brönnimann and Resig, n. sp.

(Plate 41, Figure 1-4)

\section{Description of Holotype}

The very small turborotaliid is a low trochospire of more than 12 chambers with 5 chambers in the last whorl. The outline of the test is elongate-subcircular and more or less lobate in spiral and umbilical views. In side view, the initial portion of the test is spirally strongly convex and raised as a minute obtuse cone over the level of the chamber surfaces of the final whorl. The chambers of the last whorl increase rapidly in size so that the ultimate chamber together with the penultimate chamber about equals in size the preceding portion of the test. The chambers of the final whorl are flattened on the dorsal side and strongly convex on the ventral side. The cameral and spiral sutures of the final whorl are well-incised, those of the early trochospire are masked by secondary shell substance. The intercameral sutures between the chambers of the last whorl are oblique on the spiral side and radial on the ventral side. The umbilicus is very small. The umbilicalperipheral interiomarginal aperture is an elongate, low-arched opening with an imperforate border which can be faintly differentiated from the apertural face. The calcareous walls are coarsely perforate, and the umbilically directed surfaces of the early chambers of the final whorl and the imperforate region of the apertural face just above the apertural border are 
covered with irregularly distributed, irregular-sized, blunt to pointed individual pustules. On the spiral side low, rounded probably composite pustules are still detectable on the surfaces of the early chambers of the initial cone of the trochospire. On the chambers of the final whorl, they are completely incorporated in the heavy unstructured walls surrounding the large wall pores. There is no longer any clear polygonal meshwork. Under the light microscope, the wall surface seems to be non-pustulate, smooth, and the large, widely spaced wall pores, which on the early coil measure up to 6 microns across, represent the dominant wall formation. The maximum diameter of the wall pores of the dorsal side of the final chamber is about 3 microns. The wall pores are in funnel-shaped depressions of small diameter. The walls are not transparent. The maximum diameter of the holotype is about 175 microns, its maximum axial height about 125 microns. It is illustrated on Plate 41, Figure 4. The specimen coils to the left. It is from Hole 62.1, Core 32, Section 1, 15-17 centimeters; Zone N. 14. The new species is named for W. R. Riedel, Scripps Institution of Oceanography, La Jolla, California.

\section{Remarks}

Globorotalia riedeli, n. sp., differs in its outer wall formation, by its small raised central cone, and by its usually plano-convex morphology from all other small turborotaliids encountered in Hole 62.1. It seems to be represented by a plexus of forms related by the same outer wall formations but somewhat differing in the development of the initial raised cone. Together with the form as typified by the holotype, Plate 41 , Figure 4, and also by a paratype, Plate 41, Figure 2, there exist more lobate specimens which are flat or even depressed over the center of the trochospire. Such a specimen is illustrated on Plate 41, Figure 1. In spiral view, the related but slightly more elongate and less lobate turborotalias, with the same outer wall formations but possessing chambers with a subacute periphery, as seen in side view, have also been referred to Globorotalia (T.) riedeli. Paratypes from Hole 62.1, Core 32, Section 1, 15-17 centimeters, Zone N. 14, with raised central cone and lobate outlines, corresponding well in outer wall formation and wall pores, with the holotype, have maximum diameters from 112 to 175 microns. Detailed scanning microscope observation of surface and apertural features of stratigraphically successive forms may prove that this group of minute turborotalias could perhaps be further subdivided. The more elongate, flat forms were first believed to be small representatives of Globorotalia (T.) siakensis LeRoy, 1939. Examination of specimens of Globorotalia (T.) siakensis in the collections of W. H. Blow by one of the writers (P.B.) however has shown that Globorotalia (T.) riedeli is not only much smaller than typical Globorotalia (T.) siakensis but also lacks the characteristic "comma"-shaped aperture of the siakensis group of forms. The outer wall formations are also completely different in Globorotalia (T.) siakensis as illustrated on Plate 35, Figures 1 through 8. Another turborotaliid species, Globorotalia (Turborotalia) minutissima Bolli, 1957, in its general morphology, but not in its outer wall formations, resembles somewhat the peripherally more rounded individuals of Globorotalia (T.) riedeli. Globorotalia (T.) minutissima ranges from Zone N.9 to Zone N.16, and hence overlaps typical Globorotalia (T.) riedeli in Hole 62.1. According to Blow (1969, p. 352), Globorotalia (T.) minutissima seems to be particularly common in cold-water areas, such as the Vienna Basin, Italy and California. In Hole 62.1, this species has tentatively been recorded in Core 39, Zone N. 13. Other small turborotaliids which come close to Globorotalia (T.) riedeli are Globorotalia (Turborotalia) postcretacea (Myatluk), 1953, and Globorotalia (Turborotalia) permicra Blow and Banner, 1962. However, both of these species have different apertural features, recalling the "comma"-shaped aperture of the siakensis group, and different outer wall formations. In addition, Globorotalia (T.) postcretacea has a translucent or transparent test, a feature never observed in Globorotalia (T.) riedeli.

\section{Stratigraphic Range}

Globorotalia (Turborotalia) riedeli, n. sp., extends, in its typical development, from Zone N. 14 to Zone N. 13 of Hole 62.1. Apparently related forms, listed as Globorotalia (T.) aff. G. (T.) riedeli, have been recorded from Zones N.7/N.8 to Zone N. 3 of Hole 64.1.

\section{Genus Orbulina d'Orbigny, 1839}

Orbulina universa (d'Orbigny) parkerae

Bronnimann and Resig, n. subsp.

(Plate 45, Figures 1 through 4)

\section{Description of Holotype}

The large-sized test consists of two subglobular chambers of which the penultimate is distinctly smaller than the ultimate. The ultimate chamber envelops about one half of the penultimate one. The calcareous wall of the penultimate chamber is uniformly perforate and, as shown by the scanning micrographs of the surface of the ultimate chamber (Plate 45, Figure 3), it is densely perforated by deeply-set small wall pores and irregularly distributed larger wall pores of about 150 micron maximum diameter. The suture between the two chambers is distinct, but neither depressed nor incised, and without the larger perforations. The surface of the walls is covered by blunt pustules which, according to the scanning micrographs-Plate 45, Figures 3 and 4, are composed of smaller crystalline units. The maximum diameter of the test is 680 microns, that of the penultimate chamber is 390 microns, and that of the ultimate chamber is 570 microns. The holotype is 
illustrated by Plate 45, Figure 2. It is from Hole 62.1, Core 14, Section 5, 15-17 centimeters, Zone N. 18. The new subspecies is named for Frances L. Parker, Scripps Institution of Oceanography, La Jolla, California.

\section{Remarks}

Orbulina universa parkerae, $\mathrm{n}$. subsp., is usually united with Orbulina universa bilobata d'Orbigny, 1846 (=Biorbulina bilobata (d'Orbigny)) in the same taxon.

A different stratigraphic range, however, suggests that Orbulina universa parkerae represents a distinct subspecies of Orbulina universa s.l. It appears after Orbulina universa bilobata, and is here interpreted as an evolutionary off-shoot of bilobata. Parker (1967, pl. 22, fig. 8) illustrated the new subspecies which she recorded in the Recent, whereas the bilobate individual, illustrated by her Plate 22 , Figure 7 , is considered as a Miocene form only. Parker suggested to us that the "pinched" bilobate orbuline may be different from the symmetric bilobata. The asymmetry between the ultimate and the penultimate chambers of Orbulina universa parkerae is variable, but the differentiation of the new subspecies from Orbulina universa bilobata does not present difficulties.

\section{Stratigraphic Range}

Orbulina universa parkerae, n. subsp., has been recorded in most samples from Hole 62.1, Core 8, Section 4 to Core 29, Section 4, that is, from Zone N. 20 (including N. 19) down to the base of Zone N. 16. Orbulina universa bilobata occurs in Hole 62.1, from Core 11, Section 2 to the base of Core 35, that is, from the lower part of Zone N. 20 (including N. 19) to Zone N. 13. The two subspecies therefore overlap in Hole 62.1 from the lower part of N.20 (including N. 19) to the base of N. 16. Orbulina universa parkerae extends higher in Zone N.20 (including N. 19) then universa bilobata.

\section{Genus Pulleniatina Cushman, 1927}

Pulleniatina praepulleniatina

Brönnimann and Resig, n. sp.

(Plate 20, Figures 1 through 6, and 8; Text-figure 13)

\section{Description of Holotype}

The large-sized test is a dorsally flattened, ventrally more or less convex trochospire of about 14 chambers in about 2.5 whorls, with 6 chambers in the final whorl. The chambers of the earliest portion of the trochospire are not individually discernible. The three final chambers of the last whorl progressively show onlap onto the chambers of the previous whorl, suggesting the beginning of a dorsally involute coiling. Simultaneously they become elongate in an axial direction as in Pulleniatina spectabilis spectabilis
Parker, 1965, and in Pulleniatina spectabilis praespectabilis Brönnimann and Resig, n. subsp. However, they do not cover, through the cameral sutures, the well-defined angularly contoured deep umbilical cavity of about 50 microns maximum diameter. As in Pulleniatina spectabilis praespectabilis, also in the holotype of Pulleniatina praepulleniatina, the ultimate chamber does not extend as far ventrally as the penultimate and antepenultimate chambers. In spiral view, the outline of the test is somewhat lobate, at least in the portion formed by the last four chambers. The radial cameral and the spiral sutures of the final whorl are incised. Those of the earliest portion of the trochospire are not discernible because they are masked by secondary shell material. The ventral cameral sutures are radial. In lateral view, the outline of the test is broadly rounded peripherally, flat to faintly depressed dorsally and asymmetrically convex-rounded ventrally.

In the beginning of the trochospire, the chambers are subglobular. During growth of the final whorl, they become more and more elongate in an axial direction, show onlap dorsally and extend ventrally. These ontogenetic modifications of chamber form and arrangement are accompanied by a slight change in the coiling direction of the test from a turborotaliid to a very slightly streptospiral trochospire. The aperture is an umbilical-extraumbilical slit-like opening of about 25 microns height which extends from the umbilicus up to the shoulder of the first chamber of the last whorl. The aperture of the holotype shows, in its peripheral portion, a strong rounded rim, reminiscent of that observed in Globorotalia (Turborotalia) acostaensis acostaensis Blow, 1959 (1969, pl. 9, fig. 13-15) and Globorotalia (Turborotalia) acostaensis humerosa Takayanagi and Saito, 1962. The calcareous wall is perforate and the surface of the early chambers distinctly pustulate. The surface of the three last chambers, however, is progressively more finely pustulate and approaches the surface structure as seen on the early chambers of the last whorl of primitive pulleniatines, such as, Pulleniatina primalis Banner and Blow, 1967. The pustules are composite and form through basal and lateral fusion a well-developed polygonal meshwork. Each funnel-shaped compartment surrounds a deeply set rounded wall pore. The holotype of Pulleniatina praepulleniatina coils to the right.

The maximum diameter of the holotype is 275 microns; its axial height is about 300 microns. The specimen is illustrated on Plate 20, Figures 2 and 3 . It comes from Hole 62.1, Core 21, Section 4, 15-17 centimeters, Zone N. 17, basal portion.

\section{Remarks}

Pulleniatina praepulleniatina, n. sp., is the most primitive pulleniatine described so far. It develops apparently from the Globorotalia (Turborotalia) acostaensis 
humerosa-Globorotalia (Turborotalia) acostaensis acostaensis group of forms at the base of Zone N. 17. In Hole 62.1, Globorotalia (Turborotalia) acostaensis humerosa starts in the middle of Zone N. 17, Globorotalia (Turborotalia) acostaensis acostaensis in the upper part of Zone N. 16 and intermediates between these subspecies, from which Pulleniatina praepulleniatina might evolve, are quite common. Transitional forms have been recorded in Hole 62.1, Core 15, Sections 1 to 3 , in Core 14, Sections 1, 2, 5 and 6, in Core 13, Section 2 and in Core 12, Section 5. All the paratypes from Hole 62.1, Core 21, Section 4, 15-17 centimeters, Zone N. 17 coil to the right. Pulleniatina primalis Banner and Blow, 1967, recorded in Hole 62.1 from Core 20 , Section 2 to Core 6 , Section 4 is here interpreted either as a direct descendant of Pulleniatina praepulleniatina or as a parallel development from the acostaensis acostaensis-acostaensis humerosa group of forms, independently of Pulleniatina praepulleniatina.

Pulleniatina primalis has a smoother surface and pustules on the ventral surface of the first chamber of the last whorl in front of the aperture. The chambers of the final whorl here extend much farther ventrally than in Pulleniatina praepulleniatina, where the umbilical cavity also remains open in the adult. Pulleniatina praepulleniatina is, in any case, more turborotaliid than Pulleniatina primalis. On the other hand Pulleniatina primalis is always evolute dorsally, whereas Pulleniatina praepulleniatina shows in the last chambers of the final whorl a slight tendency toward dorsal involution. In its general aspect, outline and wall surface, Pulleniatina primalis is closer to the later streptospiral typical pulleniatines than Pulleniatina praepulleniatina. Reference is made to Banner and Blow's (1967) description of the holotype of Pulleniatina primalis and their illustrations on Plate 1, Figures 3 through 8 and Plate 3 , Figures 2a-c. We have illustrated several paratypes of Pulleniatina praepulleniatina on Plate 20, Figures 1 through 6 and 8 ; of the five individuals illustrated, four coil to the right and one to the left. The ventral extension of the final chambers and their tendency to overlap dorsally is quite variable, as is also the strength of the lip-like imperforate rim. The placing of some of the individuals either in the Globorotalia (Turborotalia) acostaensis acostaensis-Globorotalia (Turborotalia) acostaensis humerosa group of forms or in Pulleniatina praepulleniatina will clearly depend on the observer's taxonomic judgement.

The maximum diameter of paratypes varies from about 350 to 415 microns, the maximum height is from about 250 to 300 microns.

\section{Stratigraphic Range}

Pulleniatina praepulleniatina, $\mathrm{n} . \mathrm{sp}$. , has been recorded from Hole 62.1, Core 12, Section 4 to Core 22, Section 3, that is, from near the base of Zone N. 17 to
Zone N. 20 (including N. 19). In the interval from Core 10, Section 6, to Core 12, Section 3, doubtful specimens of Pulleniatina praepulleniatina have been observed.

Pulleniatina spectabilis praespectabilis

Brönnimann and Resig, n. subsp.

(Plate 19, Figures 4 and 7)

Synonymy

1965. Pulleniatina semiinvoluta Germeraad-Parker, text-figure 5 , non 6 .

1967. Pulleniatina sp. ex interc. primalis Banner and Blow, n. sp. spectabilis Parker-Banner and Blow, Plate 2, Figure 1 a-c.

\section{Description of Holotype}

The large-sized test is a spirally slightly, umbilically strongly convex trochospire having six chambers in the final whorl. The total number of chambers is greater than 11. The exact number is difficult to determine because of the masking of the early trochospire by shell material. The outline, as seen from the spiral and from the umbilical side is slightly lobate in the early portion of the final whorl. This lobation disappears in the final two chambers. We refer to Banner and Blow's illustration of an apertural view (1967, pl. 2, fig. 1b) which shows that the ultimate chamber does not extend umbilically completely over the penultimate one. The dorsal cameral sutures are somewhat oblique in the early portion of the test and virtually radial between the last three chambers. In lateral view, the test shows the slightly convex dorsal surfaces of the chambers of the final whorl, the rounded convex early portion of the test, and the strong ventral convexity formed by the ventrally extended and axially overlapping chambers. There is no carina nor pseudocarina in the sense of Parker (1967), but a rounded to subrounded peripheral shoulder. The umbilical view exposes the strong axial overlapping of the penultimate chamber which closes any umbilical depression that might have existed before the addition of the penultimate chamber. The ultimate chamber does not extend over the axial portion of the test, hence it is ventrally much shorter than the penultimate chamber. The aperture is a large interiomarginal opening extending from the umbilicus almost to the periphery of the test. Its length is about 275 microns, and its height about 50 microns. The calcareous wall is thick, about 50 to 75 microns at the aperture, and the surface is smooth excepting near the aperture where the surface of the fourth and fifth chamber of the final whorl is distinctly pustulate umbilically. The holotype of Pulleniatina spectabilis praespectabilis coils to the left. The maximum diameter of the holotype is 625 microns. Its axial height is about 500 microns. It is from Hole 62.1, 
Core 12, Section 4, Zone N. 20 (including N. 19). The specimen is illustrated on Plate 19, Figures 44 and 7.

\section{Remarks}

Pulleniatina spectabilis praespectabilis differs from Pulleniatina spectabilis spectabilis Parker, 1967, by the well-rounded, not pinched-rounded, shoulders of the chambers of the last whorl as illustrated on Plate 19, Figures 4 and 7 (pseudocarina of Parker, 1967, p. 179) and by the convex-rounded initial portion of the trochospire as seen in lateral view. The ultimate chamber of Pulleniatina spectabilis spectabilis extends ventrally farther over the penultimate chamber (Parker, 1965, text-fig. $1 \mathrm{a}-\mathrm{c}$; Banner and Blow, 1967, pl. 2, fig. $2 \mathrm{a}-\mathrm{c})$. In other morphologic aspects the two subspecies are similar. We are here restricting the usage of Pulleniatina spectabilis spectabilis to those forms as illustrated by Parker (1965, text-fig. 1 a-c, 2; 1967 , pl. 28, fig. $2 \mathrm{a}-\mathrm{c}$ ) and by Banner and Blow (1967, pl. 2, fig. $2 \mathrm{a}-\mathrm{c}$ ) which show the distinctly pinched periphery. Pulleniatina spectabilis spectabilis has a very short range in Hole 62.1, from Sections 4 to 6 of Core 11 only. It seems to represent the final evolutionary development of Pulleniatina spectabilis praespectabilis which occurs shortly after the evolutionary inception of Sphaeroidinella dehiscens immatura (Cushman), 1919. This agrees well with Parker's remark (1965, p. 151) that the range of Pulleniatina spectabilis spectabilis can be placed quite precisely, at the same time, or shortly after the appearance of Sphaeroidinella dehiscens. In Hole 62.1 it occurs shortly after the first appearance of Sphaeroidinella dehiscens immatura, in Section 6 of Core 12. Pulleniatina spectabilis praespectabilis appears before Pulleniatina spectabilis spectabilis and, in the writers' opinion, is ancestral to Pulleniatina spectabilis spectabilis which has been recorded in Hole 62.1 only in Core 11, Sections 4 to 6 , Zone N. 20 (including N. 19), where it is associated with the subspecies spectabilis praespectabilis. According to Banner and Blow (1967) and to Parker (1967), Pulleniatina spectabilis spectabilis evolved from Pulleniatina primalis Banner and Blow, 1967. This seems to be quite possible in view of the earlier beginning of the morphologically affine Pulleniatina primalis in the lower to middle part of Zone N. 17, Hole 62.1, Section 2 of Core 20. Parker's remark (1967, p. 174) that untypical specimens of Pulleniatina spectabilis occur in LSDH $78 \mathrm{P}$ for about 200 centimeters above the base of Zone N. 19 (here included in Zone N.20) concerns most probably Pulleniatina spectabilis praespectabilis.

\section{Stratigraphic Range}

Pulleniatina spectabilis praespectabilis occurs in Hole 62.1 from Core 11, Section 2, to Core 18, Section 3, Zone N. 20 (including N. 19) to Zone N. 17, middle part.

\section{Genus Turborotalita Blow and Banner, 1962}

Turborotalita primitiva Brönnimann and Resig, n. sp. (Plate 26; Figures 5 through 9)

\section{Description of Holotype}

The very small-sized test is a very low tightly coiled trochospire of about twelve chambers with five chambers in he final whorl. The spiral and the umbilical sides are slightly convex. The trochospire is flat over its initial portion. The outline, as seen in spiral and in umbilical view is broad-elliptic. Ultimate and penultimate chambers are weakly lobate. This is reminiscent of the much stronger radial extension of the final chamber(s) in Turborotalita humilis (Brady), 1884, (Banner and Blow, 1960, pl. 8, fig. 1; Parker, 1967, pl. 17, fig. 10). The chambers of the last whorl increase gradually in size. They are distinctly compressed in axial direction. The cameral spiral sutures on the dorsal and the cameral sutures on the umbilical side are not incised. The cameral sutures are radial on both sides of the test. The sutures of the early coil are barely discernible. The umbilicus is partially covered by an extension of the ultimate chamber which opens with an elongate slit-like umbilical aperture with a pustulate margin. There seems to be no apertural rim or umbilical bulla. In the umbilical depression the aperture of the penultimate chamber is also visible. The thick calcareous wall is perforate and the surface pustulate. The umbilical side of the ultimate chamber exhibits very few and widely spaced wall pores. The surface between the pores is finely granular. A very few large irregularly shaped pustules of up to 6 microns in diameter occur on this finely pustulate surface. The surface of the two last-formed chambers are more strongly pustulate than are those of the earlier chambers (scanning micrograph Plate 26, Figure 7). This characteristic can also be seen in Turborotalita humilis (Brady), 1884. The blunt pustules on the umbilical side of the early chambers surround the deeply set openings of pores. The pustules seem to be composite formations. Peripherally large isolated pustules produce a finely and irregularly denticulate outline, typical of turborotalitids. The maximum diameter of the holotype is about 125 microns; its axial height about 75 microns. The specimen coils to the right. It is from Hole 64.1, Core 7, Section 2, 33-35 centimeters, Zone N. 3 and is illustrated on pl. 26 , fig. 7 .

\section{Remarks}

Turborotalita primitiva, n.sp., is the oldest turborotalitid from which Turborotalita humilis possibly derived. Turborotalita primitiva, n.sp., differs from Turborotalita humilis and from Turborotalita cristata (Heron-Allen and Earland), 1929, by the more tightly coiled trochospire, by the less lobate outline as seen in spiral view, by the less depressed sutures and by the smaller ultimate chamber, which does not extend over 
the umbilical depression into the cameral sutures. Turborotalita primitiva possesses a single slit-like primary aperture whereas Turborotalita humilis and Turborotalita cristata develop multiple tunnel-like apertures in sutural positions. The final chamber has been called "bulla-like" by Banner and Blow (1960, p. 36-37), however is in fact a normal chamber which simply extends over the umbilicus into the radial sutural depressions. These extensions are also shown in Blow's illustration (1969, p. 51, fig. 4) of an individual called Turborotalita cf. T. humilis (Brady) from Zone N. 17 (probably middle part), Kefallinia, Greece. We do not consider this chamber to be a homologue of a bulla as developed by adult individuals of Globigerinita. Blow (1969, p. 373) also referred Globigerina quinqueloba Natland, 1938, to the genus Turborotalita. This may be correct but needs corroboration. Forms described by Parker (1967, pl. 18, fig. 13-14) as Globigerina cf. G. quinqueloba Natland, are without any doubt turborotalitids. Paratypes of Turborotalita primitiva from Core 7, Section 2 of Hole 64.1 show random coiling. The maximum diameter of paratypes ranges from about 100 to 125 microns. Several paratypes are illustrated on Plate 26 by scanning micrographs of the ventral side which show the same apertural features as were described for the holotype, and the same outer wall formations. According to Blow $(1969$, p. 373$)$, the earliest turborotalitids occur within the lower parts of Zone N. 17. We have recognized forms referable to Turborotalita down in Zone N. 3, however, we did not distinguish them specifically on the range chart of Hole 64.1.

\section{Stratigraphic Range}

Turborotalita primitiva, n. sp., seems to be the earliest representative of the Turborotalita genus-group. Its range has not been established. It has been recorded in Hole 64.1, Core 7, Sections 2 to 4 , Zone N. 3 .

Genus Streptochilus Brönnimann and Resig, n. gen.

Type species: Bolivina tokelauae Boersma, 1969. Kierstead, C. H. et al., Procedings First International Conference Planktonic Microfossils. (P. Brönnimann and H. H. Renz, Eds.), 2, p. 329, pl. 1, fig. 1.

Test biserial, sometimes twisted; wall calcareous perforate; aperture a high arch, eccentric in position, extending from the base of the last chamber onto the apertural face. On the outside margin, a collar borders the aperture. Near the base of the inside margin, the collar and apertural edge are turned inward, producing a plate-like connection with the proximal margin of the collar of the previous aperture. The length of the test varies between 75 and 300 microns.
Geologic range: Lower Miocene-Recent.

Remarks: This genus probably evolved from Chiloguembelina, which it resembles, through infolding of the inner margin of the aperture. In view of its apparent close affinity to Chiloguembelina, the rather simple modification of the interior does not seem to warrant exclusion of this genus from classification within the Heterohelicidae. No tooth plates, such as characterize the Bolivinitidae, occur in members of this genus, and no stage of development other than biserial was observed in any specimens assigned to this taxon.

The generic name is derived from streptos, Gr., twisted, + cheilos, Gr., lip, denoting the change to an inward directed lip.

Streptochilus tokelauae (Boersma) 1969

(Plate 51, Figure 1)

Bolivina tokelauae Boersma. Kierstead, C.H., et al., 1969 , p. 329 , pl. 1 , fig. 1.

Although assigned to the genus Bolivina, this species was considered as possibly planktonic by the author and her fellow workers (Kierstead, op. cit.) who cited its resemblance to Chiloguembelina and association in planktonic assemblages. They reported the species in equatorial Pacific cores that penetrated the upper Pliocene and recorded fluctuations in its abundance in Zones N.21-N.23, and its absence in the upper 100 centimeters or so of the cores.

Material from DSDP Hole 62.1 and from $\mathrm{C}^{14}$-dated Recent sediment samples from the surface of the Ontong Java Plateau has established the range of Streptochilus tokelauae as Lower Pliocene (lower N. 19)-Recent. As noted by the previous investigators, the species fluctuates in abundance and at times is absent from the stratigraphic section entirely.

Length of specimens in DSDP samples and those from the Ontong Java Plateau ranges from 75 to 300 microns.

\section{Streptochilus globigerum (Schwager) 1866}

(Plate 51, Figure 2)

Textilaria globigera Schwager. Schwager, C., 1866, p. 252, pl. 7, fig. 100. Chiloguembelina globigera (Schwager). Srinivasan, M. S., and Sharma, V., 1969, p. 100 .

Specimens of Schwager's species from Car Nicobar, kindly supplied by M.S. Srinivasan, are identical with the DSDP specimens. Srinivasan's (1969) material is of late Miocene (N. 18) age and therefore falls within the upper range of the species at DSDP Site 62.1. The total 
range of $S$. globigerum at that site is middle Miocene (upper N. 13)-lower Pliocene (lower N. 19), with only rare, sporadic occurrences in the upper Miocene from mid N. 16 through mid N. 17.

Chambers of $S$. globigerum are more globose than in other members of the genus and the test is visibly rugose rather than smoothly perforate as in the other species. The aperture, however, is typical of the genus.

Test length of the species is 115 to 265 microns.

\section{Streptochilus latum Brönnimann and Resig, n. sp.} (Plate 51, Figure 3)

Test biserial, increasing rapidly in breadth; chambers semi-inflated, wider than high, with sutures sloping towards the periphery and flexed shallowly toward the mid-line of the later chambers; aperture a high arch from the base of the last septal face, offset to one side of the test with a collar at the outer margin and the opposite margin inturned to form a connection to the collar of the penultimate aperture; wall smooth, porous.

Length of holotype 242 microns, maximum breadth of holotype 137 microns; range of length of the species is $100-244$ microns, maximum breadth is 150 microns.

Age of holotype is late Miocene (Zone N. 17); geologic range of species is late Miocene mid-Zone N. 16 to mid-Zone N. 17.

Location of holotype is DSDP Hole 62.1 on the Eauripik Rise $\left(1^{\circ} 52.2^{\prime} \mathrm{N}, 141^{\circ} 56^{\prime} \mathrm{E}, 2591\right.$ meters), from a core depth of about 187 meters. Additional specimens of this species were noted in a spot sample from Zone N. 17 of the Ontong Java Plateau (DSDP Hole 64.0, Core 3).

This species is distinguished from other members of the genus by its rapidly expanding test.

Streptochilus pristinum Brönnimann and Resig, n. sp. (Plate 51, Figure 4)

Test biserial, with no chamber inflation in the early stage, and with slight inflation of the later chambers; aperture a narrow high arch with a collar at the outer margin and the opposite margin inturned to form a ramp to the collar of the previous aperture; wall smooth, porous.

Length of holotype 180 microns, maximum breadth of holotype 76 microns; length of the species ranges from 125 to 250 microns, maximum breadth is 100 microns.

Age of the holotype is middle Miocene (N. 13); age range of the species is lower Miocene (N.4)-middle Miocene (Lower N. 15).
Location of holotype is DSDP Hole 62.1 on the Eauripik Rise $\left(1^{\circ} 52.2^{\prime} \mathrm{N}, 141^{\circ} 56^{\prime} \mathrm{E}, 2591\right.$ meters) from a core depth of about 325 meters. At this location, the species ranges only down into the middle Miocene (upper N. 13). Older specimens occur in strata of the Ontong Java Plateau, Hole $64.1\left(1^{\circ} 44.5^{\prime} \mathrm{S}, 158^{\circ}\right.$ $36.5^{\prime} \mathrm{E}, 2052$ meters; core depth 460 meters).

This species differs from others of the genus in the straight lateral profile of the early portion of the test followed by the tendency toward inflation of the later chambers.

\section{b) Taxonomic Notes}

In this chapter we mainly describe skeletal formations such as "pustules", "wall-pores", and their distributional patterns as seen in the scanning micrographs of the outer wall surface of globigerinaceans from Holes 62.1 and 64.1. The descriptions of the outer wall formations, as we will call them, have to be kept in general terms because our knowledge of the original and recrystallized ultrastructures of the globigerinacean wall is not adequate to propose a well-founded morphologic terminology for the details of these complex formations. Work on the ultrastructure of the walls of Recent foraminifera is in progress in many laboratories and these studies will eventually furnish the elements for this new terminology. Wherever possible we have added scanning microscope data on the apertural features. Here also well-defined morphologic terms are lacking. The taxonomic significance of the outer wall formations is as yet not clearly understood. Before the introduction of the scanning microscope, they were either referred to in very general terms or almost completely ignored in morphologic description; and, in the present classification systems of the Globigerinacea they do not play any significant role. Hence detailed morphologic investigations need to be undertaken to evaluate the morphologic significance of the outer wall formations and to relate them with existing taxa, in particular of generic and suprageneric rank. In the writers' opinion, the outer wall formations have a direct morphologic relationship with the systematically paramount ultrastructure of the foraminiferal wall. The different types of "pustules" and of "wall pores", the presence or absence of "spines", the form of "spines", the distributional pattern of "pustules" and "wall pores", the distribution of "perforate" and "imperforate" areas-that is, everything that traditionally had been lumped together as "ornamentation"might better outline genetically related groups of forms than the gross morphology of the test alone. In any case, the combination of gross morphologic features and minute outer wall formations might eventually lead to a more natural system of the Globigerinacea than that established by any one of these groups of morphologic elements alone. The taxonomic notes in form of a catalogue of observations on outer wall 
formations are a contribution to such a systematic study. They are restricted essentially to non-carinate Globigerinacea.

In most cases, the scanning micrographs of the outer wall surfaces permit only a rather superficial qualitative description. This is naturally inadequate for the purpose of comparison and will have to be supplemented in the course of future work by measurements (dimensions, pore/surface ratio, pustule/surface ratio, etc.). The morphologic analysis of the outer wall formations will have to go into much finer details than was possible in our present work, by using the scanning microscope to the limit of its resolution.

As we are dealing almost exclusively with fossil tests with diagenetically more or less recrystallized walls and outer wall formations, morphologic features may have been secondarily changed. Such changes are in most cases difficult to evaluate or to detect. Strong recrystallization seems to enlarge "pustules" and polygonal walls, as well, and at the same time to reduce "wall pores" or the funnel-like openings of the polygonal meshwork around the "wall pores". Secondary shell thickening added in the course of growth (instars in the sense of Smout) or caused by environmental factors (cold water) often occur to such an extent that the chamber surface becomes completely masked and does not permit any statement concerning the original wall formations and the sutures. This masking effect occurs throughout the Globigerinacea by deposition of secondary shell material in the course of growth and naturally is more evident on the early portion of the trochospire than on the chamber surfaces of the final whorl. This situation will have to be considered in studying the modifications of the chamber surfaces in the course of ontogeny. The umbilical portion of the trochospire enclosed by the later whorl(s) will be closer to the original surface texture than its spiral side. In many cases we were unable to distinguish between a minute "pustule", that is a discrete original skeletal formation, and a "crystallite" which may be of secondary nature, and this difficulty may have influenced our interpretation of the surface formations. Also, a "granular" surface may originally have been a smooth surface, as shown by some pulleniatines, or it might be the original surface texture.

Environmental parameters are known to influence at least the thickness of the wall of the globigerinacean test and possibly also its outer wall formations. That is, certain outer wall formations could be of secondary nature, changed, or even created diagenetically or environmentally, and their taxonomic significance would therefore be nil. Diagenesis affects even the ultrastructure of the foraminiferal walls and different types of recrystallization have been shown to occur within the same genus of the Involutinidae (Zaninetti and Brönnimann, in press). We are fully aware of the problems involved in the morphologic study and the interpretation of the outer wall formations, but we are equally aware of their significance in globigerinacean taxonomy and evolution.

Without being able to go into evolutionary details, we may mention that we observed certain surface patterns which seemed to be limited in time and restricted to genetically linked groups of forms, such as the striking pustule-ridge pattern of the turborotaliids of the kugleri group, the individual pustule pattern of the Globorotalia (Turborotalia) cifellii-multiloba group, the tubular pattern created by extension of the wall pores in the Eocene globigerines of the angiporoides group, the individual "canaliculate" pustules in which fine spines rooted in the living forms, and which occur not only in certain globigerines but also in globigerinoids and globorotaliids, the irregularly non-polygonal pustulate pattern combined with a dense perforation as developed in the Globorotalia (Turborotalia) obesaHastigerina s.l. group of forms, the non-polygonal pattern of massive individual pustules of the Globigerinita juvenilis group, the coarse and fine pustule pattern with fine wall pores surrounding the large pustules of the Globorotalia (Turborotalia) incisaGloborotalia (Turborotalia) pseudopachyderma group, the smooth pattern with mudcrack-like crystal boundaries peculiar to the adult pulleniatine wall surface, etc. The evolutionary relationships of these and other surface patterns remain to be studied in detail. It is our opinion that these investigations, combined with those of the ontogenetic changes of the outer wall formations, will eventually lead to a better understanding of the phylogenetic relationships of the generic and suprageneric taxa of the Globigerinacea. As a first taxonomic bonus, the present notes will help to distinguish on morphologic grounds, not only on a time basis, certain taxonomically difficult quasihomeomorphs and, as a second bonus, they may demonstrate that certain evolutionary lineages are well-founded or should be refuted. It is suggested that no evolutionary derivation should be proposed without considering the outer wall formations together with the gross morphology of the test.

\section{Genus Candeina d'Orbigny, 1839}

Candeina nitida nitida d'Orbigny, 1839

(Plate 14, Figures 7 and 8)

Of particular interest in Candeina nitida nitida is the development of a secondary calcite layer(s) either completely covering the original wall pores or leaving very fine pinpoint-like openings leading to the original wall pores. This layering and the different dimensions of the wall pores in older and in younger calcite layers are well illustrated by the scanning micrographs, Plate 14, Figures 7 and 8 , showing the same individual in umbilical and oblique-lateral position. The fine openings on the final wall surface are rare, with 
maximum diameters of less than 1 to 2 microns. The average diameter of the original wall pores is distinctly larger, by about 5 microns. The surface of the walls appears to be finely granular due to abundant tightly spaced minute individual pustules or "crystallites". Further scanning observations are necessary to analyse these minute surface structures. Along the sutures between ultimate, penultimate and antepenultimate chambers, but invariably in the wall of the added chamber, there occur in the adult stage single series of small rounded pores of about 15 microns maximum diameter. These pores are bordered by a relatively thick rim of about 6 microns diameter, composed of imperforate, minute pustules-bearing wall material. This rim is also deposited on the surface of the preceding chamber so that a complete annulus surrounds each opening. In places the deposition of the rim material on the wall of the preceding chamber is only partial. Where it is complete, it produces a groove-like extension of the opening on the surface of the preceding chamber. Blow (1969, pl. 23, fig. 3) has illustrated by a scanning micrograph a sutural opening of Candeina nitida nitida. It shows the finely granular structure of the rim, the minutely granular surface of the preceding chamber wall and the presence of a few pinpoint-like pores. The illustrated specimens are not well enough preserved, however, to furnish all the structural details of the sutural openings.

\section{Genus Globigerina d'Orbigny, 1826}

\section{Globigerina angiporoides Hornibrook, 1965}

\section{(Plate 8, Figures 4 and 5)}

We have identified Eocene globigerinas, illustrated on Plate 8, Figures 4 and 5, as Globigerina angiporoides Hornibrook, 1965. These forms have a straight, thick lip-like plate with strongly pustulate border, which juts out almost at a right angle to the apertural wall of the final chamber ("shelf-like flap" in the description of Blow, 1969, explanations to pl.12, fig. 4,5). The aperture itself is an elongate narrow slit across the umbilical depression. Blow's scanning micrographs (1969, pl. 12, fig. 4, 5) of a specimen of Globigerina angiporoides from Zone P. 19, Lindi area, Tanzania, show the same apertural features. Our specimens correspond well with those figured by Blow, and we agree with Blow (1969, p. 315) that the specimen illustrated in umbilical view by Blow and Banner (1962, pl. XI, fig. H) as Globigerina linaperta linaperta Finlay, 1939, also from the upper Eocene of the Lindi area, Tanzania, represents Globigerina angiporoides.

We have illustrated a spiral and an umbilical view of two specimens of Globigerina angiporoides. The scanning micrograph of the spiral side of a right coiling individual, Plate 8 , Figure 4, represents a slightly oblique view of the surface of the two last-formed chambers. The rounded pores of 4 to 8 microns maximum diameter and well-defined outline are surrounded by numerous very small, blunt pustules. At the polygonal corners there occur slightly larger pustules. The umbilical side of a left coiling specimen is oriented in such a way that the scanning micrograph, Plate 8, Figure 5, displays clearly the outer wall formations of the final chamber. The umbilical aperture, in this view, is almost covered by the plate-like, pustulate lip. The umbilical portion of the three first-formed chambers of the final whorl exhibit strong individual pustulation. On the remainder of the surface 4 to 6 larger, blunt to somewhat pointed pustulesapparently composite structures-and very small pustules, filling the space between the larger ones, surround the deeply set wall pores and form funnel-like polygonal compartments. The umbilical surface of the ultimate chamber is covered by tubular extensions of the pore walls. The tubular walls consist of minute "pustules" or crystallites, and between the tubes there also occur short, blunt, very small "pustules". Such a well-developed tubular extension of the pore walls has been observed only in Globigerina angiporoides although indications of tubular extensions have also been noticed on certain globigerines and globigerinoids. It does not seem to occur in the specimen illustrated by Blow (1969, pl. 12, fig. 4, 5).

Globigerina angiporoides occurs in Hole 64.1, Core 9, Sections 1 and 2, and Core 10, Section 1, Zone P. 16 and Zone P. 14 or older. According to Blow (1969, p. 315) this species ranges from within Zone P. 19 to Zone P. 15.

\section{Globigerina bulbosa LeRoy, 1944}

(Plate 2, Figures 7 and 8)

The scanning micrographs, Plate 2, Figures 7 and 8 , of the apertural side of a right coiling individual of Globigerina bulbosa LeRoy, display an irregular pustulation. This impression is also conveyed by the pustules of the Venezuelan specimens referred by Blow (1969, pl. 13, fig. 5, 6) to Globigerina bulbosa. Enlargements of the surface show that the pustules vary considerably in size; and it is this idfference in height and size of the pustules which creates the impression of irregular outer wall formations. At least the larger pustules are composite structures. They are pointed and higher than the thin, often interrupted, connecting polygonal walls which in places seem to be constructed of small-size pustules or "crystallites". Furthermore, some of the wall pores of the ultimate chamber are lined by annuli of closely spaced, minute postules or "crystallites" which create a low tube-like extension of the pores. Also, in polygonal depressions, there occur smaller individual pustules. The large wide-arched aperture is bordered by a thin-walled, slightly up-turned, imperforate and finely pustulate rim. Globigerina bulbosa is 
never frequent in our samples. It has been recorded in Hole 62.1 from Zone N. 17 to Zone N. 13.

\section{Globigerina bulloides bulloides d'Orbigny, 1826} (Plate 6, Figure 3; Text-figure 5)

Globigerina bulloides bulloides, Plate 6, Figure 3, is characterized by a wide arched umbilical aperture surrounded by a wide imperforate and non-pustulate margin. The surface of this area is finely granular. The individual widely spaced pustules, toward the perforate portion of the ultimate chamber, seem to be "canaliculate". The remainder of the surface is covered by polygonal compartments with wall pores in the low funnel-like depressions. The illustrated specimen is from Zone N. 23 of Hole 62.1.

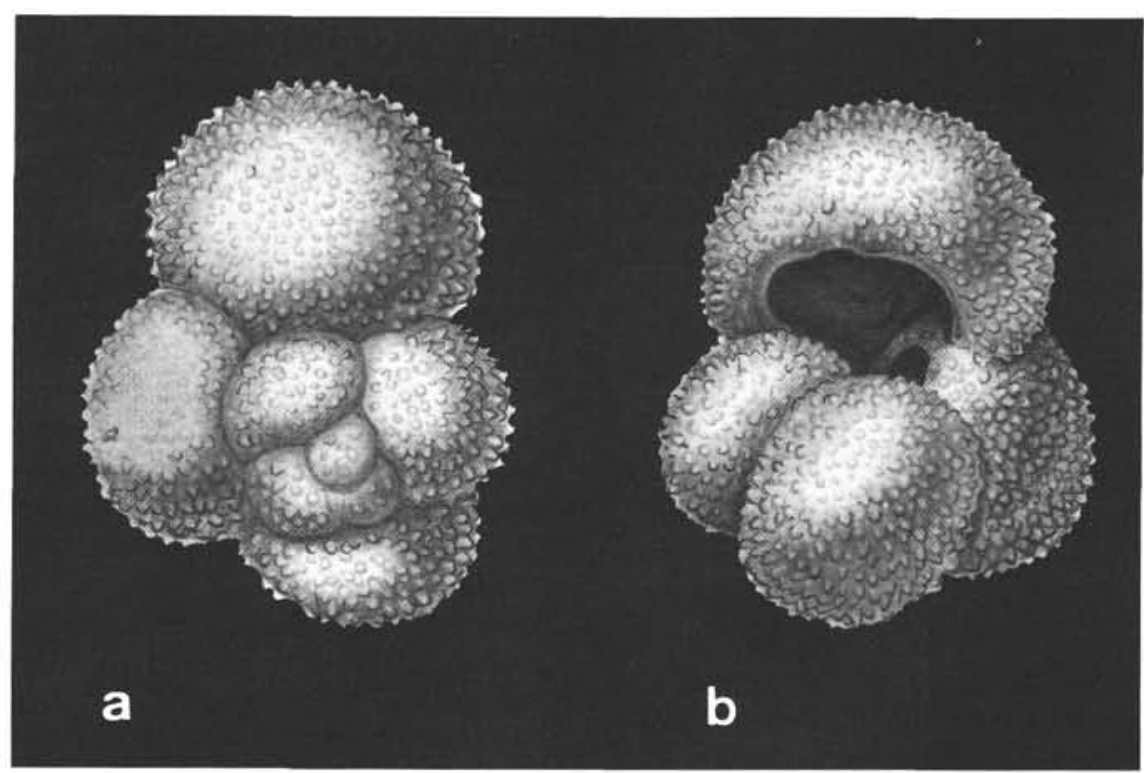

Figure 5. Globigerina bulloides bulloides d'Orbigny, 1826. Hole 64.0, Core 1, Section 4, 15-17 cm; Zone N. 22. 155 X.

Globigerina calida calida Parker, 1962

(Plate 50, Figure 1, 2 and 3)

The characteristic feature of the surface of Globigerina calida calida, Plate 50, Figures 1, 2 and 3, is the densely perforate and irregular and finely pustulate wall. In between the wall pores occur individual larger and smaller pointed pustules, which never coalesce into polygonal compartments. On the earlier chambers of the final whorl the pustules are larger than those on the youngest chambers, and they start to coalesce irregularly around the wall pores. Also, a polygonal pattern is never developed here. Our scanning micrographs, as well as those of Blow $(1969$, pl. 13, fig. 9, 10), are not of sufficient resolution to permit a statement concerning the presence or absence of "canaliculate" pustules.

Globigerina aff. Globigerina ciperoensis ciperoensis Bolli, 1957

(Plate 6, Figure 7)

The outer wall formations of Globigerina, aff. Globigerina ciperoensis, Plate 6, Figure 7 consist of a coarse polygonal meshwork whose walls and corner pustules are made-up of numerous minute elements or "crystallites". In each compartment there is a deeply set rounded wall pore.

\section{Globigerina conglomerata Schwager, 1866}

(Plate 5, Figure 8; Text-figure 6 (?))

The scanning micrograph of the umbilical side of a specimen donated by F. L. Parker, Plate 5, Figure 8, exhibits densely perforate walls, polygonal compartments surrounding the pores and, in the vicinity of the deep and large umbilicus, strong pointed pustules which also are a striking feature of the neotype chosen by Banner and Blow (1960, pl.2, fig. 3a, b). The pustules seem to be devoid of axial "canals". An imperforate, nonpustulate apertural flap is detectable on the scanning micrograph in the umbilical corner between penultimate and antepenultimate chambers. In the description of the neotype, Banner and Blow (1960, p. 70) state, however, that "no apertural lip, rim or tooth is visible on the neotype". The here illustrated large and well-preserved specimen of Globigerina conglomerata with a maximum diameter of 


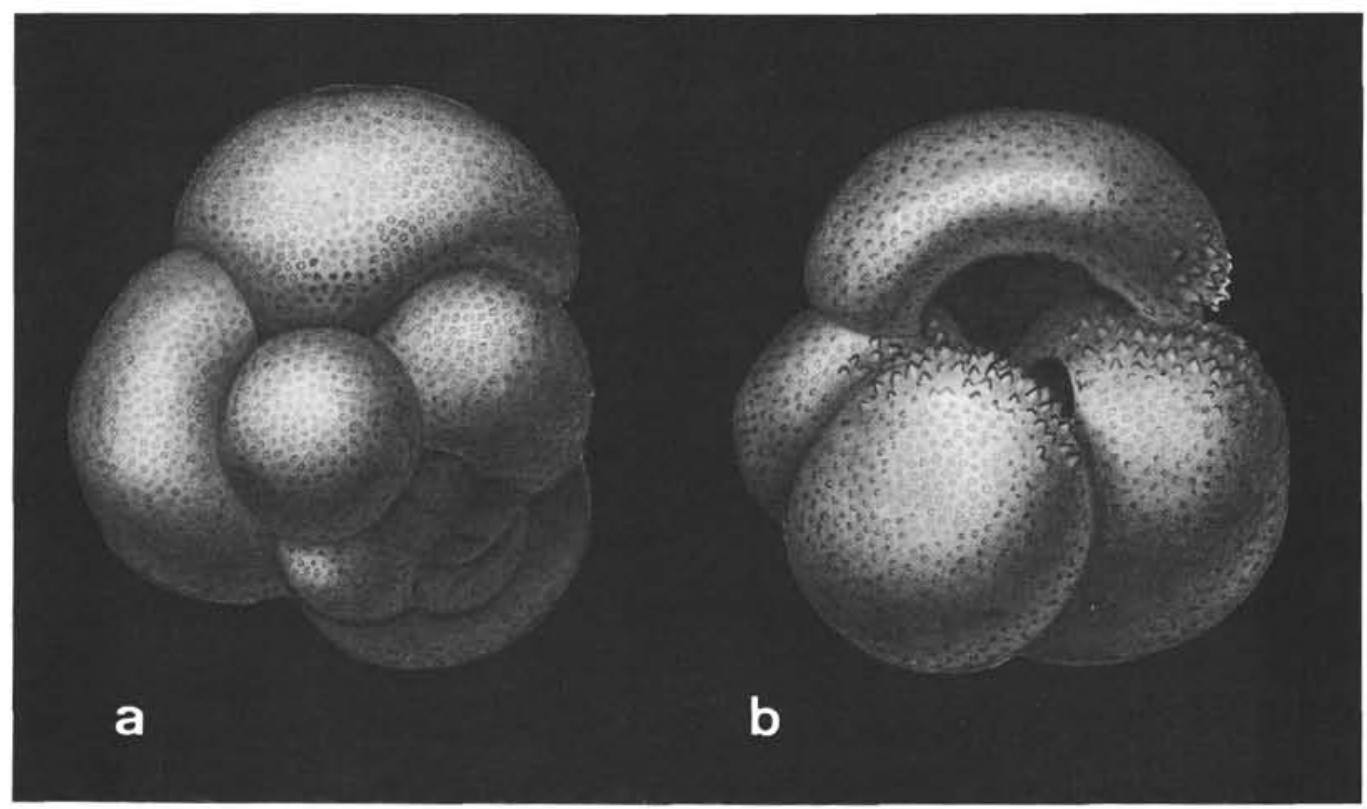

Figure 6. Globigerina sp. (close to Globigerina conglomerata Schwager, 1866). Hole 64.0, Core 1, Section 2, 15-17 cm; Zone N. 22. 71 X.

about 950 microns, comes from a surface sample of CAP HG 41. In Hole 62.1, Globigerina conglomerata has been recorded from Core 1 , Section 2 to Core 15, Section 2, that is over the interval from Zone N. 22 to the base of Zone N.18. According to Blow (1969, p. 266, fig. 2) it occurs from the upper part of Zone N. 19 to Zone N. 23.

A large globigerine of about 420 microns maximum diameter with four subglobular chambers in the final whorl, tentatively referred to Globigerina conglomerata Schwager, from Zone N. 20 (including N.9), is illustrated by the scanning micrograph of the oblique umbilical view, Plate 2, Figure 6. The aperture of this specimen is virtually hidden within the umbilicus and does not possess any flaps or teeth. The features of this individual agree well with those of the neotype of Globigerina conglomerata. The maximum diameter of the hexagonal compartments, which are partly filled in by sediment, range on the ultimate chamber from about 25 to 35 microns. The pustules here are also "non-canaliculate".

\section{Globigerina decoraperta Takayanagi and Saito, 1962} (Plate 6, Figure 2)

A representative of typical Globigerina decoraperta is illustrated by the scanning micrograph of the spiral side, Plate 6, Figure 2. The early portion of the trochospire is damaged and reveals the layers of the chamber walls. The polygonal meshwork is well developed throughout, excepting on the ultimate chamber where it is in an early incipient stage. The corner pustules and the first broad-later sharp-edgedinterconnecting walls are composed of minute elements or "crystallites". On the tips of the corner pustules and also occasionally on the interconnecting walls occur pinpoint-like pores suggesting that the living forms had fine spines.

Globigerina aff. Globigerina decoraperta

Takayanagi and Saito, 1962

(Plate 5, Figure 3; Text-figure 7)

Very high-spired tests of the decoraperta group are common. Specimens illustrated by the oblique view of a scanning micrograph, Plate 5, Figure 3 , and by text-figure 2, have been tentatively referred to Globigerina decoraperta. In the corners of the funnel-like polygonal compartments, the surface structure shows large axially "canaliculate", pointed to bluntly rounded pustules. Compared to the pustules the wall pores are very small. The strong, imperforate and pustulate apertural rim is better defined over the center of the high-arched aperture than on its sides. This aperture differs completely from that described for Globigerina rubescens Hofker, 1956, Zone N.22, Plate 1, Figures 5 and 8, where no apertural rim occurs. On the other hand, it resembles the aperture of Globigerina rubescens, Plate 6, Figure 1, which also is bordered by a thick rim.

\section{Globigerina druryi Akers, 1955}

(Plate 5, Figure 2)

The individual illustrated by the scanning micrograph, Plate 5, Figure 2, comes from Hole 62.1, Zone N. 13. 


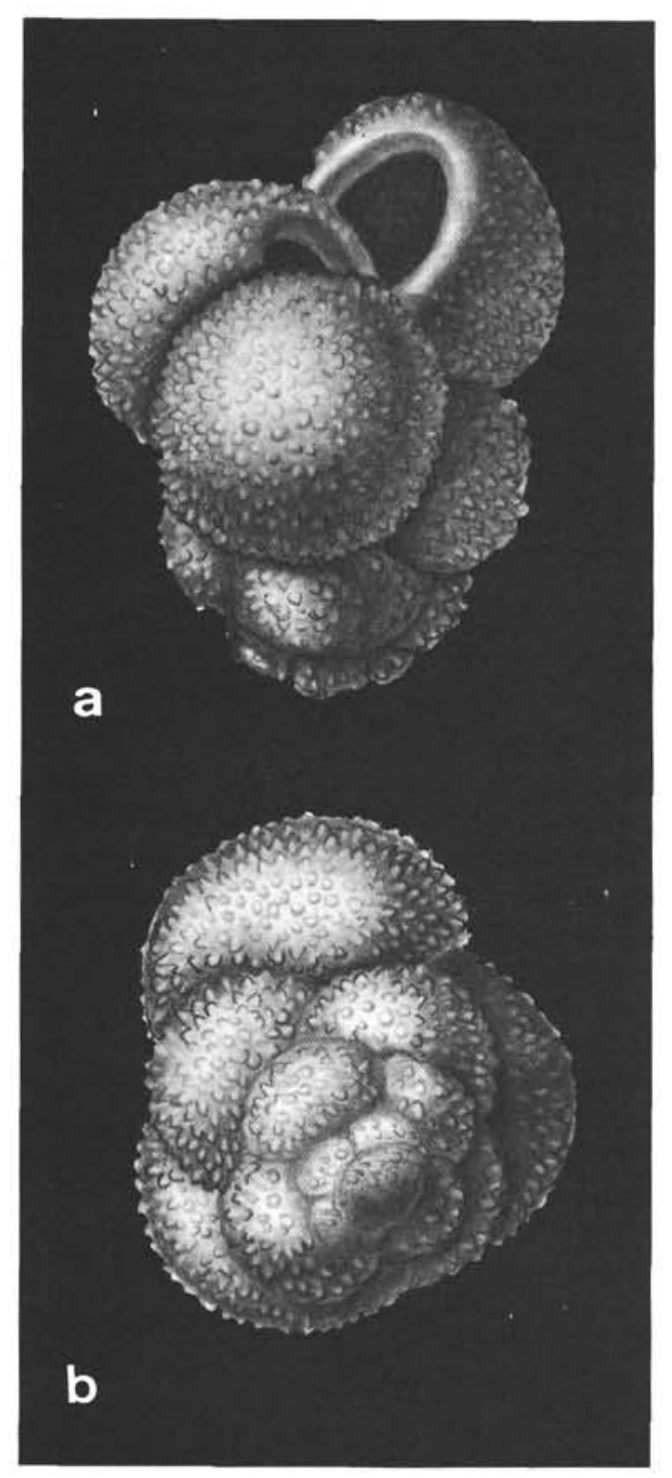

Figure 7. Globigerina aff. Globigerina decoraperta Takayanagi and Saito, 1962 group (high spired form). Hole 62.1, Core 12, Section 3, 15-17 cm; Zone N. 20 (including N. 19). $200 \times$.

The illustrated umbilical view, the dimension of the test, and the heavy outer wall formations correspond well with the individual of Globigerina druryi Akers illustrated by Blow (1969, pl. 13, fig. 4) from Zone N. 13, Montpelier Formation, Jamaica. It also corresponds well with Aker's holotype, which we examined in the collections of the U.S. National Museum. Globigerina druryi is close to Globigerina falconensis Blow as described here from Zone N. 7/N. 8, Hole 64.1 , and represented by the scanning micrographs Plate 3, Figures 1, 2, 4 and 5. A smaller specimen considered to be intermediate between Globigerina druryi and Globigerina falconensis is shown on Plate 5,
Figure 1. Such individuals are quite common and difficult to place. From the normally umbilically directed, not oblique, position of the final chamber we believe that Globigerina druryi is closer to the falconensis group of forms than to Globigerina nepenthes nepenthes Todd, 1957 (Plate 1, Figures 4 and 6). The surface of the chambers of Globigerina druryi are strongly pustulate. The pustules of the polygonal corners are large and pointed. They are composite structures and are interconnected by thin-edged, finely pustulate walls. The thick, arched, imperforate apertural rim is heavily pustulate and not drawn out as much as in typical falconensis.

\section{Globigerina dutertrei d'Orbigny, 1839 \\ (Plate 2, Figure 9; Text-figure 8)}

We have referred the wide and deeply umbilicate globigerine, illustrated by the scanning micrograph of the umbilical view, Plate 2, Figure 9, to Globigerina dutertrei d'Orbigny, as lectotypified by Banner and Blow (1960, p. 11; pl.2, fig. 1). Our specimen from Hole 62.1, Core 3, Section 2, Zone N. 22, is 5 -chambered in the final whorl. The trochospire is dorsally rather flattened, not moderately convex as described for the lectotype. Its maximum diameter is about 625 microns and its axial height about 400 microns. Banner and Blow $(1969$, p. 11$)$ note that there is "no apertural lip or rim visible on the lectotype". On the here-illustrated specimen, the relatively small, ultimate chamber possesses a very thin apertural rim, that of the penultimate chamber is larger and finely pustulate, and that of the antepenultimate is a distinct tooth-like flap, also finely pustulate. Other specimens of Globigerina dutertrei from Hole 62.1 reveal tooth-like apertural flaps as illustrated by Parker (1967, pl. 25, fig. 7) up to, and including, the ultimate chamber. The tooth-like projection is clearly a feature of the aperture which changes in the course of ontogeny. According to Parker (1967, p. 168), Globigerina dutertrei evolved in Zone N. 21 from Globorotalia (Turborotalia) acostaensis humerosa Takayanagi and Saito, 1962. It is quite possible that the apertural position in Globorotalia (Turborotalia) acostaensis humerosa is variable and either may be more umbilically directed, as in typical globigerines, or may extend up to the periphery of the test as in globorotaliids. The globorotaliid aperture is shown by Blow's scanning micrographs of Globorotalia (T.) acostaensis humerosa (1969, pl. 33, fig. 8, 9; pl. 34, fig. 1, 2). Although we have accepted here Blow's taxonomy, we are not convinced that Globorotalia (Turborotalia) acostaensis humerosa should be regarded as a subspecies of the acostaensis group of forms. In this case, as in many others, the need of new scanning observations and of the examination of ontogenetic stages over stratigraphically successive populations is obvious. Without new morphologic evidence, most of the evolutionary lineages proposed in the literature remain 


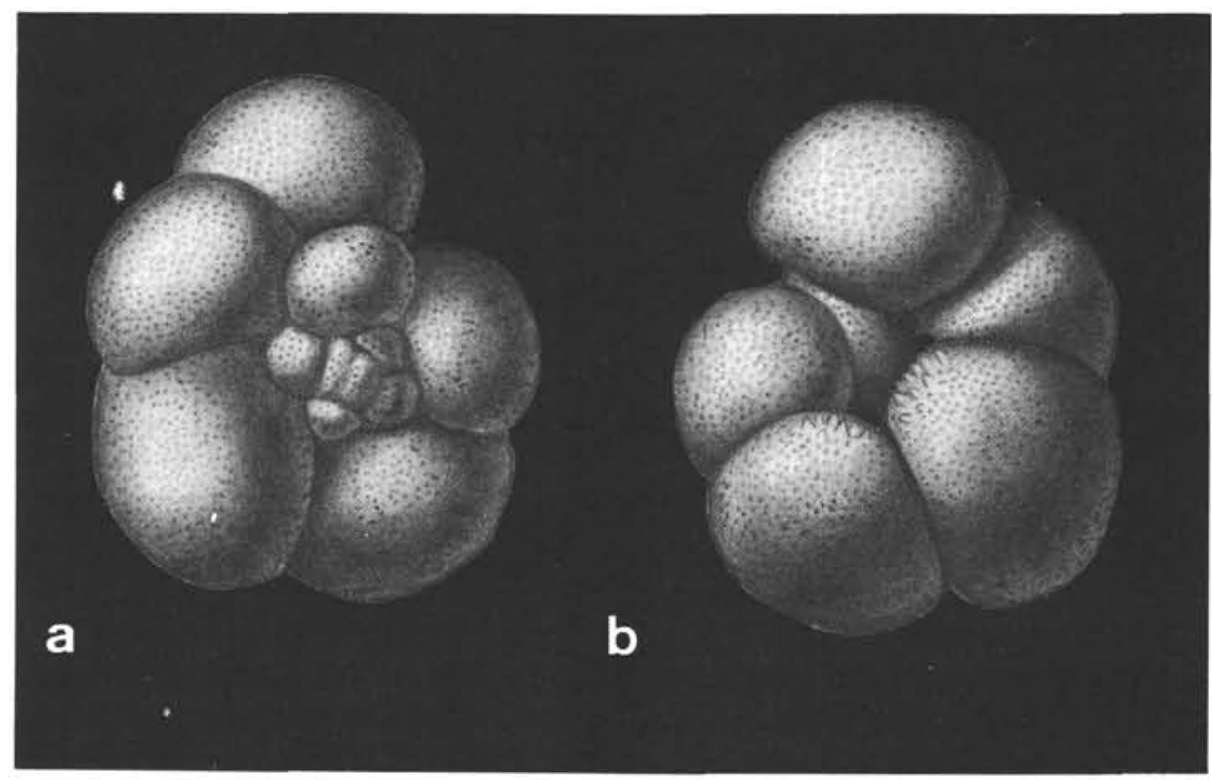

Figure 8. Globigerina dutertrei d'Orbigny, 1839. Hole 62.1, Core 1, Section 1, Top; Zone N. 23. $95 \times$.

more or less educated guesses. Until these studies have been accomplished, we also accept Parker's evolutionary suggestion only with reservation.

The surface structure of the umbilical side, Plate 2, Figure 9, reveals strong composite pustules. With the exception of the oldest chamber of the last whorl and of the umbilically directed surfaces of the other chambers, the surface is so densely pustulate that the entrances to the wall pores are completely closed up. At the same time, the polygonal meshwork which is exposed on the umbilical side of the oldest chamber of the last whorl, and locally on the ultimate and penultimate chambers, disappears and is replaced by irregularly shaped, angular to elongate pustules composed of plate-like, radially arranged "crystallites". The white line at the inner margin of the penultimate chamber is due to an electrostatic charge of the specimen. The drawing of the umbilical side of Globigerina dutertrei, text-figure 8, does not show the apertural features too well. However, examination of the specimen, which is about 575 microns across, reveals first for the final chamber a distinctly umbilically directed aperture with a narrow rim which is slightly larger toward the penultimate chamber than toward the center of the aperture, then "tooth"-like projections on the apertures of the preceding chambers. On the penultimate chamber, a minute, pointed tooth can be seen in the text-figure. The umbilically directed portions of the chamber surfaces carry individual, pointed pustules. The spiral side of this specimen is virtually flat and the chambers of the final whorl overlap somewhat on those of the preceding one.

\section{Globigerina falconensis Blow, 1959}

(Plate 3, Figures 1, 2, 4, 5, 6, 7 and 8)

Globigerina falconensis is one of the common small globigerines recorded in Hole 62.1 from Zone N. 13 to the base of Zone N. 22. In Hole 64.1 it was found to occur from the top of Zone N. 6 to Zone N. 7/N. 8. A more thin-walled, less heavily pustulate form, occurring in Hole 62.1 from the top of Zone N. 22 to Zone N. 21, which seems to be related with Globigerina falconensis, has been tentatively referred to this species. It is not illustrated by scanning micrographs.

Typical specimens of Globigerina falconensis are illustrated by the scanning micrographs, Plate 3 , Figures 1 , 2, 3, 4, 5, 6 and 7. They are from Holes 62.1 and 64.1. They are heavy-walled, coarsely pustulate, and the apertural face is drawn-out in a thick, pustulate eaves-like plate which crosses the umbilicus either in a straight line or in a low arch. These individuals correspond well with the holotype of Globigerina falconensis examined by Brönnimann in the collections of the U.S. National Museum. The holotype possesses a slightly arched, thick and heavily pustulate apertural border similar to that shown by the specimen, Plate 3, Figure 1. The tightly packed surface polygons are defined by composite pustules, larger ones in the corners and smaller ones on the interconnecting walls. On the inside, the polygons are rounded, funnel-like, deep depressions. On the early chambers, the composite pustules may enlarge and virtually close up the accesses to the deeply-set wall pores. Furthermore, the pustules tend to fuse into irregular short ridges and 
obliterate the original polygonal meshwork. This tendency to fuse can be seen on the detail illustration of the apertural region, Plate 3, Figure 5, of the specimen illustrated on Plate 3, Figure 4. The pustules do not seem to be "canaliculate".

A stratigraphically relatively young individual from Zone N. 20, here only questionably assigned to Globigerina falconensis, Plate 3 , Figure 8 , has a low, almost straight-bordered umbilical aperture. The lip is thin walled and pustulate. The tightly packed surface polygons are defined by smooth-walled, but probably composite, pustules, larger ones in the corners and smaller ones on the interconnecting walls. The polygons are small and their inner sides tend to become rounded funnel-shaped depressions. The interconnecting walls are sharp-edged and the points of the pustules exhibit the pinpoint-like openings of axial canals, indicating that the living form possessed fine spines. This specimen is nearly homeomorphic to typical Globigerina falconensis, and it may be possible that this long-ranging species consists of at least two, perhaps even more, stratigraphically different quasihomeomorphs. This possibility has been indicated already by Blow (1969, p. 266, fig. 2) who subdivided Globigerina falconensis into an older typical form, extending up to the base of Zone N. 14, and a younger typical form, with a range from Zone N. 14 to Zone N. 23. In our opinion, turborotaliids, as described under Globorotalia (Turborotalia) palpebra Brönnimann and Resig, n. sp., Plate 3, Figure 3, may also have been confounded with true Globigerina falconensis. It is noteworthy that both Globigerina falconensis ?, Plate 3, Figure 8, and Globorotalia (T.) palpebra have "canaliculate" pustules. Otherwise, the outer wall formations of falconensis ? and of palpebra are completely different.

The specimen illustrated by text-figure 9, as Globigerina aff. Globigerina falconensis, from Hole 62.1, Core 13, Section 2, Zone N. 18, resembles in its apertural features the stratigraphically younger Globigerina aff. Globigerina falconensis. Its surface structure is different, however, and resembles that described in Globorotalia (Turborotalia) palpebra. Individual pointed pustules seem to dominate, and it is quite possible that we are dealing here with still another globigerine species which is homeomorphic to the gross morphology of typical falconensis.

\section{Globigerina aff. Globigerina foliata Bolli, 1957}

(Plate 4, Figures 4 and 7)

The globigerines from Hole 64.1, Zone N. 7/N. 8, here tentatively assigned to Globigerina foliata, differ from typical foliata (Bolli, 1957, pl. 24, fig. 1a-c; Blow, 1969 , pl. 16, fig. 2,3) by the presence of the large "bulla"-like chamber covering the umbilical cavity. Blow (1969, p. 319) recorded Globigerina foliata from
Zone N. 6 to within Zone N.18. Atypical representatives have been seen as low as Zone N. 5 by this author. We found Globigerina foliata in Hole 64.1 from the top of Zone N. 4 to Zone N. 7/N. 8. The polygonal meshwork is well developed, coarse on the primary chambers and fine on the "bulla". $\mathrm{O}$ the tips of some of the composite corner pustules there occur minute pores suggestive of the presence of axial canals. The apertures are bordered by narrow, imperforate rims but no tooth-like plates, as seen in Globigerina pseudofoliata, are developed. The "bulla" seems to have a single aperture directed toward the penultimate chamber.

\section{Globigerina galavisi Bermúdez, 1961}

(Plate 8, Figures 2 and 3)

Bermúdez (1961) correctly put in synonymy with his new species Globigerina trilocularis d'Orbigny, 1826, of Bandy (1949, pl. 24, fig. 2) and Globigerina yeguaensis Weinzierl and Applin, 1929, of Bolli (1957, pl. 35, fig. 15, non fig. 14). Also, Blow and Banner's (1962, pl. 13, fig. K, L, M, non fig. H, J) specimen illustrated as Globigerina yeguaensis yeguaensis Weinzierl and Applin, from the Oligocene of the Lindi area, Tanzania, is in fact Globigerina galavisi, Globigerina galavisi has been recorded in Hole 64.1 in Core 9 , Sections 1 to 3 , and Core 10 , Section 1 , that is, only in the eocene. The total range of Globigerina galavisi Section 1, that is, only in the Eocene. The total range of Globigerina galavisi (top) to Zone P. 13. Blow (1969, pl. 5, fig. 1-3) re-illustrated the holotype and on Plate 16, Figure 4, illustrated a metatype from the upper Jackson Formation, Zone P. 16, of Mississippi, U.S.A. We agree with this identification of the specimen, which shows the elongate-triangular lip-like extensions that are pustulate and partially cover the umbilicus, and which, according to Blow (1969, explanations to pl. 16), are "fully perforated". Another individual, correctly referred by Blow (1969) to Globigerina galavisi is illustrated on Plate 16, Figure 5. This individual is from Zone P. 16 of the Lindi area, Tanzania.

We have examined the holotype of Globigerina galavisi in the U.S. National Museum and agree with its presentation by Blow (1969, pl. 5, fig. 1-3). The spiral side is rather flattened. It has a deep umbilicus and a thin plate-like lip bordering, virtually without changing its width, the elongate, arch-like, umbilical aperture. The ultimate whorl is composed of four chambers and the final chamber is distinctly compressed in radial direction. The holotype coils to the left, as does the specimen illustrated by Bolli, (1957), that by Blow and Banner (1962), and the individual illustrated by Blow (1969) from Tanzania. The other specimen from the upper Jackson Formation, Mississippi, illustrated by Blow (1969) coils to the right. The two individuals illustrated here from Hole 64.1, Core 9, Section 2, 


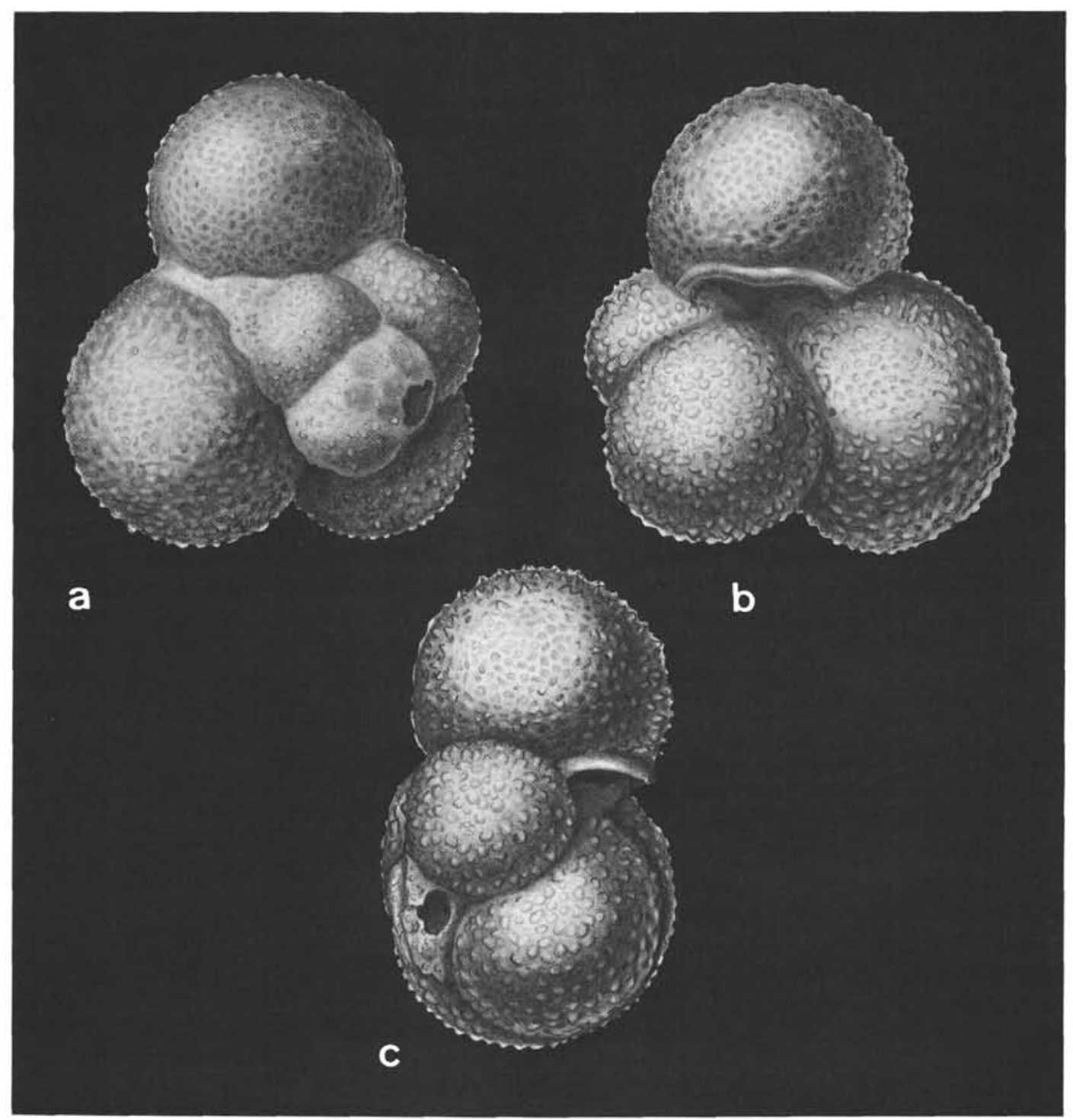

Figure 9. Globigerina aff. Globigerina falconensis Blow, 1959. Hole 62.1, Core 14, Section 2, 32-35 cm; Zone N. 18. 240X.

33-35 centimeters, Zone P. 16 coil to the left, Plate 8, Figure 2, and to the right, Plate 8, Figure 3. Most of the individuals encountered in this sample coil to the right. The umbilical side of the specimen illustrated by the scanning micrograph, Plate 8 , Figure 2, shows the remnant of a smaller end-chamber or bulla (?). The lip-like triangular plate juts out at an angle from the apertural face. It is pustulate, very finely in its marginal portion, but does not exhibit perforations at this magnification. The spiral side of the specimen illustrated by the scanning micrograph, Plate 8 , Figure 3 , is densely perforate and pustulate. The four to six blunt pustules around a pore fuse first basally, then also in their distal portions, thus creating polygonal funnellike compartments surrounding the deeply set pores. The maximum diameter of the wall pores on the ultimate chamber ranges from about 2 to 4 microns. According to Blow (1969), Globigerina galavisi may have been the ancestral form of Globigerinita pera Todd, 1957. The scanning micrograph of Globigerina galavisi Plate 8, Figure 2, shows on the right of the umbilicus the traces of a "bulla"-like chamber (?), as already mentioned. On the other hand, the gross morphologies of the trochospires of Globigerina galavisi and of Globigerinita pera are very different.

Globigerina aff. G. globorotaloidea Colom, 1954 (Plate 5, Figure 6)

In the lower part of the range of Globigerina nepenthes nepenthes Todd, 1957, we recorded from Hole 62.1, Core 28 , Section 3 to Core 30 , Section 6, Zone N. 16 
to Zone N. 15 a fairly large-sized globigerine which in its early development seems to be related with the Globorotalia (Turborotalia) acostaensis s.l. group, but in its final morphology possesses a distinctly umbilical aperture. We have referred it with reservation to Globigerina globorotaloidea Colom. The scanning micrograph, Plate 5, Figure 6, of the umbilical view of a specimen from Hole 62.1, Core 28, Section 3, 15-17 centimeters, Zone N. 16, shows a relatively small final chamber compared with the penultimate one which is displaced ventrally over the deep umbilicus. It possesses a short but distinct pustulate shelf-like protruding lip indicating that the aperture extends from the umbilicus to an extraumbilical but not peripheral position. The heavy blunt pustules fuse in their basal parts and surround the deeply set pores. The pustules are composite structures and on the surfaces of the third and fourth chamber of the final whorl they seem to consist of plate-like crystalline elements. Such "crystallites" can also be seen in the pustules of the ultimate and penultimate chambers. In the vicinity of the umbilicus on the early chambers of the final whorl, large and also some small pustules again grow into individual structures obliterating the original polygonal meshwork.

\section{"Globigerina" hexagona Natland, 1938}

(Plate 2, Figure 1-5; Text-figure 10)

We have grouped under "Globigerina" hexagona Natland different apertural morphologies which go from a rounded umbilical-extraumbilical aperture as illustrated by the scanning micrograph, Plate 2, Figure 1, similar to that illustrated by Parker (1967, pl. 25 , fig. 9a-c), to an elongate umbilical-near peripheral aperture as shown by Plate 2, Figures 2, 3 and 5. This type of aperture has also been illustrated by Parker (1967, pl. 25, fig. 10a-c). There occur even apertures which can be classed as distinctly globorotaliid. "Globigerina" hexagona occurs in Hole 62.1 from Zone N. 23 to Zone N.6, although not in all samples and never abundantly. In the interval from Zone N. 7/N. 8 to Zone N. 6, axially compressed, very flat tests with globorotaliid aperture have been recorded as Globigerina hexagona, but further studies may prove that they are older quasi-homeomorphs and should be separated taxonomically from Globigerina hexagona. "Globigerina" hexagona seems to represent a heterogeneous group which needs detail scanning analysis. We concur with Parker's suggestion (1969, p. 169) that "it would be desirable to reanalyze this long-ranging species for evolutionary changes". The holotype of Globigerina hexagona Natland was reexamined by Bronnimann in the collections of the U.S. National Museum. It possesses a relatively small, arched aperture, without lip, about halfway between the umbilicus and the periphery of the test, hence it differs in apertural features from the specimens grouped here under "Globigerina" hexagona Natland. On the other hand, it starts with the same type of dorsally flat trochospire.

The surface on spiral and umbilical sides is characterized by hexagonal-pentagonal funnel-like compartments, each with a wall pore in its center. The scanning micrographs, Plate 2, Figure 4 and 5, show around the pores a clear-colored very fine ring which may develop into a low tube, as described to exist in Globigerina nepenthes nepenthes Todd, 1957, and in Globigerinoides subquadratus subquadratus Brönnimann, 1954 (Plate 9, Figure 6). The pustules in the polygonal corners are bluntly pointed and do not surmount much of the connecting walls. Pustules and walls are composite structures. The pustules do not seem to be axially "canaliculate". The apertural lip is a thin-walled, imperforate, minutely granular, relatively broad plate. The "abortive" end-chamber, Plate 2, Figure 3, exhibits closely set pores, virtually no pustulation, and an imperforate apertural margin which is slightly upturned, particularly toward the umbilicus, and not as clearly defined as the apertural lip in the individuals shown on Plate 2, Figure 1 and 2. The specimen illustrated by text-figure 10 exhibits the same polygonal meshwork as that shown by the scanning micrographs. The aperture of the drawn specimen is bordered by narrow band which enlarges somewhat umbilically, and the last few chambers of the ultimate whorl overlap slightly on to those of the preceding one.

\section{Globigerina multiloba Romeo, 1965}

(Plate 6, Figure 9)

Globigerina multiloba Romeo occurs commonly in Hole 64.1 from Zone N. 7/N. 8 to Zone N. 2. This is a distinct species which is homeomorphic in its general morphology and in the umbilically directed final chamber to Globigerina quinqueloba Natland, 1938. The position of the aperture varies from a clearly umbilical to an umbilical-extraumbilical position.

The form described and illustrated by Blow (1969, pl. 3, fig. 15-17) as Globigerina eggeri multiloba, from the Buff Bay beds of Cushman and Jarvis, Buff Bay, Jamaica, Zone N. 18, is different from Globigerina multiloba Romeo.

The scanning micrograph, Plate 6, Figure 9, of an oblique view of the spiral side, shows a trochospire of at least 12 chambers with 6 chambers in the final whorl. The earliest portion of the trochospire is convex and the surfaces of the oldest chambers are masked by secondary shell material. The surfaces of the chambers are irregularly covered by large, blunt to pointed, individual pustules and between them occur numerous smaller "pustules" or crystallites. The smaller type pustules are typically developed on the surface of the 


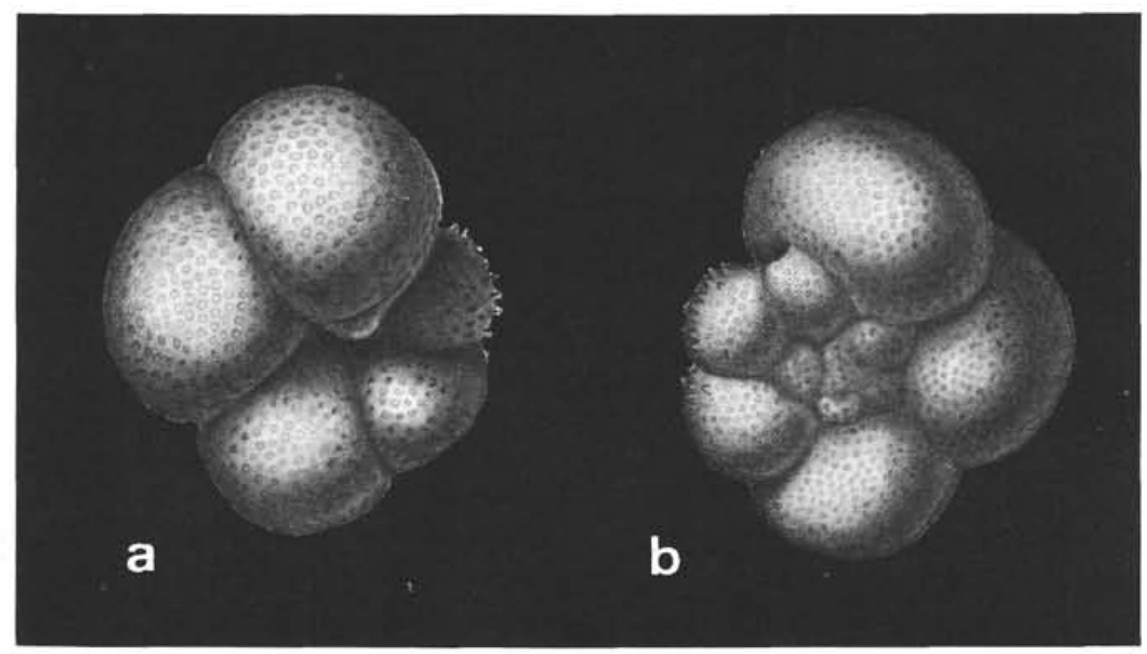

Figure 10. "Globigerina" hexagona Natland, 1938. Hole 62.1, Core 11, Section 5, 16-18 cm; Zone N. 20 (including N. 19). 130X.

early chambers of the trochospire. The larger pustules seem to be composite formations. Wall pores cannot be seen in this micrograph.

Romeo (1965) described this globigerine from the base of the Messinian, Orbulina suturalis Zone of Selli (1960).

\section{Globigerina nepenthes nepenthes Todd, 1957}

\section{(Plate 1, Figures 4 and 6)}

The scanning micrographs of two individuals of Globigerina nepenthes nepenthes, one in apertural the other in side view, Plate 1, Figures 4 and 6, show a coarse polygonal meshwork, consisting of larger corner pustules, and broadly rounded interconnecting walls, consisting of numerous smaller units or "crystallites". The wall pores in the centers of the polygons seem in places to be bordered by thin tubular walls. This may be seen on the earlier chambers of the final whorl of the specimen illustrated on Plate 1, Figure 4. The thick apertural rim is subdivided by vertical cuts into larger units which again consist of smaller ones. Globigerina nepenthes nepenthes is an important zone fossil. It occurs in Hole 62.1 from almost the base of Zone N. 14 to the lower part of Zone N. 20 (including N. 19).

\section{Globigerina nepenthes Todd picassiana Perconig, 1968 \\ (Plate 1, Figure 9)}

We have considered Globigerina picassiana Perconig, 1968 , as a subspecies in the nepenthes group. The scanning micrograph, Plate 1, Figure 9, illustrates one of these forms. The ultimate chamber has a nepenthelike position. The test however is more tightly coiled, less lobate and more heavily pustulate than Globigerina nepenthes nepenthes or Globigerina nepenthes delicatula Brönnimann and Resig, n. sp. Also the apertural border is less protruding than in the holotype of Globigerina nepenthes nepenthes or in the specimens illustrated by the scanning micrographs, Plate 1, Figures 4 and 6 . The pustules of the early chambers in the last whorl are very strong, bluntly rounded and made up of the numerous "crystallites" which in places suggest a radial structure of the pustules. The pores of the wall perforations are deeply set in the polygonal funnel-like compartments. The ultimate chamber is finely granular toward the apertural rim, with a tendency to develop a low pustulate structure on the dorsal side of the chamber. The apertural lip is also finely granular to pustulate. The specimen illustrated here is from Hole 62.1, Core 16, Section 1, 14-16 centimeters; Zone N.17. The range of Globigerina nepenthes picassiana in Hole 62.1 is from Core 12, Section 5 to Core 3, Section 1 (affine forms), that is from Zone N. 20 (including N. 19) to Zone N. 13. This range corresponds essentially with that of Globigerina nepenthes nepenthes and nepenthes delicatula.

\section{Globigerina aff. Globigerina praebulloides praebulloides Blow, 1959 (Plate 7, Figure 3)}

The outer wall formation of Globigerina aff. Globigerina praebulloides praebulloides from Hole 62.1, Zone N. 13 , is a very coarse polygonal meshwork. Corner pustules and interconnecting, rather sharpedged walls are composite structures. Each polygon enclosed a funnel-like depression with a deeply set, large, rounded wall pore. The ultrastructure of the corner pustules needs further investigation. On some of them there seem to occur pinpoint-like pores suggestive of the presence of an axial canal. 
Globigerina prasaepis Blow, 1969

(Plate 8, Figures 7 and 8)

Globigerina prasaepis Blow, 1969, is illustrated by scanning micrographs of an oblique-umbilical and a spiral view, Plate 8, Figures 7 and 8 . The apertural features resemble closely those of Globigerina tripartita Koch, 1926, in particular the plate-like, finely pustulate lip which protrudes from under the overhanging perforate and heavily pustulate apertural wall of the ultimate chamber. The aperture of this specimen is a much higher elongate arch than that of Globigerina tripartita. The pustules are composite structures and tend to develop irregular ridges in the umbilical area. There is no question in our mind that Globigerina prasaepis Blow and Globigerina tripartita Koch are closely allied.

Globigerina pseudofoliata (Parker), 1967

(Plate 4, Figures 1, 2, 3, 5, 6, 8, 9 and 10; Text-figures 11 and 12

Plate 4, Figures 1 and 3, which are scanning micrographs of Globigerina pseudofoliata (Parker), depict adult individuals, Plate 4, Figure 5 shows an almost adult one. These illustrated by Plate 4, Fig. ures $2,6,8,9$ and 10 , are young individuals. It is possible, however, that they could represent, and perhaps they do in part, young stages of Globigerina conglomerata Schwager, 1866. According to Parker $(1967$, p. 165,166$)$ "there are several species which resemble each other closely and which have similar juvenile stages", such as Globigerina conglomerata, Globigerina venezuelana Hedberg, 1937, and Globigerina pseudofoliata. Both Globigerina conglomerata and Globigerina pseudofoliata have apparently Globigerina venezuelana as ancestor (Parker, 1969). This suggestion would have to be supported by scanning microscope investigation of the ontogenetic stages of these species and by the analysis of their surface and apertural formations in stratigraphically successive populations.

Spiral and umbilical surfaces are densely perforate. The pores lie in the centers of the polygonal compartments whose pointed pustules are much higher than the sharp-edged connecting walls between them. The young stage, illustrated by Plate 4 , Figure 2, is umbilically largely imperforate, and the surface has a granular aspect. Toward the perforate portions of the wall, it is sparsely pustulate. As can be seen in Plate 2, Figure 10 , the pustules are pointed or bluntly rounded composite structures and do not seem to be "canaliculate". The finely granular sparsely pustulate, imperforate apertural wall is also shown by the scanning micrograph of a side view, Plate 4, Figure 6. The apertures of the young individuals do not possess the large thin-walled imperforate flaps typical of the adult stages, rather they are bordered by strong imperforate smooth-walled (Plate 4, Figure 2) to pustulate (Plate 4,
Figure 6) ridges. The adults show densely set wall pores. The specimen illustrated on Plate 4, Figure 1, exhibits individual, elongate, pointed pustules in the vicinity of the deep and large umbilical cavity. The rest of the polygonally structured surface is devoid of such pointed pustules. Some of them seem to "canaliculate". The apertural wall extends into a thin, imperforate, smooth to finely granular, irregularly bordered, plate-like lip. The apertural wall is perforate down to its contact with the lip, but large pustules disappear on this area which, in this specimen, has a finely granular surface but in the specimen illustrated on Plate 4, Figure 8 , has an almost smooth to finely granular surface.

Text-figures 11 and 12 illustrate umbilical and spiral views of a young (?) and of an adult individual of Globigerina pseudofoliata. On the young specimen, which is dorsally flat, the aperture appears to extend to the periphery of the test. Examination of the aperture on the specimen, however, reveals that, although it is an elongate arch, it is umbilically directed. The thin-walled lip is larger toward the penultimate chamber than toward the periphery. The maximum diameter of the young specimen is about 400 microns. It is from Hole 62.1, Core 11, Section 4, 17-19 centime ters; Zone N. 20 (including N. 19). The adult specimen with a maximum diameter of about 800 microns, is from Hole 62.1, Core 4, Section 5, 16-18 centime ters; Zone N. 22. It is a dorsally, almost flat trochospire with four subglobular chambers in the final whorl. The apertures are umbilically directed, and those of the ultimate and penultimate chambers carry "tooth"-like flaps. The surface formations and the wall pores are identical with those of the specimens illustrated by the scanning micrograph, Plate 4, Figure 3.

\section{Globigerina aff. Globigerina}

quinqueloba Natland, 1938

(Plate 43, Figures 8 and 9)

The outer wall formations of the umbilical sides of two specimens illustrated by Plate 43, Figures 8 and 9 , are dominated by rare widely-spaced wall pores and low rounded pustules. There is no suggestion of a polygonal meshwork. The pustules are best developed on the penultimate and antepenultimate chambers. The surface between the pustules and wall pores is finely granular. The edges of the wall pores are beveled.

Globigerina rubescens Hofker, 1956

(Plate 1, Figures 5 and 8; Plate 6, Figure 1)

We have illustrated the scanning micrographs of two specimens of Globigerina rubescens which differ in their apertural features. The specimen on Plate 1, Figures 5 and 8 possesses a high arched aperture which is heavily pustulate, and the one on Plate 6, Figure 1, has an aperture which is surrounded by a rim, as developed in Globigerina decoraperta Takayanagi and 


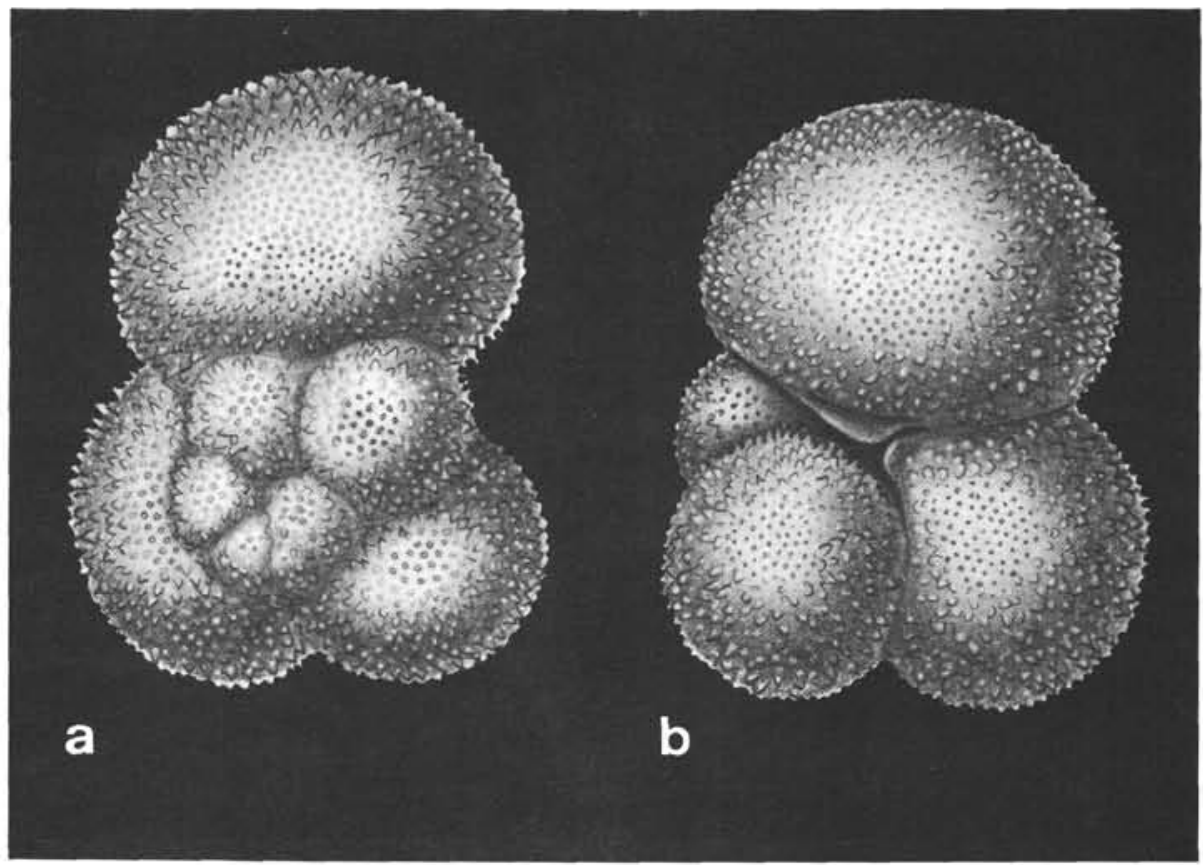

Figure 11. Globigerina pseudofoliata Parker, 1967. Hole 62.1, Core 4, Section 5, 16-18 cm; Zone N. 22. 80 X.

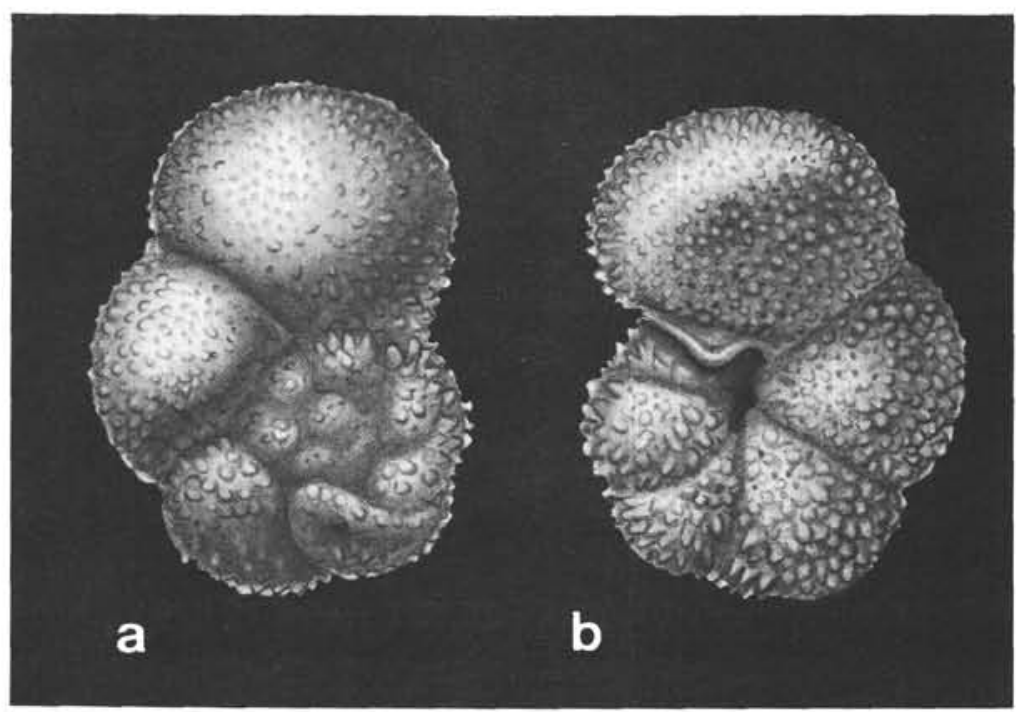

Figure 12. Globigerina pseudofoliata Parker, 1967(?) young specimen. Hole 62.1, Core 11, Section 4, 17-19 cm; Zone N. 20 (including N. 19). 130X.

Saito, 1962. It is quite possible that Globigerina rubescens may have evolved from Globigerina decoraperta (Parker, 1967, p. 152; Blow, 1969, p. 318, 322). Stratigraphically, Globigerina decoraperta occurs in Hole 62.1 from near the base of Zone N. 14 to the upper part of Zone N. 22 and Globigerina rubescens occurs from the base of Zone N. 20 (including N. 19) to Zone N.23. Red-colored rubescens has been recorded in the interval from Core 2, Section 4 to the surface sample of Hole 62.1. However, the different apertural features encountered in Globigerina rubescens may be suggestive of either a polyphletic taxon or an ontogenetic differentiation of the aperture, that is, the specimen illustrated by Plate 1, Figures 5 and 8 , would not represent the adult stage. As these questions need further investigation, we have treated rubescens 
and decoraperta as different species. The outer wall formations are very similar in both species and may suggest a subspecies relationship of rubescens and decoraperta.

The scanning micrograph of an umbilical view of Globigerina rubescens, Plate 1, Figures 5 and 8, shows a pustulate and perforate wall. Wall pores are absent near the aperture whose border is covered by individual pointed pustules. In the apertural region, the pustules are less dense than on the rest of the surface of the ultimate chamber. The wall pores are widely spaced and surrounded by blunt to pointed composite pustules which may laterally-basally coalesce and develop a polygonal meshwork. The pustules of the last chamber of the trochospire are axially "canaliculate". In the living form, fine spines are rooted in these axial canals. Reference is made to the scanning micrograph of Globigerina aff. Globigerina decoraperta, Plate 5, Figure 3, which also exhibits "canaliculate" pustules.

Globigerina sellii Borsetti, 1959

(Plate 8, Figure 9)

The scanning micrograph, Plate 8 , Figure 9 , of the umbilical side of a typical individual of Globigerina sellii from Hole 64.1, Core 1, Zone N. 7/N. 8 shows an elongate aperture covered by a plate-like lip which, in its central and largest portion, protrudes in the form of a triangle. The lip is imperforate, shows a finely granular surface and, in its central portion, a few larger composite pustules. The apertural wall is flattened and, with the exception of its lowermost portion, perforate. It is covered toward the aperture by numerous individual, minute and large composite pustules. On the upper portion of the apertural wall and on the spiral side, the large blunt pustules form the corners of a polygonal meshwork. In the center of each polygon is a deeply set wall pore. The remains of an "abortive" chamber are discernible on he left. Apart from the flattened apertural wall, the surface formations and the apertural features place Globigerina sellii in the neighborhood of Globigerina tripartita Koch and Globigerina prasaepis Blow. According to Blow (1969, p. 265 , fig. 1 and p. 267, fig. 3), Globigerina tripartita (= Globigerina rohri Bolli, 1957) occurs as low as Zone P. 14, whereas Globigerina sellii starts only at the base of Zone P. 19 and Globigerina prasaepis only in the upper part of Zone P. 17. The three species disappear almost together, either near the base of or within Zone N. 3. In Hole 64.1, Globigerina tripartita and Globigerina sellii have the same extensions from Zones N. 3 to N.4. Globigerina prasaepis has been recorded in Hole 64.1 in Zones N. 2 and N. 3.

Globigerina senni (Beckmann), 1953

(Plate 8, Figure 1)

Globigerina senni occurs commonly in Hole 64.1, Core 10 , Section 1 , Zone P. 14 or older. It is a very tightly-coiled, almost globular to elongate globular globigerine with a very small umbilicus. The individual coils to the right. Strong pustules surround the umbilical cavity (Bolli, 1957, pl. 35, fig. 10-12). The scanning micrograph, Plate 8 , Figure 1, of a specimen from Hole 64.1 exhibits the umbilical region, which occupies only the central portion of the figure. The surfaces of the walls are strongly pustulate. The pustules are largest on the surfaces of the first chambers of the final whorl. Comments on this illustration would have been hardly necessary if it were not for the occurrence, in the upper part of the almost closed umbilical cavity, of at least three large ring-like structures of about 30 microns maximum diameter. These structures have a certain depth and seem to be part of the globigerine. Their signficance is unknown.

\section{Globigerina tripartita Koch, 1926}

\section{(Plate 8, Figure 6)}

The scanning micrograph of the umbilical side of Globigerina tripartita, Plate 8, Figure 6, shows composite, heavy, bluntly rounded pustules which, in the neighborhood of the shallow umbilicus, fuse into irregular non-polygonal patterns and virtually close the accesses to the wall pores. On the spiral side, the pustules fuse to form the formal polygonal compartments surrounding the deeply-set pores. The elongate vertical body across the aperture is foreign to the test. The elongate, low aperture possesses, in its central portion, a plate-like lip which protrudes from under the overhanging perforate, apertural wall. The margin of the lip is irregular and the lip itself is covered with small pustules.

\section{Globigerina venezuelana Hedberg, 1937}

(Plate 5, Figure 7; Text-figures 13 and 14)

The wall of the umbilical side of Globigerina venezuelana, illustrated by the scanning micrograph, Plate 5, Figure 7 , is very finely perforate. The pores are in the centers of minute polygonal compartments formed by basal and lateral fusion of pustules. The maximum diameter of the polygons measures on the antepenultimate chamber around 7 microns, that on the same chamber of Globigerina conglomerata, Plate 5, Figure 8 , ranges from about 10 to 20 microns. In the vicinity of the umbilicus, certain of the polygonal pustules grow into large, pointed, individual composite structures. The aperture of the ultimate chamber is bordered by a thin-walled imperforate, finely granular lip which juts out perpendicularly from the flattened apertural wall. In its central portion it expands into a small triangular "tooth"-like apertural flap. The umbilicus is much more closed and the wall structures are finer than in the stratigraphically younger nearhomeomorph Globigerina conglomerata Schwager (Plate 5, Figure 8). A striking feature of both species is the axial elongation of the chambers of the final whorl, 
the flattening of the apertural walls and the "rectangular" outline of the umbilicus which, in Globigerina venezuelana, however is more closed than in Globigerina conglomerata. Stratigraphically, Globigerina venezuelana occurs before Globigerina conglomerata, and in Hole 62.1 the two species overlap in Zones N. 18 and the lowermost part of Zone N. 20 (including N. 19). Parker (1967) placed these near-homeomorphs in Globoquadrina Finlay, 1947, amended Parker, 1967, and considers Globigerina venezuelana as the ancestor of Globigerina conglomerata. In the beginning of our work we had accepted Parker's evolutionary idea, but after having seen many more individuals in stratigraphically successive populations and after having studied scanning micrographs we came to the conclusion that these species, also taxonomically maintained by Parker, should be regarded as close homeomorphs, most probably deriving from different ancestors. For the time, therefore, we are inclined to accept Blow's (1969, p. 322) suggestion "that the relationship between $G$. conglomerata and $G$. venezuelana is one of homeomorphy rather than direct phyletic relationship". It is even possible, and should be investigated in detail, that the long-ranging Globigerina venezuelana, which starts in Zone N. 3 (Blow, 1969) and ends in Zone N. 19 (Blow, 1969) just before Globigerina conglomerata makes its first appearance in the upper part of Zone N. 19, is composed of a series of not directly genetically related quasi-homeomorphs. In Hole 62.1, we have recorded Globigerina conglomerata as low as the base of Zone N. 18. This difference with respect to Blow's range may be due to differences in the personal concepts of the morphology of Globigerina conglomerata and Globigerina venezuelana. A typical Globigerina venezuelana from Hole 62.1, Core 13, Section 2, 36-38 centimeters, Zone N. 18, is illustrated by Text-figures 13 and 14. The large, nearly globular test is an initially low-coiled trochospire with 4 subglobular, axially elongate chambers in the final whorl. The umbilicus is almost closed, the umbilical walls are strongly pustulate, and the virtually hidden aperture is bordered by an elongate thin-walled lip. The specifically unidentified globigerine, illustrated by Text-figure 6, is from Hole 64.0, Core 1, Section 2, 15-17 centimeters; Zone N. 22. It has a similar arrangement of chambers to Globigerina conglomerata or Globigerina venezuelana and similar highly pustulate umbilical walls, but the large arched aperture of the final chamber differs from those of both these species. It is bordered by a thin-walled narrow, imperforate lip. If the final chamber should tend to close the umbilicus slightly more than it actually does, then this specimen could not be distinguished in its general morphology from Globigerina venezuelana.

\section{Globigerina sp.}

(Plate 5, Figures 4 and 5)

The scanning micrographs, Plate 5, Figures 4 and 5, of an unidentified globigerine from Hole 64.1, Core 2,
Zone N. $7 /$ N. 8 is reproduced here because of its apertural features. The aperture is umbilical and that of the penultimate chamber is bordered by a narrow imperforate rim which carries a few pointed pustules in its central portion, suggesting an earlier development of the aperture of the ultimate chamber which possesses a central triangular, protruding, imperforate "tooth" that is covered by large, pointed, composite pustules. On both sides of the "tooth", the imperforate pustulate rim forming the lateral portions of the aperture can be seen. The surface of the rim is finely granular and similar to that of the rim bordering the penultimate chamber. Between the large, pointed individual pustules of the "tooth"-like projection occur a few smaller pustules or "crystallites". Individual large, pointed composite pustules and minute pustules or "crystallites" in between the larger ones occur on the perforate portion of the apertural wall of the ultimate chamber. On the rest of the umbilical surfaces the pustules fuse into polygonal compartments surrounding the deeply set rounded wall pores. In the vicinity of the umbilicus, the pustules of the pentagonal corners grow again into individual structures which somewhat mask the basic polygonal pattern.

This specimen resembles Globoquadrina larmeui larmeui Akers, 1955, sensu Blow (1969, pl. 28, fig. 5). We have examined Globoquadrina larmeui in the collections of the U.S. National Museum, and its dehiscenslike test, the closed umbilicus and the elongate "tooth" completely covering the aperture distinguish it from Globigerina sp., as here illustrated.

\section{Genus Globigerinita Brönnimann, 1957}

\section{Globigerinita dissimilis Cushman}

and Bermúdez) 1937

(Plate 25, Figures 7 and 8)

The scanning micrograph of the oblique umbilical view of Globigerinita dissimilis, Plate 25, Figure 7, exhibits large composite pustules on the primary chambers. They are individualized near the umbilicus and composed of large, frequently radially arranged "crystallites". On the rest of the surfaces, the normal polygonal compartments occur as shown by the scanning micrograph, Plate 25, Figure 8. The wall of the "bulla" is less coarsely structured and more densely perforate than the walls of the primary chambers. This characteristic is similar in Globigerinita pera (Todd), 1957, and Globigerinita unicava unicava (Bolli, Loeblich and Tappan), 1957. The apertural border of the bulla is undifferentiated and covered by abundant, minute pustules.

Globigerinita glutinata (Egger) flparkerae

Brönnimann and Resig, nom. nov.

(Plate 23, Figures 1 through 4; Plate 50, Figure 6; Text-figure 15)

Bermúdez (1961, p. 1232, pl. 10, fig. 10,11) introduced Globigerinoides parkerae for minute trochoid 


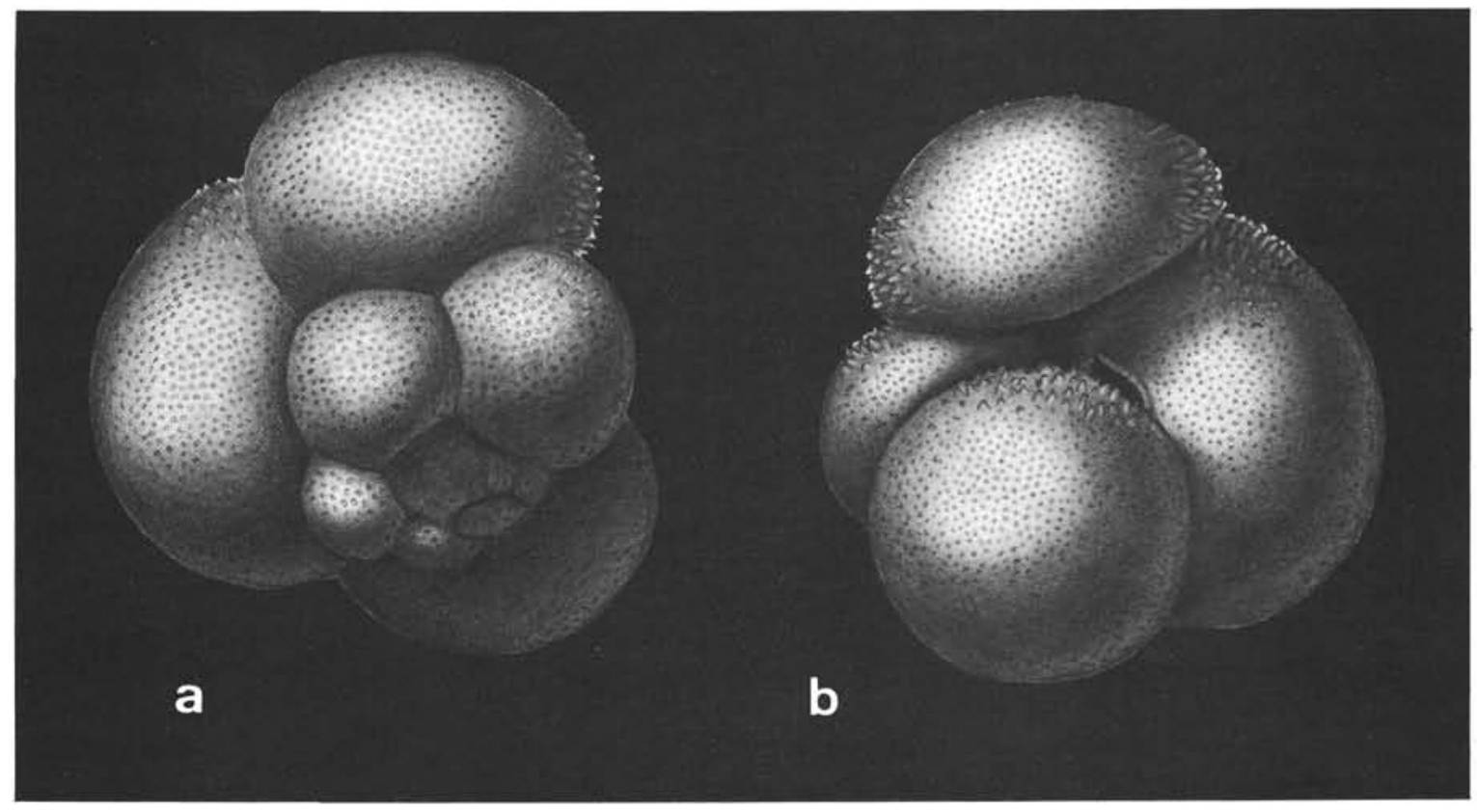

Figure 13. Globigerina venezuelana Hedberg, 1937. Hole 62.1, Core 6, Section 1, 18-20 cm; Zone N.

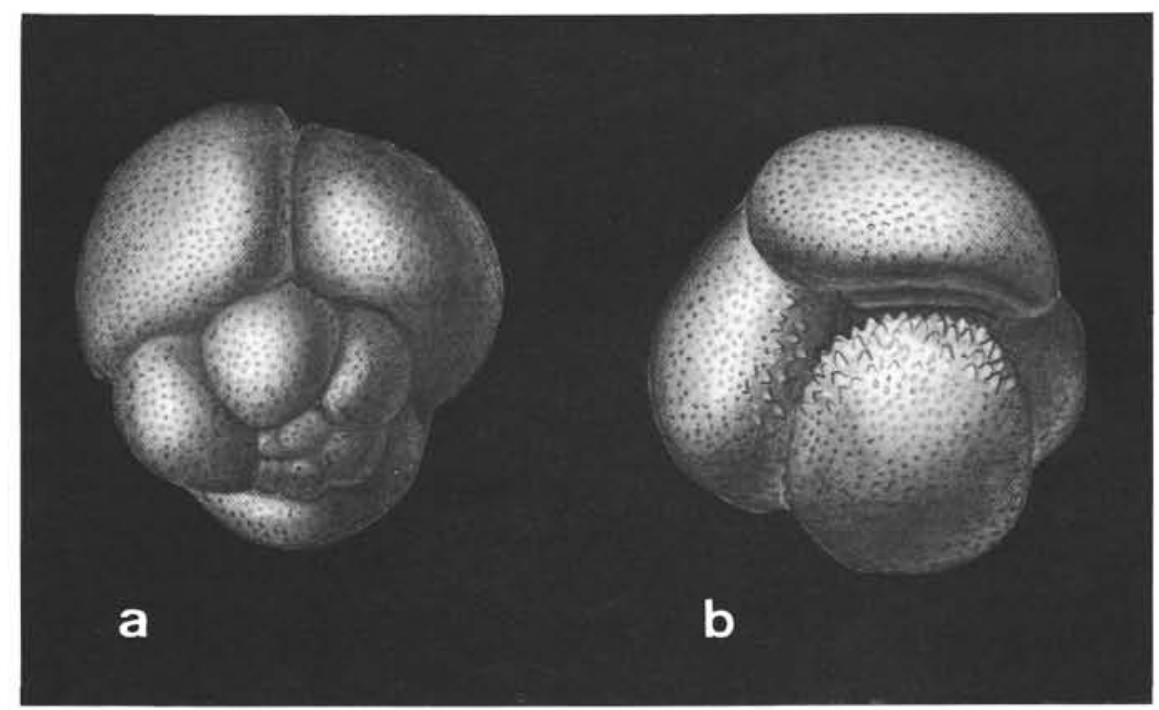

Figure 14. Globigerina venezuelana Hedberg, 1937. Hole 62.1, Core 13, Section 2, 36-38 cm; Zone N. 18. 80 X.

forms possessing a thin wall, a glossy, smooth to very finely hispid or pustulate surface and a single supplementary aperture in the spiral suture of the last-formed chamber. In our material we find that this supplementary aperture varies from a rounded to an elongate opening, and we find also specimens referable to this subspecies which develop more than one sutural opening in the spiral suture of the final chamber (Plate 50, Figure 6). This opening (or openings) is usually provided with a very thin upturned, imperforate and faintly pustulate rim. We have illustrated a specimen with a single sutural aperture on Plate 23, Figure 1. The specimen shown on Plate 23, Figures 2 and 4, may have a second sutural opening at the intersection of the suture between penultimate and antepenultimate chambers and the spiral suture.

Blow (1969) figured on Plate 22, Figure 1, a specimen with a typical elongate slit-like supplementary aperture with a weak but distinct lip along the entire spiral suture, and on Plate 22, Figure 3, a specimen with a somewhat reduced supplementary aperture. Plate 22, 
Figure 4, shows one of his specimens with two supplementary apertures at the intersections between spiral suture and the radial suture between ultimate and penultimate chamber, and that between the fourth and the fifth chamber. Also, Parker (1962, p. 249) noticed these different supplementary apertures in forms referred by her to Globigerinita glutinata. She wrote that "Specimens may have a single primary aperture (Globigerinita glutinata juvelinis in the present usage); the last chamber may be attached in such a way as to divide the aperture into two or three parts; there may be a single or double dorsal aperture(s) or none, some have a multiple-apertured umbilical bulla (Globigerinita glutinata in the present usage); there may be additional bullae over the dorsal aperture(s)".
The variability in the shape and the number of the dorsal supplementary aperture in Globigerinita glutinata flparkerae suggests that this opening is not a homologue of the sutural supplementary apertures of Globigerinoides which are invariably at the intersection of spiral and radial sutures. The presence of supplementary dorsal sutural openings does not refer a globigerine trochospire automatically to Globigerinoides Cushman, 1927. On the basis of the outer wall aspects of Bermúdez' Globigerinoides parkerae we feel that it should be assigned to the group of forms represented by Globigerinita glutinata glutinata (Egger), 1893, Globigerinita glutinata juvenilis (Bolli), 1957, and Globigerinita uvula (Ehrenberg), 1861. This

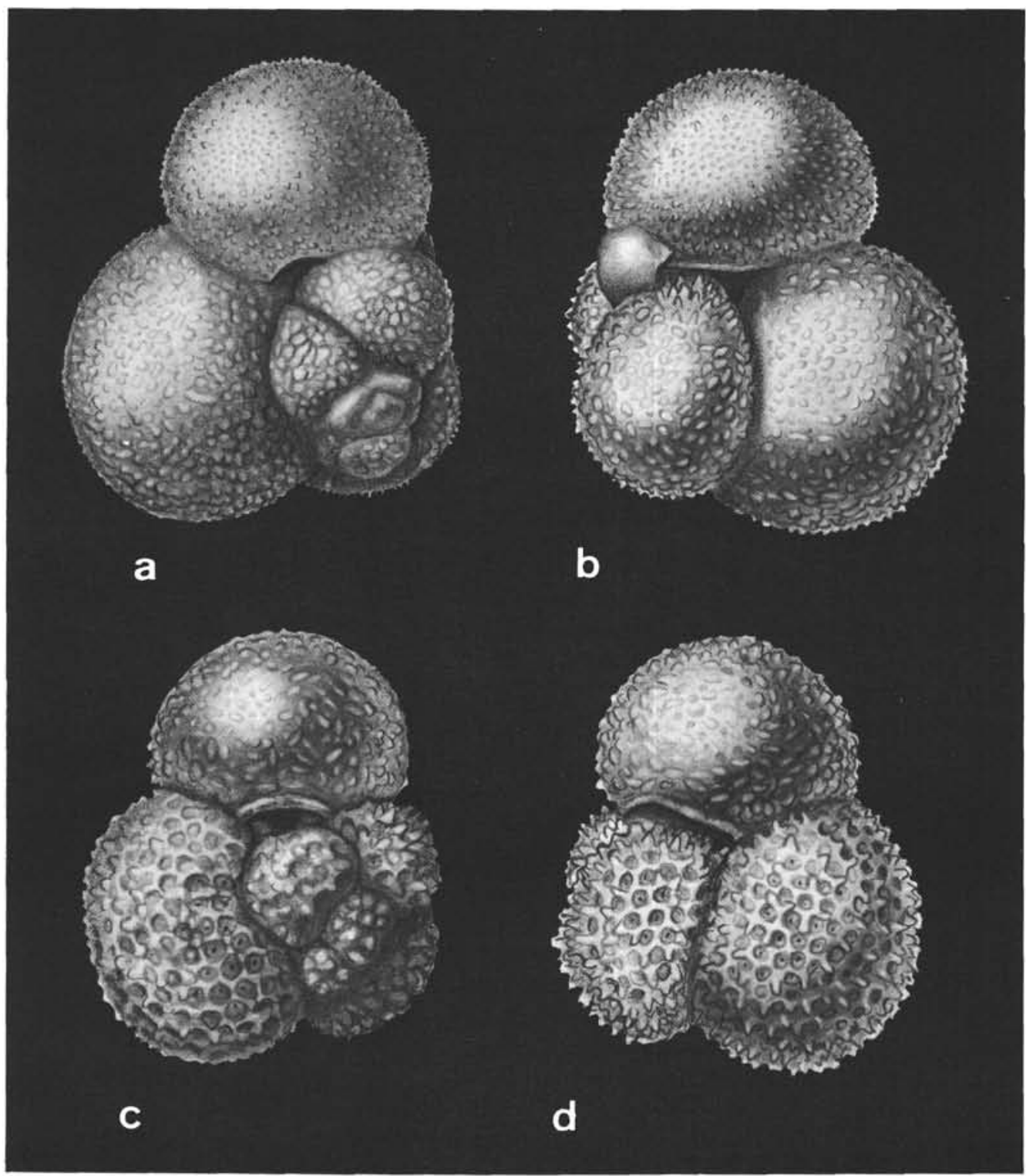

Figure 15. Globigerinita glutinata flparkerae (Bermudez), 1961. All figures from Hole 64.0, Core 1, Section 4, 15-17 cm; Zone N. 22. 200X. 
group of globigerinitas represents a genetic unit characterized by similar coiling and similar outer wall features. It needs further morphologic investigation with the help of scanning micrographs and stratigraphic evaluation. In the present writers' opinion this group differs from the globigerinitas with umbilical "bulla" as represented by "Globigerinita" dissimilis, "Globigerinita" pera, "Globigerinita" unicava, etc. which, however, have not been generically separated in this paper.

As the name parkerae has already been used by Loeblich and Tappan (1957) within the genus Globigerinita for a form described in 1954 by Parker from the Recent of the Gulf of Mexico as Globigerina sp., we propose to change the name introduced by Bermudez (1961) from parkerae to flparkerae.

The outer wall formations of the Globigerinita glutinata group of forms is characterized by individual composite-structured pustules which never develop a polygonal meshwork. On the final chamber, which is usually thin-walled and fragile as shown by the scanning micrograph Plate 50, Figure 3, they are irregularly distributed and widely spaced, and of very different dimensions. The wall surface between the pustules has a finely granular appearance and seems to be perforated by numerous pinpoint-like pores. The individual, more or less bluntly rounded pustules do not seem to be "canaliculate". On the earlier chambers of the trochospire, the individual pustules are larger, more pointed, and on the earliest chambers they almost touch each other. On the younger chambers they are still irregularly and widely spaced, and on the penultimate chamber of the specimen, Plate 50, Figures 2 and 4 , minute pustules occur between the larger ones in the region toward the spiral suture. Pinpointlike wall pores are more easily detected on this chamber; on the earlier trochospiral chambers they surround the large pustules not vice versa as in most Globigerinacea. We further noticed that the trochospiral beginning is never well exposed, probably due to accumulation of secondary shell substance. This may also be the reason why on the "first" chamber, as shown on Plate 50, Figure 1, and Figure 4, the number of pustules and of wall pores is reduced.

\section{Stratigraphic Range}

Globigerinita glutinata flparkerae has been recorded in Hole 62.1, from Core 1, Section 1 to Core 35, Section 5 , that is, over a range from N. 13 to N.23. It is quite possible that it ranges stratigraphically further downwards than is here indicated.

\section{Globigerinita glutinata glutinata (Egger), 1893} (Plate 23, Figure 5)

The same outer wall formations as described for Globigerinita glutinata flparkerae occur on Globigerinita glutinata glutinata, Plate 23, Figure 5.
Globigerinita glutinata (Egger) juvenilis Bolli, 1957 (Plate 50, Figure 5; Text-figure 16)

Globigerinita glutinata juvenilis, Plate 50, Figure 5, is characterized by the same outer wall formations as Globigerinita glutinata flparkerae.

Globigerinita parvula (Bolli,

Loeblich and Tappan), 1957

(Plate 24, Figures 5, 6 and 7)

The umbilical structures of the two specimens of Globigerinita parvula from Hole 64.1, Core 1, Zone N. $7 /$ N. 8 , as illustrated by the scanning micrographs, Plate 24, Figures 5, 6 and 7, are somewhat different. That of the specimen, Plate 24, Figure 6, exhibits the normal polygonal compartments each surrounding a wall pore. The polygonal walls are rather thick and finely pustulate. In the umbilical depression there occur a few isolated composite pustules. The outer wall formations of the specimen, Plate 24, Figure 5, are basically similar to those of the above described specimen, but the growth of the composite pustules went much farther so that the polygonal compartments are strongly reduced and the polygonal meshwork more or less obliterated. In fact, the pustulate walls start to form irregular, elongate ridges perpendicular to the chamber base. This structure can be seen on the left of the ultimate chamber. The "bulla" of this specimen is extremely thick-walled and pustulate with the same surface structures as the primary walls. The "bulla" of the specimen, Plate 24, Figure 6, is shown enlarged in Figure 7 and also reveals a strongly pustulate surface, but no polygonal structure. The wall of this "bulla" is thinner than of that of the other specimen.

The specimen illustrated on Plate 25, Figure 6 has been placed with reservation in Globigerinita parvula. Composite pustules occur on the surface of the primary chambers where they form the usual polygonal pattern and occasionally elongate, irregular ridges similar to those described for the individual illustrated on Plate 24 , Figure 5 . On the surface of the very flat, large, single-apertured "bulla", the pustules tend to coalesce around the wall pores into irregularly contoured broad and flat walls.

Globigerinita pera (Todd), 1957

(Plate 25, Figures 1, 2 and 3)

The scanning micrographs, Plate 25, Figures 1, 2 and 3, of Globigerinita pera show on the chamber surfaces in the vicinity of the umbilicus large, blunt, composite pustules which may either remain individual or fuse in groups of 2 or 3 to produce short irregularly curved ridges (Plate 25, Figure 1). The major part of the chamber surfaces are covered by polygonal compartments, each surrounding a deeply set wall pore. The pustules slightly surmount the polygonal walls and, on the earlier chambers, may enlarge so as to reduce the 


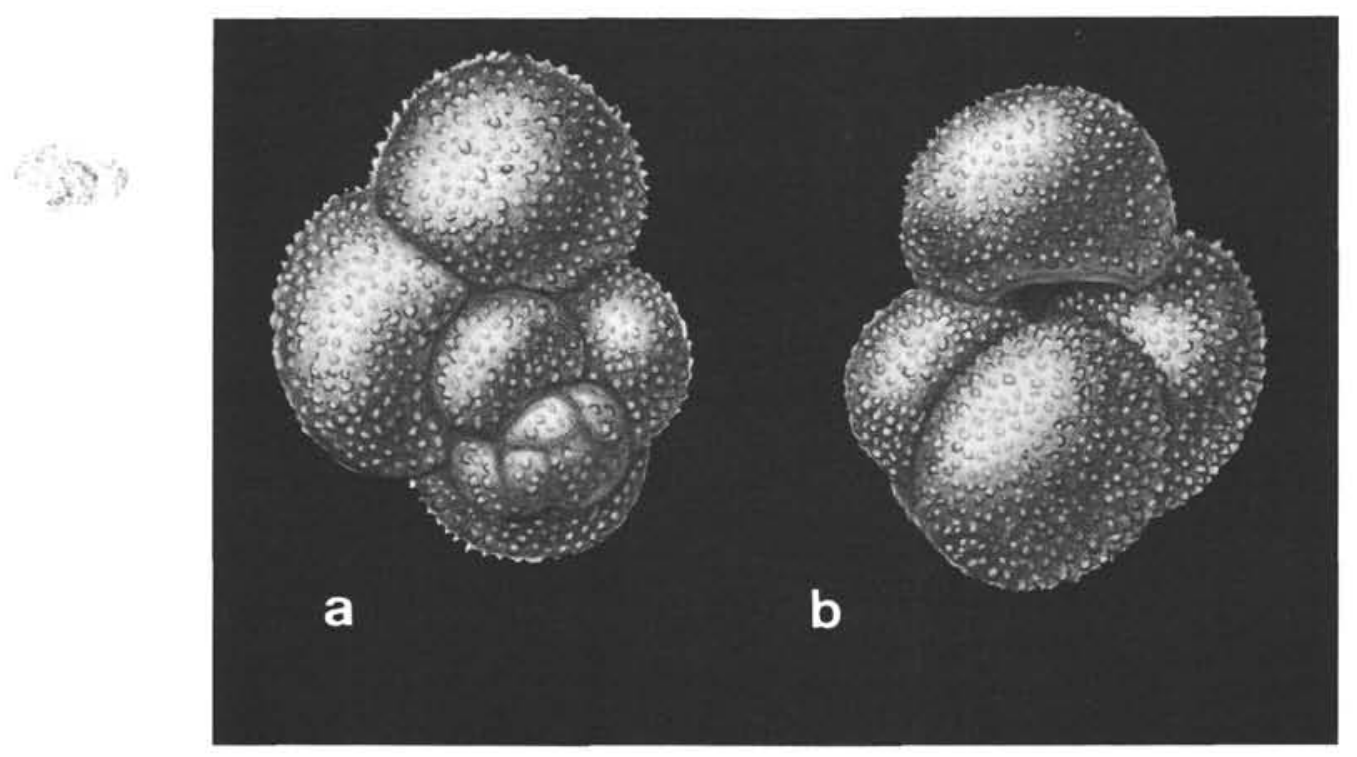

Figure 16. Globigerinita glutinata (Egger) juvenilis Bolli, 1957. Hole 62.1, Core 12, Section 3, 15-17 cm; Zone N. 20 (including N. 19). 240 X.

accesses to the wall pores. The surface of the "bulla" is identically structured, although the wall pores are perhaps smaller and more numerous than on the normal chambers and the pustulation weaker. Blow and Banner (1962, p. 112) describe the wall structure of Globigerinita pera as fundamentally similar to that of the primary chambers, but write that "it is slightly thinner and very slightly less coarsely perforate and punctate". Blow (1969) further states that on dissection of the "bulla", as can be seen on the scanning micrograph, Plate 25, Figure 2, the wall of the single aperture of the "bulla" appears smooth to minutely granular with sparse irregularly distributed wall pores which extend close to the apertural border.

Globigerinita stainforthi stainforthi

(Bolli, Loeblich and Tappan), 1957

(Plate 24, Figures 1 through 4)

The scanning micrographs of Globigerinita stainforthi stainforthi, Plate 24, Figures 1 through 4, represent the umbilical sides with the flattened "bulla" with four secondary apertures over the cameral sutures. The surface of the primary chambers is polygonally structured, and the wall pores are deeply set in the funnel-like depressions. The large pustules at the corners of the polygons and the smaller ones of the connecting walls are composite structures. The principal pustules at the corners of the original polygons grow in height more than the others and individualize again. The surface of the "bulla" is granular to finely pustulate and sparsely perforated by minute wall pores. The polygonal to irregularly rounded structure of the primary chambers is absent on the surfaces of the "bulla". This wall characteristic is different in the specimen illustrated by Blow (1969, pl.25, fig. 10) where the "bulla" also shows the same surface structure as the primary chambers. The margins of the secondary apertures are irregularly pustulate.

Globigerinita unicava (Bolli, Loeblich and Tappan) primitiva Blow and Banner, 1962

(Plate 25, Figure 5)

A striking feature of Globigerinita unicava primitiva as shown by the scanning micrograph, Plate 25, Figure 5, is the virtual absence of large individualized composite pustules. Even the polygonal corners consist of many small pustules and are only slightly higher than the broadly rounded connecting walls. The apertural wall of the "bulla" is finely pustulate.

Globigerinita unicava unicava (Bolli, Loeblich and Tappan), 1957

(Plate 25, Figure 4)

The scanning micrograph of the umbilical side of Globigerinita unicava unicava, Plate 25, Figure 4, illustrates strongly pustulate and perforate walls. The pustules are blunt to pointed, composite structures either individual or fused in the form of polygonal compartments around deeply set pores. The surface structure of the "bulla" is, though not as heavy, identical with that of the normal chambers. Here, also, the wall pores of the bulla seem to be more numerous than on the normal chambers.

\section{Genus Globigerinatella Cushman and Stainforth, 1945}

Globigerinatella insueta Cushman and Stainforth, 1945 (Plate 21, Figures 1 through 5)

The scanning micrographs of a typical specimen of Globigerinatella insueta, Plate 21, Figures 1 and 2, 
reveal areal and sutural apertural pores. The areal apertural pores are completely surrounded by lowelevated pustulate rims; and, the sutural ones, Plate 21, Figure 2, are bordered by a thick lid-like pustulate plate which juts out from the apertural wall. The two types of apertural pores are also exhibited by the scanning micrographs of a dissectioned individual, Plate 21, Figures 3 and 5. The interior of an areal apertural pore, illustrated by Plate 21 , Figure 4 , has a granular texture due to minute "crystallites". The inner opening of the areal pore is beveled. The surface of the walls are covered by individual, strong, pointed, composite non-canaliculate pustules. The early ontogenetic stage of the dissected specimen shows individual, large, pointed, composite, widely spaced pustules which grow up from a minutely granular surface, composed of individual small pustules or "crystallites". Between these pustules or "crystallites" occur minute, irregularly shaped cavities which may represent openings of minute wall pores. The absence of a polygonal meshwork is noteworthy.

\section{Genus Globigerinoides Cushman, 1927}

\section{Globigerinoides bollii Blow, 1959}

\section{(Plate 11, Figure 2)}

The scanning micrograph of the umbilical side of Globigerinoides bollii, Plate 11, Figure 2, shows an imperforate coarsely granular wall above the small, rounded primary aperture. The coarse granules or "crystallites" completely cover the apertural border. They may be representative of the original wall surface or the result of recrystallization. The large, bluntly rounded pustules and interconnecting walls of the polygons of the perforate portion of the wall are composite structures consisting of numerous "crystallites". They enclose funnel-like depressions leading to deeply-set wall pores. On the early trochospiral chambers the depressions may be virtually closed. No "canaliculate" pustules occur.

Globigerinoides conglobatus (Brady), 1879, s. 1. (Plate 11, Figures 1, 3, and 5; Text-figure 17)

The scanning micrograph, Plate 11, Figure 5, exhibits on both imperforate and perforate portions of the apertural face individual "canaliculate" pustules. In between the larger pointed pustules, especially toward the perforate portion of the apertural face, occur minute pustules which give the surface a granular appearance. The primary aperture of this specimen is a large arch bordered by an imperforate smooth margin covered irregularly by widely spaced pointed "canaliculate" pustules. A similar type of primary aperture also exists on the specimen, Text-figure 17, from Hole 64.0, Core 0 , surface sample, Zone N.23. The primary aperture of the lectotype of Globigerina conglobata (Banner and Blow, 1960, pl. 4, fig. 4a-c) is described as having neither lip nor rim, although its illustration exhibits a narrow apertural rim. It seems to us that the edge of the aperture may or may not give the impression of the presence of a very narrow rim, according to the incidence of light. Narrow rims are well developed on the secondary apertures of the specimen illustrated by the scanning micrograph, Plate 11, Figure 1.

Of particular interest on this specimen are the needlelike spines projecting from the apertural border into the secondary aperture which lies at the intersection of the spiral suture at the base of the penultimate chamber and the radial suture between the penultimate and ultimate chambers of the preceding whorl. "Canaliculate" pustules also occur on the spiral sides of the tests. They are clearly discernible on the surface of the ultimate chamber of the penultimate whorl of the specimen illustrated by the scanning micrograph, Plate 11, Figure 3. In the "canals" which open at the tips of the pustules as needle-point pores, the fine spines described above rooted, in the living form.

The surfaces of the perforate walls are otherwise covered by the polygonal compartments created through the basal-lateral fusion of pustules. On the early chambers of the spiral, slightly convex trochospire, these pustules may again become individualized, long, pointed "canaliculate" structures.

The illustrated adult specimens are large-sized. The maximum diameter of the one shown in the scanning micrograph, Plate 11, Figure 1, is about 900 microns. Those of specimens illustrated by Text-figure 17 are about 675 microns (upper row) and 580 microns (lower row). The structure seen in the aperture of the specimen illustrated by Text-figure 17 (lower row) is a fragment of a test, not an apertural feature. In fact, the aperture of this specimen, which is hidden within the umbilicus, is bordered by an imperforate, pustulate edge. In Text-figure 17 we have presented the extreme forms of Globigerinoides conglobatus (Brady). The specimen illustrated by Text-figure $17 \mathrm{a}, \mathrm{b}$ has much more rounded and less compressed chambers of the final whorl than does the specimen shown by Textfigure $17 \mathrm{c}, \mathrm{d}$, whose chambers of the final whorl are also more elongate axially. For forms which are more globular and robust than Globigerinoides conglobatus, and which have narrow supplementary dorsal apertures, Bermúdez (1960, pl. 10, fig. 5) proposed the species Globigerinoides canimarensis. Blow (1969) considers these forms as only subspecifically distinct and Globigerinoides conglobatus canimarensis as the ancestral subspecies. It is possible that the long-ranging Globigerinoides conglobatus which we recorded in Hole 62.1, from Core 24, Section 4 to Core 1, Section 1, that is, from Zone N. 16 to Zone N. 23, can be subdivided into two subspecies in the sense of Blow. However, Bermúdez' Globigerinoides canimarensis is 


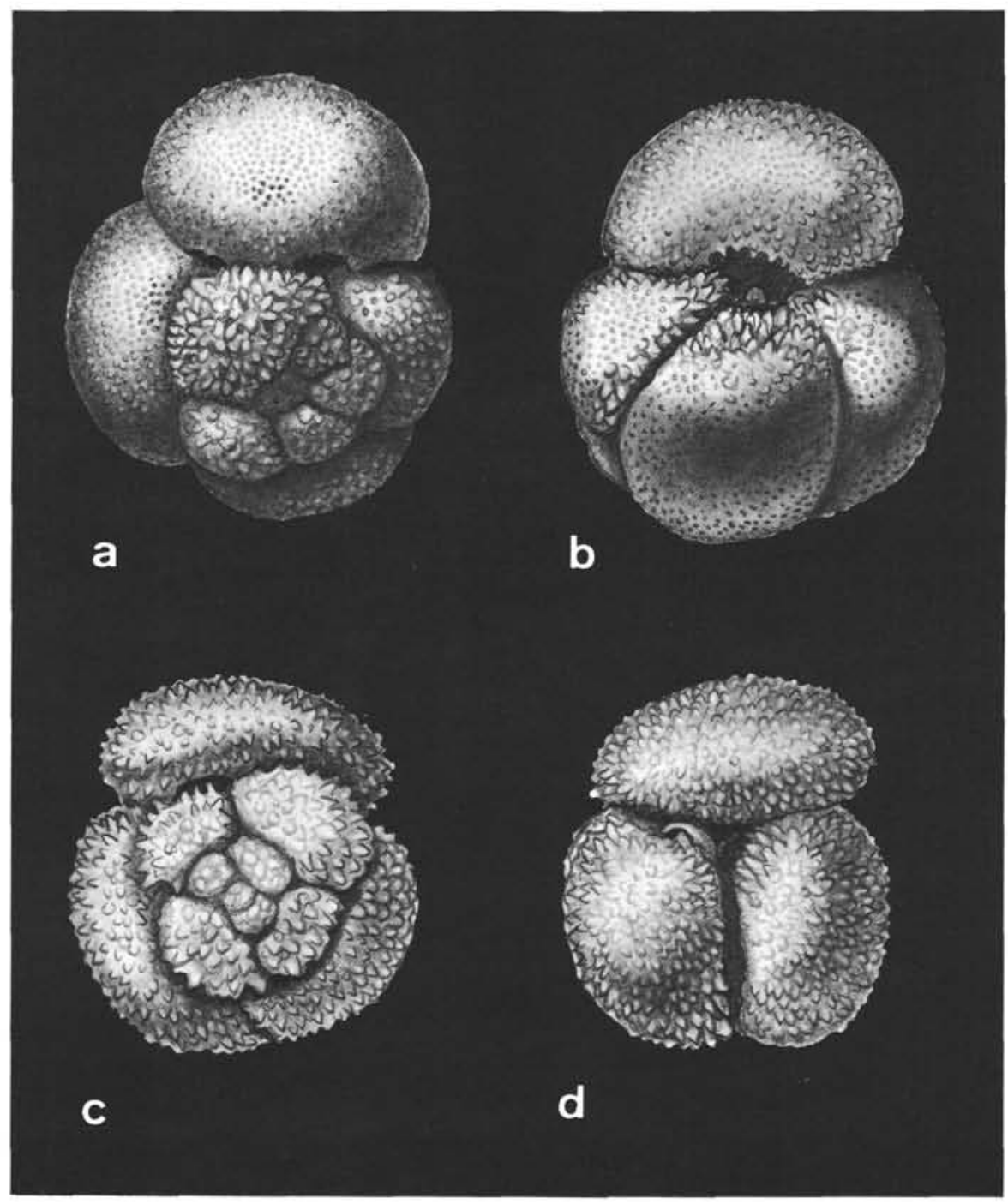

Figure 17. Globigerinoides conglobatus (Brady), 1879, s.l.

$a, b$ : Hole 64.0, Core 0, Surface sample; Zone N. 23.

c, d: Hole 62.1, Core 8, Section 3, 15-17 cm; Zone N. 20 (including N. 19).

difficult to distinguish from Globigerinoides conglobatus on the basis of the features listed by this author, hence we tentatively include Globigerinoides canimarensis in a wide concept of Globigerinoides conglobatus as shown by the scanning micrographs of Plate 11 and the Text-figure 17.

Globigerinoides elongatus (d'Orbigny), 1826

(Plate 12, Figures 4 and 6; Plate 13, Figure 3)

The scanning micrograph of Globigerinoides elongatus, Plate 13, Figure 3, shows individual, pointed pustules with minute pores to the left of the apertural region of the flattened ultimate chamber, suggesting the presence of an axial canal. A few small wall pores can be seen between the "canaliculate" pustules. The surface of the antepenultimate chamber, which dominates the lower portion of the micrograph, shows virtually equidistant wall pores of 3 to 8 microns in diameter. These wall pores are in the centers of polygonal funnel-like depressions. On this wall, there also appear pustules which show on their tips the fine opening of the axial canal. Apart from the pustules and in places where these are normally to be found, there occur, emplaced in socket-like sheaths, hollow spines which are invariably broken-off. The basal diameters of these hollow structures are slightly less than those of the wall pores. Although pustules and interconnecting walls are smooth-surfaced, they are most probably composite structures. The apertural imperforate border is strongly pustulate in the lower lateral portions. The scanning micrographs of the specimen, seen in Plate 12, Figures 4 and 6, exhibit the polygonal meshwork, minute openings of axial canals on the tips of corner pustules, and occasionally also on the interconnecting walls. A 
veneer-like ultrastructure of the polygonal walls and pustules can be seen on the detail illustration, Plate 12 , Figure 4. It recalls that described for Globigerinoides nuber, Plate 11, Figure 6.

Globigerinoides obliquus obliquus and its subspecies obliquus extremus Bolli and Bermúdez, 1965, are placed in this group. The distinction between obliquus and extremus is based on the more oblique and laterally more compressed form of the last chambers of the final whorl of Globigerinoides obliquus extremus (Bermudez and Bolli, 1969, p. 162, pl. 7, fig. 4-6). According to Blow (1969) the stratigraphic range of obliquus obliquus extends from Zones N. 5 to N. 22, and that of obliquus extremus extends from Zones N. 16 to N. 22. We recorded Globigerinoides obliquus obliquus in Hole 62.1 from Zone N. 13 to Zone N. 23 and in Hole 64.1 from Zone N. 4 to Zone N. 7/N. 8 . Typical Globigerinoides obliquus extremus seem to be restricted to Hole 62.1 from Zone N. 14 to the top of Zone N. 20 (including N. 19).

The surface structure of these subspecies, as illustrated on Plate 11, Figure 4 and Plate 12, Figure 8, depicts the same outer wall pattern as that described for Globigerinoides ruber and Globigerinoides elongatus. "Canaliculate" pustules, from which fine spines arose in the living form, also occur here. The imperforate smooth to finely granular apertural margin is more strongly pustulate than in Globigerinoides ruber. The veneer-like ultrastructure of the pustules seems to be the same as in Globigerinoides ruber and in Globigerinoides elongatus.

Globigerinoides quadrilobatus (d'Orbigny) altiaperturus Bolli, 1957

(Plate 13, Figures 7 and 8)

The strongly pustulate surface of Globigerinoides quadrilobatus altiaperturus depicted by the scanning micrographs, Plate 13, Figures 7 and 8 , seems to have individual canaliculate (?) pointed to blunt pustules in the region just above the primary aperture. These large pustules are composite structures and on the rest of the surface fuse laterally into polygons which surround funnel-like depressions with deeply set pores. The walls between the larger pustules at the corners of the polygons consist of smaller pustules or "crystallites". The large, arched imperforate apertural border is covered with numerous individual, pointed large pustules. The surface of the apertural border has a finely granular texture. The early trochospiral chambers of the specimen, Plate 13, Figure 8, show a polygonal meshwork which is not well developed, recalling the surface structure of Globigerinoides quadrilobatus primordius, Plate 13, Figures 6 and 9.
Globigerinoides quadrilobatus (d'Orbigny) primordius Blow and Banner, 1962

(Plate 13, Figures 6 and 9)

The scanning micrograph, Plate 13 , Figure 6 , of the dorsal surface of this primitive Globigerinoides from Hole 64.1, Core 6, Section 1, Zone N. 4, shows composite pustules either as individual angular-to-elongate protuberances or as walls forming around pores by the fusion of the bases of 2 to 5 pustules. The polygonal meshwork is not well developed. Between the large pustules and on the inside of the funnel-like depressions there occur numerous minute pustules or "crystallites". The composite structure of the large pustules is clearly recognizable in the scanning micrograph of the umbilical side of Globigerinoides quadrilobatus primordius, Plate 13, Figure 9, where individual pustules occur only above the arch-like primary aperture which borders a smooth to minutely pustulate imperforate undifferentiated margin. The umbilical side of the specimen Plate 13, Figure 6, shows, better than the spiral side, the polygonal meshwork whose walls consist of minute crystalline elements. The pustules are doubtfully "canaliculate".

\section{Globigerinoides quadrilobatus quadrilobatus (d'Orbigny), 1846}

(Plate 12, Figure 7)

The scanning micrograph of the spiral side of Globigerinoides quadrilobatus quadrilobatus, Plate 12, Figure 7, from Hole 62.1, Core 1, Section 1, Top, Zone N. 23, that is, of a virtually Recent individual, shows on the ultimate chamber polygonal compartments with 4 to 6 more or less pointed large corner pustules connected by rather sharp-edged walls. In places the walls between the large pustules seem to consist of a single row of smaller pustules or "crystallites". On the penultimate chamber the walls of the pentagonal and hexagonal compartments are much more rounded than on the ultimate chamber and consist of numerous minute pustules or "crystallites" which also make up the larger, bluntly rounded pustules in the corners of the polygons. The polygonal compartments surround funnel-like depressions with deeply set rounded wall pores. On the early trochospiral chambers the pustules are very large and have virtually closed off the accesses to the wall pores. We did observe a few "canaliculate" pustules on this individual. The borders of the secondary apertures are lined by a single series of heavy, rounded pustules.

Globigerinoides quadrilobatus sacculifer (Brady), 1874 Group

(Plate 12, Figures 1 and 2)

Both illustrated specimens of the Globigerinoides sacculifer group came from Hole 62.1, Core 1, Section 1, Top, Zone N.23. The scanning micrograph of the 
typical form, in the sense of Blow (1969), Plate 12, Figure 2, exhibits on the corner pustules of the polygons, pinpoint-like openings from which most probably in the living form fine spines arose. No such openings are discernible on the ultimate or earlier chambers of the trochospire probably because the openings of the axial canals are filled by sediment. The pustules of the antepenultimate and earlier chambers are composite structures made up of minute elements or "crystallites" as described for Globigerinoides quadrilobatus quadrilobatus. The polygonal compartments enclose funnel-like depressions, each with a deeply-set, rounded wall pore. On the early trochospiral chambers the accesses to the wall pores are much reduced or completely closed-up. The scanning micrograph of the forma $\alpha$ in the sense of Blow (1969), Plate 12, Figure 1, does not seem to possess any "canaliculate" pustules, which at least on the early chambers of the trochospire are also composite structures. The imperforate apertural margin of the typical form is minutely granular. That of forma $\alpha$ is better defined by a narrow imperforate band lined by a single series of large pustules which are linked by perpendicular connecting walls with the polygonal fields above the aperture.

\section{Globigerinoides ruber (d'Orbigny), 1839}

(Plate 11, Figures 6 and 7; Plate 12, Figures 3 and 5)

The scanning micrographs of details of the surface structure of Globigerinoides ruber, Plate 11, Figures 6 and 7 , show the polygonal compartments surrounding deeply-set wall pores in funnel-like depressions. At the polygonal corners and also occasionally elsewhere on the relatively sharp-edged interconnecting walls occur irregularly rounded small pores which represent the empty sockets where fine spines originally arose. A pustule of Globigerinoides ruber, Plate 11, Figure 5, seems to be made up of thin calcite veneers and not of fused minute pustulate structures of "crystallites" as described for other globigerinoids. Also the single, large "canaliculate" pustule above the imperforate apertural rim of the specimen, Plate 12, Figures 3 and 5, most probably represents the hollow base from which fine spines issued in the living individual. The edge of the well-defined smooth apertural margin is devoid of pustules.

\section{Globigerinoides sicanus sicanus De Stefani, 1950} (Plate 10, Figures 2 and 3)

The dissected specimen of Globigerinoides sicanus sicanus, Plate 10, Figure 2, clearly exhibits the layered composition of the chamber walls. The polygonal meshwork is characterized by long, bluntly pointed corner pustules which are "canaliculate" throughout. The original polygonal meshwork has been superseded, in the course of growth, by tightly packed, irregularly fused or individual pustules, as can be seen on the spiral side of the specimen, Plate 10, Figure 3. It is of interest to note that the pustules of this specimen do not seem to be "canaliculate", hence external examination alone may not be adequate to demonstrate presence or absence of axial canals. The dissected specimen exposes the umbilical surfaces of the earliest chambers. They appear to be minutely granular and perforate, with the exception of the apertural margins.

Globigerinoides subquadratus subquadratus Brönnimann, 1954

(Plate 9, Figures 5 and 6)

This near-homeomorph of Globigerinoides ruber (d'Orbigny), 1839, has been recorded in Hole 62.1, in Zone N. 13, and in Hole 64.1 from Zone N. 7/N. 8 to Zone N.4. The two illustrated specimens, Plate 9, Figures 5 and 6 , are from Zone N.7/N. 8. The large, individual, apparently "canaliculate", pointed pustules on the imperforate apertural margin seem to be composite structures. A coarse polygonal meshwork with protruding corner pustules occurs on the perforate portions of the walls. The outer wall formations of the specimen, Plate 9, Figure 6, are characterized by coarse irregular pustulation. The basic polygonal meshwork is superseded by short irregular ridges formed through coalescing pustules. On the ultimate chambers an area is cleared of pustules and reveals tightly packed, round wall pores with upturned rims that produce short tubular extensions of the wall pores. It is possible that these tubular extensions are the result of a secondary regeneration process. The tubes are composite structures made up of many minute "crystallites". The polygonal walls of the surface around the cleared-off area exhibit distinct pinpoint-like pores, suggesting the existence of fine axial canals, which in the living form sheathed the bases of fine spines.

\section{Genus Globorotalia Cushman, 1927}

Subgenus Globorotalia Cushman, 1927

Globorotalia (Globorotalia) renzi Bolli, 1957

(Plate 32, Figures 7 and 8)

The scanning micrographs, Plate 32 , Figures 7 and 8 , of Globorotalia (G.) renzi show a similar pustulation to that described on the umbilical side of Globorotalia (T.) broedermanni Cushman and Bermúdez, 1949. In fact, the irregularly shaped, blunt, large composite pustules of the umbilical side are virtually identical in both species. On the spiral side of Globorotalia (G.) renzi, Plate 32, Figure 7, the pustules surrounding the wall pores fuse basally and produce funnel-like polygonal compartments. On the spiral and umbilical side of ultimate and penultimate chambers large pustules are sparse, and the micrographs exhibit essentially the granular to finely pustulate surface mentioned for Globorotalia (T.) broedermanni. The keel is clearly recognizable in the scanning micrograph of the spiral side. Its surface is granular to finely pustulate, which agrees well with Bolli's (1957) description of the keel as being spineless. According to Bolli (1957, p. 159, 
fig. 26) Globorotalia (T.) broedermanni predates Globorotalia ( $G$.) renzi and may be its ancestor.

\section{Genus Globorotalia Cushman, 1927 \\ Subgenus Turborotalia Cushman and Bermudez, 1949}

Globorotalia (Turborotalia) acostaensis acostaensis Blow, 1959

(Plate 33, Figures 2, 4 and 5; Text-figure 18)

The less recrystallized of the illustrated specimens of Globorotalia (T.) acostaensis acostaensis, Plate 33, Figures 4 and 5 , shows strong umbilical pustulation. The pustules are composite structures made up of large "crystallites". They are bluntly pointed and laterally interconnected by walls also composed of "crystallites". The large pustules form the corner points of a system of polygons in the centers of which are the deeply-set, rounded wall pores. The wall pores are surrounded by "crystallites". On the insides of the pore canals and on the walls of the funnel-like depressions minute pustules occur. The surface of the smaller, somewhat umbilically displaced, ultimate chamber is covered by small "crystallites", giving it a granular texture. Its wall pores differ considerably in size and occur up to the strong, rounded, finely pustulate, imperforate apertural rim. On the more recrystallized specimen, Plate 33 , Figure 2, the strong pustules consist of radially arranged "crystallites". The openings to the wall pores are much, or completely, reduced. The surface structure of both Globorotalia (T.) acostaensis tegillata Brönnimann and Resig, n. subsp., and Globorotalia (T.) pseudopima Blow, 1969, is identical with that of Globorotalia (T.) acostaensis acostaensis.

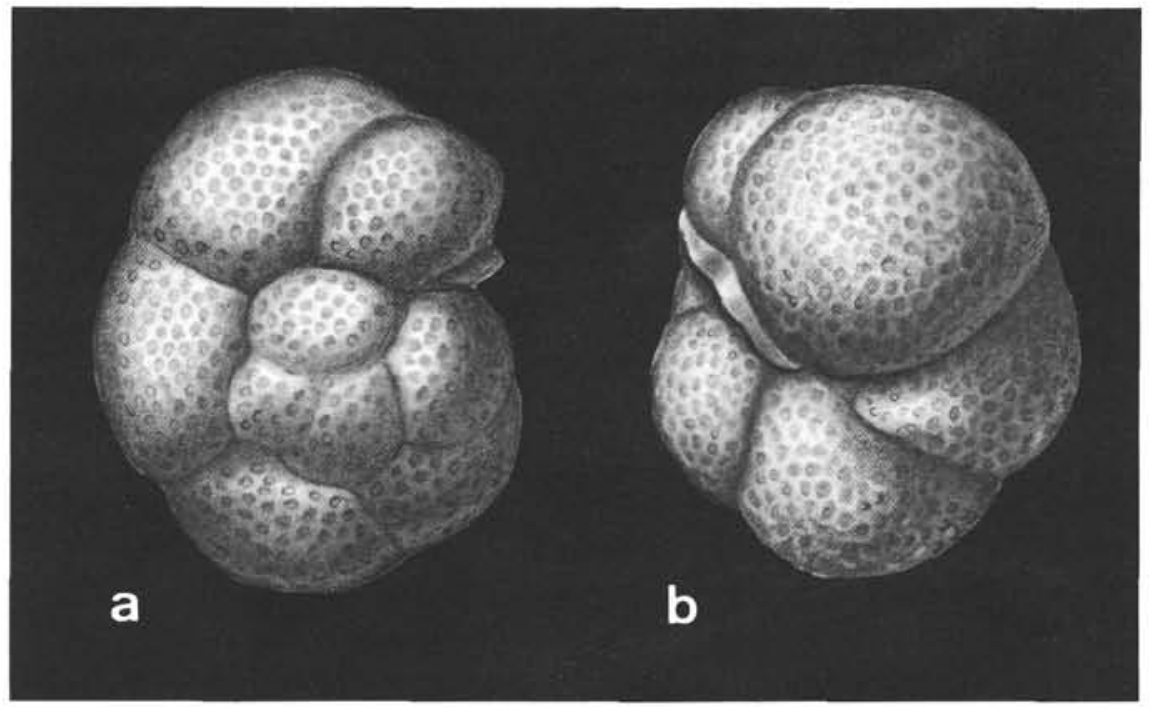

Figure 18. Globorotalia (Turborotalia) acostaensis acostaensis Blow, 1959. Hole 62.1, Core 7, Section 2, 15-17 cm; Zone N. 20 including N. 19). 155X.

Globorotalia (Turborotalia) broedermanni Cushman and Bermúdez, 1949

(Plate 32, Figure 4)

The umbilical side of Globorotalia (T.) broedermannii, scanning micrograph-Plate 32, Figure 4, is covered with densely packed large, irregularly shaped, generally blunt, composite, individual pustules. On the sutural depressions and on the apertural margin there also occur smaller pustules, granules, or "crystallites". Large rounded wall pores can be detected between the large pustules. There is a certain tendency to develop short ridges through the lateral fusion of pustules, as on the apertural face where these ridges are oriented perpendicular to the apertural margin. The imperforate apertural margin is pustulate, and the aperture is not bordered by a lip or a rim.
Globorotalia (Turborotalia) centralis Cushman and Bermudez, 1937

(Plate 32, Figure 6)

The scanning micrograph of the oblique side view of Globorotalia (T.) centralis, Plate 32, Figure 6, exhibits strong composite blunt pustules only in the neighborhood of the umbilicus, where they rise above the basic polygonal meshwork, as developed on the rest of the surface, and are associated with a reduction in the accesses to the wall pores. The apertural border is lined by blunt to pointed individual pustules; in its upper middle part a short series of tightly packed pustules, arranged perpendicularly to the apertural border, develops a strong rounded rim. The pustules seem to be "non-canaliculate", at least from their outside appearance. 


\section{Globorotalia (Turborotalia) clemenciae Bermúdez, 1961}

(Plate 34, Figure 3)

A well-preserved typical specimen of Globorotalia (T.) clemenciae has been illustrated by the scanning micrograph of the umbilical side, Plate 34, Figure 3, to show the apertural features and the outer wall formations. The ultimate chamber follows the penultimate one in such a way that the rounded, finely pustulate apertural borders of both chambers join in a composite border, as described for Globorotalia (T.) siakensis. There is no rim or lip, as in Globorotalia (T.) siakensis. The base of a broken off chamber rests on the apertural face of the ultimate chamber. This basal portion does not cut the surface of the ultimate chamber indiscriminately with regard to the distribution of its wall pores but zig-zags between the pores and follows the interporal area in short, concave and convex segments. Large, composite, pointed to blunt pustules at the corner-points grow above the basic polygonal meshwork. They do not seem to be "canaliculate". Minute pustules or "crystallites" cover the funnel-like depression which surrounds each wall pore and the interconnecting polygonal walls. The wall pores are defined by whitish lines composed of a series of minute pustules which may join laterally into a low tubular extension of the pore. Such structures are well developed around the pores of the umbilical wall portions.

\section{Globorotalia (Turborotalia) continuosa Blow, 1959} (Plate 36, Figures 7 and 8)

Both scanning micrographs of Globorotalia (T.) continuosa, Plate 36, Figures 7 and 8, show a heavy, coarsely pustulate surface. The composite pustules are recrystallized, and most of the wall pores have been closed up on the umbilical side of the test, probably due to secondary enlargement of the pustules and polygonal walls. The low-arched, "comma-shaped" aperture is one of the characteristic features of Globorotalia (T.) continuosa. The apertural border is strongly pustulate and undifferentiated.

\section{Globorotalia (Turborotalia) gemma Jenkins, 1965} (Plate 32, Figures 2 and 3)

We have referred the specimens illustrated by the scanning micrographs of the umbilical and spiral sides, Plate 32, Figures 2 and 3, to Globorotalia (T.) gemma, although the surface is not as clearly perforate and not as "smooth and polished" as mentioned by Blow and Banner (1962, p. 120,121, under Globorotalia (T.) postcretacea Myatliuk, 1950). In all other respects our specimens agree well with Blow and Banner's description. The scanning micrographs exhibit strongly pustulate surfaces. Enlargements of the individual, large, blunt pustules show them to be made up of radially arranged "crystallites". Larger individual pustules are so tightly packed on the spiral side that only on the ultimate chamber, where they are not yet as well developed, can portions of the finely granular surface be recognized. On the umbilical side, the pustules are larger and, on the first four chambers of the final whorl, more widely spaced than on the spiral side. The umbilical surface of the ultimate chamber is devoid of large composite individual pustules and is covered by densely spaced, minute granules or "crystallites". In peripheral regions pustules seem to fuse into short, thin plate-like ridges. Rare wall pores are discernible as minute dark spots, irregularly distributed between the larger pustules. The plate-like lip shows the same granular to pustulate surface as the umbilical wall of the final chamber.

Globorotalia (Turborotalia) inflata (d'Orbigny), 1839 (Plate 36, Figures 1 and 2)

The outer wall formations of Globorotalia (T.) inflata are characterized by a heavily developed polygonal meshwork. The large pustules at the polygonal corners and the broadly rounded interconnecting walls are composite structures. They consist of numerous minute elements or "crystallites", as can be seen on the scanning micrograph of the side view, Plate 36, Figure 2. On the early chambers of the final whorl, the interconnecting polygonal walls enlarge to such an extent that the accesses to the wall pores are strongly reduced or even completely closed. Toward the umbilical cavity, on the early chambers of the final whorl, the large corner pustules of the polygonal meshwork grow above the interconnecting walls and form large, pointed to blunt individual pustules. They do not seem to be "canaliculate". The imperforate apertural border, almost hidden under the strong pustules of the perforate wall, is smooth to minutely granular.

\section{Globorotalia (Turborotalia) kugleri Bolli, 1957}

(Plate 39, Figures 1, 3, 4 and 5)

Globorotalia (T.) kugleri is a biochronologically important turborotaliid. Its extinction horizon defines the limit between Zones N.4 and N. 5. Its surface structure, as seen from the spiral and umbilical sides, is illustrated by the scanning micrographs, Plate 39 , Figures 1, 3, 4 and 5. The large blunt pustules consist of numerous smaller pustules or "crystallites", which also form the low, rounded walls of the polygonal meshwork as exposed on the dorsal side of the antepenultimate and penultimate chambers. The wall pores are relatively large openings in the polygonal centers. The original polygonal meshwork is modified on the dorsal sides of the earlier chambers of the low trochospire by the formation of short irregular ridges, which do not follow the polygonal pattern. On the umbilical side, illustrated by Plate 39, Figures 3 and 4, the polygonal meshwork exists only on the ultimate chamber. On the earlier chambers, the main pustules tend to become much stronger and fuse laterally into 
irregular ridges. In places the polygonal meshwork is still recognizable. The low-arched composite aperture is made up of the apertures of the last three chambers of the final whorl, Plate 39, Figure 5. The aperture of the ultimate chamber is bordered by a round-edged, thick-walled, finely pustulate, imperforate lip-like plate which merges gradually in a peripheral direction with the imperforate apertural face covered by small and, in its upper portion, by larger and smaller individual blunt pustules.

Globorotalia (T.) pseudokugleri Blow, 1969, Plate 39, Figure 2, and Globorotalia (T.) mendacis Blow, 1969, Plate 39, Figures 6, 7 and 8 , possess essentially the same surface and apertural features as Globorotalia (T.) kugleri. The two first mentioned species have been proposed by Blow (1969) on the basis of slight morphologic differences, essentially concerning the height of the trochospire and the inclination of the intercameral sutures of the final whorl. It is our impression, after having seen several populations in stratigraphic succession, that Globorotalia (T.) mendacis and Globorotalia (T.) kugleri may be recognized in extreme specimens but that there exist transitional specimens difficult to place in either of them. Stratigraphically, Globorotalia (T.) pseudokugleri occurs in Hole 64.1 before the advent of Globorotalia (T.) kugleri and Globorotalia (T.) mendacis. Globorotalia (T.) kugleri and Globorotalia (T.) mendacis occur together in Core 6, from Section 1 to 4 , and doubtfully in Core 7, Section 2. A population study of the kugleri group of forms is necessary and may show that the forms recognized by Blow as species should be given only subspecific rank.
Globorotalia (Turborotalia) obesa Bolli, 1957 (Plate 50, Figures 7 and 8; Text-figure 19)

The scanning micrographs of two spiral views of Globorotalia (T.) obesa, Plate 50, Figures 7 and 8, exhibit strong, individual, pointed, "canaliculate" pustules which, on the apertural face, are aligned into series or ridges arranged perpendicularly to the apertural border. There is no indication of a polygonal meshwork, but fine radiating walls may link groups of pustules, as can be seen on the ultimate chamber of the specimen illustrated by Plate 50, Figure 7 . There, the individual pustules are fairly wide-spaced, leaving room for the irregularly distributed, numerous, relatively small, rounded wall pores. On the earlier chambers of the final whorl, the individual pustules are larger and more tightly packed so that some of the original wall pores are eliminated. On the early portion of the trochospire, which is slightly depressed in respect to the final whorl, wall pores occur only along the spiral suture. Also, on the specimen, Plate 50, Figure 8 , the early trochospire is depressed and the rare wall pores usually lie in the spiral suture. On this specimen, neighboring large pustules may occasionally coalesce into short ridges or incomplete polygonal compartments. From the point of view of gross morphology and outer wall formations, as seen under the light microscope, we have placed certain specimens, such as the one illustrated by Plate 50 , Figure 4 , as intermediate forms between Hastigerina siphonifera siphonifera (d'Orbigny), 1839, and Globorotalia (T.) obesa Bolli. This linking of Hastigerina and Globorotalia (Turborotalia) does not seem to be justified on the basis of the present analysis of the outer wall formations.

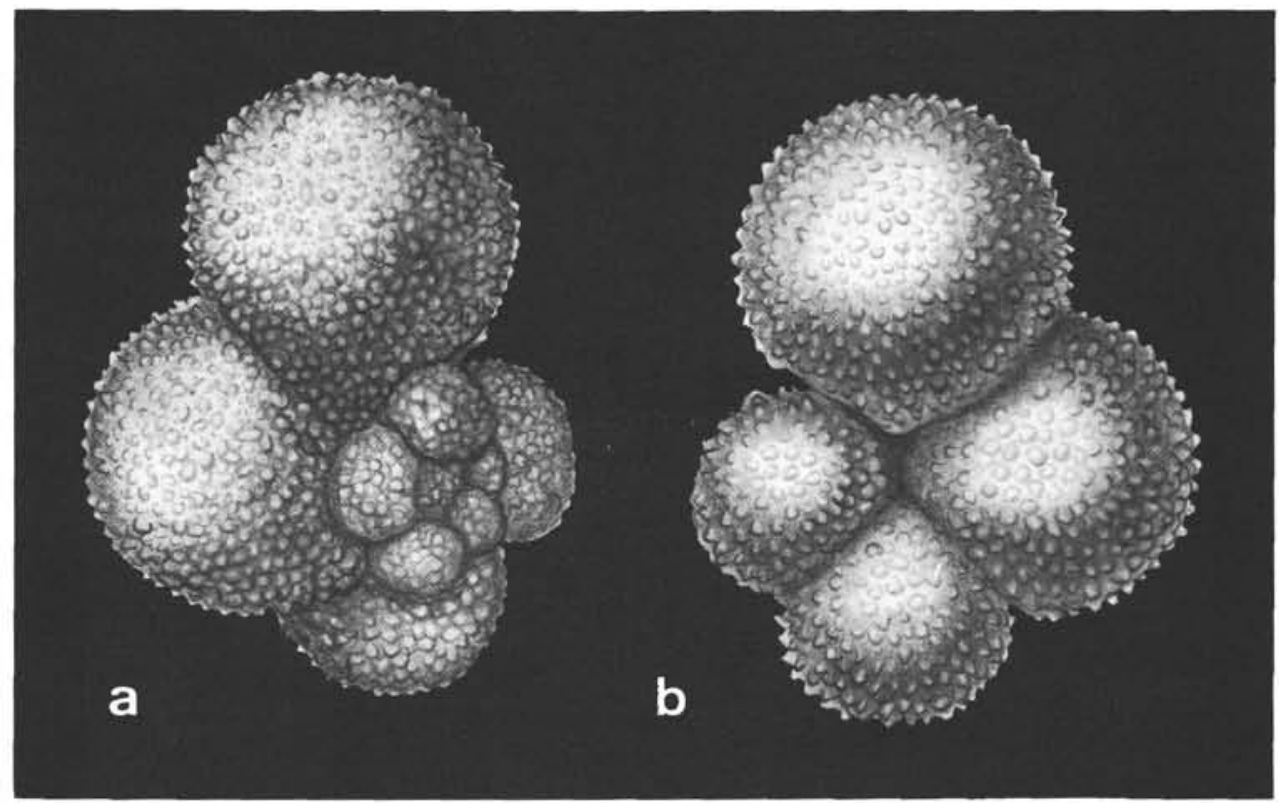

Figure 19. Globorotalia (Turborotalia) obesa Bolli, 1957. Hole 62.1, Core 12, Section 3, $15-17 \mathrm{~cm}$; Zone N. 20 (including N. 19). 155X. 
Globorotalia (Turborotalia) pseudopima Blow, 1969 (Plate 31, Figure 3; Plate 33, Figures 8 and 9. Textfigure 20)

The scanning micrograph, Plate 33 , Figure 8 , of the umbilical view of a strongly recrystallized specimen of Globorotalia (T.) pseudopima exhibits the same surface structure as described for Globorotalia (T.) acostaensis acostaensis. The details of the umbilicus of this specimen are illustrated on Plate 31, Figure 3. The less recrystallized specimen, Plate 33 , Figure 9, exhibits a well-developed polygonal meshwork. Also in Globorotalia (T.) pseudopima, pustules and interconnecting polygonal walls consist of smaller units or "crystallites". The arched aperture is bordered by an imperforate, pustulate rim which extends in a narrow lip-like plate toward the umbilicus, as shown by Plate 31 , Figure 3. The apertural rim is finer than in acostaensis acostaensis. The side view, Plate 33, Figure 9, shows a large, arched aperture bordered by a fine edge. The adjoining margin of the apertural face is imperforate and granular. There are a few larger individual pustules and they become more common toward the perforate area of the wall. The maximum length of this aperture is about 155 microns, and its maximum height about 50 microns.

Globorotalia (Turborotalia) siakensis LeRoy, 1939 (Plate 34, Figures 1, 2 and 4; Plate 35, Figures 1 through 8)

The extinction of Globorotalia (T.) siakensis defines the top of Zone N. 14 and, according to Blow (1969, p. 273, fig. 9), it starts in the upper part of Zone N. 2.
It is therefore one of the more important taxa biochronologically, and the long range may be suggestive of its heterogeneous composition. This possibility is already indicated by Blow's (1969) separation of Globorotalia (T.) cf. G. (T.) siakensis which extends from within Zone N. 1 to within Zone N. 3 and, hence, overlaps with typical siakensis. For these reasons we have extensively illustrated, by scanning micrographs, the forms here assigned to Globorotalia (T.) siakensis. We agree with Blow (1969) that the specimen figured by Bolli (1957, pl. 28, fig. $4 \mathrm{a}-\mathrm{c})$ under the name Globorotalia mayeri Cushman and Ellisor, 1939, should be placed in Globorotalia (T.) siakensis. The specimen originating from the Telisa Formation, Sumatra, donated by W. H. Blow and here illustrated by Plate 34 , Figure 1 , does not possess as clearly as one would have liked the "virtually radial intercameral sutures", in the sense of Blow (1969). The sutures between the early chambers are slightly curved and only that between the ultimate and penultimate chambers is virtually radial. The examination of the original specimen confirms the interpretation of the sutures, as shown by the scanning micrograph. In fact, the sutures are even more strongly curved than indicated by the scanning micrograph. The ventral intercameral sutures of the holotype (Blow, 1969 , pl. 10, fig. 7-9, redrawn from a photograph), on the other hand, are clearly radial, and are similar to those of the specimen from Hole 64.1, Core 2, Zone N. $7 /$ N. 8 base, Plate 34 , Figure 2, which, on the dorsal side, also possesses curved intercameral sutures between the early chambers of the final whorl. As the

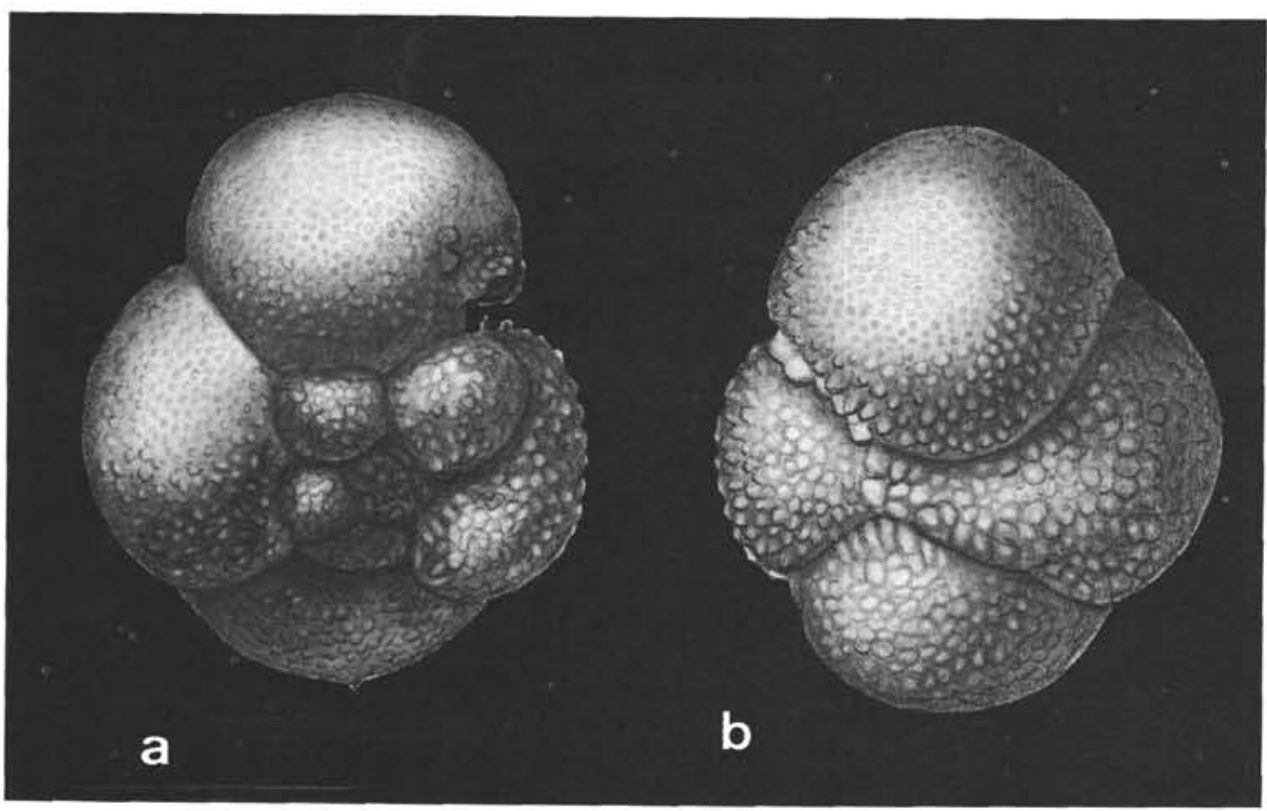

Figure 20. Globorotalia (Turborotalia) pseudopima Blow, 1969. Hole 62.1, Core 5, Section 3, Top sample; Zone N. 21. 155X. 
holotype of Globorotalia (T.) siakensis is dorsally obliquely drawn, it is difficult to say much about the curvature of the early, intercameral sutures, but they also seem to be slightly curved. Globorotalia (T.) siakensis, in the concept of the present writers, possesses intercameral sutures which are, dorsally, first slightly curved then straight radial, and ventrally straight radial throughout. So far, only by sutural features and the shape of the final chamber is it possible to distinguish Globorotalia (T.) siakensis from Globorotalia (T.) mayeri Cushman and Ellisor, 1939, illustrated here by the scanning micrograph Plate 34, Figure 8, and from Globorotalia (T.) peripheroronda Blow and Banner, 1966, forma $\alpha$, illustrated here on Plate 34, Figures 5 and 7. Apertural features and coiling are very similar in these taxa. In fact, the so-called "comma-shaped" aperture, as seen in side view, in the sense of Blow (1959)-a term introduced in the original description of Globorotalia (T.) continuosa Blow, 1959-seems to link the turborotaliids of the peripheroronda, mayeri, siakensis and continuosa type and helps to distinguish them from the stratigraphically younger turborotaliids of the acostaensis pseudopima and humerosa type. The slightly curved, early, dorsal intercameral sutures of Globorotalia (T.) siakensis is also an indication of the morphologic relationship between this species and the mayeri-peripheroronda group, in which curved dorsal and ventral intercameral sutures occur throughout the final whorl.

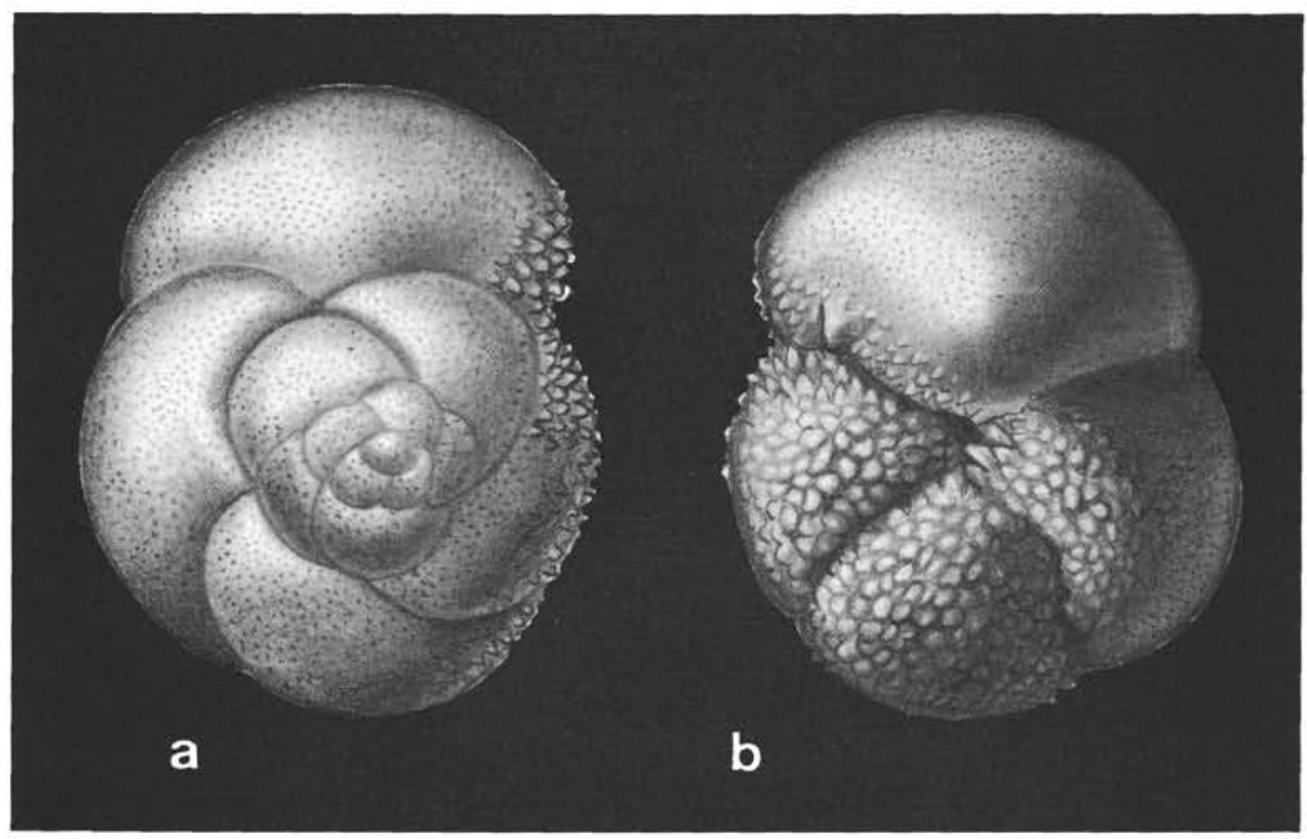

Figure 21. Globorotalia (Turborotalia) aff. Globorotalia subscitula Conato, 1964. Hole 64.0, Core 0, Surface sample; Zone N. 23. 130X.

The outer wall formations of Globorotalia (T.) siakensis, Plate 34, Figures 1, 2 and 4, are characterized dorsally and ventrally by densely set wall pores surrounded by thickened walls developed from a basic polygonal system which, in the course of growth through addition of secondary shell material, is masked by coalescing and thickening of the polygonal walls enclosing the wall pores. This process can go so far, that the openings of the wall pores are reduced or completely closed, as can be seen on the early dorsal portion of the trochospire of the specimen from the Telisa Formation, Plate 34, Figure 1. On the umbilical side, some of the polygonal corner pustules grow above the polygonal pattern and become individualized. The low-arched, "comma-shaped" aperture of the ultimate chamber is bordered by a thin-walled, very finely granular, imperforate, lip-like plate which in a peripheral direction turns up and forms a rounded rim that is closely appressed to the perforate lowermost portion of the apertural face. The lip-like structure of the aperture of the final chamber connects umbilically with that of the penultimate one, which in turn connects with that of the antepenultimate chamber. These connecting apertures produce a long, low-arched umbilical-peripheral composite aperture. The same type of composite aperture is also shown by the scanning micrographs of the umbilical sides of the specimens illustrated on Plate 35, Figures 1 through 8, which all came from the western Pacific. In these specimens, the umbilically directed lip-like plate is thicker, more coarsely pustulate, and turns up more rapidly into a strong, rounded appressed rim that 
occurs in the individual from Zone N. 7/N. 8, Plate 34, Figures 2 and 4 . On the umbilical sides of the earlier chambers of all these specimens, the meshwork becomes so coarse that the wall pores open into narrow canals which may be strongly reduced or even completely closed, through lateral enlargement of the pustules. These pustules are composite structures and, in and around the umbilicus, they may grow up into more or less pointed individual elements. They do not seem to be "canaliculate". The specimen, illustrated by Plate 35, Figures 2 and 3, shows 3 to 4 parallel ridges formed through the lateral fusion of pustules on the umbilical side of the chamber, partly visible through the apertural opening. Some of the wall pores on the umbilical side of the first chamber of the final whorl of the specimen from Hole 64.1, illustrated by Plate 34, Figures 2 and 4, contain peculiar thin-walled, cone-like structures which open in the form of lenticular white-bordered slits. The cone-like structures may be perfectly centered or they may be oblique in respect to the axis of the pore. They have been observed on all chambers of this specimen, though not as well developed as on the first chamber of the final whorl. Indications of similar structures have also been seen on the dorsal side of the specimen from the Telisa Formation, Sumatra, Plate 34, Figure 1. On the other hand, they seem to be absent in the specimens illustrated on Plate 35, Figures 1 through 8. It is not clear whether these cone-like intraporal structures are formations of the foraminifers themselves or whether they represent structures produced by a foreign microorganism.

\section{Genus Hastigerina Thomson, 1876}

Hastigerina adamsi Banner and Blow, 1959 (Plate 14, Figures 1 and 2)

Hastigerina adamsi has only been recorded in Zone N. 23. This species is illustrated by the scanning micrograph, Plate 14, Figures 1 and 2. The thin walls are densely perforate. The maximum diameter of the irregularly rounded wall pores reach about 10 microns on the ultimate chamber. In the spaces between the wall pores, bluntly rounded, apparently "noncanaliculate", individual pustules occur. They seem to be composite structures. The pustules are not regularly arranged, so that no polygonal pattern is developed. Occasionally two adjoining pustules may fuse into very short ridges. There is no difference between the first and the last chamber of the final whorl regarding this feature. However, the surface of the oldest chamber of the final whorl is finely granular. One of the wall pores is surrounded by a finely pustulate annulus reminiscent of the "block"-structure encircling the wall pores of Nummulites rectus Curry (Murray and Wright), 1970, pl. 38, fig. 2). The high-arched, equatorialinteriomarginal aperture is bordered by a thin, imperforate pustulate rim. The perforation of the chamber wall extends up this rim.
Hastigerina siphonifera (d'Orbigny) involuta (Cushman), 1917

(Plate 14, Figures 4 and 5)

The surface structure of the illustrated specimen of Hastigerina siphonifera involuta from Zone N. 20 (including N. 19) is much heavier than that of Hastigerina siphonifera siphonifera (d'Orbigny), 1839, from Zone N. 23. The individual larger and smaller pustules, at least those on the imperforate margin near the aperture, are coarsely "canaliculate". The wall of the ultimate chamber is densely perforate and the pustules are irregular, composite, generally pointed structures which may coalesce laterally but never develop a polygonal pattern. Going from the ultimate chamber to the early chambers of the final planispiral whorl, the pustulation becomes gradually stronger and, through enlargement and lateral fusion of the pustules, most of the wall pores are reduced or even closed, so that on the first chamber of the planispire only a few, very small wall pores remain open. The aperture is an equatorial, interiomarginal arch without a differentiated band. A narrow region above the aperture, having individual, larger pustules with a granular surface between, is imperforate.

Hastigerina siphonifera siphonifera (d'Orbigny), 1839 (Plate 14, Figure 6)

The wall and apertural features of Hastigerina siphonifera siphonifera are quite similar to those of Hastigerina adamsi Banner and Blow, 1959. The scanning micrograph of the side view, Plate 14, Figure 6, exhibits the densely perforate walls and the generally non-coalescent pointed and "canaliculate" individual pustules. There are relatively few, and widely spaced, low, conical to rounded individual pustules on the ultimate chamber. On the penultimate one, their number increases and they are higher. Occasionally two adjoining pustules may fuse in to a short ridge, or more rarely, several pustules may form an annulus around a pore. The pustules on the penultimate chamber are also more pointed than those on the ultimate one. On the antepenultimate chambers the pustules are larger, in transverse section irregular angular, apparently "canaliculate" structures so large and densely set that they almost touch each other, leaving only enough space for the wall pores. Occasionally, also, these pustules may fuse laterally, but only a few at a time, to produce short, irregular ridges. On the preceding chambers, the wall structure is similar, the individual, apparently "canaliculate" pustules become even larger and higher and coalesce more frequently to form irregular-bordered depressions around wall pores. The equatorial-interiomarginal aperture of the ultimate chamber possesses a narrow, apparently finely pustulate, imperforate band. The apertural wall is perforate up to this band. The total aperture is a composite structure consisting of the joined apertures of the chambers of the final whorl. 


\section{Genus Hastigerinella Cushman, 1927}

\section{Hastigerinella digitata 1911}

\section{(Plate 14, Figure 3)}

The scanning micrograph of the apertural side of Hastigerinella digitata, Plate 14, Figure 3, is not of good quality. It shows, nevertheless, that the surface structure is quite similar to that of Hastigerina adamsi Banner and Blow, 1959. The densely distributed wall pores seem to lie in the centers of rounded funnel-like depressions. The pustules are irregularly distributed and do not coalesce in polygonal compartments. The high-arched aperture is bordered by a narrow, pustulate, imperforate rim.

\section{Hastigerinella digitata (Rhumbler) praedigitata (Parker), 1967 \\ (Plate 50, Figure 9)}

The walls of Hastigerinella digitata praedigitata, Plate 50, Figure 9, are perforated by irregularly distributed and fairly large wall pores. As can be clearly seen on the antepenultimate chamber, the wall pores are surrounded by crater-like formations which seem to be some sort of rudimentary polygonal compartments, as they are well developed on ultimate and penultimate chambers. But as the wall pores are widely spaced, so the rudimentary compartments are spaced, thus giving the impression of crater-like formations. Larger pustules occur irregularly distributed in the corners of the polygonal compartments. In between the wall pores, the surface is minutely granular. The aperture is bordered by an imperforate, upturned, thin-walled rim of granular texture.

\section{Genus Pulleniatina Cushman, 1927}

Pulleniatina obliquiloculata obliquiloculata (Parker and Jones), 1862

(Plate 16, Figures 1 through 11; Plate 17, Figures 1 through 4, 5? and 6?; Plate 18, Figures 1 through 7; Plate 19, Figure 6)

The morphology of the early ontogenetic stages, particularly apertural features and wall structures, is important for the determination of the suprageneric affiliation of Pulleniatina Cushman, 1927 (Parker, 1967 , p. 172). Therefore, we have extensively illustrated by scanning micrographs entire and dissected adults and entire young specimens of Pulleniatina obliquiloculata obliquiloculata, the type species of Pulleniatina. On Plate 16, Figures 1 through 11, we have figured the general morphology of the test, including surface and apertural features, of a series of ontogenetic stages going from about 9-chambered young to about 15- to 18-chambered adult individuals. We have shown this series of specimens to F. L. Parker, who agreed that they are different ontogenetic stages of Pulleniatina obliquiloculata obliquiloculata. The earliest ontogenetic stages recognized in our samples, from Zone N. 23, are illustrated on Plate 16, Figures 1 through 4. The scanning micrograph, Plate 16,
Figure 1, of an umbilical view exhibits four subglobular and, peripherally, somewhat flattened chambers which increase gradually in size over the first three chambers, then rapidly from the third to the fourth chamber, which makes up about one third to one half of the total test. The ultimate chamber wall is densely perforated by rounded, beveled-edged pores which reach about 4 microns diameter. Each pore is defined by a thin whitish annulus which, on the earlier chambers, seems occasionally to rise above the surface of the wall. This presumed tubular structure needs to be further investigated by scanning micrographs. On the somewhat flattened apertural face of the ultimate chamber, which is imperforate toward the large, arched aperture, occur individual, blunt to pointed, apparently "non-canaliculate" pustules of different lengths arranged in irregularly concentric rows. On both sides of the apertural face, these pustules tend to fuse laterally into short, irregular, more or less concentric ridges. The pustules are composite structures. Laterally the ridges and pustules are superseded by low, rounded, more or less concentric ridges consisting of numerous minute pustules. This portion of the wall surface, therefore, gives the impression of being finely granular. It is noteworthy that on the ultimate chamber the ridge structure is stronger than the polygonal compartment structure which also, but very weakly, starts to develop on its dorsal side. The penultimate chamber exhibits an imperforate narrow band bordering the wide-arched umbilical aperture. The imperforate lower portion of the apertural face is covered by irregular-sized and irregularly distributed pointed individual pustules. The apertural rim also seems to be minutely granular. On the perforate upper portion of the apertural face, the individual pustules tend to fuse in vertical rows. On the lateral portion of the surface of the penultimate chamber, the pustules surrounding the wall pores start to fuse laterally creating funnel-like compartments in which the pustules rise distinctly above the fused, thin-edged interconnecting walls. On the antepenultimate chamber, only the perforate portion of the apertural face is visible. There we find large, pointed, individual pustules and, on the low interconnecting walls linking the large pustules in irregular fashion, minute pustules or "crystallites". Away from the apertural face, the tendency to fuse increases and irregular funnel-like compartments are developed, with the strong pointed pustules rising above the interconnecting walls. The same surface structure exists on the first chamber of the final whorl. The scanning micrograph of the side view of another young stage of Pulleniatina obliquiloculata obliquiloculata, Plate 16, Figure 2, shows the same wall structure as described above. The scanning micrograph, Plate 16, Figure 3, of the dorsal side of an ontogenetic stage comparable to those described above, shows a very flat trochospire of three whorls composed of a total of 14 chambers. The first whorl consists of about seven chambers, including the proloculus, which 


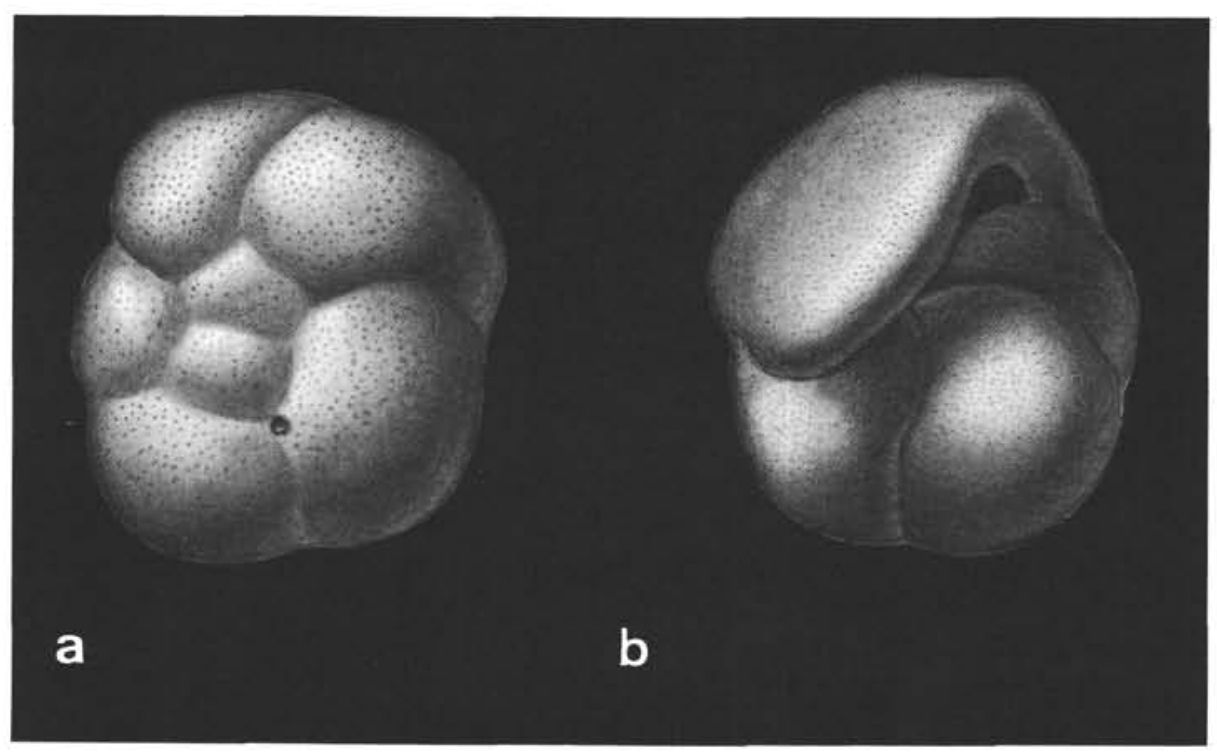

Figure 22. Pulleniatina aff. Pulleniatina obliquiloculata praecursor Banner and Blow, 1967. Hole 62.1, Core 4, Section 1, 15-17 cm; Zone N. 22. 95X.

increases gradually in size, the second whorl of four chambers which increase rapidly in size, and the third whorl, which is incomplete, of three, also rapidly increasing, chambers, The ultimate chamber almost equals in size that of the previously completed test. The irregularly rounded wall pores are the dominant feature of the spiral side. The proloculus, of about 25 microns maximum diameter, has about four elongate wall pores of from 7 to 8 microns maximum diameter, in a spiral-sutural position. Also, the following three chambers have a few elongate-rounded pores in a sutural position; the first really areal wall pores of about 5 microns maximum diameter appear only on the fourth chamber. On the fifth chamber an areal wall pore measures about 5 microns in its greatest diameter. Wall pores, in the form of elongate slits about 5 to 10 microns long continue to occur in the spiral and radial sutures. During ontogeny, the number of dorsal areal wall pores increases, and simultaneously their diameter decreases. Table 5 refers to the specimen illustrated on Plate 16, Figure 3. The parameter (Column 4) furnishes a base to compare ontogenetic series of dorsal areal wall pores which might be significant on a species level.

The surface pattern of the illustrated specimen is dominated, on the early chambers, by non-continuous concentric ridges. No clear-cut polygonal pattern exists.

The scanning micrograph of the oblique dorsal view of a very young specimen referred to Pulleniatina obliquiloculata obliquiloculata, Plate 16, Figure 4, with 9 or 10 chambers arranged in not quite two whorls, shows a distinct polygonal surface pattern whose ridges are low, broadly rounded and consist of numerous minute pustules or "crystallites".

Of particular interest are the advanced adult individuals represented by the scanning micrographs, Plate 16 , Figures 6 through 9. In Plate 16, Figure 7, the layering of the chamber walls is well exposed on the ultimate chamber, where the last layer with a rather smooth surface texture is broken-off revealing underneath a granular wall of the same surface structures as described in the individual on Plate 16, Figure 4. The umbilical portions of the specimen, Plate 16, Figure 7, display strong, individual, generally pointed composite pustules. Above the thin imperforate apertural rim there also occur pointed to blunt individual pustules which, above the central portion of the aperture, fuse into short ridges arranged perpendicularly to the apertural rim. This structure is also shown by the scanning micrograph, Plate 16, Figures 6 and 8 , where the pustules do not coalesce as clearly as in the individual on Plate 16, Figure 7.

On the early chambers, the specimen, Plate 16, Figure 6, develops coalescing composite low pustules that considerably reduce the openings to the wall pores. This is reminiscent of the surface structure of Pulleniatina primalis Banner and Blow (Plate 20, Figure 7). The pre-adults, Plate 16, Figures 9 and 10, are characterized by a brilliant transparent surface layer which virtually closes the wall pores, but shows them underneath as dark points. The low pustulate structure of the early portion of the dorsal side of the trochospire is more or less masked by this transparent 


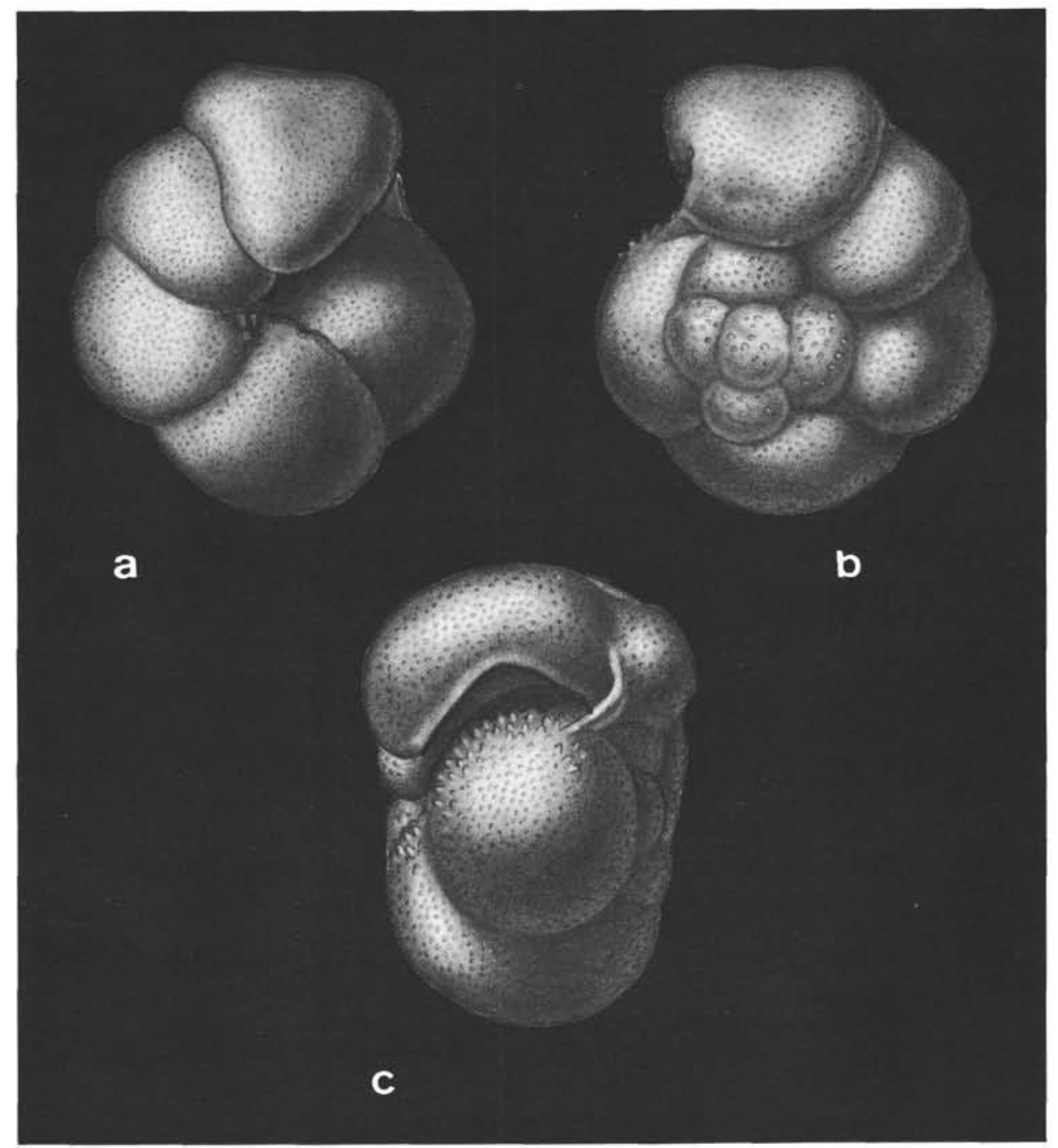

Figure 23. Pulleniatina praepulleniatina Bronnimann and Resig, n. sp. Hole 62.1, Core 20, Section 2, 15-17 cm; Zone N. 17. 130X.

layer. The umbilical view, Plate 16, Figure 10, still exhibits some of the blunt to pointed, composite umbilical pustules. The adult specimen, Plate 16, Figure 11, possesses the same brilliant surface, but the pustulate pre-adult structure is now completely masked on the dorsal side. The umbilical portions of the early chambers and the apertural region, however, still reveal the pre-adult pustulate surface structure. A new feature, which was not observed on the pre-adults, Plate 16, Figures 9 and 10, are rare, fine, irregularly distributed wall pores of about 2 microns maximum diameter. Jammed in the aperture of this individual is a fragment of an early ontogenetic chamber of Pulleniatina obliquiloculata obliquiloculata (?). The abovementioned rare wall pores also exist on the adult specimen, Plate 19, Figure 6 and Plate 17, Figure 1, and on the adults of Pulleniatina obliquiloculata finalis Banner and Blow, Plate 19, Figures 1, 2 and 3. On the other hand, we did not notice these fine wall pores on the adults of Pulleniatina spectabilis Parker, Plate 19, Figure 5, and Pulleniatina spectabilis praespectabilis Brönnimann and Resig, n. subsp., Plate 19, Figures 4 and 7.

Details of ontogenetic stages of Pulleniatina obliquiloculata obliquiloculata are also illustrated by the scanning micrographs, Plate 17, Figures 1 through 4, possibly also Figures 5 and 6 . Figure 1, shows the surface of an adult specimen. The calcite layer is finely fissured through the crystal boundaries and the openings of the wall pores are restricted and surrounded by a mound of radially arranged granules or "crystallites". Plate 17, Figure 2, reveals the crystalline structure of the walls encircling the wall pores on the inner surface. Plate 17, Figures 3 and 4 are micrographs 


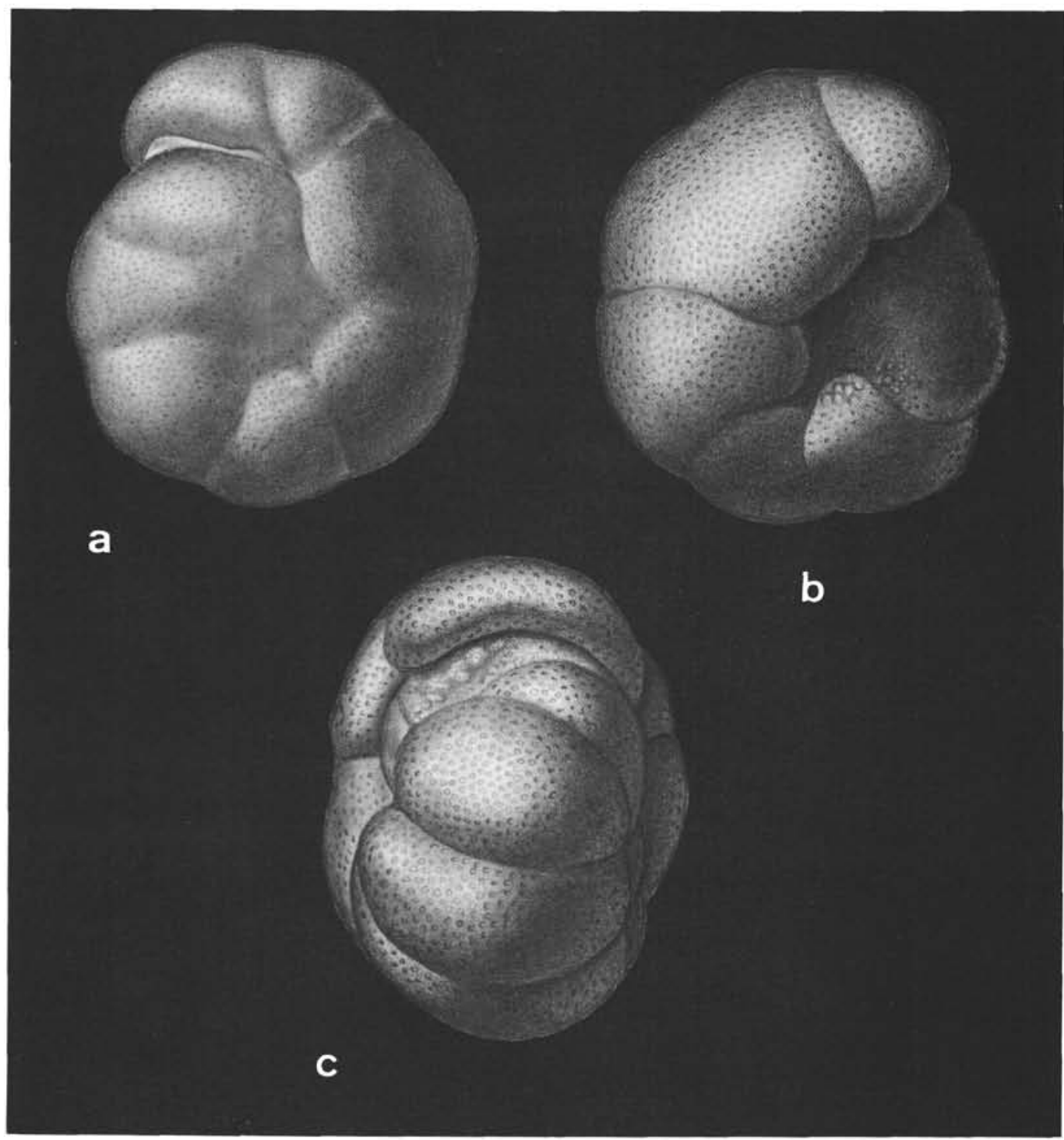

Figure 24. Pulleniatina primalis Banner and Blow, 1967. Hole 62.1, Core 19, Section 1, 51-56 cm; Zone N. 17. 130X.

of the fractured wall of the same specimen as illustrated by Plate 17, Figure 2. The hairline cutting the wall in its lower quarter, parallel to its inner and outer surface, is interpreted here as caused by an organic lamella. Two such lines are visible toward the inner surface of a chamber wall in the micrograph, Plate 18, Figure 2, which is a detail from the dissectioned specimen, Plate 18, Figure 5. The very minutely, pustulate, polygonal surface structure of the earliest ontogenetic chamber exposed by the dissectioned specimen, Plate 18, Figure 4, corresponds well with that of the early ontogenetic stage illustrated by Plate 16, Figure 4. The fractured wall of the Plate 18, Figure 7, reveals numerous parallel calcareous lamellae which locally seem to be separated by hairline cuts, as described above.
Genus Sphaeroidinella Cushman, 1927

Sphaeroidinella dehiscens dehiscens (Parker and Jones), 1865

(Plate 15, Figure 1)

The upturned apertural rims of Sphaeroidinella dehiscens dehiscens are imperforate, and along their sharp edges, Plate 15, Figure 1, occur minute irregularities, probably minute pustules or "crystallites". The surface of the chambers, including that of the upturned apertural rim, is not smooth but covered by minute, low pustules which are more visible on the earlier chambers of the test and on the regions between upturned apertural rims and perforate walls than on the surface of the ultimate chamber. These pustules, the largest of which measures about 5 microns in 


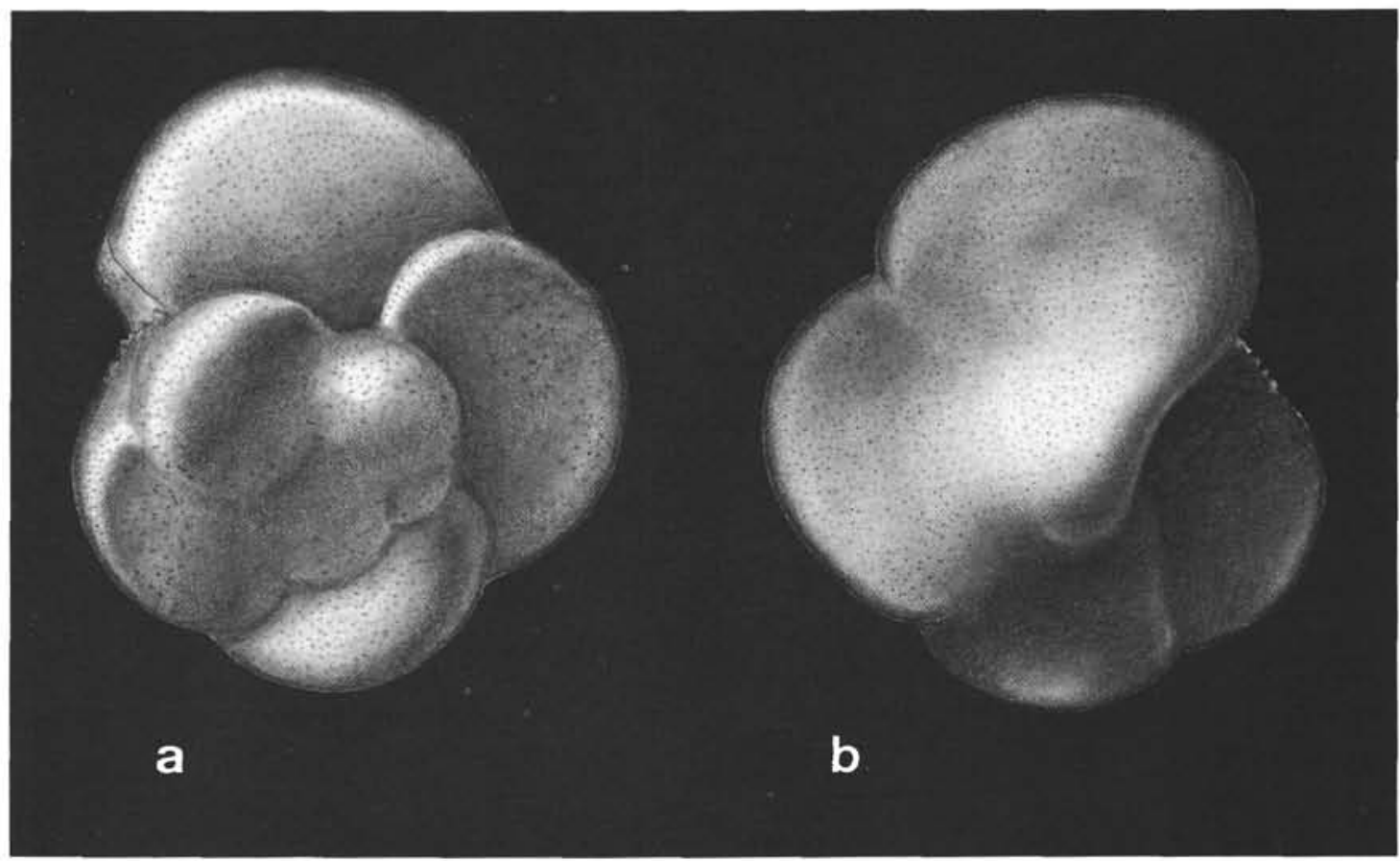

Figure 25. Pulleniatina spectabilis Parker, 1965. Hole 62.1, Core 11, Section 5, 16-18 cm; Zone N. 20 (including N. 19). 118X.

diameter, produce a finely granular aspect of the surface. Another interesting feature of the wall is the numerous small, irregular-rounded pores which measure up to 10 microns in diameter. They are defined by whitish-colored annuli which seem to rise very slightly above the surface of the wall. These annuli seem to consist of adjoining minute granules or "crystallites". Their detailed morphology needs to be analyzed by further studies with the scanning microscope. According to Blow $(1969$, p. 335,336 , also explanation to pl.29, fig. $6,7,8$ and 9) the lamellar "cortex" enveloping the original walls "appears to be largely imperforate in the sense that most of the normal pores of the underlying test wall do not pass through the cortex to the exterior or are restricted by the cortex". This would suggest a similar structure to that found in Candeina nitida nitida d'Orbigny, 1839, where the final wall pores are strongly restricted in comparison to the wall pores of the first formed chamber. Blow (1969) further notices the existence of a very fine, anastomosing system of canaliculae within the cortex, which open as pinpoint pores on the surface of the test.

Sphaeroidinella dehiscens (Parker and Jones) immatura (Cushman), 1919

(Plate 15, Figure 3)

We have elevated this forma to subspecific rank because of the morphologic and stratigraphic differences between immatura and dehiscens. In Hole 62.1, we have recorded rare but typical specimens of immatura in the interval from Core 9, Section 1 to Core 12, Section 6, whereas Sphaeroidinella dehiscens dehiscens appears in Core 10, Section 2 and continues up to Zone N. 23. Blow (1969) interprets immatura as the ancestral form of dehiscens. The scanning micrograph, Plate 15, Figure 3, illustrates the "dorsal view" with the sutural opening which is still relatively large in this specimen. In other specimens it may be a very small, sutural, elongate, irregularly outlined opening with upturned borders. Considering this feature alone, there exists only a difference of degree between immatura and dehiscens and at what point to draw a taxonomic line in the presumed morphologic evolution from immatura to dehiscens is up to the subjective decision of the observer. Blow's (1969) inclusion of the large tests of paenedehiscens in Sphaeroidinellopsis is difficult to understand. If there is an evolutionary series from immatura to dehiscens then we could as well go a step further and propose an evolutionary series from paenedehiscens without "dorsal" aperture to immatura with a small "dorsal" sutural aperture to dehiscens with a large "dorsal" sutural aperture to excavata in which "ventral" and "dorsal" sutural apertures are laterally connected and form a single enveloping sutural aperture. Stratigraphically such an evolutionary series of forms, all included in Sphaeroidinella Cushman, 1927, would work out perfectly on the basis of Blow's (1969) range charts: paenedehiscens extends from Zone N.17 to Zone N. 20 (basal portion), immatura from Zone N. 19 (bottom) to Zone N. 19 (top portion), dehiscens from 
Zone N. 19 (basal portion) to Zone N. 23, and excavata would be restricted to Zone N. 23 .

The apertural features of Sphaeroidinella dehiscens immatura Plate 15, Figure 3, are characterized by upturned finely pustulate edges similar to those observed in dehiscens and in "Sphaeroidinellopsis" subdehiscens paenedehiscens. The aperture extends along the horizontal suture and to some degree along the vertical suture. The surface structure of the early chambers is finely granular; that of the large ultimate chamber seems to be essentially smooth. Perforations occur all over the surface, except for a fairly welldefined border area around the sutural aperture. The very small, pinpoint-like wall pores occur on the tops of minute cones. These cones develop into pointed structures in the upper portion of the ultimate chamber and could be compared with the "canaliculate" pustules of certain globigerines.

\section{Genus Sphaeroidinellopsis Banner and Blow, 1959}

Sphaeroidinellopsis seminulina seminulina (Schwager), 1866

(Plate 15, Figures 7 and 8)

The surface structures of the specimens of Sphaeroidinellopsis seminulina seminulina, illustrated by the scanning micrographs of the umbilical views, Plate 15 , Figures 7 and 8 , are well-preserved. The surface of the specimen from Zone N. 13, Plate 15, Figure 7, is finely granular on the ultimate and more coarsely granular on the preceding chambers of the final whorl. The granules seem to be minute pustules or "crystallites". Wall pores are present on the ultimate, penultimate and antepenultimate chambers. They occur at minute openings of up to 5 microns maximum diameter on top of small cones which rise above the surface of the wall. The aperture is a large, low arch with a thick, imperforate and rounded border. This border is strongly developed and finely pustulate on the specimen from Zone N. 16 and it exists also, but more weakly in Sphaeroidinellopsis seminulina kochi (Caudri), 1934, Plate 15, Figure 9. The surface structure of the individual, Plate 15 , Figure 8 , is much more coarsely granular than that described above for the specimen, Plate 15, Figure 7. In both individuals, the umbilical portions of the pre-ultimate chambers form coarsely pustulate and irregular edges which, in Sphaeroidinellopsis subdehiscens subdehiscens (Blow), 1959, Plate 15, Figure 4, virtually close the aperture. Minute wall pores occur on all chambers. Their maximum diameter measures about 2 microns on the ultimate chamber. They are surrounded by elevated cone-like walls which consist of a single annulus of minute pustules or "crystallites", as described by Murray and Wright (1970) pl. 38, fig. 2) for the wall pores of Nummulites rectus Curry. The apertural features of Sphaeroidinellopsis seminulina seminulina need to be studied in more detail and may perhaps be useful to establish evolutionary series within this taxon.

"Sphaeroidinellopsis" subdehiscens Blow paenede(Plate 15, Figure 2)

Blow's (1969, pl. 30, fig. 4, 5, 9) scanning micrographs of "Sphaeroidinellopsis" subdehiscens paenedehiscens show similar pore structures as described from Sphaeroidinella dehiscens dehiscens (Parker and Jones), 1965. In fact, the annuli around the small wall pores rise, comparable to minute cones, above the surface of the test wall. The grain of the reproduction in Blow's paper does not permit any detailed observations of the surface structure, which in our scanning micrograph, Plate 15, Figure 2, of the side opposite the single large, slit-like "ventral" aperture is distinctly granular. This side of the test seems to be virtually devoid of perforations with the exception of the slight "dorsal" depression linking both extremities of the "ventral" aperture where a linear series of 5 to 6 larger wall pores is discernible. They are rounded to irregular in shape, of about 20 microns diameter, and rise cone-like above the surface of the test wall. This linear series of wall pores cannot be explained without further scanning observations and dissections of the test. The scanning micrographs of the holotype (Blow, 1969, pl.30, fig. 4 a) show in contrast to our specimen the "dorsal" side of the test to be densely perforate.

Sphaeroidinellopsis subdehiscens subdehiscens (Blow), 1959

(Plate 15, Figures 4, 5 and 6)

Sphaeroidinellopsis subdehiscens subdehiscens is one of the biochronologically more important species of the genus because its evolutionary appearance defines the limit between Zones N. 12 and N. 13. The individual from Core 35, Zone N. 13, Plate 15, Figure 4, possesses an aperture which is almost closed by large irregular projections from the penultimate chamber. The surface is granular and strongly recrystallized so that structural details are not preserved. The specimen from Core 11, Zone N. 20 (including N. 19), Plate 15, Figures 5 and 6 , is diagenetically less modified. The open aperture is in umbilical-sutural position, recalling in its general form the single aperture of Sphaeroidinella dehiscens immatura (Cushman), Plate 15, Figure 3. It is bordered by a pustulate imperforate edge which, however, is not up-turned. The surface is minutely pustulate and makes a granular impression. There are a few very small, pinpoint-like wall pores. On the top of the ultimate chamber, there are numerous conical pustules, probably extensions of the walls of the pores as already described in "Sphaeroidinellopsis" subdehiscens paenedehiscens Blow, 1959, and in Sphaeroidinella 
dehiscens immatura (Cushman), 1919. It should be mentioned that the specimen from Zone N. 20 (including N. 19) exhibits between the three chambers distinct but very fine sutures. The one between the penultimate and antepenultimate chambers extends as a straight thin line from the aperture vertically to the base of the test. The sutures are more incised and better perceptible in the specimen from Zone N. 13. The apertural and sutural features differ considerably between the older and the younger form, and future scanning work may perhaps demonstrate the presence of quasi-homeomorphs in the interval from Zone N. 13 to Zone N. 19 in the sense of Blow (1969) which now are grouped in the same taxon.

\section{Genus Turborotalita Blow and Banner, 1962}

\section{Turborotalita humilis (Brady), 1884, Group}

(Plate 21, Figures 6 and 7)

The scanning micrographs of the umbilical side of two different individuals of Turborotalita humilis, Plate 21, Figure 7 , display coarsely structured surfaces, excepting the lip-like umbilical-sutural extension of the ultimate chamber (bulla-according to Blow, 1969), which is minutely granular. The polygonal meshwork consists of stronger, blunt, composite corner pustules interconnected by slightly lower, equally finely pustulate broad rounded walls. In the center of each polygon is a deeply set wall pore. The peripheral margin of the ultimate chamber is covered by a more delicate polygonal meshwork with long and pointed pustules and thin-edged, low interconnecting polygonal walls. This peripheral structure produces the more or less developed denticular outline of the ultimate chamber.

Turborotalita iota (Parker), 1962

(Plate 23, Figures 6, 7 and 8(?))

The dissected specimen of Turborotalita iota, Plate 23, Figure 6, reveals that the umbilically directed apertural wall changes ontogenetically from a single apertural to a multiple apertural umbilical-sutural extension. The single-apertural stage is also illustrated by the umbilical view of the specimen, Plate 23, Figure 7, where the extension of the apertural wall in the form of a triangular tongue covers a single aperture which seems to extend from the umbilicus toward the periphery. A similar aperture has been drawn by Parker (1962, pl. 10, fig. $29 \mathrm{a}-\mathrm{c})$. The specimen with a radially elongate final chamber (pl. 10, fig. $30 \mathrm{a}, \mathrm{b}$ ), referred by Parker to Globigerinita iota, is probably a representative of Globorotalia (T.) parkerae Brönnimann and Resig, n. sp. We do not interpret the umbilical extensions of the apertural walls as "bullae" and refer Parker's forms to the genus Turborotalita Blow and Banner, 1962. The dissected specimen further reveals the layering of the chamber walls. On the antepenultimate chamber at least three different layers can be distinguished. The innermost layer discernible on this specimen possesses a finely granular surface with widely spaced small "wall pores" which seem to open on the tips of minute "pustules". It is possible that these "wall pores" represent, in fact, the openings of "canaliculate" pustules, and that the real wall pores are not discernible on the granular surface. The second wall layer is exposed on a small umbilically directed area not covered by the third and final layer. The second layer displays individual pustules of different dimensions. A large rounded wall pore can be detected toward the radial suture between antepenultimate and penultimate chamber. The third and final wall layer is of finely granular surface texture and is perforated by large beveled-edged widely spaced wall pores surrounded by an incipient polygonal meshwork. These three differently structured layers represent three different ontogenetic stages in the development of the outer wall formations. On the penultimate chamber, the final wall layer is removed on the umbilically directed extension of the apertural tongue. Its surface texture is coarsely granular and the wall is perforated by scarce pores. The appearance of this layer is reminiscent of that exposed by the middle layer of the antepenultimate chamber. On the specimen, Plate 23, Figure 7 , the polygonal meshwork is stronger than on the specimen described above, Plate 23, Figure 6, but the basic outer wall pattern is identical in both. The specimen illustrated by the scanning micrograph, Plate 23 , Figure 8 , is completely recrystallized. It has only questionably been referred to Turborotalita iota. The umbilical tongue of the ultimate chamber extends into radial sutures where it covers two sutural openings. The recrystallization has here altered the original outer wall formation so that they are no longer recognizable. Indications of scarce rounded wall pores are still detectable.

\section{REFERENCES}

Akers, W. H., 1955. Some planktonic foraminifera of the Ame-Gulf Coast and suggested correlations with the Caribbean Tertiary. J. Paleontol. 29, 647.

Arkell, W. J., 1956. Jurassic Geology of the World. Oliver and Boyd (Eds.), Edinburgh and London (p. XV + 804)

Asano, K., Ingle, J. C., Jr. and Takayanagi, 1968. Globigerina quinqueloba Natland: origin and distribution in late Cenozoic of the north Pacific. Giorn. Geol. 35, 217.

Bandy, O. L., and Casey, R. E., 1969. Major Late Cenozoic planktonic datum planes, Antarctica to the Tropics. Antarctic J. 4, 170.

Bandy, O. L., and Ingle, J. C., 1970. Neogene planktonic events and radiometric scale, California. Geol. Soc. Am. Spec. Papers. 124, 131.

Bandy, O. L., Morin, R. W. and Wright, R. C., 1969. Definition of the Catapsydrax stainforthi Zone in the Saucesian Stage, California. Nature. 222, 468. 
Bandy, O. L., Vincent, E. and Wright, R. C., 1969. Chronologic relationship of Orbulines to the Globorotalia fohsi lineage. Rev. Esp. Micropaleontol. 1, 131.

Banner, F. L. and Blow, W. H., 1965. Two new taxa of the Globorotaliinae (Globigerinacea, Foraminifera) assisting determination of the late Miocene/middle Miocene boundary. Nature. 201 (5004), 1351.

Banner, F. L. and Blow, W. H., 1965. Globigerinoides quadrilobatus (d'Orbigny) and related forms: their taxonomy, nomenclature and stratigraphy. Contrib. Cushman Found. 16, 105.

Banner, F. T. and Blow, W. H., 1966. Progress in the planktonic foraminiferal biostratigraphy of the Neogene. Nature. 208, 1164.

Banner, F. T. and Blow, W. H., 1967. The origin, evolution and taxonomy of the foraminiferal genus Pulleniatina Cushman, 1927. Micropaleontol. 13, 133.

Barbieri, F. and Medioli, F., 1969. Distribution of foraminifera on the Scotian Shelf (Canada). Riv. Ital. Paleontology. 75, 849 .

Bé, A. W. H., 1960. Ecology of Recent planktonic foraminifera: Part 2, Bathymetric and seasonal distributions in the Sargasso Sea off Bermuda. Micropaleontology. 6,373 .

Bé, A. W. H. and Hemleben, Ch., 1970. Calcitisation in a living planktonic foraminifer, Globigerinoides sacculifer (Brady). Nues Jahrb. Geol. Palaont., Abhandl. 134, 221.

Beard, J. H., 1969. Pleistocene paleotemperature record based on planktonic foraminifers, Gulf of Mexico. Trans. Gulf Coast Assoc. Geol. Soc. 19, 535 .

Beckmann, J. P., 1957. Chiloguembelina Loeblich and Tappan and related foraminifera from the lower Tertiary of Trinidad, B.W.I. U. S. Nat. Museum Bull. 215,83 .

Berger, W., 1967. Planktonic foraminifera: Selective solution and paleoclimatic interpretation. Deep-Sea Res. $15,31$.

Berger, W. H., 1969. Planktonic foraminifera. Basic morphology and ecologic implications. J. Paleontol. 43, 1369.

Berger, W. H., 1969. Ecologic pattern of living planktonic foraminfers. Deep-Sea Res. 16, 1.

Berggren, W. A., 1969. Cenozoic chronostratigraphy, planktonic foraminiferal zonation and the radiometric time scale. Nature. 224, 1072.

Berggren, W. A., 1969. Rates of evolution in some Cenozoic planktonic foraminifera. Micropaleontol. 16 (3).

Bermúdez, P. J., 1961. Contribucion al estudio de las Globigerinidea de la region Caribe-Antillana. Caracas (Editional Sucre), 1119.

Bermúdez, P. J. and Bolli, H. M., 1969. Consideraciones sobre los sedimentos del Mioceno medio al
Reciente de las costas central y oriente de Venezuela (Tercera Parte). Venezuela Min. Minas, Bol. Geol. 10, 137.

Bettenstaedt, F., 1962. Evolutionsvorgänge bei fossilen Foraminiferen. Mitt. Geol. Staatsinst. Hamburg. Heft 31, 385 .

Blow, W. H., 1969. Late Middle Eocene to Recent planktonic biostratigraphy. P. Bronnimann and H. H. Renz (Eds.), Proc. First. Intern. Conf. Plankt. Microfossils, Geneva. 199.

Blow, W. H., 1970. Validity of biostratigraphic correlations based on the Globigerinacea. Micropaleontol. 16, 257.

Blow, W. H., and Banner, F. T., 1966. The morphology, taxonomy and biostratigraphy of Globorotalia barisanensis LeRoy, Globorotalia fohsi, and related taxa. Micropaleontol. 12 (3), 286.

Bolli, H. M., 1957. Planktonic foraminifera from the Oligocene-Miocene Cipero and Lengua formations of Trinidad, B.W.I. U. S. Nat. Museum Bull. 215, 97.

Bolli, H. M. and Bermudez, P. J., 1965. Zonation based on planktonic foraminifera of Middle Miocene to Pliocene warm water sediments. Bol. Asoc. Venezolana Geol. Mineria Petrol. 8, 121.

Boltovskoy, E., 1968. Living planktonic foraminifera of the eastern part of the tropical Atlantic. Rev. Micropaleontol. 11, 85 .

Boltovskoy, E., 1969. Living planktonic foraminifera of the $90^{\circ} \mathrm{E}$ meridian from the Equator to the Antarctic. Micropaleontol. 15, 237.

Boltovskoy, E., 1969. Tanatocenosis de foraminiferos planktonicos en el estrecho de Mozambique. Rev. Esp. Micropaleontol. 1, 117.

Bradshaw, J. S., 1959. Ecology of living planktonic foraminifera in the north and equatorial Pacific Ocean. Contrib. Cushman Found. 10, 25.

Catalano, R. and Sprovieri, R., 1969. Stratigrafia e micropaleontologia dell'intervallo tripolaceo di torrente Rossi (Enna). Atti Acad. Gioenia Sc. Nat. Catania. 1, 513.

Cifelli, R., 1962. Some dynamic aspects of the distribution of planktonic foraminifera in the western North Atlantic. J. Marine Res. 20, 201.

Cifelli, R., 1969. Radiation of Cenozoic planktonic foraminifera. System. Zool. 18 (2), 154.

Cifelli, R., 1970. Age relationship of Mid-Atlantic Ridge sediments. Geol. Soc. Am., Spec. Papers. 124, 48.

Cifelli, R. and Smith, R. K., 1969. Problems in the distribution of Recent planktonic foraminifera and their relationship with water mass boundaries in the North Atlantic. P. Brönnimann and H. H. Renz (Ed.), Proc. First Intern. Conf. Plankt. Microfossils, Geneva, 1967. 68.

Cifelli, R. and Smith, R. K., 1970. Distribution of planktonic foraminifera in the vicinity of the North Atlantic Current. Smithsonian Contrib. Paleobio. (4), 1. 
Cordey, W. G., 1967. The development of Globigerinoides ruber (d'Orbigny, 1839) from the Miocene to the Recent. Paleontology. 10, 647.

Eames, F. E., 1970. Some thoughts on the Neogene/ Palaeogene boundary. Paleogeogr., Paleocol., Paleochim. 8, 37 .

Eames, F. E., Banner, F. T., Blow, W. H. and Clarke, W. J., 1962. Fundamentals of Mid-Tertiary Stratigraphical Correlation. London (Cambridge Univ. Press) $163 \mathrm{p}$.

Emiliani, C., 1969. A new paleontology. Micropaleontology. 15, 265 .

Glacon, G. and Sigal, J., 1969. Precisions morphologiques sur la paroi du test de Globorotalia truncatulinoides (d'Orbigny), Globigerinoides ruber (d'Orbigny) et Globigerinoides trilobus (Reuss). Reflexions sur la valeur taxinomique des details observes. C. R. Acad. Sci., 269, 987.

Grabert, B., 1959. Phylogenetische Untersuchungen an Gaudryina und Spiroplectinata (Foram.) besonders aus dem nordwestdeutschen Apt und Alb. Abhandl. Senckenberg. Naturforsch. Gesell. 49, 1.

Gradstein, F. M., 1970. Foraminifera from the type Sicilian at Ficarazzi, Sicily (Lower Pleistocene). Proc. K. Acad. Wetenschaf. 73, 305.

Gygi, R. A. and Mac Dowell, F. W., 1970. PotassiumArgon ages of glauconites from a biochronologically dated Upper Jurassic sequence of Northern Switzerland. Eclogae Geol. Helv. 63 (1), 111.

Hansen, H. J., Reiss, Z. and Schneidermann, N., 1969. Ultramicrostructure of bilamellar walls in Foraminiferida. Rev. Esp. Micropaleontol. 1, 293.

Harrington, H. J., 1965. Space, things, time and events-an essay on stratigraphy. A.A.P.G. Bull. 49 (10), 1601.

Harrington, H. J., 1966. Reply. A.A.P.G. Bull. 50, 1521 .

Hays, J. D., Saito, T., Opdyke, N. D. and Burckle, L. H., 1969. Pliocene-Pleistocene sediments of the equatorial Pacific: Their paleomagnetic, biostratigraphic, and climatic record. Bull. Geol. Soc. Am. 80,1481 .

Hemleben, Ch., 1969. Ultrastrukturen bei kalkschaligen Foraminiferen. Naturwiss. 56, 534.

Hemleben, Ch., 1969. Ultramicroscopic shell and spine structure of some spinose planktonic foraminifera. P. Brönnimann and H. H. Renz (Ed.) Proc. First Intern. Conf. Plankt. Microfossils, Geneva, 1967. 254.

Hemleben, Ch., 1969. Zur Morphogenese planktonischer Foraminiferen. Zitteliana. 1, 91.

Hofker, J., 1963. Stainforthia Hofker or Chiloguembelina Loeblich and Tappan? Contr. Cushman Found. Foram. Res. 14, 150.

Howarth, M. K., 1964. The Jurassic period. In The Phanerozoic Time-scale (Harland, W. B. et al., ed.). A supplement to the Quart. J. Geol. Soc. London. 203.
Jenkins, D. G., 1969. Foraminiferida and New Zealand Tertiary Biostratigraphy. Rev. Esp. Micropaleontol. 1,13 .

Kennett, J. P., 1968. Paleo-oceanographic aspects of the foraminiferal zonation in the upper Miocenelower Pliocene of New Zealand. Proc. IV Session Committee Mediterranean Neogene Strat. Geol. (2) 35,143 ,

Kennett, J. P., 1969. Foraminiferal studies of southern Ocean deep sea cores. Antarctic J. 4 (5), 178.

Kennett, J. P. and Geitzenauer, K. R., 1969. PliocenePleistocene boundary in a South Pacific deep sea core. Nature. 224 (5222), 899.

Kierstead, C. H., Leidy, R. R. D., Fleisher, R. L., and Boersma, A., 1969. Neogene zonation of tropical Pacific cores. P. Brönnimann and H. H. Renz (Eds.). Proc. First Intern. Conf. Plankt. Microfossils, Geneva. 2, 328.

LeRoy, L. W., 1939. Some small foraminifera, Ostracoda and otolithes from the Neogene (Miocene) of the Rokan-Tanpanoeli area, central Sumatra. Naturk. Tijdschr. Nederl.-Indie. 99, 215.

Lidz, L., 1966. Planktonic foraminifera in the water column of the mainland shelf off Newport Beach, California. Limnology and Oceanography. 11, 257.

Lipps, J. H., 1966. Wall structure, systematics, and phylogeny studies of Cenozoic planktonic foraminifera. J. Paleontol. 40, 1257.

Lipps, J. H., 1964. Miocene planktonic foraminifera from Newport Bay, California. Tulane Studies Geol. 2, 109.

Lipps, J. H. and Ribbe, P. H., 1967. Electron-probe microanalysis of planktonic foraminifera. J. Paleontol. $41,492$.

Loeblich, A. R. and Tappan, H., 1957. The new planktonic foraminiferal genus Tinophodella, and an emendation of Globigerinita Brönnimann. J. Wash. Acad. Sci. 47, 112.

Loeblich, A. R., Jr. et al., 1957. Studies in foraminifera. U. S. Nat. Museum Bull. 215.

Lynts, G. W. and Pfister, R. M., 1967. Surface ultrastructure of some tests of Recent Foraminiferida from the Dry Tortugas, Florida. J. Protozool. 14 (3), 387.

Martini, E. and Worsley, T., 1970. Standard Neogene Calcareous Nannoplankton Zonation. Nature. 225 (5229), 284

Murray, J. M. and Wright, C. A., 1970. Surface textures of calcareous foraminiferids. Paleontology. 13, 184.

Oba, T., 1969. Biostratigraphy and isotopic paleotemperatures of some deep-sea cores from the Indian Ocean. Sci. Rept., Tohoku Univ., Second Sr. $41,129$.

Olsson, R. K., 1970. Planktonic foraminifera from base of Tertiary, Millers Ferry, Alabama. J. Paleontolog. 44,598 . 
Parker, F. L., 1954. Distribution of the foraminifera in the northeastern Gulf of Mexico. Bull. Museum Comp. Zool. III, 453.

Parker, F. L., 1965. A new planktonic species (Foraminiferida) from the Pliocene of Pacific deep-sea cores. Contrib. Cushman Found. 16, 151.

Parker, F. L., 1967. Late Tertiary biostratigraphy (planktonic foraminifera) of tropical Indo-Pacific deep-sea cores. Bull. Am. Paleontol. 52 (235), 115.

Patterson, J. R., 1966. Space, things, time and eventsan essay on stratigraphy: Discussion. A.A.P.G., Bull. $50,1519$.

Perconig, E., 1968a. Biostratigrafia della sezione di Carmona (Andalusia, Spagna) in base ai Foraminiferi planctonici. Giorn. Geol. 35, 191.

Perconig, E., 1968b. Nuove specie di Foraminiferi planctonici della sezione di Carmona (Andalusia, Spagna). Giorn. Geol. 35, 219.

Perconig, E., 1969. Evolucion de los Globigerinoides amplus, obliquus, extremus y elongatus en el Neogeno de Andalucia (Espana). Rev. Esp. Micropaleontol. 1, 37 .

Reiss, Z. and Luz, B., 1970. Test formation pattern in planktonic Foraminiferids. Rev. Esp. Micropaleontol. 2,85 .
Romeo, M., 1965. Globigerina multiloba nuova specie del Messiniano della Calabria e Sicilia. Riv. Ital. Paleontol. 71, 1265.

Schwager, C., 1866. Fossile Foraminiferen von Kar Nikobar. Novara Exped. 1857-1859. 2, 252.

Selli, R., 1960. Il Messiniano di Mayer-Eymar 1867. Proposta di un Neostratotipo. Giorn. Geol., Sr. 2, $28,1$.

Soediono, H., 1969. Planktonic foraminifera from the Velez Rubio region, S.E. Spain. Rev. Esp. Micropaleontol. 1 (3), 335.

Srinivasan, M. S. and Sharma, V., 1969. A new planktonic foraminifer from the late Tertiary of Car Nicobar Island, Bay of Bengal. Contr. Cushman Found. Foram. Res. 20, 100.

Viotti, C. and Mansour, A., 1969. Tertiary planktonic foraminifera zonation from the Nile Delta, Egypt. U.A.R. Proc. Third African Micropaleontol. Coll., Cairo, Egypt, 425.

Wasfi, S. M., 1969. Miocene planktonic foraminiferal zones from the Gulf of Suez-Egypt. Proc. Third African Micropaleontol. Coll., Cairo, Egypt. 461.

Zaninetti, L. and Brönnimann, P., 1971. Les effets de recristallisation sur la paroi des Involutinidae (Foraminiferes) triasiques. Z. Paleontol. (in press). 
PLATE 1

Figures 1, 2, 3, Globigerina nepenthes Todd delicatula Brönnimann 7 and 10 and Resig, n. subsp.

1: Hole 62.1, Core 13, Section 2, 36-38 cm; Zone N. $18.211 \mathrm{X}$.

2: Hole 62.1, Core 12, Section 5, 16-18 cm; Zone N. 20 (incl. N. 19). 178X.

Figures 3 and 10: Hole 62.1, Core 14, Section 1, 60-62 cm; Zone N. 18.

3: $182 X$.

10: $145 X$.

7: Hole 62.1, Core 13, Section 2, 36-38 cm; Zone N. 18. 94X. Holotype.

Figures 4 \& $6 \quad$ Globigerina nepenthes nepenthes Todd, 1957. Both figures from Hole 64.0, Core 3, Core Catcher.

4: $404 X$.

6: $250 \mathrm{X}$

Figures 5 \& 8 Globigerina rubescens Hofker, 1956. Hole 62.1, Core 2, Section 2, 15-17 cm; Zone N. 22.

5: $660 \mathrm{X}$.

8: $250 X$.

Figure 9 Globigerina nepenthes Todd picassiana Perconig, 1969. Hole 62.1, Core 16, Section 1, 14-16 cm; Zone N. 17. 264X. 

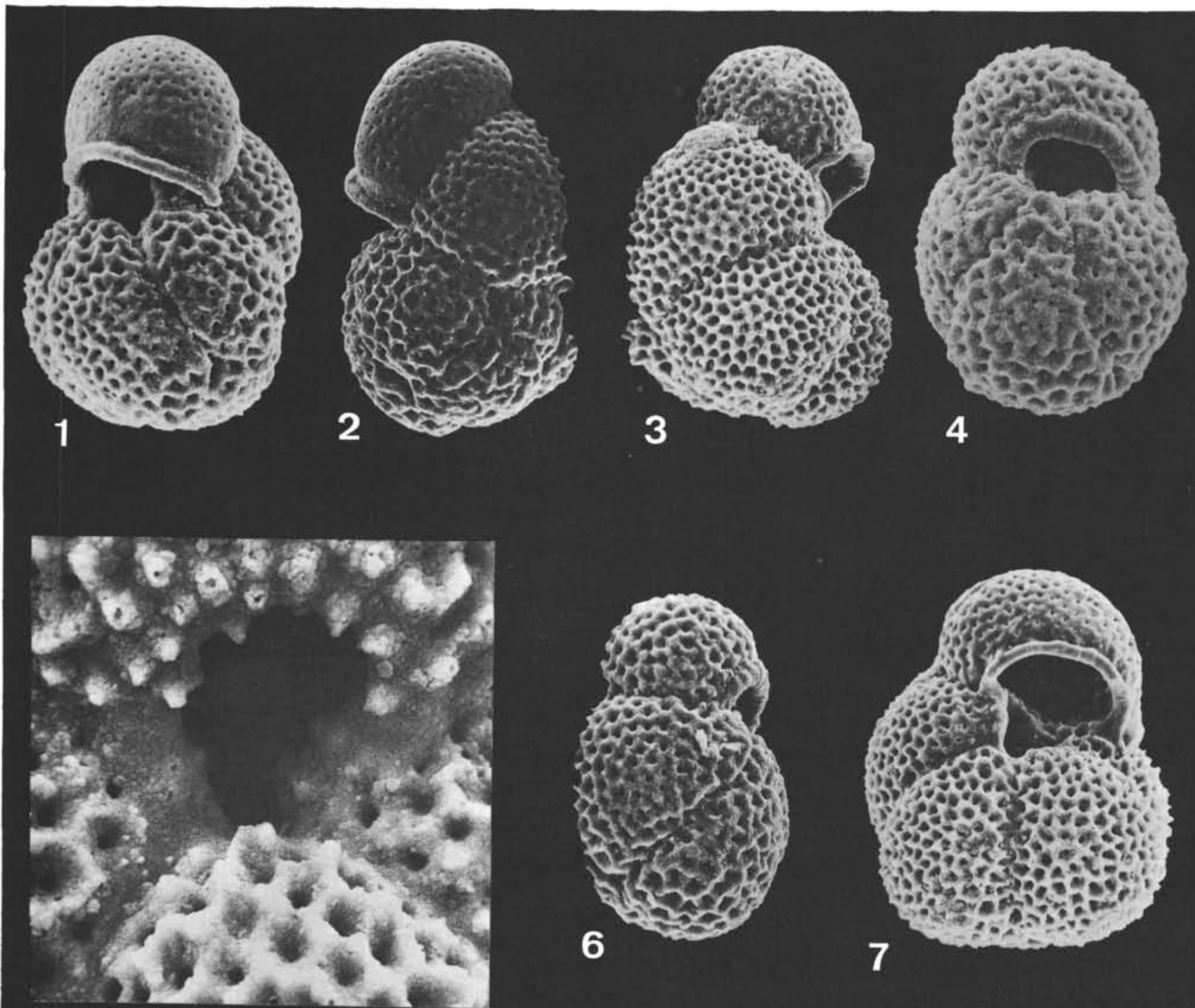

5
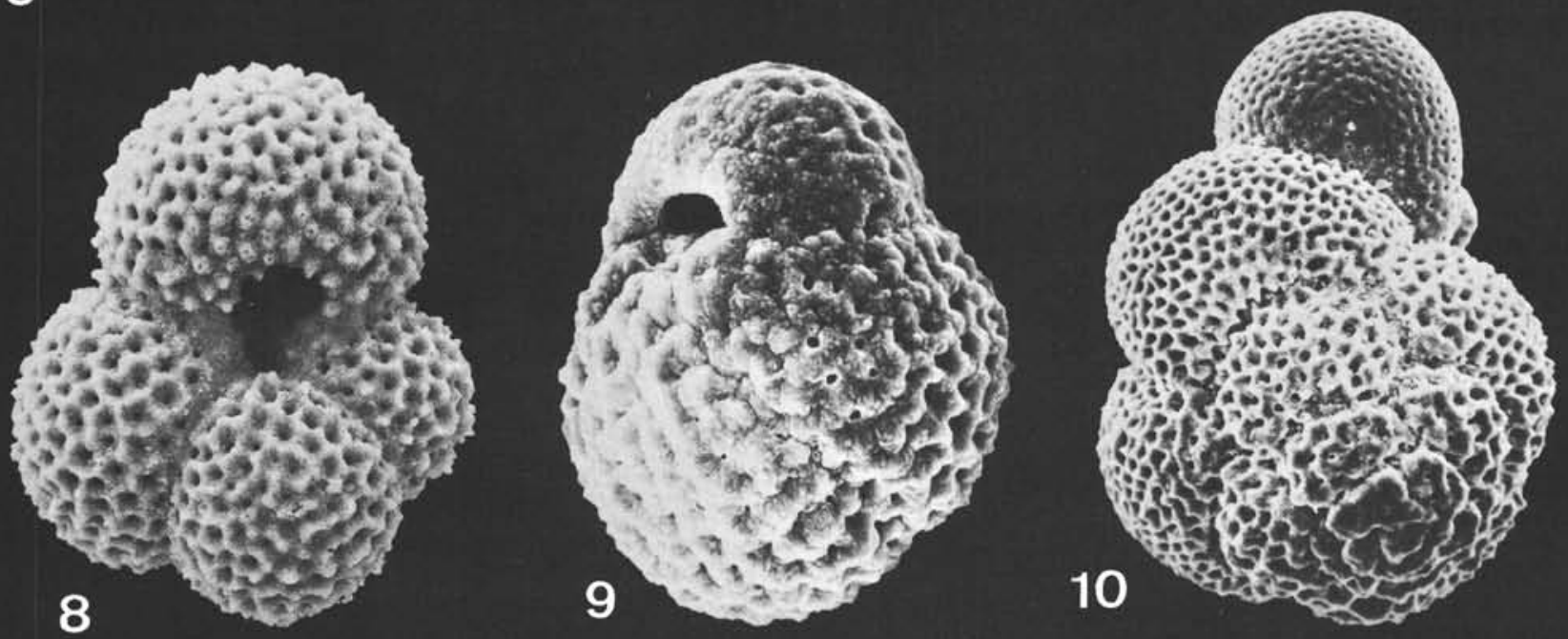
PLATE 2

Figures 1-5 "Globigerina" hexagona Natland, 1938.

1, 2, 4 \& 5: CAP HG-41, 0-1 cm. Don F. L. Parker.

1: $165 \times$. Umbilical view.

2: 180X. Umbilical view.

4: 192X. Spiral view.

5: 196X. Oblique spiral view of the same specimen as Figure 4.

3: Hole 62.1, Core 8, Section 5, 16-18 cm; Zone N. 20 (including N. 19). 158X. Umbilical view.

Figure 6

Globigerina aff. Globigerina conglomerata Schwager, 1866.

Hole 62.1, Core 11, Section 6, 17.19 cm; Zone N. 20 (including N. 19). 96X. Oblique umbilical view. The specimen does not possess imperforate apertural flaps and starts with a dorsally flat trochospire similar to that encountered in young stages of Globigerina pseudofoliata (Parker), 1967.

Figures 7 \& $8 \quad$ Globigerina bulbosa LeRoy, 1944.

Both figures from Hole 62.1, Core 11, Section 6, $17-19 \mathrm{~cm}$; Zone N. 20 (including N. 19).

7: $188 \mathrm{X}$. Umbilical view.

8: $183 \mathrm{X}$. Oblique umbilical view of the same specimen.

Figure 9 Globigerina dutertrei d'Orbigny, 1839.

Hole 62.1, Core 3, Section 2, Bottom; Zone N. 22. $98 \times$. 


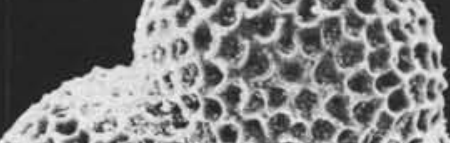

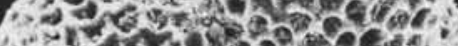

$20 x-30$.

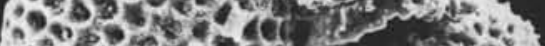

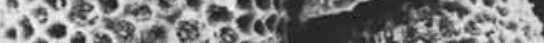

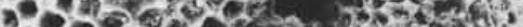

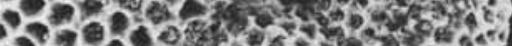

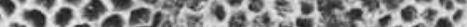

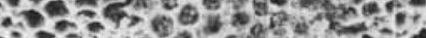

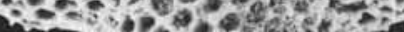

is is oceris

130.

1

. 3.9

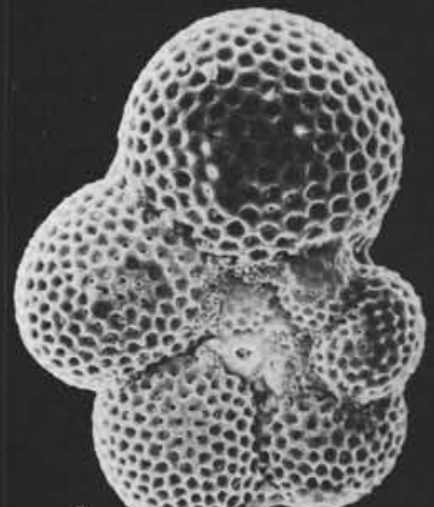

4 (3)

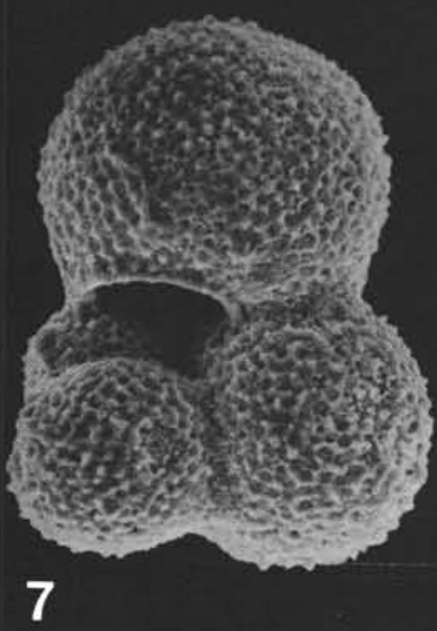

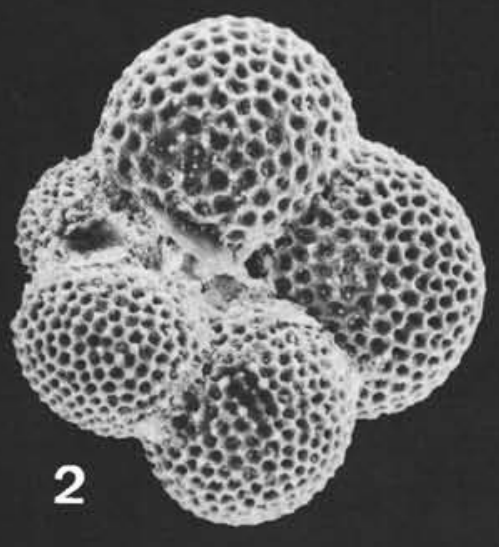
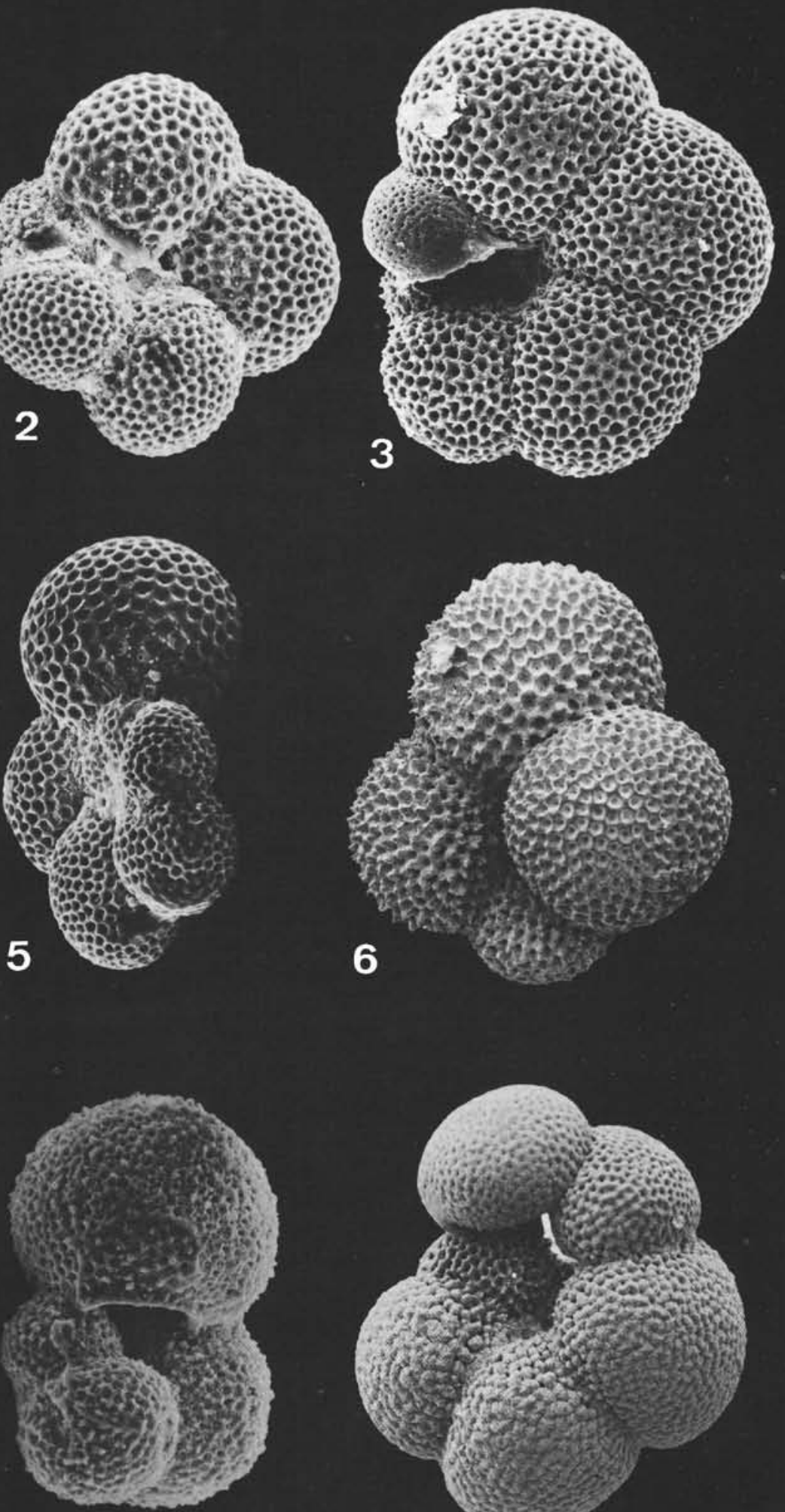

8

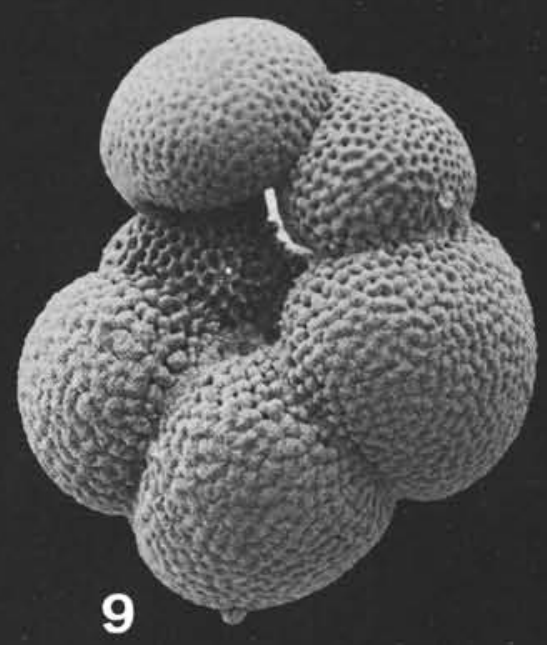




\section{PLATE 3}

Figures 1, 2, 4, Globigerina falconensis Blow, 1959.

5, 6 and 7 Figures 1, 2, 4 \& 5: Hole 64.1, Core 1, Section 2, $33-35 \mathrm{~cm}$; Zone N. $7 /$ N. 8 .

1: $231 \times$.

2: $198 X$.

4: $195 \mathrm{X}$.

5: 445X. Detail of Figure 4.

Figures 6 \& 7: Hole 62.1, Core 19, Section 3, 15-17 cm; Zone N. 17.

6: $180 \mathrm{X}$.

7: $166 \times$. Side view of the same specimen as Figure 6.

Figure 3 Globorotalia (Turborotalia) palpebra Brönnimann and Resig, n. sp. Holotype.

Hole 62.1, Core 6, Section 5, 15-17 cm; Zone N. 21. $357 \times$.

Figure $8 \quad$ Globigerina falconensis Blow, 1959?.

Hole 62.1, Core 8, Section 3, 15-17 cm; Zone N. 20 (including N. 19). 165X. 


\section{PLATE 3}

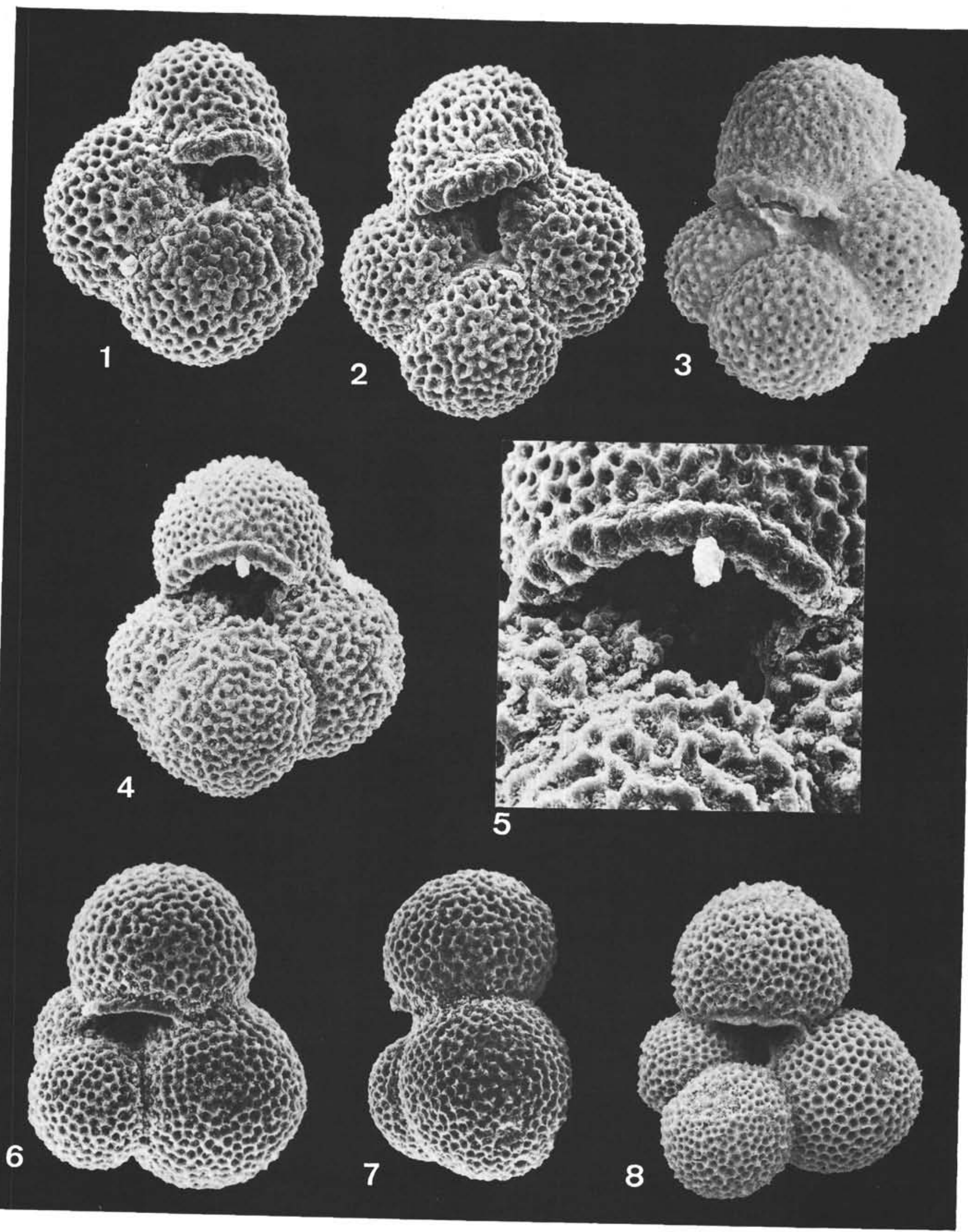




\section{PLATE 4}

Figures 1, 2, 3, Globigerina pseudofoliata (Parker), 1967.

$5,6,8,9 \& 10$ 1: Station LSDH-78 P, $74-77 \mathrm{~cm}$, Pliocene or lower? Pleistocene. Don F. L. Parker. 99X. Umbilical view showing apertural flaps.

Figures 2, 5, 6, 8, 9 and 10: Hole 62.1, Core 2, Section 4, 23-25 cm; Zone N. 22.

2: $99 \times$. Immature specimen in apertural view.

5: 119X. Small almost mature specimen in umbilical view, showing large imperforate apertural flaps.

6: 175X. Immature specimen in apertural view.

8: $672 X$. Detail of aperture of specimen illustrated by Figure 5. Spiral arrangement of apertural flaps.

9: $175 \times$. Immature specimen in spiral view.

10: $330 X$. Detail of aperture of specimen illustrated by Figure 6 .

Figures $4 \& 7 \quad$ Globigerina aff. foliata Bolli, 1957.

Both figures from Hole 64.1, Core 1, Section 4, $33-35 \mathrm{~cm}$; Zone N. 7/N. 8.

4: $92 \times$.

7: $99 x$. 
PLATE 4

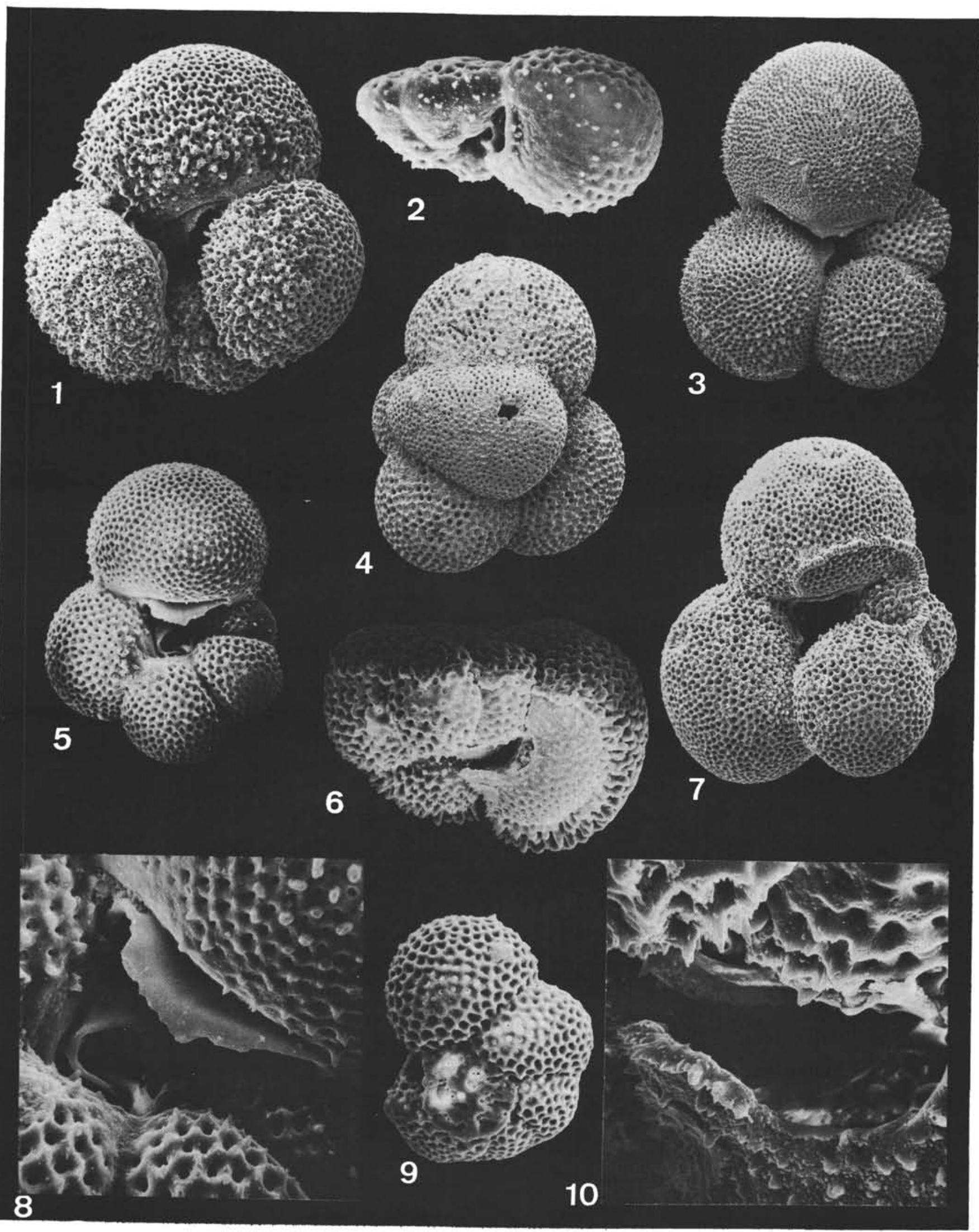




\section{PLATE 5}

Figure 1 Intermediate specimen between Globigerina falconensis Blow, 1959, and Globigerina druryi Akers, 1955. Specimen lost. 257X.

Figure 2 Globigerina druryi Akers, 1955.

Hole 64.1, Core 2, Section 6, 15-17 cm; Zone N. 13. $178 \times$.

Figure 3 Globigerina aff. Globigerina decoraperta decoraperta Takayanagi and Saito, 1962.

Hole 62.1, Core 6, Section 1, 18-20 cm; Zone N. 21. $214 X$. Umbilical view.

Figures 4 \& 5 Globigerina sp. Hole 64.1, Core 2, Section 6, $15-17 \mathrm{~cm}$; Zone N. 7/N. 8.

4: 380X. Umbilical view.

5: 1140X. Detail of Figure 4.

Figure 6

Globigerina aff. Globigerina globorotaloidea Colom, 1954.

Hole 62.1, Core 28, Section 3, 15-17 cm; Zone N. 16. $211 \times$.

Figure $7 \quad$ Globigerina venezuelana Hedberg, 1937.

Hole 62.1, Core 18, Section 4, 15-17 cm; Zone N. 17. 90X.

Figure $8 \quad$ Globigerina conglomerata Schwager, 1866.

CAP-HG 41, 0-1 cm. Don F. L. Parker. 63X. 

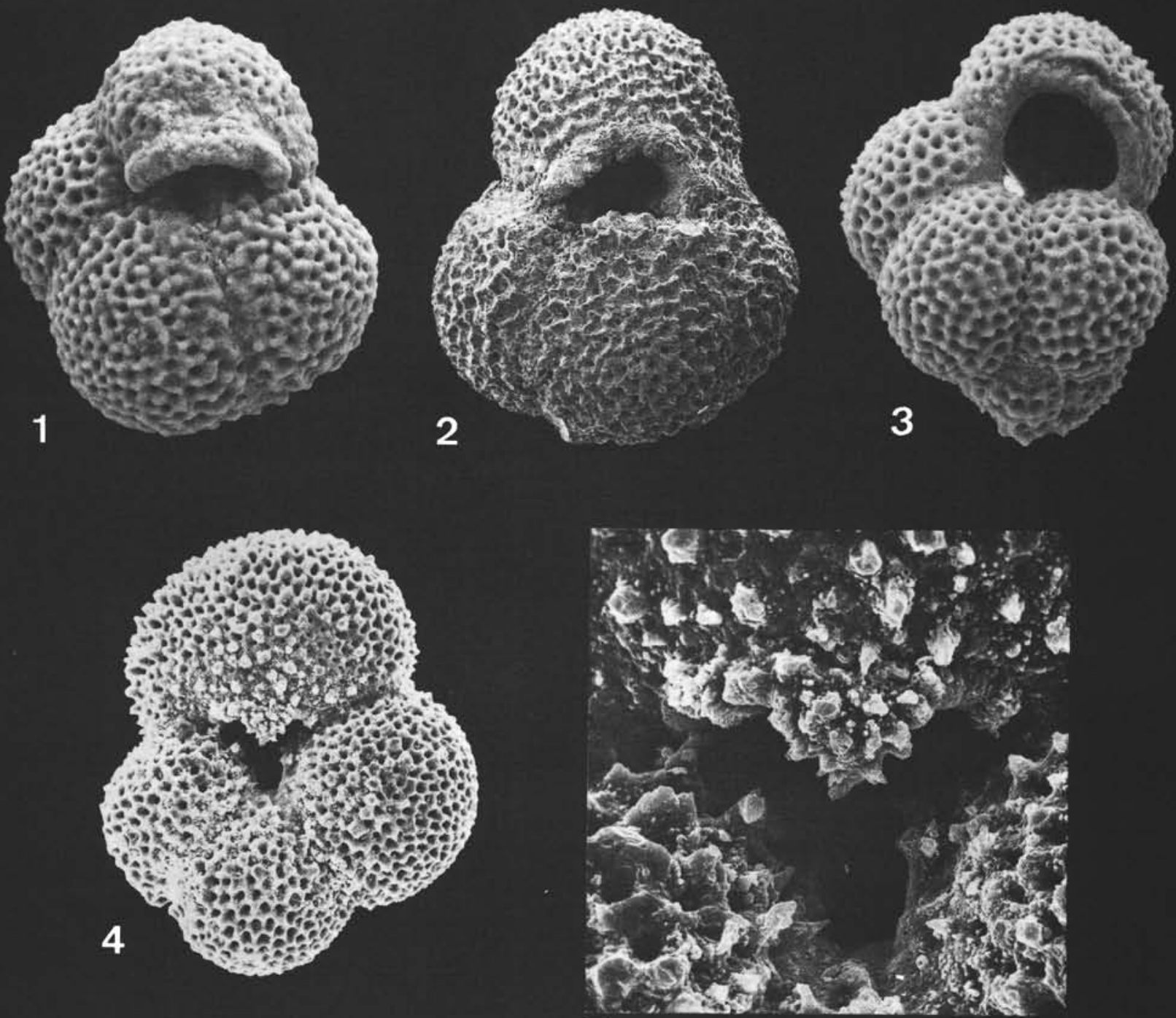

5
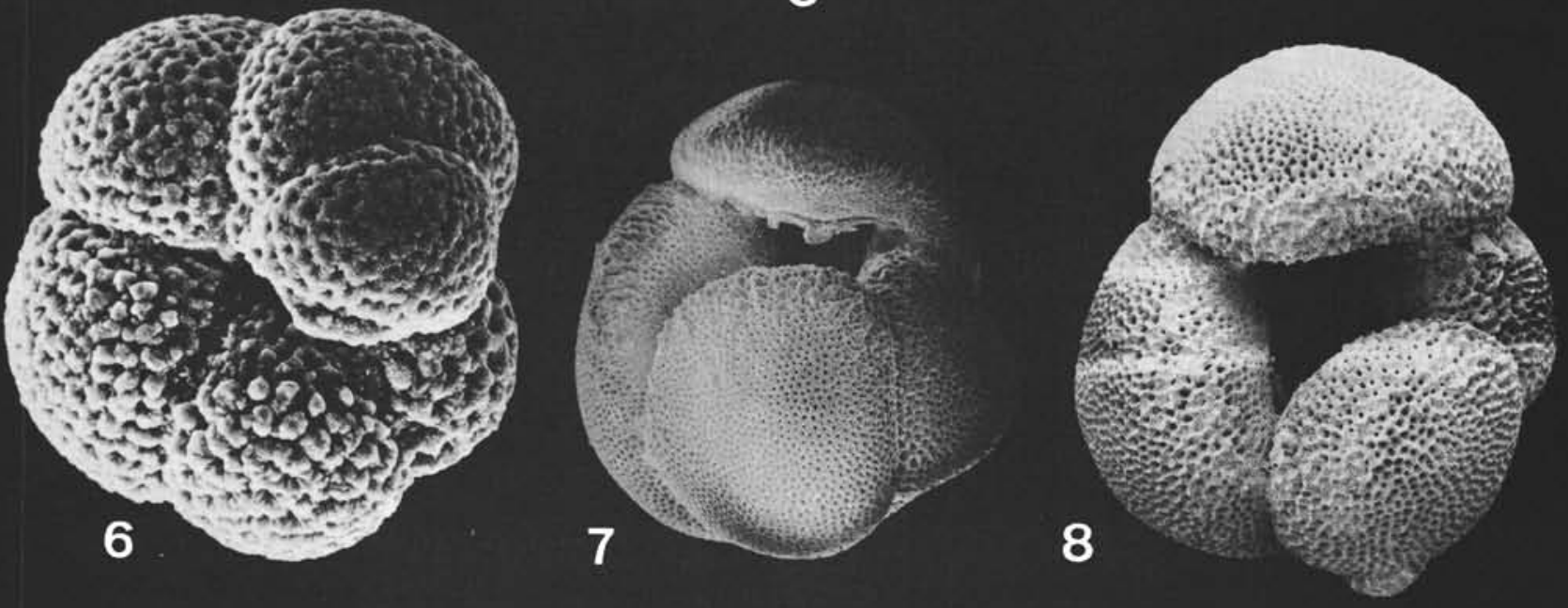


\section{PLATE 6}

Figure 1 Globigerina rubescens Hofker, 1956.

Hole 62.1, Core 1, Section 1, Top; Zone N. 23. $444 X$.

Figure 2 Globigerina decoraperta Takayanagi and Saito, 1962 (normal form).

Hole 62.1, Core 6, Section 2, 17-19 cm; Zone N. 21. 266X.

Figure 3 Globigerina bulloides bulloides d'Orbigny, 1826.

Hole 62.1, Core 1, Section 1, Top; Zone N. 23. 170X.

Figures 4, 5 \& 6 Globigerina microfoliata Brönnimann and Resig, $\mathrm{n}$.

sp.

All figures from Hole 62.1, Core 8, Section 5, 16-18 $\mathrm{cm}$; Zone N.20 (including N. 19).

4\& 5: $415 X$.

6: 419X. Holotype.

Figure $7 \quad$ Globigerina aff. Globigerina ciperoensis ciperoensis Bolli, 1957.

Hole 64.1, Core 6, Section 4, 33-35 cm; Zone N. 4. $142 X$.

Figure 8

Globorotalia aff. Globorotalia (turborotalia) mendacis Blow, 1969.

Hole 64.1, Core 6, Section 4, 33-35 cm; Zone N. 4. $361 X$.

Figure 9 Globigerina multiloba Romeo, 1965.

Hole 64.1, Core 1, Section 2, 33-35 cm; Zone N. 7/N. 8. $392 \times$. 


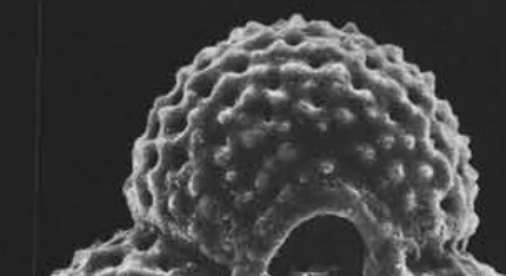

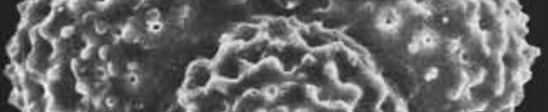

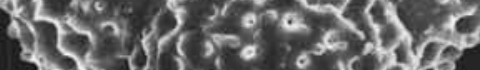

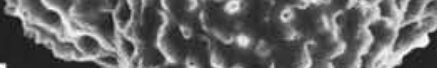

1 $x_{2}-2,+8$ $\int_{x \rightarrow 3} x^{2}, x^{2}$
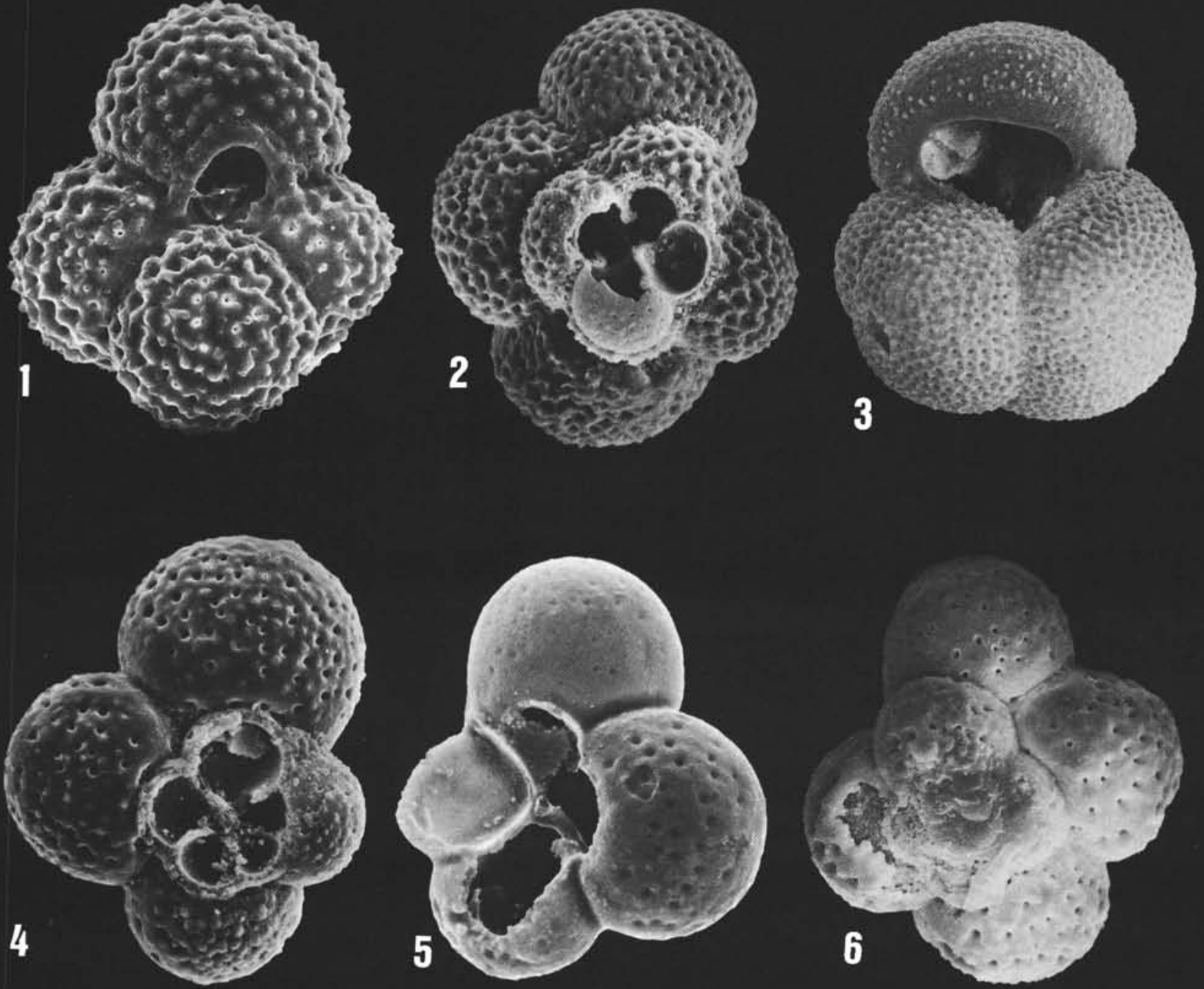

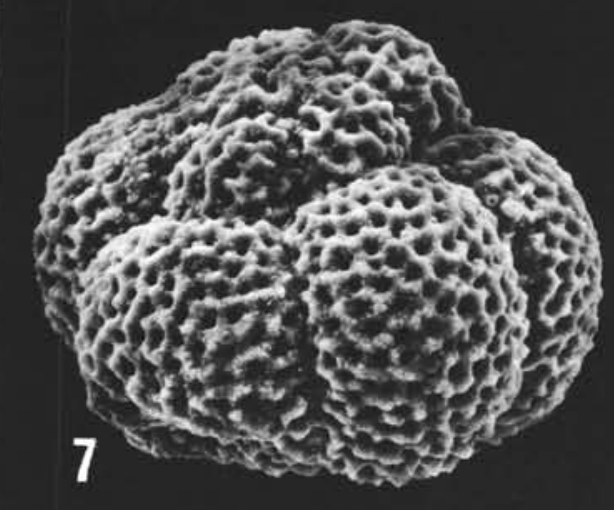

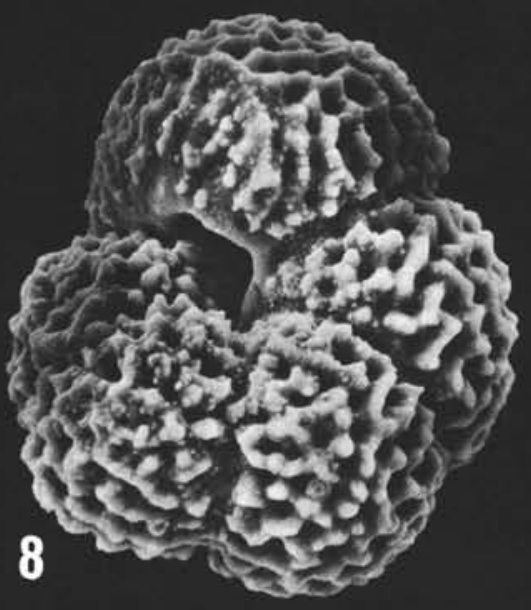

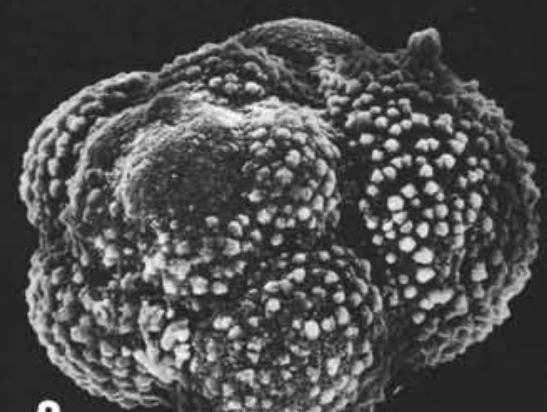

9

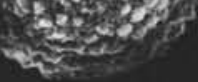




\section{PLATE 7}

Figures $1 \& 2$ Globigerina pseudodruryi Brönnimann and Resig, n. sp.

Both figures from the same specimen from Hole 64.1, Core 4, Section 2, 33-35 cm; Zone N. 6 (probably including N. 5).

1: 186X. Holotype.

2: $185 \times$. Holotype.

Figure 3 Globigerina aff. Globigerina praebulloides praebulloides Blow, 1959

Hole 62.1, Core 35, Section 3, 15-17 cm; Zone N. 13. $162 X$.

Figures 4-9 Globigerina nepenthoides Brönnimann and Resig, n. sp.

Figures 4, 5, 7 \& 9: Hole 64.1, Core 1, Section 2, 33-35 cm; Zone N. 7/N. 8.

4: $333 \times$. Holotype.

5: $178 \mathrm{X}$.

7: $835 \mathrm{X}$. Detail of Figure 4.

9: $313 \mathrm{X}$.

6: Hole 62.1, Core 35, Section 5, 15-17 cm; Zone N. $13.284 X$.

8: Hole 64.1, Core 4, Section 2, 33-35 cm; Zone N. 6 (probably including N. 5). 161X. 

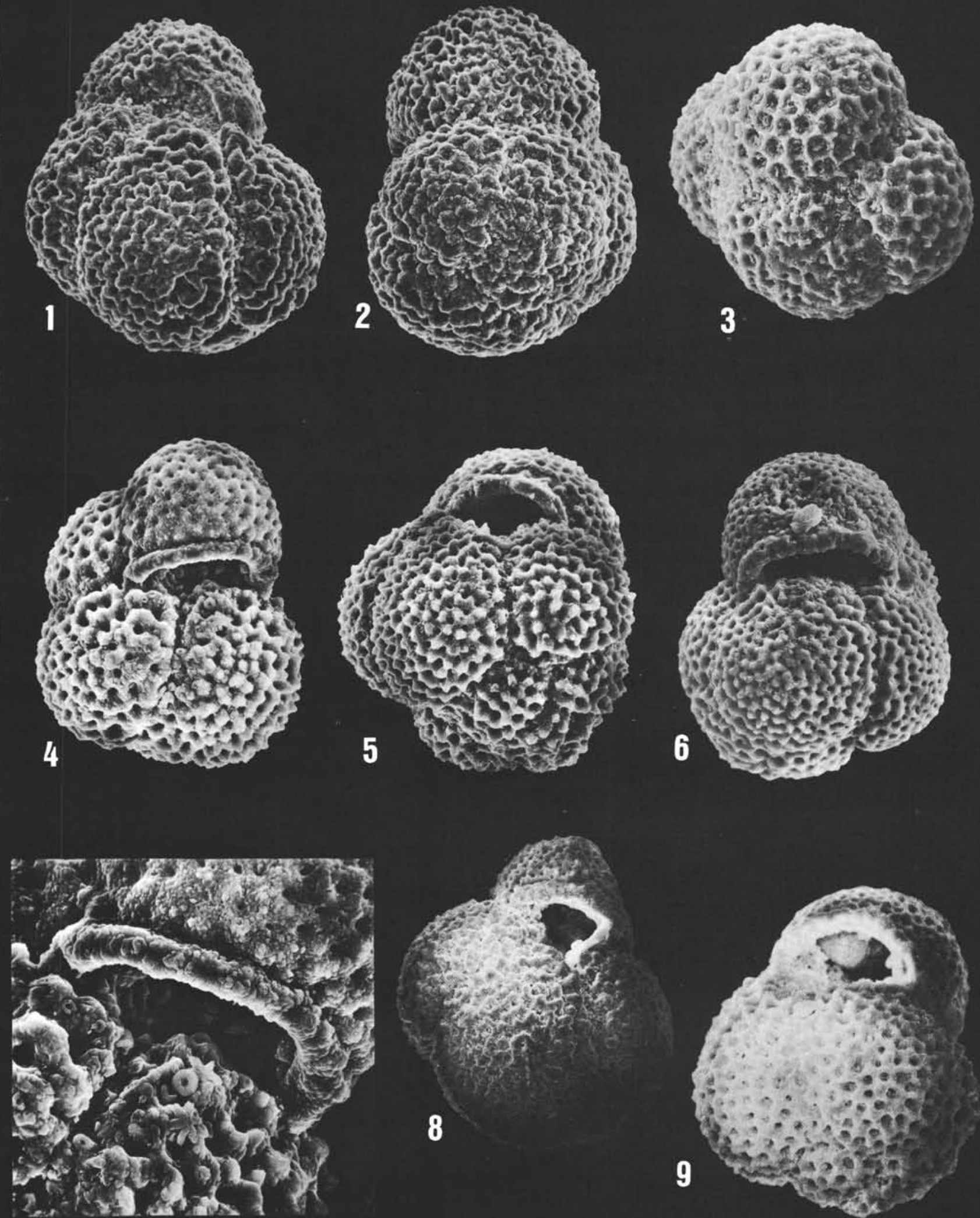
PLATE 8

Figure 1

Figures $2 \& 3$

Globigerina senni (Beckmann), 1953.

Hole 64.1, Core 10, Section 1, 33-35 cm; Zone P. 14 or older. $177 \mathrm{X}$. Umbilical side.

Globigerina galavisi Bermudez, 1961.

Both figures from Hole 64.1, Core 9, Section 2, 33-35 cm; Zone P. 16.

2: $250 \mathrm{X}$. Umbilical side.

3: $281 \mathrm{X}$. Spiral side.

Figures 4 \& $5 \quad$ Globigerina angiporoides Hormibrook, 1965.

Both figures from Hole 64.1, Core 9, Section 2, 33-35 cm; Zone P. 16.

4: 204X. Oblique spiral view.

5: $238 X$. Slightly oblique umbilical view.

Figure 6

Globigerina tripartita Koch, 1926.

Hole 64.1, Core 6, Section 1, 33-35 cm; Zone N. 4. 147X. Umbilical side.

Figures 7 \& $8 \quad$ Globigerina prasaepis Blow, 1969.

Both figures from Hole 64.1, Core 7, Section 2, 33-35 cm; Zone N. 3.

7: 177X. Oblique umbilical view.

8: 160X. Spiral view.

Figure 9

Globigerina sellii Borsetti, 1959.

Hole 64.1, Core 6, Section 1, 33-35 cm; Zone N. 4. 139X. Umbilical side. 

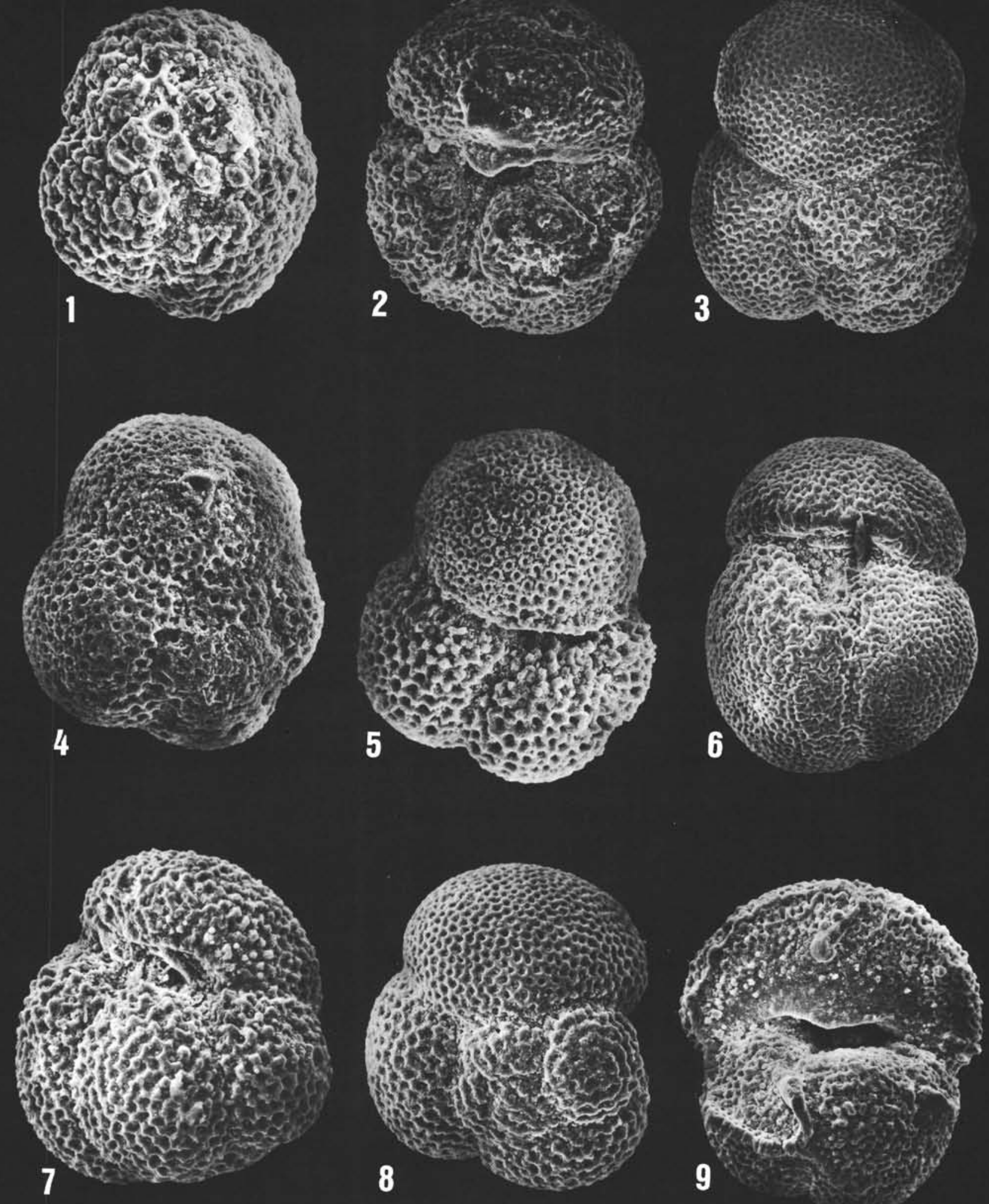


\section{PLATE 9}

Figures 1-4 Globigerinoides quadrilobatus (d'Orbigny) praeimmaturus Brönnimann and Resig, n. subsp.

Figures 1, 2 \& 4: Hole 64.1, Core 2, Section 6, $15-17 \mathrm{~cm} ;$ Zone N. 7/N. 8.

1: 260X. Holotype.

2: $200 X$.

4: 500X. Detail of Figure 1.

3: Hole 64.1, Core 7, Section 2, 33-35 cm; Zone N. $3.267 X$.

Figures 5 \& 6 Globigerinoides subquadratus subquadratus Brönnimann, 1954.

5: Hole 64.1, Core 2, Section 5, 33-35 cm; Zone

N. $7 /$ N. $8.165 \mathrm{X}$.

6: Hole 64.1, Core 4, Section 2, 33-35 cm; Zone

N. $7 /$ N. $8.548 X$.

Figures 7,8\& 9 Globigerinoides pseudosellii Brönnimann and Resig, n. sp.

7: Hole 64.1, Core 1, Section 1, 22-24 cm. Zone N. $7 /$ N. $8.590 \mathrm{X}$.

8\&9: Hole 64.1, Core 3, Section 6, 33-35 cm; Zone N. 6 (probably including N. 5).

8: 231X. Holotype.

9: $220 \times$. Oblique view of spiral side with single supplementary aperture on the left. 

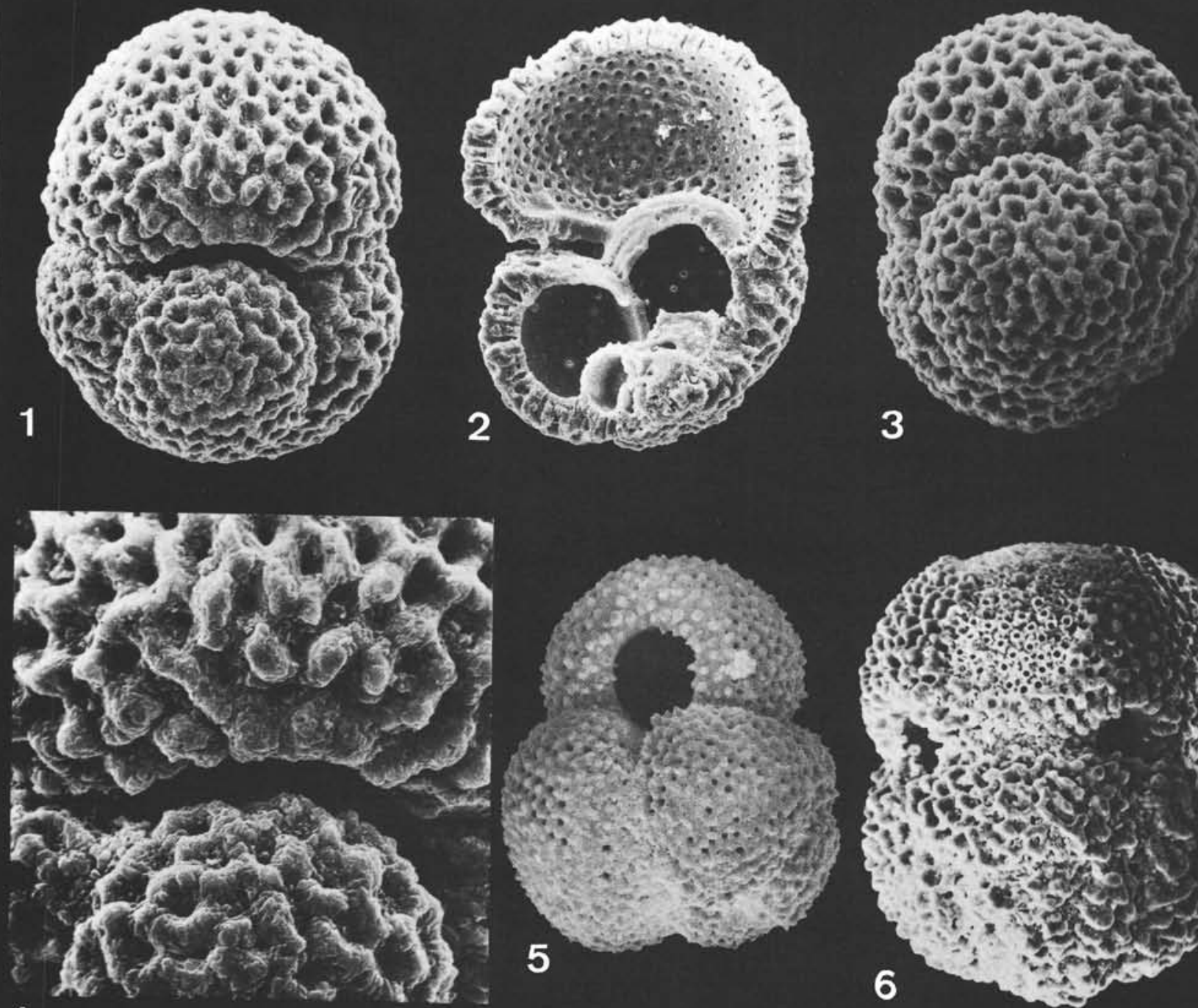

4
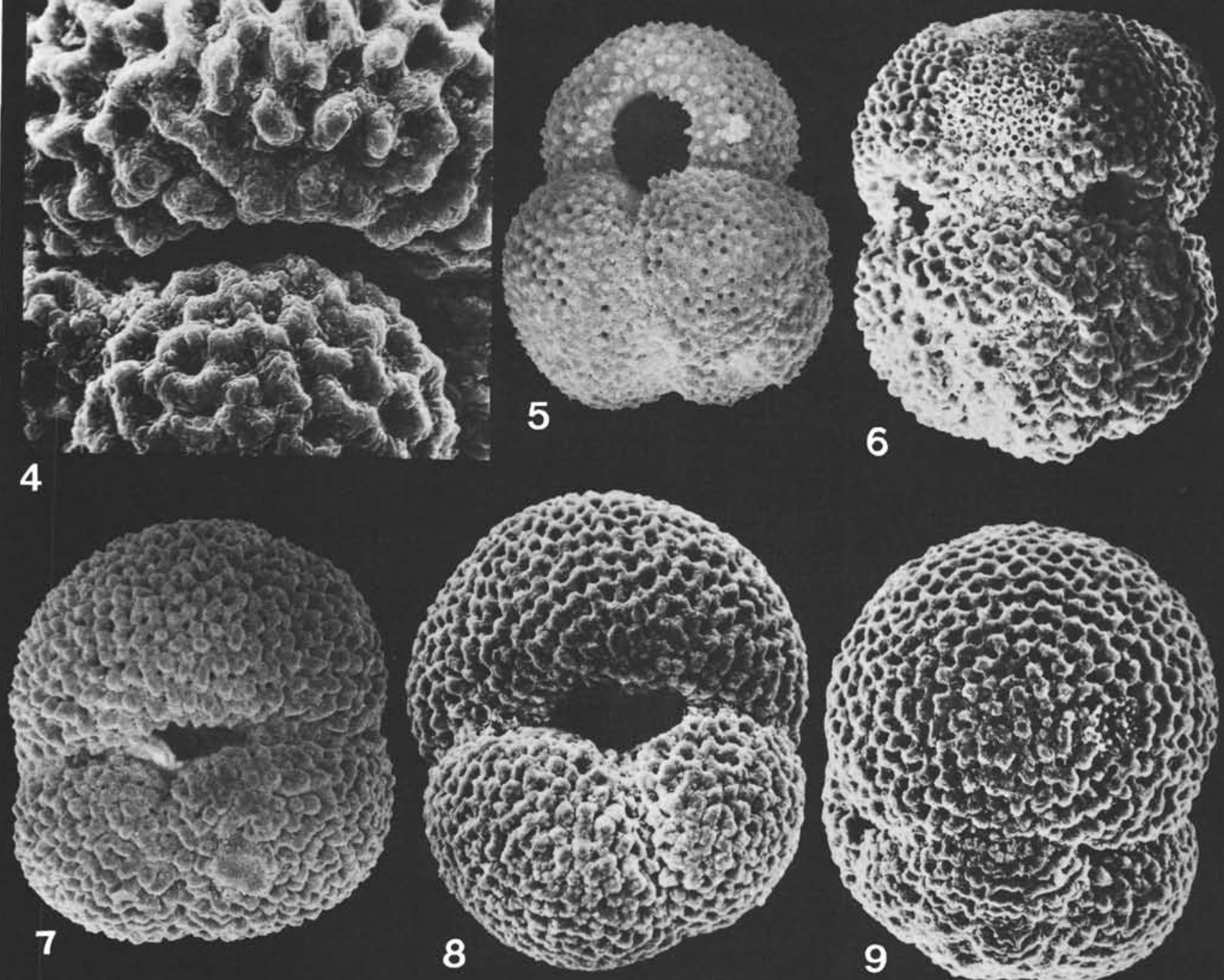


\section{PLATE 10}

Figures 1, 4\& 7 Intermediate specimens between Globigerinoides sicanus sicanus De Stefani, 1950, and Globigerinoides sicanus praesicanus Brönnimann and Resig, n. subsp. All figures from Hole 64.1, Core 1, Section 2, $33-35 \mathrm{~cm}$; Zone N. 7/N. 8.

1: $132 X$.

4: $158 X$.

7: 290X. Detail of Figure 4.

Figures 2 \& $3 \quad$ Globigerinoides sicanus sicanus De Stefani, 1950.

2: Hole 64.1, Core 2, Section 6, 15-17 cm; Zone N. $7 /$ N. 8. $120 X$.

3: Hole 64.1, Core 4, Section 2, 33-35 cm; Zone N. 6 (probably including N. 5).

View of spiral side. 112X.

Figures 5, 6 \& 8 Globigerinoides sicanus praesicanus Brönnimann and Resig, n. subsp.

5\&8: Hole 64.1, Core 4, Section 3, 17-19 cm; Zone N. 6 (probably including N. 5).

5: $199 X$.

8: 201X. Holotype.

6: Hole 64.1, Core 3, Section 1,33-35 cm; Zone N. 6 (probably including N.5). Oblique spiral view showing one of the supplementary sutural openings. 201X. 


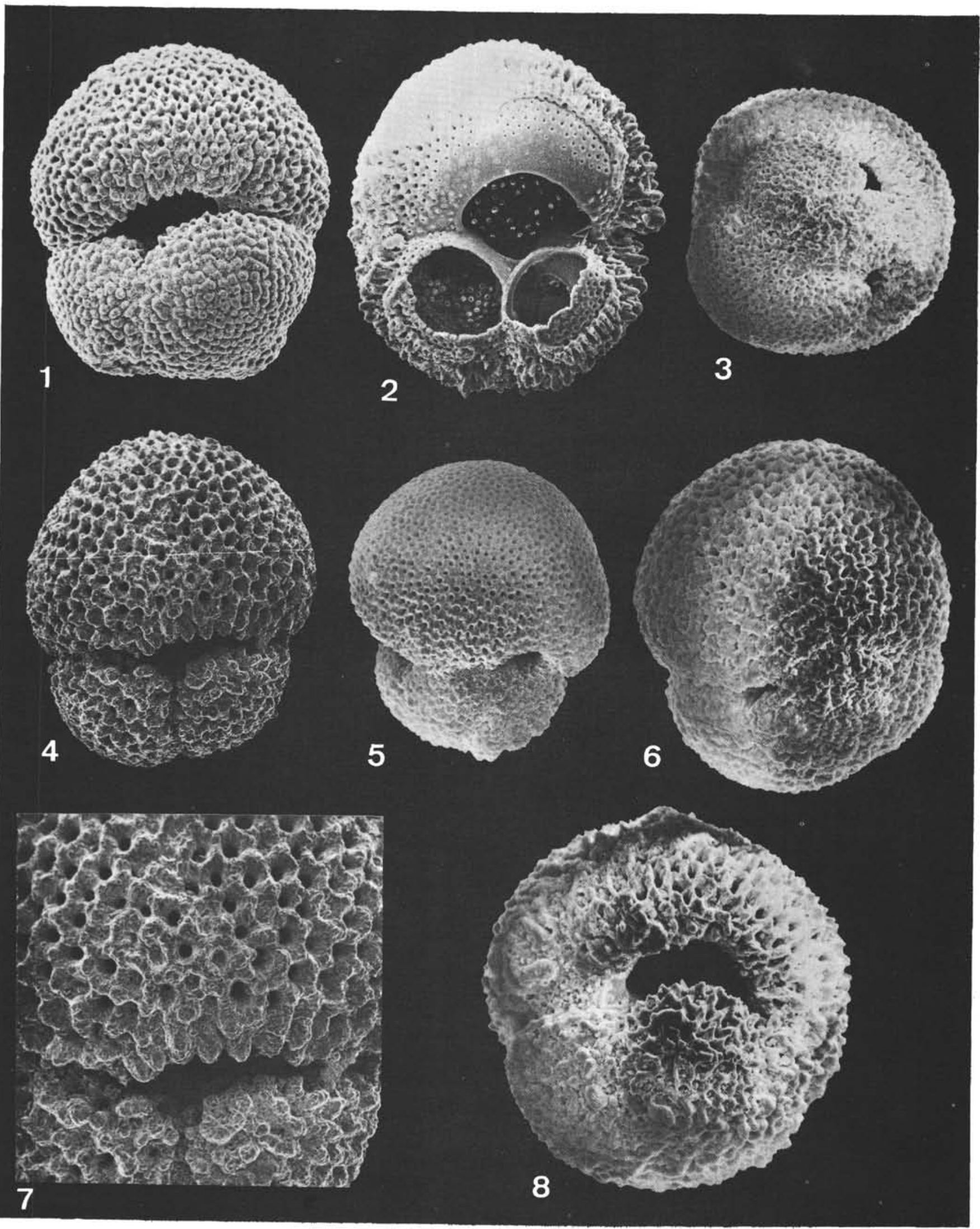




\section{PLATE 11}

Figures 1, 3 \& 5 Globigerinoides conglobatus (Brady), 1879.

1: Hole 62.1, Core 1, Section 1, Top; Zone N. 23. 66X. Spiral side.

3: From the same sample as Figure 1, Zone N. 23. $440 \times$. Spiral side of a young specimen,

5: Hole 62.1, Core 19, Section 2, 50-54 cm; Zone

N. 17. $125 \times$. Side view.

Figure $2 \quad$ Globigerinoides bolli Blow, 1959.

Hole 62.1, Core 27, Section 1, Top; Zone N. 16. 290X. Umbilical view.

Figure 4 Globigerinoides ex group Globigerinoides obliquus obliquus Bolli, 1957-obliquus extremus Bolli and Bermudez, 1965.

Hole 62.1, Core 5, Section 2, Top; Zone N. 21. 135X.

Figures 6 \& $7 \quad$ Globigerinoides ruber (d'Orbigny), 1839.

Both figures from Hole 62.1, Core 1, Section 1, Top; Zone N. 23.

6: $725 \mathrm{X}$.

7: 2000X. (see Plate 12, Figures 3 and 5). Details of pore fields. 


\section{PLATE 11}

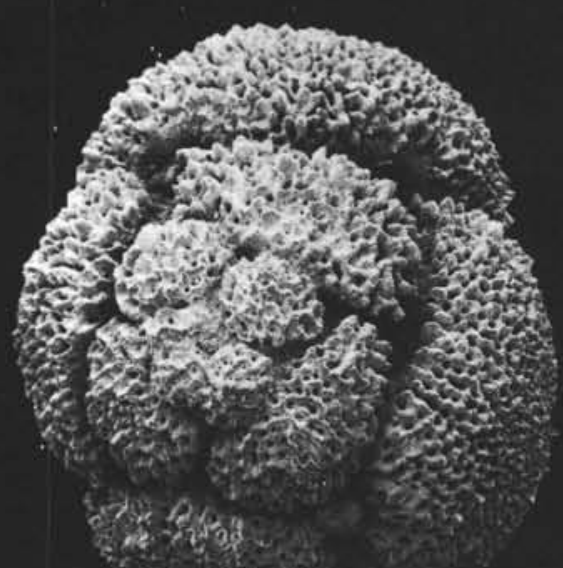

1

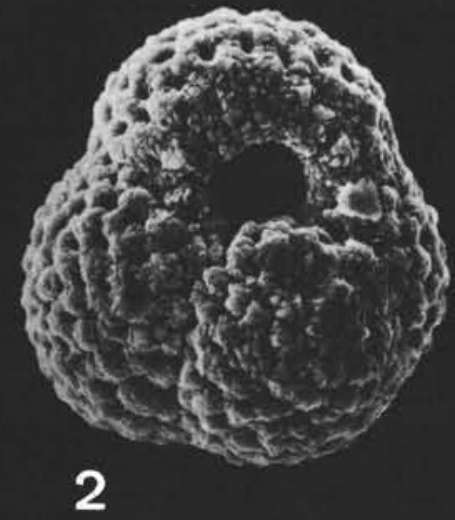

3
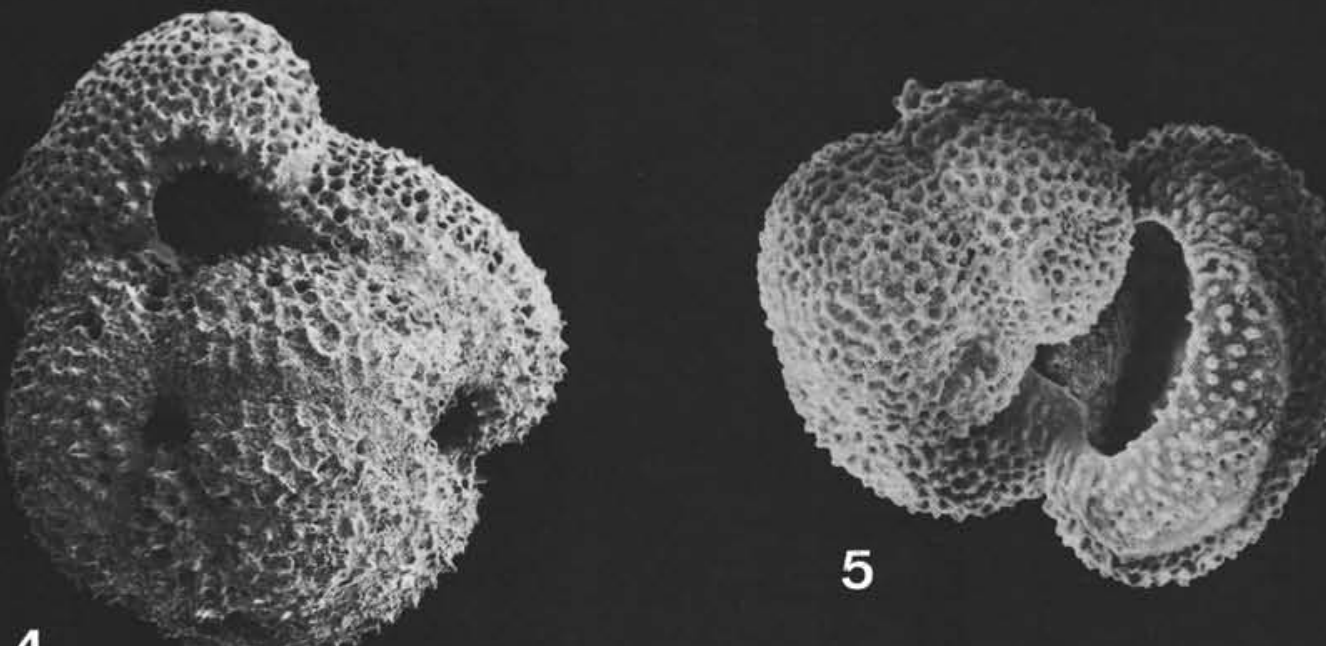

4

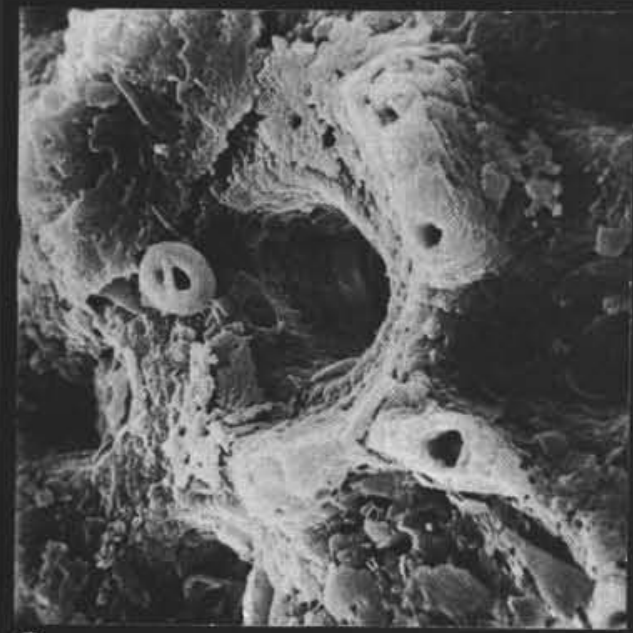

6

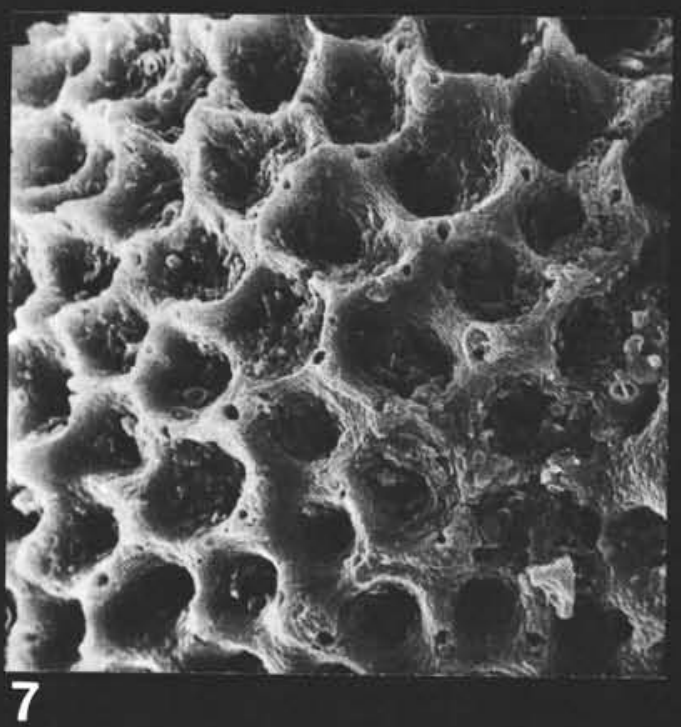


PLATE 12

Figure 1

Figure 2

Figures $3 \& 5$

Figure 8
Globigerinoides quadrilobatus (d'Orbigny) sacculifer (Brady), 1877, forma $\alpha$ of Banner and Blow, 1960. Hole 62.1, Core 1, Section 1, Top; Zone N. 23. 67X. Oblique spiral view.

Globigerinoides quadrilobatus (d'Orbigny) sacculifer (Brady), 1877, forma typica of Banner and Blow, 1960.

Hole 62.1, Core 1, Section 1, Top; Zone N. 23. 66X. Spiral view.

Globigerinoides ruber (d'Orbigny), 1839.

Both figures from the same specimen from Hole 62.1, Core 1, Section 1, Top; Zone N. 23.

3: $145 \times$. Spiral view.

5: 330X. Detail of Figure 1.

(see also Plate 11, Figures 6 and 7).

Figures 4 \& $6 \quad$ Globigerinoides elongatus (d'Orbigny), 1826.

Both figures from the same specimen from Hole 62.1, Core 5, Section 2, Top; Zone N. 21.

4: 300X. Detail of Figure 6.

6: $132 \times$. Oblique spiral view.

Globigerinoides quadrilobatus quadrilobatus (d'Orbigny), 1846.

Hole 62.1, Core 1, Section 1, Top; Zone N. 23. 89X. Spiral view.

Globigerinoides obliquus Bolli extremus Bolli and Bermudez, 1965.

Hole 62.1, Core 7, Section 3, 15-17 cm; Zone N. 20 (incl. N. 19). 182X. Umbilical view. 

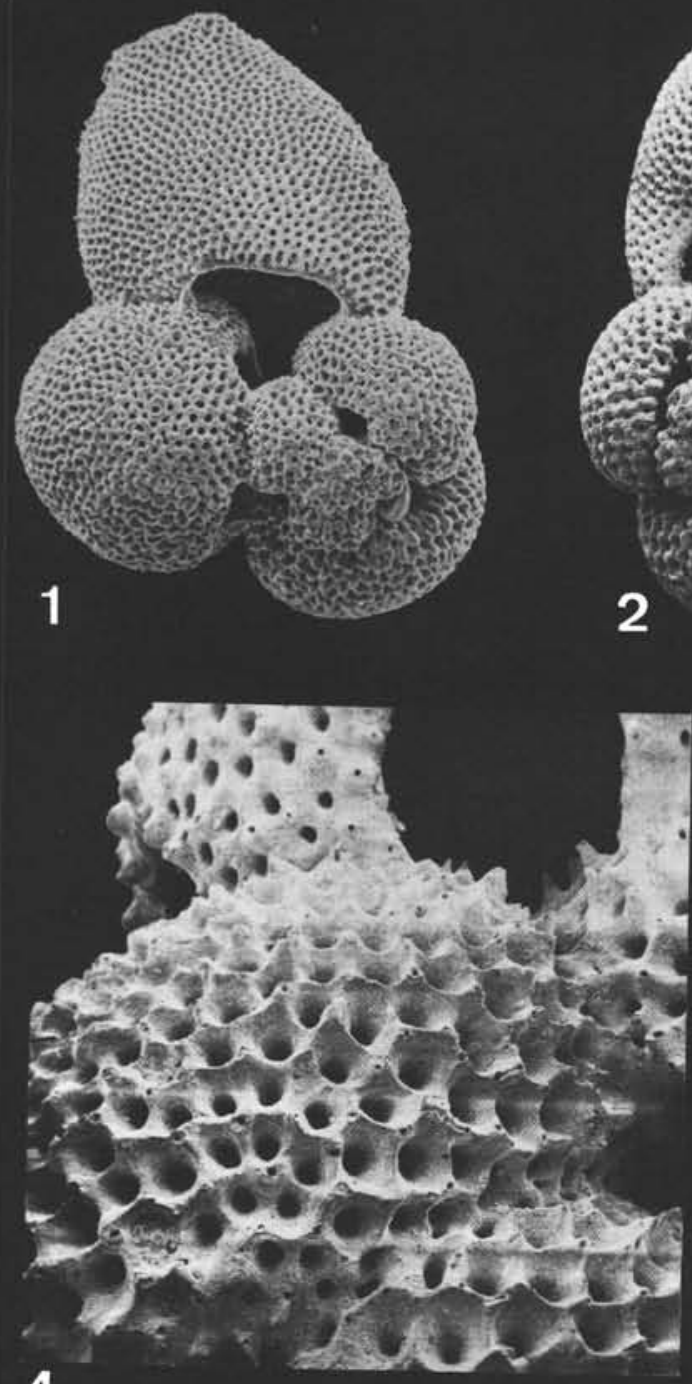

2
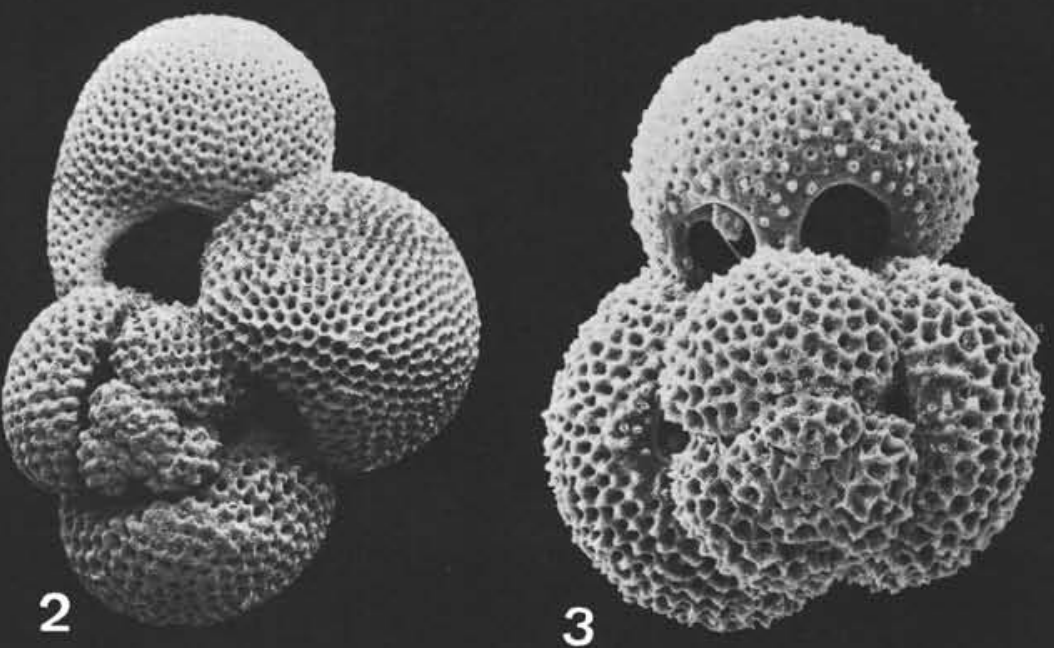

3
4

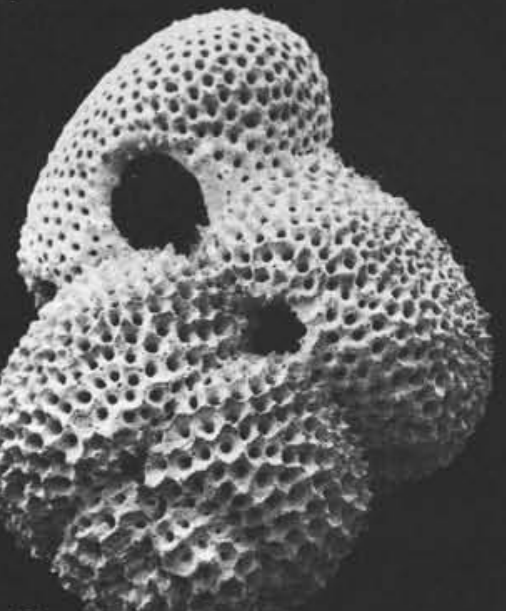

6

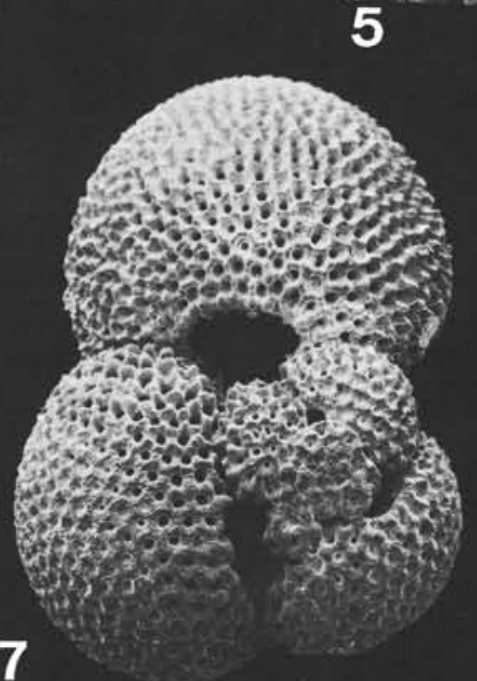

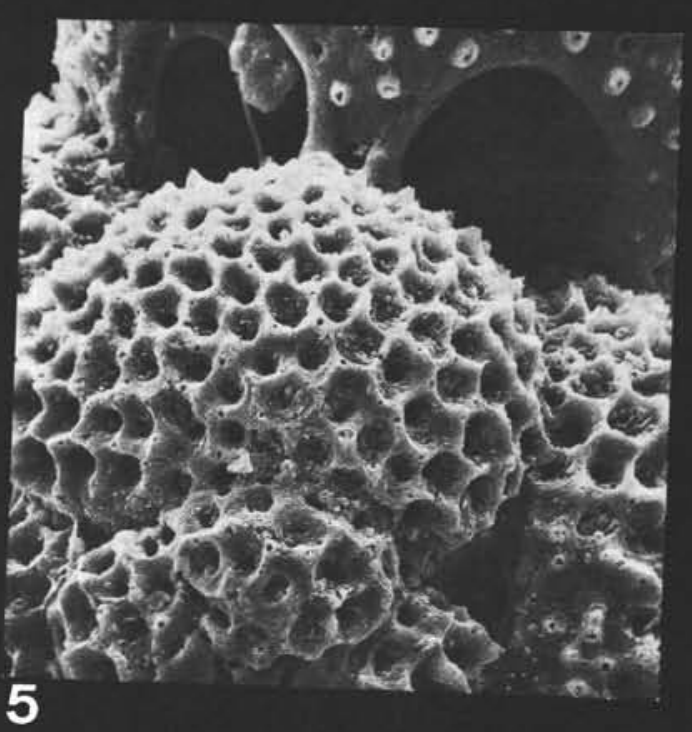




\section{PLATE 13}

Figures 1,2, Globigerinoides subquadratus Brönnimann subelong$4 \& 5$ atus Brönnimann and Resig. n. subsp.

1: Hole 64.1, Core 1, Section 5, 33-35 cm; Zone N. $7 /$ N. $8.178 X$. Side view of holotype.

2: From the same sample as Figure 1; Zone N. $7 /$ N. $8.141 X$. Side view of paratype.

4: From the same sample as Figure 1; Zone N. $7 /$ N. 8. 259X. Umbilical view with principal aperture of paratype.

5: From the same sample as Figure 1; Zone N. $7 /$ N. 8. 203X. Umbilical view with principal aperture of paratype.

Figure $3 \quad$ Globigerinoides elongatus (d'Orbigny), 1826.

Hole 62.1, Core 6, Section 1, 18-20 cm; Zone N. 21. 177X. Side view.

Figures 6 \& 9 Globigerinoides quadrilobatus (d'Orbigny) primordius Blow and Banner, 1962.

Both figures from Hole 64.1, Core 6, Section 1, 33-35 cm; Zone N. 4.

6: $266 \mathrm{X}$. Oblique spiral side with single supplementary sutural aperture.

9: 195X. Umbilical side.

Figures $7 \& 8 \quad$ Globigerinoides quadrilobatus (d'Orbigny) altiaperturus Bolli, 1957.

Both figures from Hole 64.1, Core 5, Section 6, 33-35 cm; Zone N. 6.

7: 220X. Umbilical view.

8: $294 X$. Oblique umbilical view. 

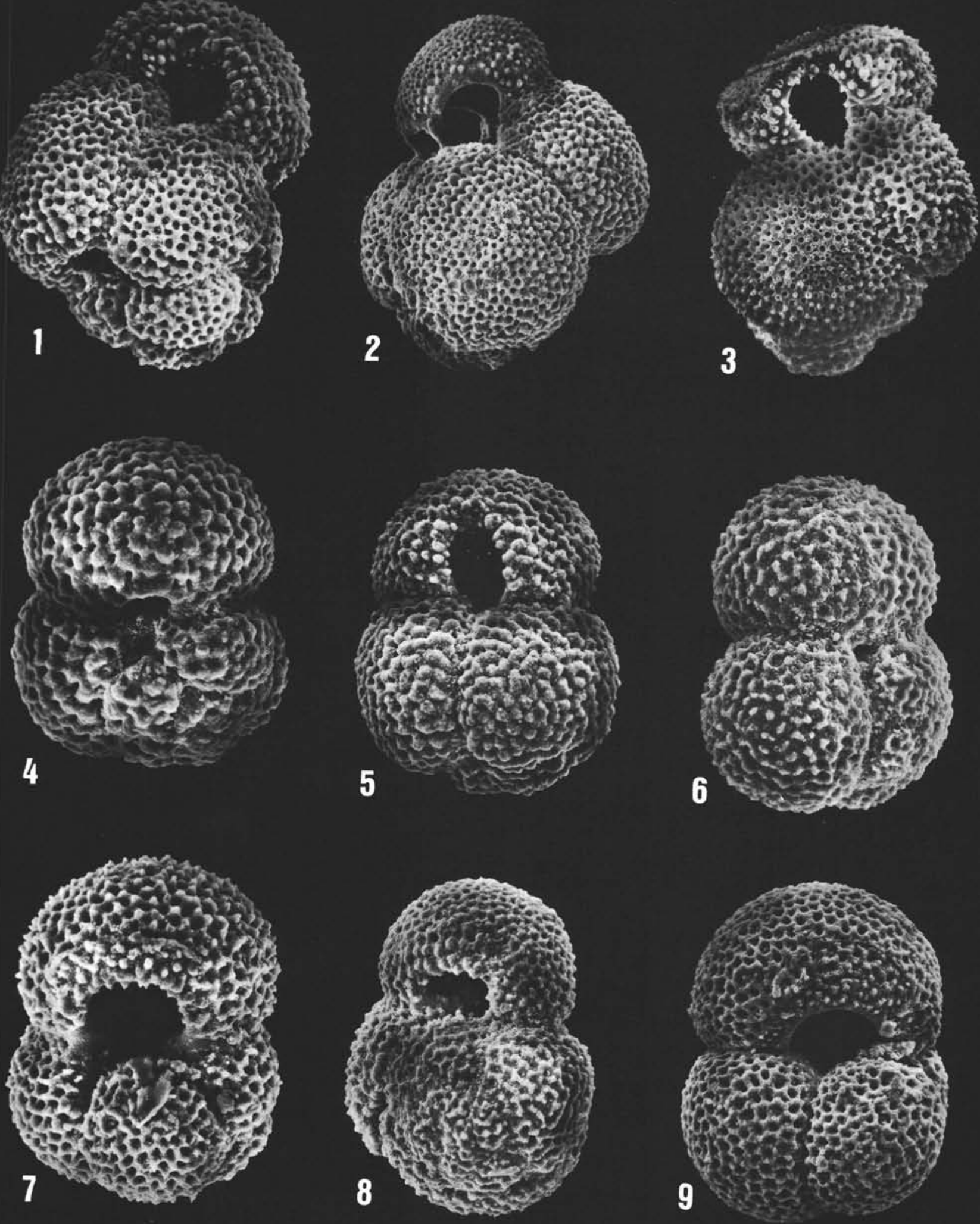


\section{PLATE 14}

Figures 1 \& 2 Hastigerina adamsi Banner and Blow, 1959.

Both figures from Hole 62.1, Core 1, Section 1, Top;

Zone N. 23.

1: $66 \times$.

2: 211X.(same specimen as Figure 1).

Figure $3 \quad$ Hastigerinella digitata (Rhumbler), 1911.

Hole 62.1, Core 1, Section 1, Top; Zone N. 23. 144X.

Figures 4 \& 5 Hastigerina siphonifera (d'Orbigny) involuta (Cushman), 1917.

Both figures from Hole 62.1, Core 12, Section 5, 16-18 cm; Zone N. 20 (including N. 19).

4: 450X. Detail of aperture of Figure 5.

5: $145 X$.

Figure 6

Hastigerina siphonifera siphonifera (d'Orbigny), 1839.

Hole 62.1, Core 1, Section 1, Top; Zone N. 23.102X.

Figures $7 \& 8$ Candeina nitida d'Orbigny, 1839 .

Both figures from Hole 62.1, Core 1, Section 1, Top;

Zone N. 23.

7: $138 X$.

8: $137 \times$ (same specimen as Figure 7). 

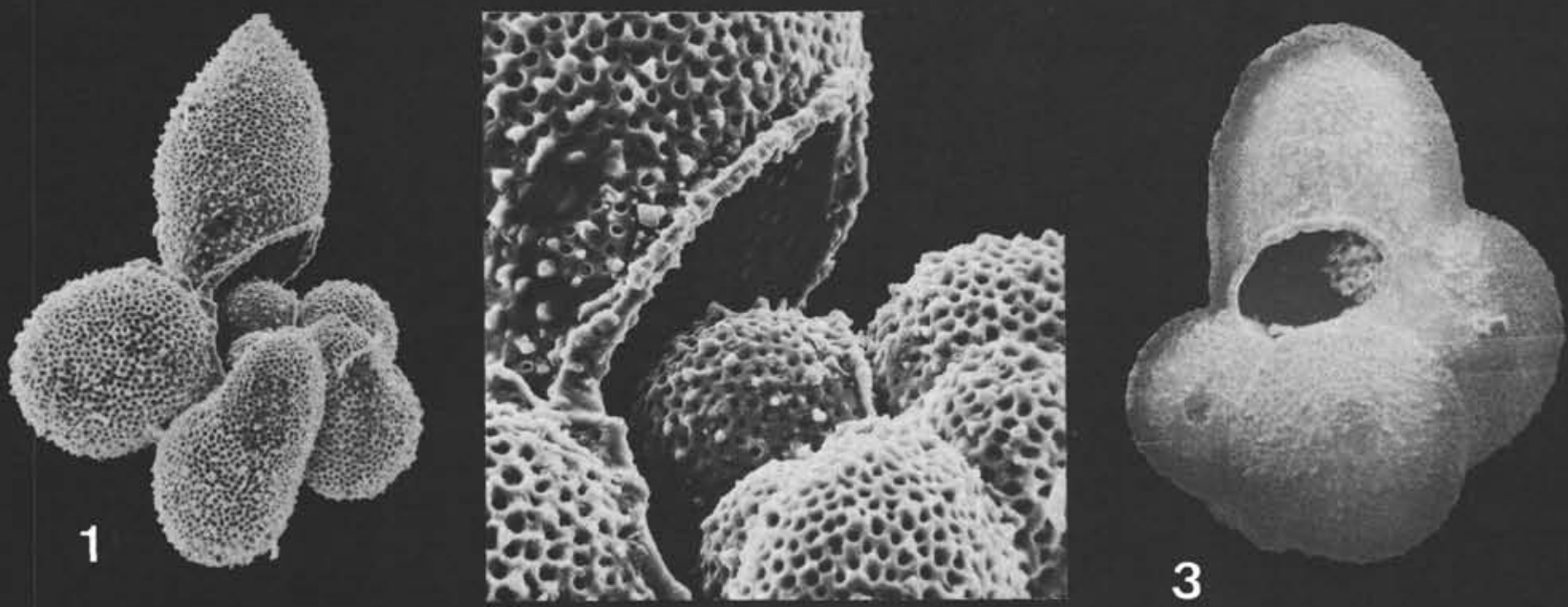

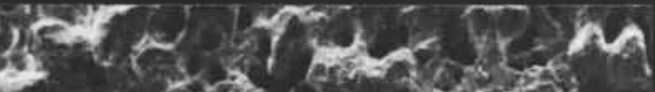

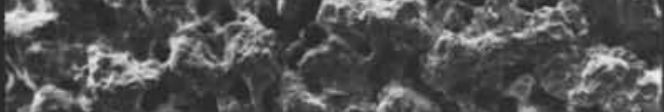

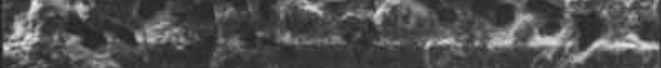

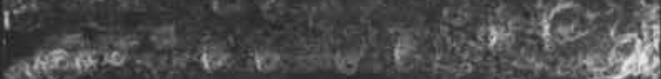

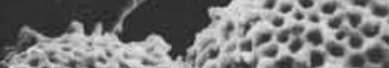
Stif rosini

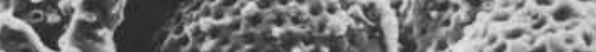
2.

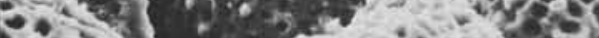

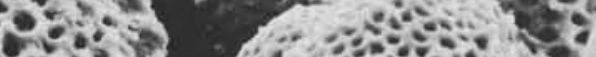
$7 \cos ^{2}$ \& if 0 -

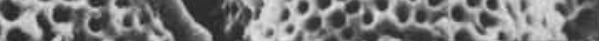

2

Shivengey

Sots 7

sox

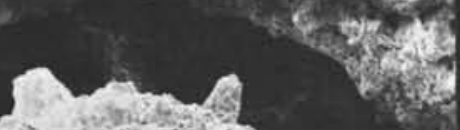

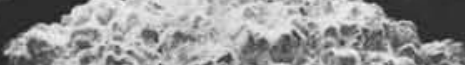

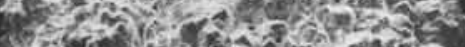

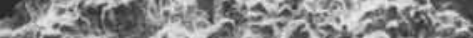

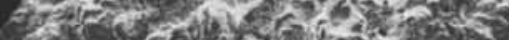

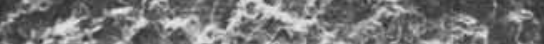

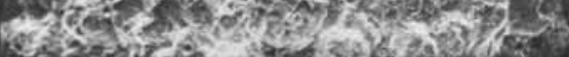

4

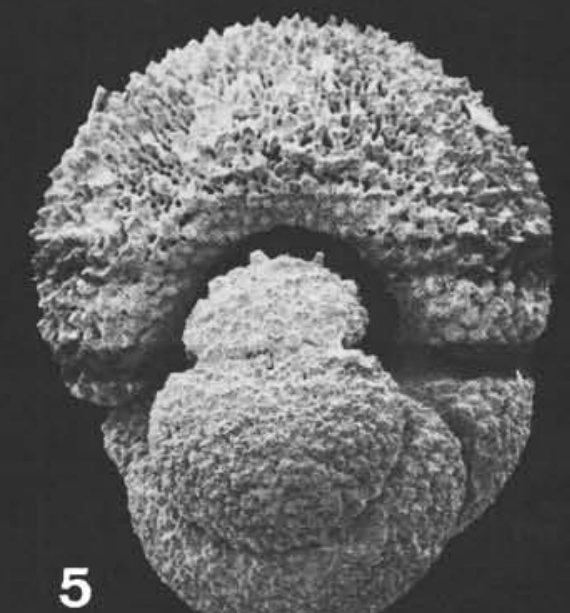

6
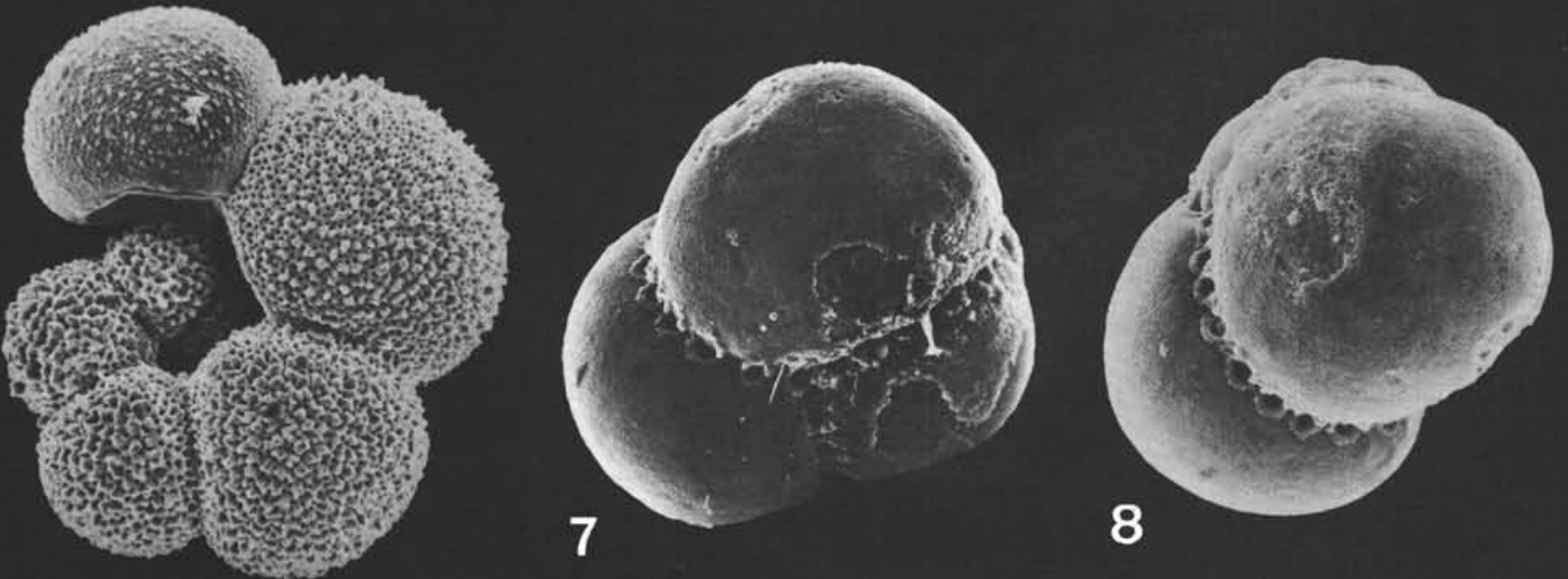


\section{PLATE 15}

Figure 1 Sphaeroidinella dehiscens dehiscens (Parker and Jones), 1865.

Hole 62.1, Core 2, Section 2, 15-17 cm; Zone N. 22. 66X.

Figure 2 "Sphaeroidinellopsis" subdehiscens Blow paenedehiscens Blow, 1969.

Hole 62.1, Core 11, Section 1, 15-17 cm; Zone N. 20 (including N. 19). 73X.

Figure 3 Sphaeroidinella dehiscens (Parker and Jones) immatura (Cushman), 1919.

Hole 62.1, Core 2, Section 2, 15-17 cm; Zone N. 22. $86 \mathrm{X}$.

Figures 4, 5 \& 6 Sphaeroidinellopsis subdehiscens subdehiscens (Blow), 1959.

4: Hole 62.1 , Core 35 , Section $5,15-17 \mathrm{~cm}$; Zone N. 13. $148 \mathrm{X}$.

5\&6: Hole 62.1, Core 11, Section 1, 15-17 cm; Zone N. 20 (including N. 19).

5: $562 \times$ (detail of aperture of Figure 6).

6: $148 \mathrm{x}$.

Figures $7 \& 8 \quad$ Sphaeroidinellopsis seminulina seminulina (Schwager), 1866.

7: Hole 62.1, Core 35, Section 5, 15-17 cm; Zone N. 13. $129 \mathrm{X}$.

8: Hole 62.1, Core 27, Section 1, Top sample; Zone N. 16. $158 \mathrm{X}$.

Figure $9 \quad$ Sphaeroidinellopsis seminulina (Schwager) kochi (Caudri), 1934.

Hole 62.1, Core 35, Section 5, 15-17 cm; Zone N. 13. $133 \mathrm{X}$. 
Plate 15

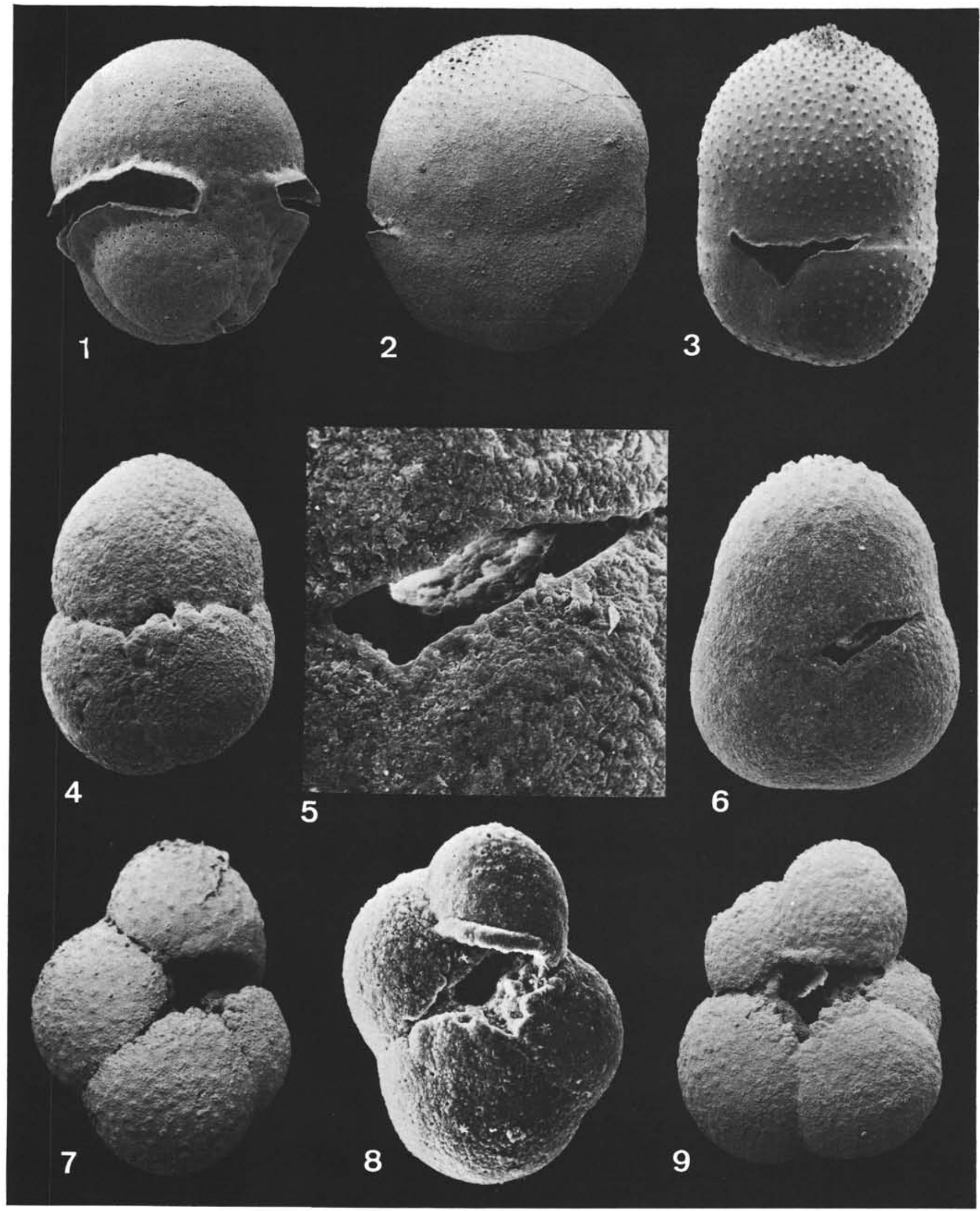




\section{PLATE 16}

Figures 1-11 Pulleniatina obliquiloculata obliquiloculata (Parker and Jones), 1862.

Figures 1, 2, 4 and 10: Hole 64.0, Core 0, Surface Sample; Zone N. 23.

1: 162X. Early ontogenetic stage.

2: 162X. Early ontogenetic stage.

4: 270X. Early ontogenetic stage of ? representative of $P$. obliquiloculata obliquiloculata.

10: $145 \mathrm{X}$. Almost mature individual.

Figures 3, 5, 6, 7, 8, 9 and 11: Hole 62.1, Core 1, Section 1, Top Sample; Zone N. 23.

3: $137 X$. Early ontogenetic stage.

5: $168 \times$. Middle ontogenetic stage.

6: 191X. Advanced, premature individual.

7: 131X. Advanced, premature individual.

8: 112X. Advanced, premature individual.

9: $135 \times$. Advanced, premature individual.

11: $108 \times$. Adult individual. 


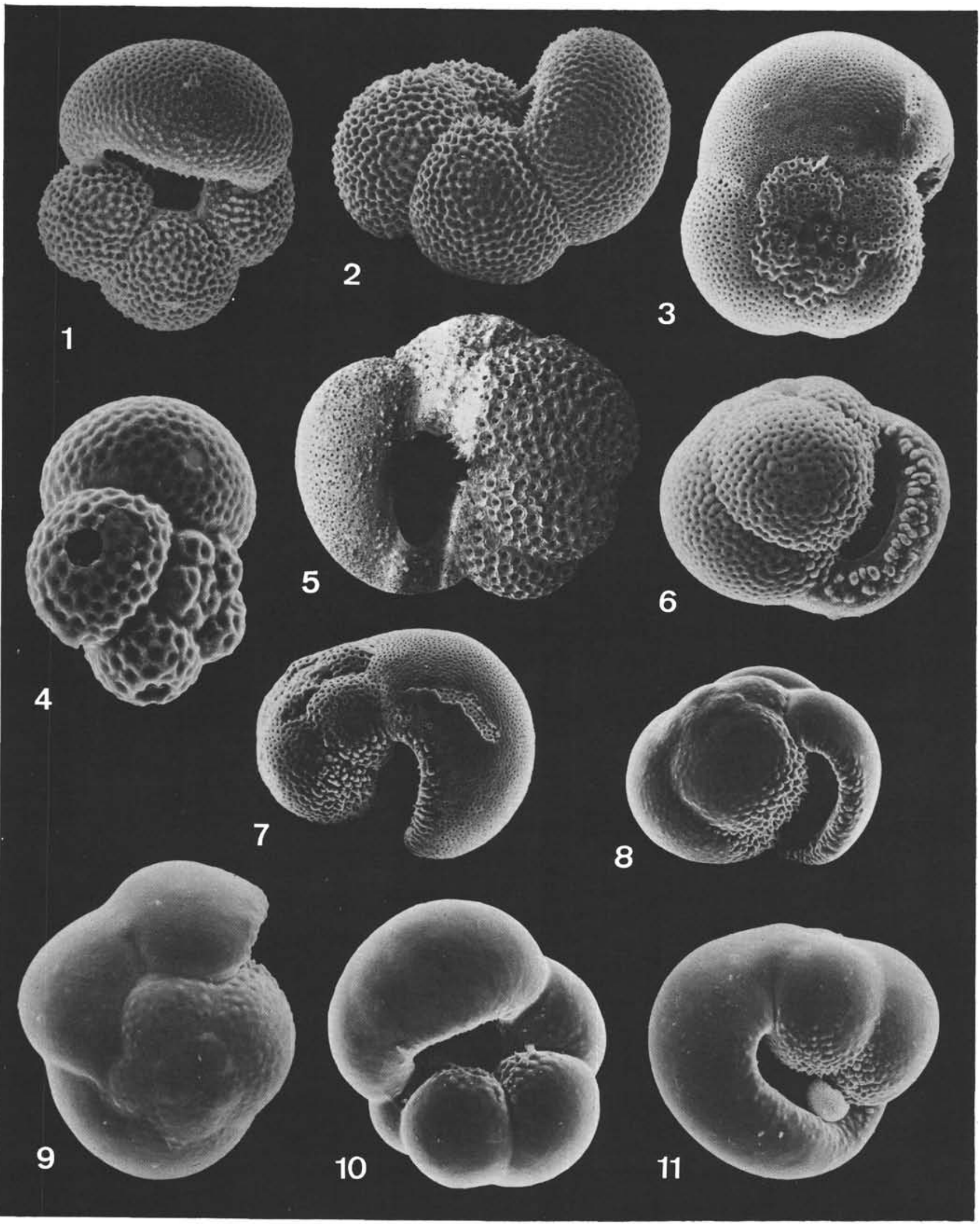




\section{PLATE 17}

Figures 1-4 Pulleniatina obliquiloculata obliquiloculata (Parker and Jones), 1862.

All figures from Hole 64.0, Core 0, Surface Sample; Zone N. 23.

1: 2110X. Outer surface of wall of adult individual. 2: 3300X. Inner surface of wall of early ontogenetic stage.

3: 1450X. Transverse cut of wall of the same specimen as Figure 2.

4: 7250X. Transverse cut of wall of the same specimen as Figure 3.

Figures 5 \& $6 \quad$ Pulleniatina obliquiloculata obliquiloculata (Parker and Jones), 1866 ?.

Both figures from hole 64.0, Core 0, Surface Sample; Zone N. 23.

5: $858 \times$. Early ontogenetic stage.

6: 528X. Early ontogenetic stage (Embryo ?). Same specimen as illustrated by Plate 19, Figure 6. 

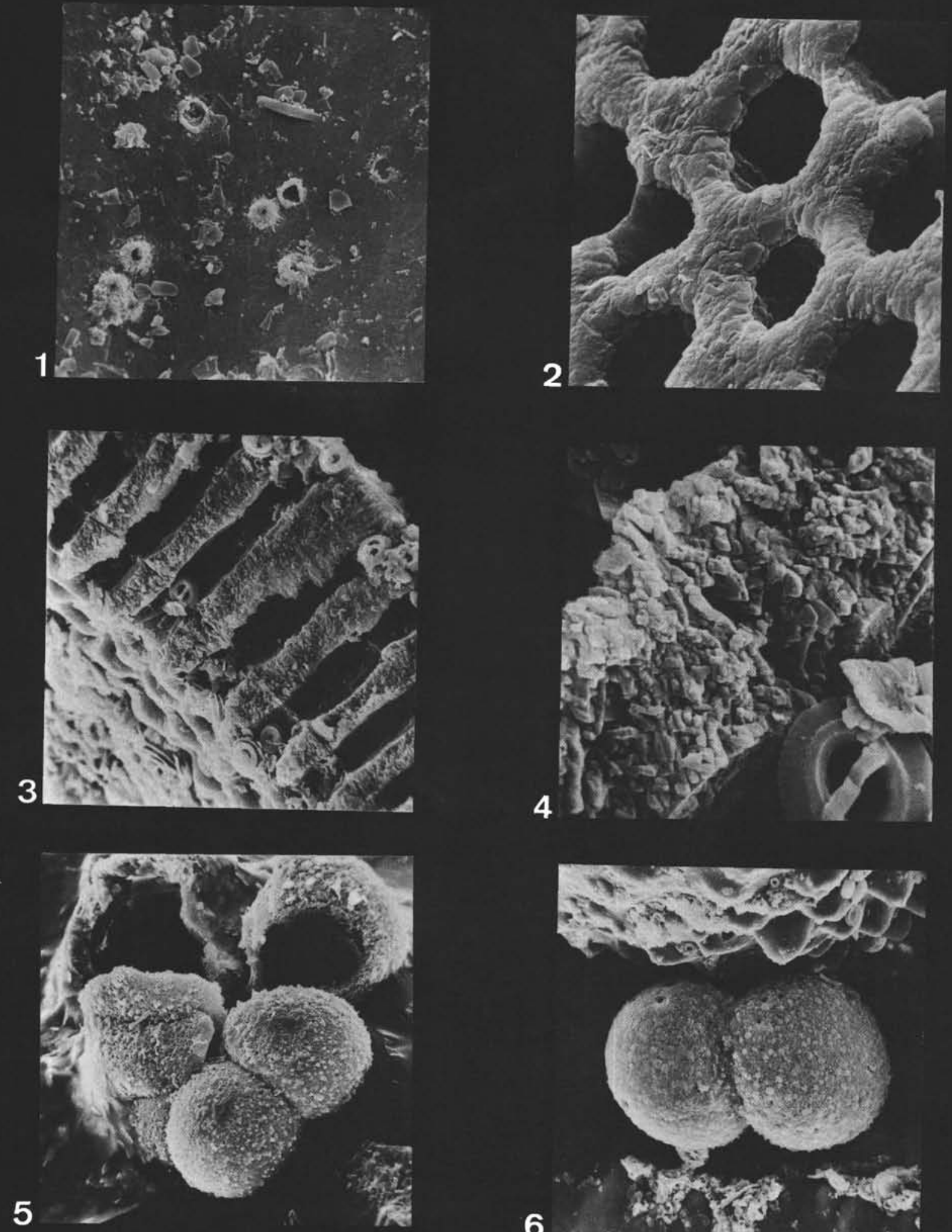


\section{PLATE 18}

Figures 1-7 Pulleniatina obliquiloculata obliquiloculata (Parker and Jones), 1862.

All figures from Hole 64.0, Core 0, Surface Sample;

Zone N. 23.

1: $1080 X$. Detail of Figure 4.

2: $942 X$. Detail of Figure 5.

3: $87 X$.

4: $108 \mathrm{X}$.

5: $94 X$.

6: $872 X$. Detail of Figure 3.

7: 1080X. Detail of Figure 3. 


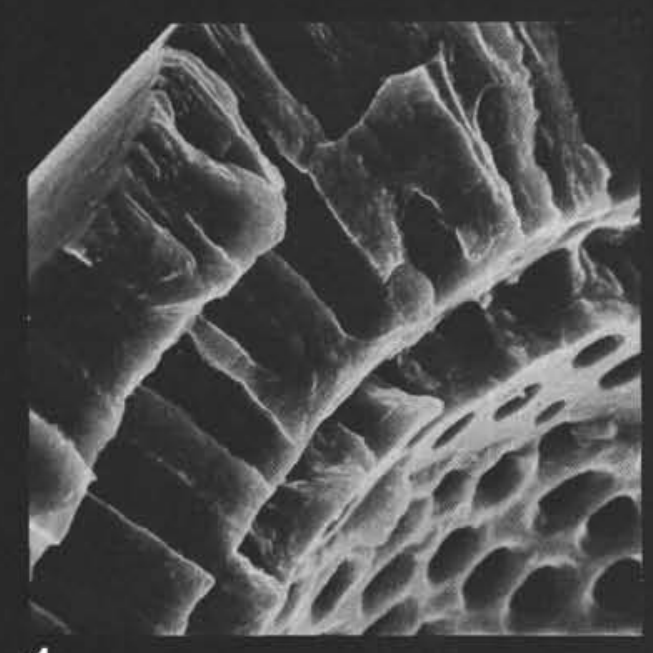

1
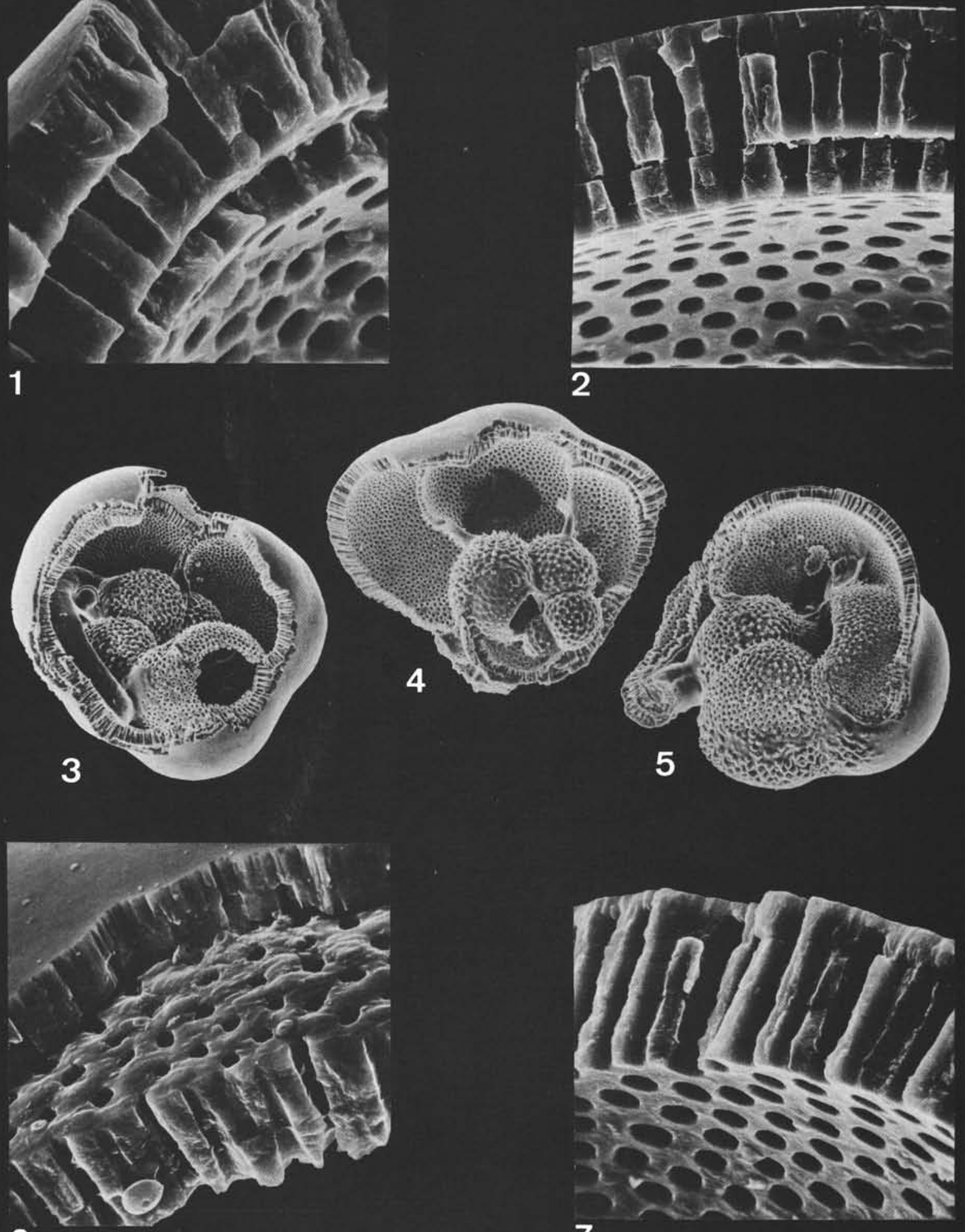

6

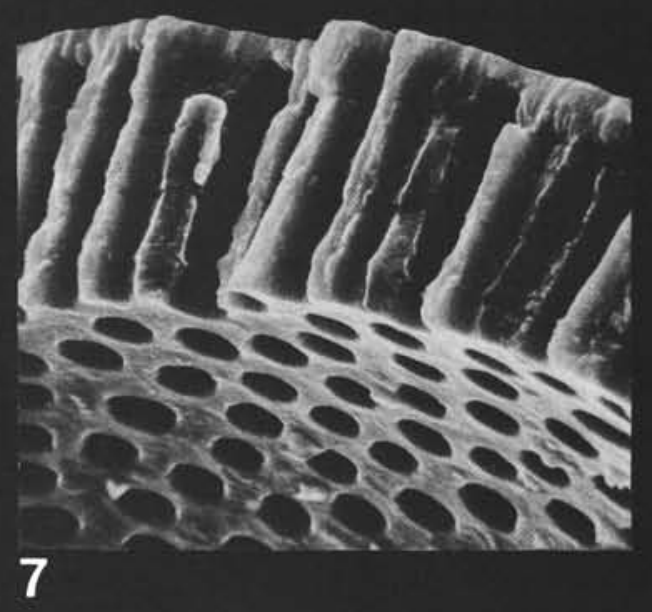




\section{PLATE 19}

Figures 1, 2 \& 3 Pulleniatina obliquiloculata (Parker and Jones), 1862, finalis Banner and Blow, 1967.

All figures from the same specimen from Hole 62.1, Core 1, Section 1, Top; Zone N. 23.

1: $110 \times$. Tilt $20^{\circ}$.

2: $115 \mathrm{X}$. Tilt $5^{\circ}$.

3: $550 \times$. Detail of aperture.

Figures 4 \& 7 Pulleniatina spectabilis Parker, 1965, praespectabilis Brönnimann and Resig, n. subsp.

Both figures from the same specimen. Holotype. Hole 62.1, Core 12, Section 4, 15-17 cm; Zone N. 20 (including N. 19).

4: 1190X. Detail of aperture of specimen illustrated by Figure 7 .

7: $83 \times$.

Figure $5 \quad$ Pulleniatina spectabilis Parker, 1965.

LSDH-78 P, 100-102 cm; Zone N. 19. Donated by Dr. F. L. Parker. $92 X$.

Figure $6 \quad$ Pulleniatina obliquiloculata obliquiloculata (Parker and Jones), 1862.

Hole 62.1, Core 1, Section 1, Top; Zone N. 23. 66X. Adult specimen. 

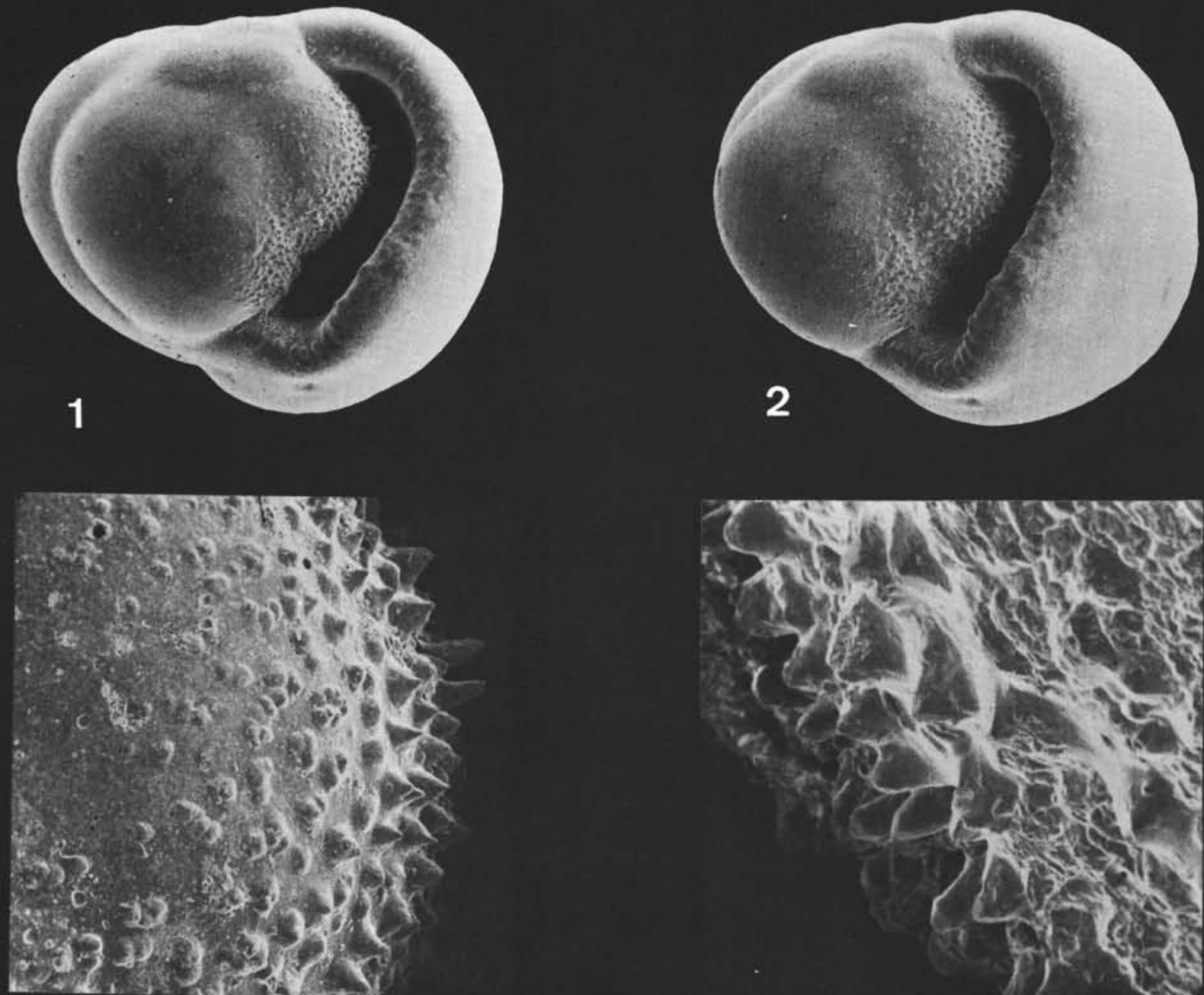

3
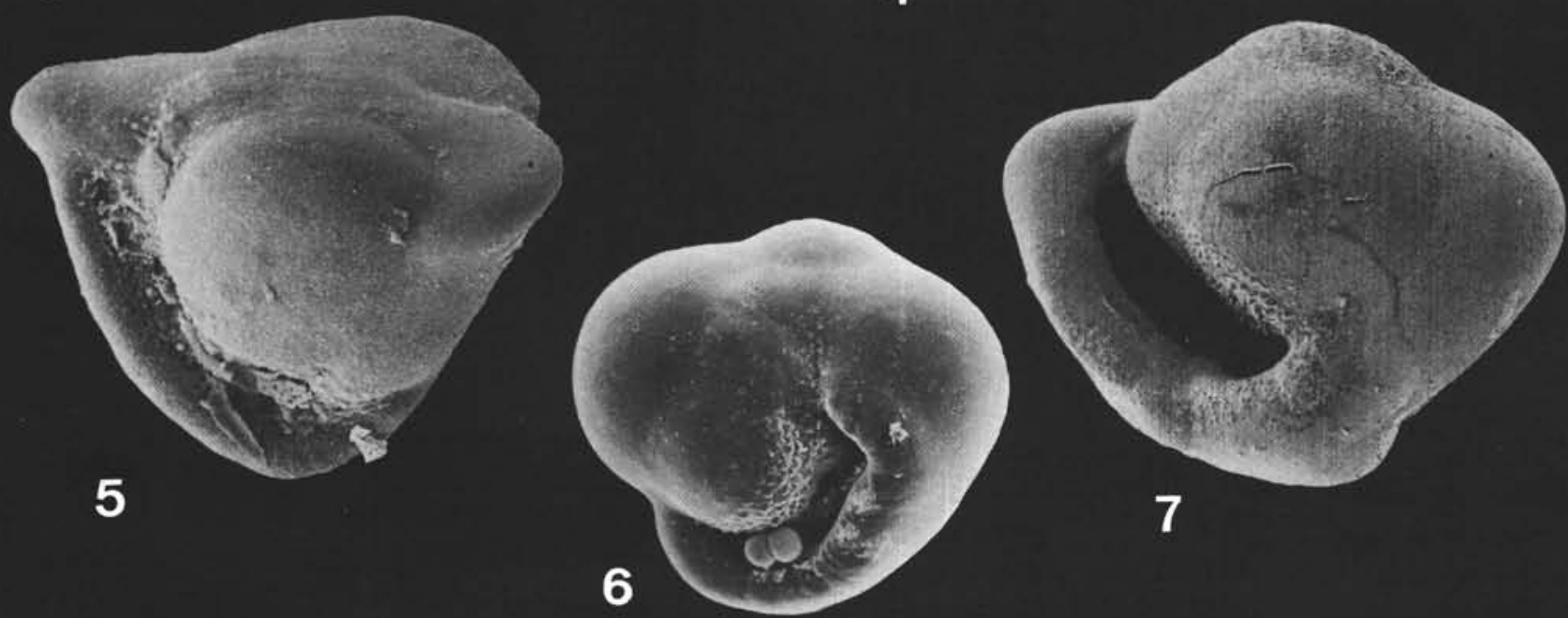
PLATE 20

Figures 1,2,3, Pulleniatina praepulleniatina Brönnimann and Resig, $4,5,6 \& 8$

n. sp.

1: Hole 62.1, Core 29, Section 5, 26-28 cm; Zone N. $16.133 X$

2,3,4,5,6\&8: Hole 62.1, Core 21, Section 4, 15-17 cm; Zone N. 17.

2\&3: 145X. Holotype.

4: $172 X$.

5: 610X. Detail of Figure 8.

6: $135 \mathrm{X}$.

8: $122 \mathrm{X}$

Figure 7

Pulleniatina primalis Banner and Blow, 1967.

Hole 62.1, Core 13, Section 1, Top; Zone N. 18. $132 x$ 

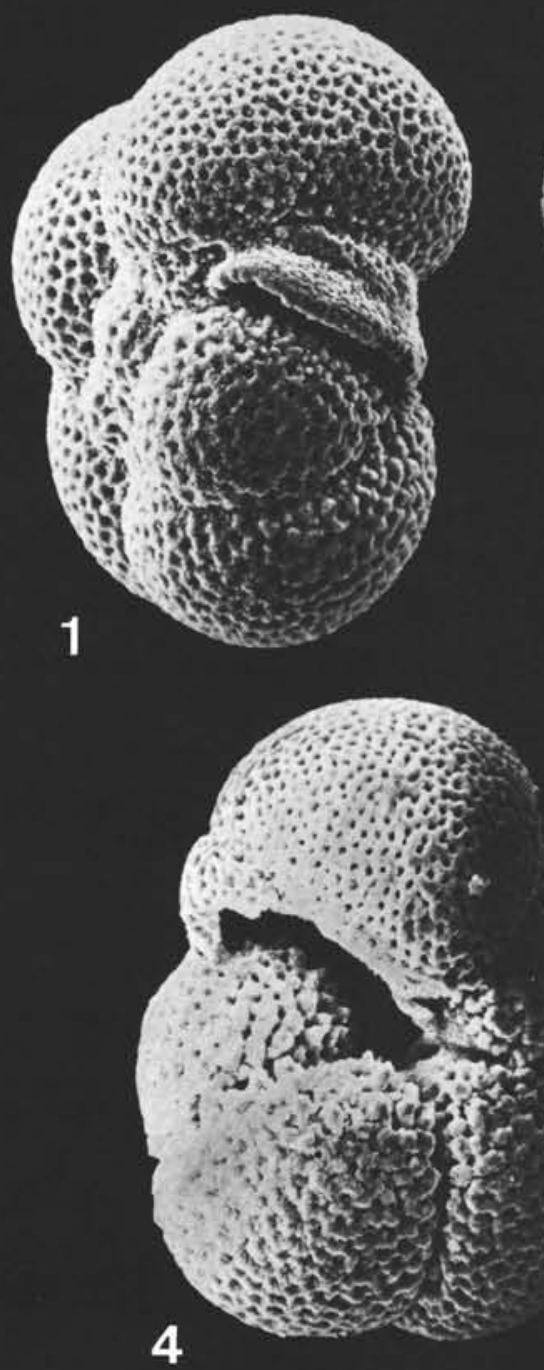
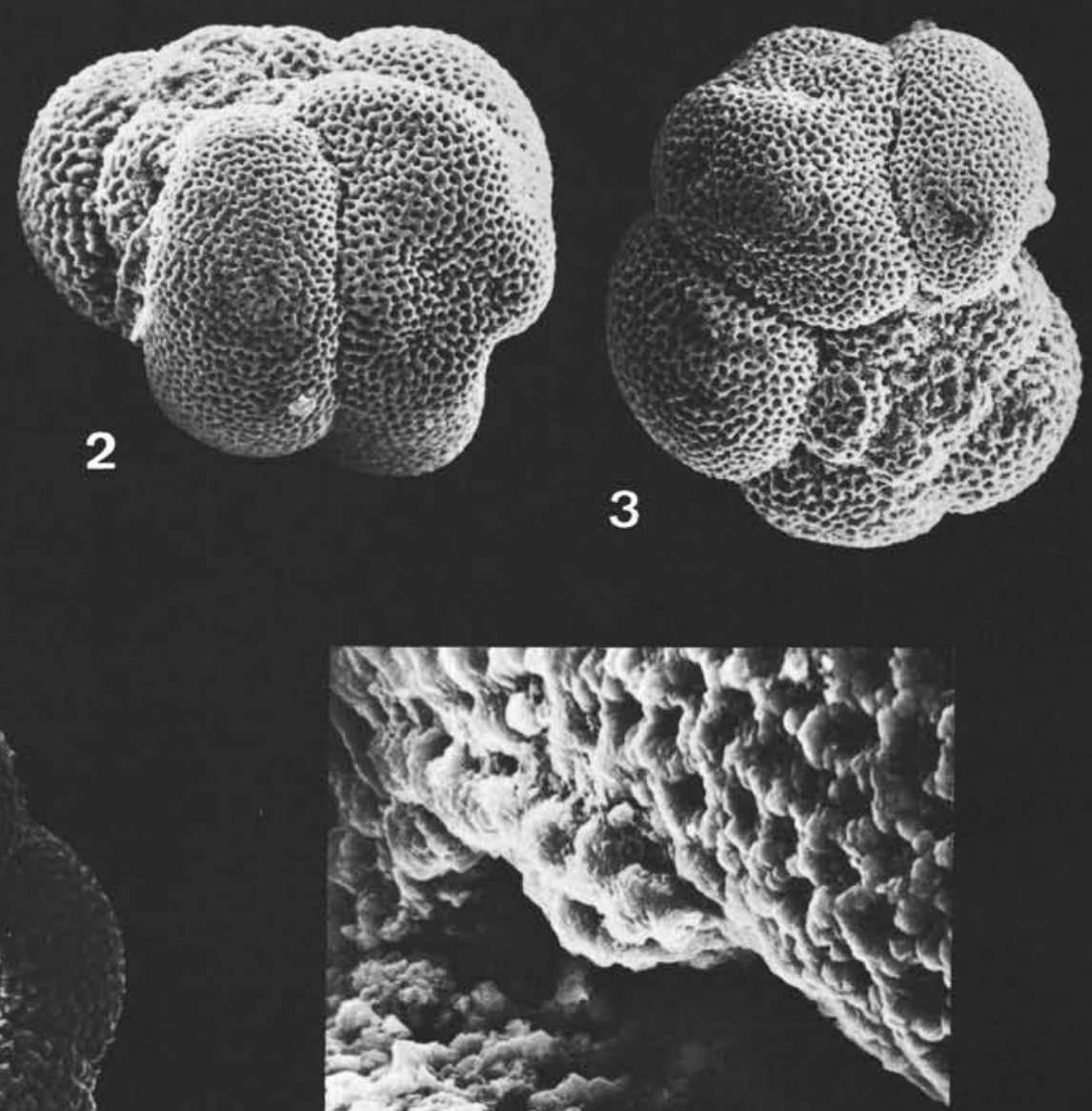

tor क:

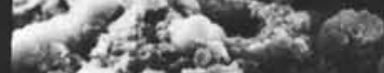

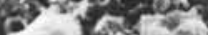

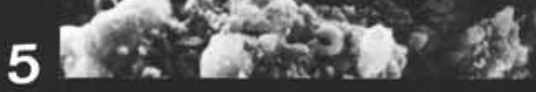
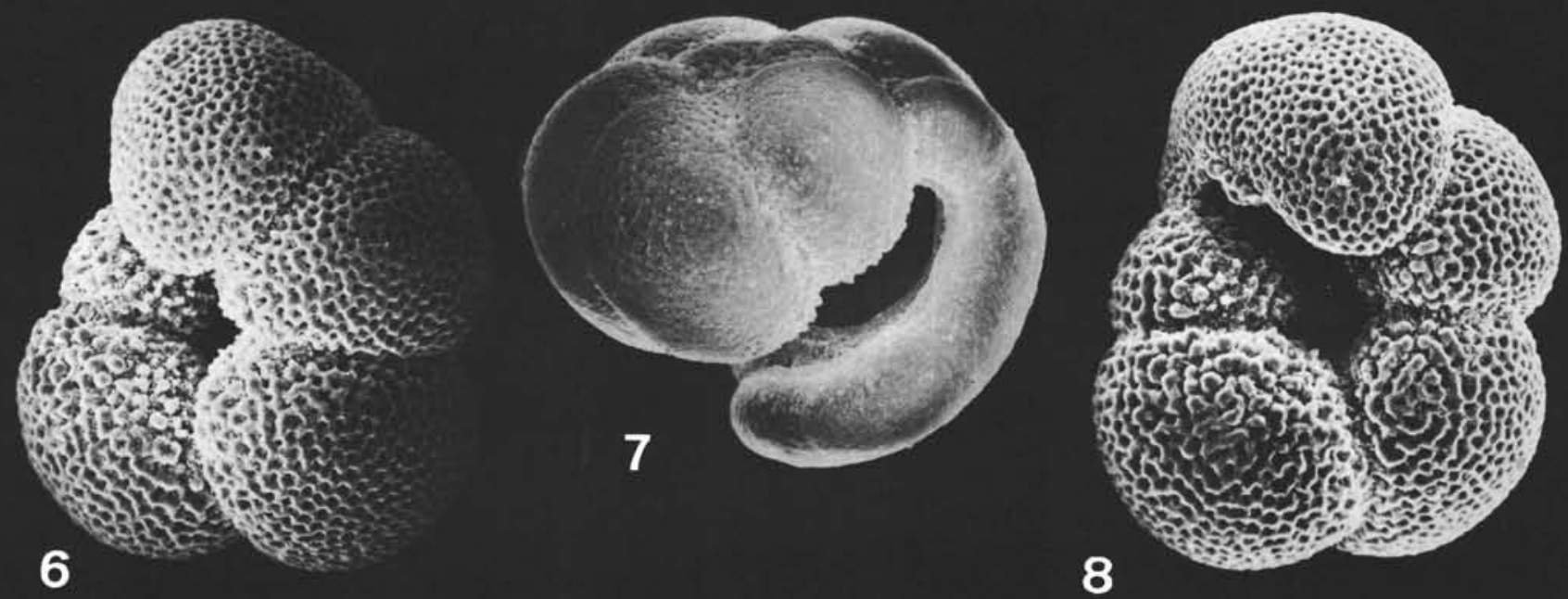


\section{PLATE 21}

Figures 1-5 Globigerinatella insueta Cushman and Stainforth, 1945.

Hole 64.1, Core 1, Section 2, 33-35 cm; Zone N. $6 /$ N. 8 .

1: $240 \mathrm{X}$.

2: 920X. Detail of Figure 1.

3: $300 X$.

4: 2000X. Detail of Figure 3.

5: 2000X. Detail of Figure 3.

Figures 6 \& 7 Turborotalita humilis (Brady), 1884, group.

6: Hole 62.1, Core 1, Section 1, Top; Zone N. 23. $343 \times$.

7: Hole 64.0, Core 0, Section 0, Surface Sample; Zone N. 23. 313X. 
Plate 21
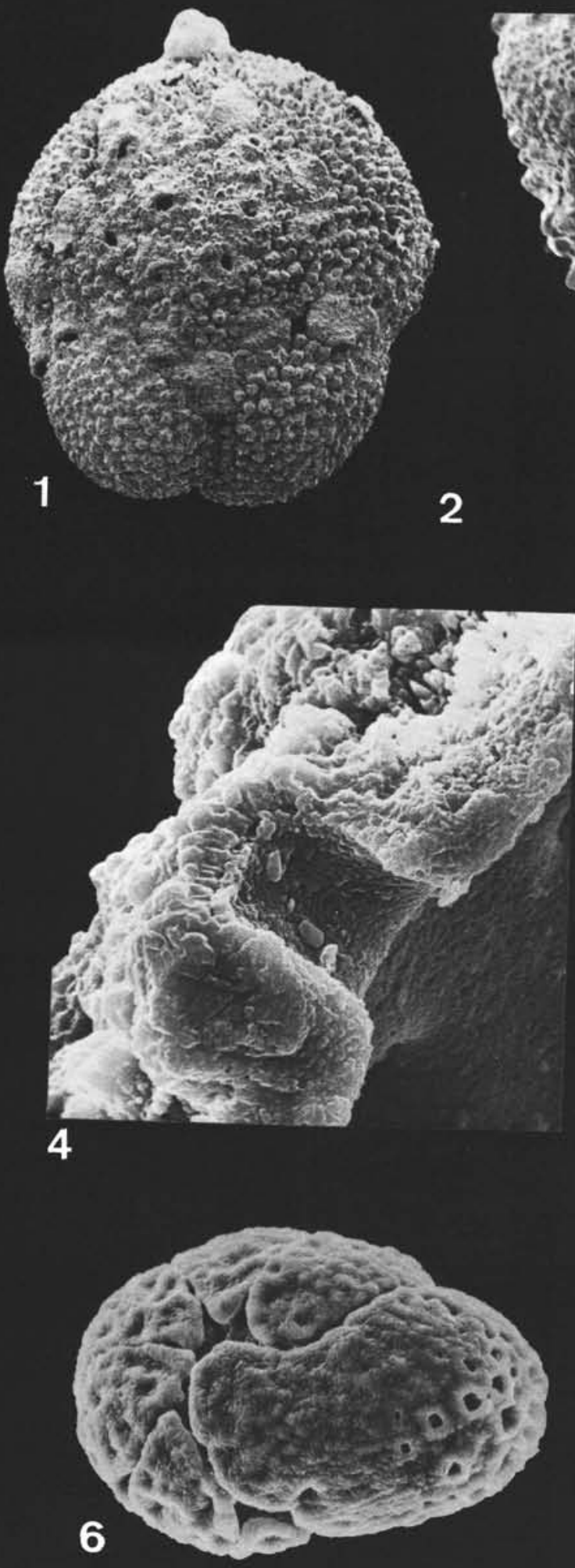
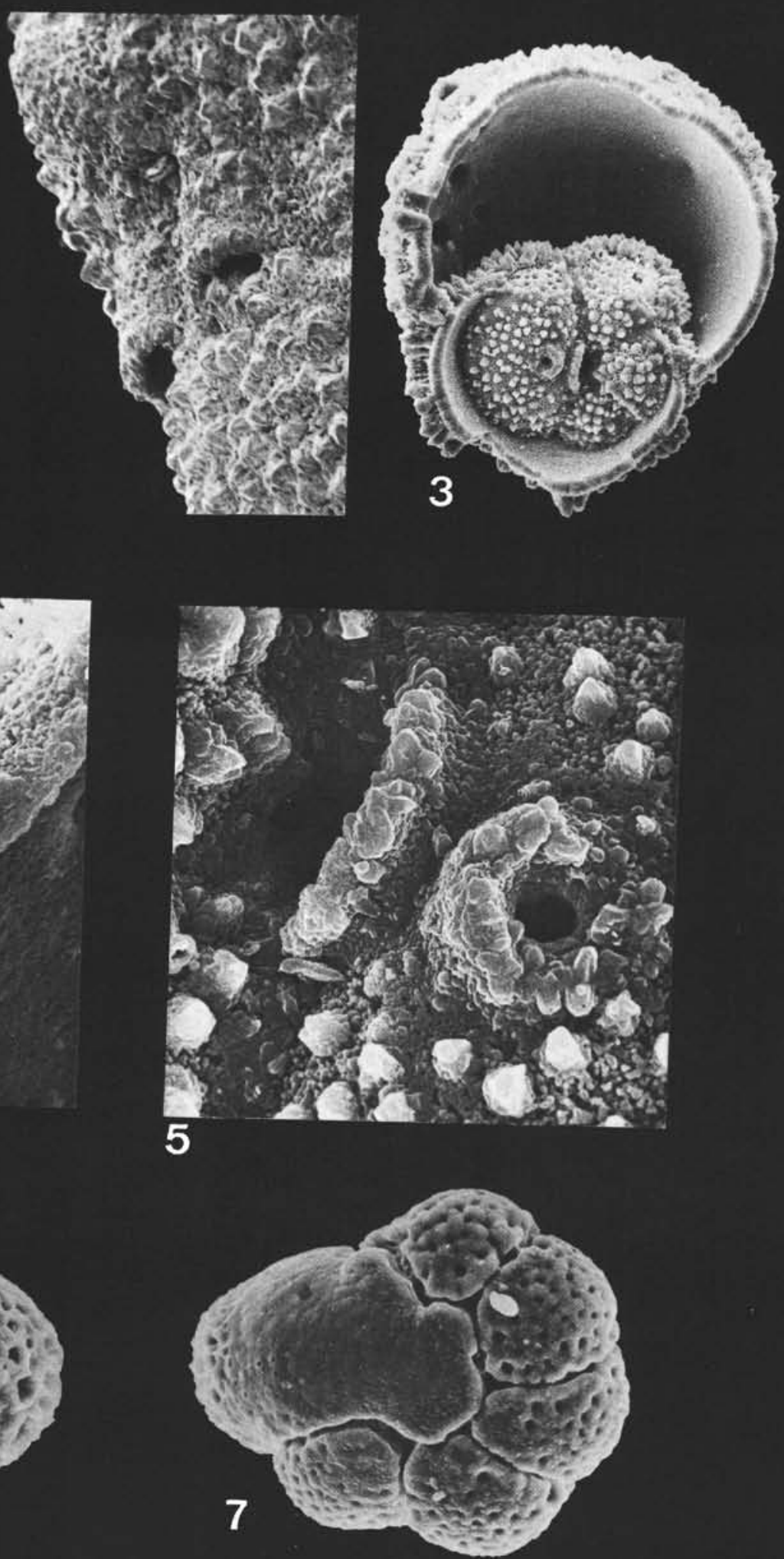
PLATE 22

Figure 1 Globoquadrina altispira (Cushman and Jarvis) conica Brönnimann and Resig, n. subsp.

Hole 62.1, Core 30, Section 1, 15-17 cm; Zone N. 15. $150 \times$.

Figure 2 Globoquadrina dehiscens (Cushman, Parr and Collins) group.

Hole 62.1, Core 18, Section 4, 15-17 cm; Zone N. 17. $118 \mathrm{X}$.

Figure 3

Globoquadrina altispira (Cushman and Jarvis) globosa Bolli, 1957.

Hole 62.1, Core 27, Section 4, 17-19 cm; Zone N. 16. $114 X$.

Figure $4 \quad$ Globorotalia (Turborotalia) opima opima Bolli, 1957. Hole 64.1, Core 7, Section 4, 33-35 cm; Zone N. 2. 89X.

Figure $5 \quad$ Globorotalia (Turborotalia) opima nana Bolli, 1957. Hole 64,1, Core 8, Section 1, 112-114 cm; Zone N. 2. $95 \times$.

Figures $6 \& 9$ Globigerinita aff. Globigerinita uvula (Ehrenberg), 1861

Both figures from Hole 64.1, Core 6, Section 1, 33-35 cm; Zone N. 4.

6: $698 \mathrm{X}$.

9: $632 \mathrm{X}$.

Figures $7 \& 8 \quad$ Globigerinita uvula (Ehrenberg), 1861.

7: Hole 62.1, Core 6, Section 1, 18-20 cm; Zone

N. 21.209X.

8: Hole 62.1, Core 3, Section 3, Bottom; Zone

N. $22.800 \mathrm{X}$. 

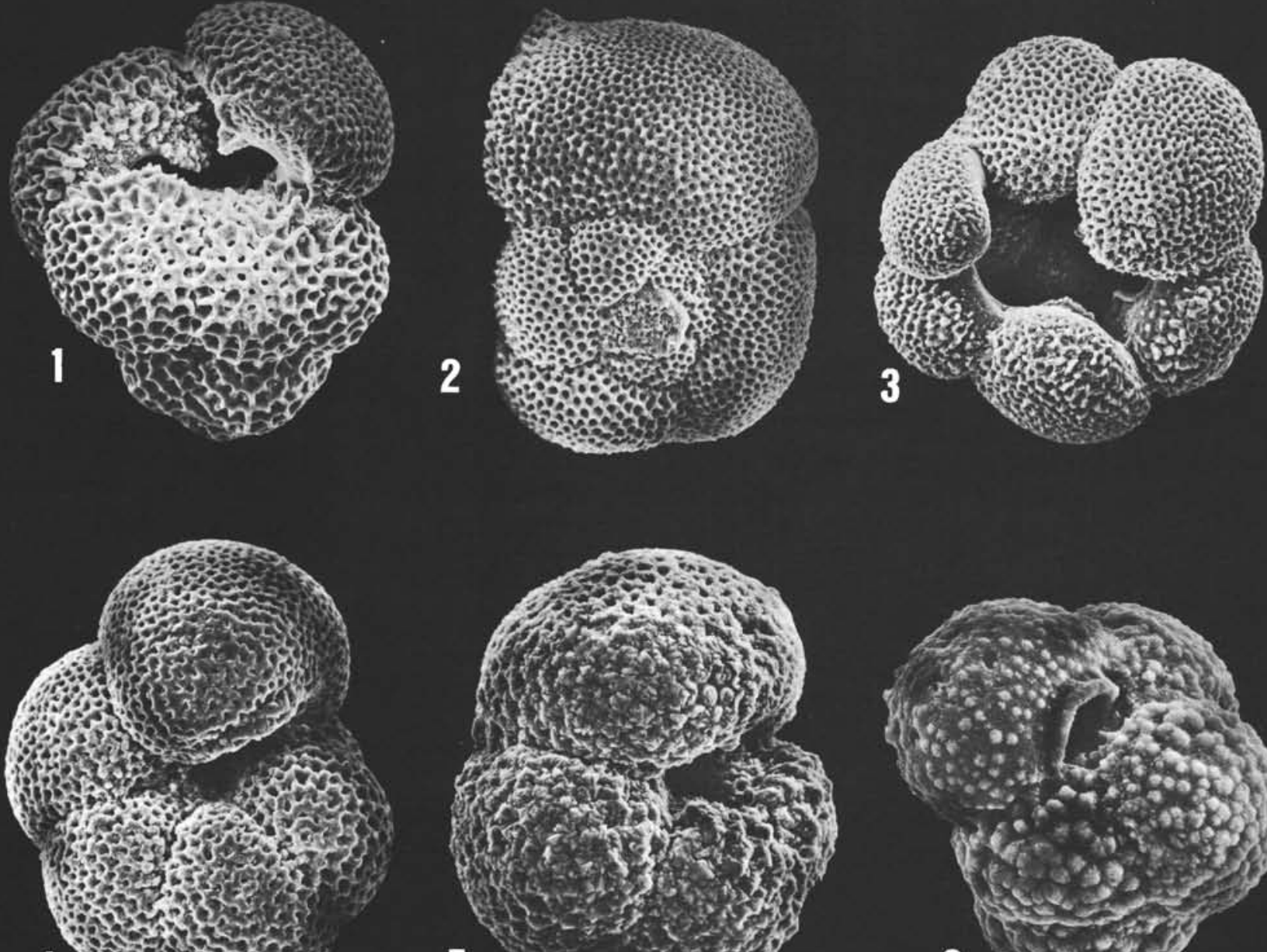

4 sustars
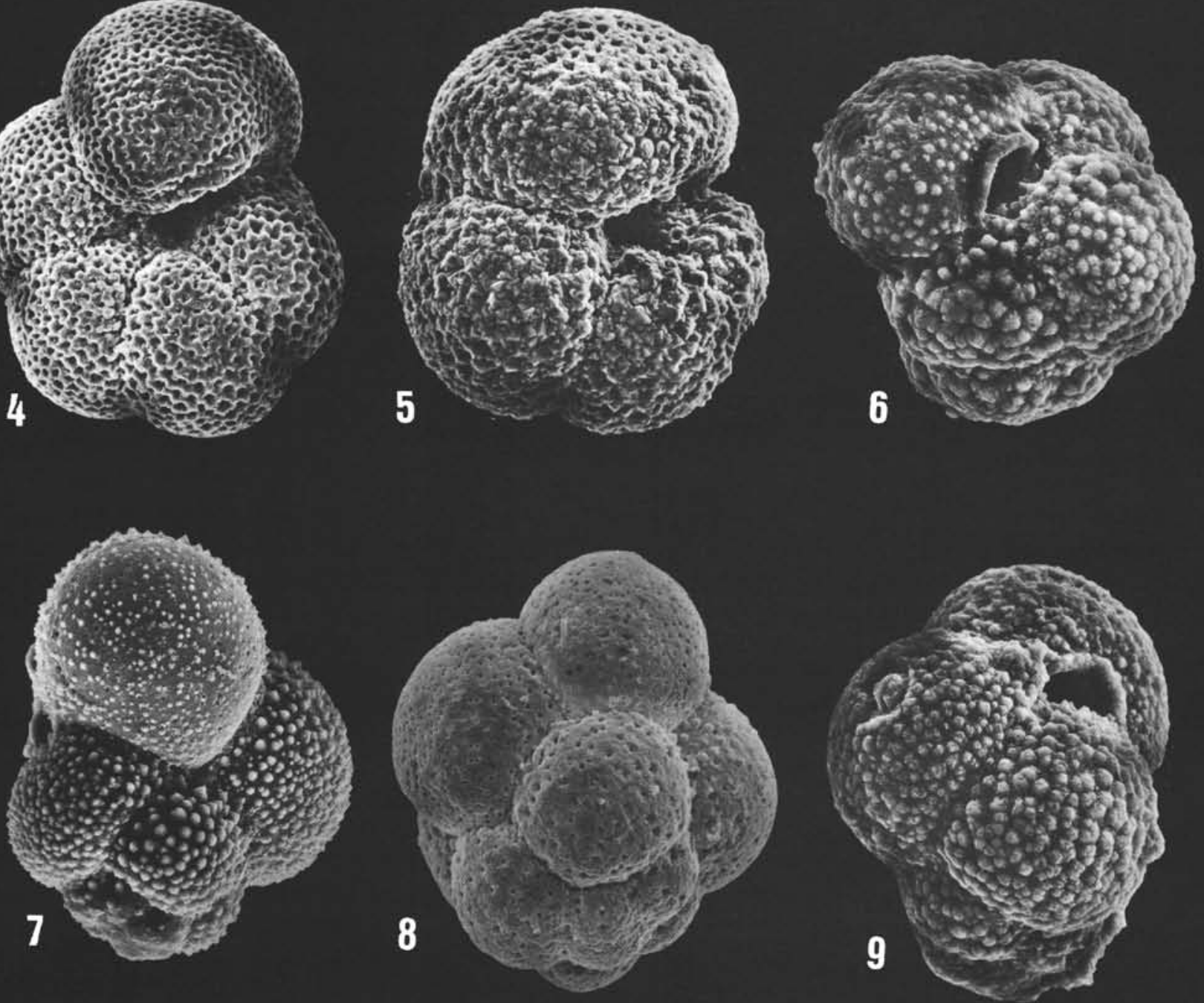


\section{PLATE 23}

Figures 1-4 Globigerinita glutinata (Egger) flparkerae Brönnimann and Resig, nom. nov.

Hole 62.1, Core 1, Section 1, Top; Zone N. 23.

1: $261 \mathrm{X}$.

2: $257 \mathrm{X}$.

3: 356X. Broken ultimate chamber.

4: 301X. Detail of Figure 2.

Figure $5 \quad$ Globigerinita glutinata glutinata (Egger), 1893.

Hole 64.0, Core 0, Section 0, Surface Sample, Zone N. 23. Bulla damaged, with multiple apertures. 334X.

Figures 6 \& 7 Turborotalita iota (Parker), 1962.

Hole 62.1, Core 2, Section 1, Top; Zone N. 22.

6: $505 x$.

7: $551 X$.

Figure $8 \quad$ Turborotalita iota (Parker), 1962 ?.

Hole 62.1, Core 3, Section 2, Bottom; Zone N. 22. $553 \mathrm{X}$. 
PLATE 23

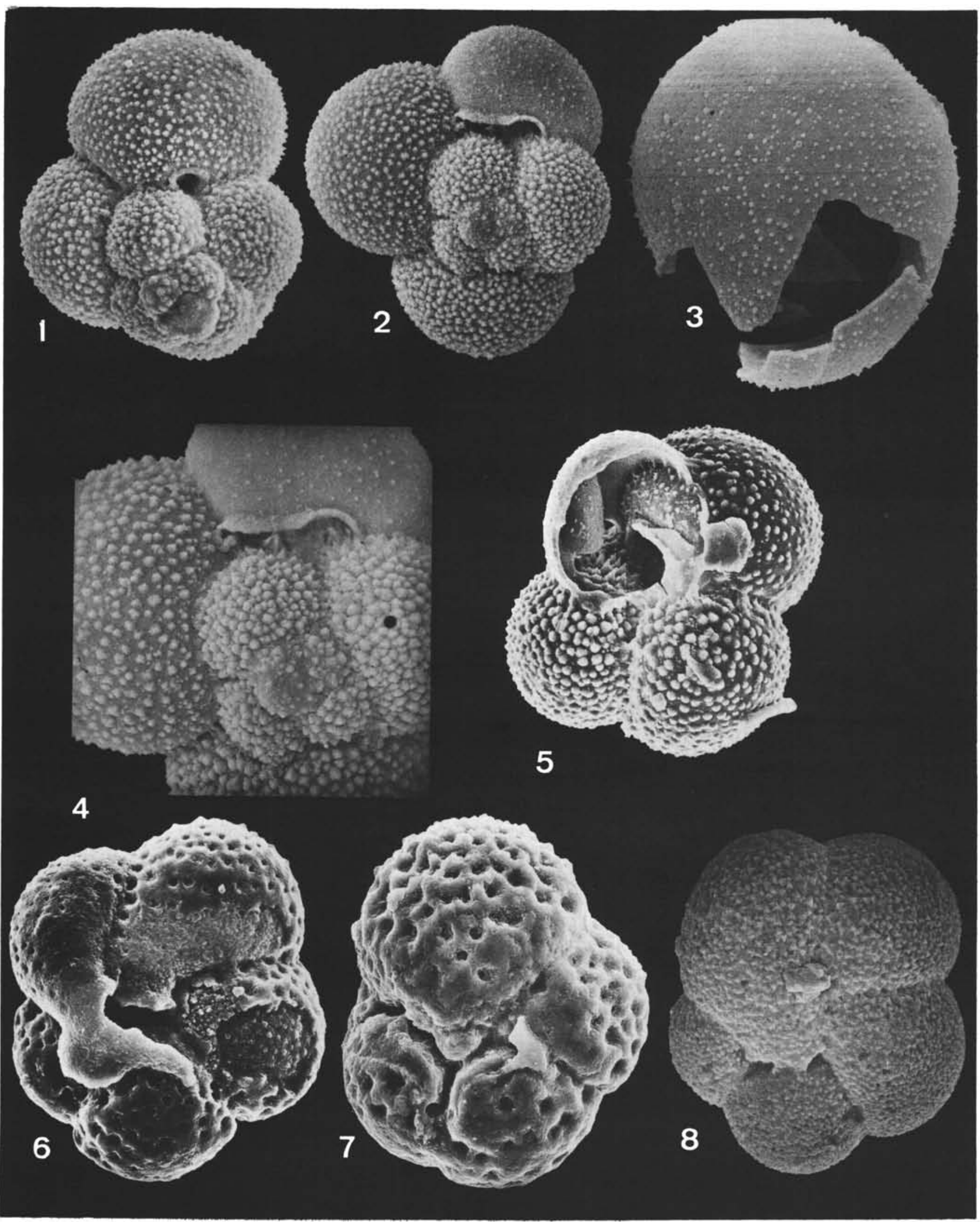




\section{PLATE 24}

Figures 1 \& 2 Enlarged views of the "bulla" in specimens illustrated in Figures 3 and 4 respectively.

Figures $3 \& 4 \quad$ Views of the umbilical sides of specimens of Globigerinita stainforthi stainforthi (Bolli, Loeblich and Tappan) 1957.

Figures 5 \& 6 Globigerinita parvula (Bolli, Loeblich and Tappan) 1957.

Figure 7 Enlarged view of the "bulla" of specimen illustrated in Figure 6. 


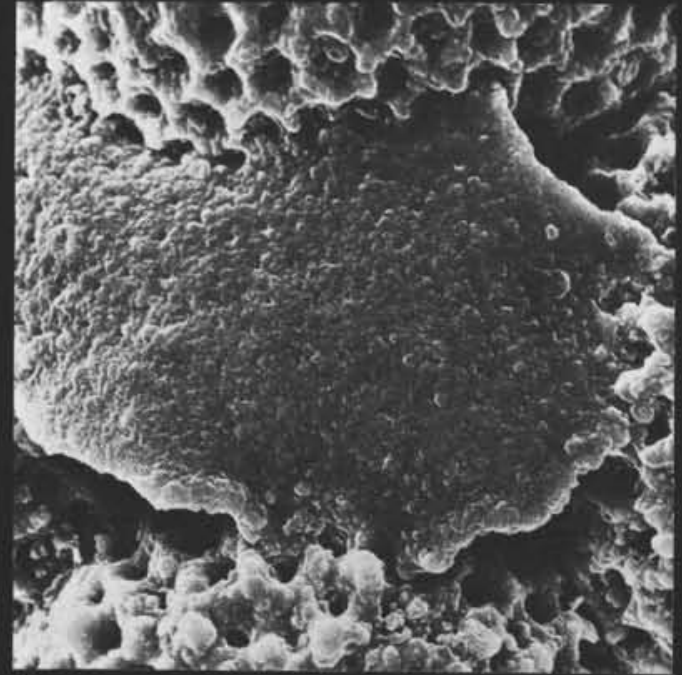

1

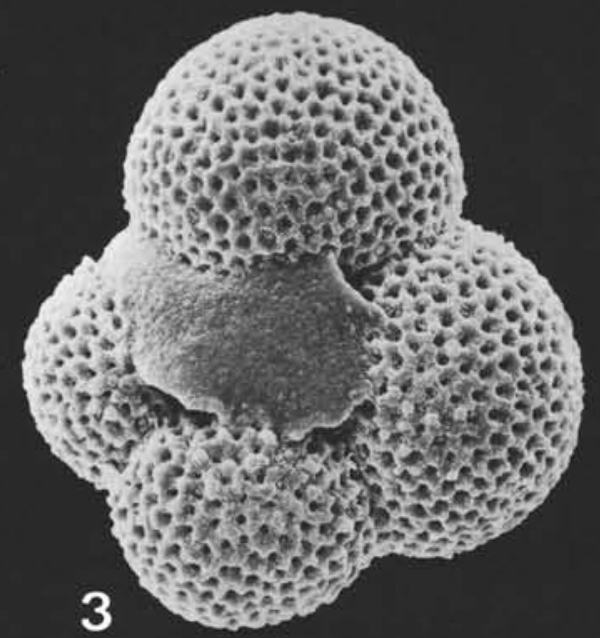

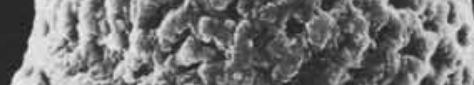

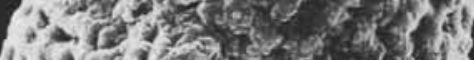
(i+k) 1 -

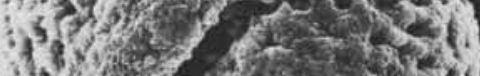

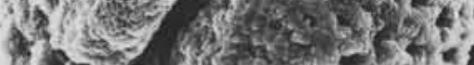

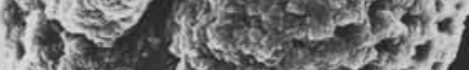

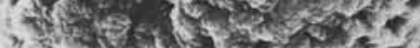

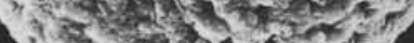

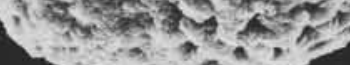

5

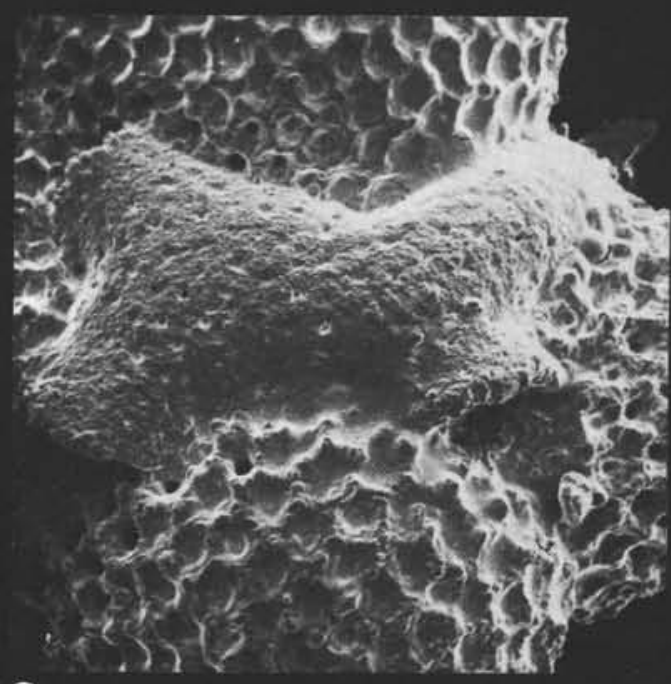

2

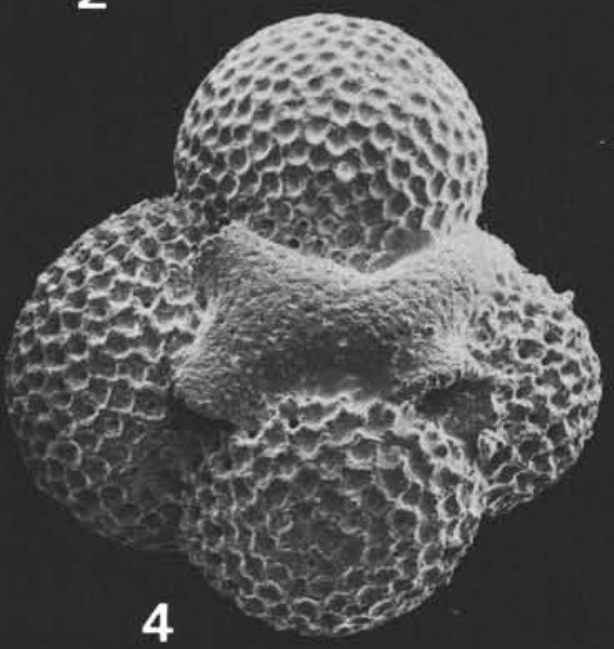

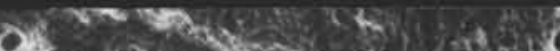
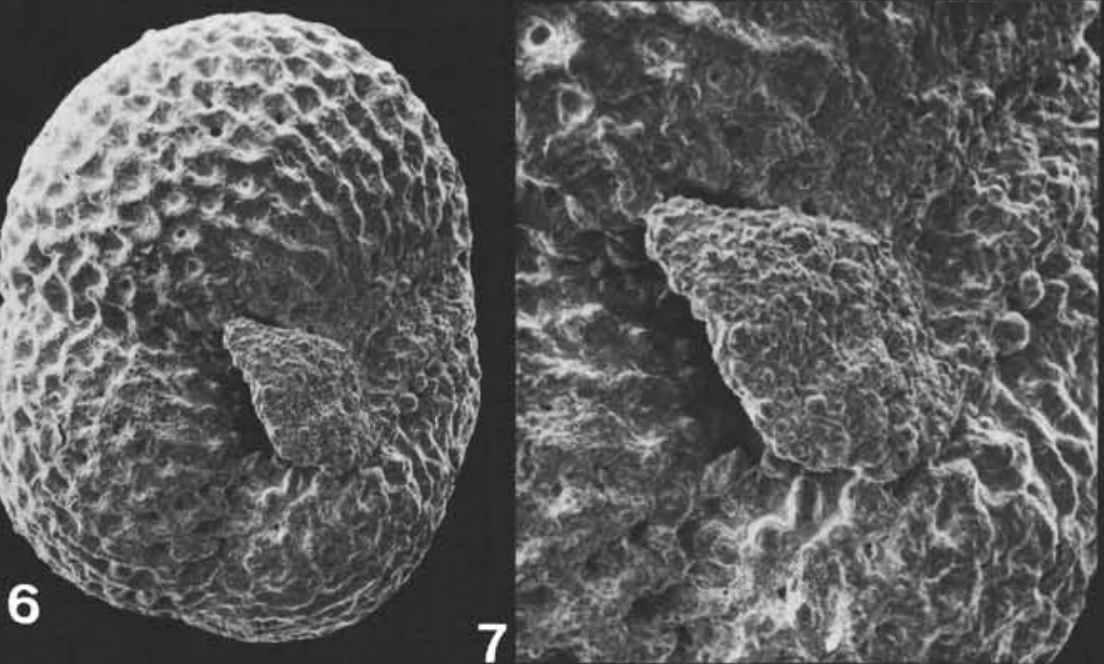


\section{PLATE 25}

Figures 1,2 \& 3 Globigerinita pera (Todd), 1957.

All figures from Hole 64.1, Core 7, Section 2, 33-35 cm; Zone N. 3.

1: 160X. View of umbilicus and "bulla".

2: 93X. Oblique view of umbilicus and aperture of "bulla".

3: $177 \mathrm{X}$. Oblique spiral view.

Figure 4 Globigerinita unicava unicava (Bolli, Loeblich and Tappan), 1957.

Hole 64.1, Core 3, Section 1, 33-35 cm; Zone N. 6. 276X. View of umbilicus and "bulla".

Figure $5 \quad$ Globigerinita unicava (Bolli, Loeblich and Tappan) primitiva Blow and Banner, 1962.

Hole 64.1, Core 8, Section 1, 112-114 cm; Zone N. 2. $270 X$. Side view with aperture of "bulla".

Figure 6 Globigerinita aff. Globigerinita parvula (Bolli, Loeblich and Tappan), 1957.

Hole 62.1, Core 34, Section 6, 15-17 cm; Zone N. 13. $444 X$. Umbilical view with "bulla".

Figures $7 \& 8$ Globigerinita dissimilis (Cushman and Bermudez), 1937.

Both figures from Hole 64.1, Core 6, Section 1, 33-35 cm; Zone N. 4.

7: 289X. Oblique view of umbilicus and "bulla".

8: 174X. Side view with one aperture of the "bulla".

Figure 9 Globigerinatheka barri Brönnimann, 1952.

Hole 64.1, Core 10, Section 1, 32-35 cm; Zone P. 14 or older. $172 X$. Side view with large ultimate chamber and small "bulla". 

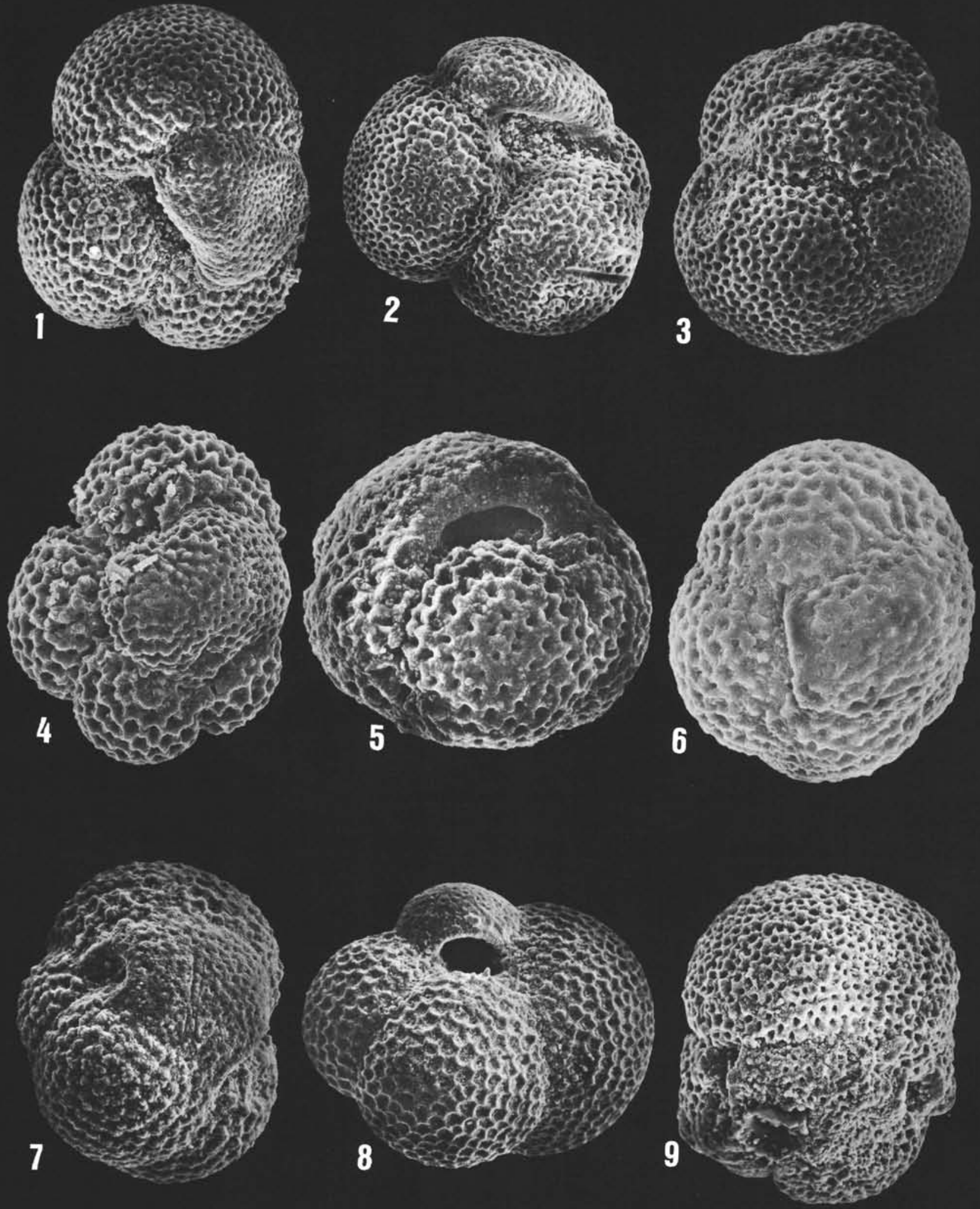


\section{PLATE 26}

Figures 1-4 Globigerinita boweni Brönnimann and Resig, n.sp.

All figures from Hole 64.1, Core 7, Section 2, 33-35

cm; Zone N. 3.

1: 644X. Holotype.

2: $356 \mathrm{X}$. Bulla broken off.

3: 548X. Bulla broken off.

4: $356 \times$. Pre-bulla stage.

Figures 5-9 Turborotalita primitiva Brönnimann and Resig, n.sp.

All figures from Hole 64.1, Core 7, Section 2, 33-35

cm; Zone N. 3.

5: $636 \mathrm{X}$

7: 696X. Holotype.

8: $666 \mathrm{X}$. 

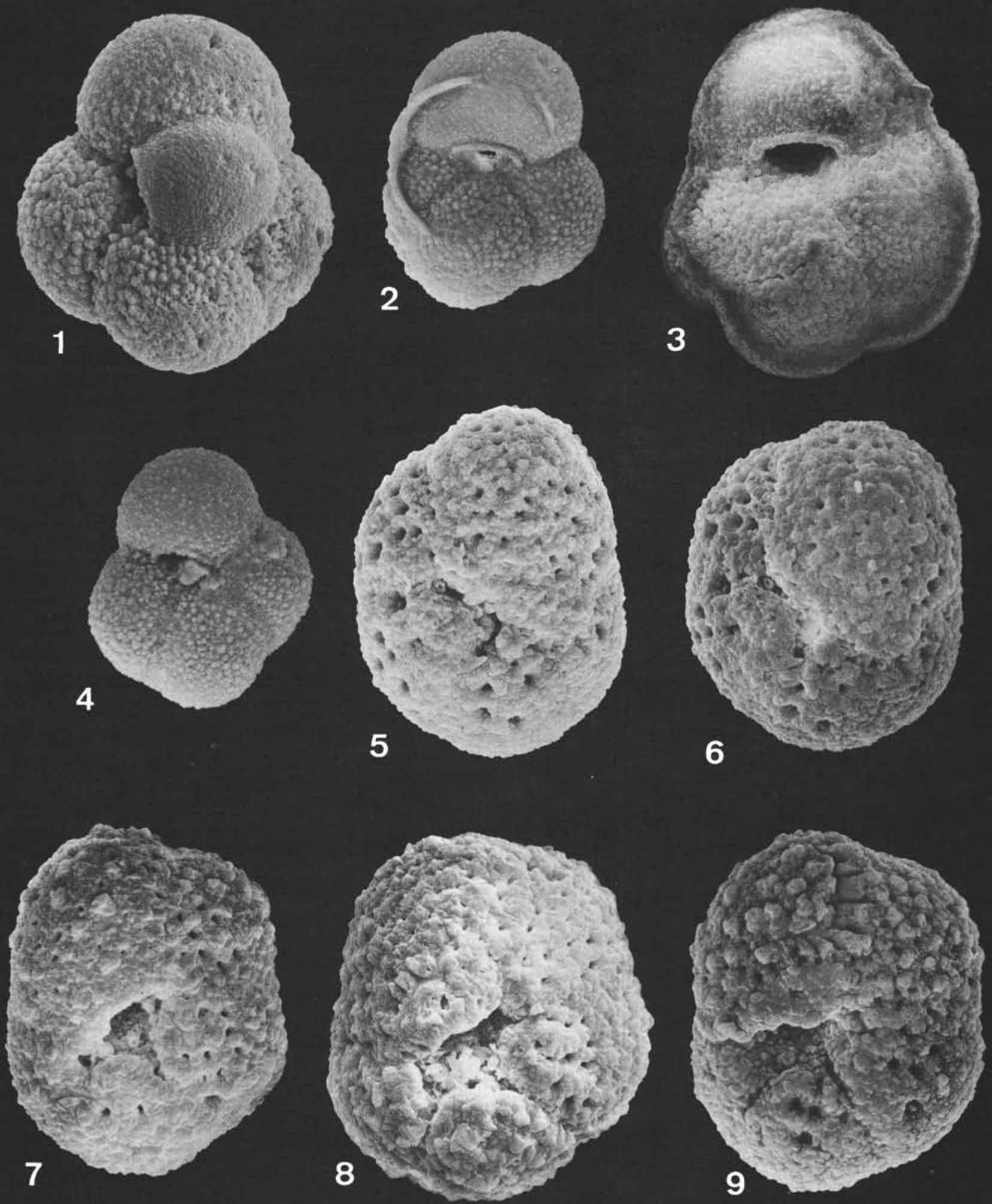
PLATE 27

Figures 1, 2 \& 4 Globorotalia (Globorotalia) truncatulinoides (d'Orbigny), 1839.

Figures 1 \& 4: Hole 62.1, Core 2, Section 4, 23-25

cm; Zone N.22.

1: $97 X$.

4: $290 \times$. Detail of Figure 1.

2: Hole 62.1, Core 4, Section 2, 15-17 cm; Zone N. 22. $121 X$.

Figures 3 \& $5 \quad$ Globorotalia (Turborotalia) tosaensis Takayanagi and Saito, 1962.

Both figures from the same specimen from Hole 62.1, Core 4, Section 2, 15-17 cm; Zone N. 22.

3: $89 \times$.

5: $178 \times$. Detail of Figure 3.

Figures 6 \& 7 Globorotalia (Turborotalia) crassaformis (Galloway and Wissler) oceanica Cushman and Bermúdez, 1949. Both figures from the same specimen from Hole 62.1, Core 1, Section 2, $41-43 \mathrm{~cm}$; Zone N. 22.

6: $89 \mathrm{X}$.

7: 224X. Detail of Figure 6.

Figure $8 \quad$ Globorotalia (Turborotalia) crassaformis (Galloway and Wissler) ronda Blow, 1969.

Hole 62.1, Core 5, Section 3, Top; Zone N. 21. 102X. 

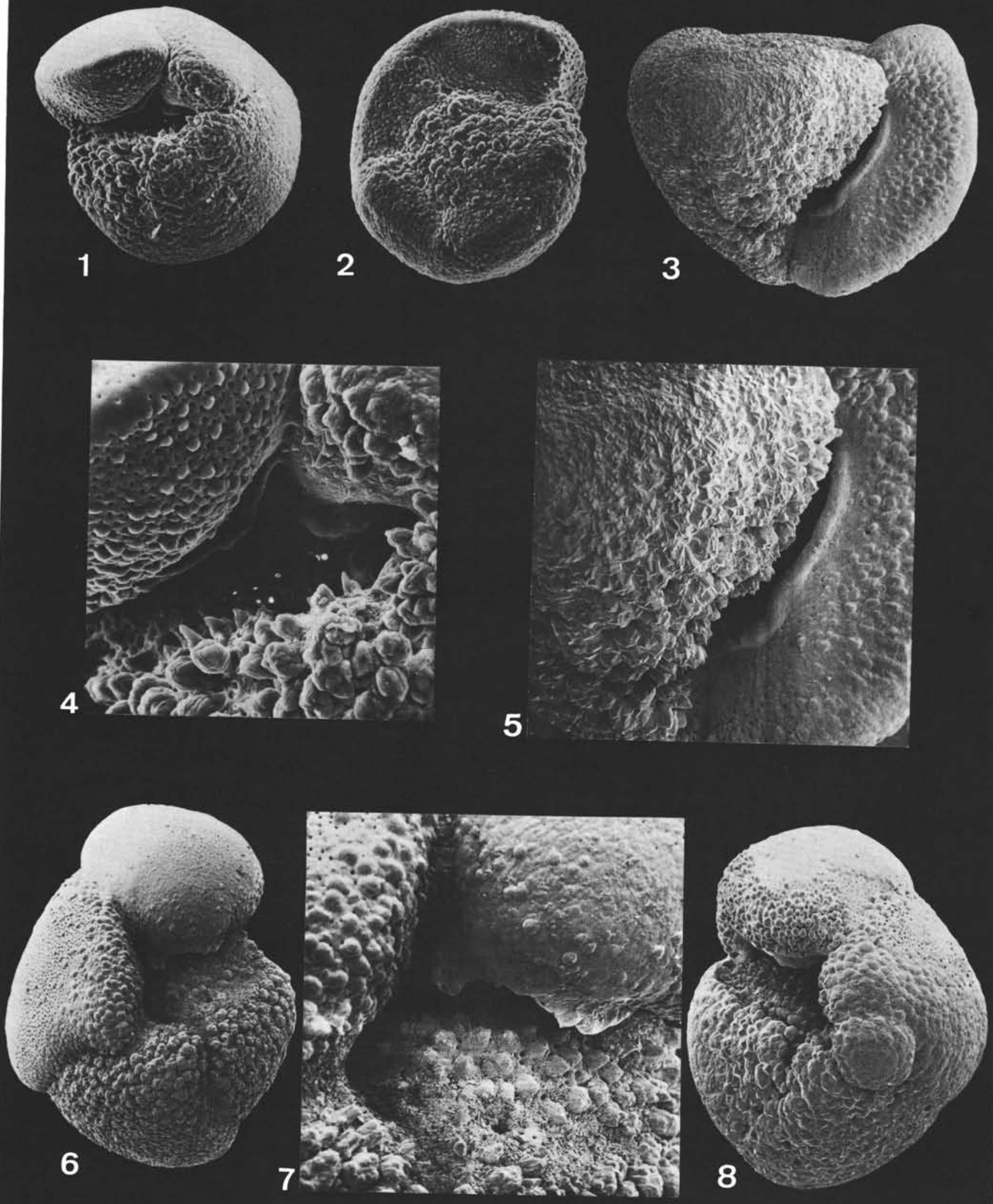


\section{PLATE 28}

Figures 1-6 Globorotalia (Globorotalia) truncatulinoides (d'Orbigny), 1839.

Figures 1,3 \& 5 from the same specimen from Hole 62.1, Core 2, Section 4, 23-25 cm; Zone N. 22.

1: 297X. Detail of Figure 3.

3: $142 X$. Thin shelled specimen.

5: 297X. Detail of Figure 3.

Figures $2,4 \& 6$ from the same specimen from Hole 62.1, Core 2, Section 4, 23-25 cm;Zone N. 22.

2: $297 X$. Detail of Figure 4.

4: 132X. Completely keeled specimen.

6: 297X. Detail of Figure 4. 

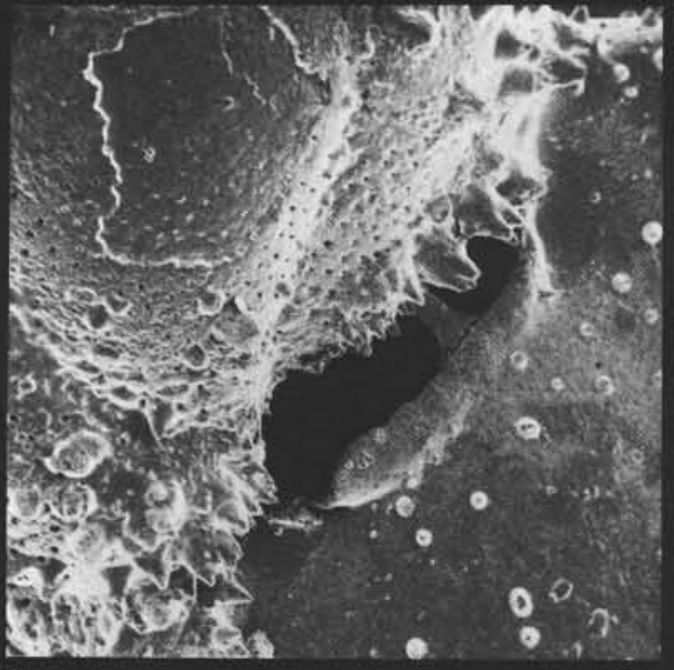

1

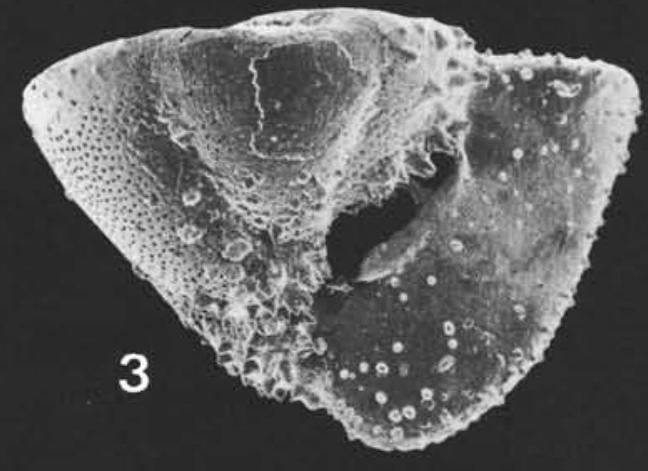

5

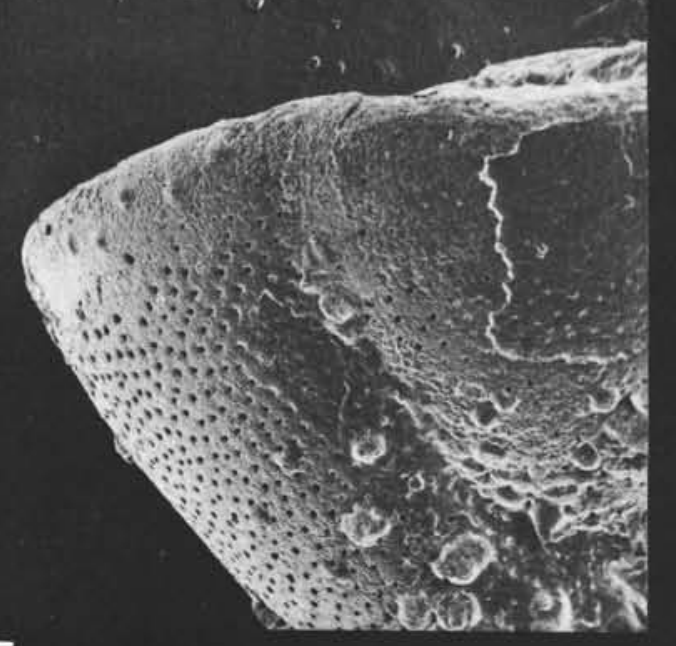

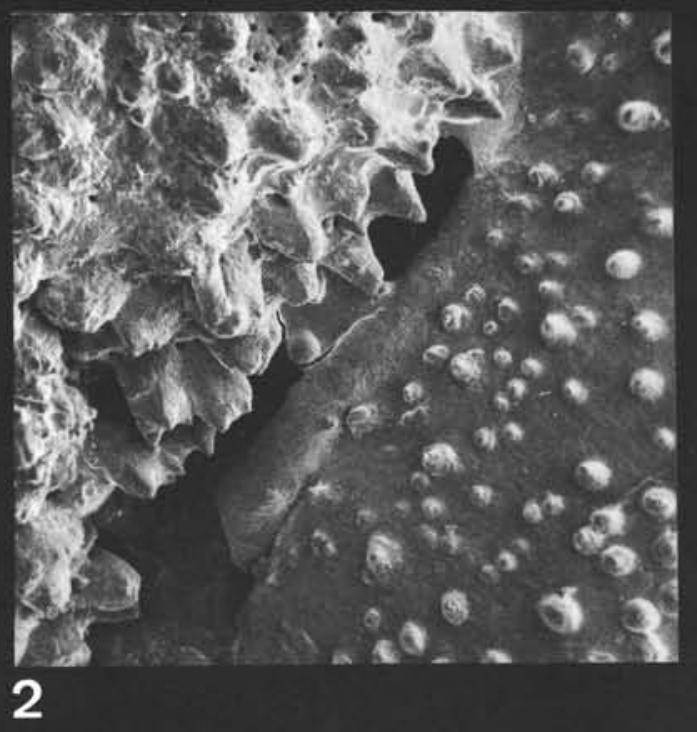
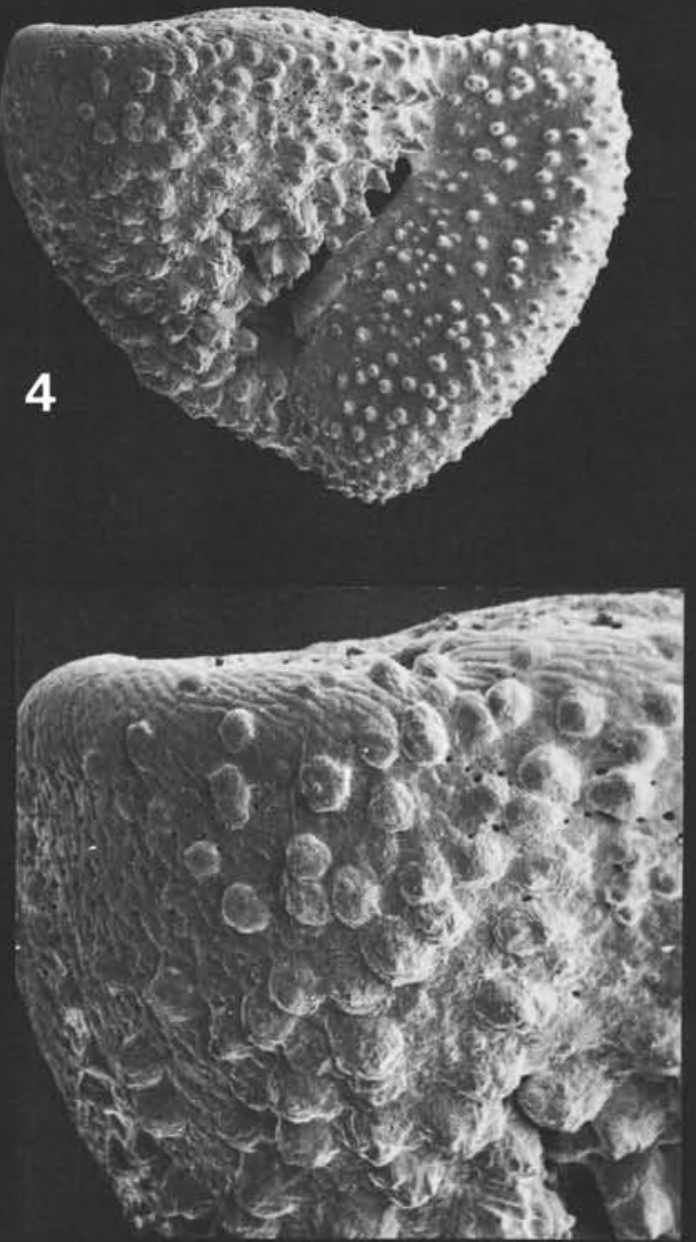

6 
PLATE 29

Figures 1 \& 2 Globorotalia (Globorotalia) cultrata cultrata (d'Orbigny), 1839.

1: Hole 62.1, Core 1, Section 1, Top; Zone N. 23. $56 \mathrm{X}$.

2: Hole 62.1, Core 18, Section 4, 15-17 cm; Zone N. 17. $74 X$.

Figure 3 Globorotalia (Globorotalia) tumida (Brady) lata Brönnimann and Resig, n. subsp.

Hole 62.1, Core 4, Section 5, 16-18 cm; Zone N. 22. Holotype. 73X.

Figures 4 \& 5 Globorotalia (Globorotalia) cultrata (d'Orbigny) limbata (Fornasini), 1902.

Both figures from the same specimen from Hole 62.1, Core 17, Section 2, 40-43 cm; Zone N. 17.

4: $86 \mathrm{X}$.

5: $87 X$

Figure 6

Globorotalia (Globorotalia) tumida (Brady) flexuosa (Koch), 1923.

Hole 62.1, Core 8, Section 6, 109-111 cm; Zone N. 20 (including N. 19). 53X.

Figure 7 Globorotalia (Globorotalia) cultrata (d'Orbigny) menardii (Parker, Jones and Brady), 1865.

Hole 62.1, Core 1, Section 1, Top; Zone N. 23. 73X.

Figures 8 \& 9 Globorotalia (Globorotalia) tumida (Brady) plesiotumida Blow and Banner, 1965.

Both figures from same specimen from Hole 62.1, Core 16, Section 6, 15-17 cm; Zone N. 17.

8: $108 \mathrm{x}$.

9: $106 \mathrm{X}$.

Figures 10 \& 11 Globorotalia (Globorotalia) merotumida Blow and Banner, 1965.

Both figures from the same specimen from Hole 62.1, Core 17, Section 2, 40-43 cm; Zone N. 17.

10: $133 \times$.

11: $168 \mathrm{X}$. 
PLATE 29

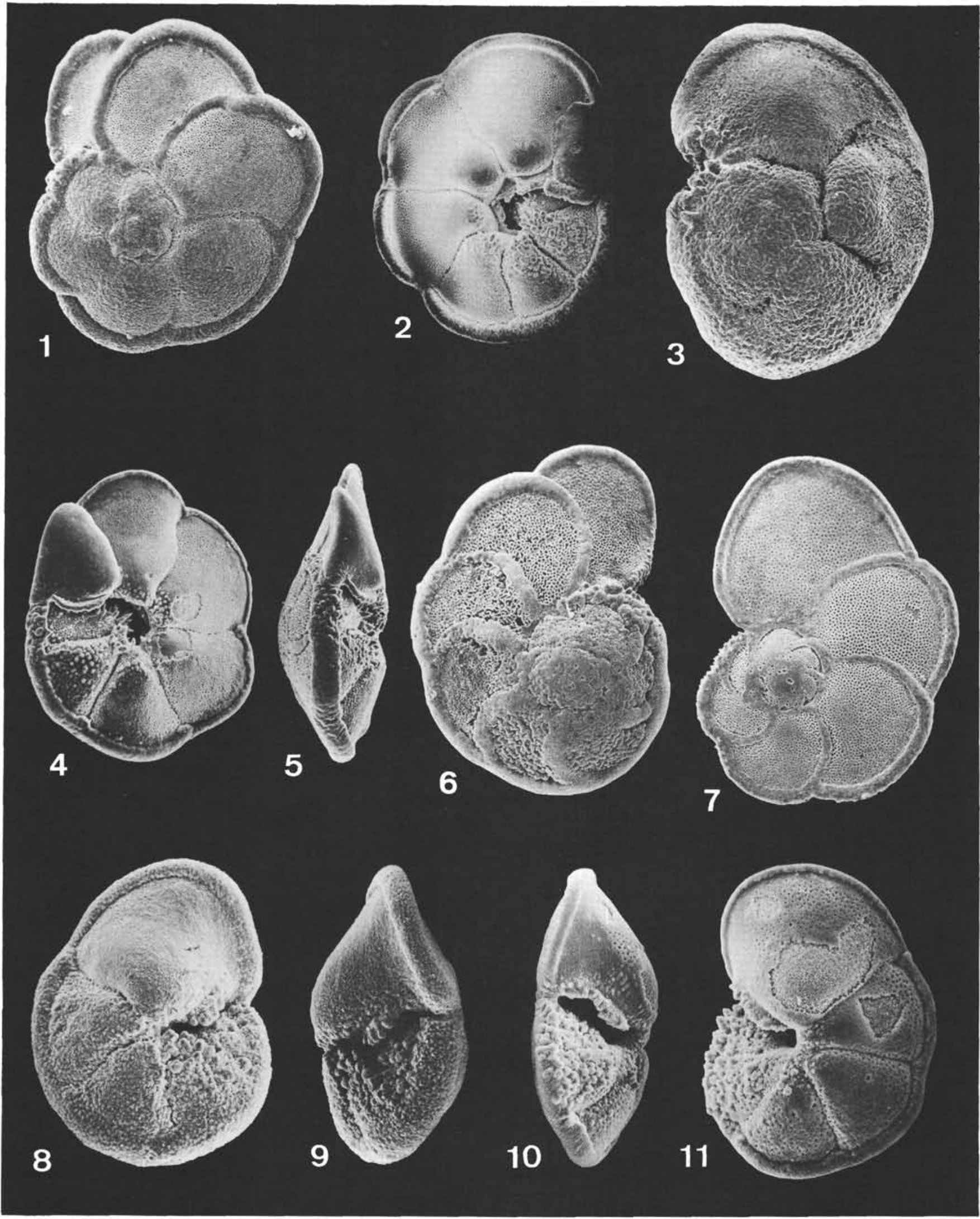




\section{PLATE 30}

Figures 1 \& 2 Globorotalia(Globorotalia)praemenardii praemenardii Cushman and Stainforth, 1945.

Both figures from Hole 62.1, Core 34, Section 5, 15-17 cm; Zone N. 13.

1: $132 X$.

2: $142 X$.

Figure 3 Globorotalia (Globorotalia) merotumida Blow and Banner, 1965.

Hole 62.1, Core 35, Section 5, 15-17 cm; Zone N. 13. Primitive form according to W. H. Blow. 231X.

Figure 4 Globorotalia aff. Globorotalia (Globorotalia) hirsuta (d'Orbigny), 1839.

Hole 62.1, Core 10, Section 4, 15-17 cm; Zone N. 20 (including N. 19). Same specimen as Plate 31, Figure 2. $102 X$.

Figure 5

Globorotalia (Globorotalia) fohsi Cushman and Ellisor, 1939.

Hole 62.1, Core 35, Section 5, 15-17 cm; Zone N. 13. Same specimen as Plate 31, Figure 1. 79X.

Figure 6 Globorotalia (Globorotalia) merotumida Blow and Banner, 1965.

Hole 62.1, Core 17, Section 2, 40-43 cm; Zone N. 17. Same specimen as Plate 31, Figure 5. 165X.

Figure $7 \quad$ Globorotalia (Turborotalia) lenguaensis Bolli, 1957. Hole 62.1, Core 35, Section 3, 15-17 cm; Zone N. 13. $234 X$.

Figure $8 \quad$ Globorotalia (Globorotalia) hirsuta (d'Orbigny) praehirsuta Blow, 1969.

Hole 62.1, Core 12, Section 4, 15-17 cm; Zone N. 20 (including N. 19). 167X.

Figure $9 \quad$ Globorotalia praemenardii Cushman and Stainforth archeomenardii Bolli, 1957.

Hole 64.1, Core 1, Section 2, 33-35 cm; Zone N. 7/N. 8. $172 X$. 
Plate $\mathbf{3 0}$
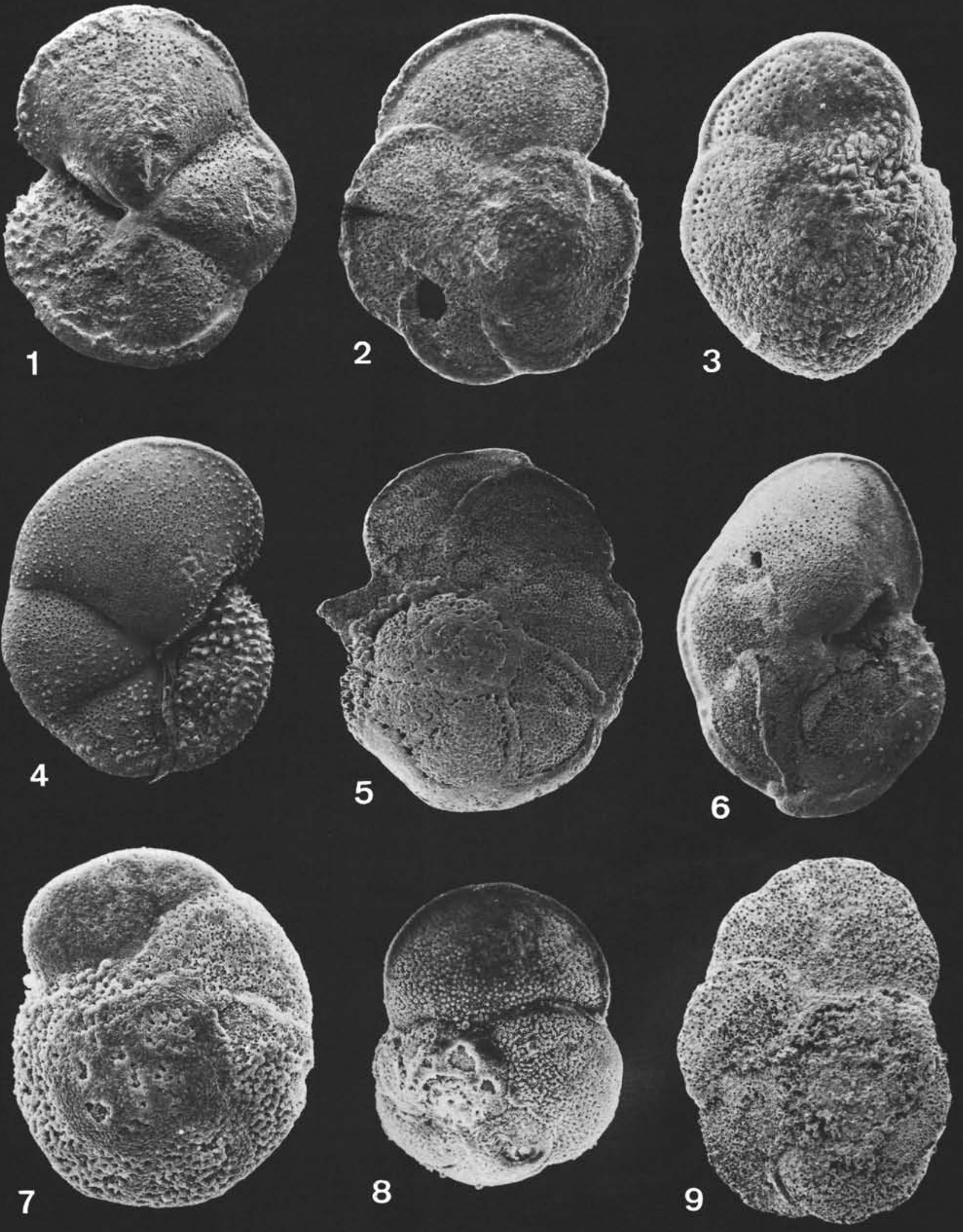


\section{PLATE 31}

Figure 1 Globorotalia (Globorotalia) fohsi Cushman and Ellisor, 1939.

Hole 62.1, Core 35, Section 5, 15-17 cm;Zone N. 13. Detail of specimen Plate 30, Figure 5. 330X.

Figure 2 Globorotalia aff. Globorotalia (Globorotalia) hirsuta (d'Orbigny), 1839.

Hole 62.1, Core 10, Section 4, 15-17 cm; Zone N. 20 (including N. 19). 189X. Detail of specimen illustrated Plate 30, Figure 4.

Figure 3 Globorotalia (Turborotalia) pseudopima Blow, 1969. Hole 62.1, Core 3, Section 2, Top; Zone N.22. Detail of specimen Plate 33, Figure 8. 304X.

Figure 4 Globorotalia (Turborotalia) acostaensis Blow humerosa Takayanagi and Saito, 1962.

Hole 62.1, Core 3, Section 2, Top; Zone N.22. Detail of specimen Plate 33, Figure 1. 178X.

Figures 5 \& 6 Globorotalia (Globorotalia) merotumida Blow and Banner, 1965.

5: Hole 62.1, Core 17, Section 2, 40-43 cm; Zone N. 17. Detail of specimen Plate 30, Figure 6. $594 \times$.

6: Hole 62.1, Core 16, Section 6, 15-17 cm; Zone N. 17. Detail of specimen Plate 29, Figures 10 \& 11. $1155 x$. 


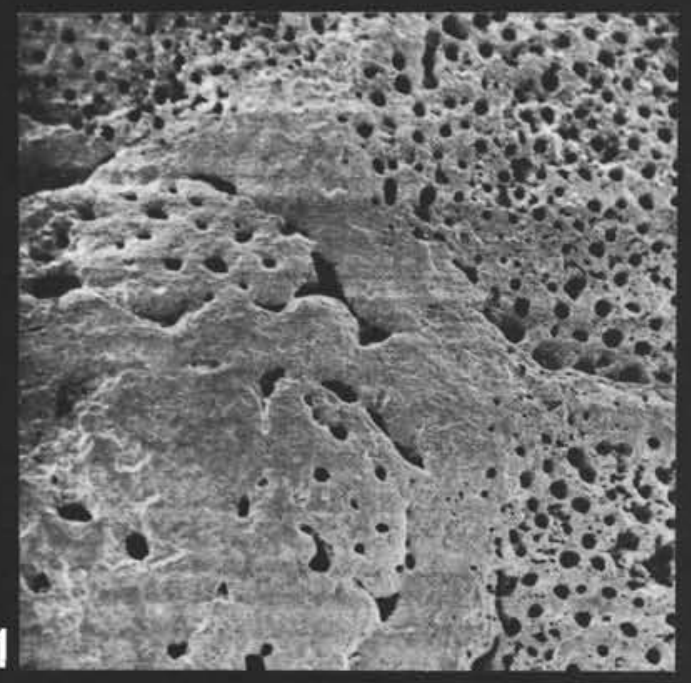

ing $\Rightarrow$ क

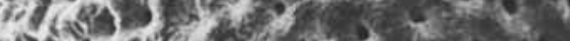
entoris

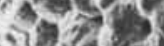
Q 720

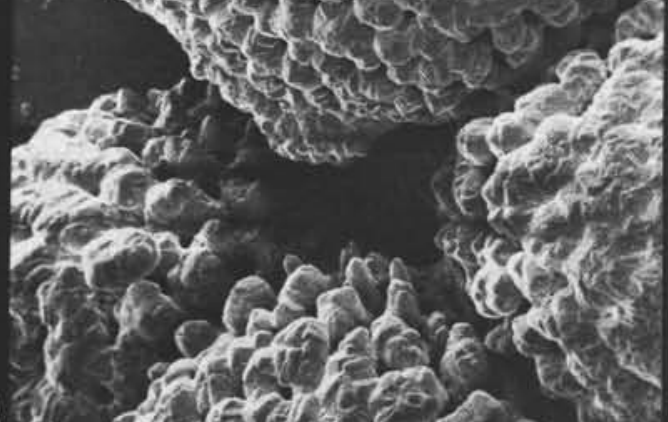

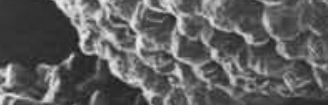

3
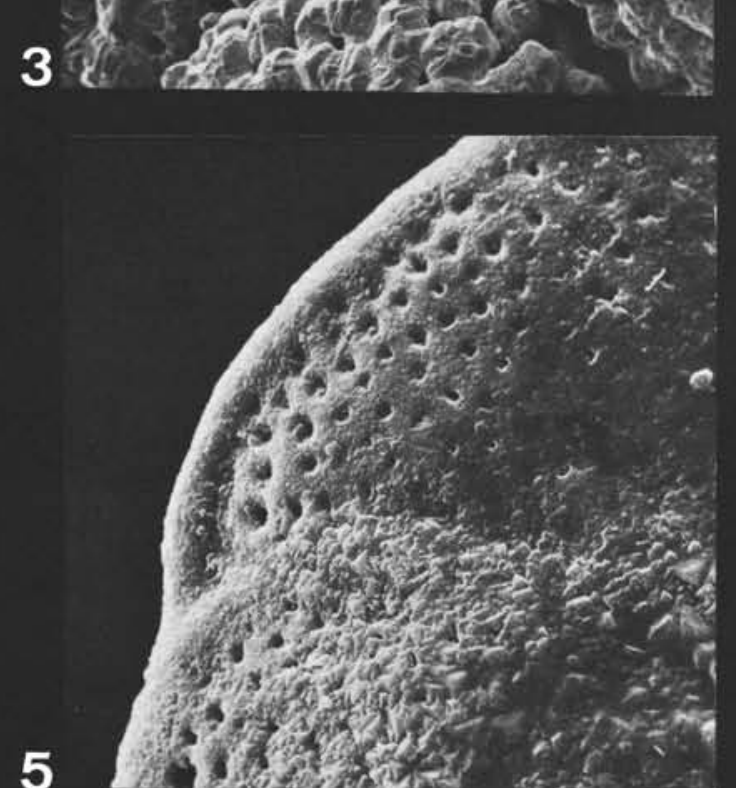
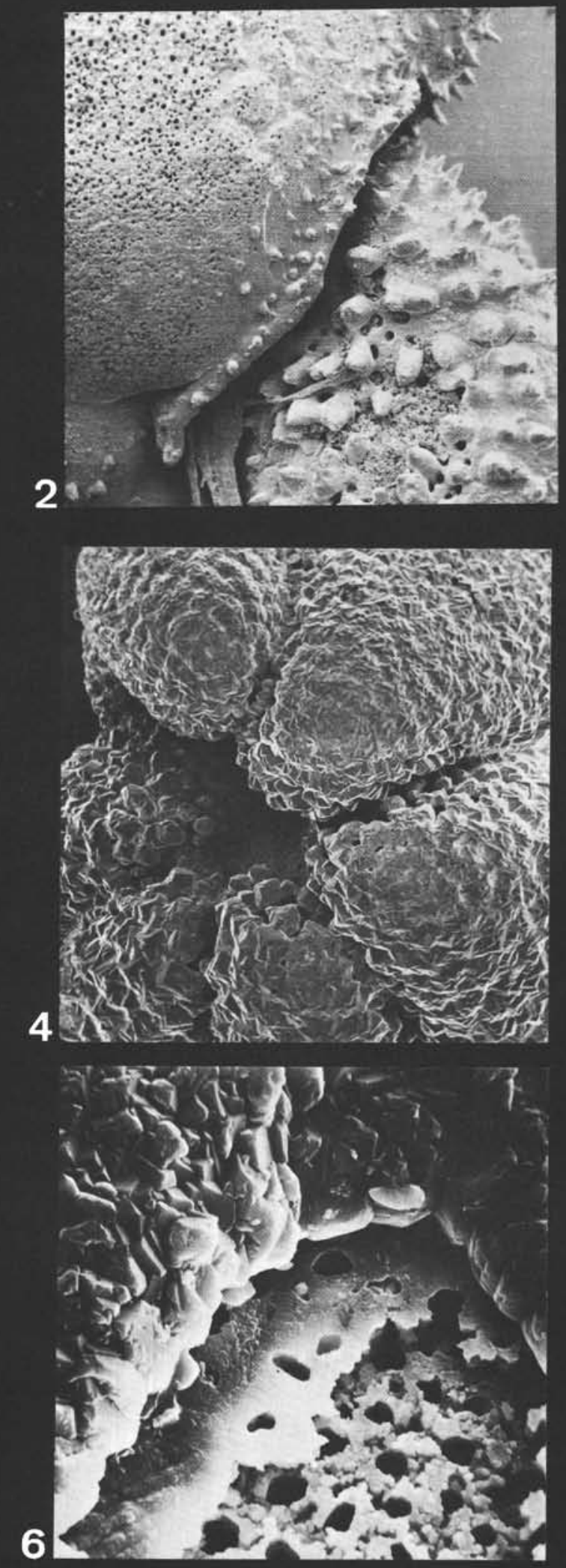


\section{PLATE 32}

Figure 1

Globorotalia (Globorotalia) "spinulosa" of Bolli, 1957, non-Cushman, 1927.

Hole 64.1, Core 10, Section 1, 32-35 cm; Zone P. 14 or older. 90X. Oblique view of umbilical side.

Figures 2 \& 3 Globorotalia (Turborotalia) gemma Jenkins, 1965. Both figures from Hole 64.1, Core 8, Section 2, 33-35 cm; Zone N. 2.

2: $376 \times$. Spiral view.

3: $511 \times$. Umbilical view.

Figure 4 Globorotalia (Turborotalia) broedermanni Cushman and Bermúdez, 1949.

Hole 64.1, Core 10, Section 1, 33-35 cm; Zone P. 14 or older. $284 X$. Umbilical view.

Figure $5 \quad$ Hantkenina alabamensis Cushman, 1925.

Hole 64.1, Core 9, Section 1, 33-35 cm; Zone P. 16. $157 \mathrm{X}$. Oblique side view.

Figure 6 Globorotalia (Turborotalia) centralis Cushman and Bermúdez, 1937.

Hole 64.1, Core 9, Section 3, 33-35 cm; Zone P. 16. $170 \mathrm{X}$. Oblique side view showing an almost umbilical position of the aperture.

Figures $7 \& 8 \quad$ Globorotalia (Globorotalia) renzi Bolli, 1957. Both figures from Hole 64.1, Core 10, Section 1, 32-35 $\mathrm{cm}$; Zone P. 14 or older.

7: 386X. Spiral view.

8: 444X. Umbilical view.

Figure $9 \quad$ Pseudohastigerina micra (Cole), 1927.

Hole 64.1, Core 9, Section 2, 33-35 cm; Zone P. 16. $372 X$. Side view. 


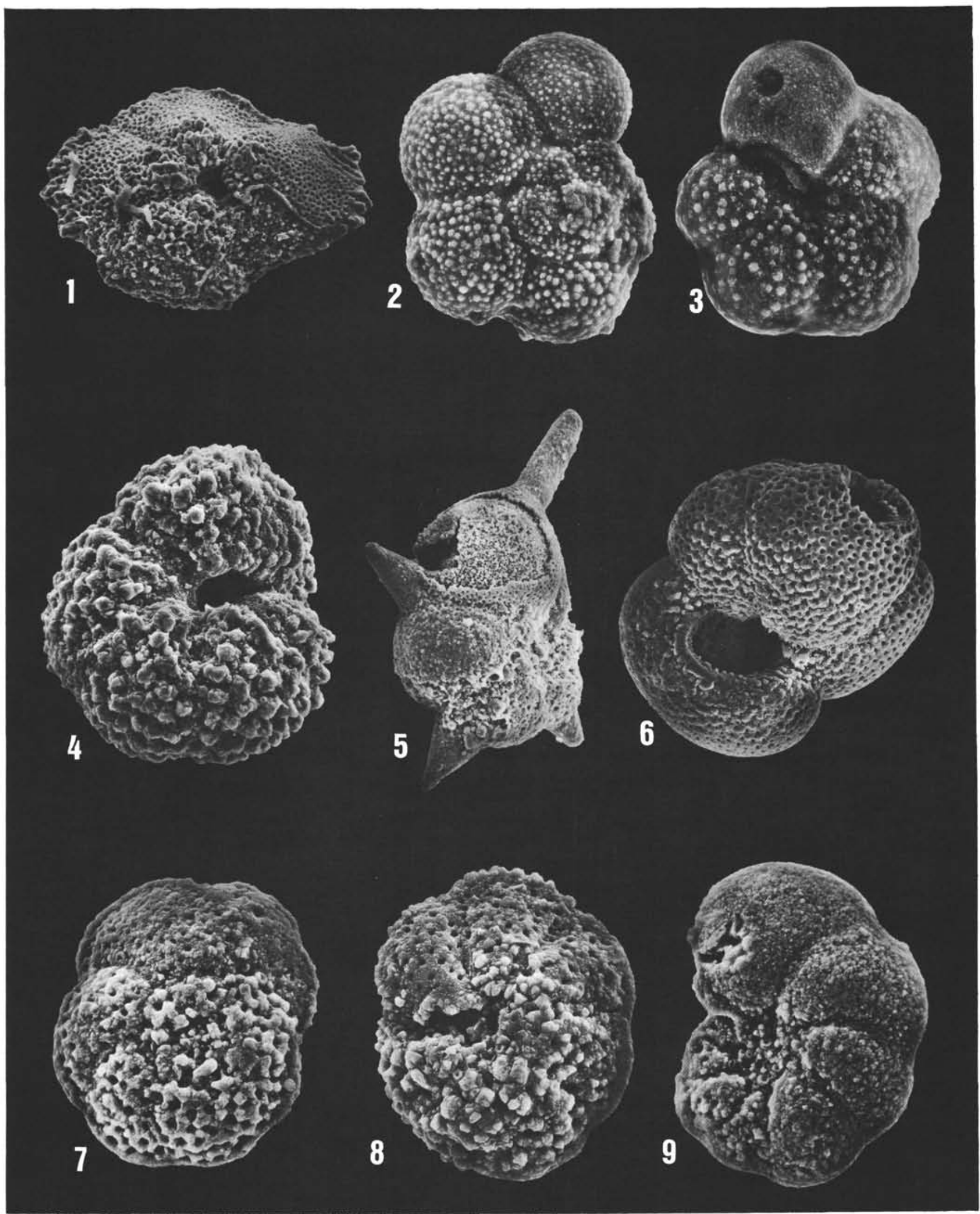




\section{PLATE 33}

Figure 1 Globorotalia (Turborotalia) acostaensis Blow humerosa Takayanagi and Saito, 1962.

Hole 62.1, Core 3, Section 2, Top; Zone N. 22. 112X. (see also Plate 31, Figure 4).

Figures 2, 4 \& 5 Globorotalia (Turborotalia) acostaensis acostaensis Blow, 1959.

2: Hole 62.1, Core 7, Section 3, 15-17 cm; Zone N. 20 (including N. 19). 260X.

4 \& 5: Hole 62.1, Core 16, Section 1, 14-16 cm; Zone N. 17.

4: 528X. Detail of Figure 5.

5: $218 \mathrm{X}$

Figures 3, 6, 7 Globorotalia (Turborotalia) acostaensis Blow tegillata $\& 10$

Brönnimann and Resig, n. subsp.

3: Hole 62.1, Core 15, Section 1, 15-17 cm; Zone N. 18. 172X. Holotype.

6: Hole 62.1, Core 17, Section 2, 40-43 cm; Zone N. 17. $373 \mathrm{X}$.

10: Hole 62.1, Core 21, Section 4, 15-17 cm; Zone N. 17. 156X.

7: Hole 62.1, Core 15, Section 1, 15.17 cm; Zone N. $18.196 \mathrm{X}$.

Figures 8 \& 9 Globorotalia (Turborotalia) pseudopima Blow, 1969. 8: Hole 62.1, Core 3, Section 2, Top; Zone N. 22. $119 \times$.

9: Hole 62.1, Core 5, Section 3, Top; Zone N. 21. $145 X$. 


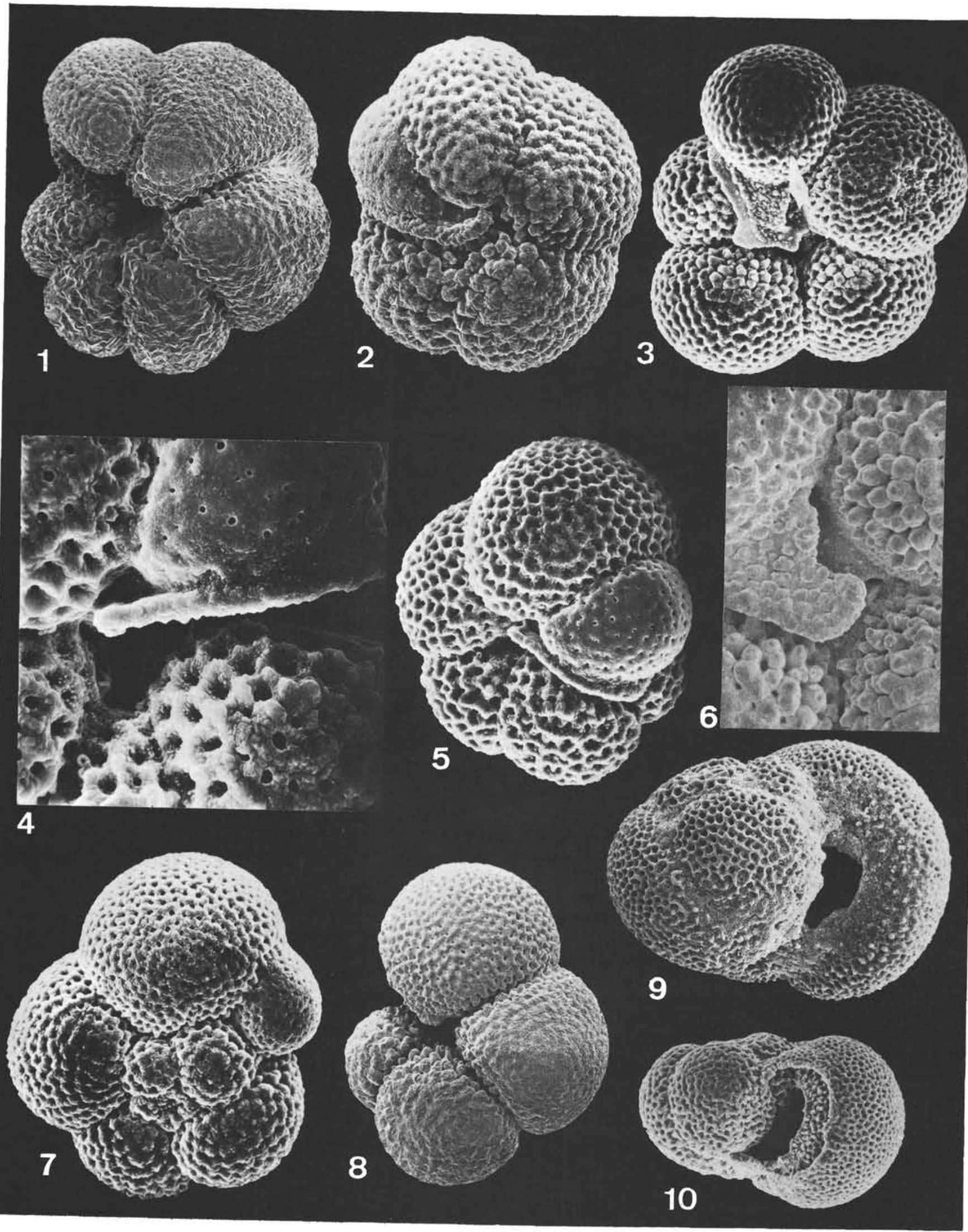


PLATE 34

Figures 1, 2 \& 4 Globorotalia (Turborotalia) siakensis LeRoy, 1939.

1: From the Telisa Formation, Zone N. 8. Sumatra. Donated by W. H. Blow. 195X.

2 \& 4: Hole 64.1, Core 2, Section 6, $15-17 \mathrm{~cm}$; Zone N. $7 /$ N. 8 base.

2: $145 X$.

4: 363X. Detail of Figure 2.

Figure 3 Globorotalia (Turborotalia) clemenciae Bermúdez, 1961.

Hole 62.1, Core 24, Section 4, 15-17 cm; Zone N. 16. $264 X$.

Figures 5 \& $7 \quad$ Globorotalia (Turborotalia) peripherorunda Blow and Banner, 1966, forma $\alpha$.

Hole 64.1, Core 3, Section 1, 33-35 cm; Zone N. 6. 5: 297X. Detail of Figure 7.

7: $172 X$.

Figure 6 Globorotalia (Turborotalia) pseudopachyderma Cita, Premoli Silva and Rossi, 1965.

Hole 62.1, Core 8, Section 3, 15-17 cm; Zone N. 20 (including N. 19). 178X.

Figure $8 \quad$ Globorotalia (Turborotalia) mayeri Cushman and Ellisor, 1939.

Tortonian, Europe. Donated by W. H. Blow, 156X. 

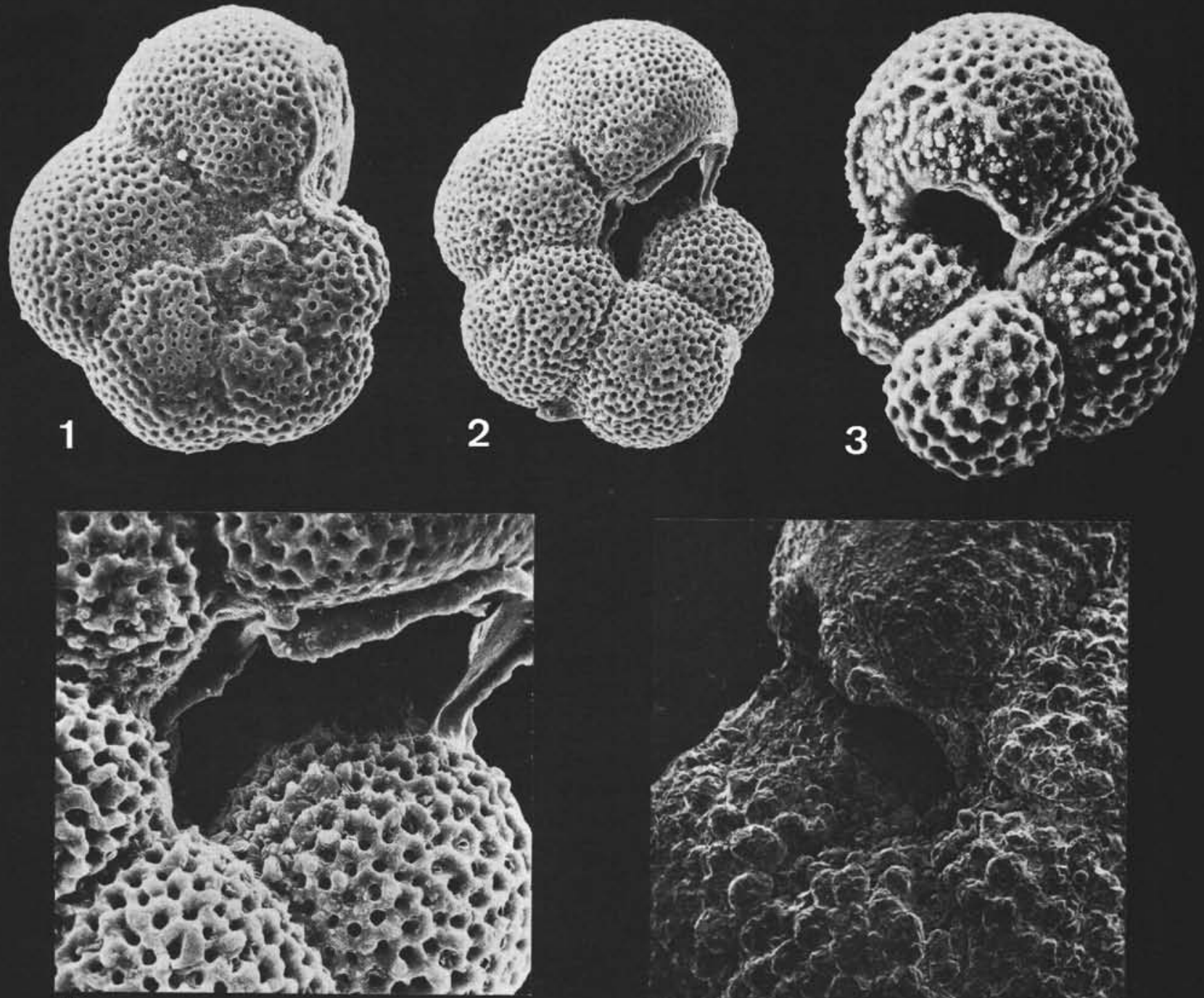

4

5

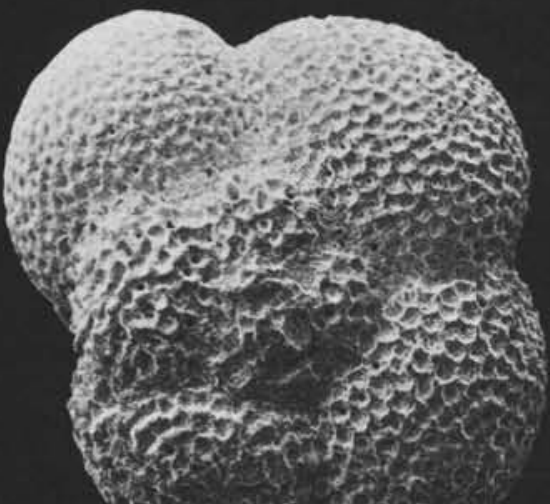

6
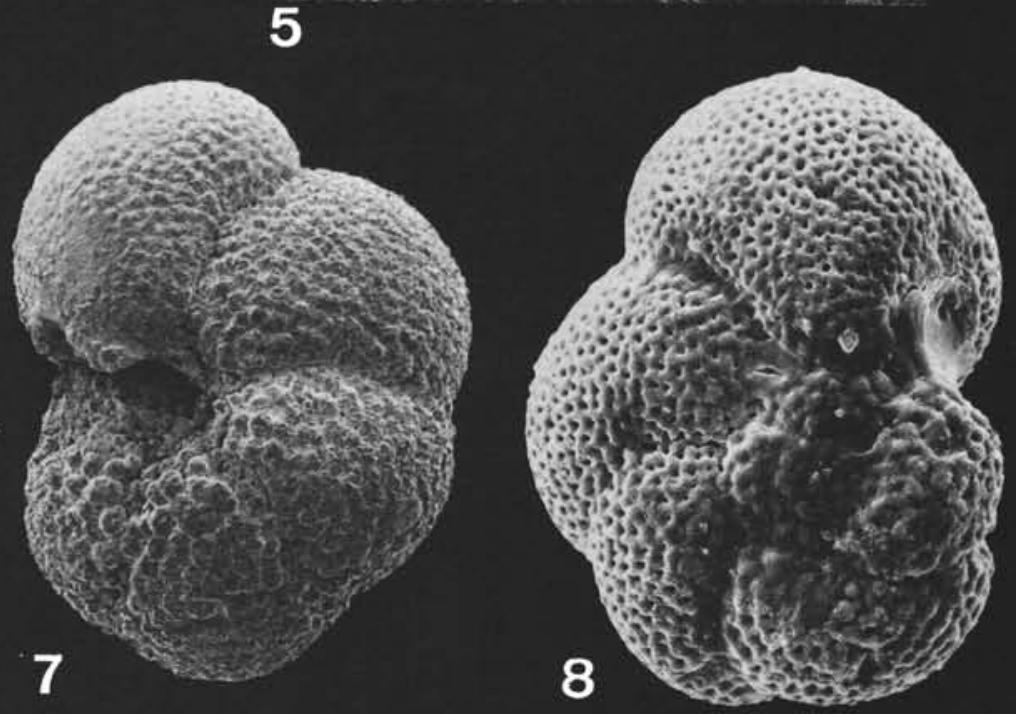


\section{PLATE 35}

Figures 1-8 Globorotalia (Turborotalia) siakensis LeRoy, 1939. 1 \& 4: Hole 62.1, Core 35, Section 2, $15-17 \mathrm{~cm}$; Zone N. 13 .

1: $183 \times$.

4: 413X. Detail of Figure 1.

2 and 3: Hole 64.1, Core 1, Section 2, 33-35 cm; Zone N. $7 / \mathrm{N} 8$.

2: 396X. Detail of Figure 3.

3: $158 \mathrm{X}$.

5 \& 6: Hole 62.1, Core 35, Section 3, 15-17 cm; Zone N. 13.

5: $353 \times$. Detail of Figure 6.

6: $156 \times$.

7 \& 8: Hole 64.1, Core 1, Section 2, 33-35 cm; Zone N. 7/N. 8 .

7: $528 \times$. Detail of Figure 8.

8: $215 X$. 


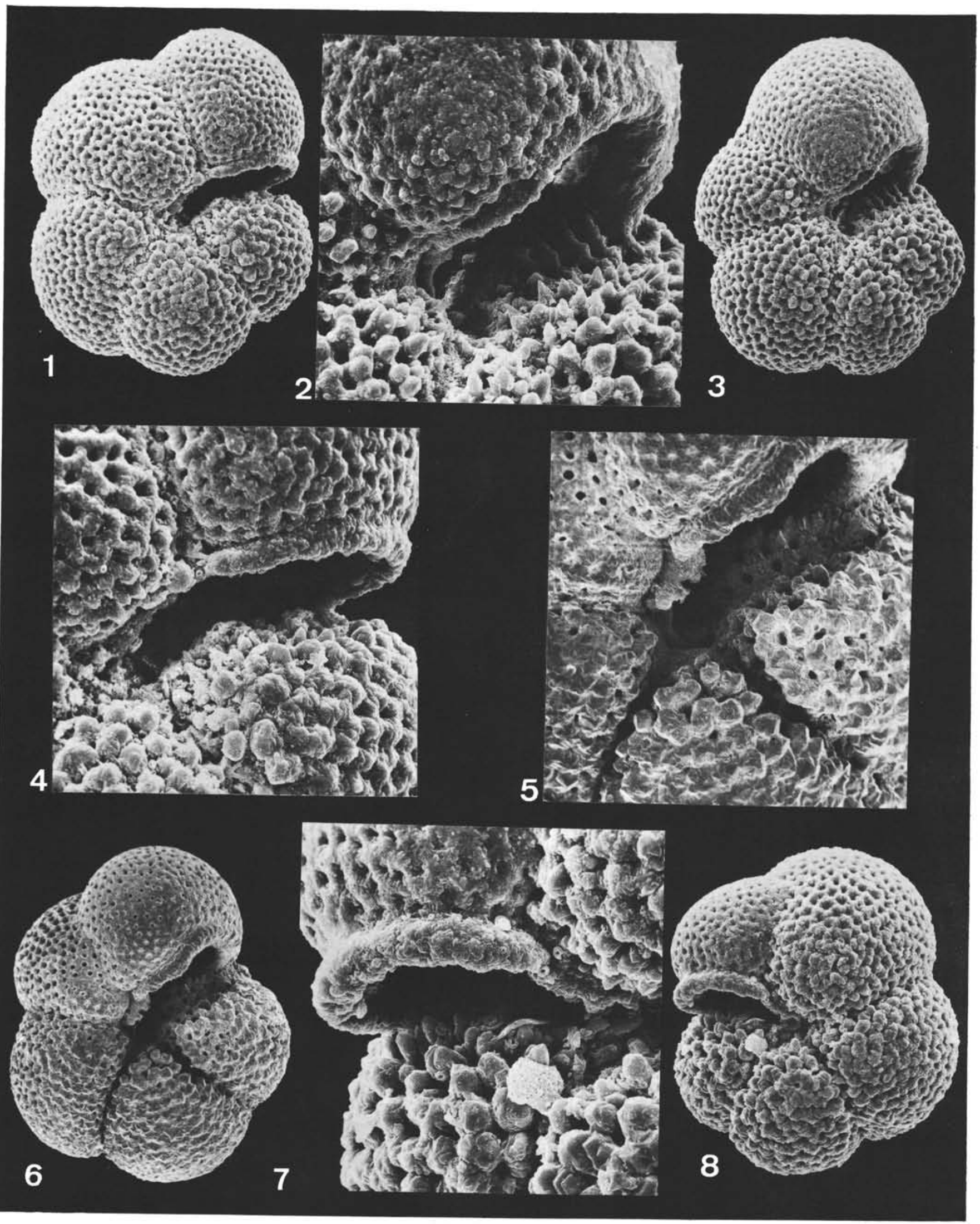




\section{PLATE 36}

Figures 1 \& 2 Globorotalia (Turborotalia) inflata (d'Orbigny), 1839.

1: Hole 62.1, Core 6, Section 6, 15-17 cm; Zone N. 21.115X.

2: Hole 62.1, Core 7, Section 2, 15-17 cm; Zone N. 20 (including N. 19). 185X.

Figures 3 \& $5 \quad$ Globorotalia (Turborotalia) obesa Bolli, 1957.

Both figures from the same specimen from Hole 62.1, Core 8, Section 4, 15-17 cm; Zone N. 22.

3: $115 \mathrm{X}$.

5: 287X. Detail of Figure 3.

Figures 4 \& 6 Globorotalia (Turborotalia) planispira Brönnimann and Resig, n.sp.

Both figures from the same specimen from Hole 62.1, Core 6, Section 5, 15-17 cm; Zone N. 21.

4: 416X. Detail of Figure 6.

6: $277 \mathrm{X}$.

Figure 7 \& $8 \quad$ Globorotalia (Turborotalia) continuosa Blow, 1959. 7: Hole 62.1, Core 35, Section 3, 15-17 cm; Zone N. 13.139X.

8: Hole 62.1, Core 33, Section 3, 15-17 cm; Zone N. 13.211X. 


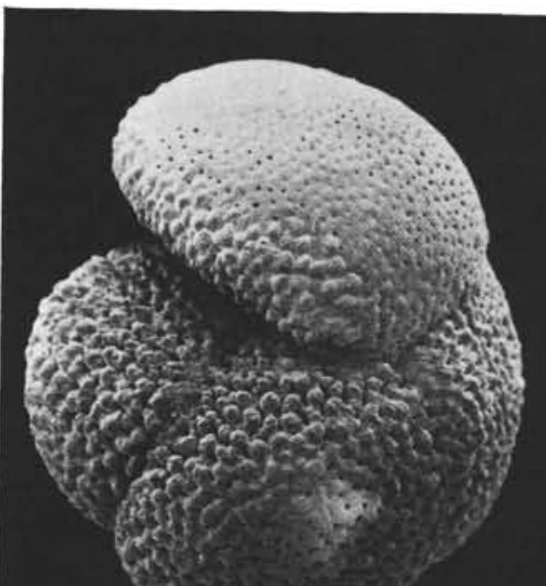

1

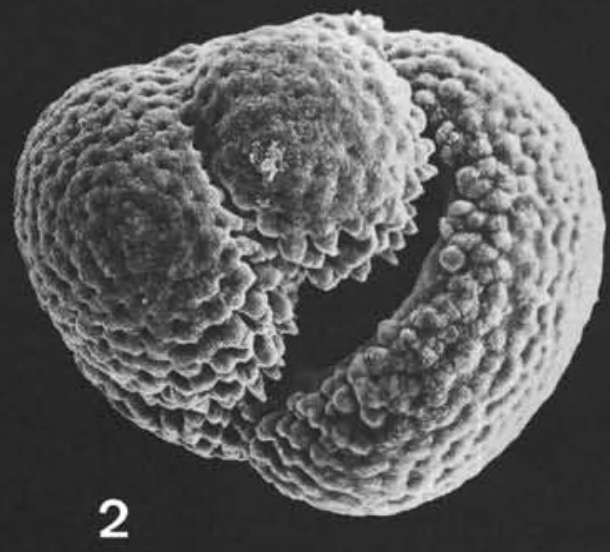

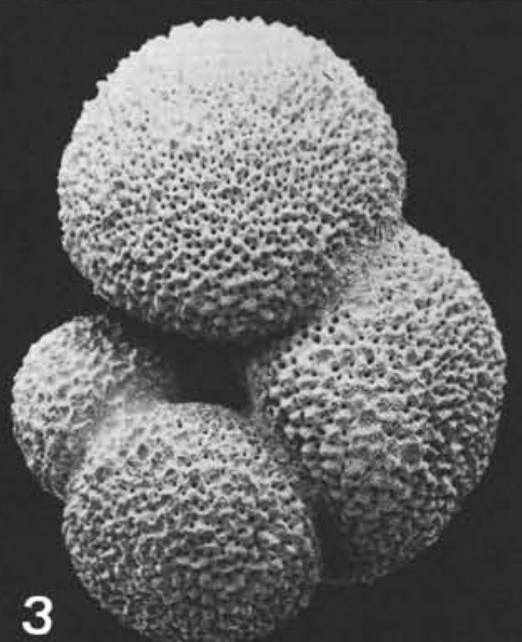

3

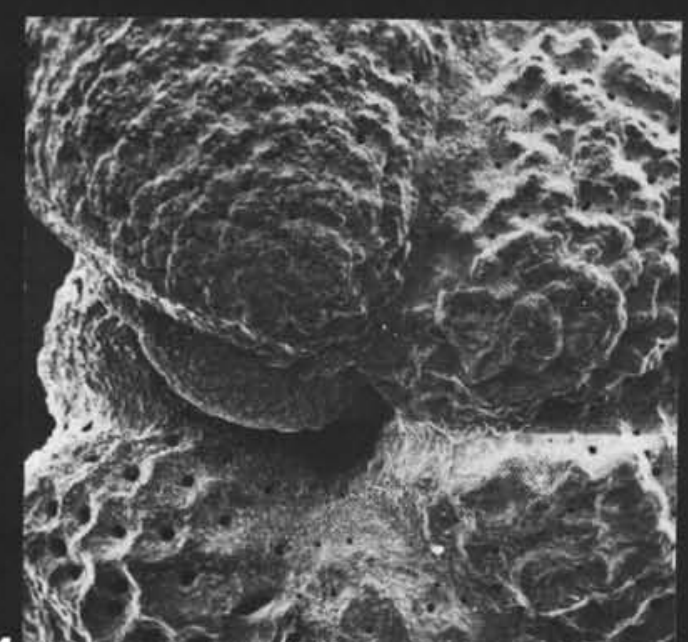

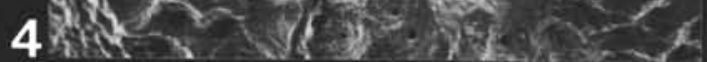

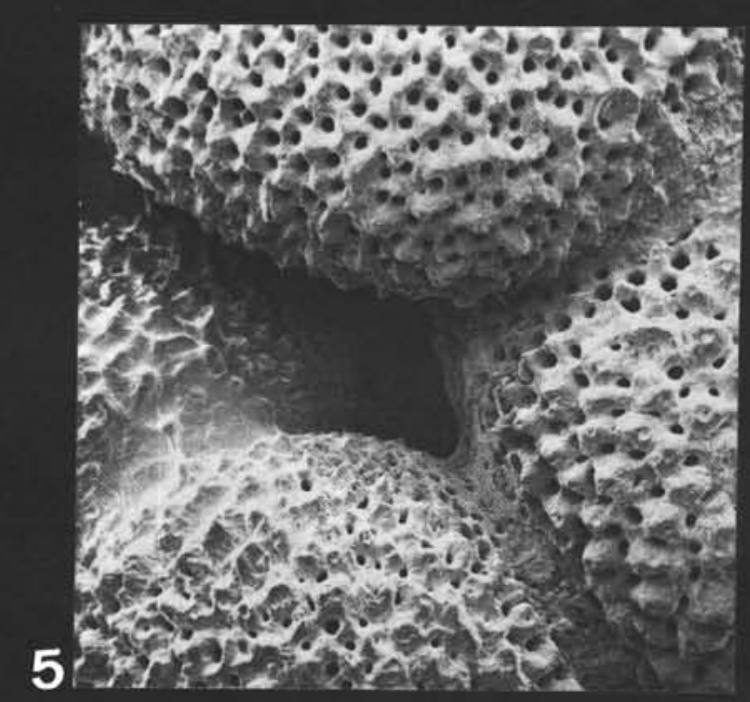

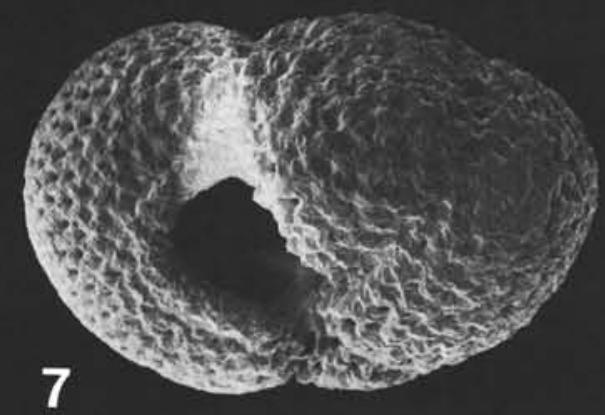

8

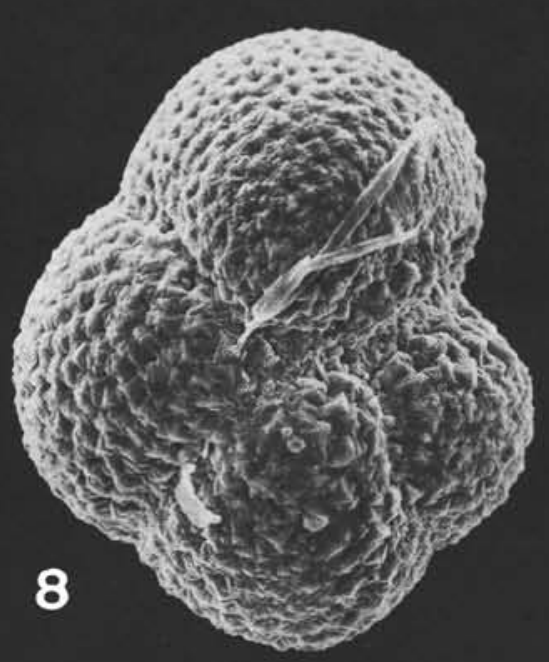




\section{PLATE 37}

Figures 1, 2 \& 8 Globorotalia (Turborotalia) minima Akers, 1955. All figures from Hole 64.1, Core 2, Section 6, 15-17 cm; Zone N. $7 /$ N. 8.

1: $132 X$

2: 330X. Detail of Figure 1.

8: $198 \times$.

Figures 3 \& $7 \quad$ Globorotalia aff. Globorotalia (Turborotalia) subscitula Comato, 1964.

Both figures from the same specimen from Hole 62.1, Core 1, Section 1, Top; Zone N. 23.

3: $128 \mathrm{x}$

7: $148 \mathrm{X}$

Figures 4 \& 5 Globorotalia (Globorotalia) hirsuta praehirsuta Blow, 1969.

Both figures from the same specimen from Hole 62.1, Core 10, Section 4, 15-17 cm; Zone N. 20 (including N. 19).

4: $162 \mathrm{X}$.

5: 1820X. Detail of Figure 4.

Figures 6,10 Globorotalia (Turborotalia) scitula (Brady), 1882, $\& 11$ group.

Figures $6 \&$ 10: Hole 62.1, Core 1, Section 1, Top; Zone N. 23.

6: $246 X$.

10: 198X. Same specimen as Figure 6.

11: Hole 64.0, Core 0, Section 0, Surface Sample; Zone N. 23. $84 \mathrm{X}$.

Figure 9 Globorotalia (Globorotalia) cibaoensis Bermúdez, 1949. Hole 62.1, Core 17, Section 5, $25-28 \mathrm{~cm}$; Zone N. 17. 115X. 

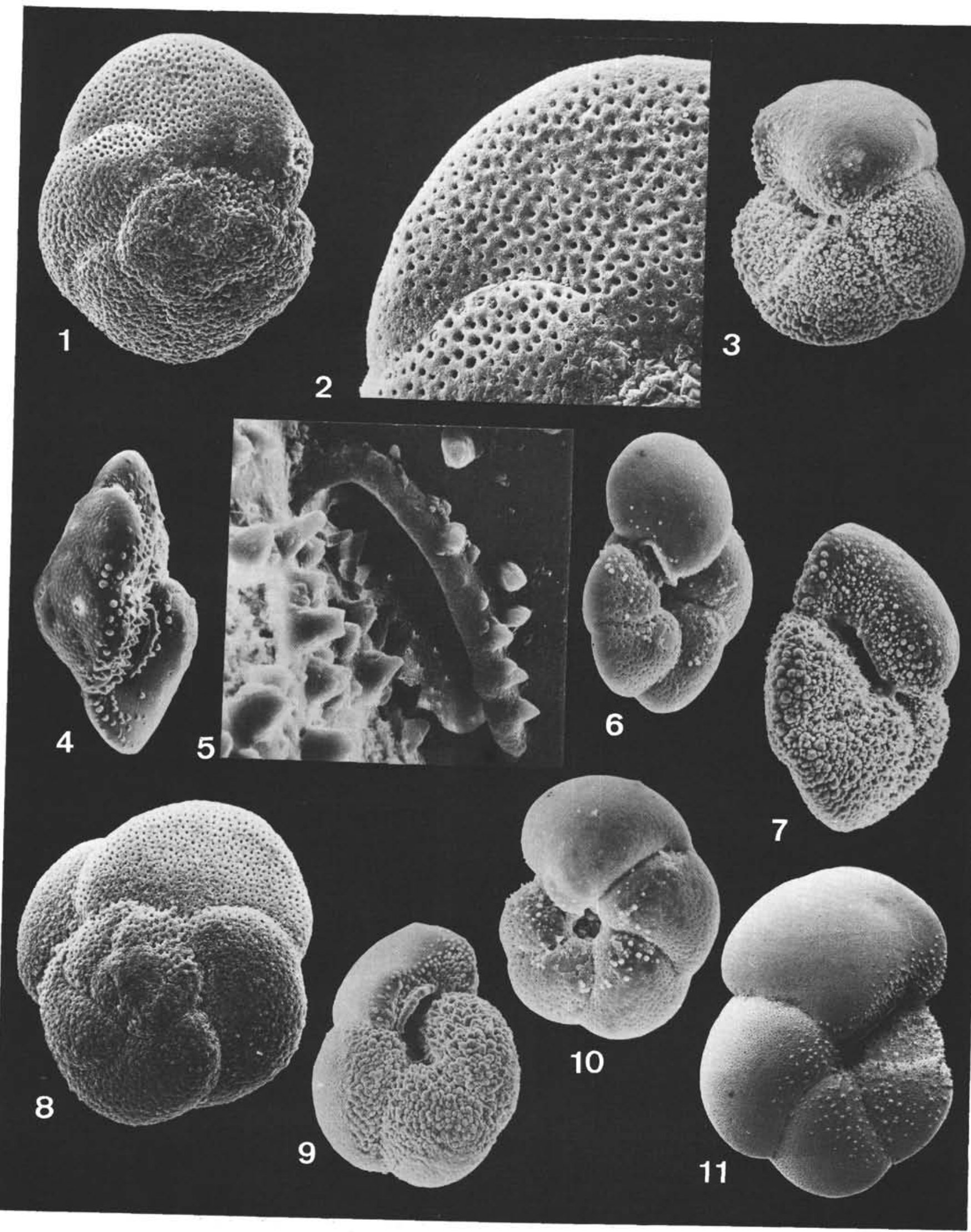


\section{PLATE 38}

Figure 1 Globoquadrina altispira altispira (Cushman and Jarvis), 1936.

Hole 62.1, Core 9, Section 3, 15-17 cm; Zone N. 20 (including N. 19). 132X.

Figures 2 \& 3 Globoquadrina altispira Cushman and Jarvis) globosa Bolli, 1957.

2: Hole 62.1, Core 17, Section 2, 49-53 cm; Zone N. $17135 \times$.

3: Hole 62.1, Core 27, Section 4, 17-19 cm; Zone N. 16. $133 \mathrm{X}$.

Figure $4 \quad$ Globorotalia (Turborotalia) scitula (Brady) praescitula Blow, 1969.

Hole 64.1, Core 2, Section 4, 33-35 cm; Zone N. 7/N. 8. $182 X$.

Figure 5 Globorotalia (Globorotalia) hirsuta (d'Orbigny) praehirsuta Blow, 1969.

Hole 62.1, Core 12, Section 4, 15-17 cm; Zone N. 20 (including N. 19). 96X.

Figure 6 Globorotalia (Globorotalia) multicamerata Cushman and Jarvis, 1930.

Hole 62.1, Core 28, Section 2, 16-18 cm; Zone N. 16. $152 X$. 


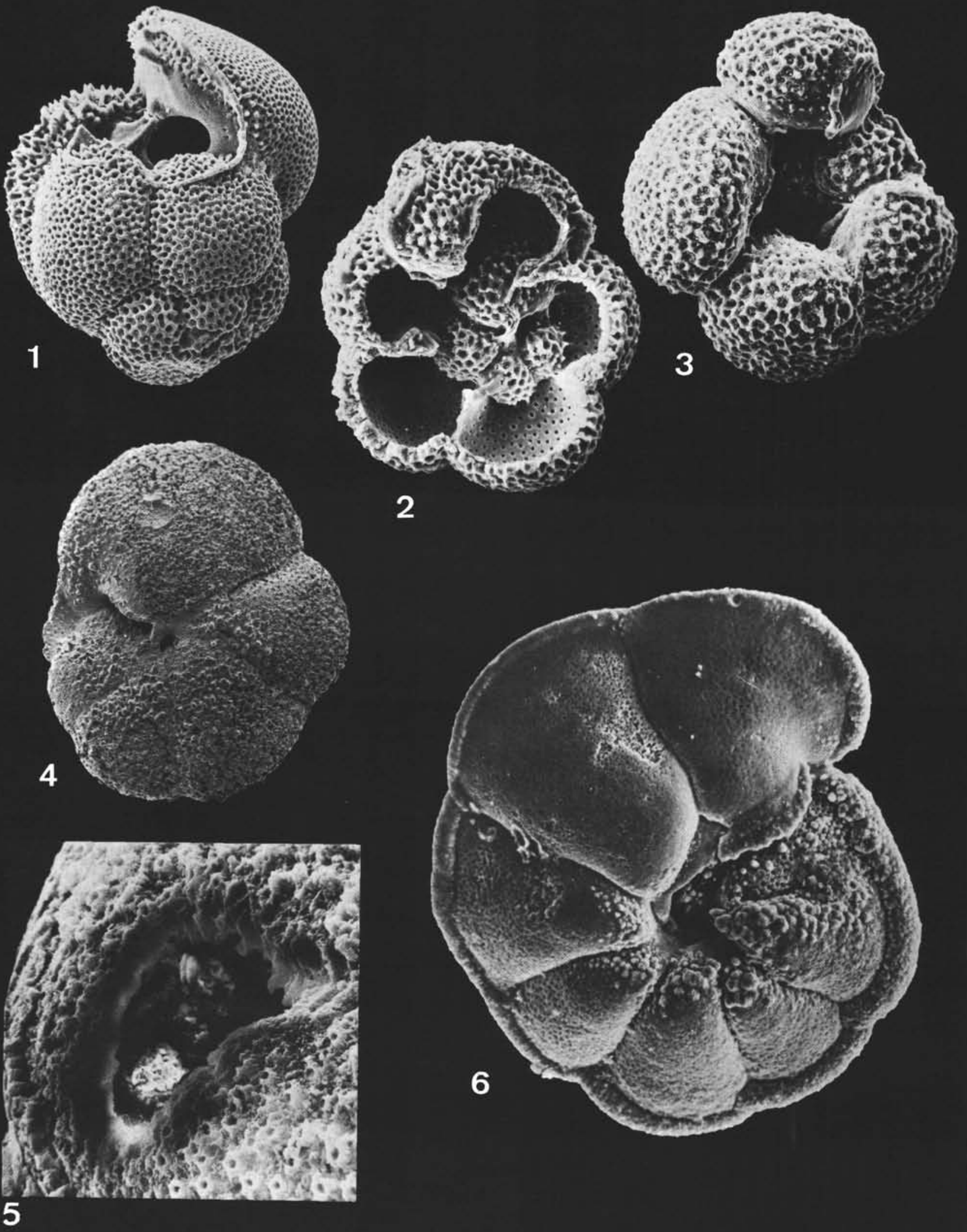




\section{PLATE 39}

Figures 1, 3, 4 Globorotalia (Turborotalia) kugleri Bolli, 1957.

$\& 5$

All figures from Hole 64.1, Core 6, Section 1, 33-35 cm; Zone N. 4.

1: $283 X$.

3: $296 X$

4: $355 X$

5: $638 \times$. Detail of Figure 3.

Figure 2 Globorotalia (Turborotalia)pseudokugleri Blow, 1969. Hole 64.1, Core 7, Section 2, 33-35 cm; Zone N. 3. 296X.

Figures 6, 7 \& 8 Globorotalia (Turborotalia) mendacis Blow, 1969. All figures from Hole 64.1, Core 6, Section 1, 33-35 cm; Zone N. 4.

6: $296 X$.

7: $329 x$.

8: 399X. 


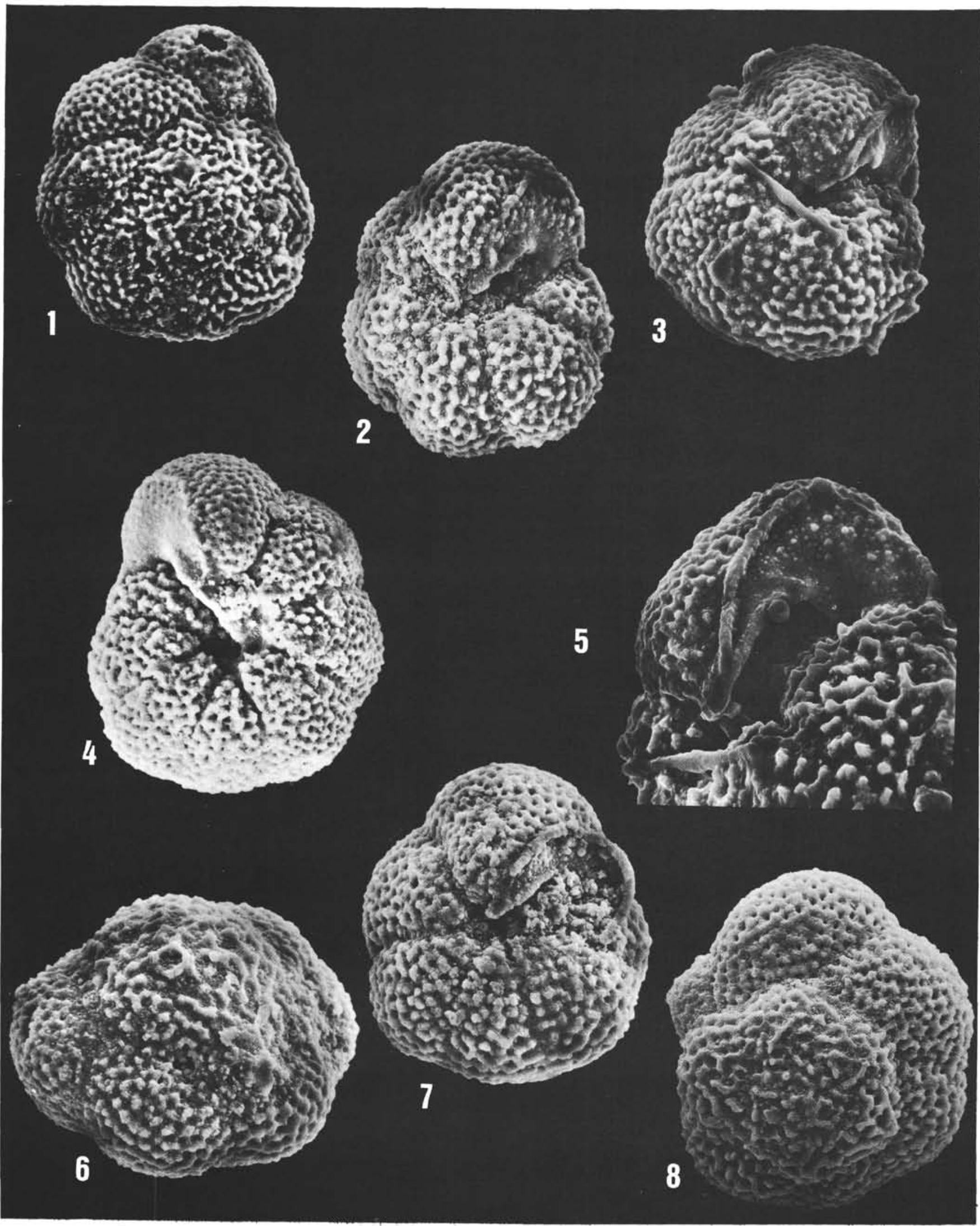


PLATE 40

Figures 1-8 Globorotalia (Turborotalia) nkbrowni Brönnimann and Resig, n.sp.

1-6: Hole 64.1, Core 7, Section 2, 33-35 cm; Zone N. 3.

1: 1420X. Supplementary sutural aperture. Same specimen as Figure 4.

2: $651 \times$. Holotype.

3: $714 X$.

4: $714 \mathrm{X}$. Same as specimen as Figure 2.

5: $753 X$.

6: $640 \mathrm{X}$.

7 and 8: Hole 64.1, Core 6, Section 1, 33-35 cm; Zone N. 4.

7: $541 X$

8: $2152 \times$. Detail of Figure 7. 


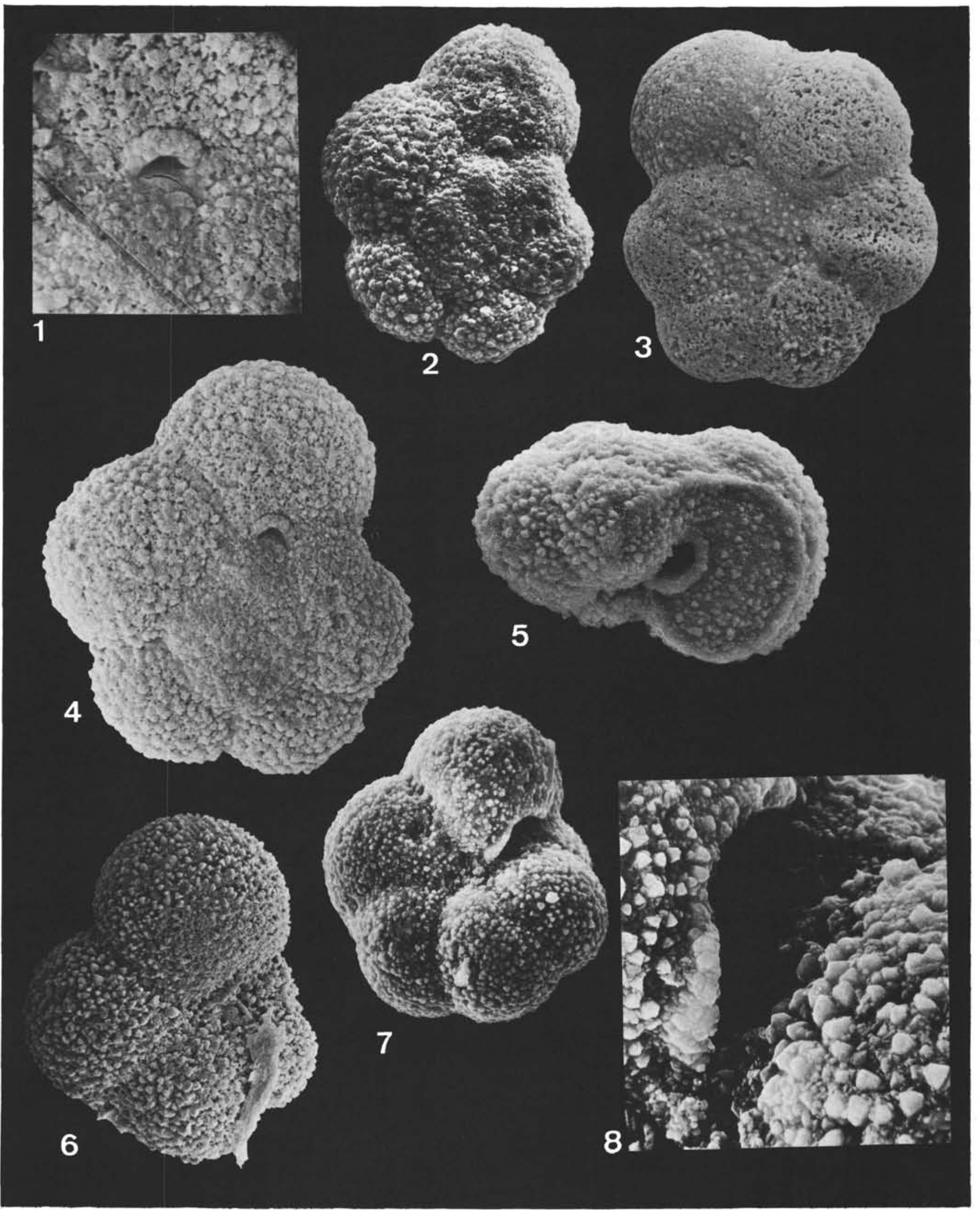




\section{PLATE 41}

Figure $1 \quad$ Globorotalia ex gr. Globorotalia (Turborotalia) riedeli Brönnimann and Resig, n.sp.

Hole 62.1, Core 32, Section 1, 15-17 cm; Zone N. 14. $758 \times$.

Figures 2, 3 \& 4 Globorotalia (Turborotalia) riedeli Brönnimann and Resig, n.sp.

From Hole 62.1, Core 32, Section 1, $15-17 \mathrm{~cm}$; Zone N. 14.

2: $1060 X$.

3: 795X. Holotype dorsal.

4: 1060X. Holotype ventral. 


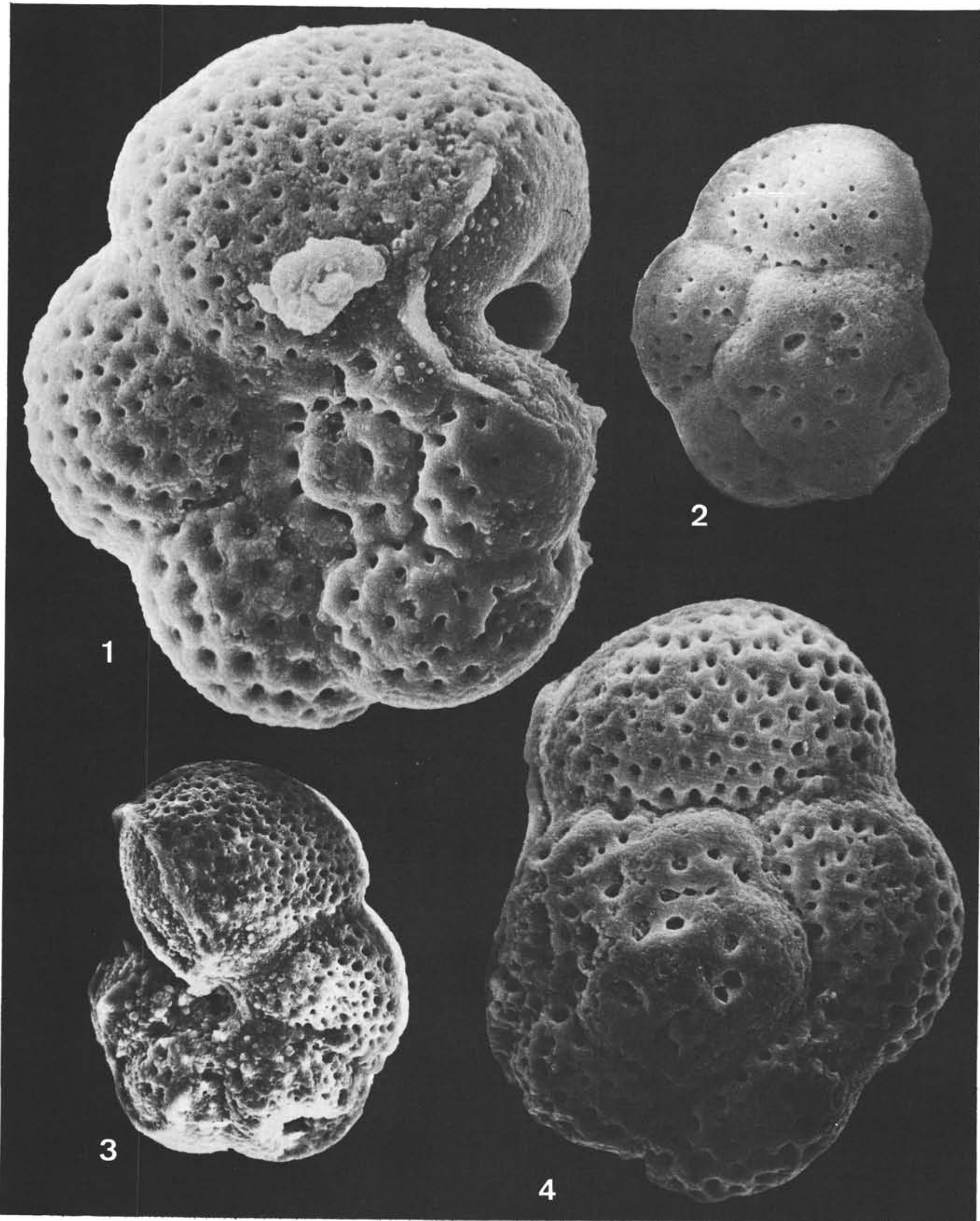




\section{PLATE 42}

Figures 1-9 Globorotalia (Turborotalia) cifellii Brönnimann and Resig, n.sp.

All figures from Hole 64.1, Core 7, Section 2, 33-35

cm; Zone N. 3.

1: $444 X$.

2: 437X. Holotype.

3: 444X. Holotype.

4: 1755X. Detail of Figures 2 and 3. Holotype.

5: $694 X$.

6: $622 X$.

7: $399 X$.

8: $434 X$.

9: $399 X$. 


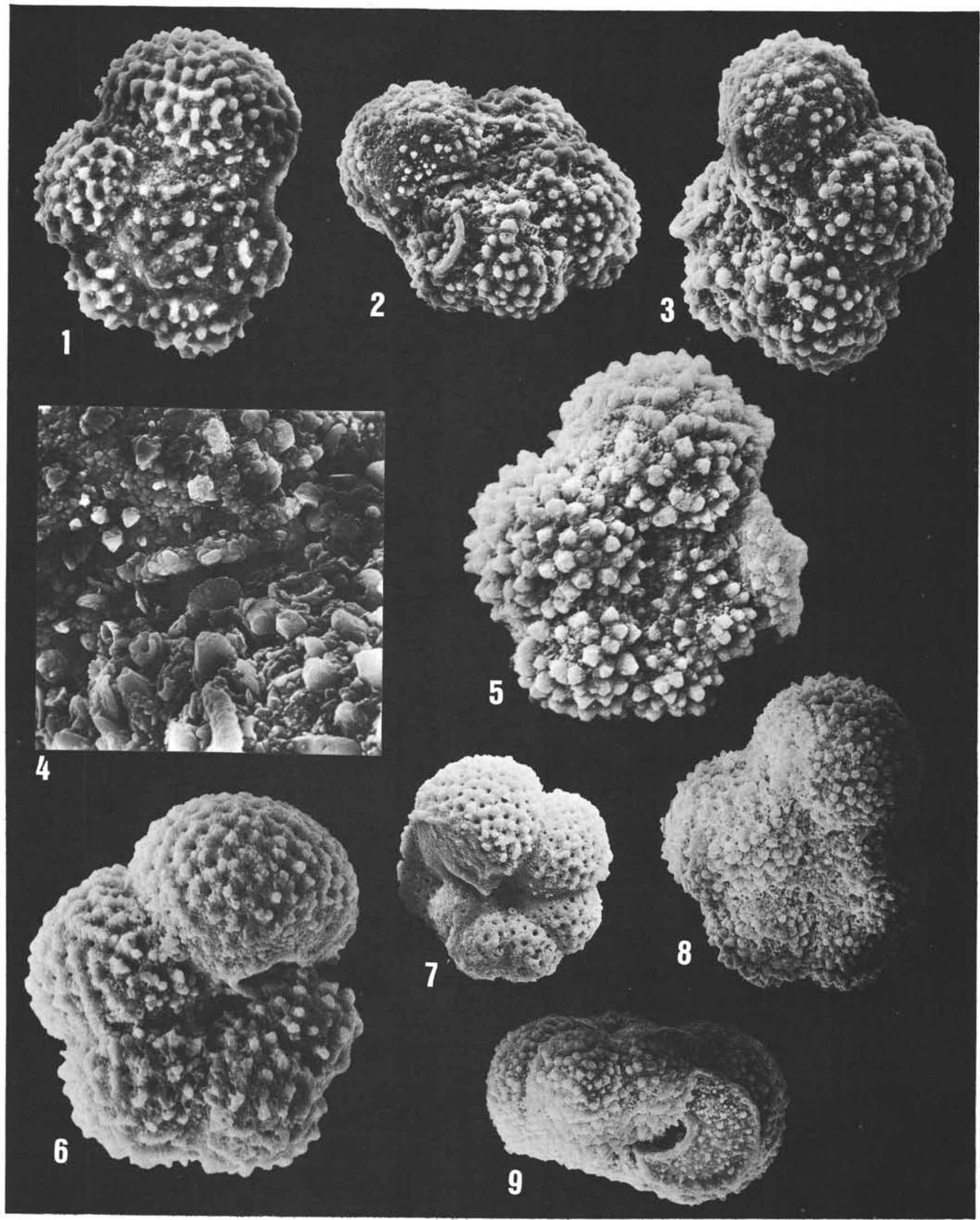




\section{PLATE 43}

Figure 1 Globigerina microfoliata Brönnimann and Resig, n.sp. Hole 62.1, Core 8, Section 5, 16-18 cm; Zone N. 20 (including N. 19). 356X.

Figures 2,3 \& 6 Globorotalia (Turborotalia) anfracta Parker, 1967. All figures from Hole 62.1, Core 3, Section 2, Bottom; Zone N. 22.

2: $639 X$.

3: $646 \mathrm{X}$.

6: 624X.

(See Plate 48, Figure 4).

Figures 4 \& $5 \quad$ Globorotalia (Turborotalia) pseudopumilio Brönnimann and Resig, n.sp.

Both figures from Hole 62.1, Core 6, Section 5, 15-17 cm; Zone N. 21.

4: 498X. Holotype.

5: $472 X$.

Figures 7 \& 10 Globorotalia(Turborotalia) parkerae Brönnimann and Resig, n.sp.

Both figures from CAP HG-41, 0-1 cm. Donated by F. L. Parker.

7: 552X. Holotype.

10: $584 X$.

Figures 8 \& 9 Globigerina aff. Globigerina quinqueloba Natland, 1938.

Both figures from Hole 62.1, Core 3, Section 2, Bottom; Zone N. 22.

8 and 9: 356X. 


\section{PLATE 43}

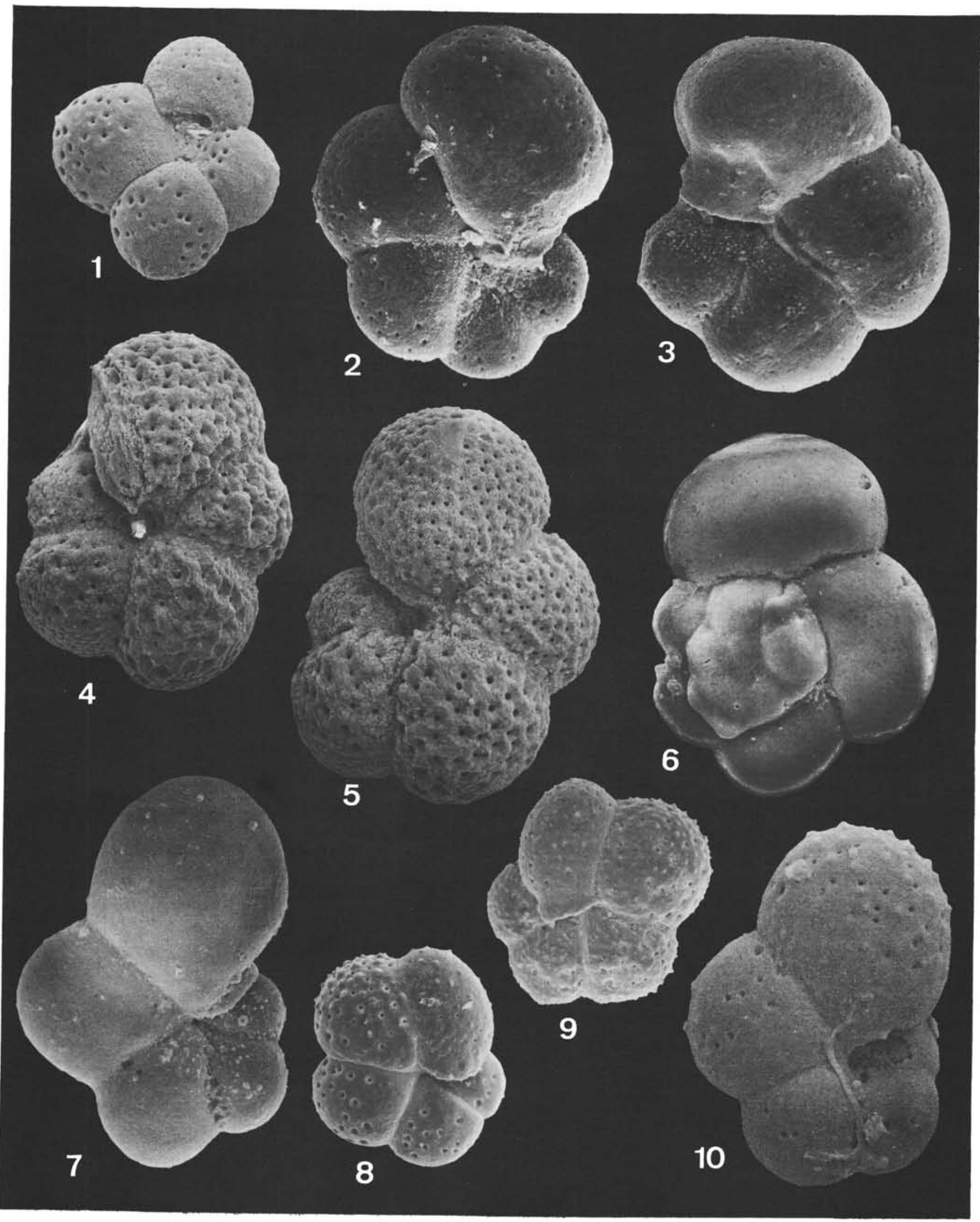




\section{PLATE 44}

Figures 1,2, 4, Globorotalia (Turborotalia) planispira Brönnimann $5,7 \& 8$ and Resig, n.sp.

All figures from Hole 62.1, Core 6, Section 5, 15-17 cm; Zone N. 21.

1\& 2: $356 X$.

5: $396 \mathrm{X}$.

4: 497X. Holotype.

7: $518 X$.

8: $452 X$.

Figure 3

Globorotalia (Turborotalia) planispira Brönnimann and Resig, n.sp. ?.

Hole 62.1, Core 6, Section 5, 15-17 cm; Zone N. 21. 197X.

Figure 6

Globigerinita uvula (Ehrenberg), 1861.

Hole 62.1, Core 27, Section 1, Top; Zone N. 16. 363X. Well-developed finely granular bulla. 

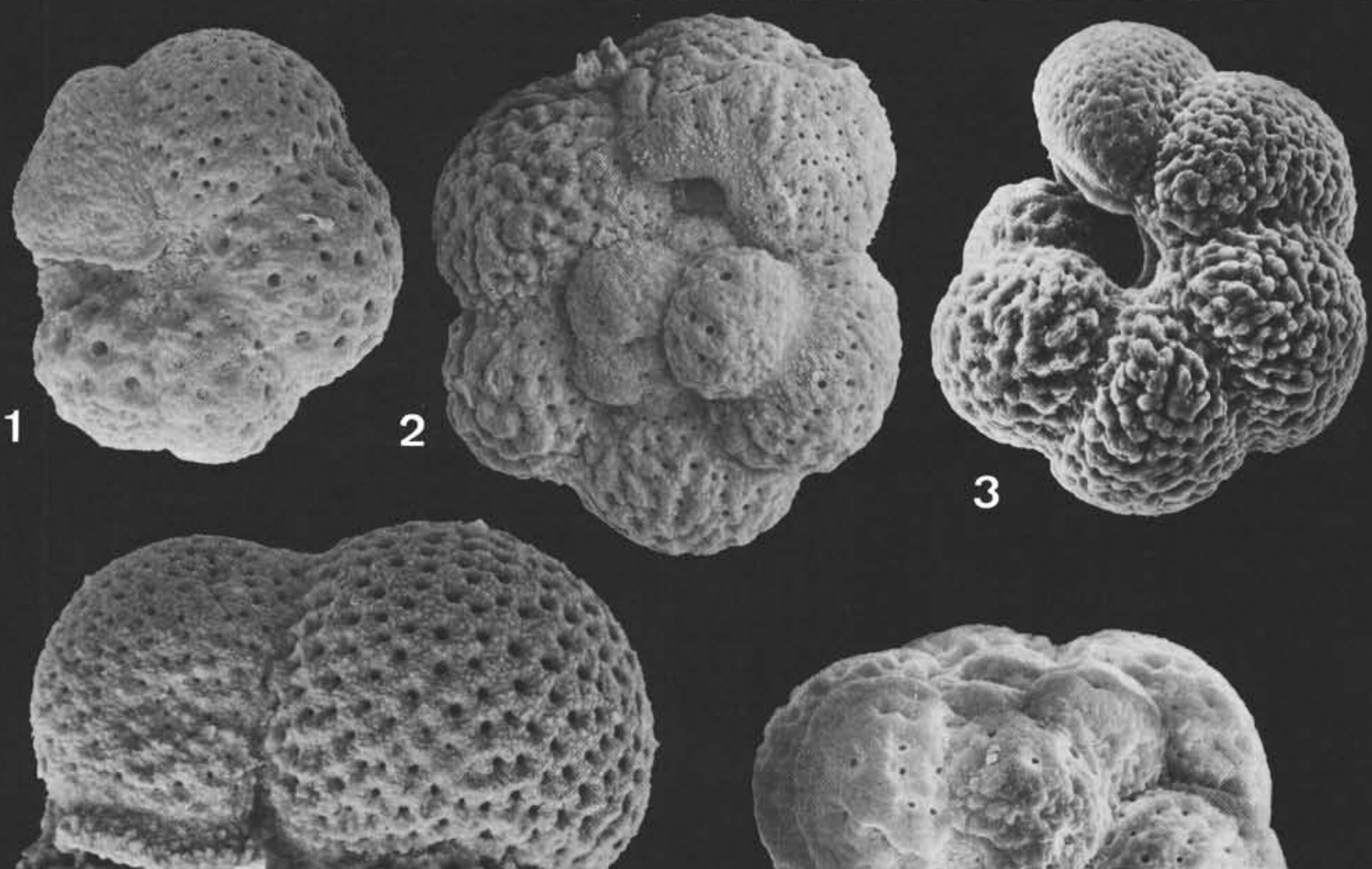

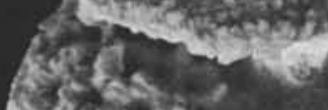

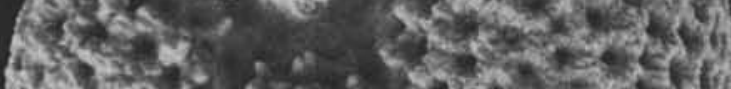

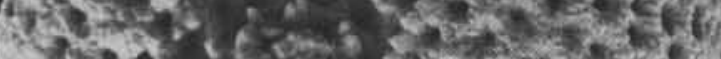

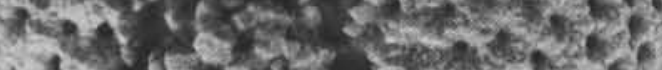

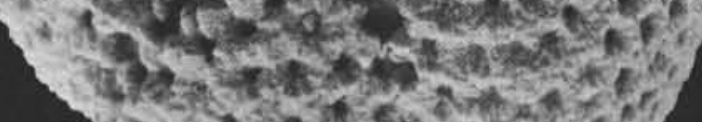

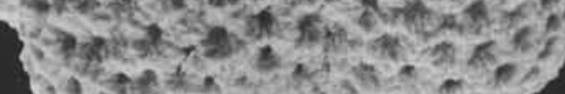
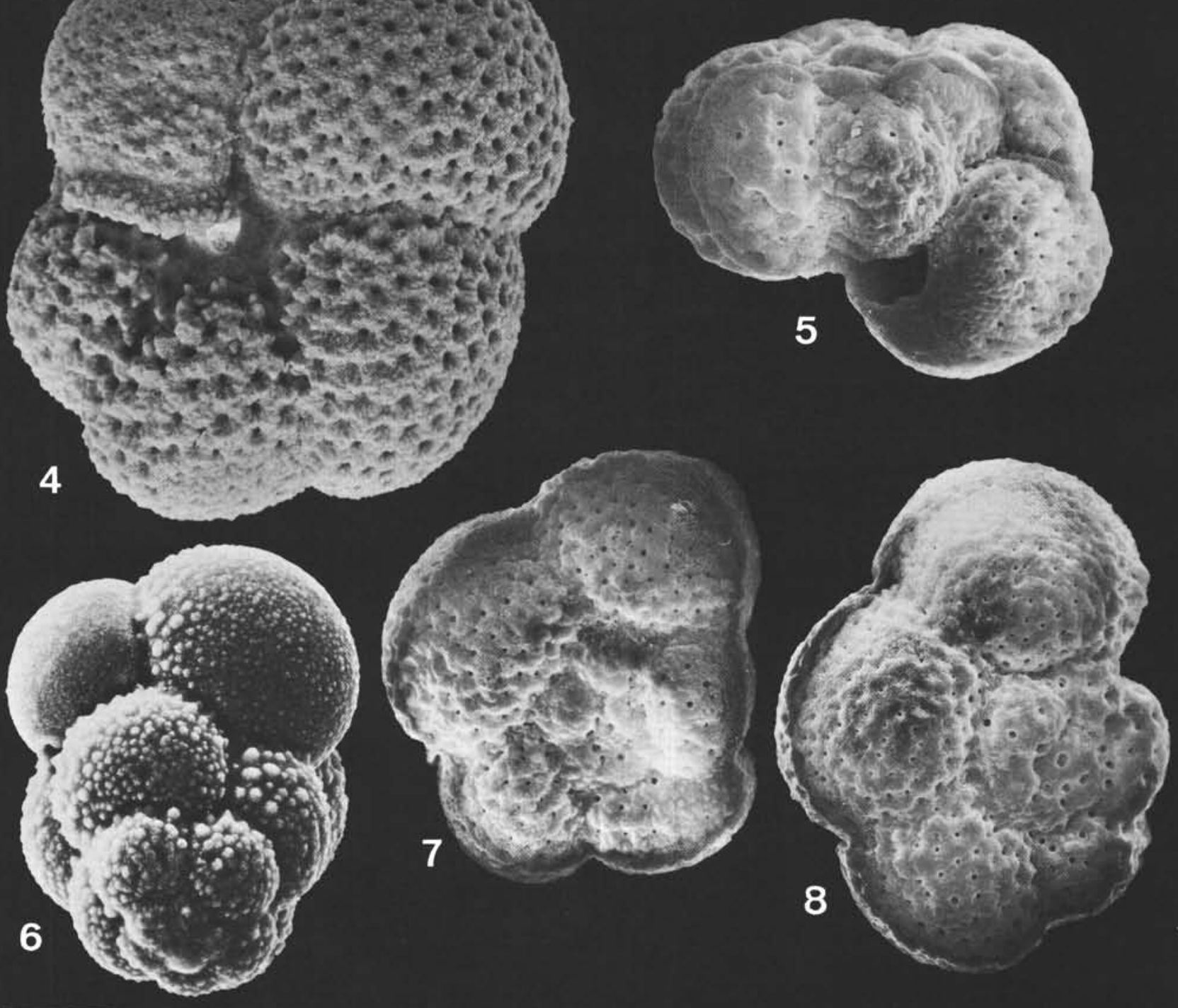
PLATE 45

Figures 1-4 Orbulina universa d'Orbigny parkerae Brönnimann and Resig, n.subsp.

All figures from Hole 62.1, Core 14, Section 5, 15-17 cm; Zone N. 18.

1: $107 \times$.

2: $96 \times$. Holotype

3: 389X. Detail of Figure 2.

4: $1552 \times$. Detail of Figure 2 and 3.

Figures 5 \& 7 Globorotalia (Turborotalia) incisa Brönnimann and Resig, n.sp.

Both figures from Hole 62.1, Core 8, Section 3, 15-17 cm; Zone N. 20 (including N. 19).

5: $271 X$.

7: 214X. Same specimen as Figure 5.

(See Plate 46, Figures 1-8).

Figure 6 Cassigerinella chipolensis (Cushman and Panton), 1932. Hole 64.1, Core 7, Section 2, 33-35 cm; Zone N. 20 (including N. 19). 558X.

Figure $8 \quad$ Globorotalia pseudopachyderma Cita, Premoli Silva and Rossi, 1965.

Hole 62.1, Core 8, Section 3, 15-17 cm; Zone N. 20 (including N. 19). 231X. 

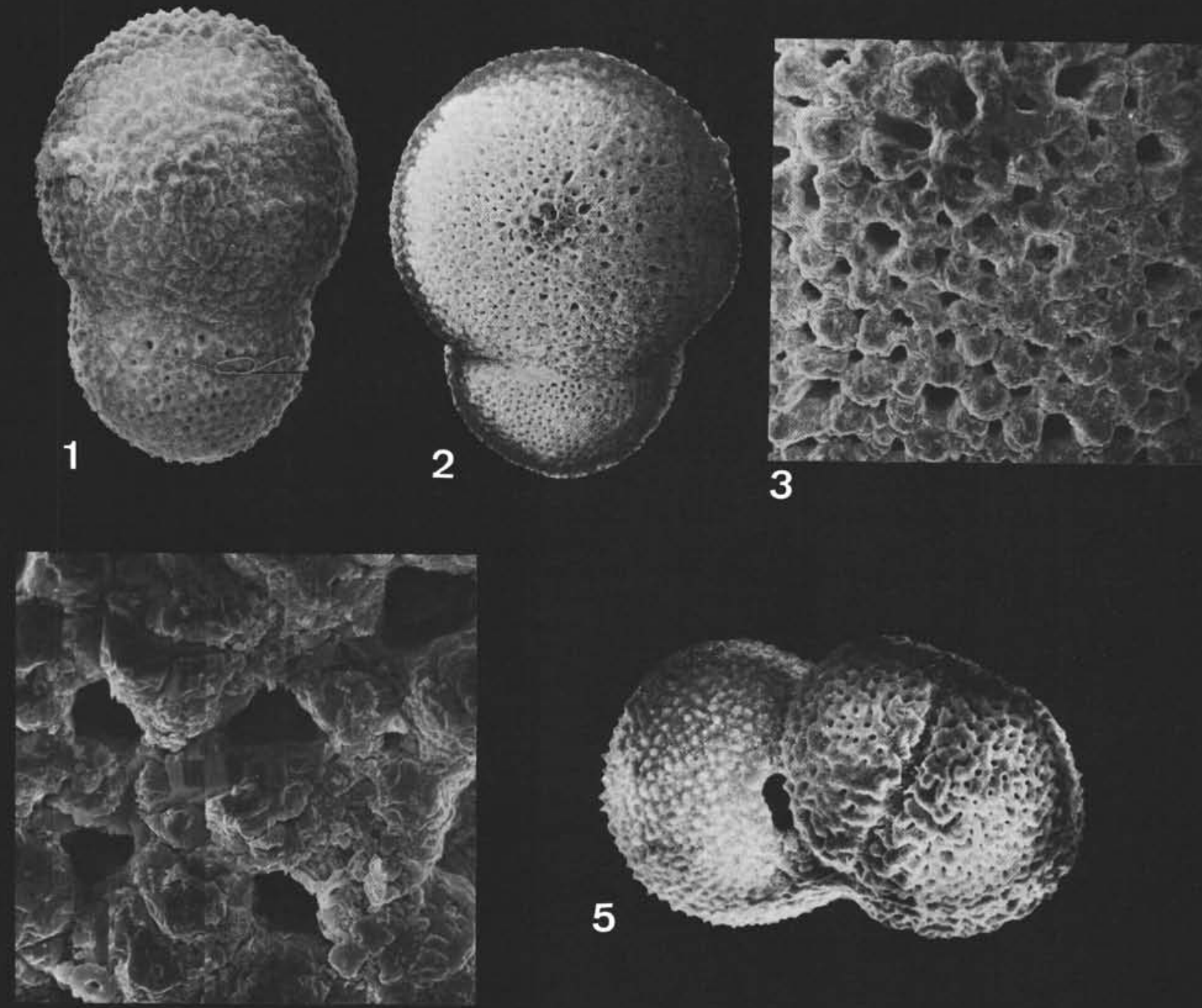

4
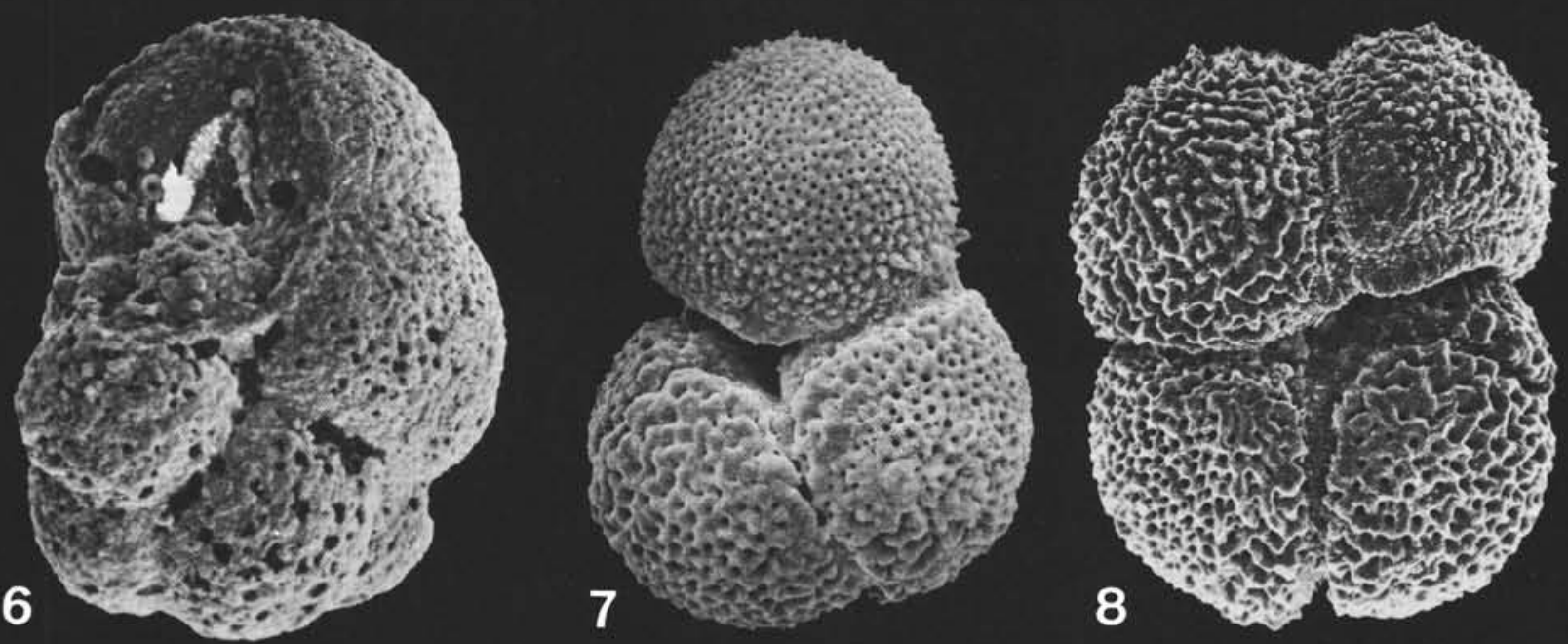


\section{PLATE 46}

Figures 1-8 Globorotalia (Turborotalia) incisa Brönnimann and Resig, n.sp.

All figures from Hole 62.1, Core 8, Section 3, 15-17 cm; Zone N. 20 (including N. 19).

1: 307X. Holotype.

2: $287 X$.

3: $260 X$.

4: $255 X$.

5: $301 X$.

6: $286 \mathrm{X}$.

7: 472X. Detail of Figure 3.

8: $912 X$. Detail of Figure 3. 


\section{PLATE 46}

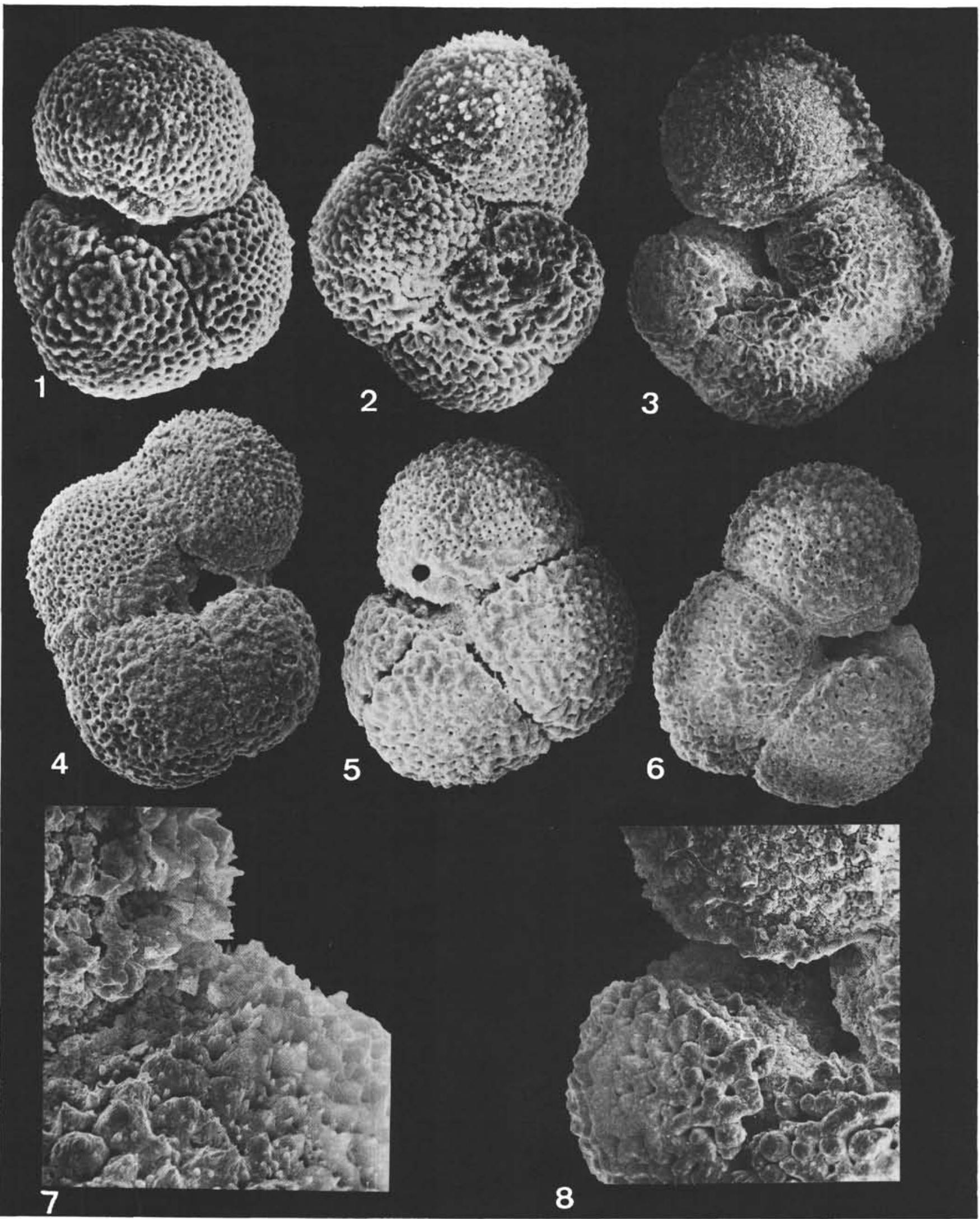




\section{PLATE 47}

Figure 1 Globorotalia (Turborotalia) planispira Brönnimann and Resig, n.sp.

Hole 62.1, Core 6, Section 5, 15-17 cm; Zone N. 21. Outer wall formations and unbeveled wall pores. $1545 \times$.

Figure 2 Globorotalia (Turborotalia) anfracta Parker, 1967. Hole 62.1, Core 3, Section 2, Bottom; Zone N. 22. Minutely granular surface. $611 X$.

Figures 3 \& 5 Globorotalia (Turborotalia) pseudopumilio Brönnimann and Resig, n.sp.

Hole 62.1, Core 6, Section 5, 15-17 cm; Zone N. 21. Outer wall formation and beveled wall pores

3: $1815 X$.

5: 5590X. Detail of Figure 3.

Figures $4 \& 6 \quad$ Globorotalia(Turborotalia) parkerae Brönnimann and Resig, n.sp.

CAP HG-41, 0-1 cm.

4: 5050X.

6: $5220 \times$. Detail of Figure 4. 

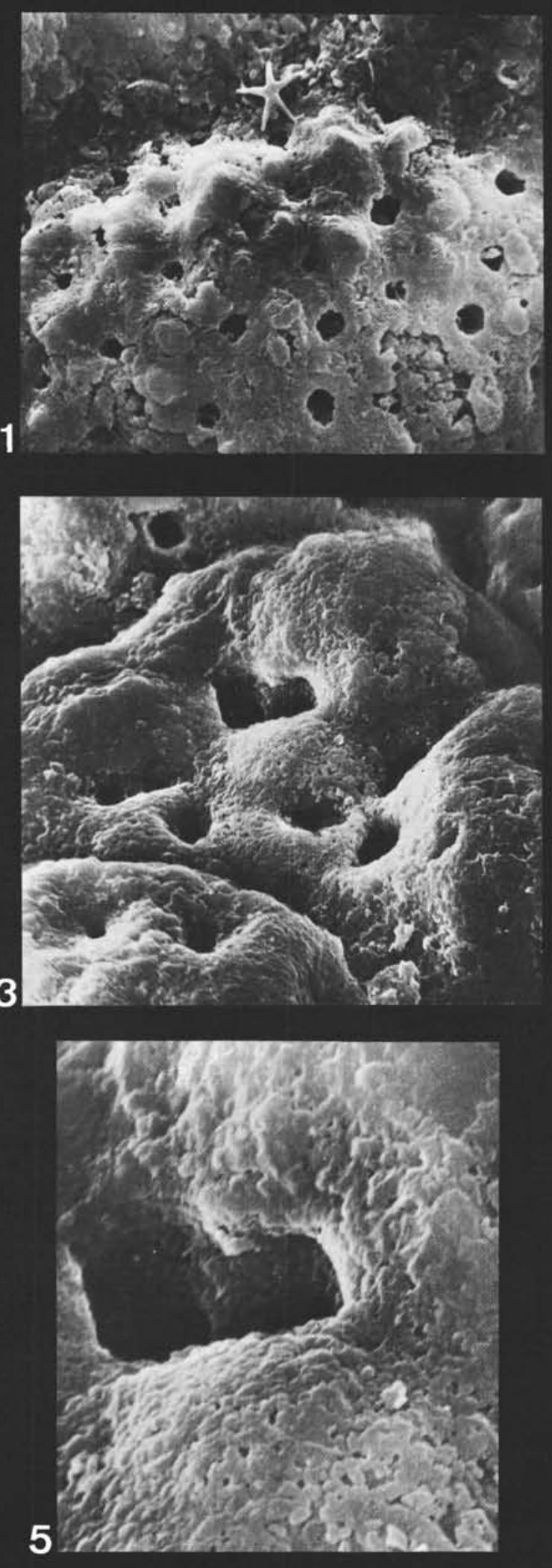
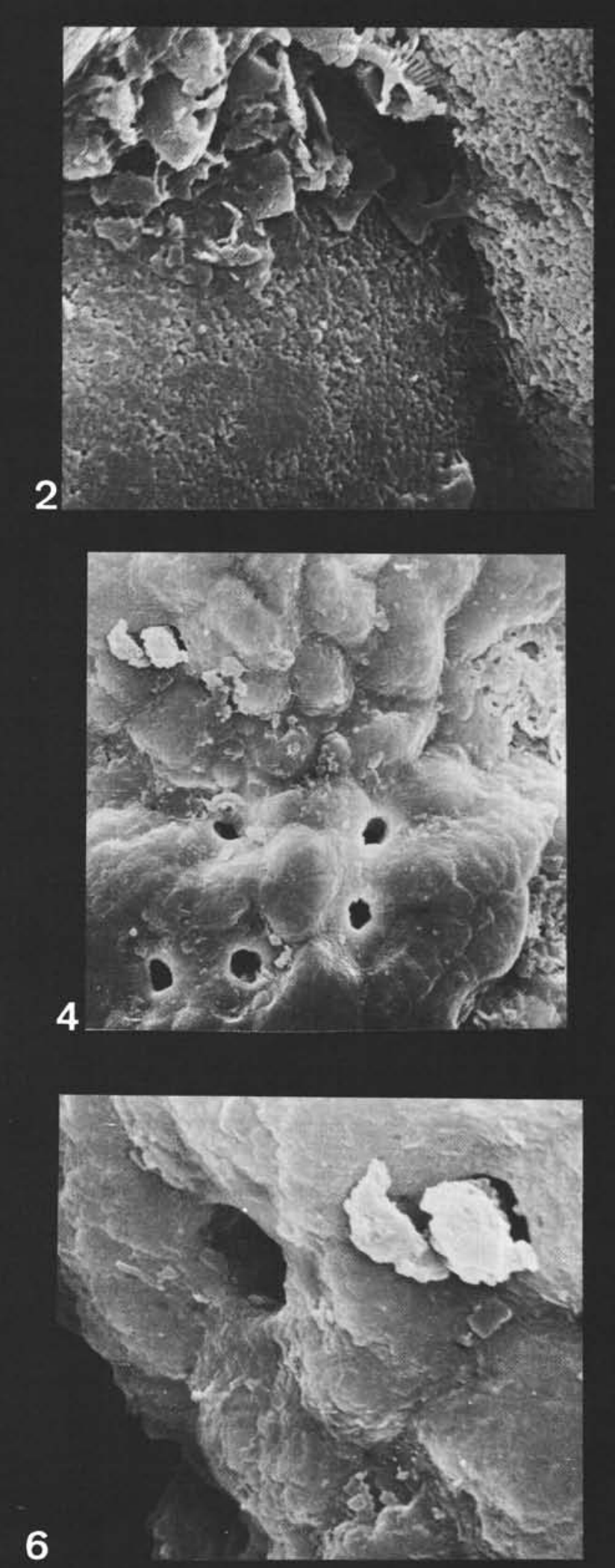


\section{PLATE 48}

Figure $1 \quad$ Globorotalia (Turborotalia) pumilio Parker, 1962. CAP HG-41, 0-1 cm. Don Dr. F. L. Parker. 554X.

Figures 2 \& 3 Globorotalia (Turborotalia) parkerae Brönnimann and Resig, n.sp.

Both figures from CAP HG-41, 0-1 cm. Don Dr. F. L. Parker.

2: $561 \mathrm{X}$.

3: $634 X$.

Figure $4 \quad$ Globorotalia (Turborotalia) anfracta Parker, 1967. Hole 62.1, Core 3, Section 2, Bottom; Zone N. 22. $654 \mathrm{X}$.

(See Plate 43, Figures 2, $3 \&$ 6).

Figures 5, 6 \& 7 Globorotalia (Turborotalia) anfracta Parker, 1967. Hole 62.1, Core 3, Section 2, Bottom; Zone N. 22. (See Plate 43, Figures 2, $3 \& 6$ ).

Figures 5, 6 \& 7 Globorotalia (Turborotalia) sp. related with the anfracta-parkerae group of forms.

All figures from Hole 62.1, Core 3, Section 2, Bottom; Zone N. 22.

5: $627 X$.

6: $693 X$

7: $551 X$.

Figure 8 Globorotalia (Turborotalia) sp., affin with the Globorotalia (Turborotalia) planispira Brönnimann and Resig, n.sp., group.

Hole 62.1, Core 6, Section 5, 15-17 cm; Zone N. 21. $538 \times$. 
PLATE 48
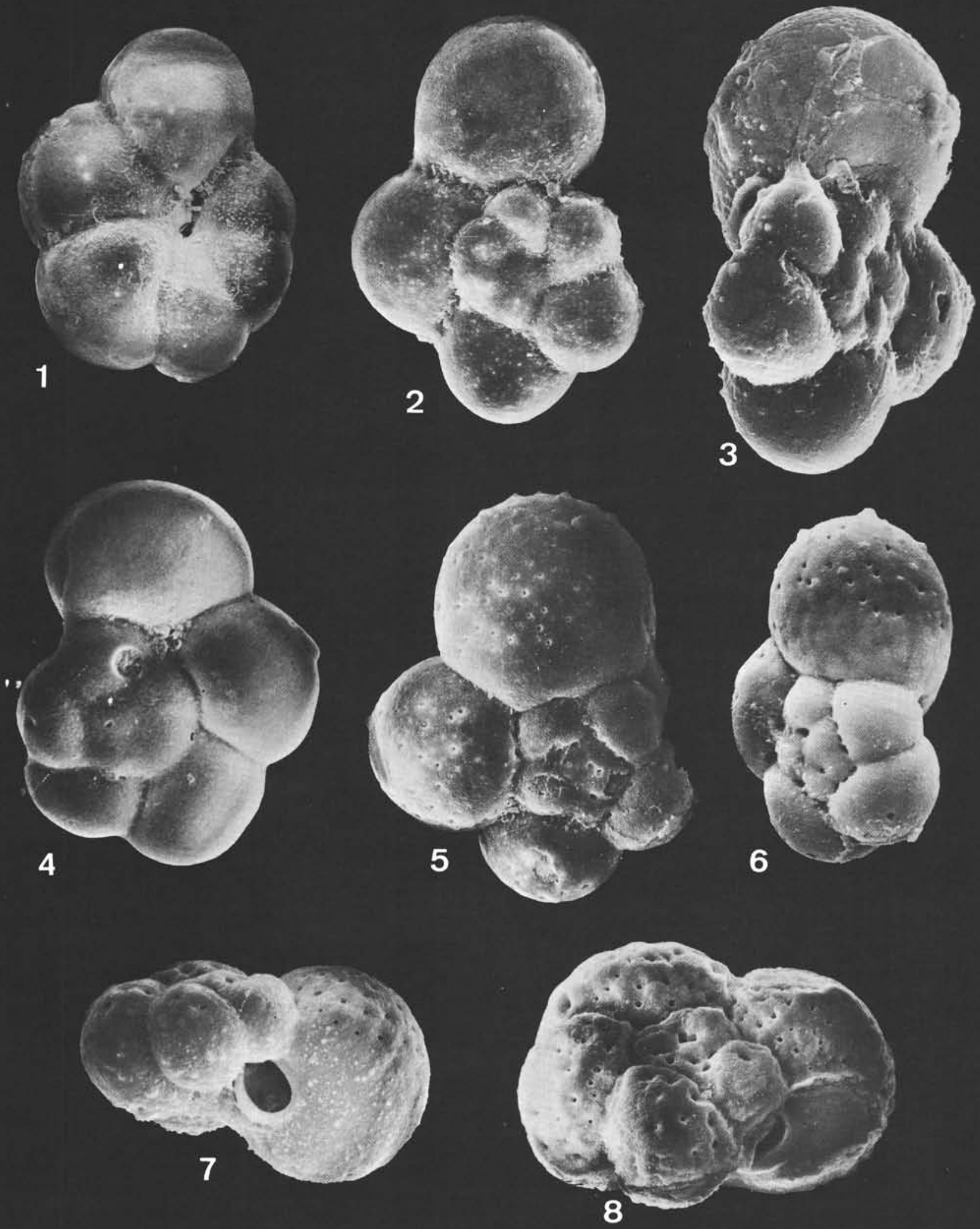


\section{PLATE 49}

Figures 1 \& 2 Globorotalia (Globorotalia) hirsuta (d'Orbigny) praehirsuta Blow, 1969.

Both figures from Hole 62.1, Core 10, Section 4, 15-17 cm; Zone N. 20 (including N. 19).

1: 264X. Ventral side.

2: $281 X$. Dorsal side.

Figure 3

Globorotalia (Globorotalia) cultrata (d'Orbigny) exilis Blow, 1969.

Hole 62.1, Core 1, Section 1, Top; Zone N. 23. 63X.

Figures 4 \& 5 Globorotalia (Globorotalia) tumida (Brady) lata Brönnimann and Resig, n.subsp.

Both figures from the same specimen from Hole 62.1, Core 4, Section 5, 16-18 cm; Zone N. 22.

4: $166 \mathrm{X}$.

5: 1395X. Detail of Figure 4.

(See Plate 29, Figure 3, holotype). 


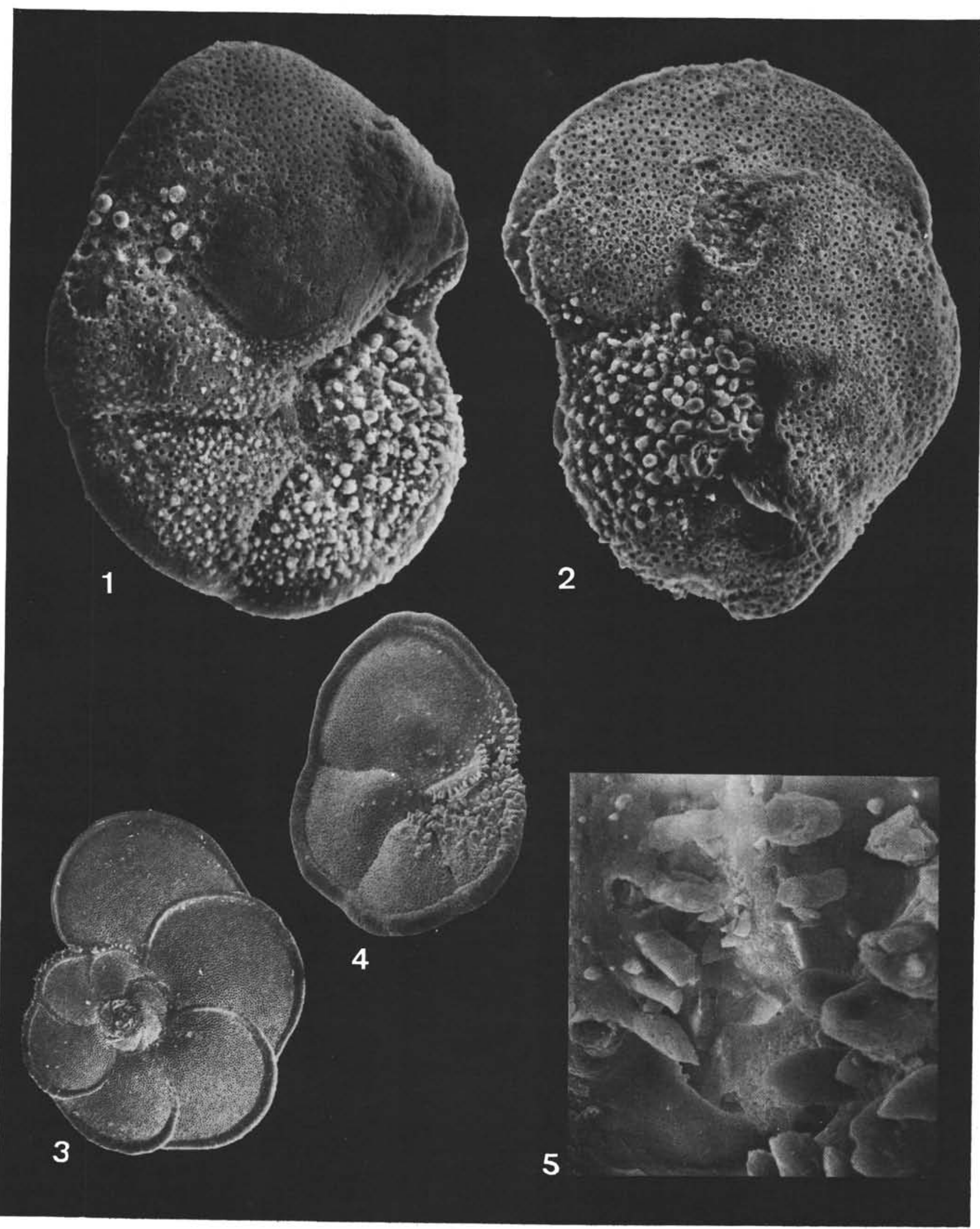




\section{PLATE 50}

Figures 1,2 \& 3 Globigerina calida calida Parker, 1962.

1 \& 2: Hole 64.0, Core 0, Surface Sample; Zone

N. 23.

1: $119 \mathrm{X}$.

2: $81 X$.

3: Hole 62.1, Core 1, Section 1, Top; Zone N. 23. $139 \times$.

Figure 4 Transitional form from Globigerina obesa Bolli, 1957 to Hastigerina siphonifera siphonifera (d'Orbigny), 1839.

Hole 62.1, Core 1, Section 1, Top; Zone N. 23. $127 \times$.

Figure 5 Globigerinita glutinata (Egger), 1893 juvenilis (Bolli), 1957.

Hole 62.1, Core 1, Section 1, Top; Zone N. 23. $238 \mathrm{X}$.

Figure $6 \quad$ Globigerinita glutinata (Egger) flparkerae Brönnimann and Resig, nom. nov.

Hole 62.1, Core 1, Section 1, Top; Zone N. 23. 211X. (See Plate 23, Figures 1 - 5).

Figures 7 \& $8 \quad$ Globorotalia (Turborotalia) obesa Bolli, 1957.

7: Hole 62.1, Core 1, Section 1, Top; Zone N. 23. $231 \mathrm{X}$

8: Hole 62.1, Core 6, Section 4, $15-17 \mathrm{~cm}$; Zone N. 21. $241 X$.

Figure 9 Hastigerinella digitata (Brady) praedigitata (Parker), 1967.

Hole 62.1, Core 1, Section 1, Top; Zone N. 23. $259 \times$. 


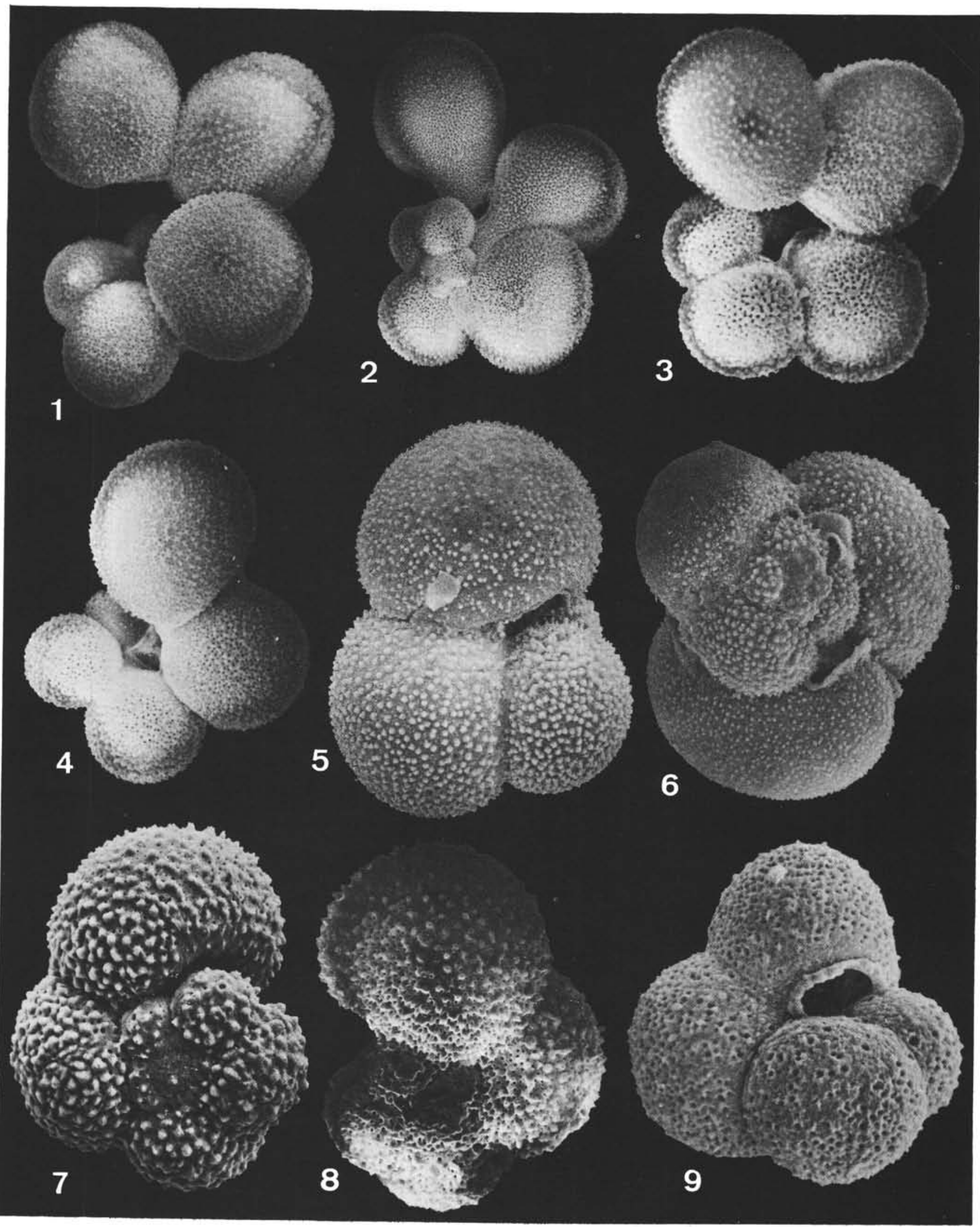




\section{PLATE 51}

Figure 1 Streptochilus tokelauae (Boersma) $\times$ 400; Recent, Ontong Java Plateau, Haw. Inst. Geophys. Core S-67-27. Ocm.

Figure 2 Streptochilus globigerum $($ Schwager $) \times 400$; 62.1-26-1 (109-111).

Figure $3 \quad$ Streptochilus latum n.sp. X 350; 62.1-20-1 (109-111); front and side views of holotype, repository U.S.N.M.

Figure $4 \quad$ Streptochilus pristinum n.sp. $\times$ 500; 62.1-34-2 (1.09111); front view of holotype, repository U.S.N.M. 


$$
\text { Nit }
$$





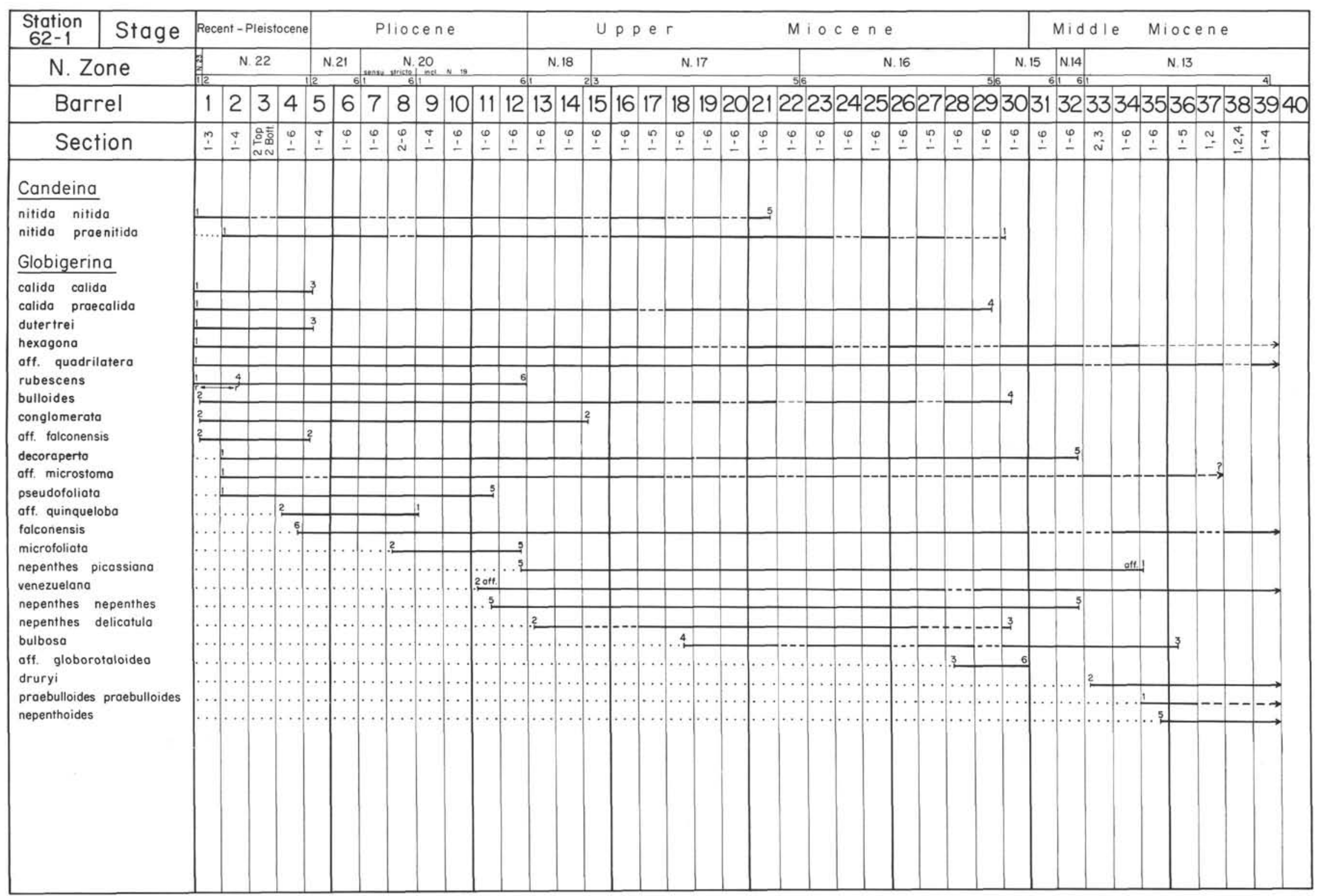






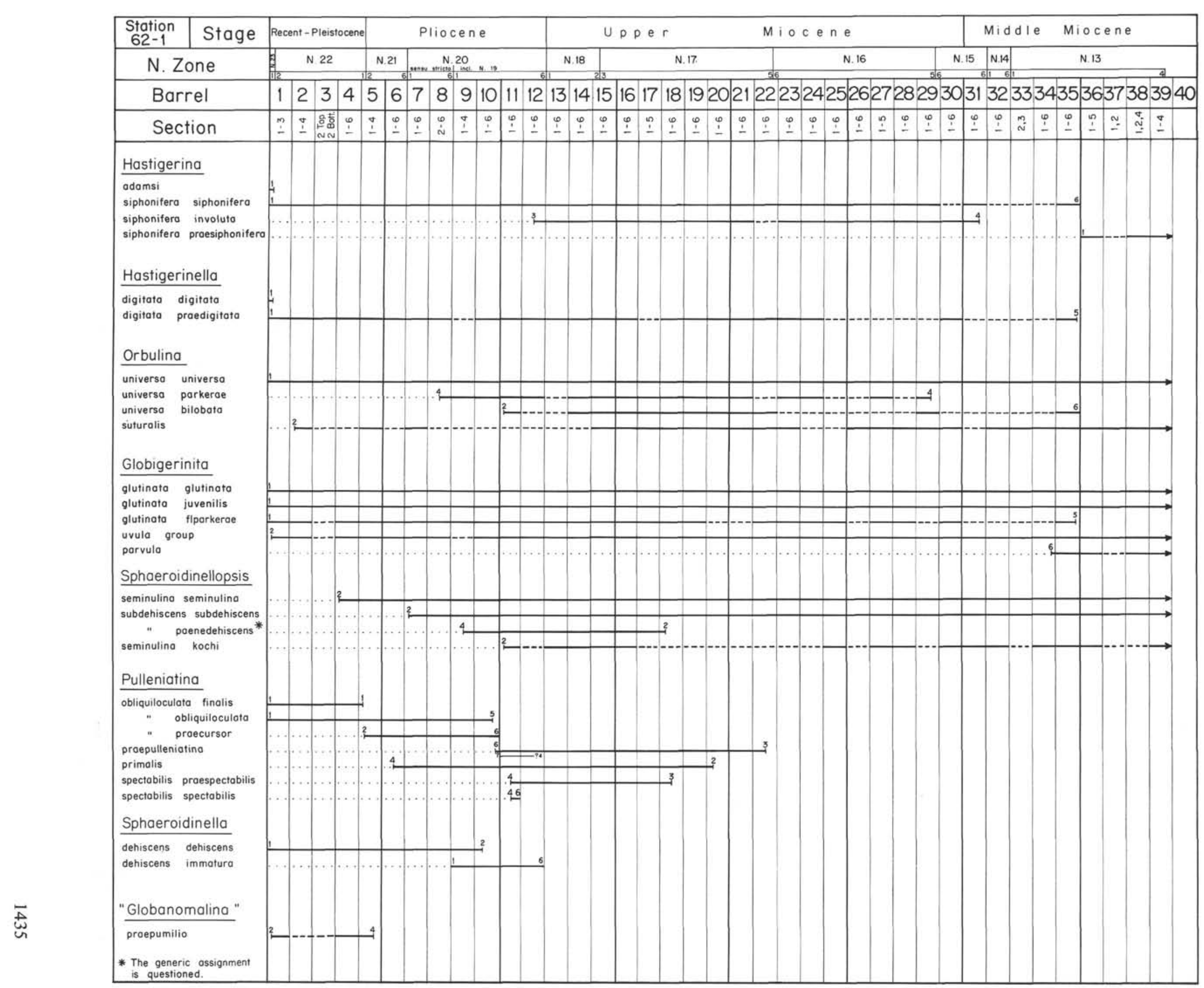





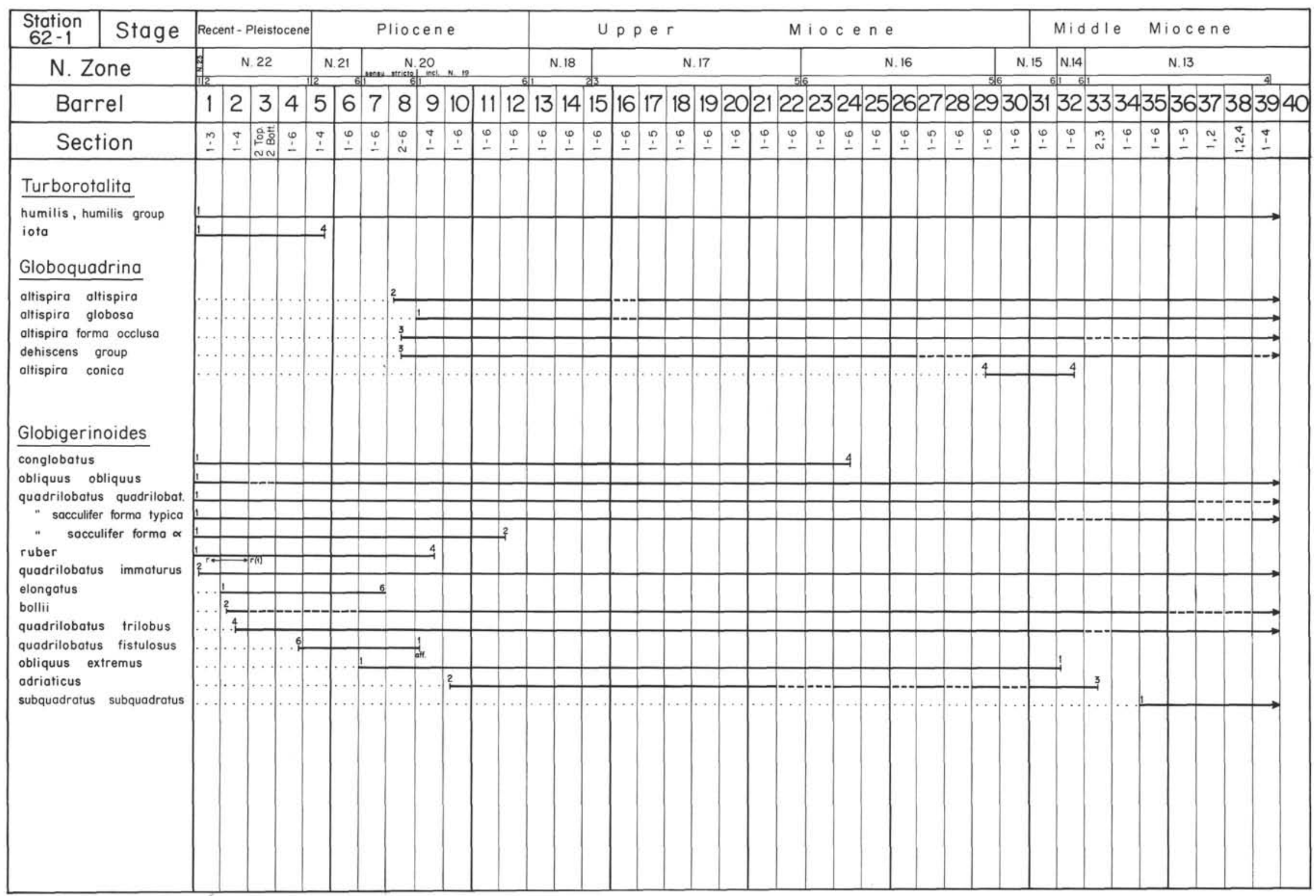





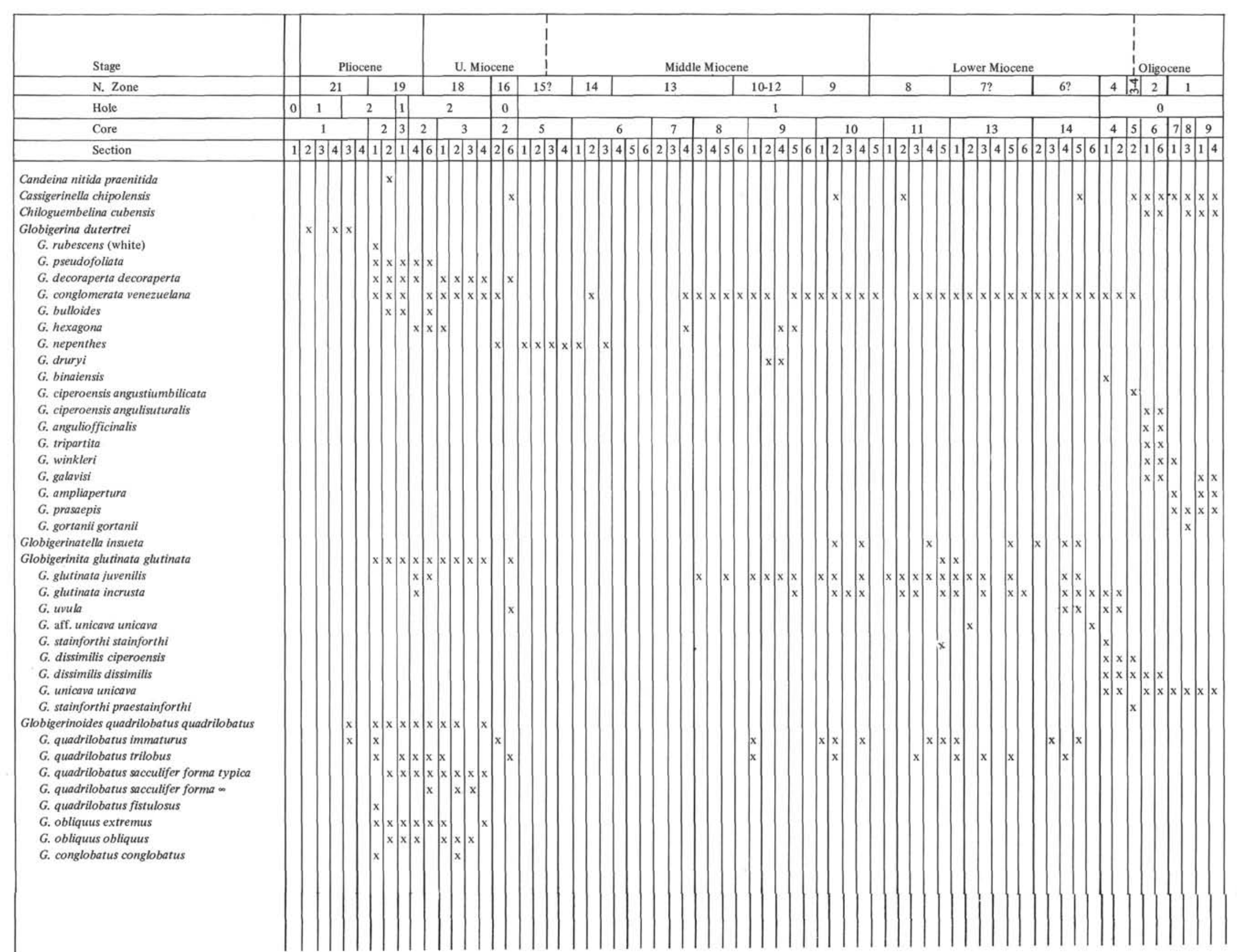




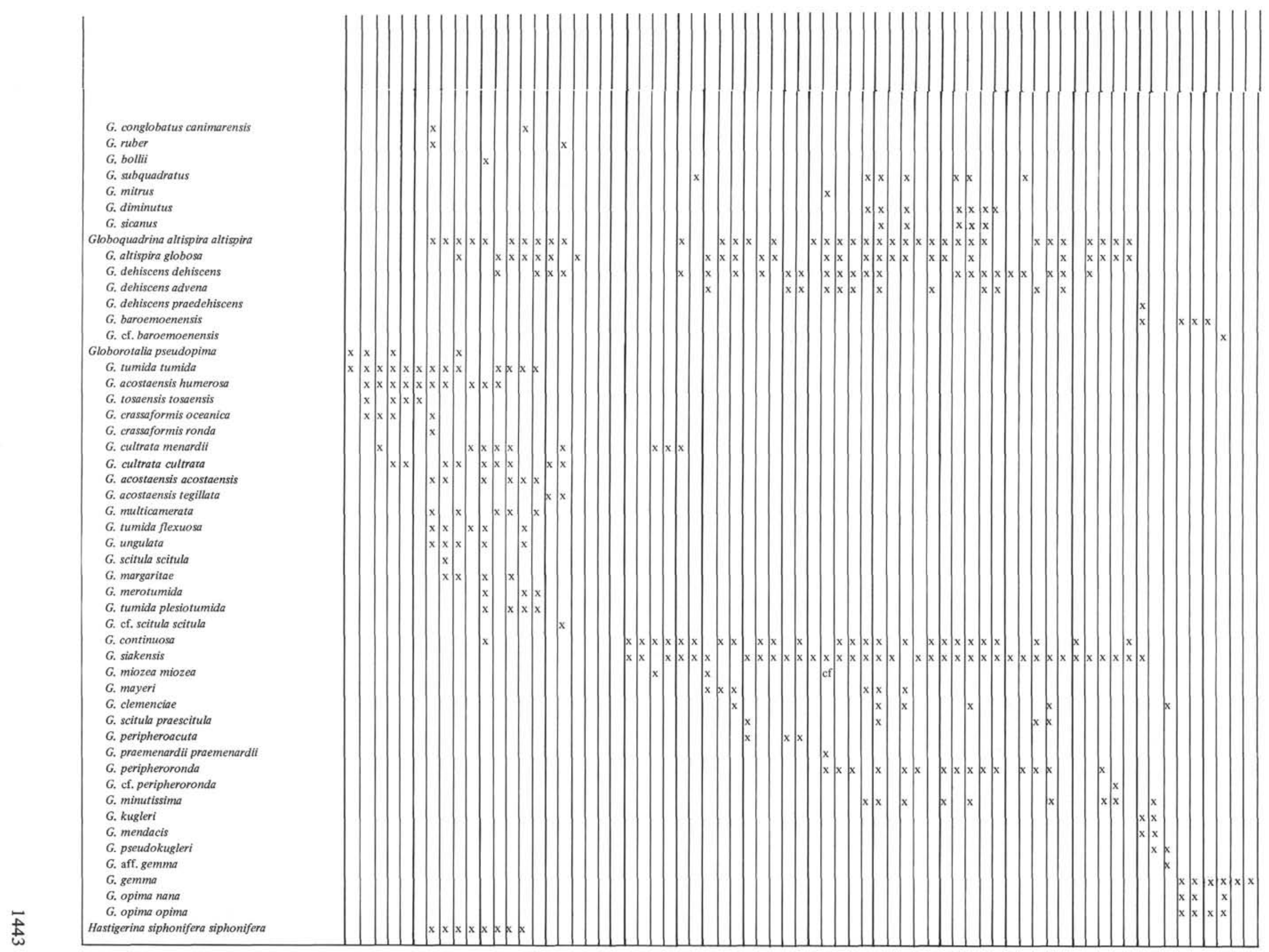





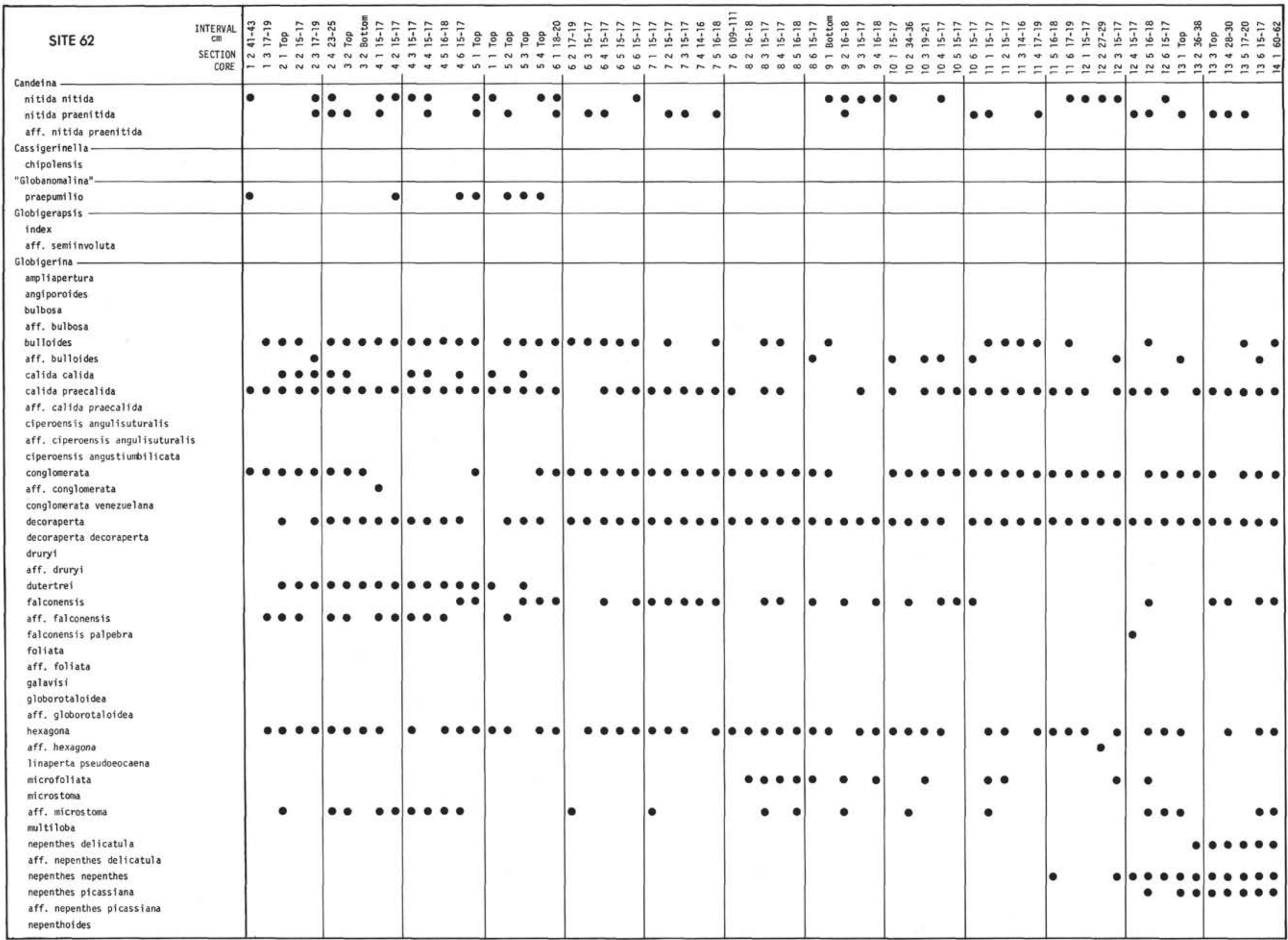




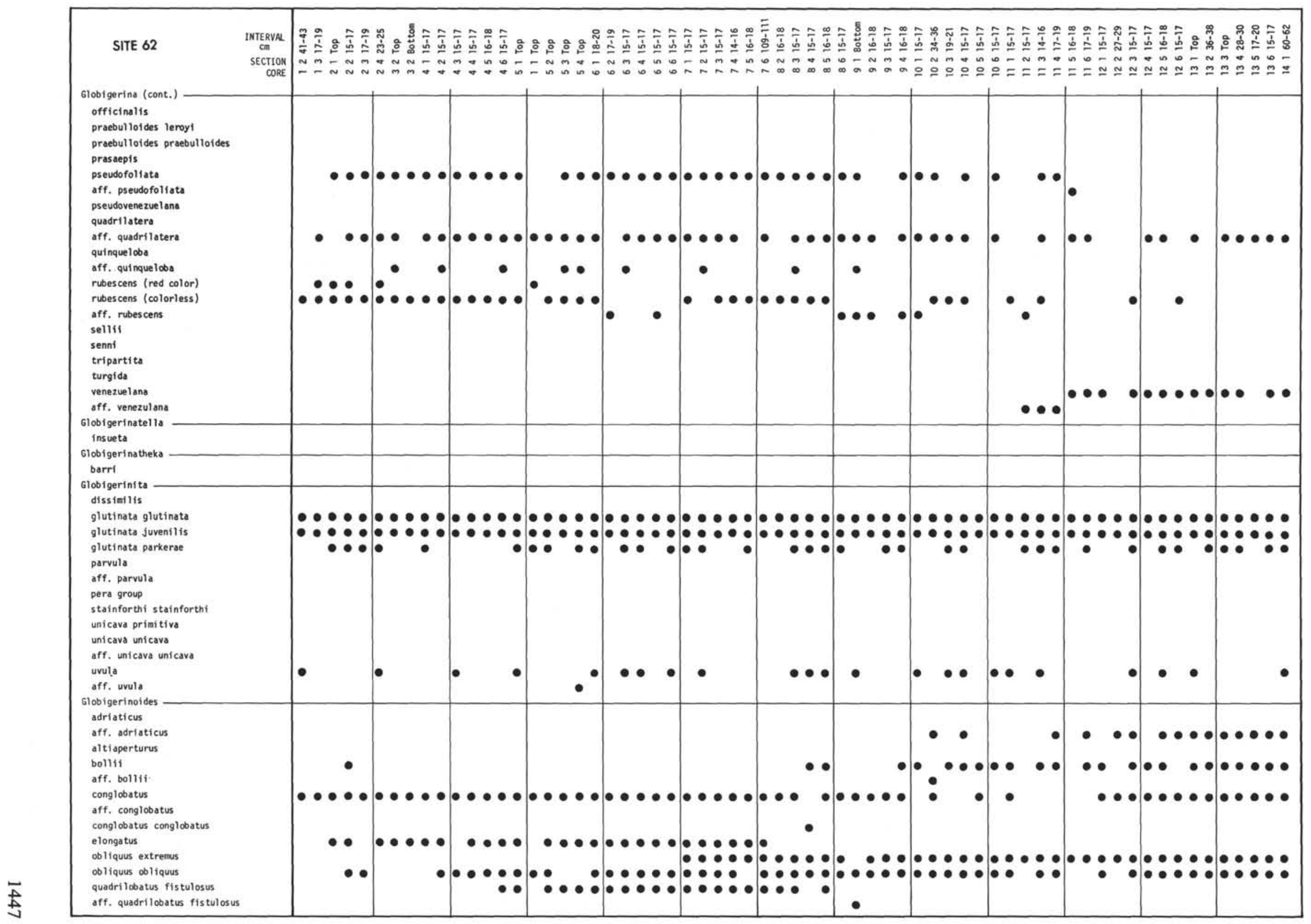




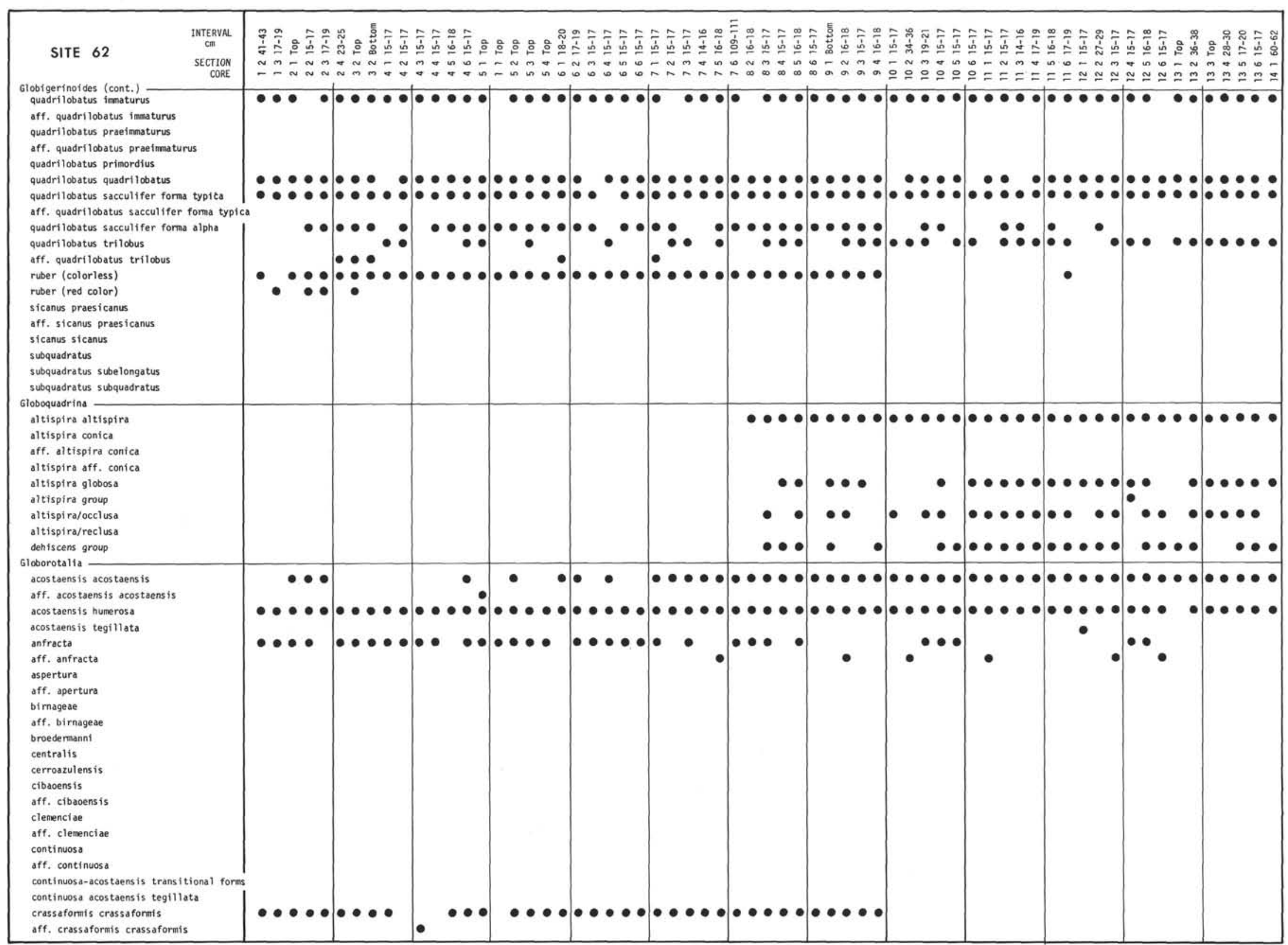




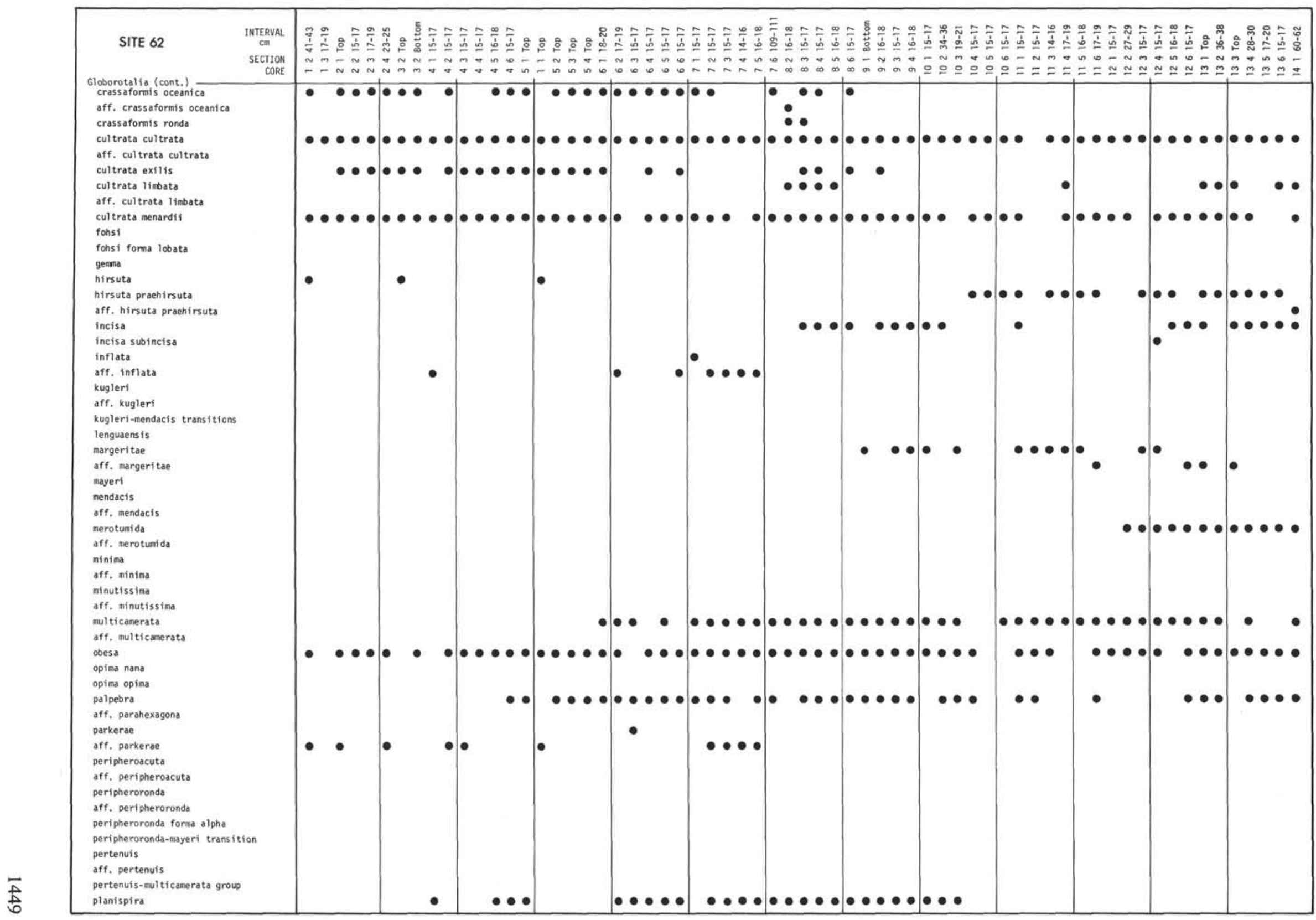




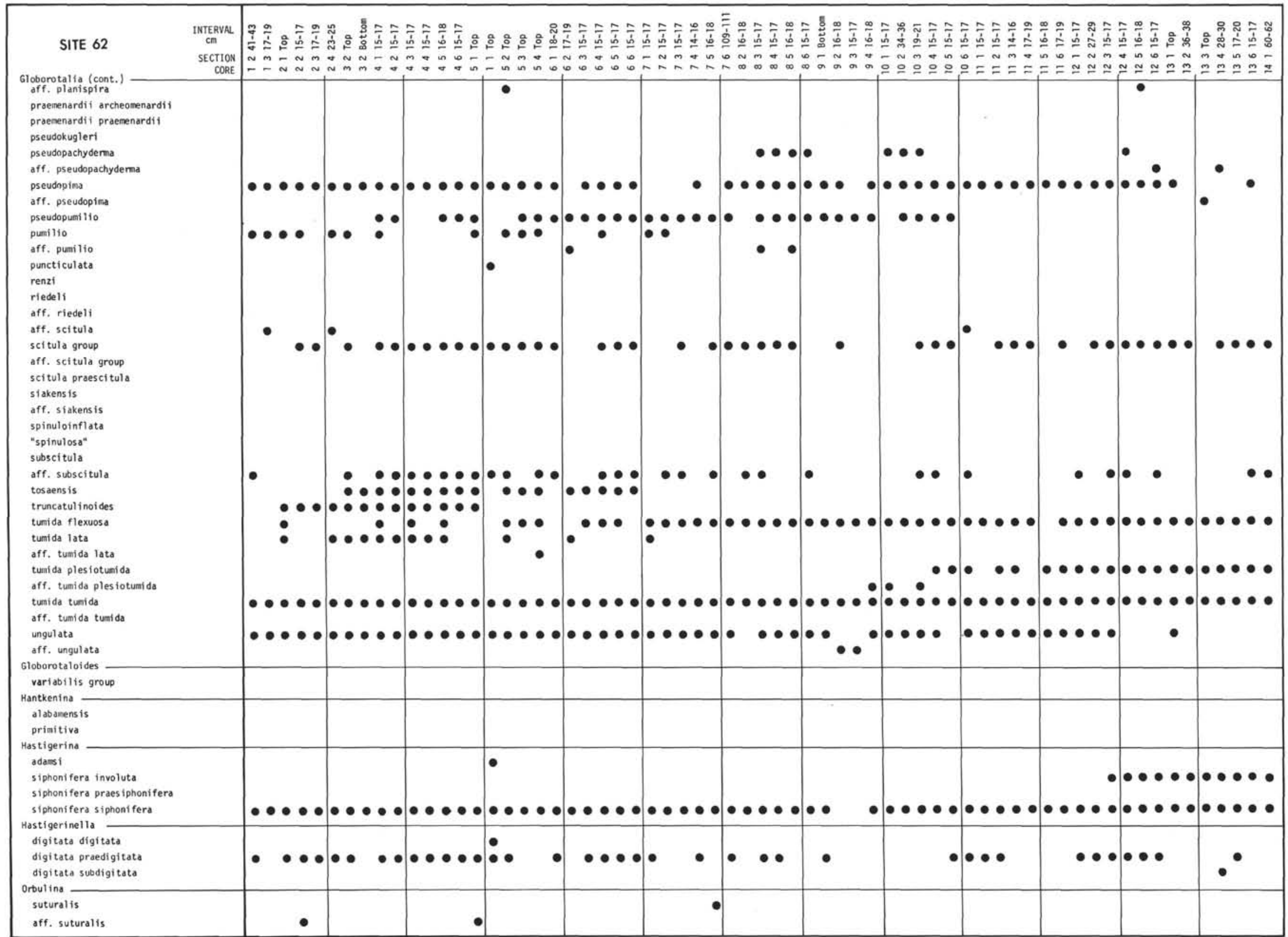




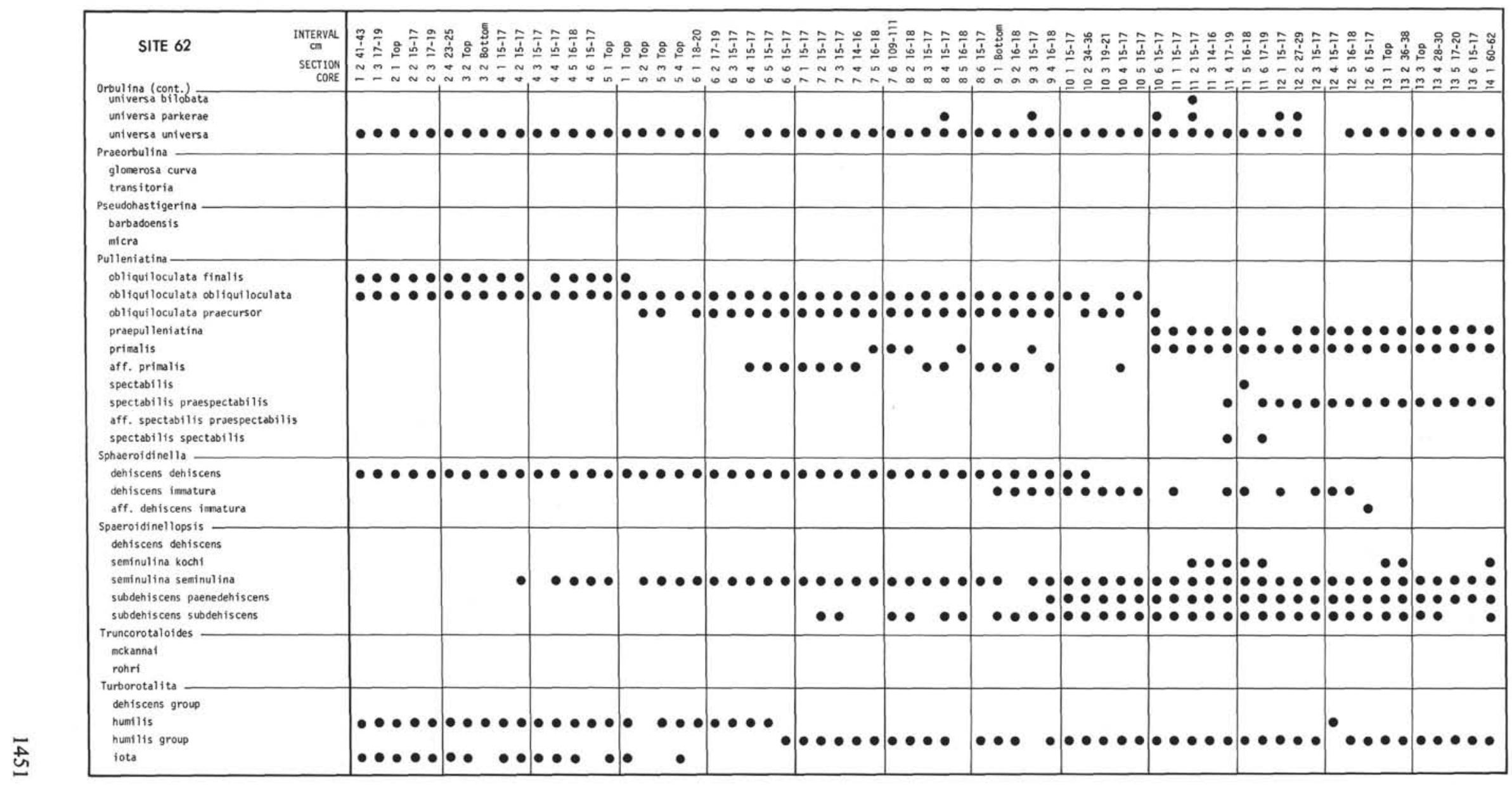




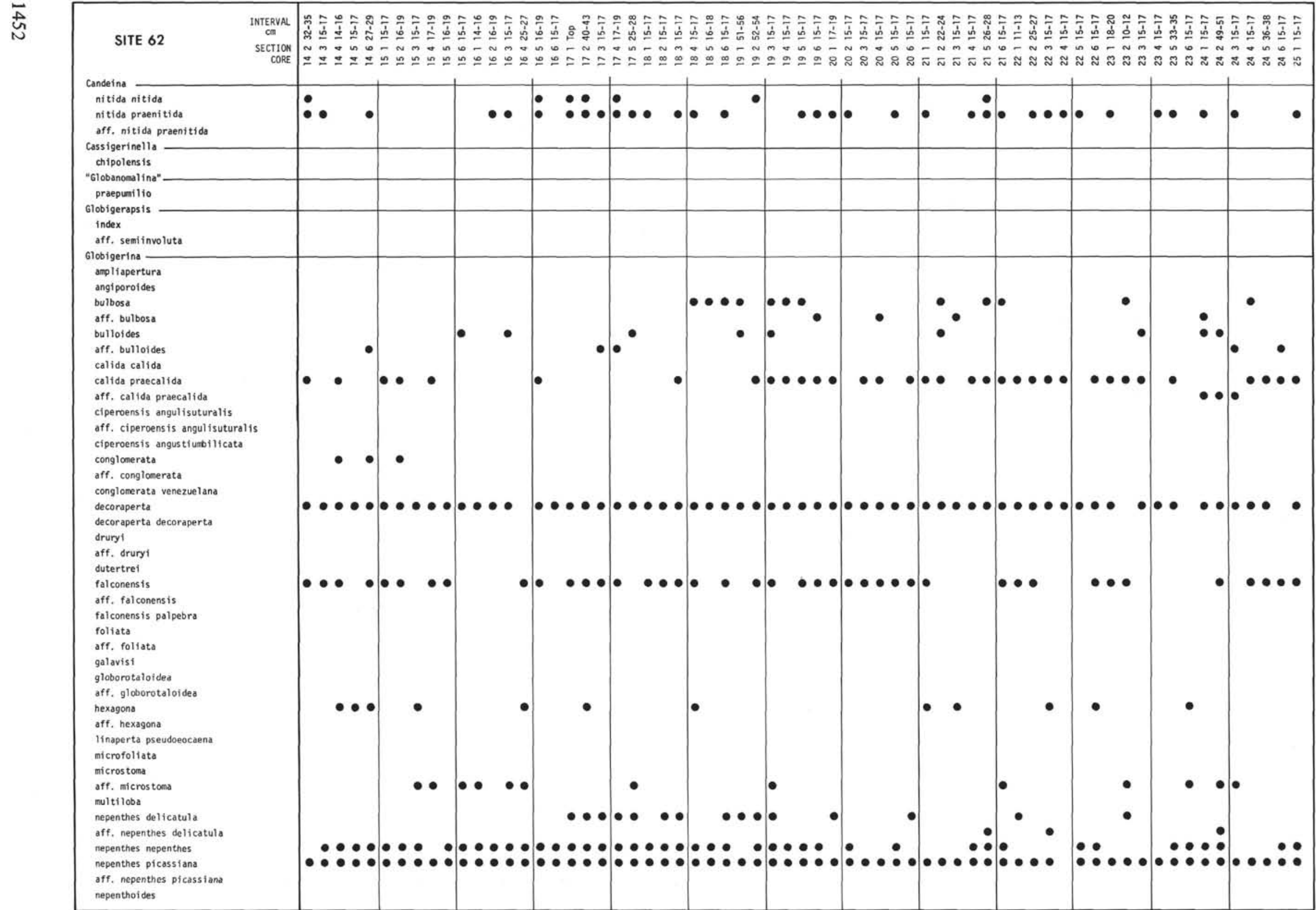




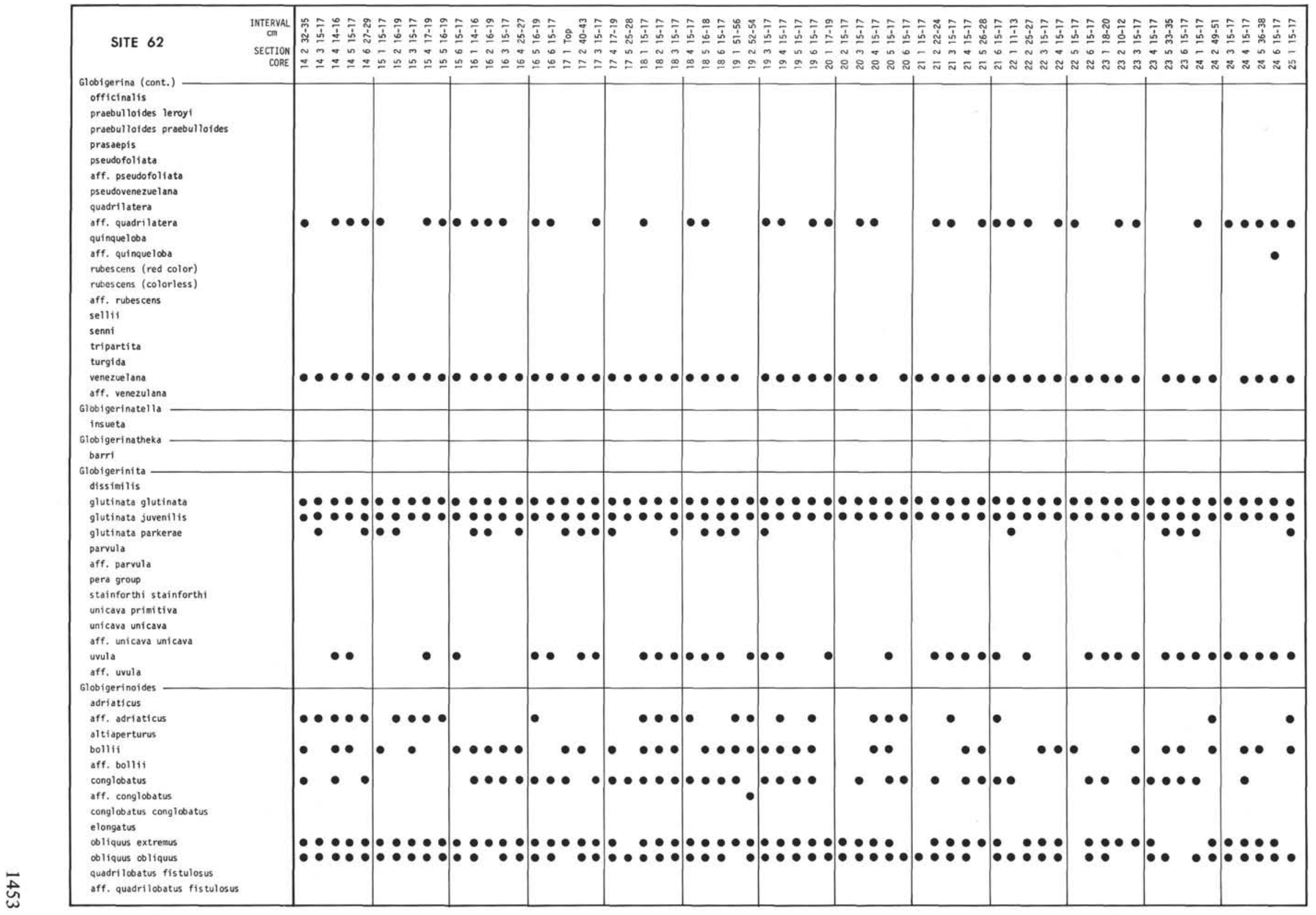




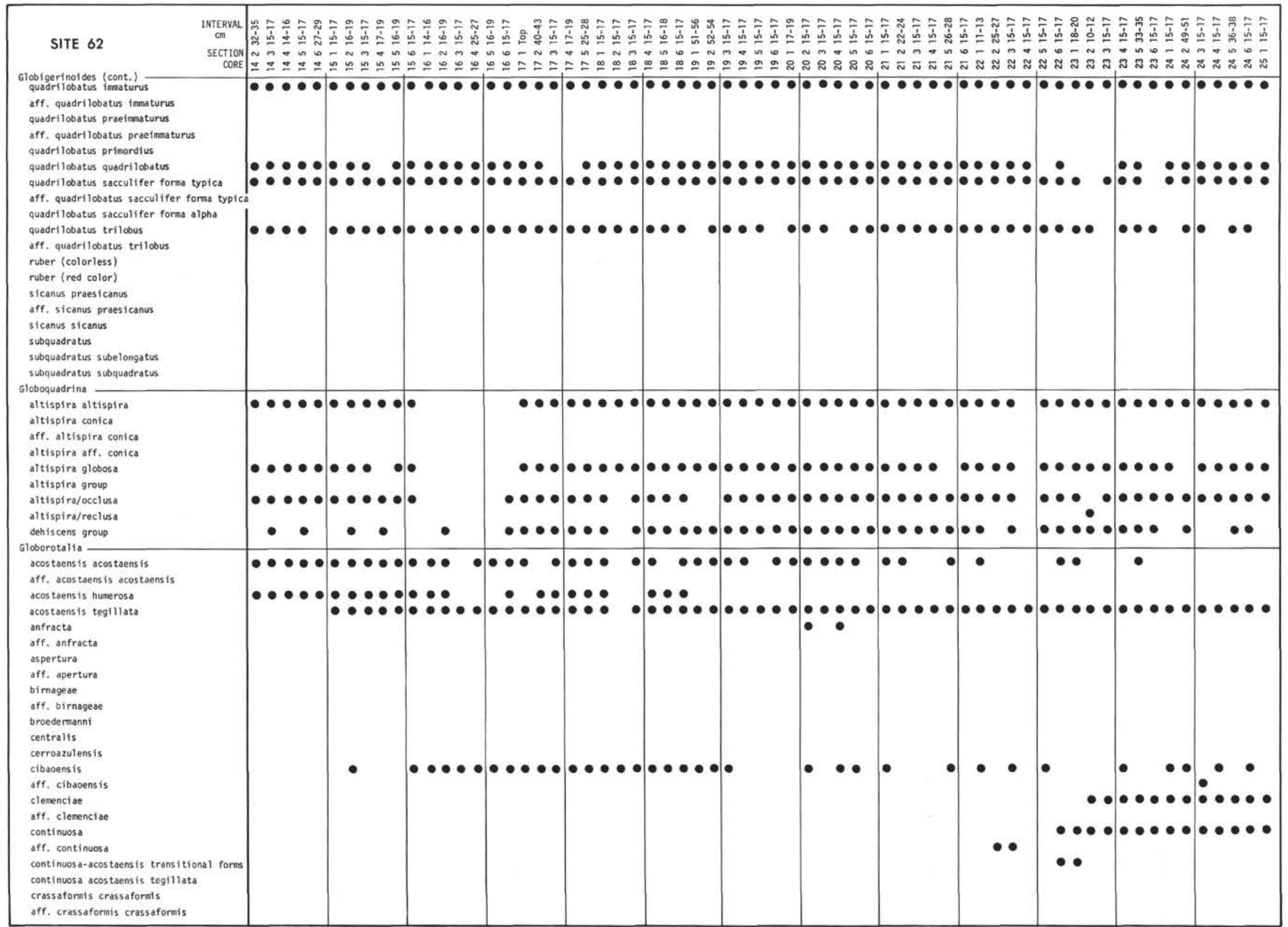




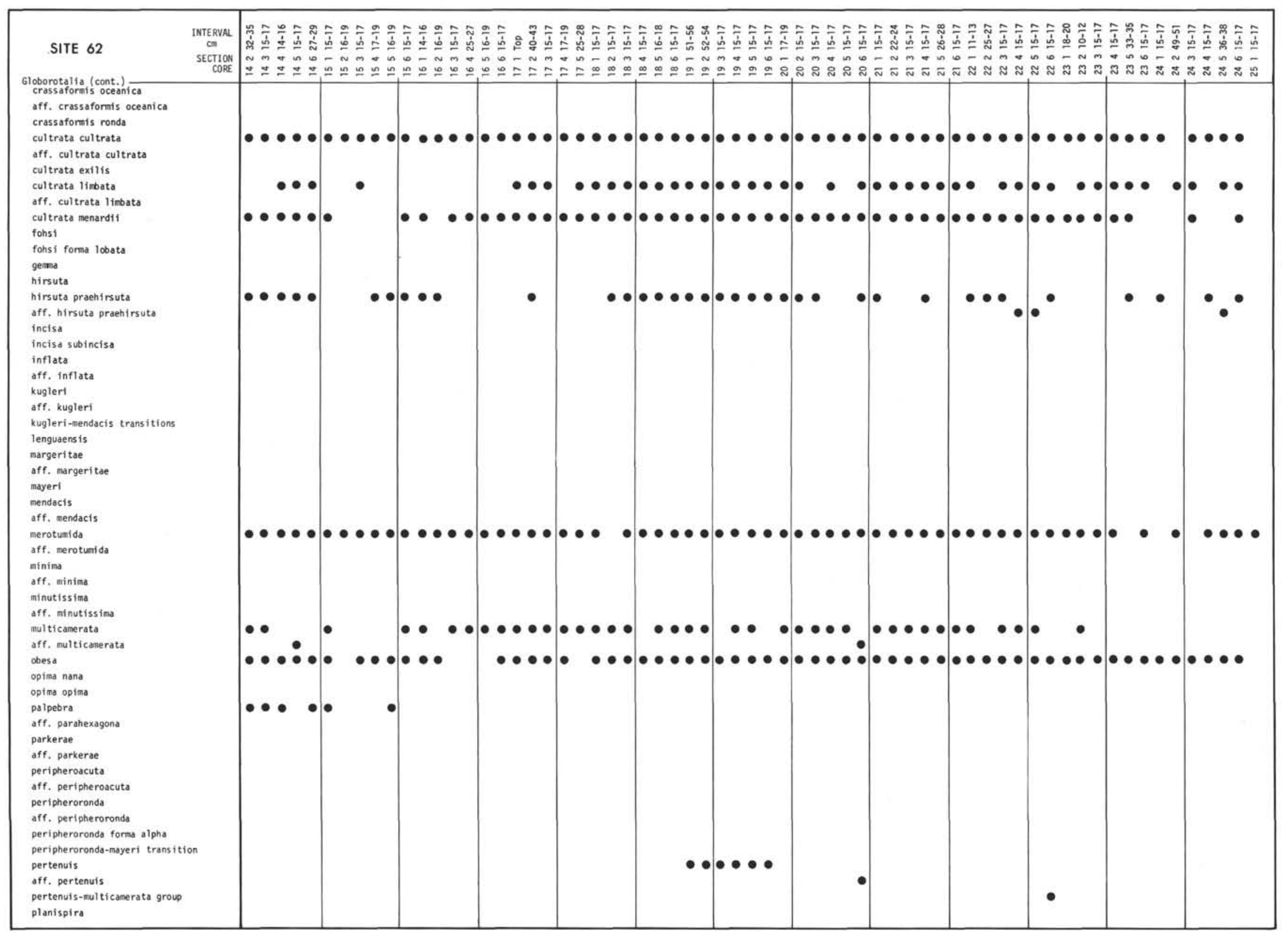




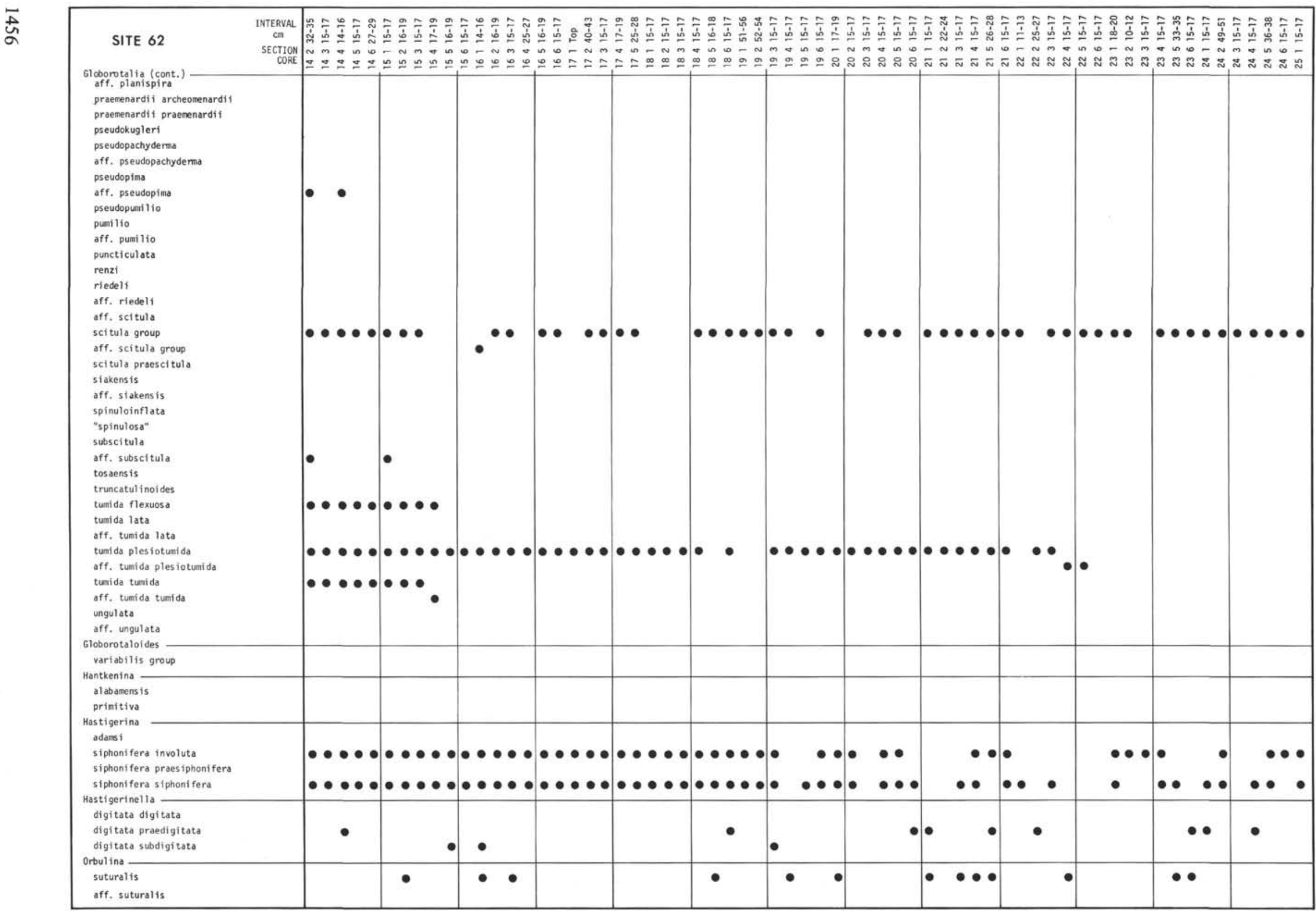




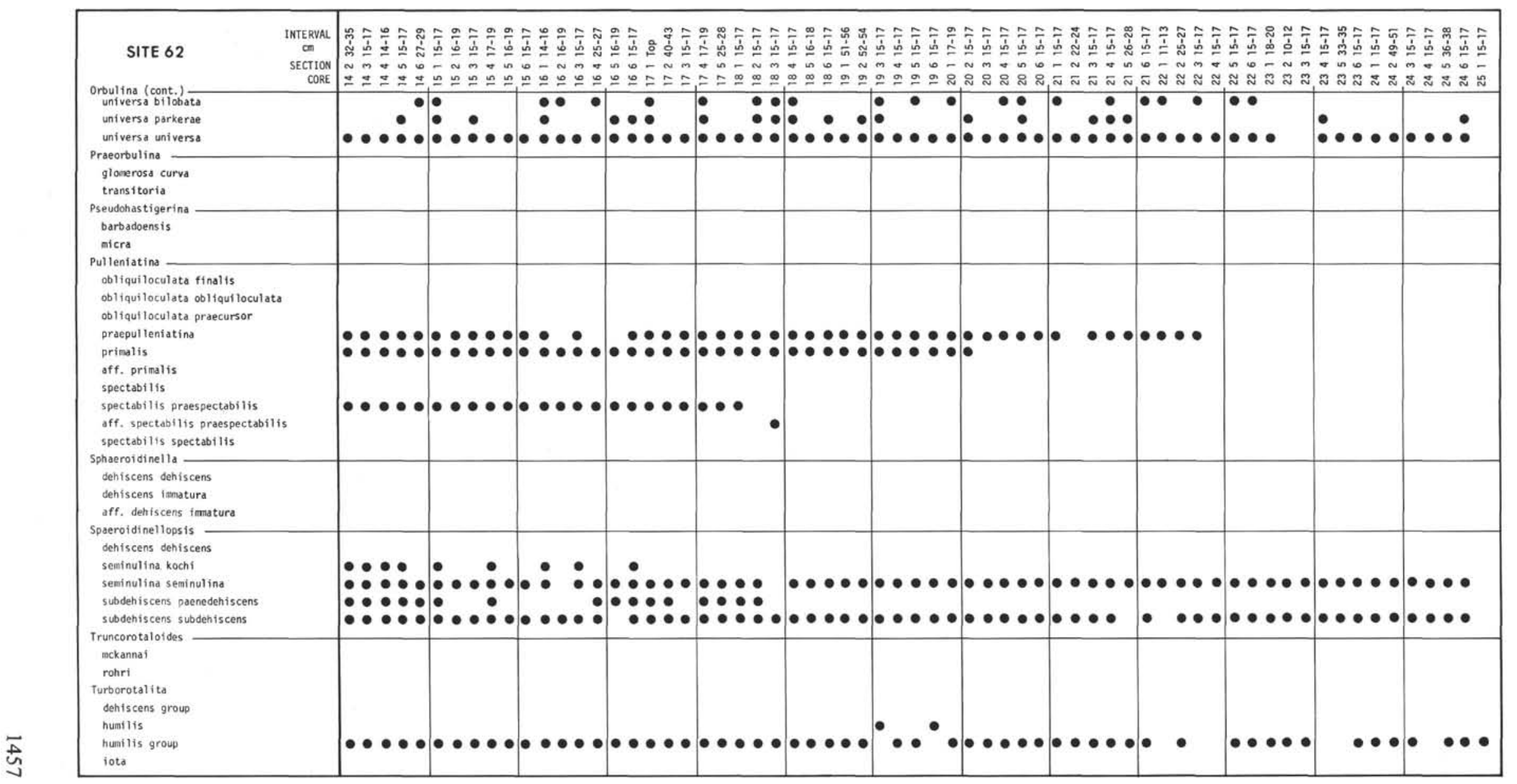




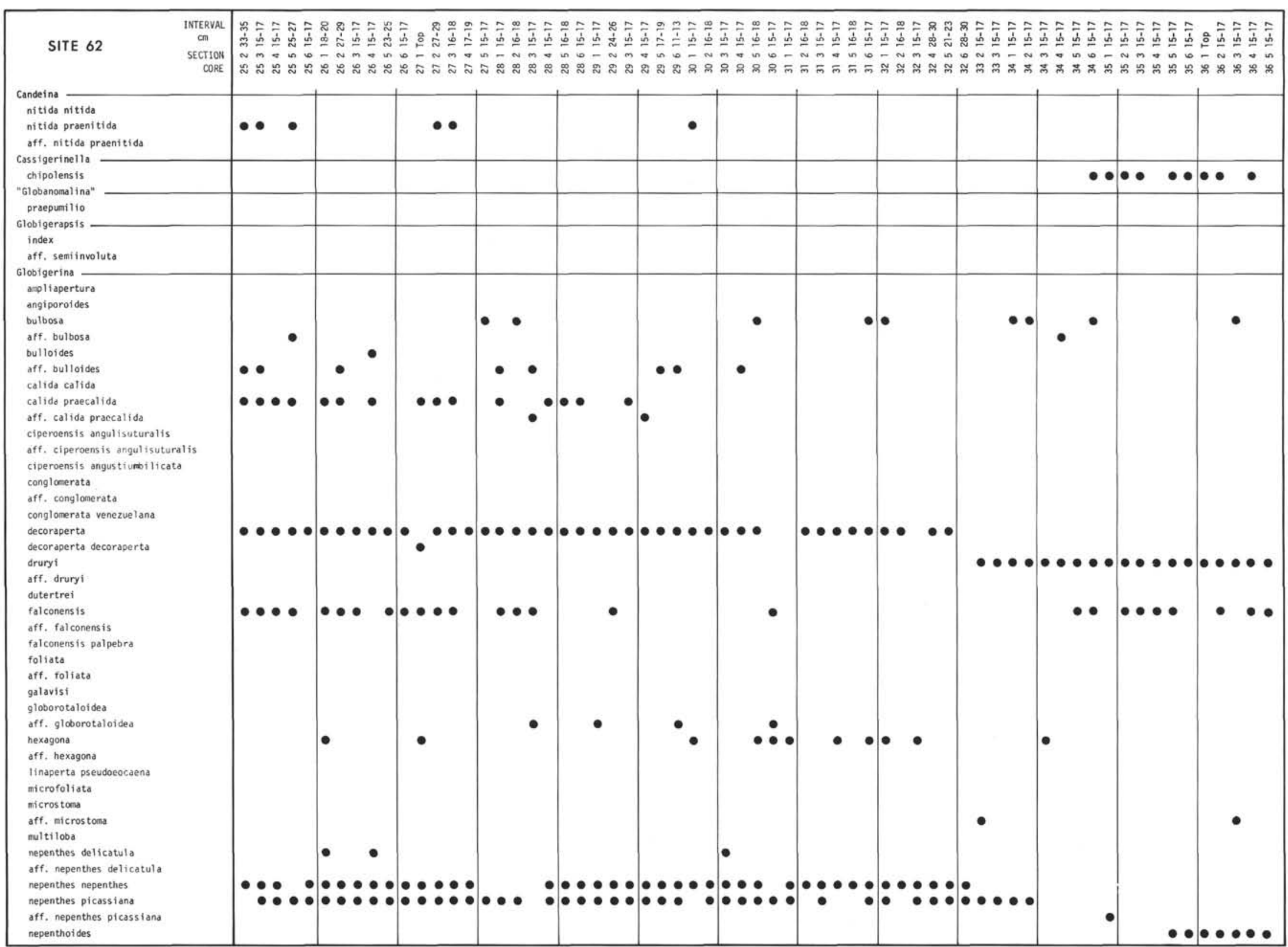




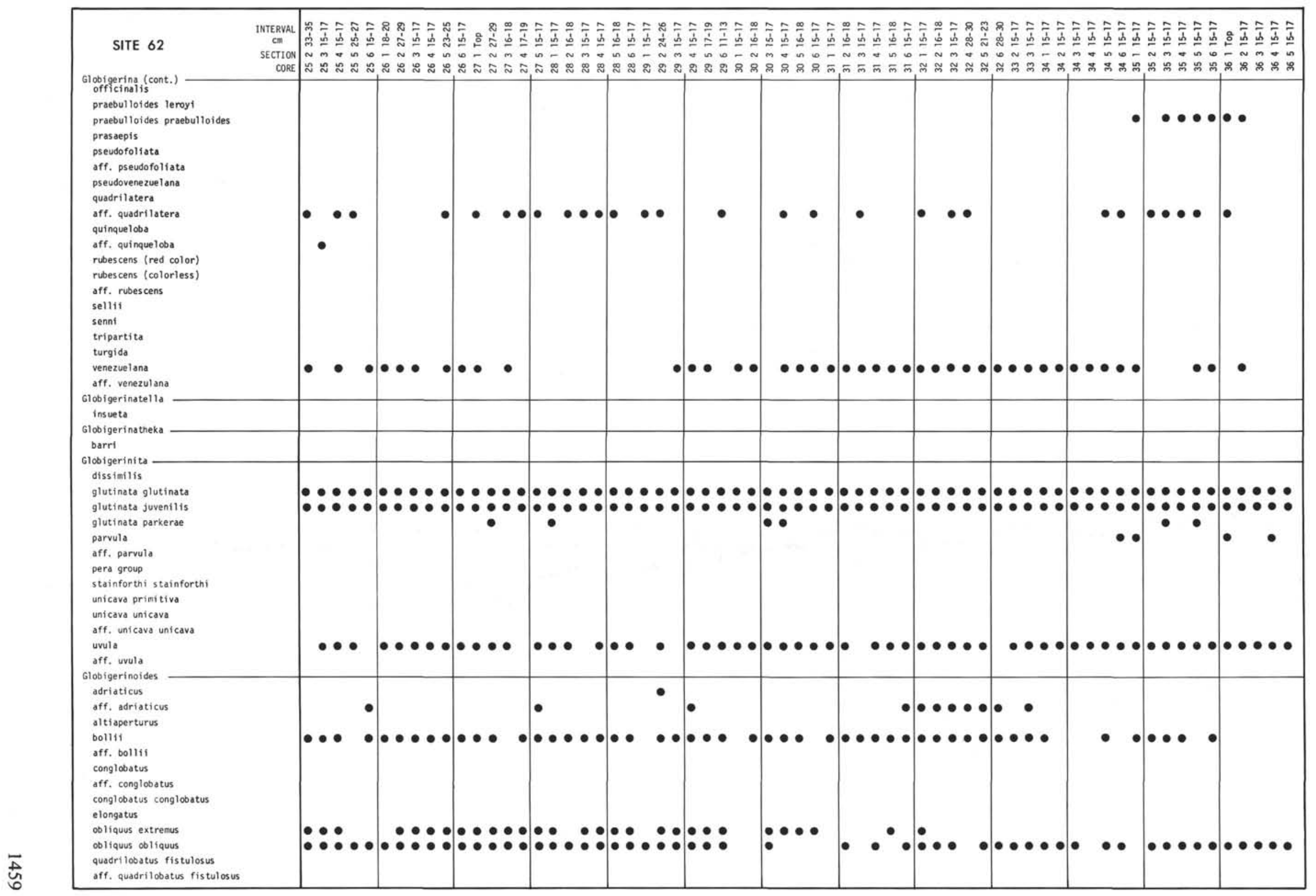




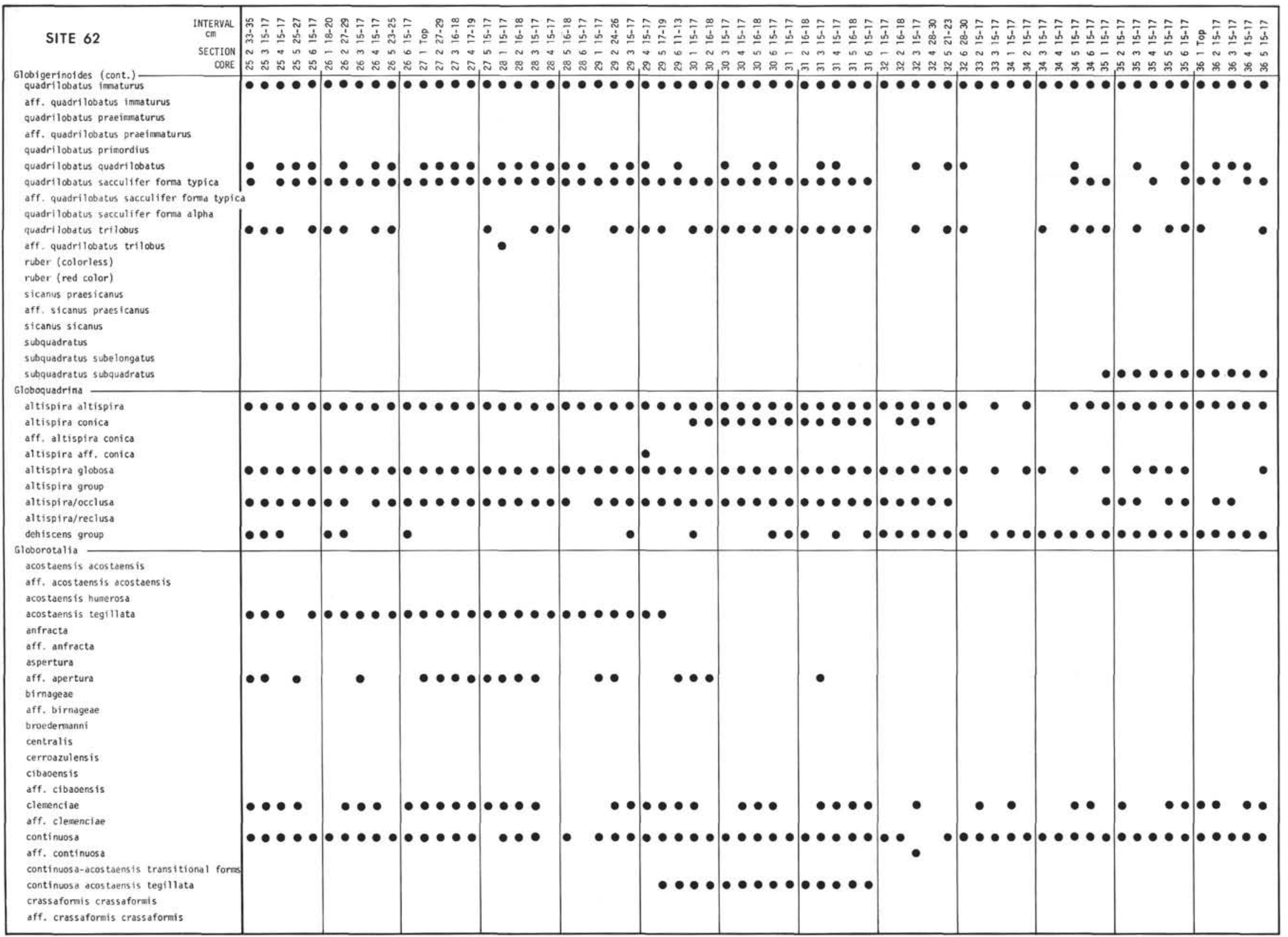




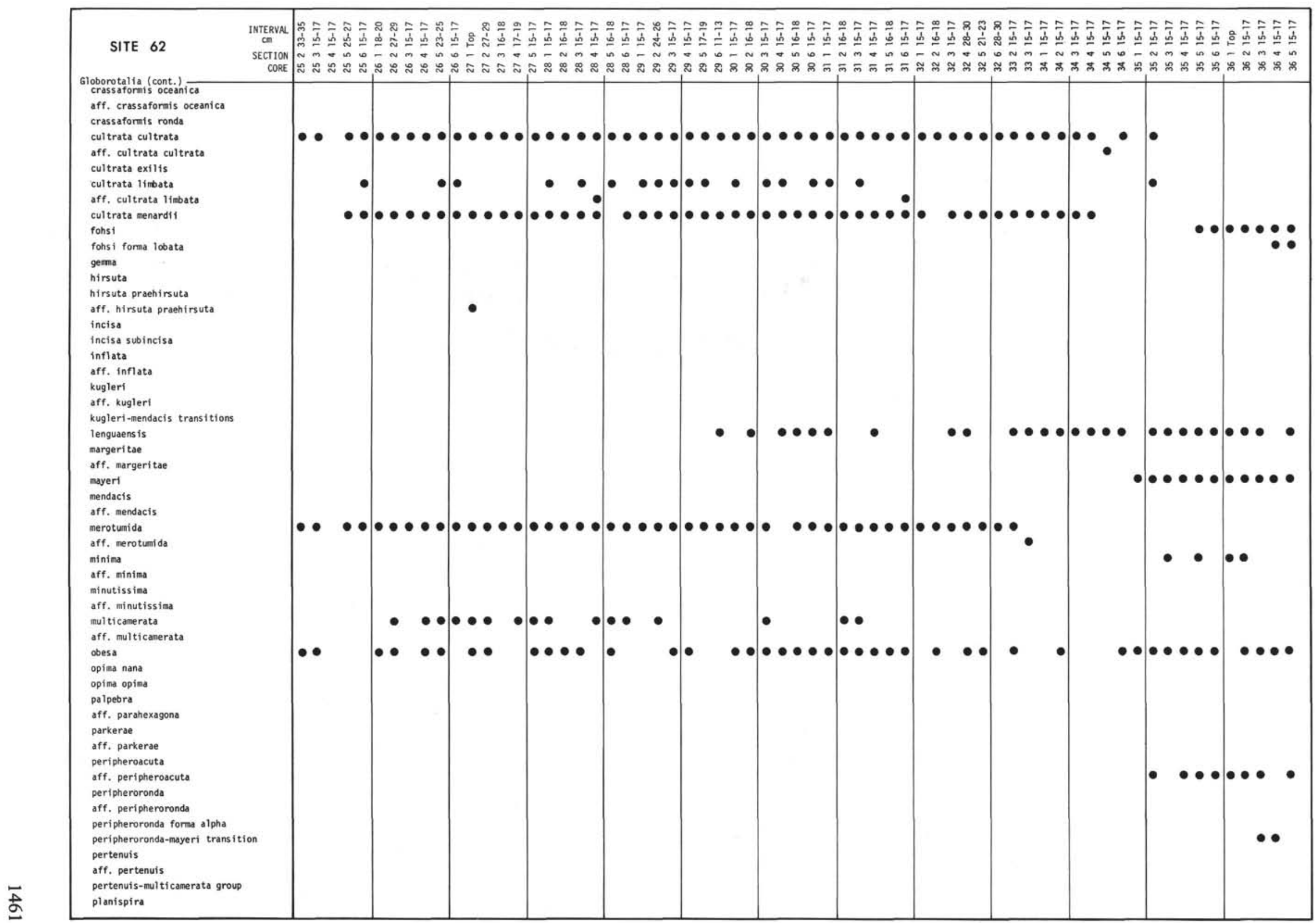




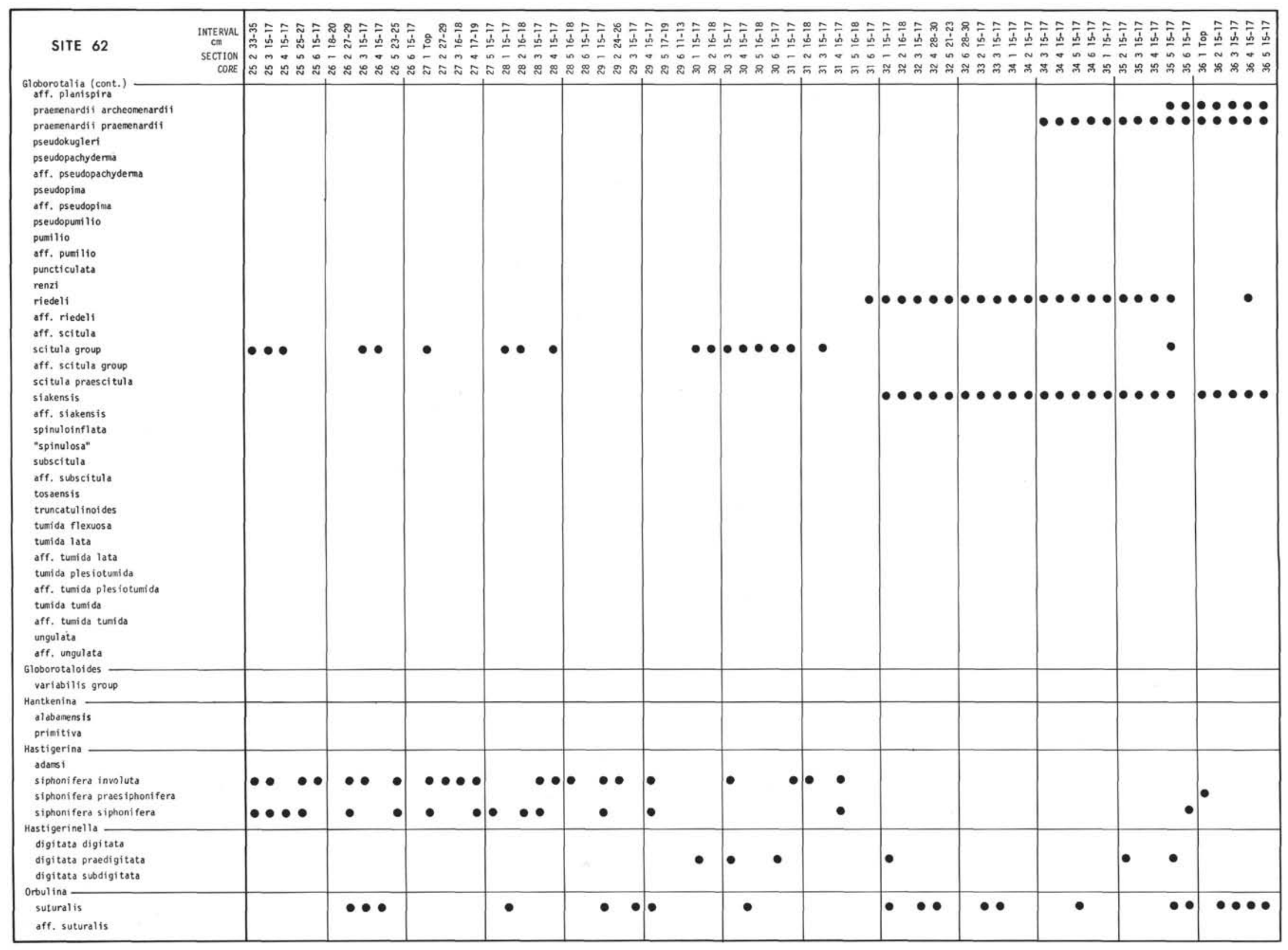




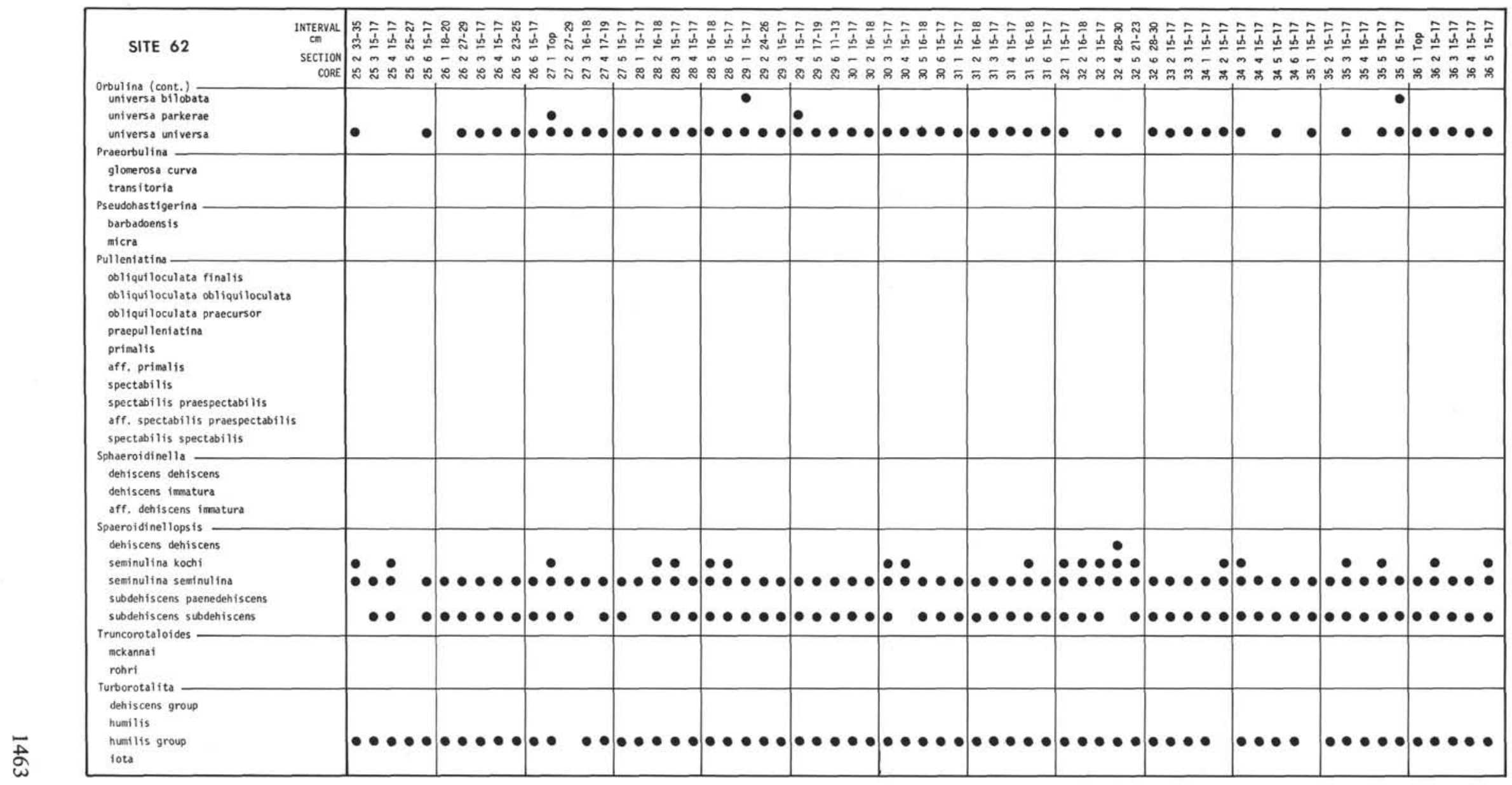




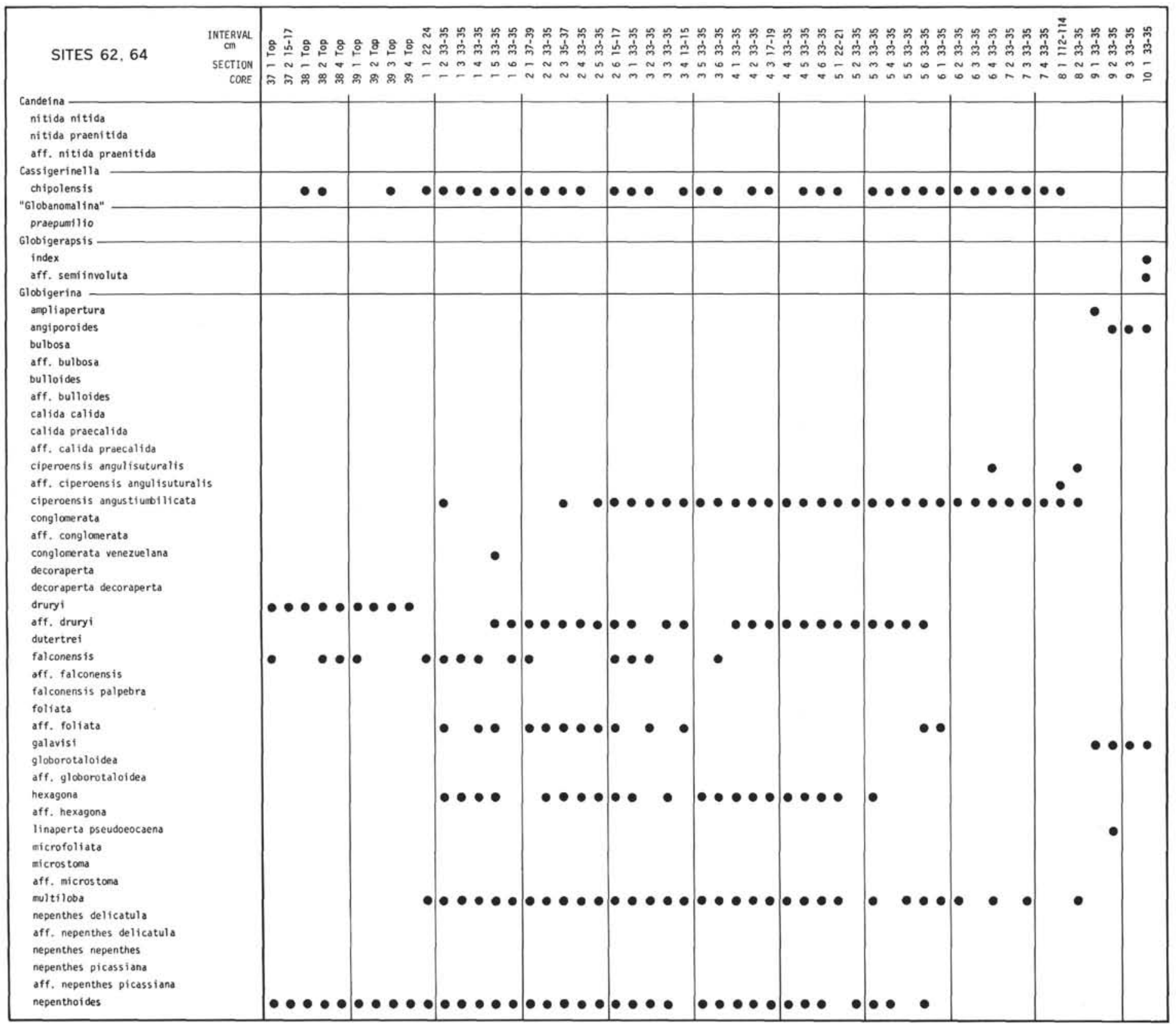




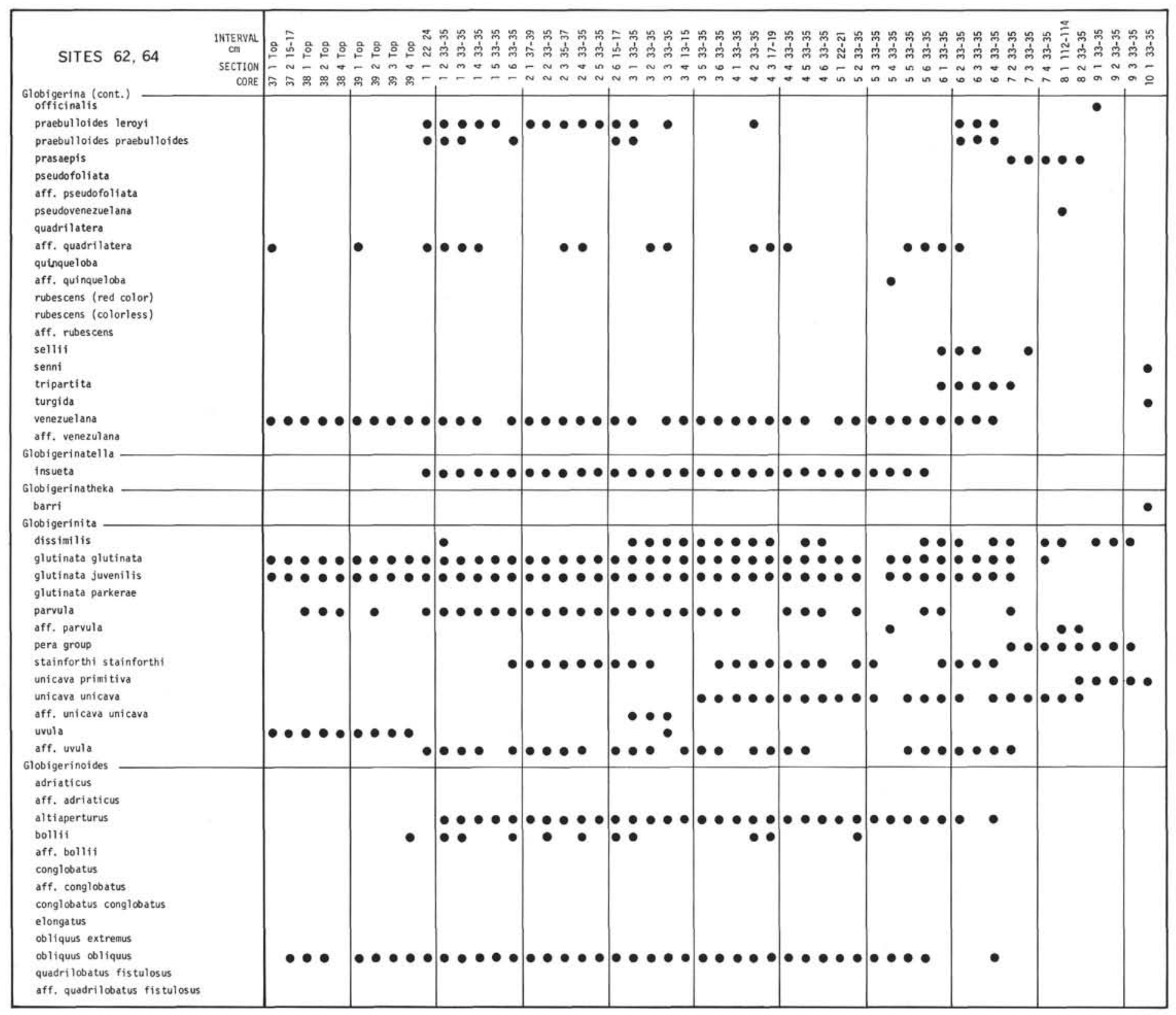




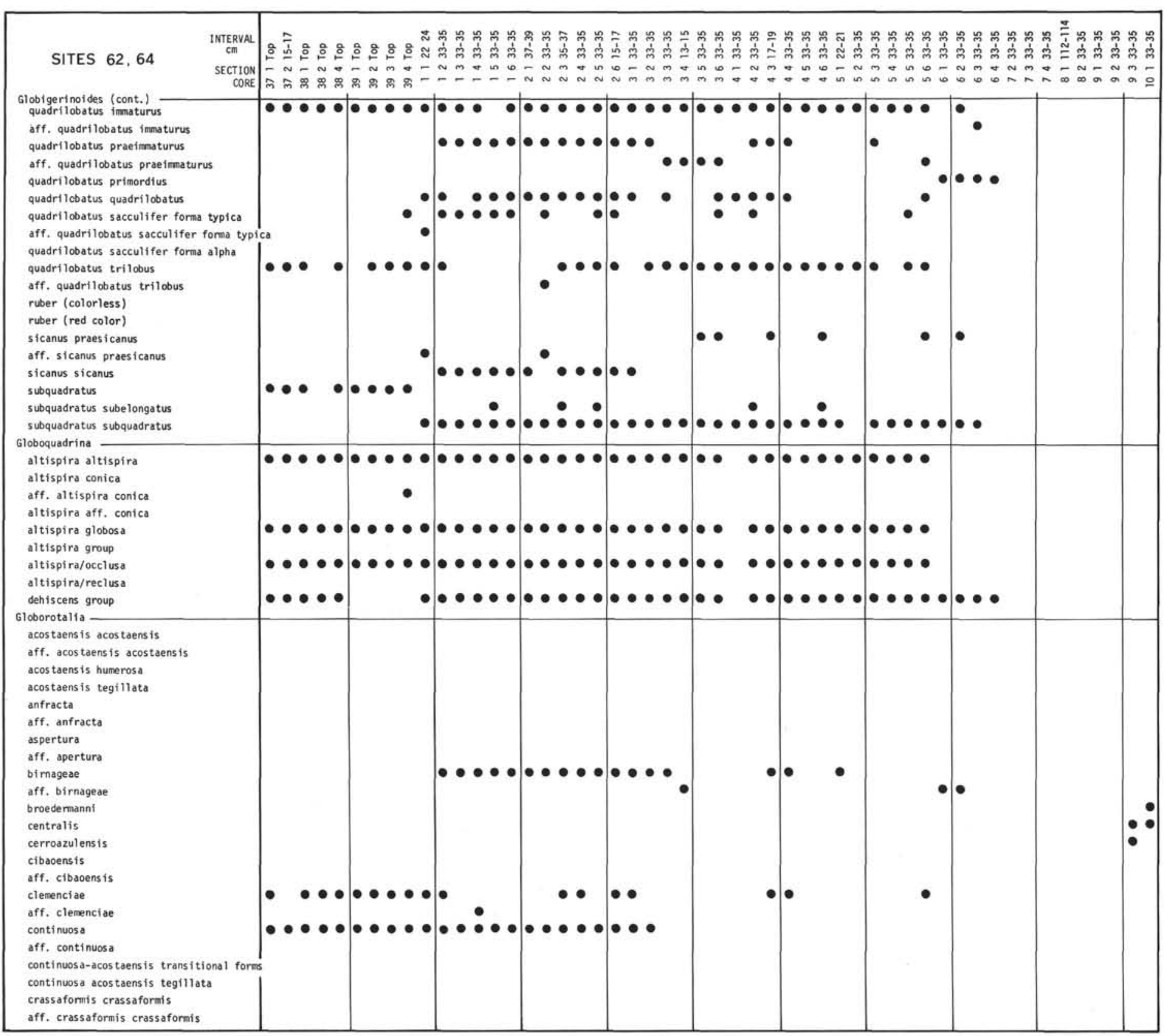




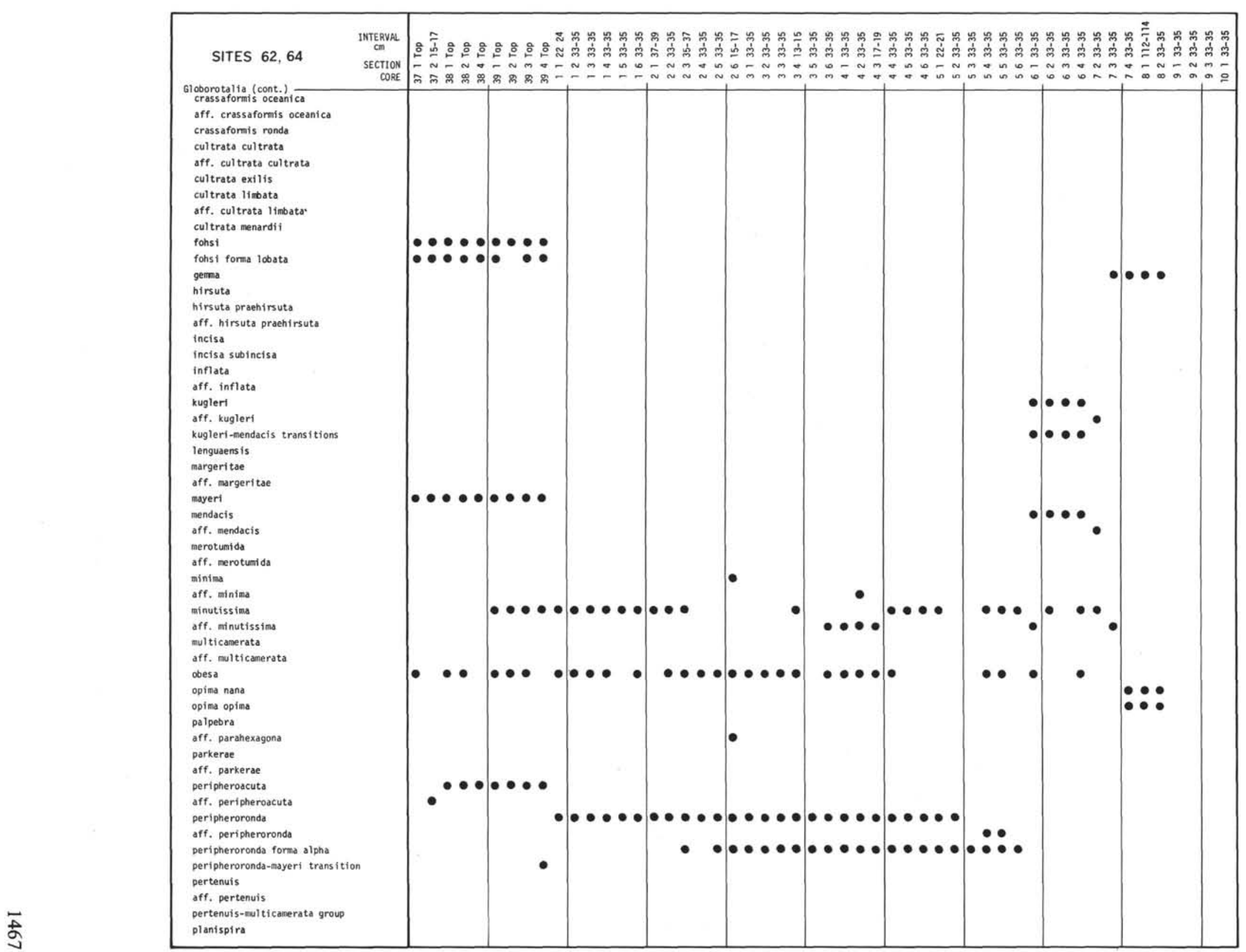




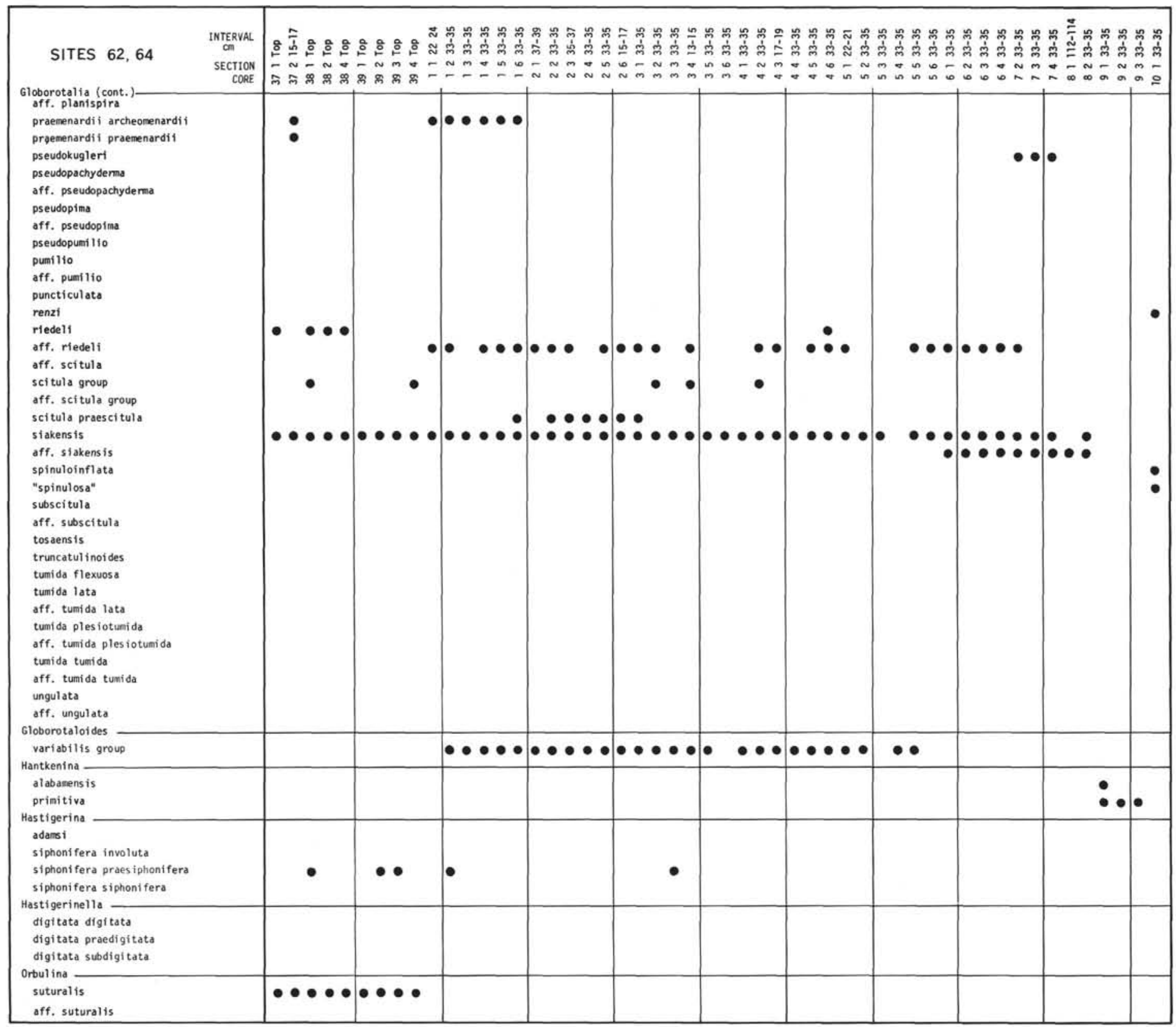




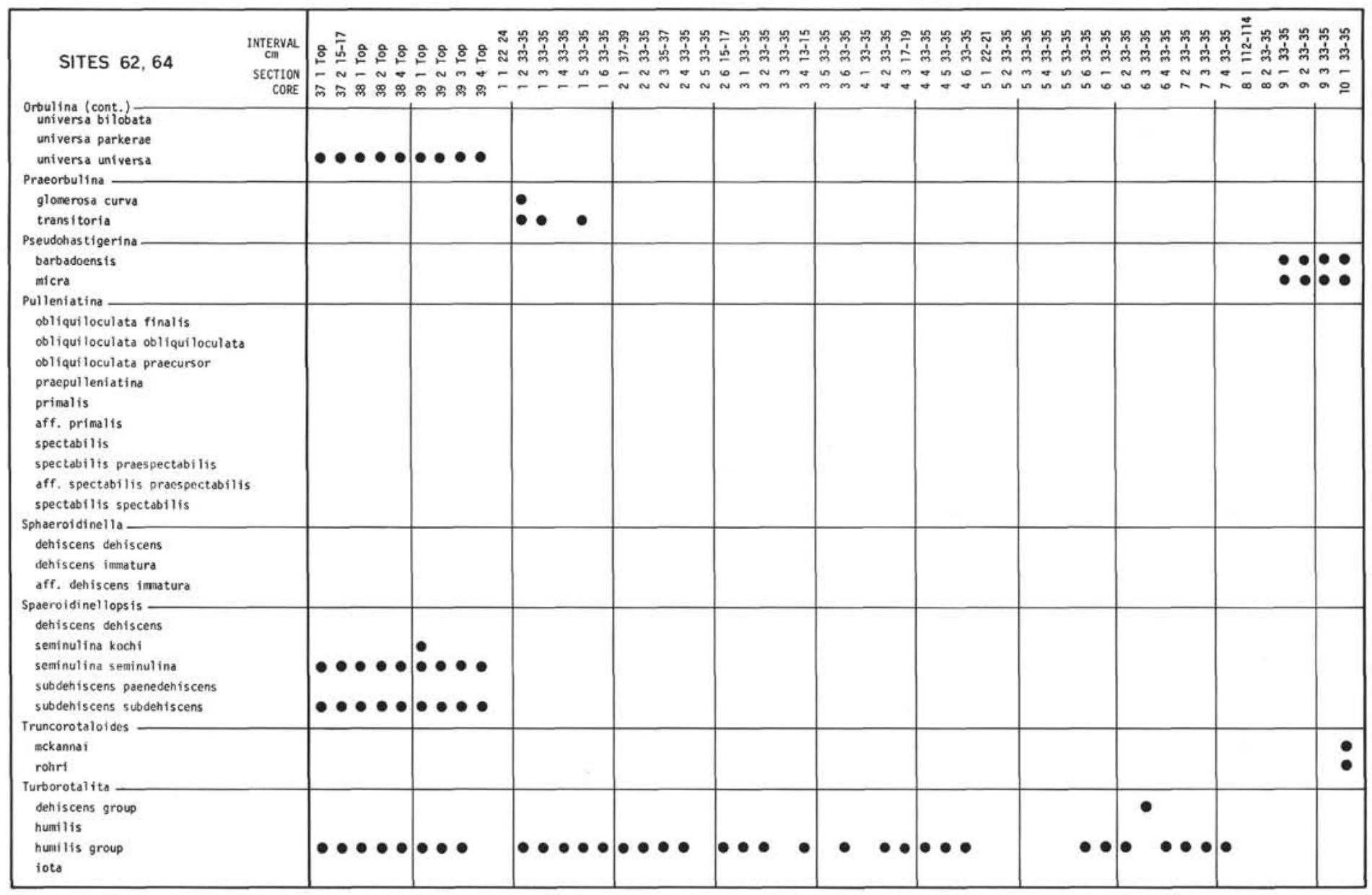

